University of New Hampshire

University of New Hampshire Scholars' Repository

\title{
Analysis of Vibracores from the New Hampshire Continental Shelf from 1984 and 1988
}

\author{
Larry G. Ward \\ Igward@ad.unh.edu \\ Rachel C. Morrison \\ rmorrison@ccom.unh.edu \\ Zachary S. McAvoy \\ University of New Hampshire, Durham, Zachary.McAvoy@unh.edu \\ Maxlimer Coromoto Vallee-Anziani
}

Follow this and additional works at: https://scholars.unh.edu/ccom

Part of the Geology Commons, Oceanography Commons, Sedimentology Commons, and the Stratigraphy Commons

\section{Recommended Citation \\ Ward, L.G., Morrison, R.C., McAvoy, Z.S., and Vallee-Anziani, M., 2021, Analysis of Vibracores from the New Hampshire Continental Shelf from 1984 and 1988: BOEM/New Hampshire Cooperative Agreement (Contract M14AC00010) Technical Report, Department of Interior, Bureau of Ocean Energy Management, Marine Minerals Division, 45600 Woodland Road, Sterling, VA, 20166, 173 pp. https://dx.doi.org/ $10.34051 / \mathrm{p} / 2021.26$}

This Report is brought to you for free and open access by the Center for Coastal and Ocean Mapping at University of New Hampshire Scholars' Repository. It has been accepted for inclusion in Center for Coastal and Ocean Mapping by an authorized administrator of University of New Hampshire Scholars' Repository. For more information, please contact Scholarly.Communication@unh.edu. 

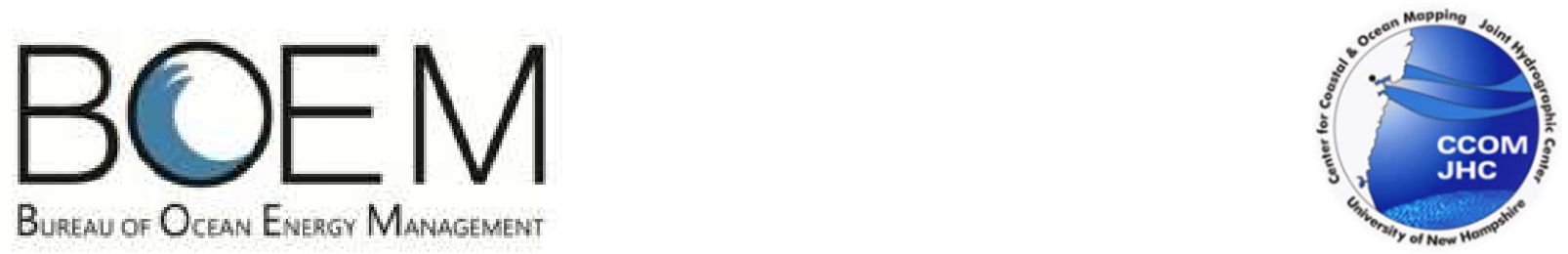

BOEM/New Hampshire Cooperative Agreement (Contract M14ACO0010) Technical Report

\section{Analysis of Vibracores from the New Hampshire Continental Shelf from 1984 and 1988}

Ward, L.G., Morrison, R.C., McAvoy, Z.S. and Vallee-Anziani, M.

University of New Hampshire Center for Coastal and Ocean Mapping/Joint Hydrographic Center

24 Colovos Road, Durham, NH 03824

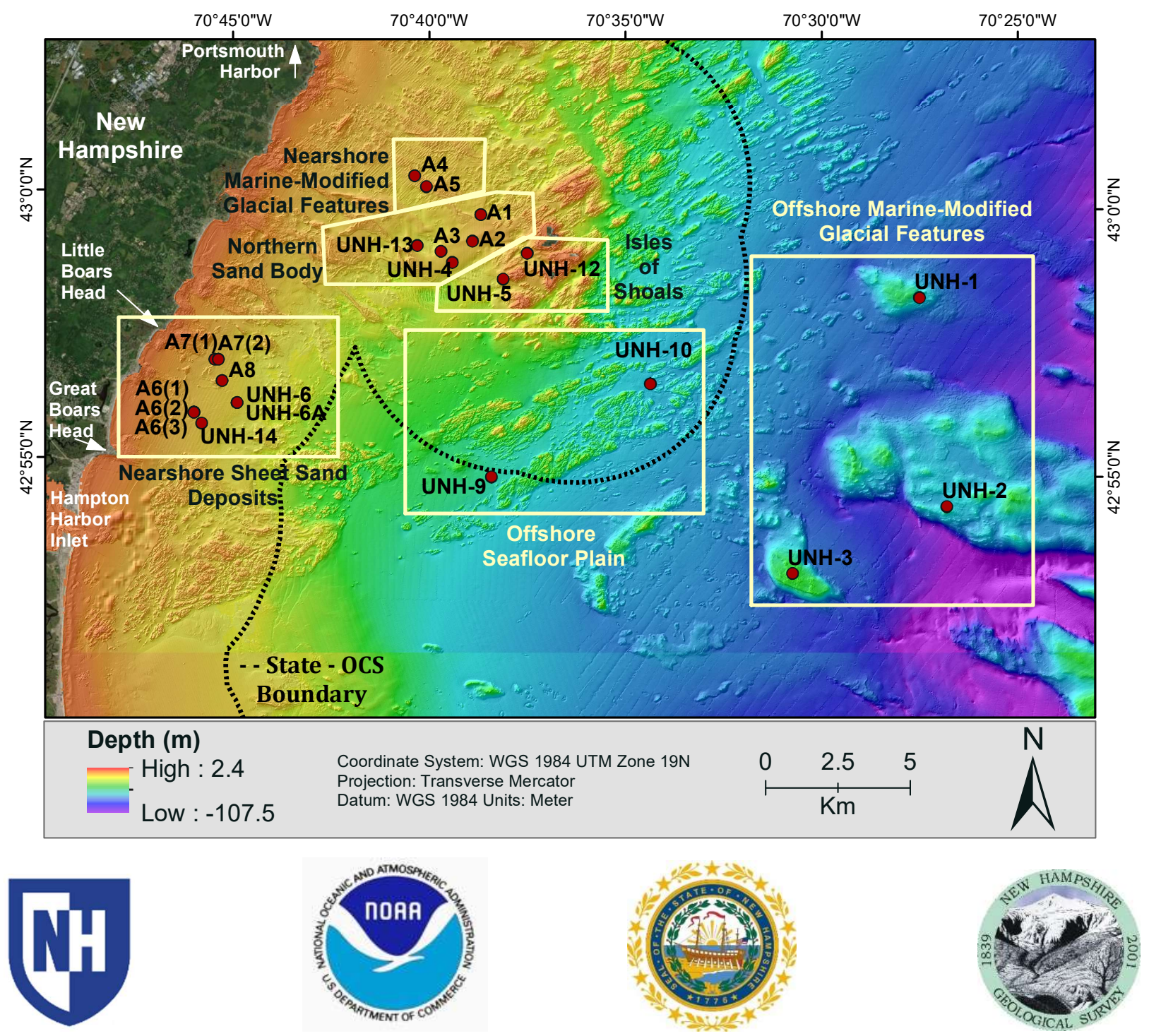




\section{Acknowledgements}

The work presented in this report was supported by the Bureau of Ocean Energy Management Award Number M14AC00010 and University of New Hampshire/National Oceanic and Atmospheric Administration Joint Hydrographic Center Award Number NA10NOS4000073. We gratefully acknowledge the United States Geological Survey at Woods Hole Coastal and Marine Science Center Sample Repository and Data Archives for access to the archived vibracores from the New Hampshire continental shelf. Brian Buczkowski and VeeAnn Cross provided expert help in locating, photographing, and sampling the vibracores. A number of colleagues at the University of New Hampshire Center for Coastal and Ocean Mapping/Joint Hydrographic Center provided scientific and technical support, advice, and insight including Will Fessenden (IT Group), Paul Johnson (Data Management), Larry Mayer, David Mosher and a number of other faculty and research scientists. Collection and original description of the vibracores was funded by a Minerals Management Service (MMS) - Coastal States Cooperative Agreements (14-12-000130115 in 1984 and 14-12-0001-30116 in 1988).

\section{In Memoriam}

Maxlimer Coromoto Vallee-Anziani was a valued colleague and a major contributor to the description and analysis of the vibracores discussed in this report. Sadly, Maxlimer passed away on January 24, 2017. However, her original work was a significant contribution to this report and our overall research on the $\mathrm{NH}$ continental shelf.

\section{Map Coordinate System, Projection and Datum}

Coordinate System: WGS 1984 UTM Zone 19N

Projection: Transverse Mercator

Horizontal Datum: WGS 1984

Vertical Datum: MLLW

\section{Recommended Citation}

Ward, L.G., Morrison, R.C., McAvoy, Z.S., and Vallee-Anziani, M., 2021, Analysis of Vibracores from the New Hampshire Continental Shelf from 1984 and 1988: BOEM/New Hampshire Cooperative Agreement (Contract M14AC00010) Technical Report, Department of Interior, Bureau of Ocean Energy Management, Marine Minerals Division, 45600 Woodland Road, Sterling, VA, 20166, 173 pp.

https://dx.doi.org/10.34051/p/2021.26

April 10, 2021 


\section{Table of Contents}

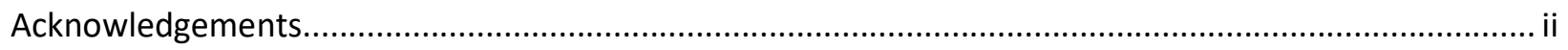

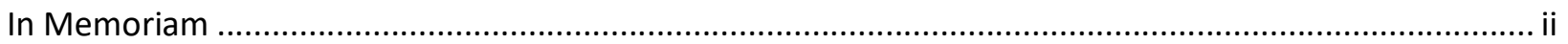

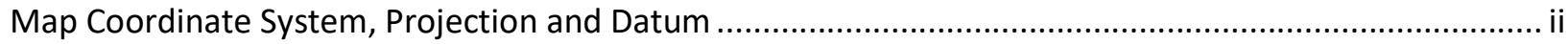

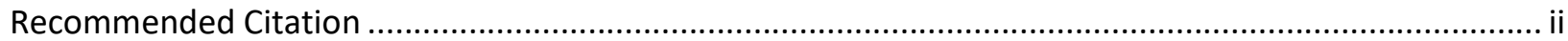

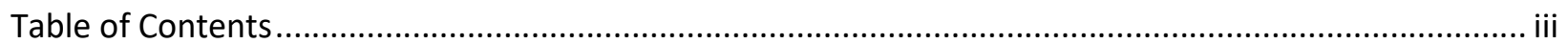

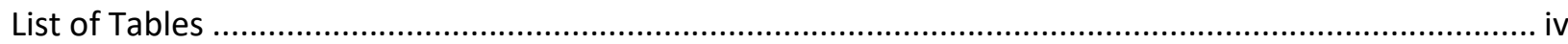

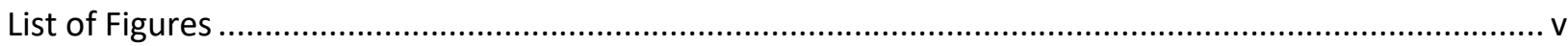

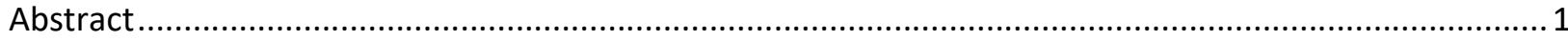

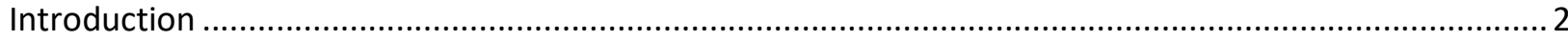

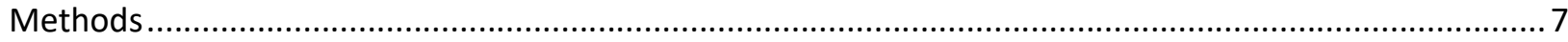

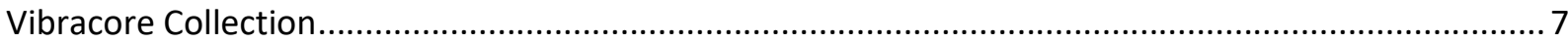

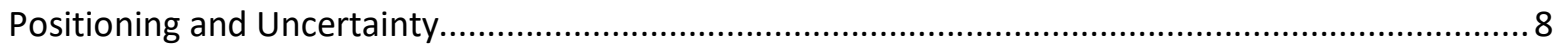

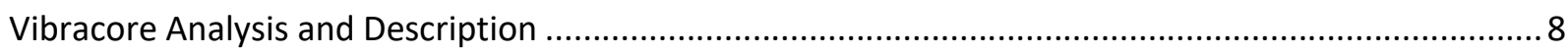

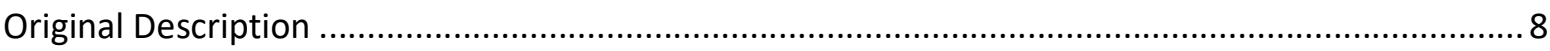

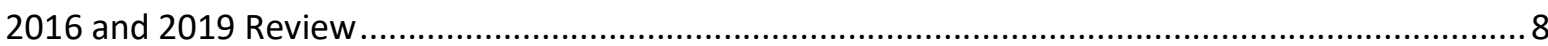

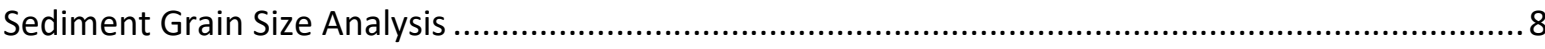

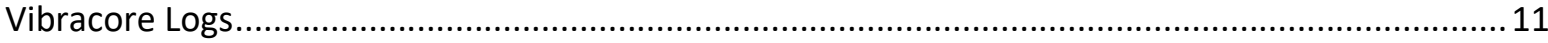

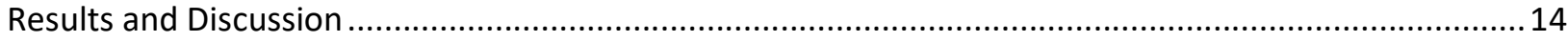

Offshore Marine-Modified Glacial Features (Drumlins and Lodgement Till Deposits) .........................15

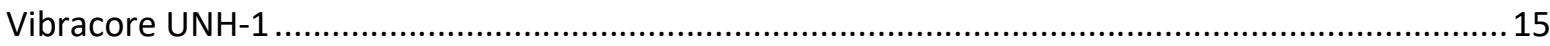

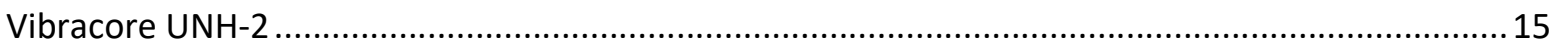

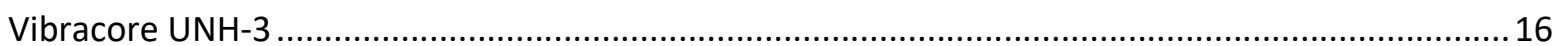

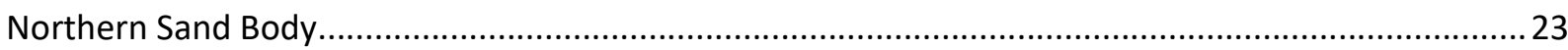

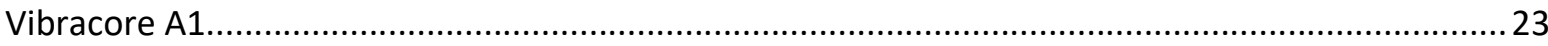

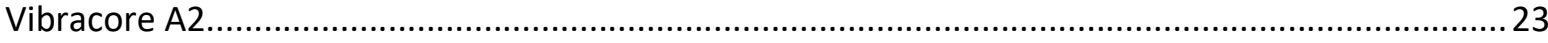

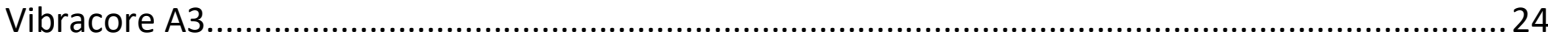

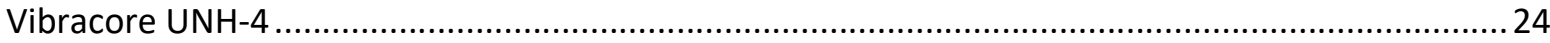

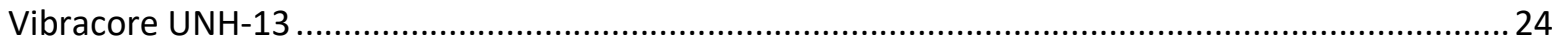

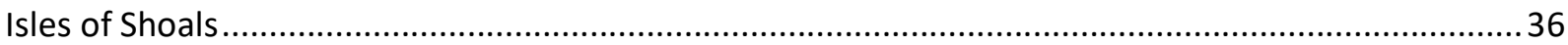

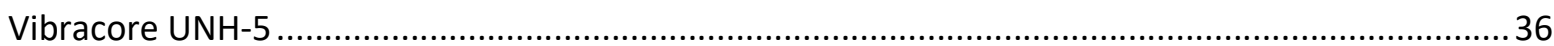

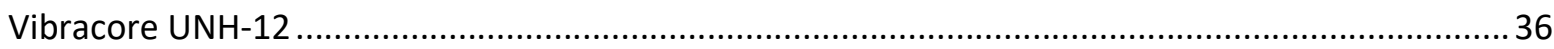

Nearshore Marine-Modified Glacial Features (Eskers and Drumlins) ................................................ 41 
Vibracore A4

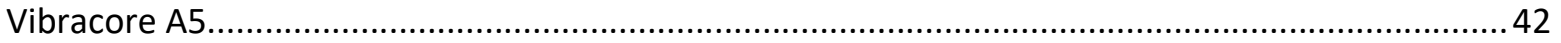

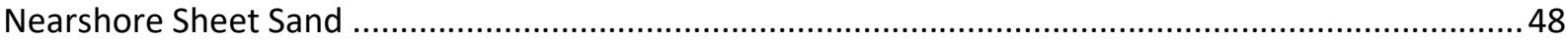

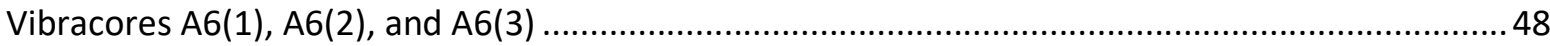

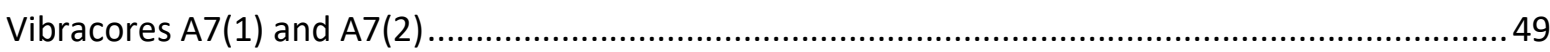

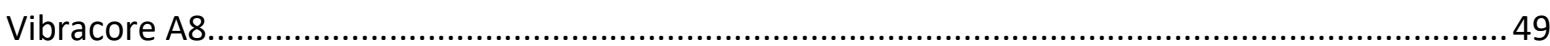

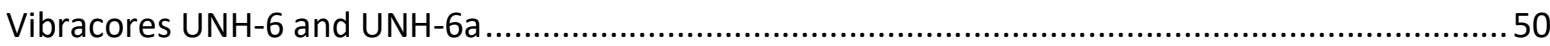

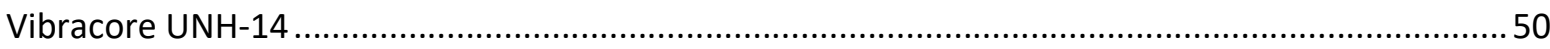

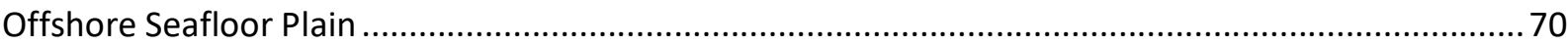

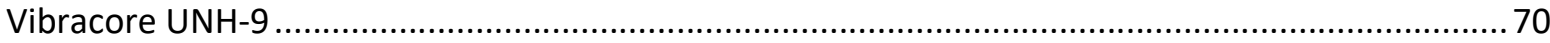

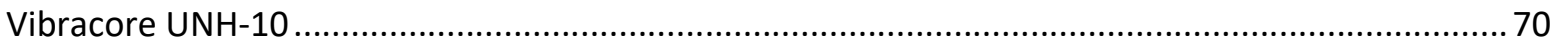

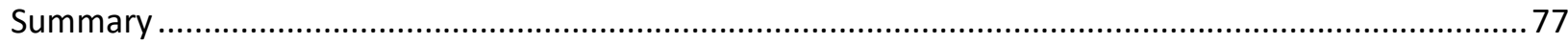

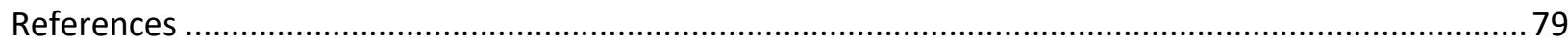

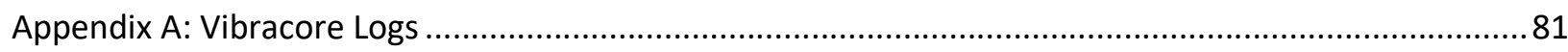

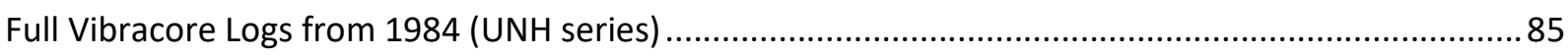

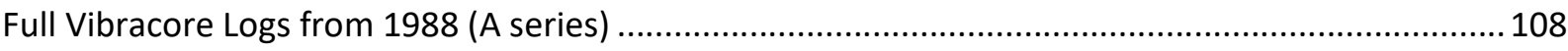

Appendix B: Complete Grain Size Data for Vibracore Sediment Samples ............................................ 125

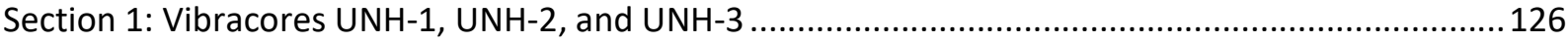

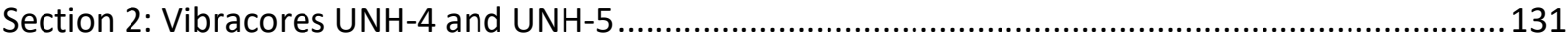

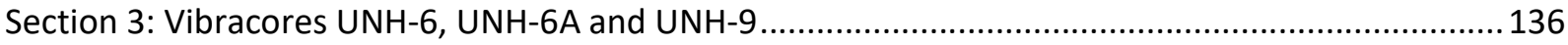

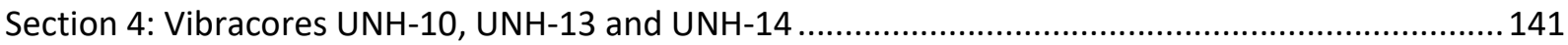

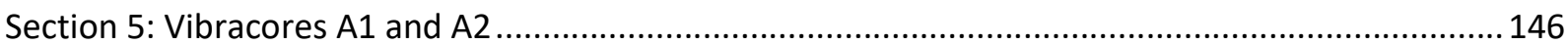

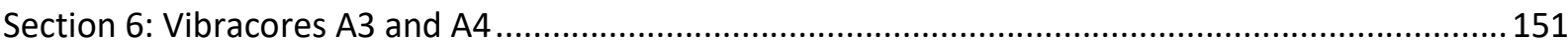

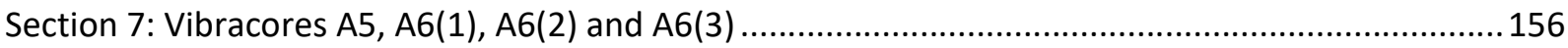

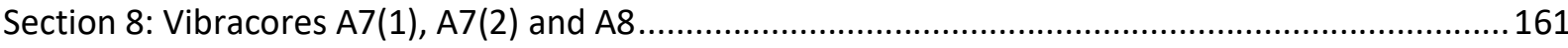

Appendix C: Archived Grain Size Data for Vibracores......................................................................... 166

\section{List of Tables}

Table 1. Vibracore location, water depth (MLLW), and recovered core length ....................................

Table 2. Sediment grain size classifications based on mean phi size (including unit conversions) shown for the Wentworth (1922) and Gradistat (Blott and Pye, 2001) size classifications................................. 9

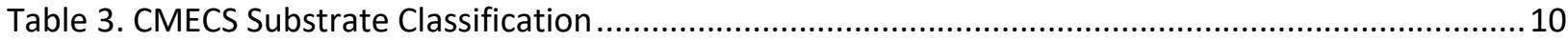


Table 4. Grain size data for the vibracores from the Offshore Marine-Modified Glacial Features (Drumlins and Lodgement Till Deposits) including UNH-1, UNH-2, and UNH-3..................................................18

Table 5. Grain size data for the vibracores from the Northern Sand Body including A1, A2, and A3 .......25

Table 6. Grain size data for the vibracores taken at the Northern Sand Body including UNH-4 and UNH13

Table 7. Grain size data for vibracore UNH-5 taken near the Isles of Shoals

Table 8. Grain size data for vibracores taken in the Nearshore Marine-Modified Glacial Features (Eskers and Drumlins).

Table 9. Grain size data for the vibracores taken in the Nearshore Sheet Sand Deposits including A6(1), $A 6(2), A 6(3), A 7(1), A 7(2)$, and $A 8$ 51

Table 10. Grain size data for the vibracores taken in the Nearshore Sheet Sand Deposits including UNH-6, UNH-6a, and UNH-14. 52

Table 11. Grain size data for vibracores taken in the Offshore Seafloor Plain .70

Table 12. Sand and gravel thicknesses in the vibracores taken on the NH continental shelf...... .78

\section{List of Figures}

Figure 1. Bathymetry map of the continental shelf off New Hampshire to Jeffreys Ledge. Vibracore locations are shown by dark blue circles with white halos. 3

Figure 2. Aerial exposure of the NH continental shelf during the last sea-level lowstand..... 4

Figure 3. Major geoforms (physiographic features) found on the New Hampshire continental shelf ........ 5

Figure 4. Surficial sediment distribution on the New Hampshire continental shelf based on the CMECS Substrate Classes

Figure 5a. Template used for the abbreviated vibracore logs presented in the Results and Discussion section.

Figure 5b. Symbology used for the abbreviated vibracore logs presented in the Results and Discussion section

Figure 6. Bathymetric map $(1: 150,000)$ of the New Hampshire continental shelf with locations of vibracores taken in 1984 (UNH series) and 1988 (A series).

Figure 7. Bathymetric map of the vibracores taken in the Offshore Marine-Modified Glacial Features (Drumlins and Lodgement Till Deposits).

Figure 8. Major geoforms (physiographic features; top) and surficial sediment map (substrate classes; bottom) of the Offshore Marine-Modified Glacial Features (Drumlins and Lodgement Till Deposits)......17

Figure 9. Photograph of the surface of vibracore UNH-1 …................................................................ 19

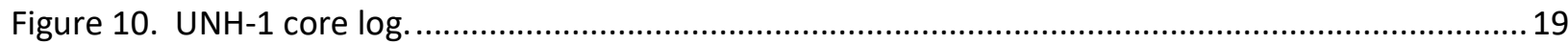

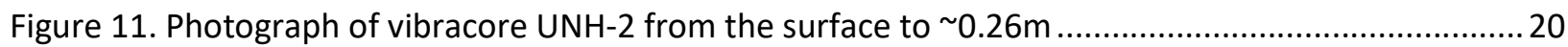

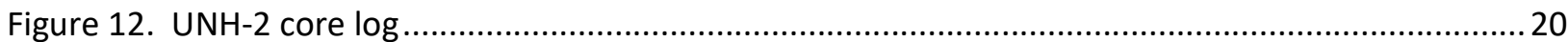




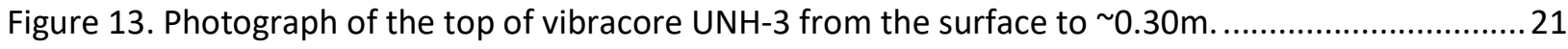

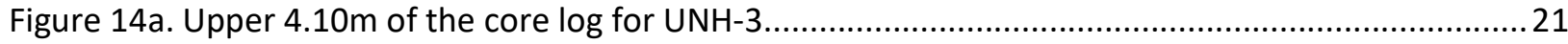

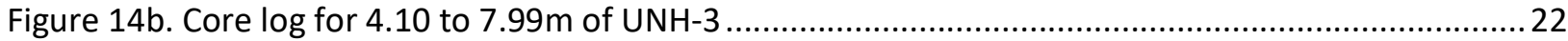

Figure 15. Bathymetric map and location of the vibracores taken in and around the Northern Sand Body

Figure 16. Major geoforms (physiographic features; top) and surficial sediment map (substrate classes; bottom) of the vibracores taken in and around the Northern Sand Body..... .28

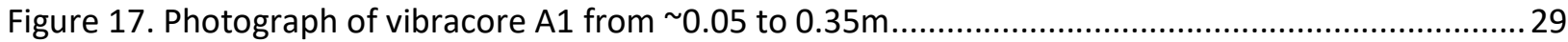

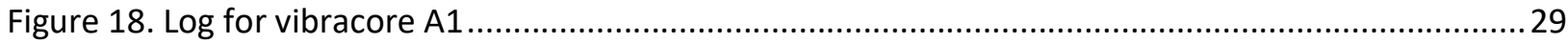

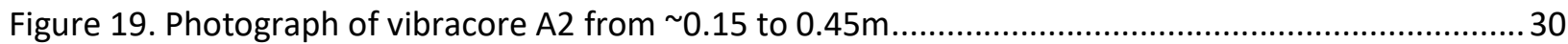

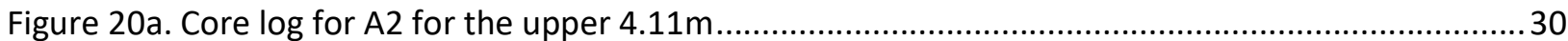

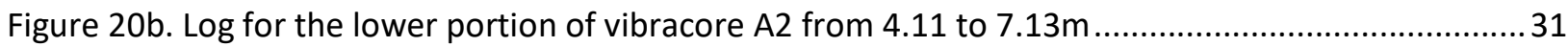

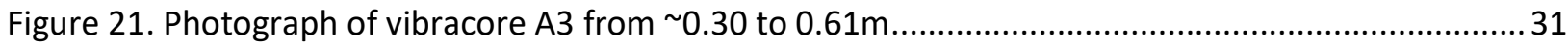

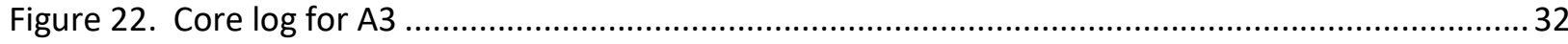

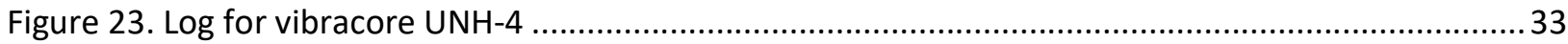

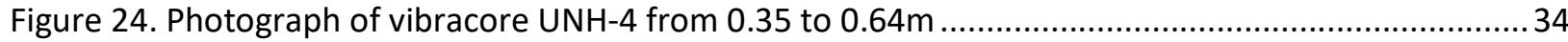

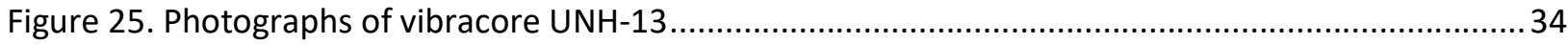

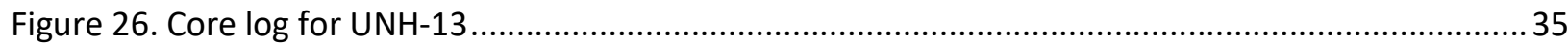

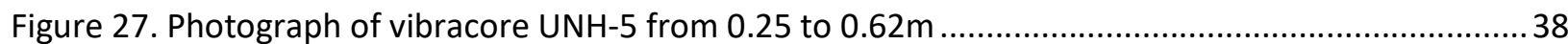

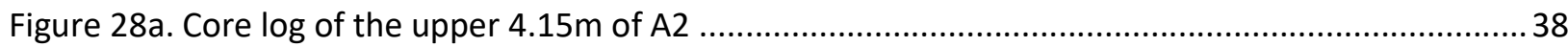

Figure $28 \mathrm{~b}$. UNH-5 core log for the lower section $(4.26$ to $7.13 \mathrm{~m})$....................................................39

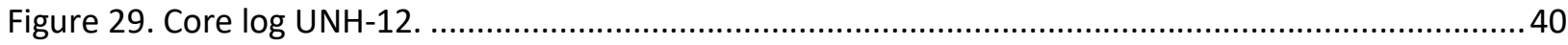

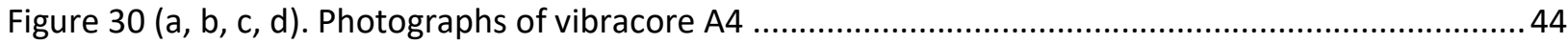

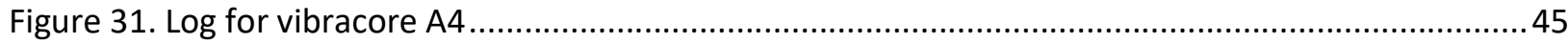

Figure $32(\mathrm{a}, \mathrm{b}, \mathrm{c})$. Photographs of vibracore A5 from $\sim 0.25$ to $0.59 \mathrm{~m}(\mathrm{a})$, from $\sim 1.70$ to $2.04 \mathrm{~m}$ (b), and

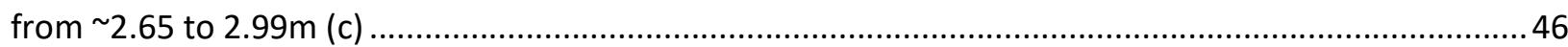

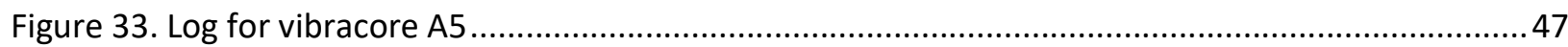

Figure 34. Bathymetric map of the vibracores taken in the Nearshore Sheet Sand Deposits .................. 53

Figure 35. Major geoforms (physiographic features; top) and surficial sediment map (substrate classes; bottom) of the vibracores taken in the Nearshore Sheet Sand Deposits................................................5 54

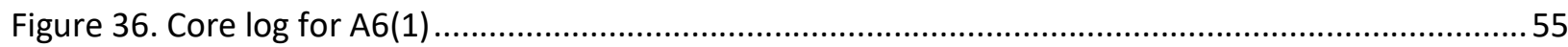

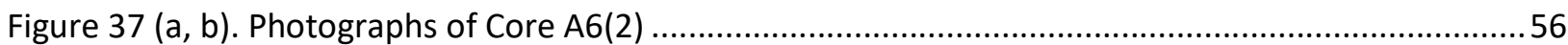

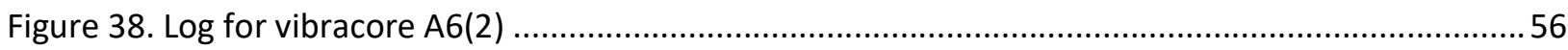

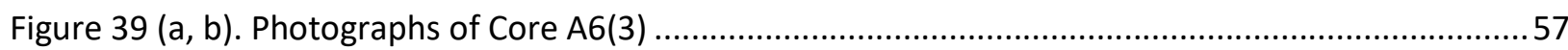




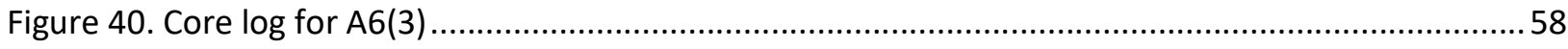

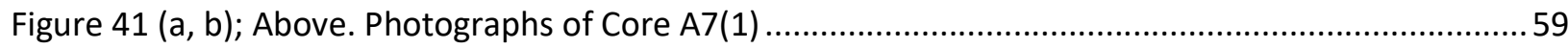

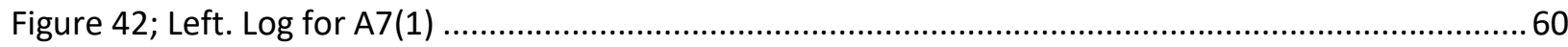

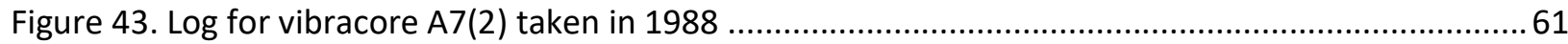

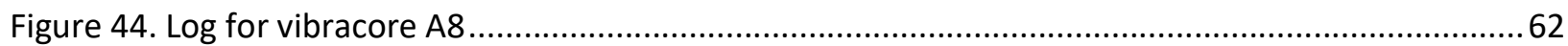

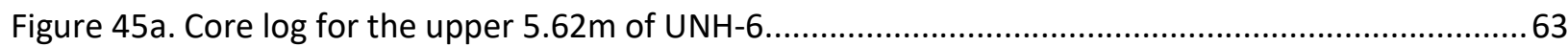

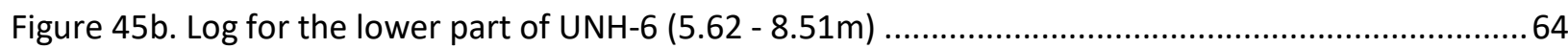

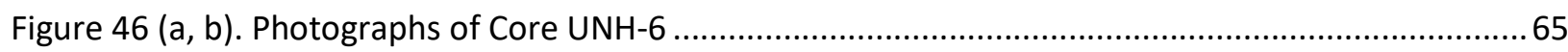

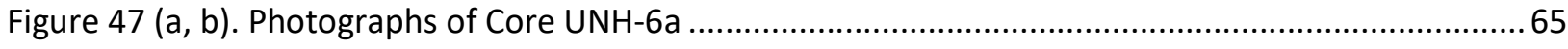

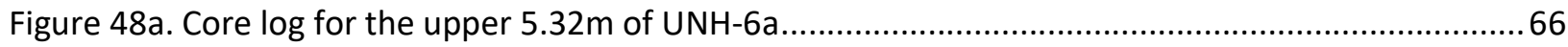

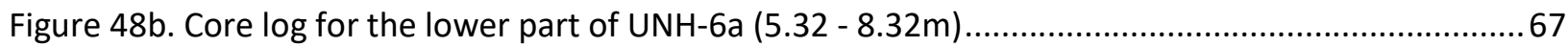

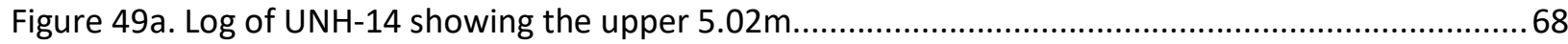

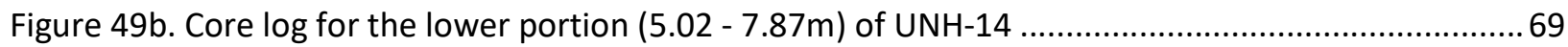

Figure 50. Bathymetric map of the vibracores taken in the Offshore Seafloor Plain.............................. 71

Figure 51. Major geoforms (physiographic features; top) and surficial sediment map (substrate classes; bottom) of the vibracores taken in the Offshore Seafloor Plain ........................................................... 72

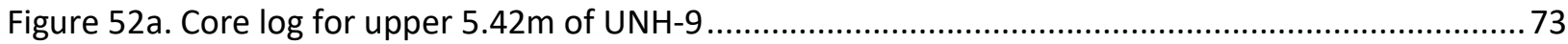

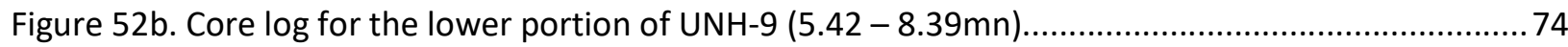

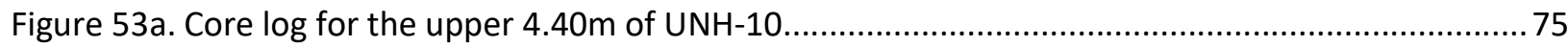

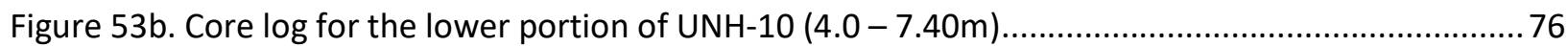

Figure Appendix-1. Complete core log description template................................................................. 82

Figure Appendix-2(a). Complete core log symbol, pattern, and color key ............................................ 83

Figure Appendix-2(b). Complete core log Munsell color key ............................................................. 84 


\title{
Analysis of Vibracores from the New Hampshire Continental Shelf from 1984 and 1988
}

\author{
By Ward, L.G., Morrison, R.C., McAvoy, Z.S. and Vallee-Anziani, M. \\ University of New Hampshire Center for Coastal and Ocean Mapping/Joint Hydrographic Center \\ 24 Colovos Road, Durham, NH 03824
}

\section{Abstract}

The New Hampshire (NH) continental shelf is extremely heterogeneous and has been shaped by multiple glaciations, a complex sea-level history, fluvial inputs, and marine processes. The seafloor reflects this complex history and is composed of large bedrock outcrops, marine-modified or eroded glacial deposits (e.g., drumlins, eskers, marine deltas and outwash sediments) and Holocene marine deposits. Sediments range from mud to gravel and megaclast platforms, often changing dramatically over relatively short distances (tens of meters). Of major importance to the study presented here are several potential marine sand and gravel deposits on the NH shelf. The distribution and characteristics of the deposits were first described based on subbottom reflection profiling (Birch, 1984) and vibracores taken in 1984 (Birch, 1986b) and 1988 (Ward, 1989). These vibracores are the only direct source of information available to characterize the subsurface sediments on the NH shelf.

During this study, the twenty-three vibracores taken in 1984 and 1988 were reexamined, original descriptions verified and significantly expanded, and the cores sampled to provide complete grain size data (i.e. the original sediment grain size analyses were limited). The vibracores were grouped by location with respect to major physiographic features (geoforms) or surficial sediment type including Offshore Marine-Modified Glacial Features (Drumlins and Lodgement Till Deposits), Northern Sand Body, Isles of Shoals, Nearshore Marine-Modified Glacial Features (Eskers and Drumlins), Nearshore Sheet Sand, and Offshore Seafloor Plain.

The Northern Sand Body (NSB), located near the Isles of Shoals $\sim 10 \mathrm{~km}$ from shore, is relatively large measuring $\sim 3.2 \mathrm{~km}$ in length and $\sim 1.3 \mathrm{~km}$ in width, with a maximum relief of $\sim 7 \mathrm{~m}$. Earlier studies estimated the NSB may contain as much as 17 million $\mathrm{m}^{3}$ of sand and gravel, but this has not been verified. One of the vibracores taken at the northern end of the NSB has $\sim 3.6 \mathrm{~m}$ of medium to coarse sand with varying amounts of fine gravel overlying fine sand. Similarly, a vibracore from near the center of the NSB has $\sim 3.1 \mathrm{~m}$ of slightly granuley medium sand with shell fragments and scattered pebbles overlying fine sands. However, other vibracores taken at the NSB are largely fine to very fine sand of varying thickness. The NSB likely formed from deposits that were originally either a marine glacial delta, a subaqueous delta, or sandy outwash that was heavily modified by marine processes.

A vibracore taken on top of an offshore drumlin-like feature located $\sim 24 \mathrm{~km}$ from shore has $\sim 4.7 \mathrm{~m}$ of medium to coarse sand overlying fine sand and silty very fine sand to silt deposits. The upper sands likely represent a lag deposit formed by wave action during the last sea-level lowstand. However, it is not known if this lag deposit continues over the surface of the entire drumlin. Except for the NSB, and potentially the offshore drumlin, the other sand and gravel deposits examined are relatively small in aerial extent. However, several of the marine-modified glacial deposits have approximately three to five meters of sand and gravel. For example, a vibracore taken near an esker-like feature had $\sim 5.75 \mathrm{~m}$ of very coarse sand to gravelly sediments composing the matrix (the largest clasts were not measured due to limited sample size). The eskers were exposed during the last sea-level lowstand and were modified by shallow water 
waves and nearshore process during the Holocene transgression. The esker was likely eroded, the large gravel left as a lag deposit, and the finer sediment deposited as nearby shoals. The Nearshore Sheet Sand deposits located within a few kilometers of the coast are relatively thin (less than $\sim 2.5 \mathrm{~m}$ ), flat-lying layers of sand and gravel unconformably overlying glacial marine sandy mud which were likely formed from reworked glacial marine sediment during the last transgression, especially wave-modified marine deltas or outwash. In addition, the deposits are likely part of the nearshore sand ramp extending from the beaches in southern $\mathrm{NH}$.

High-resolution subbottom seismic reflection surveys and additional vibracores are needed to map and verify the potential sand and gravel resources on the $\mathrm{NH}$ continental shelf.

\section{Introduction}

The physiography and geology of the New Hampshire $(\mathrm{NH})$ continental shelf is extremely complex as a result of multiple glaciations, sea-level fluctuations, and marine processes (Figure 1). Consequently, the seafloor is characterized by extensive bedrock outcrops, marine-modified glacial deposits, and marinemodified-fluvial deposits. Sediments range from gravel to mud and can change greatly over short distances, often on the order of tens of meters. Part of the variability of the NH continental shelf can be attributed to a complex sea-level history. This includes a late Pleistocene transgression as the sea level followed the ice front retreat, a late Pleistocene - early Holocene regression due to isostatic rebound with a lowstand at $\sim 12,500$ yrs B.P. (years before present), and the recent transgression over the last 12,000 years due to eustatic sea-level rise (Barnhardt et al., 2007; Kelley et al., 2010). At the sea-level lowstand, estimated at -50 to $-60 \mathrm{~m}$, the inner $\mathrm{NH}$ continental shelf was exposed to subaerial erosion and shallow water processes (Figure 2).

The surficial geology of the continental shelf off NH was mapped by Ward et al. (2021b) using highresolution bathymetry and an extensive geophysical database. The physiographic features (geoforms) (Figure 3) and surficial sediment distribution (Figure 4) were described using the Coastal and Marine Ecological Classification Standard or CMECS (FGDC, 2012). Potential sand and gravel deposits on the NH shelf were mapped most recently by Ward et al. (2021a), based largely on the synthesis of earlier work including seismic surveys (Birch, 1984; 1986a), an extensive surficial sediment database (Ward et al., 2021b), and vibracores (Birch, 1986a; 1986b; 1988; 1989; Ward, 1989; 2007). The vibracores were collected in 1984 and 1988 to provide ground truth for seismic reflection studies and to map the major sedimentary units (Birch, 1984), as well as to verify potential sand and gravel deposits. From the original work, Birch (1984) identified four major seismic stratigraphic units on the NH continental shelf including: glacial drift or lodgement tills (referred to as Unit 1); Pleistocene discontinuous glaciomarine silts and clay which drape over the lodgement tills or bedrock (Unit 2); late Pleistocene - early Holocene muddy sediments deposited in deeper water (typically greater than $40 \mathrm{~m}$ ) that fill basins and low areas (Unit 3: Deep-Water Deposits); deltaic sandy sediments from the Merrimack River deposited during the sea-level lowstand in shallow water (Unit 3: Shallow-Water Deposits); and late Holocene sands (Unit 4) which formed mounds or isolated sheets often cut into the glacial marine muds. Although these seismic stratigraphic units are somewhat general, they include the bulk of the subsurface deposits on the New Hampshire continental shelf. For the most part, the vibracores taken in 1984 verified the seismic units described by Birch (1986b; 1989). The vibracores taken in 1988 focused on the Holocene sand bodies (Ward, 1989). 


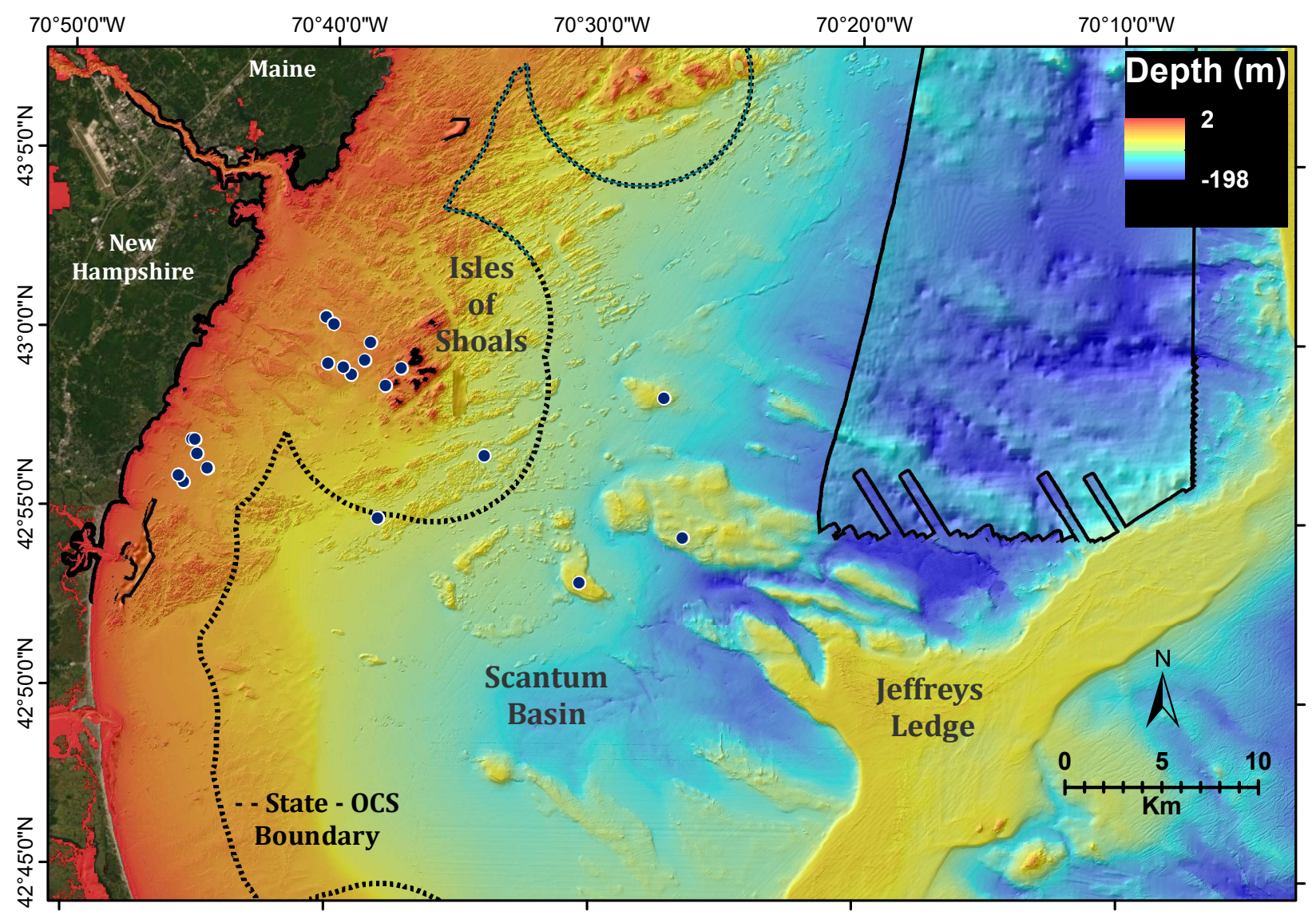

Figure 1. Bathymetry map of the continental shelf off New Hampshire to Jeffreys Ledge. Vibracore locations are shown by dark blue circles with white halos. The bathymetry was primarily developed from high-resolution multibeam surveys and lidar and is gridded at $4 \mathrm{~m}$. The exception is the area outlined in black in the upper right that is based on a compilation of lower-resolution single beam surveys and regional coverages. This area is gridded at $16 \mathrm{~m}$.

Although the original analyses of the vibracores were valuable, subsequent review of the database showed more detailed descriptions would be very beneficial and additional grain size information was needed in order to characterize the major sedimentary deposits. Therefore, the original vibracore descriptions were reviewed and updated as needed in 2016 and 2019. During this review, 162 new sediment samples were collected, and complete grain size analyses conducted. The results from the 1984, 1988, 2016, and 2019 analyses and descriptions are presented here in updated core logs and sediment databases. In addition, the descriptions of the vibracores include a discussion of their depositional environment or potential source of sediment where possible. The results presented here provide additional detail on the composition of the sediments found on the $\mathrm{NH}$ continental shelf, especially the sand and gravel deposits described in Ward et al. (2021a).

The detailed vibracore logs and sediment data are shown in Appendices A, B and C. Appendices A and B can also downloaded at Ward et al. (2021c) ( https://dx.doi.org/10.34051/d/2021.4). 


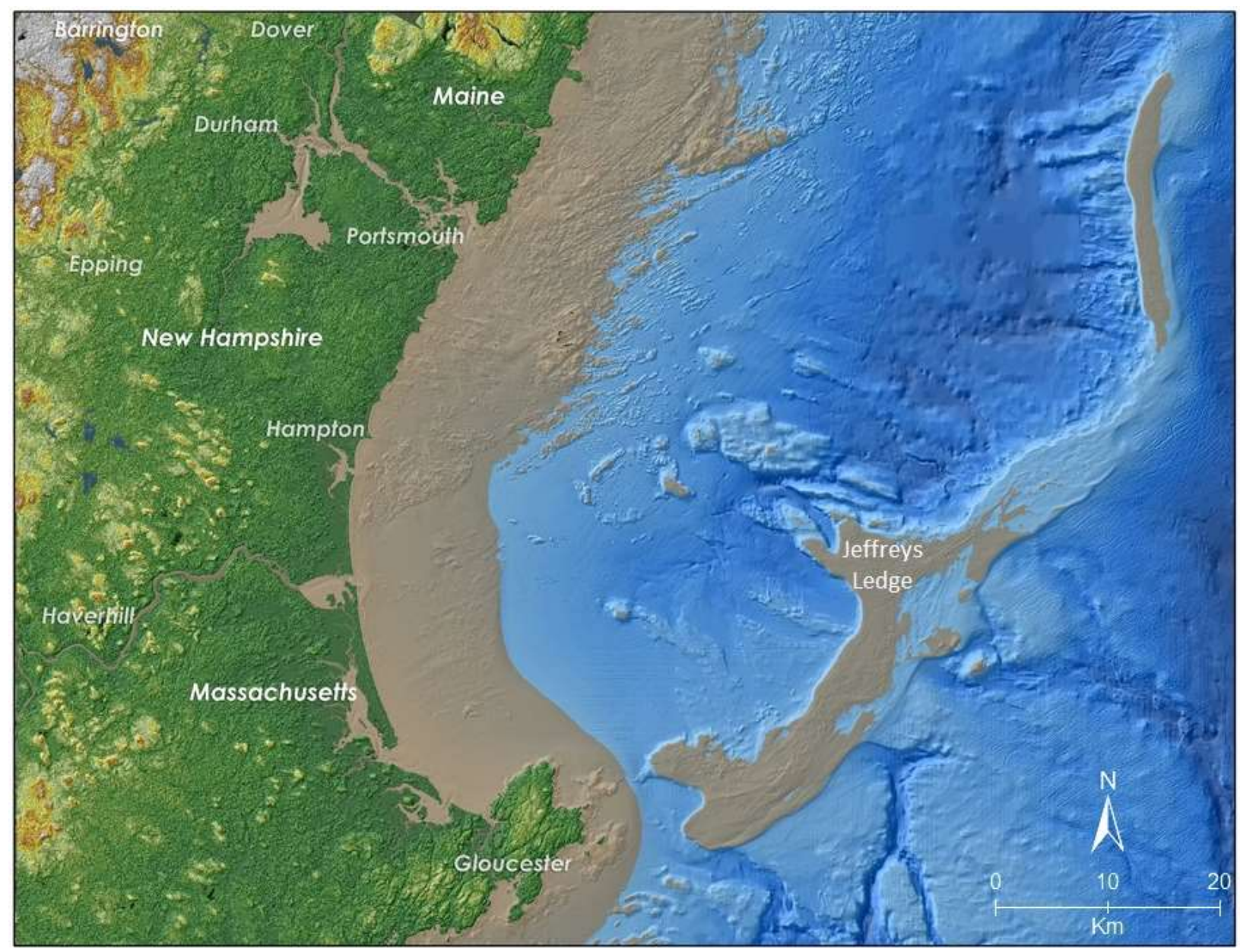

Figure 2. Aerial exposure of the NH continental shelf during the last sea-level lowstand ( $12.5 k$ yrs B.P) which reached approximately $-60 m$ (Kelley et al., 2010). The present upland is shown in green, the exposed shelf during the last lowstand is shown in brown, and the submerged shelf is shown in blue. Note the surface of Jeffreys Ledge and some of the offshore drumlins are near or above sea level. 


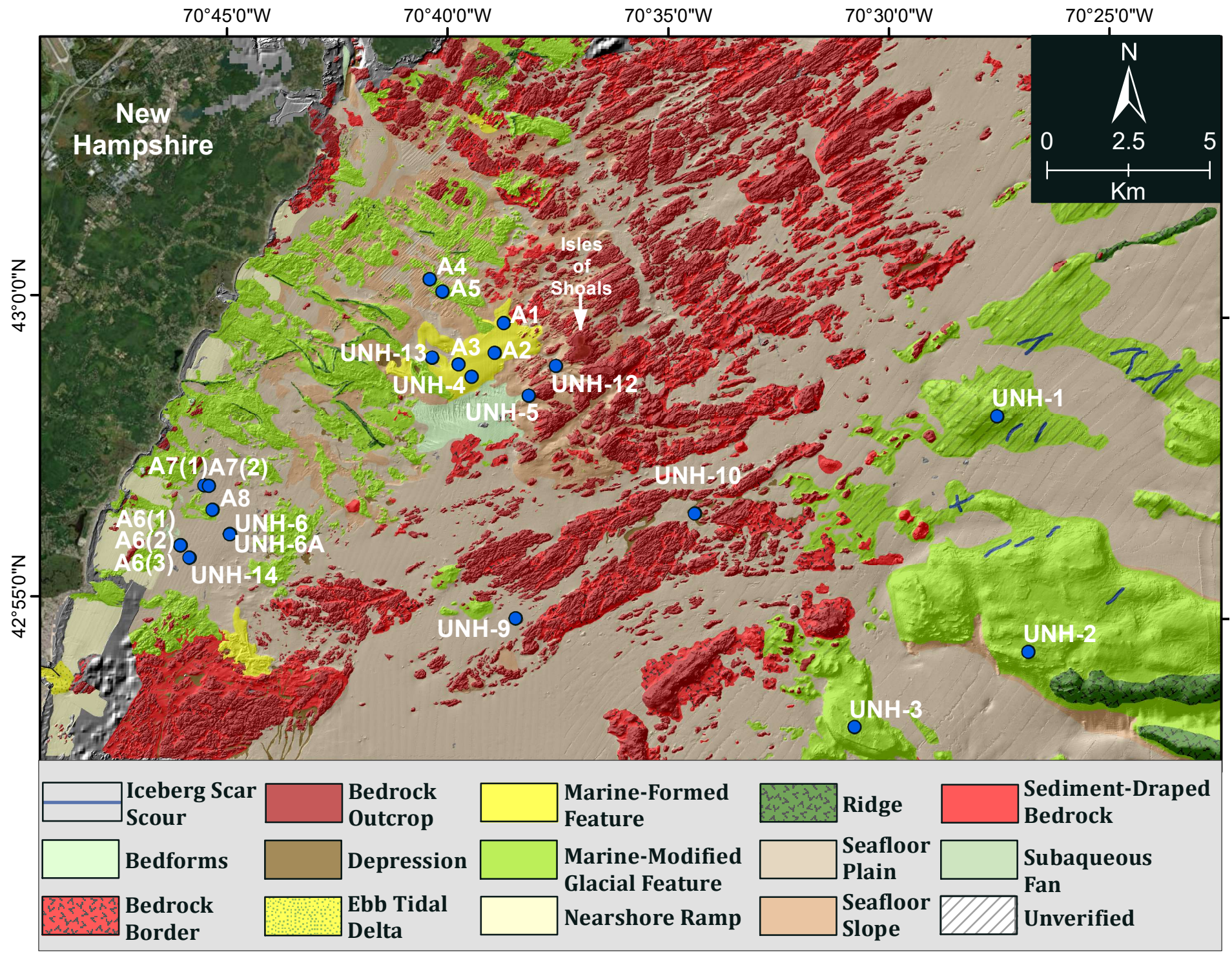

Figure 3. Major geoforms (physiographic features) found on the New Hampshire continental shelf. The geoform terminology is based on a modification of CMECS (FGDC, 2012). The geoforms map is from Ward et al. (2021b). The geoform categories have been simplified due to the scale of the map (1:150,000). Blue circles show the locations of vibracores taken in 1984 and 1988. 


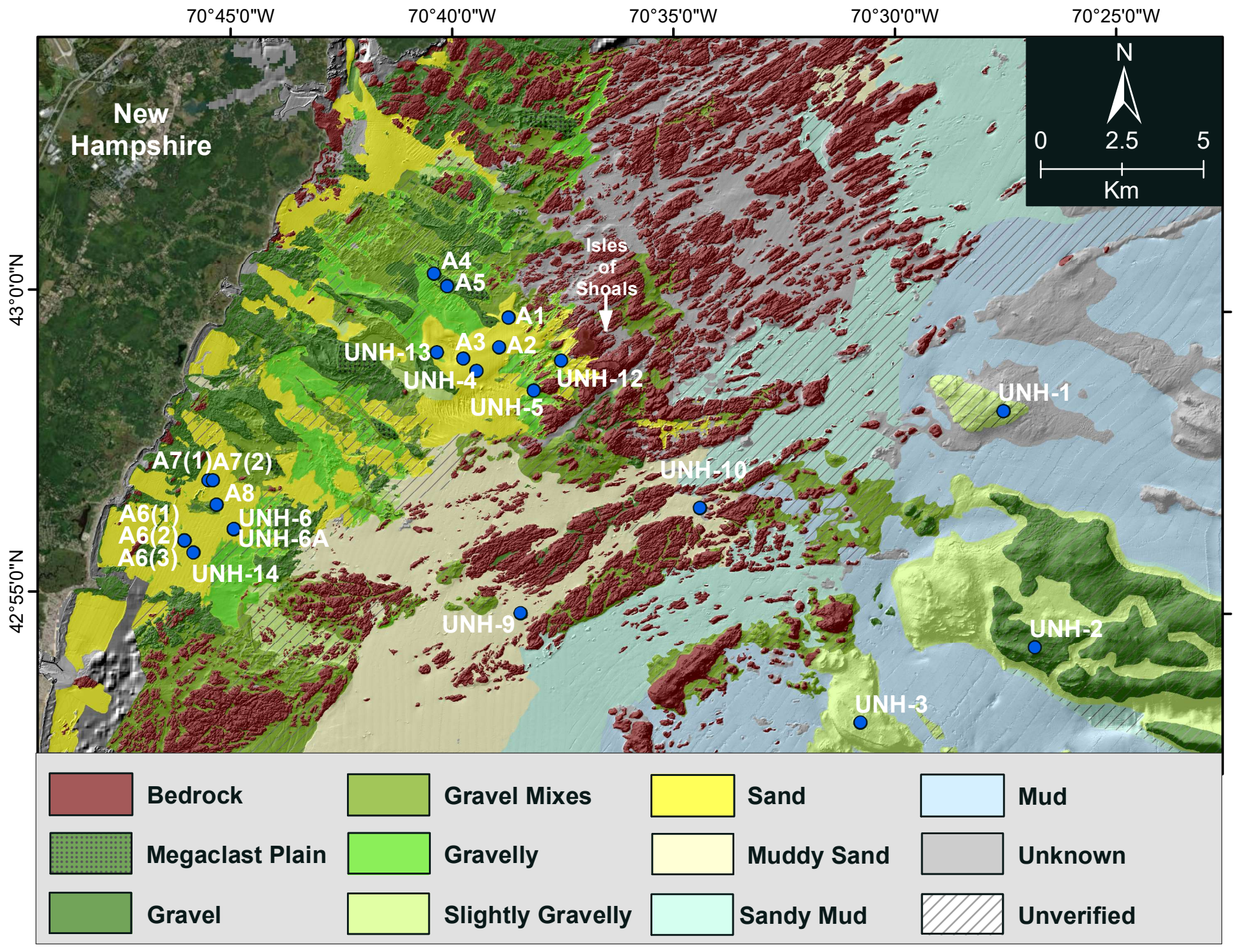

Figure 4. Surficial sediment distribution on the New Hampshire continental shelf based on the CMECS Substrate Classes (FGDC, 2012). Bedrock and megaclast plains (cobbles and boulders) are also shown. Blue circles show the locations of vibracores taken in 1984 and 1988. The map is shown at a scale of 1:150,000. 


\section{Methods}

\section{Vibracore Collection}

All vibracores were collected in 1984 and in 1988 aboard the R/V Atlantic Twin, a twin-hull vessel run by Alpine Geophysical Associates, Inc. The coring sites were determined from analysis of subbottom seismic surveys conducted in 1981, 1982, and 1985 by Birch (1984; 1986a; 1988). The vibracorer consisted of a pneumatic, vibrating hammer-driven system. The vibrator was attached to the top of a standard $10.1 \mathrm{~cm}$ $\left(4^{\prime \prime}\right)$ core pipe fitted with a $~ 9 \mathrm{~cm}\left(3.5^{\prime \prime}\right)$ diameter plastic core liner. The recovered cores ranged in length from $\sim 1.5 \mathrm{~m}$ to $\sim 8.5 \mathrm{~m}$. Water depths ranged from $\sim 21 \mathrm{~m}$ to $\sim 76 \mathrm{~m}$ (Table 1$)$. Once recovered, the plastic core liners were cut into $\sim 1.0-1.5 \mathrm{~m}$ sections on board the R/V Atlantic Twin to facilitate transportation to the United States Geological Survey (USGS) Woods Hole Coastal and Marine Science Center Samples Repository in Massachusetts. At the USGS the cores were split lengthwise in their liners, half for archiving and half for sampling, photography, and description. The initial sampling and descriptions occurred in the same time period that the vibracores were collected. The additional sampling for this study occurred in 2016 and 2019.

Table 1. Vibracore location, water depth (MLLW), and recovered core length. The vibracore locations are given in decimal degrees to four places which provides positions to within 8 to $11 \mathrm{~m}$. However, the accuracy is the Loran $C$ navigation used during the collection of the vibracores in 1984 and 1988 and is estimated at $\sim 250 \mathrm{~m}$.

\begin{tabular}{|cccccc|}
\hline Core ID & $\begin{array}{c}\text { Latitude } \\
\text { (NAD83) }\end{array}$ & $\begin{array}{c}\text { Longitude } \\
\text { (NAD83) }\end{array}$ & $\begin{array}{c}\text { Water } \\
\text { Depth }(\mathbf{m})\end{array}$ & $\begin{array}{c}\text { Total Length } \\
\text { of Core } \\
\text { Recovered (m) }\end{array}$ & $\begin{array}{c}\text { Vibracore } \\
\text { Collected }\end{array}$ \\
\hline UNH-1 & 42.9717 & -70.4567 & 57.0 & 3.42 & $10 / 11 / 1984$ \\
UNH-2 & 42.9067 & -70.4433 & 76.0 & 1.56 & $10 / 11 / 1984$ \\
UNH-3 & 42.8850 & -70.5083 & 57.0 & 7.09 & $10 / 11 / 1984$ \\
UNH-4 & 42.9800 & -70.6550 & 25.0 & 6.46 & $10 / 11 / 1984$ \\
UNH-5 & 42.9750 & -70.6333 & 22.0 & 7.13 & $10 / 11 / 1984$ \\
UNH-6 & 42.9350 & -70.7450 & 30.0 & 8.50 & $10 / 11 / 1984$ \\
UNH-6A & 42.9350 & -70.7450 & 30.0 & 8.32 & $10 / 11 / 1984$ \\
UNH-9 & 42.9133 & -70.6367 & 61.0 & 8.39 & $10 / 11 / 1984$ \\
UNH-10 & 42.9433 & -70.5700 & 70.0 & 7.40 & $10 / 11 / 1984$ \\
UNH-12 & 42.9833 & -70.6233 & 28.0 & 2.44 & $10 / 12 / 1984$ \\
UNH-13 & 42.9850 & -70.6700 & 28.0 & 6.41 & $10 / 12 / 1984$ \\
UNH-14 & 42.9283 & -70.7600 & 23.0 & 7.87 & $10 / 12 / 1984$ \\
A1 & 42.9950 & -70.6433 & 21.0 & 4.39 & $09 / 22-25 / 1988$ \\
A2 & 42.9867 & -70.6467 & 22.3 & 7.13 & $09 / 22-25 / 1988$ \\
A3 & 42.9833 & -70.6600 & 25.0 & 5.81 & $09 / 22-25 / 1988$ \\
A4 & 43.0067 & -70.6717 & $20.0 *$ & 5.81 & $09 / 22-25 / 1988$ \\
A5 & 43.0033 & -70.6667 & $19.0 *$ & 3.36 & $09 / 22-25 / 1988$ \\
A6 (1) & 42.9317 & -70.7633 & 22.1 & 2.27 & $09 / 22-25 / 1988$ \\
A6 (2) & 42.9317 & -70.7633 & 22.9 & 1.62 & $09 / 22-25 / 1988$ \\
A6 (3) & 42.9317 & -70.7633 & 22.9 & 5.92 & $09 / 22-25 / 1988$ \\
A7 (1) & 42.9483 & -70.7533 & 24.4 & 1.32 & $09 / 22-25 / 1988$ \\
A7 (2) & 42.9483 & -70.7533 & 25.0 & 2.05 & $09 / 22-25 / 1988$ \\
A8 & 42.9417 & -70.7517 & 24.7 & 4.04 & $09 / 22-25 / 1988$ \\
\hline
\end{tabular}

*Estimated from high-resolution bathymetry map 


\section{Positioning and Uncertainty}

Loran $\mathrm{C}$ was used for ship positioning during the collection of the vibracores. Loran $\mathrm{C}$ inherently has an error in absolute position between $\sim 185 \mathrm{~m}$ ( 0.1 nautical miles) and $\sim 463 \mathrm{~m}(0.25$ nautical miles) depending on obstructions, conditions, and location. Here, an uncertainty of $\sim 250 \mathrm{~m}$ was used for locating the vibracores, realizing that the uncertainty could be larger, but likely was less as the vibracores were collected during favorable weather conditions and without obstructions.

For reference see the United States Coast Guard Navigation Center web site and report (http://www.navcen.uscg.gov/pdf/loran/handbook/CHAPTER3.pdf; accessed March 2020).

\section{Vibracore Analysis and Description}

\section{Original Description}

The cores were originally described by Birch (1986a; 1986b; 1988) and Ward (1989). The vibracores collected in 1984 were sectioned and photographed in black and white at the USGS at Woods Hole. The vibracores collected in 1988 were also sectioned at the USGS, but were not photographed. Following sectioning, the working half of each core was transported to the University of New Hampshire where they were described and subsampled for grain size analysis. Analysis of the vibracores by different investigators at different times resulted in inconsistencies in the core logs and sediment grain size analyses. This problem was partially addressed with MMS funding in 2007 during which the working halves of both the 1984 and 1988 vibracores were described using the same methodologies (Ward, 2007).

\section{6 and 2019 Review}

The purpose of the present program was to create a more consistent and complete record of the archived vibracores through verifying descriptions, re-photographing, resampling, and running additional grain size analyses. The archived halves of the vibracores stored at the USGS were reviewed in 2016 (vibracores $A 1$, A2, A4, A6(3), UNH-3, and UNH-4), and in 2019 (vibracores A3, A5, A6(1), A6(2), A7(1), A7(2), A8, UNH-1, UNH-2, UNH-5, UNH-6, UNH-6a, UNH-9, UNH-10, UNH-12, UNH-13, and UNH-14). The previous core descriptions from the 1980s and 2007 were verified, corrected where necessary, or expanded. The cores were also photographed at a higher resolution (photos were taken approximately every $0.30 \mathrm{~m}$ along each core) and in color. Although the vibracores had desiccated and changed color, photography was still useful as the 1984 cores were originally photographed in black and white and not at a high-resolution and the 1988 vibracores had no associated photographs. During the 2016 and 2019 reviews, subsamples were taken for grain size analysis from all archived cores except one (UNH-12) at depths where sediment composition changed or where an interesting feature was found (for example above and below a contact). All information was synthesized, and comprehensive and updated core logs were developed for all vibracores (Appendix A). The archived halves of the vibracores remain the USGS Woods Hole Coastal and Marine Science Center Samples Repository: https://www.usgs.gov/centers/whcmsc/labs/samplesrepository?qt-science support page related con=0\#qt-science support page related con ; accessed March 2020). Metadata for the 1984 cores can be found at the USGS Coastal and Marine Geology Program (http://cmgds.marine.usgs.gov/fan info.php?fa=1984-016-FA ; accessed March 2020).

\section{Sediment Grain Size Analysis}

The vibracore sediment samples collected in 2016 and 2019 were analyzed for grain size using standard sieve and pipette techniques after Folk (1980), including digestion to remove organics and full pipette analysis for samples with a mud fraction greater than or equal to 5 percent. Statistics and sediment classifications were determined in Gradistat (Blot and Pye, 2001). The Gradistat classification scheme is 
based on mean grain size and is largely the same as the commonly used Wentworth classification (Wentworth, 1922), but with more detail in gravel sizes and a shift of the silt-clay boundary to 9.0 $\phi$ (phi) or $0.002 \mathrm{~mm}$ (Table 2). Gradistat also provides very useful sediment classifications based on percentages of gravel, sand, and mud (textural group), as well as mode (represented in the sediment name). The textural group is very similar to the Folk (1980) classification. The sediment samples were also classified utilizing the CMECS classifications (FGDC, 2012) (Table 3). The CMECS geologic substrate classification is built on a simplification of the Wentworth $(1922)$ and Folk $(1954 ; 1980)$ classification schemes. Complete grain size results are reported in Appendix B.

Table 2. Sediment grain size classifications based on mean phi size (including unit conversions) shown for the Wentworth (1922) and Gradistat (Blott and Pye, 2001) size classifications.

\begin{tabular}{|c|c|c|c|c|}
\hline Phi Size & Millimeters (mm) & $\begin{array}{l}\text { Microns } \\
(\mu \text { or } \mu \mathrm{m})\end{array}$ & \begin{tabular}{|c|}
$\begin{array}{c}\text { Wentworth Size } \\
\text { Class }\end{array}$ \\
\end{tabular} & \begin{tabular}{|c|}
$\begin{array}{c}\text { Gradistat Modified } \\
\text { Class }\end{array}$ \\
\end{tabular} \\
\hline$>-10.0 \phi$ & $>1024 \mathrm{~mm}$ & ------- & Boulder Gravel & Very Large Boulder \\
\hline-9.0 to $-10.0 \phi$ & 512 to $1024 \mathrm{~mm}$ & -------- & Boulder Gravel & Large Boulder \\
\hline-8.0 to $-9.0 \phi$ & 256 to $512 \mathrm{~mm}$ & -------- & Boulder Gravel & Medium Boulder \\
\hline-7.0 to $-8.0 \phi$ & 128 to $256 \mathrm{~mm}$ & -------- & Cobble Gravel & Small Boulder \\
\hline-6.0 to $-7.0 \phi$ & 64 to $128 \mathrm{~mm}$ & -------- & Cobble Gravel & Very Small Boulder \\
\hline-5.0 to $-6.0 \phi$ & 32 to $64 \mathrm{~mm}$ & -------- & Pebble Gravel & Very Coarse Gravel \\
\hline-4.0 to $-5.0 \phi$ & 16 to $32 \mathrm{~mm}$ & ------- & Pebble Gravel & Coarse Gravel \\
\hline-3.0 to $-4.0 \phi$ & 8.0 to $16 \mathrm{~mm}$ & -------- & Pebble Gravel & Medium Gravel \\
\hline-2.0 to $-3.0 \phi$ & 4.0 to $8.0 \mathrm{~mm}$ & -------- & Pebble Gravel & Fine Gravel \\
\hline-1.0 to $-2.0 \phi$ & 2.0 to $4.0 \mathrm{~mm}$ & -------- & Granule Gravel & Very Fine Gravel \\
\hline 0.0 to $-1.0 \phi$ & 1.0 to $2.0 \mathrm{~mm}$ & -------- & Very Coarse Sand & Very Coarse Sand \\
\hline 1.0 to $0.0 \phi$ & 0.5 to $1.0 \mathrm{~mm}$ & -------- & Coarse Sand & Coarse Sand \\
\hline 2.0 to $1.0 \phi$ & 0.25 to $0.5 \mathrm{~mm}$ & $500 \mu$ & Medium Sand & Medium Sand \\
\hline 3.0 to $2.0 \phi$ & 0.125 to $0.25 \mathrm{~mm}$ & $250 \mu$ & Fine Sand & Fine Sand \\
\hline 4.0 to $3.0 \phi$ & 0.0625 to $0.125 \mathrm{~mm}$ & $125 \mu$ & Very Fine Sand & Very Fine Sand \\
\hline 5.0 to $4.0 \phi$ & 0.031 to $0.0625 \mathrm{~mm}$ & $63 \mu$ & Coarse Silt & Very Coarse Silt \\
\hline 6.0 to $5.0 \phi$ & 0.0156 to $0.031 \mathrm{~mm}$ & $31 \mu$ & Medium Silt & Coarse Silt \\
\hline 7.0 to $6.0 \phi$ & 0.0078 to $0.0156 \mathrm{~mm}$ & $15.6 \mu$ & Fine Silt & Medium Silt \\
\hline 8.0 to $7.0 \phi$ & 0.0039 to $0.0078 \mathrm{~mm}$ & $7.8 \mu$ & Very Fine Silt & Fine Silt \\
\hline 9.0 to $8.0 \phi$ & 0.0002 to $0.0039 \mathrm{~mm}$ & $3.9 \mu$ & Clay & Very Fine Silt \\
\hline$<9.0 \phi$ & $<0.0002 \mathrm{~mm}$ & $2.0 \mu$ & Clay & Clay \\
\hline $14.0 \phi$ & $0.00006 \mathrm{~mm}$ & $0.06 \mu$ & Clay & Clay \\
\hline
\end{tabular}


Table 3. CMECS Substrate Classification (FGDC, 2012).

\begin{tabular}{|c|c|c|c|c|}
\hline $\begin{array}{l}\text { Substrate } \\
\text { Origin }\end{array}$ & $\begin{array}{l}\text { Substrate } \\
\text { Class }\end{array}$ & $\begin{array}{l}\text { Substrate } \\
\text { Subclass }\end{array}$ & $\begin{array}{l}\text { Substrate } \\
\text { Group }\end{array}$ & $\begin{array}{l}\text { Substrate } \\
\text { Subgroup }\end{array}$ \\
\hline \multirow{29}{*}{$\begin{array}{l}\text { Geologic } \\
\text { Substrate }\end{array}$} & Rock Substrate & Bedrock & & \\
\hline & \multirow{28}{*}{$\begin{array}{c}\text { Unconsolidated } \\
\text { Mineral } \\
\text { Substrate }\end{array}$} & \multirow{10}{*}{$\begin{array}{c}\text { Coarse } \\
\text { Unconsolidated } \\
\text { Substrate }\end{array}$} & \multirow{4}{*}{ Gravel } & Boulder \\
\hline & & & & Cobble \\
\hline & & & & Pebble \\
\hline & & & & Granule \\
\hline & & & \multirow{3}{*}{ Gravel Mixes } & Sandy Gravel \\
\hline & & & & Muddy Sandy Gravel \\
\hline & & & & Muddy Gravel \\
\hline & & & \multirow{3}{*}{ Gravelly } & Gravelly Sand \\
\hline & & & & Gravelly Muddy Sand \\
\hline & & & & Gravelly Mud \\
\hline & & \multirow{18}{*}{$\begin{array}{c}\text { Fine } \\
\text { Unconsolidated } \\
\text { Substrate }\end{array}$} & \multirow{4}{*}{ Slightly Gravelly } & Slightly Gravelly Sand \\
\hline & & & & Slightly Gravelly Muddy Sand \\
\hline & & & & Slightly Gravelly Sandy Mud \\
\hline & & & & Slightly Gravelly Mud \\
\hline & & & \multirow{5}{*}{ Sand } & Very Coarse Sand \\
\hline & & & & Coarse Sand \\
\hline & & & & Medium Sand \\
\hline & & & & Fine Sand \\
\hline & & & & Very Fine Sand \\
\hline & & & \multirow{3}{*}{ Muddy Sand } & Silty Sand \\
\hline & & & & Silty-Clayey Sand \\
\hline & & & & Clayey Sand \\
\hline & & & \multirow{3}{*}{ Sandy Mud } & Sandy Silt \\
\hline & & & & Sandy Silt-Clay \\
\hline & & & & Sandy Clay \\
\hline & & & \multirow{3}{*}{ Mud } & Silt \\
\hline & & & & Silt-Clay \\
\hline & & & & Clay \\
\hline
\end{tabular}

The grain size analysis methods used during earlier studies of the vibracores had some slight variations compared to those used for the comprehensive sampling and analyses conducted in 2016 and 2019. The sediment samples from 1988 (described in Ward, 1989) used very similar laboratory methods as the more recent analysis for the preparation and determination of the percent gravel (\%G), sand (\%S), and mud $(\% \mathrm{M})$; however, full grain size analysis was only run on the sand fraction. Therefore, the analyses from Ward (1989) are presented in this report as \%G, \%S, \%M, graphic mean grain size, and graphic sorting for the sand fraction only (shown in Appendix C). The sediment samples from the vibracores collected and analyzed in 1984 (described in Birch, 1986b) also used very similar laboratory methods as the samples analyzed in 2016 and 2019 except for the size of the sieve $(0.0 \phi$, or $1.00 \mathrm{~mm})$ used for separating the gravel fraction from the sand fraction. All other grain size analyses of the vibracore samples used a $-1 \phi$ $(2 \mathrm{~mm})$ sieve for separating sand and gravel as prescribed in Folk (1980) and is more standardly used in 
sedimentology. Therefore, only the results of samples reported in Birch (1986b) that contained no gravel or only trace amounts $(<0.9 \%)$ were included in this report, making the results for the $\% \mathrm{G}, \% \mathrm{~S}$, and $\% \mathrm{M}$ comparable among all of the studies (shown in Appendix C). Birch (1986b) did not include mean size and sorting values.

\section{Vibracore Logs}

The vibracore logs are presented in two manners in this report. Within the Results and Discussion section, the core logs include photographs and a schematic showing the lithology (template and symbology shown in Figure $5 a$ and $5 b$, respectively). A more comprehensive vibracore log is given in Appendix A that includes the original (and verified) descriptions, Munsell colors, grain size data from both the earlier studies and the more recent analyses, and photographs (where available). Color were assigned during the original description of the cores using a combination of the Munsell Soil-Color Chart and the Geological Society of America (GSA) Rock-Color Chart. In order to make color names, hues, values, and chromas consistent and comparable, all Soil-Colors were converted to the Rock-Color Chart (Geological Society of America and Munsell Color, 2009) for this report. The closest equivalent colors were chosen where necessary (template shown in Appendix A).

All the vibracore logs were made in CorelDraw 7x (64 bit). The color photographs of the vibracores taken in 2016 and 2019 were stitched together using Microsoft PowerPoint by overlapping each picture to create a complete and higher-resolution photograph of the whole core. The photographs taken in 2019 had improved lighting compared to 2016 which produced a more uniform appearance. The original black and white photos taken for the 1984 vibracore series are included in addition to the newer photos on the logs where available. Lithology and interesting features are presented along with core descriptions and grain size statistics from all analyses.

Note: The detailed vibracore logs shown in Appendix A are best viewed digitally at a higher magnification. The vibracore logs can also be downloaded at Ward et al. (2021c) (https://dx.doi.org/10.34051/d/2021.4). 


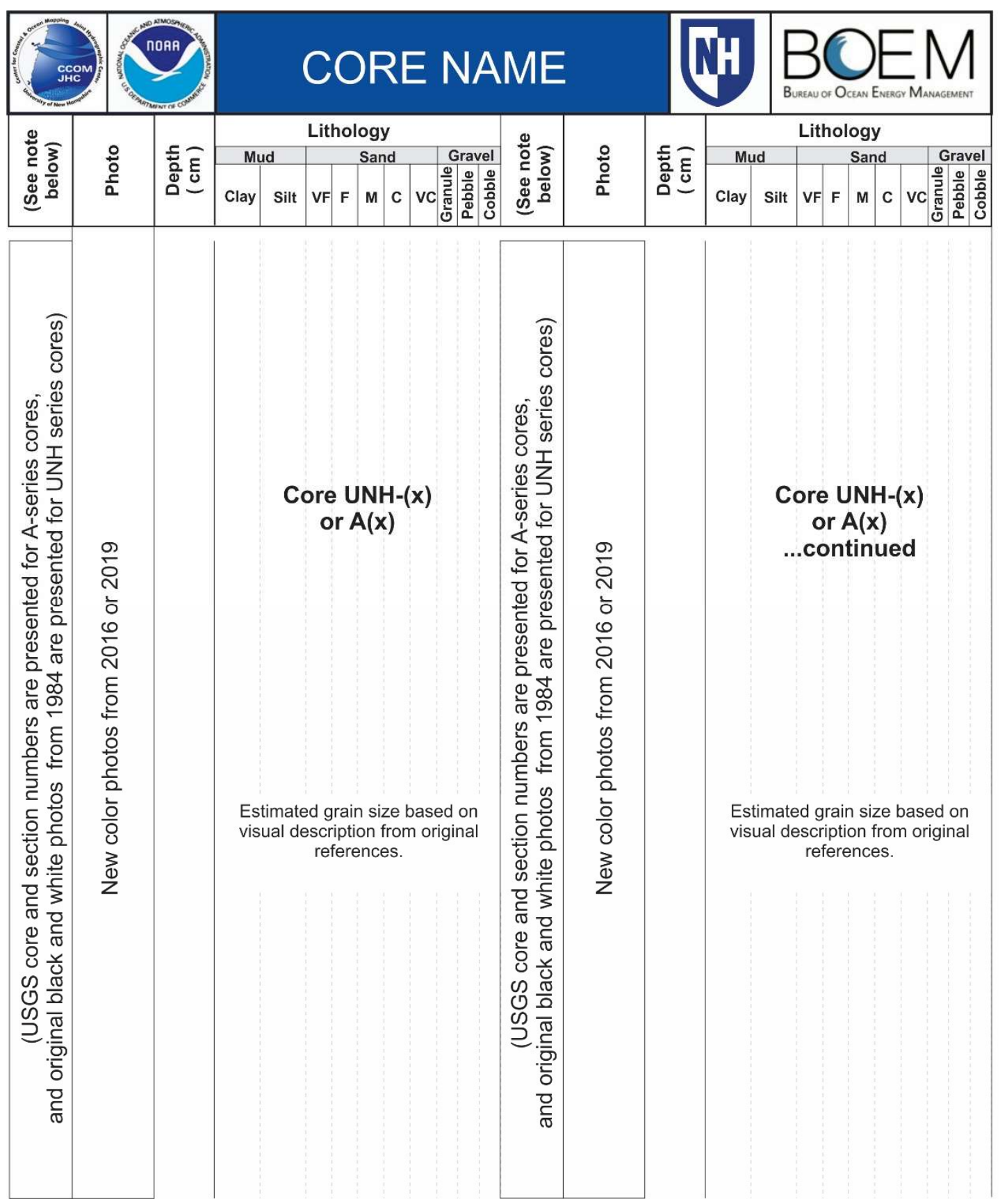

Figure 5a. Template used for the abbreviated vibracore logs presented in the Results and Discussion section. 


Lithological Patterns
Muddy Sand
Sandy Mud
Mud Sand

Figure 5b. Symbology used for the abbreviated vibracore logs presented in the Results and Discussion section. 


\section{Results and Discussion}

Descriptions of the vibracores collected in 1984 and 1988 from the $\mathrm{NH}$ continental shelf are presented in this section. The vibracores are grouped by location with respect to major physiographic features or geoforms (Figure 3) and surficial sediment type (Figure 4), including Offshore Marine-Modified Glacial Features (Drumlins and Lodgement Till Deposits), Northern Sand Body, Isles of Shoals, Nearshore MarineModified Glacial Features (Eskers and Drumlins), Nearshore Sheet Sand, and Offshore Seafloor Plain. These areas are outlined in Figure 6. The general depositional setting is presented for each grouping along with potential sources of sediments. Each vibracore is described in detail and includes a core log (abbreviated in this section) with general sediment classifications based on visual inspection and grain size data, shell remains and dropstones if present, a table with grain size data and classifications (abbreviated in this section) and a composite photograph. The complete core logs are shown in Appendix A and include grain size data from all studies, core descriptions based on visual inspections, depositional units based on Birch (1986b) and Ward (2007), and seismic units based on Birch (1984). Complete grain size data and sediment classifications for the sediment samples analyzed during the present study are given in Appendix $B$. Archived grain size data from earlier studies that were reviewed and vetted for compatibility with this study are given in Appendix C.

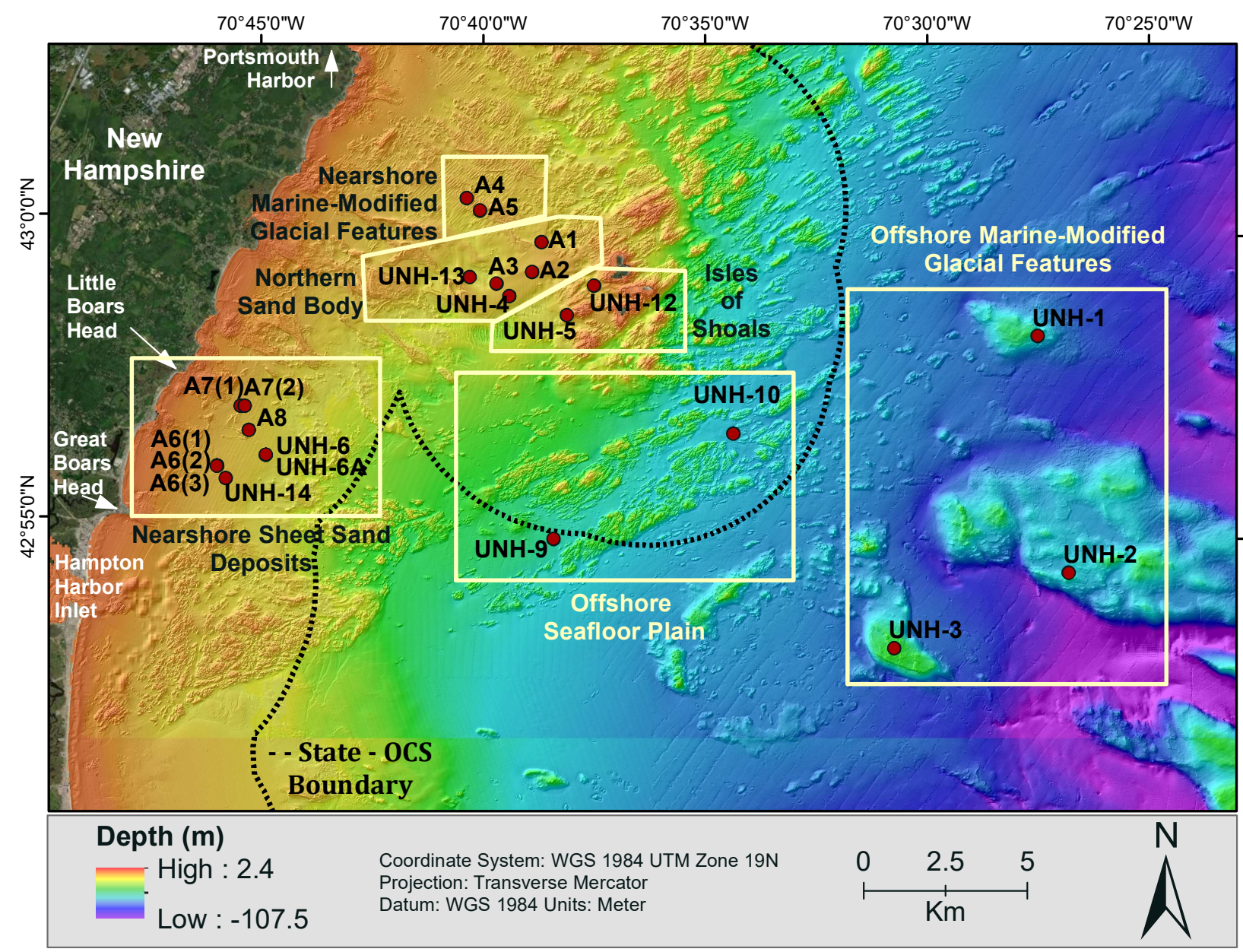

Figure 6. Bathymetric map $(1: 150,000)$ of the New Hampshire continental shelf with locations of vibracores taken in 1984 (UNH series) and 1988 (A series). The vibracores are grouped (yellow outlines) and discussed by their depositional environments (labels near groupings). 


\section{Offshore Marine-Modified Glacial Features (Drumlins and Lodgement Till Deposits)}

Note: this area was referred to as the Offshore Drumlins in earlier reports on sand bodies on the $\mathrm{NH}$ continental shelf (see Ward et al., 2021a).

Three vibracores (UNH-1, UNH-2, and UNH-3) were collected on three drumlin-like features found $\sim 23$ to $27 \mathrm{~km}$ offshore on the $\mathrm{NH}$ shelf (Figure 6). All three drumlins are oriented in a northwest-southeast direction but vary greatly in size. According to Birch $(1984 ; 1989)$ the drumlins are composed of a coarse diamicton and likely contain equal amounts of sand, silt, and clay with large cobble clasts. However, the offshore drumlins have not been well sampled overall and the composition is speculative. The drumlins have been modified by the marine environment and the shallower areas were likely subaerial or very near intertidal during the last sea-level lowstand (Figure 2). As a result, the surfaces of the drumlins were likely exposed to wave action resulting in winnowing and a redistribution of the surficial sediments.

\section{Vibracore UNH-1}

UNH-1 is $\sim 3.42 \mathrm{~m}$ in length and was taken from the northernmost drumlin in the study area located $\sim 22 \mathrm{~km}$ from shore in $\sim 57 \mathrm{~m}$ water depth (Figures 6,7 , and 8 ). The drumlin is $\sim 2.5 \mathrm{~km}$ in length and $\sim 1.3 \mathrm{~km}$ in width at its widest point. Birch (1984) described the sediment at this site as a lodgement till. The vibracore location was likely exposed or close to the surface during the last sea-level lowstand (Figure 2) which allowed the surface to be eroded. The upper $\sim 0.10 \mathrm{~m}$ of the vibracore contains a sandy pebble matrix with very large pebbles and cobbles in size overlying a thin $(0.04 \mathrm{~m})$ medium sand layer containing shell fragments (Figures 9 and 10). The pebble and sand layer is interpreted as a lag deposit winnowed by wave action during the lowstand. The surficial sediment map in Figure 8 shows this feature as being slightly gravelly, which is inconsistent with the gravel lag deposit shown at the top of the vibracore but is consistent with the remainder of the core below the lag deposit (Table 4).

Sediment grain size follows expected trends from the top to the bottom of the core with a steady decrease in sand content from 84 to $25 \%$ with depth accompanied by an increase in mud content from $~ 13$ to $74 \%$ (Table 4). Rock fragments are found throughout the core. Sediment composition transitions from slightly granuley silty clayey fine sand in the upper meter to slightly granuley very fine sandy silt-clay in the lower half of the core. The overall composition is consistent with Birch's (1984) description as a lodgement till. The apparent lag deposit at the surface reflects the winnowing by wave action at the sea-level lowstand.

\section{Vibracore UNH-2}

$\mathrm{UNH}-2$ is $1.56 \mathrm{~m}$ in length and was taken in $\sim 76 \mathrm{~m}$ of water from a marine-modified glacial deposit, most likely a drumlin, described by Birch (1984) as a lodgement till (Figures 6, 7, and 8). The drumlin is large, measuring $\sim 11.5 \mathrm{~km}$ along its longest axis and $\sim 4.5 \mathrm{~km}$ at its widest point. The feature likely includes multiple drumlins based on its ridges and size. The vibracore location was too deep to be exposed during the presumed sea-level lowstand (Figure 2) but would have been affected by storm waves. Examination of the photograph of the core top shows a lag deposit composed of pebbles with shell fragments (Figure 11). This agrees with the surficial sediment map (Figure 8).

Below the lag deposit, the core coarsens downward from a clayey silt to a poorly sorted fine sand at $\sim 1.20 \mathrm{~m}$ (Figure 12). Grain size analysis of a sediment sample taken from $0.33-0.35 \mathrm{~m}$ was a granuley siltclay with $\sim 6 \%$ gravel, $45 \%$ sand, and $49 \%$ mud and a mean grain size of $4.05 \phi(0.06 \mathrm{~mm})$ (Table 4). However, a sample from $1.43-1.45 \mathrm{~m}$ was a slightly granuley silty very fine sand with $\sim 4 \%$ gravel, $49 \%$ sand, and $47 \%$ mud, but with a mean grain size of $2.87 \phi(0.137 \mathrm{~mm})$. Similar to vibracore UNH-1, the overall sediment composition is consistent with Birch's (1984) description as a lodgement till. Also similar to vibracore UNH-1, the apparent lag deposit at the surface reflects the winnowing at the sea-level lowstand. 


\section{Vibracore UNH-3}

UNH-3 was taken on top of what appears to be a marine-modified drumlin located $\sim 24.2 \mathrm{~km}$ from shore in $\sim 57 \mathrm{~m}$ of water (Figures 1, 6, 7, and 8). The drumlin is $\sim 2.5 \mathrm{~km}$ in length and $1.2 \mathrm{~km}$ at its widest point. The core is $7.09 \mathrm{~m}$ in length. It is very likely UNH-3 was exposed or very close to sea level during the last lowstand and subjected to wave-induced erosion or winnowing (Figure 2 ). In general, the upper $\sim 5.28 \mathrm{~m}$ of the core is composed of medium to coarse sand which fines downward (separated by distinct contacts) into fine sand and ultimately overlies silty very fine sand to silt deposits (Figures 13 and 14). The thick sequence of sand indicates the likely erosion of the drumlin surface and the formation of a beach or shallow water shoal deposit during the early Holocene sea-level lowstand and transgression.

The upper $\sim 2.56 \mathrm{~m}$ of the core is comprised of medium to coarse sand with shell fragments and small pebbles (Figure 14). However, unlike the surfaces of UNH-1 and UNH-2, which are located nearby and also appear to be winnowed, no coarse pebble lag deposit occurs at the surface. Three sediment samples taken in the upper core $(0.23-0.25 \mathrm{~m}, 0.71-0.73 \mathrm{~m}$, and $135-137 \mathrm{~m})$ were slightly granuley medium sand with $\sim 96 \%$ sand and mean grain sizes from $1.48 \phi$ to $1.16 \phi(0.358$ to $0.448 \mathrm{~mm}$ ) (Table 4$)$. From $\sim 1.9$ to $2.84 \mathrm{~m}$ the sediments are granuley coarse sand to medium sand with lenses of coarse sand and gravel with pebbles. From $\sim 2.84$ to $3.04 \mathrm{~m}$, fine sands dominate ending in sandy mud. The sediments coarsen again from $\sim 3.12$ to $4.22 \mathrm{~m}$ ending with granuley coarse sand to a slightly pebbly medium sand. Below $\sim 4.22 \mathrm{~m}$ the sediments continue to fine, becoming siltier to a slightly granuley very fine sandy silt. Below an unconformity at $\sim 6.07 \mathrm{~m}$ the sediments change to a very fine sandy silt, extending to the base at $\sim 7.09 \mathrm{~m}$. A sediment sample taken at $6.64-6.66 \mathrm{~m}$ shows the highest mud (primarily silt) content of any samples taken in this core ( $82 \%$ mud).

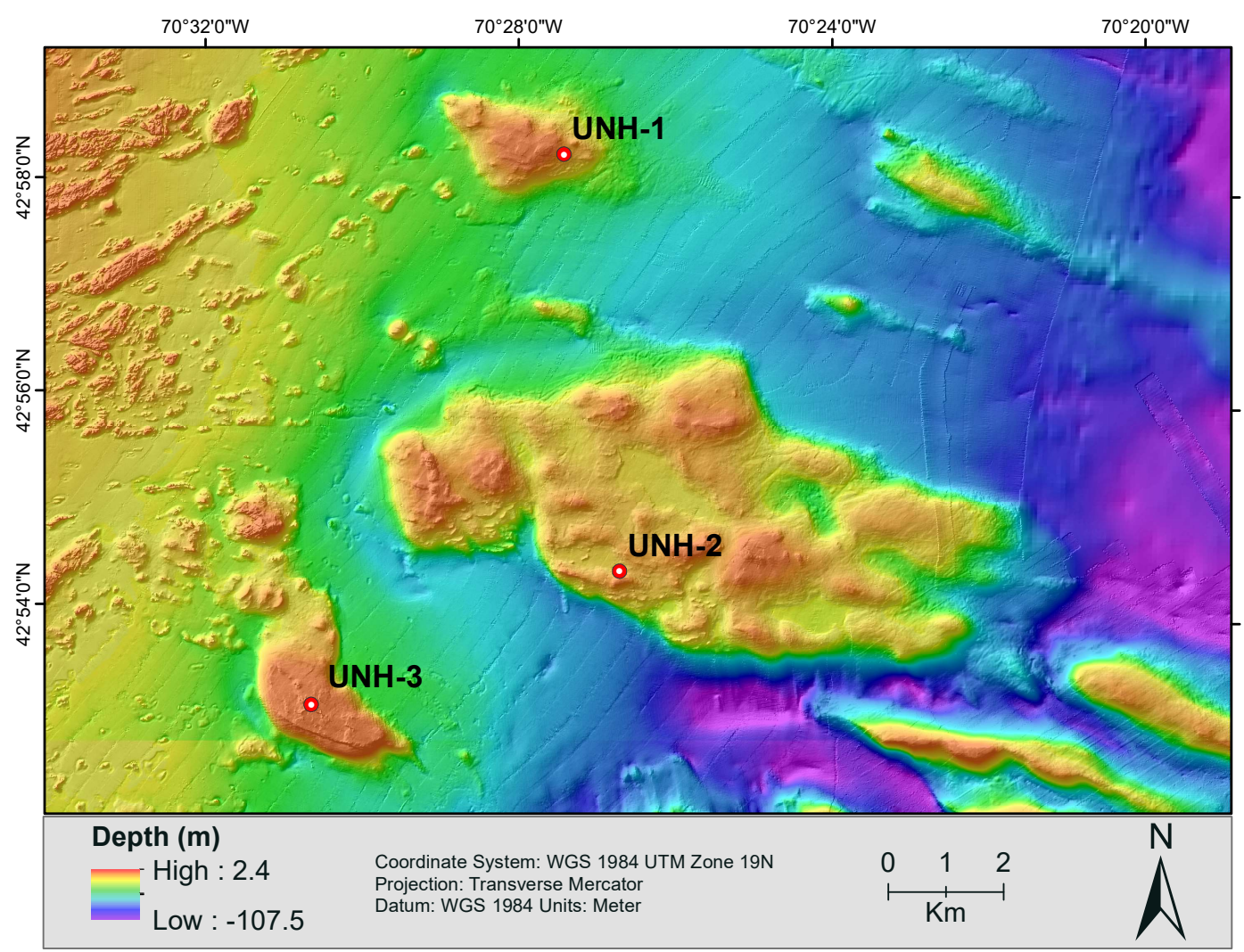

Figure 7. Bathymetric map of the vibracores taken in the Offshore Marine-Modified Glacial Features (Drumlins and Lodgement Till Deposits). Map is shown at a scale of 1:85,000. 

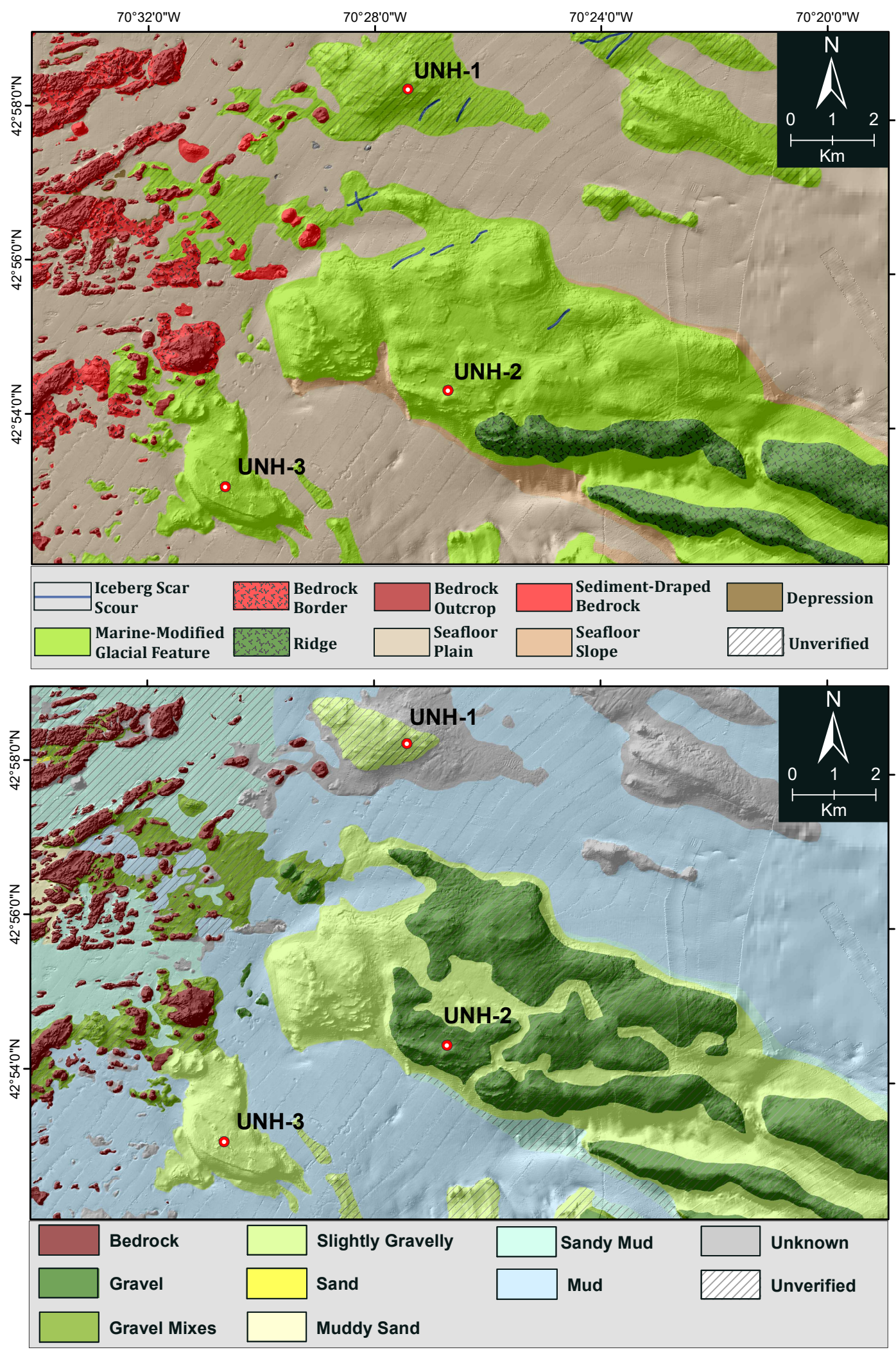

Figure 8. Major geoforms (physiographic features; top) and surficial sediment map (substrate classes; bottom) of the Offshore Marine-Modified Glacial Features (Drumlins and Lodgement Till Deposits). Shown at a scale of 1:85,000. 
Table 4. Grain size data for the vibracores from the Offshore Marine-Modified Glacial Features (Drumlins and Lodgement Till Deposits) including UNH-1, UNH-2, and UNH-3 (Figures 6 and 7). Complete grain size classifications and statistics are given in Appendix $B$.

\begin{tabular}{|c|c|c|c|c|c|c|c|c|c|c|}
\hline UNH Sample ID & $\begin{array}{l}\text { Gravel } \\
\%\end{array}$ & $\begin{array}{l}\text { Pebble } \\
\%\end{array}$ & $\begin{array}{l}\text { Granule } \\
\%\end{array}$ & $\begin{array}{l}\text { Sand } \\
\%\end{array}$ & $\begin{array}{l}\text { Mud } \\
\%\end{array}$ & $\begin{array}{l}\text { Silt } \\
\%\end{array}$ & $\begin{array}{l}\text { Clay } \\
\%\end{array}$ & $\begin{array}{l}\text { Mean Size } \\
\text { (phi) }\end{array}$ & $\begin{array}{l}\text { Sorting } \\
\text { (phi) }\end{array}$ & $\begin{array}{l}\text { CMECS (FGDC 2012) } \\
\text { Substrate Component } \\
\text { Subgroup (Specific) }\end{array}$ \\
\hline UNH-1_0-1cm & 3.65 & 1.56 & 2.09 & 83.67 & 12.68 & 6.67 & 6.01 & 1.90 & 2.25 & $\begin{array}{l}\text { Slightly Granuley Silty- } \\
\text { Clayey Medium Sand }\end{array}$ \\
\hline UNH-1_8-10cm & 1.81 & 0.32 & 1.49 & 53.71 & 44.48 & 21.96 & 22.52 & 4.98 & 3.94 & $\begin{array}{l}\text { Slightly Granuley Silty- } \\
\text { Clayey Fine Sand }\end{array}$ \\
\hline UNH-1_88-90cm & 1.15 & 0.00 & 1.15 & 50.54 & 48.31 & 24.23 & 24.08 & 5.24 & 3.85 & $\begin{array}{l}\text { Slightly Granuley Silty- } \\
\text { Clayey Fine Sand }\end{array}$ \\
\hline UNH-1_141-143cm & 0.74 & 0.00 & 0.74 & 40.83 & 58.43 & 27.22 & 31.21 & 5.92 & 4.10 & $\begin{array}{l}\text { Slightly Granuley Very } \\
\text { Fine Sandy Silt-Clay }\end{array}$ \\
\hline UNH-1_156-158cm & 0.97 & 0.68 & 0.30 & 27.02 & 72.01 & 33.04 & 38.97 & 7.01 & 3.91 & $\begin{array}{l}\text { Slightly Granuley Very } \\
\text { Fine Sandy Silt-Clay }\end{array}$ \\
\hline UNH-1_178-180cm & 0.80 & 0.00 & 0.80 & 18.42 & 80.78 & 36.39 & 44.39 & 7.63 & 3.82 & $\begin{array}{l}\text { Slightly Granuley Very } \\
\text { Fine Sandy Silt-Clay }\end{array}$ \\
\hline UNH-1_292-294cm & 0.48 & 0.00 & 0.48 & 25.47 & 74.05 & 33.67 & 40.38 & 7.07 & 3.83 & $\begin{array}{l}\text { Slightly Granuley Very } \\
\text { Fine Sandy Silt-Clay }\end{array}$ \\
\hline UNH-2_33-35cm & 5.83 & 2.77 & 3.06 & 44.93 & 49.24 & 29.09 & 20.15 & 4.62 & 4.05 & Granuley Silt-Clay \\
\hline UNH-2_143-145cm & 4.33 & 1.78 & 2.55 & 48.57 & 47.10 & 39.10 & 8.00 & 3.80 & 2.87 & $\begin{array}{l}\text { Slightly Granuley Silty } \\
\text { Very Fine Sand }\end{array}$ \\
\hline UNH-3_23-25cm & 2.32 & 0.39 & 1.93 & 96.22 & 1.46 & NA & NA & 1.48 & 1.06 & $\begin{array}{l}\text { Slightly Granuley Medium } \\
\text { Sand }\end{array}$ \\
\hline UNH-3_71-73cm & 2.60 & 0.66 & 1.94 & 96.89 & 0.51 & NA & NA & 1.27 & 1.04 & $\begin{array}{l}\text { Slightly Granuley Medium } \\
\text { Sand }\end{array}$ \\
\hline UNH-3_135-137cm & 3.62 & 0.30 & 3.32 & 96.29 & 0.09 & NA & NA & 1.16 & 0.98 & $\begin{array}{l}\text { Slightly Granuley Medium } \\
\text { Sand }\end{array}$ \\
\hline UNH-3_225-227cm & 11.97 & 5.80 & 6.18 & 85.47 & 2.56 & NA & NA & 0.65 & 1.50 & Granuley Coarse Sand \\
\hline UNH-3_278-281cm & 5.30 & 4.03 & 1.27 & 93.57 & 1.13 & NA & NA & 1.73 & 1.13 & Pebbly Medium Sand \\
\hline UNH-3_324-326cm & 0.00 & 0.00 & 0.00 & 98.19 & 1.81 & NA & NA & 2.57 & 0.54 & Fine Sand \\
\hline UNH-3_384-386cm & 20.87 & 11.46 & 9.41 & 79.13 & 0.00 & NA & NA & 0.18 & 1.56 & Granuley Coarse Sand \\
\hline UNH-3_428-430cm & 2.96 & 1.83 & 1.13 & 96.64 & 0.40 & NA & NA & 1.18 & 0.89 & $\begin{array}{l}\text { Slightly Pebbly Medium } \\
\text { Sand }\end{array}$ \\
\hline UNH-3_478-480cm & 3.95 & 3.67 & 0.28 & 85.78 & 10.27 & 10.25 & 0.02 & 2.59 & 1.18 & $\begin{array}{l}\text { Slightly Pebbly Silty Fine } \\
\text { Sand }\end{array}$ \\
\hline UNH-3_538-540cm & 0.20 & 0.00 & 0.20 & 37.72 & 62.08 & 61.21 & 0.87 & 4.11 & 0.90 & $\begin{array}{l}\text { Slightly Granuley Very } \\
\text { Fine Sandy Silt }\end{array}$ \\
\hline UNH-3_592-594cm & 0.02 & 0.00 & 0.02 & 42.31 & 57.67 & 42.51 & 15.16 & 5.05 & 2.58 & $\begin{array}{l}\text { Slightly Granuley Very } \\
\text { Fine Sandy Silt }\end{array}$ \\
\hline UNH-3_664-666cm & 0.00 & 0.00 & 0.00 & 17.97 & 82.03 & 68.14 & 13.89 & 5.30 & 2.11 & Very Fine Sandy Silt \\
\hline
\end{tabular}




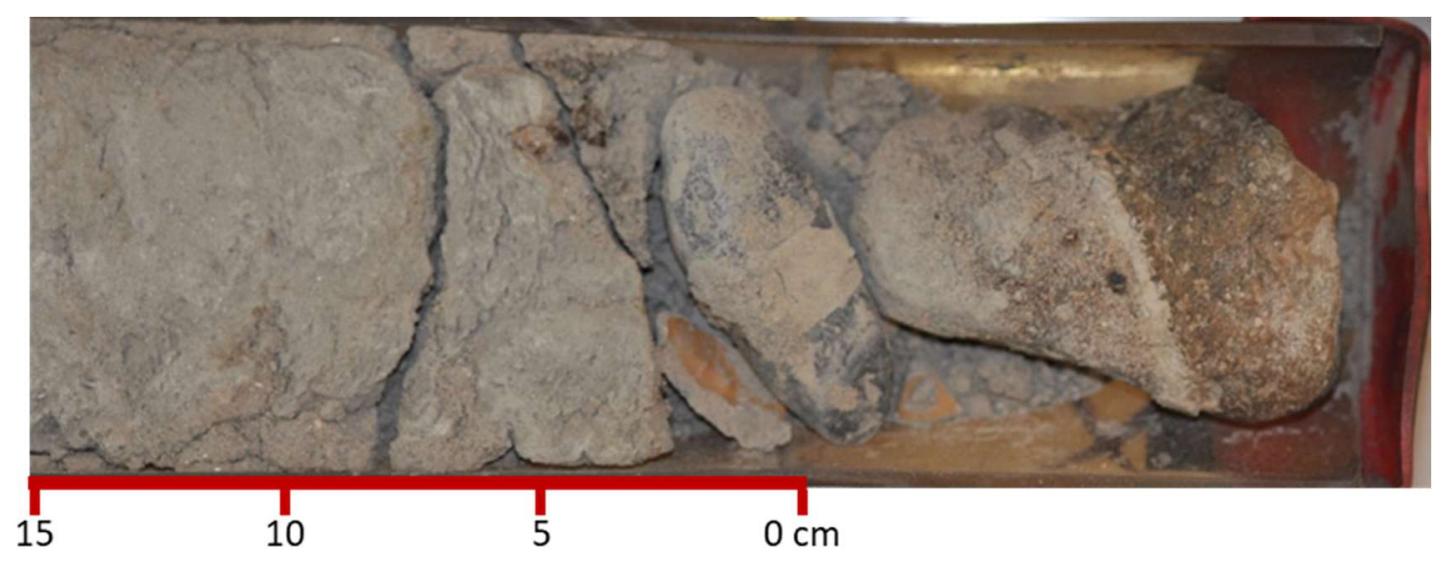

Figure 9. Photograph of the surface of vibracore UNH-1. Note lag deposit with cobble at surface of vibracore (above scale). Top of the core is to the right.

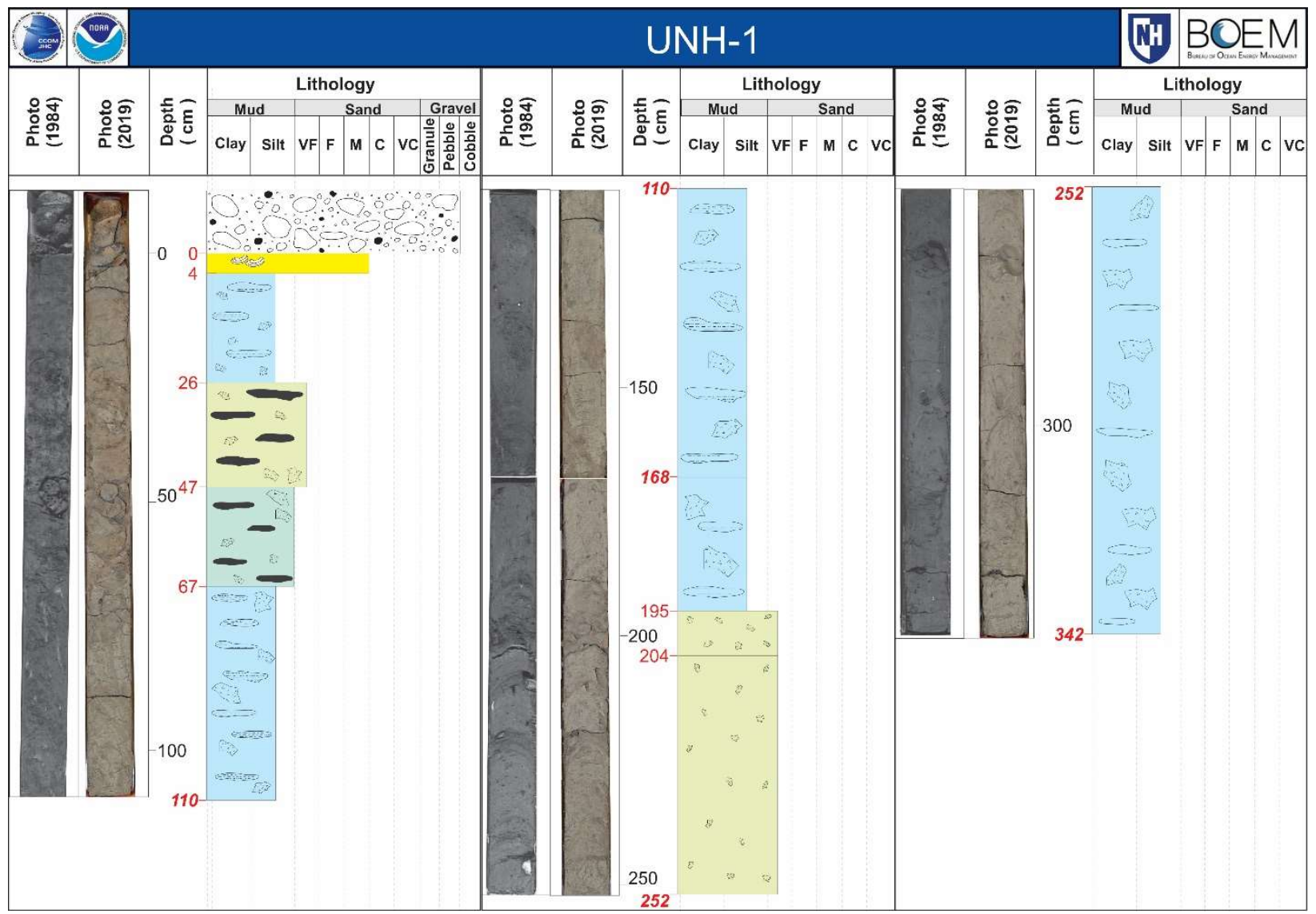

Figure 10. UNH-1 core log. The location of the vibracore is shown in Figures 6, 7, and 8. The full core log with greater detail is given in Appendix A. Note the measurement of the core depth starts $10 \mathrm{~cm}$ below the surface of the core case (see photograph in Figure 9). This was done because it is not clear where the actual surface starts due to the presence of a cobble. Therefore, the depth below surface starts where the sediment is continuous. 


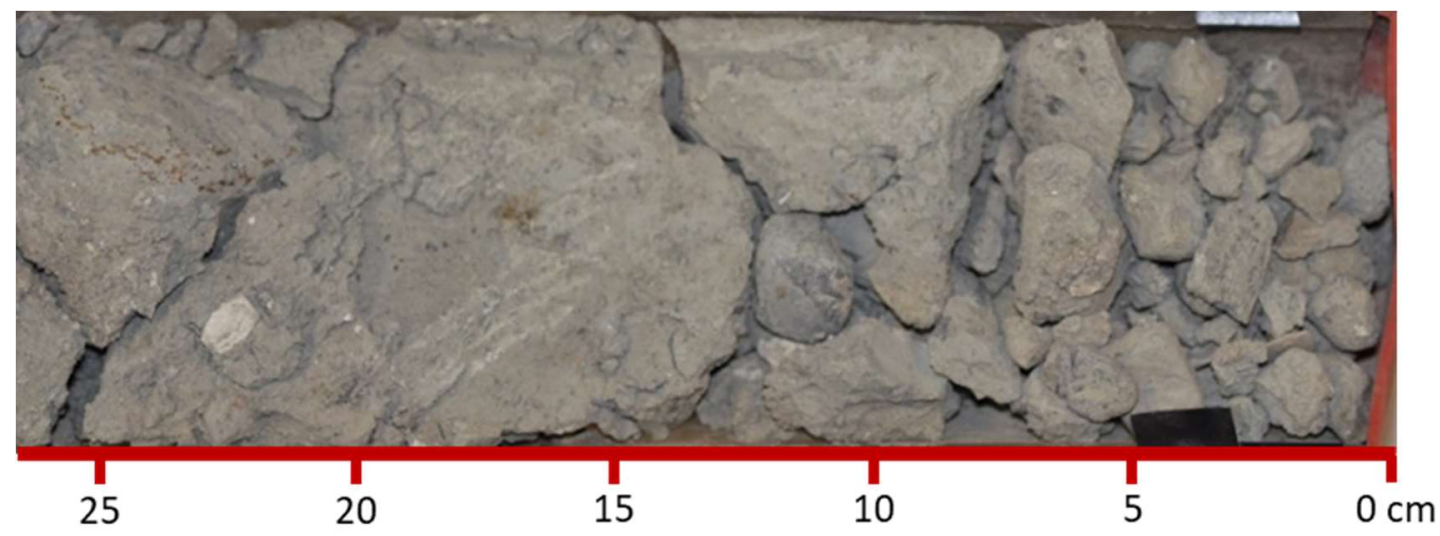

Figure 11. Photograph of vibracore UNH-2 from the surface to $\sim 0.26 \mathrm{~m}$. Note pebble lag deposit at the surface of the core. The sediment below the pebbles is broken up due to desiccation.

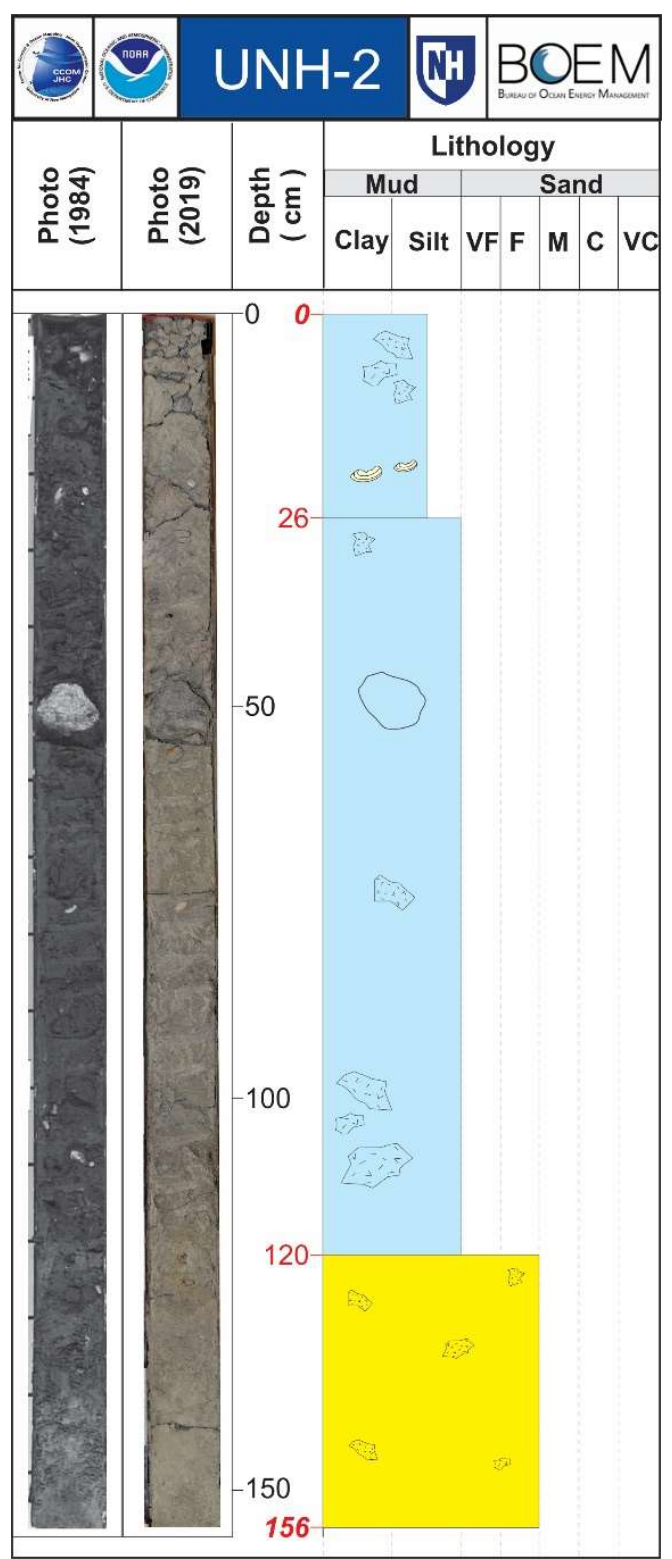

Figure 12. UNH-2 core log. The location of the vibracore is shown in Figures 6, 7, and 8. A photograph of the top of the core is shown in Figure 11. The full core log with greater detail is given in Appendix A. 


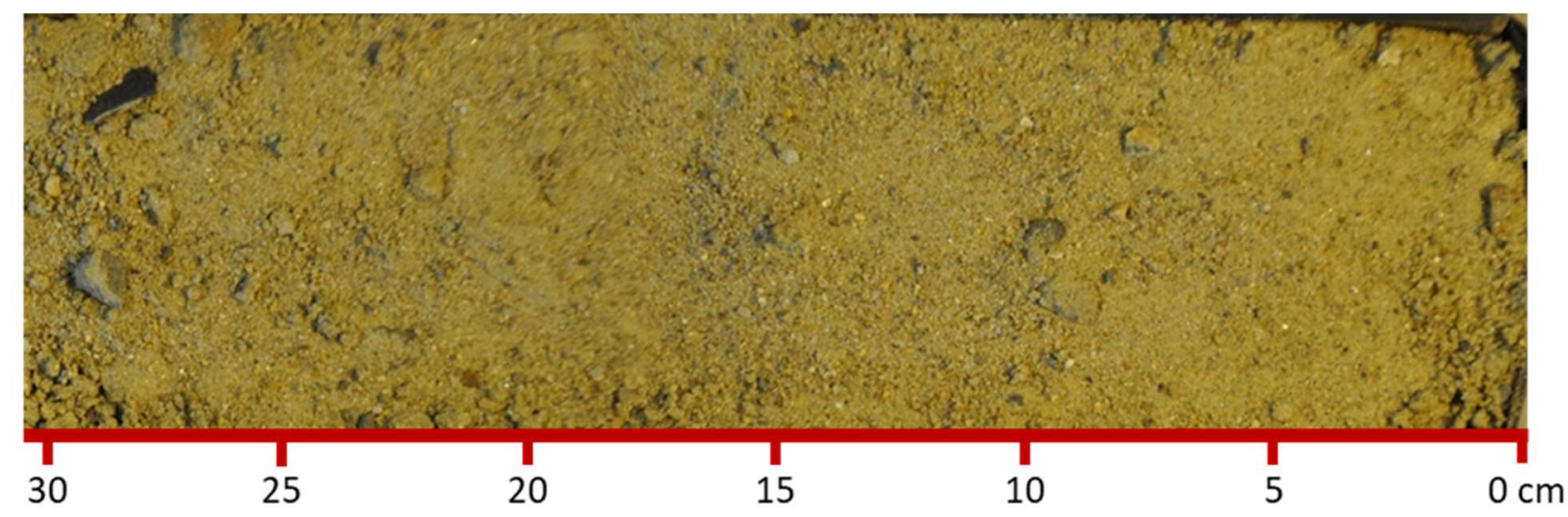

Figure 13. Photograph of the top of vibracore UNH-3 from the surface to $\sim 0.30 \mathrm{~m}$.

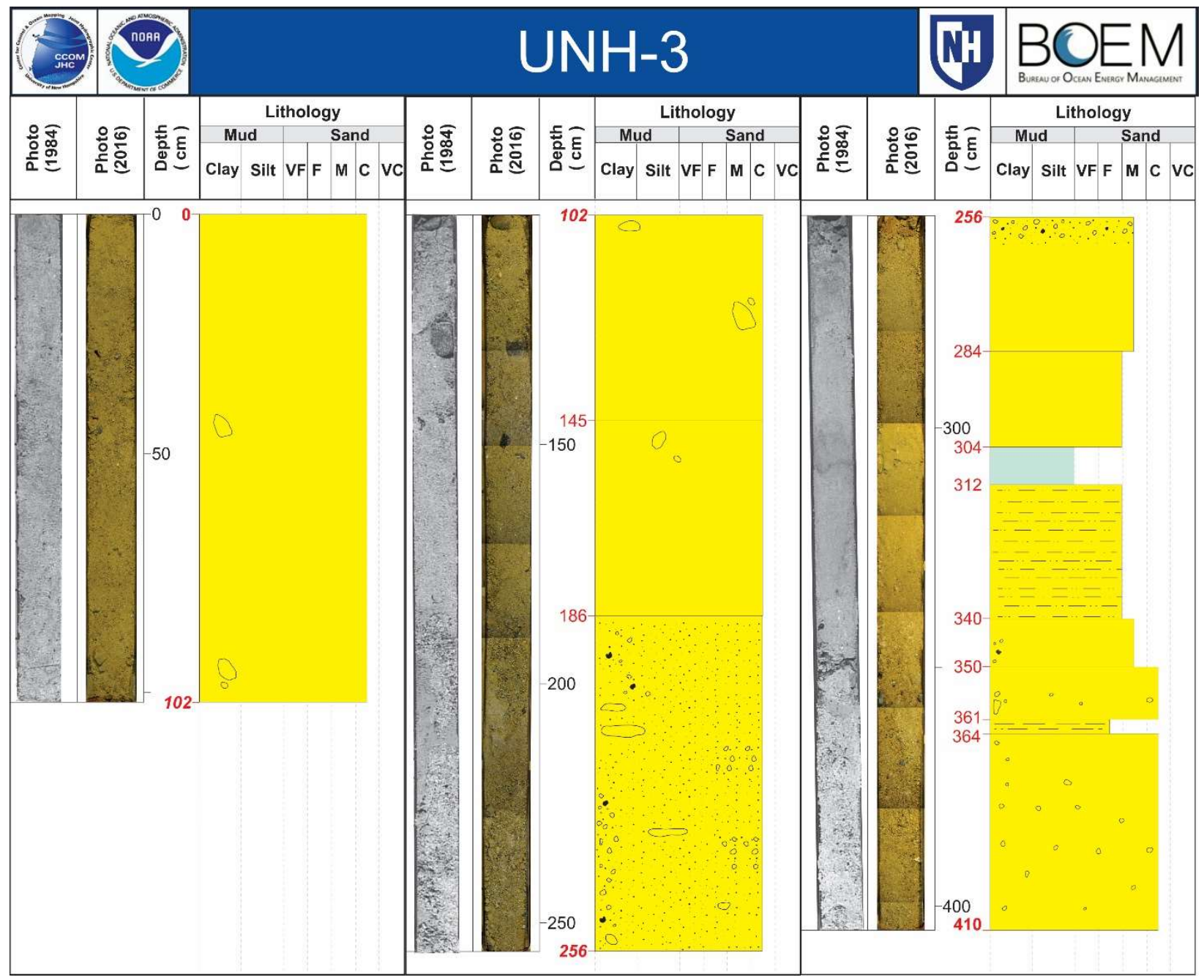

Figure 14a. Upper $4.10 \mathrm{~m}$ of the core log for UNH-3. The core log from 4.10 to $7.99 \mathrm{~m}$ in shown Figure $14 b$. The location of the vibracore is shown in Figures 6 and 7. A photograph of the top of the vibracore is shown in Figure 13. The full core log with greater detail is given in Appendix $A$. 


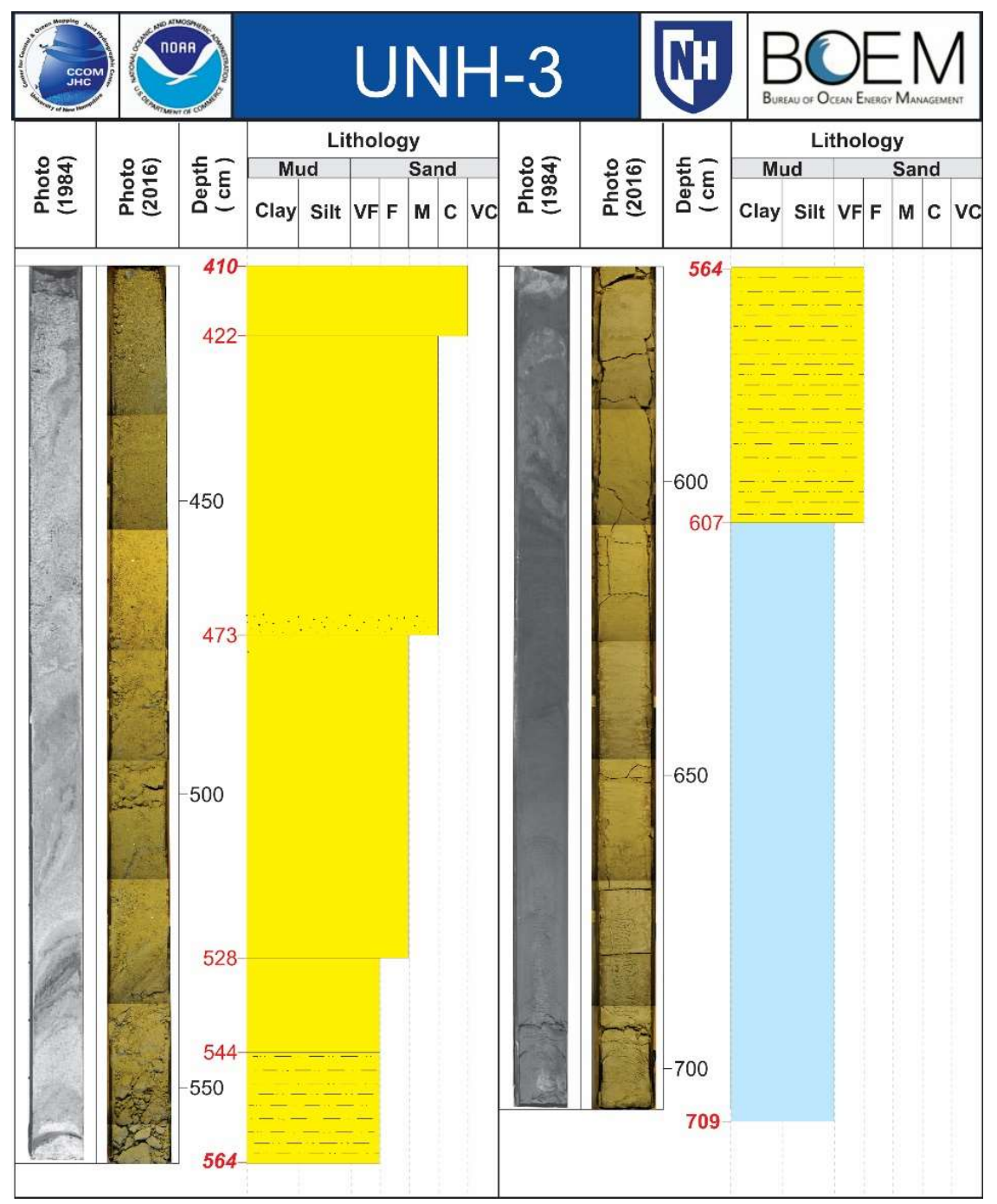

Figure $14 b$. Core log for 4.10 to $7.99 m$ of $U N H-3$ (the upper $4.10 m$ is shown in Figure $14 a$ ). 


\section{Northern Sand Body}

The Northern Sand Body (NSB), which is located $\sim 10 \mathrm{~km}$ offshore near the Isles of Shoals, is $\sim 3.2 \mathrm{~km}$ in length, $\sim 1.3 \mathrm{~km}$ in width, and has a maximum relief of $\sim 7 \mathrm{~m}$ in comparison to the surrounding seafloor (Figures 6 and 15). The NSB extends between what appears to be the roots of two eroded drumlins (Figure 16). The NSB was first described by Birch (1986a; 1988) and later in more detail by Ward et al. (2021a), and has an estimated volume of sand of $\sim 17$ million $\mathrm{m}^{3}$, but this remains to be verified. The origin of the NSB is not clear. Birch (1984) speculated that some of the sand deposits on the NH continental shelf originated from the erosion and winnowing of the glacial marine sediments deposited during the last major glaciation (Wisconsin). The NSB area was certainly supratidal during the last sea-level lowstand (Figure 2), exposing the seafloor to nearshore processes (e.g., waves, longshore currents, etc.); however, this would not account for the mounding of the sand body. Ward et al (2021a) hypothesized that the NSB may have formed from sediments eroded from glacial features, specifically drumlins, as described by Carter and Orford (1988) in similar paraglacial environments in Canada. However, it is not clear whether this would provide the needed sand volume. A simpler explanation is that the NSB originated from deposits that were originally either a marine glacial delta, a subaqueous delta, or a sandy outwash that have been heavily modified by marine processes. The origin of the NSB remains to be determined, but a glacial deposit laid down near the ice front and subsequently modified by marine processes is reasonable.

Five vibracores were taken in and around the NSB area to better describe the main sand body and the adjacent deposits (A1, A2, A3, UNH-4, and UNH-13).

\section{Vibracore A1}

A1 was taken from the northern end of the NSB in at a water depth of $\sim 21 \mathrm{~m}$ where the sand body appears to become significantly thinner (Figures 6,15 , and 16 ). The core is $4.39 \mathrm{~m}$ in length. The upper $\sim 3.5 \mathrm{~m}$ of the core is composed of medium to coarse sand with varying amounts of gravel (Figures 17 and 18). For example, the core from the surface to $1.92 \mathrm{~m}$ is largely slightly granuley medium sand. Sediment samples from $0.35-0.37 \mathrm{~m}, 1.00-1.02 \mathrm{~m}$, and $1.62-1.64 \mathrm{~m}$ are $\sim 98 \%$ sand with mean grain sizes varying between 1.04 and $1.14 \phi(0.486$ to $0.454 \mathrm{~mm}$ ) (Table 5$)$. From 1.92 to $3.50 \mathrm{~m}$ the core is largely a granuley coarse sand. Sediment samples from $2.47-2.49 \mathrm{~m}$ and $3.08-3.10 \mathrm{~m}$ are $\sim 88 \%$ sand, but the gravel content increases to $\sim 9-11 \%$ with most of the gravel being granule. The mean grain size is $0.56 \phi(0.678 \mathrm{~mm})$ and $0.59 \phi$ $(0.664 \mathrm{~mm})$, respectively. Below $3.5 \mathrm{~m}$ to the base of the core the sediment fines. Samples taken at 3.65$3.67 \mathrm{~m}$ and $4.23-4.25 \mathrm{~m}$ are a slightly granuley fine sand and fine sand, respectively. A small mud ball was also found at the base of $A 1$ in the lower $0.1 \mathrm{~m}$ of the core, suggesting that the sand sequence unconformably overlies fine grained deposits, most likely the glacial marine muds of the Presumpscot Formation.

\section{Vibracore A2}

$\mathrm{A} 2$ is located near the center of the NSB in a water depth of $22 \mathrm{~m}$ (Figures 6,15 , and 16). It is the longest of the vibracores taken on the NSB with a length of $7.13 \mathrm{~m}$. The upper $~ 3.1 \mathrm{~m}$ of the sediment column is composed of primarily slightly granuley medium sand with shell fragments and scattered pebbles with a mean grain size between 1.00 and $1.20 \phi(0.500$ to $0.435 \mathrm{~mm})$ (Figures 19 and 20). All sediment samples from this section have $>97 \%$ sand and less than $1 \%$ mud (Table 5). From $\sim 3.1$ to $4.1 \mathrm{~m}$ the sediment is slightly granuley fine sand with a mean grain size between 2.56 and $3.12 \phi(0.170$ to $0.115 \mathrm{~mm})$. Mud content increases to between $\sim 6$ and $9 \%$. From $\sim 4.1$ to $5.6 \mathrm{~m}$ the core is slightly granuley silty fine sand with shell fragments and increasing mud content ( 10 to $14 \%$ ). Below $\sim 5.6 \mathrm{~m}$ to the base of the core at $\sim 7.1 \mathrm{~m}$ the sediments are still slightly granuley silty fine sand, but mud content increases to 30 to $35 \%$. Mean grain size reduces to $\sim 3.6 \phi(0.082 \mathrm{~mm})$. This bottom section contains shell fragments and mica suggesting lower energy conditions. 


\section{Vibracore A3}

A3 is located close to the southwestern end of the axis of the NSB (Figures 6, 15, and 16) at a water depth of $\sim 25 \mathrm{~m}$. It is a relatively long core penetrating $5.81 \mathrm{~m}$. The entire length of $A 3$ is dominated by fine to very fine sand, with scattered shell fragments, occasional pebbles, and sand pods (Figures 21 and 22). The first $\sim 3.0 \mathrm{~m}$ of the core is a fine sand with sand fractions greater than $97 \%$ and mean phi sizes between 2.40 and $2.48 \phi(0.189$ to $0.179 \mathrm{~mm}$ ) (Table 5$)$. Below $\sim 3.0 \mathrm{~m}$ the sediment is a silty very fine sand or a slightly granuley silty very fine sand with mean grain size increasing to $\sim 3.8 \phi(0.072 \mathrm{~mm})$ near the bottom. Mud content increases to between $\sim 32$ and $35 \%$.

\section{Vibracore UNH-4}

UNH-4 was collected from the southeastern side of the NSB at a depth of $\sim 25 \mathrm{~m}$ (Figures 6,15 , and 16). The recovered core is $6.46 \mathrm{~m}$ in length. The upper $0.14 \mathrm{~m}$ of the vibracore is a surface lag deposit that was likely winnowed at lower sea levels and as a result is coarser than the underlying sands (Figures 23 and 24). The surface layer (top $0.04 \mathrm{~m}$ ) is comprised of a slightly granuley medium sand with rock fragments that is $>99 \%$ sand (excluding the scattered rock fragments) and has a mean grain size of $1.57 \phi(0.337 \mathrm{~mm})$. A sample from $0.10-0.12 \mathrm{~m}$ is a slightly granuley fine sand with a mean grain size of $2.24 \phi(0.212 \mathrm{~mm})$ (Table 6). From 0.14 to $1.45 \mathrm{~m}$ the sand becomes finer transitioning from a slightly granuley fine sand (>99\% sand) to fine sand with a higher mud content. A sediment sample taken at $1.43-1.45 \mathrm{~m}$ has $92 \%$ sand and $\sim 8 \%$ mud. The mud content continues to increase with depth to the base of the core. A sample from $1.92-1.94 \mathrm{~m}$ is a silty very fine sand with $\sim 75 \%$ sand, $25 \%$ mud, and a mean grain size of $3.62 \phi$ $(0.081 \mathrm{~mm})$. A sample from $4.66-4.68 \mathrm{~m}$ is a slightly granuley silty very fine sand with $\sim 53 \%$ sand, $47 \%$ mud, with a mean grain size of $4.04 \phi(0.061 \mathrm{~mm})$. Below this, sediments are slightly granuley very fine sandy silt. At $5.69 \mathrm{~m}$ a relatively distinct contact represents the transition to a sandy silt and appears to be fine grained glacial marine sediments associated with the Presumpscot Formation. A sample from near the bottom of the core at $5.87-5.89 \mathrm{~m}$ is $\sim 34 \%$ sand, $65 \%$ mud, and has a mean grain size of $6.41 \phi(0.012 \mathrm{~mm})$.

Clearly the NSB was eroded into the underlying glacial marine muds as indicated by the unconformity between the sand and the mud. The stratigraphic relationship argues that the sand body is younger than the glaciomarine mud but does not preclude that the origin of the sand was glacial deltaic or outwash.

\section{Vibracore UNH-13}

UNH-13 was taken in a water depth of $28 \mathrm{~m}$ on the southwestern side of the NSB near where the sand body becomes very thin (Figures 6,15 , and 16 ). The core is $6.41 \mathrm{~m}$ in length. The upper $1.58 \mathrm{~m}$ of the core is mostly comprised of fine sand, with shell and rock fragments and an increasing presence of small clay lenses towards the bottom of the sandy section (Figures 25 and 26). The remainder of the core below $1.58 \mathrm{~m}$ is glacial marine mud. An apparent lag deposit caps the core. A sediment sample taken near the surface $(0.25-0.27 \mathrm{~m})$ is a slightly granuley fine sand with $\sim 92 \%$ sand and a mean grain size of $2.48 \phi$ $(0.179 \mathrm{~mm})$ (Table 6). However, the slightly granuley fine sand fines downward into a fine sand. Samples from $0.65-0.67 \mathrm{~m}$ and $0.93-0.95 \mathrm{~m}$ are fine sand with $\sim 91$ to $94 \%$ sand. The mean grain size of the lower sample is $4.00 \phi(0.063 \mathrm{~mm})$. A distinct contact at the base of the sandy sediments signals the transition to the glacial marine muds (Figure 26), again likely that of the Presumpscot Formation. A series of sediment samples throughout the mud shows a fining down sequence from a very fine sandy silt-clay at $1.61-1.63 \mathrm{~m}$ with a mud content of $\sim 79 \%$ and a mean grain size of $7.44 \phi(0.006 \mathrm{~mm})$ to a silt-clay at $5.73-5.75 \mathrm{~m}$ with the mud content increasing to $\sim 90 \%$ and mean grain size decreasing to $8.60 \phi(0.003 \mathrm{~mm})$. However, the sediment between these two samples vary due to sand pods. For example, a sand pod at $2.86-2.88 \mathrm{~m}$ is a slightly pebbly silty clayey fine sand with a sand content of $\sim 76 \%$ and a mean grain size of $3.74 \phi$ $(0.075 \mathrm{~mm})$. The sharp contact and what appear to be rip-up clasts argue that the glacial marine mud was eroded at the sea-level lowstand and the fine sand is a Holocene deposit (Birch, 1984). 
Table 5. Grain size data for the vibracores from the Northern Sand Body including A1, A2, and A3 (Figure 16). Complete grain size classifications and statistics are given in Appendix B.

\begin{tabular}{|c|c|c|c|c|c|c|c|c|c|c|}
\hline UNH Sample ID & $\begin{array}{l}\text { Gravel } \\
\%\end{array}$ & $\begin{array}{l}\text { Pebble } \\
\%\end{array}$ & $\begin{array}{l}\text { Granule } \\
\%\end{array}$ & $\begin{array}{l}\text { Sand } \\
\%\end{array}$ & $\begin{array}{l}\text { Mud } \\
\%\end{array}$ & $\begin{array}{l}\text { Silt } \\
\%\end{array}$ & $\begin{array}{l}\text { Clay } \\
\%\end{array}$ & $\begin{array}{l}\text { Mean Size } \\
\text { (phi) }\end{array}$ & $\begin{array}{l}\text { Sorting } \\
\text { (phi) }\end{array}$ & $\begin{array}{l}\text { CMECS (FGDC 2012) } \\
\text { Substrate Component } \\
\text { Subgroup (Specific) }\end{array}$ \\
\hline A1_35-37cm & 2.04 & 0.49 & 1.55 & 97.92 & 0.04 & NA & NA & 1.04 & 0.62 & $\begin{array}{l}\text { Slightly Granuley Medium } \\
\text { Sand }\end{array}$ \\
\hline A1_100-102cm & 2.15 & 1.69 & 0.45 & 97.85 & 0.00 & NA & NA & 1.14 & 0.56 & $\begin{array}{l}\text { Slightly Pebbly Medium } \\
\text { Sand }\end{array}$ \\
\hline A1_162-164cm & 1.82 & 1.31 & 0.52 & 97.78 & 0.40 & NA & NA & 1.09 & 0.53 & $\begin{array}{l}\text { Slightly Pebbly Medium } \\
\text { Sand }\end{array}$ \\
\hline A1_247-249cm & 11.21 & 2.71 & 8.50 & 88.56 & 0.23 & NA & NA & 0.56 & 1.08 & Granuley Coarse Sand \\
\hline A1_308-310cm & 8.59 & 0.93 & 7.66 & 90.08 & 1.33 & NA & NA & 0.59 & 1.01 & Granuley Coarse Sand \\
\hline A1_365-367cm & 3.27 & 0.50 & 2.77 & 89.94 & 6.79 & NA & NA & 1.53 & 1.51 & $\begin{array}{l}\text { Slightly Granuley Fine } \\
\text { Sand }\end{array}$ \\
\hline A1_423-425cm & 0.00 & 0.00 & 0.00 & 96.32 & 3.68 & NA & NA & 2.61 & 0.55 & Fine Sand \\
\hline A2_40-42cm & 1.98 & 0.88 & 1.10 & 97.46 & 0.56 & NA & NA & 1.22 & 0.65 & $\begin{array}{l}\text { Slightly Granuley Medium } \\
\text { Sand }\end{array}$ \\
\hline A2_ $78-80 \mathrm{~cm}$ & 0.52 & 0.00 & 0.52 & 99.21 & 0.27 & NA & NA & 1.20 & 0.62 & $\begin{array}{l}\text { Slightly Granuley Medium } \\
\text { Sand }\end{array}$ \\
\hline A2_141-143cm & 0.46 & 0.00 & 0.46 & 98.99 & 0.55 & NA & NA & 1.03 & 0.60 & $\begin{array}{l}\text { Slightly Granuley Medium } \\
\text { Sand }\end{array}$ \\
\hline A2_223-225cm & 0.50 & 0.12 & 0.39 & 98.95 & 0.55 & NA & NA & 1.17 & 0.69 & $\begin{array}{l}\text { Slightly Granuley Medium } \\
\text { Sand }\end{array}$ \\
\hline A2_273-275cm & 0.05 & 0.00 & 0.05 & 99.94 & 0.01 & NA & NA & 1.17 & 0.60 & $\begin{array}{l}\text { Slightly Granuley Medium } \\
\text { Sand }\end{array}$ \\
\hline A2_313-315cm & 0.33 & 0.00 & 0.33 & 92.93 & 6.74 & 4.61 & 2.13 & 2.56 & 0.86 & $\begin{array}{l}\text { Slightly Granuley Fine } \\
\text { Sand }\end{array}$ \\
\hline A2_383-385cm & 0.21 & 0.00 & 0.21 & 90.70 & 9.09 & 6.39 & 2.70 & 3.12 & 0.67 & $\begin{array}{l}\text { Slightly Granuley Very } \\
\text { Fine Sand }\end{array}$ \\
\hline A2_439-441cm & 0.03 & 0.00 & 0.03 & 89.45 & 10.52 & 8.30 & 2.22 & 3.27 & 0.62 & $\begin{array}{l}\text { Slightly Granuley Silty } \\
\text { Very Fine Sand }\end{array}$ \\
\hline A2_519-521cm & 0.00 & 0.00 & 0.00 & 85.46 & 14.54 & 13.16 & 1.38 & 3.44 & 0.59 & Silty Very Fine Sand \\
\hline A2_599-601cm & 0.46 & 0.00 & 0.46 & 68.82 & 30.72 & 26.22 & 4.50 & 3.67 & 1.34 & $\begin{array}{l}\text { Slightly Granuley Silty } \\
\text { Very Fine Sand }\end{array}$ \\
\hline A2_669-671cm & 0.23 & 0.00 & 0.23 & 64.45 & 35.32 & 31.88 & 3.44 & 3.74 & 1.10 & $\begin{array}{l}\text { Slightly Granuley Silty } \\
\text { Very Fine Sand }\end{array}$ \\
\hline A3_20-22cm & 0.00 & 0.00 & 0.00 & 97.59 & 2.41 & NA & NA & 2.40 & 0.57 & Fine Sand \\
\hline A3_100-102cm & 0.00 & 0.00 & 0.00 & 97.66 & 2.34 & NA & NA & 2.42 & 0.55 & Fine Sand \\
\hline A3_145-147cm & 0.00 & 0.00 & 0.00 & 97.50 & 2.50 & NA & NA & 2.45 & 0.55 & Fine Sand \\
\hline A3_265-267cm & 0.00 & 0.00 & 0.00 & 98.22 & 1.78 & NA & NA & 2.48 & 0.58 & Fine Sand \\
\hline A3_302-304cm & 0.00 & 0.00 & 0.00 & 93.53 & 6.47 & 4.22 & 2.25 & 2.78 & 0.69 & Fine Sand \\
\hline A3_422-424cm & 0.00 & 0.00 & 0.00 & 86.67 & 13.33 & 9.24 & 4.09 & 3.26 & 1.04 & Silty Very Fine Sand \\
\hline A3_464-466cm & 0.11 & 0.00 & 0.11 & 67.95 & 31.94 & 27.07 & 4.87 & 3.77 & 1.30 & $\begin{array}{l}\text { Slightly Granuley Silty } \\
\text { Very Fine Sand }\end{array}$ \\
\hline A3_564-566cm & 0.06 & 0.00 & 0.06 & 64.90 & 35.04 & 29.83 & 5.21 & 3.82 & 1.38 & $\begin{array}{l}\text { Slightly Granuley Silty } \\
\text { Very Fine Sand }\end{array}$ \\
\hline
\end{tabular}


Table 6. Grain size data for the vibracores taken at the Northern Sand Body including UNH-4 and UNH-13 (Figure 16). Complete grain size classifications and statistics are given in Appendix $B$.

\begin{tabular}{|c|c|c|c|c|c|c|c|c|c|c|}
\hline UNH Sample ID & $\begin{array}{l}\text { Gravel } \\
\%\end{array}$ & $\begin{array}{l}\text { Pebble } \\
\%\end{array}$ & $\begin{array}{l}\text { Granule } \\
\%\end{array}$ & $\begin{array}{l}\text { Sand } \\
\%\end{array}$ & $\begin{array}{l}\text { Mud } \\
\%\end{array}$ & $\begin{array}{l}\text { Silt } \\
\%\end{array}$ & $\begin{array}{l}\text { Clay } \\
\%\end{array}$ & $\begin{array}{l}\text { Mean Size } \\
\text { (phi) }\end{array}$ & $\begin{array}{l}\text { Sorting } \\
\text { (phi) }\end{array}$ & $\begin{array}{l}\text { CMECS (FGDC 2012) } \\
\text { Substrate Component } \\
\text { Subgroup (Specific) }\end{array}$ \\
\hline UNH-4_0-4cm & 0.30 & 0.00 & 0.30 & 99.70 & 0.00 & NA & NA & 1.57 & 0.83 & $\begin{array}{l}\text { Slightly Granuley Medium } \\
\text { Sand }\end{array}$ \\
\hline UNH-4_10-12cm & 0.02 & 0.00 & 0.02 & 99.94 & 0.04 & NA & NA & 2.24 & 0.56 & $\begin{array}{l}\text { Slightly Granuley Fine } \\
\text { Sand }\end{array}$ \\
\hline UNH-4_40-42cm & 0.05 & 0.01 & 0.05 & 99.95 & 0.00 & NA & NA & 2.44 & 0.45 & $\begin{array}{l}\text { Slightly Granuley Fine } \\
\text { Sand }\end{array}$ \\
\hline UNH-4_68-70cm & 0.00 & 0.00 & 0.00 & 98.39 & 1.61 & NA & NA & 2.53 & 0.48 & Fine Sand \\
\hline UNH-4_98-100cm & 0.00 & 0.00 & 0.00 & 96.48 & 3.52 & NA & NA & 2.52 & 0.55 & Fine Sand \\
\hline UNH-4_143-145cm & 0.00 & 0.00 & 0.00 & 92.00 & 8.00 & 6.22 & 1.78 & 2.95 & 0.63 & Fine Sand \\
\hline UNH-4_192-194cm & 0.00 & 0.00 & 0.00 & 75.37 & 24.63 & 19.33 & 5.30 & 3.62 & 1.44 & Silty Very Fine Sand \\
\hline UNH-4_242-244cm & 0.00 & 0.00 & 0.00 & 73.42 & 26.58 & 22.82 & 3.76 & 3.59 & 1.15 & Silty Very Fine Sand \\
\hline UNH-4_267-269cm & 0.05 & 0.00 & 0.05 & 69.10 & 30.85 & 26.33 & 4.52 & 3.70 & 1.29 & $\begin{array}{l}\text { Slightly Granuley Silty } \\
\text { Very Fine Sand }\end{array}$ \\
\hline UNH-4_317-319cm & 0.00 & 0.00 & 0.00 & 67.78 & 32.22 & 26.39 & 5.83 & 3.72 & 1.51 & Silty Very Fine Sand \\
\hline UNH-4_376-378cm & 0.00 & 0.00 & 0.00 & 58.44 & 41.56 & 36.60 & 4.96 & 3.94 & 1.28 & Silty Very Fine Sand \\
\hline UNH-4_466-468cm & 0.01 & 0.01 & 0.00 & 52.75 & 47.24 & 41.83 & 5.41 & 4.04 & 1.36 & $\begin{array}{l}\text { Slightly Granuley Silty } \\
\text { Very Fine Sand }\end{array}$ \\
\hline UNH-4_527-529cm & 0.48 & 0.42 & 0.06 & 30.37 & 69.15 & 62.42 & 6.73 & 4.56 & 1.52 & $\begin{array}{l}\text { Slightly Granuley Very } \\
\text { Fine Sandy Silt }\end{array}$ \\
\hline UNH-4_587-589cm & 0.06 & 0.01 & 0.06 & 34.45 & 65.49 & 33.25 & 32.24 & 6.41 & 3.54 & $\begin{array}{l}\text { Slightly Granuley Very } \\
\text { Fine Sandy Silt-Clay }\end{array}$ \\
\hline UNH-13_25-27cm & 0.02 & 0.00 & 0.02 & 92.44 & 7.54 & 5.06 & 2.48 & 2.87 & 0.76 & $\begin{array}{l}\text { Slightly Granuley Fine } \\
\text { Sand }\end{array}$ \\
\hline UNH-13_65-67cm & 0.00 & 0.00 & 0.00 & 93.90 & 6.10 & 3.08 & 3.02 & 2.86 & 0.63 & Fine Sand \\
\hline UNH-13_93-95cm & 0.00 & 0.00 & 0.00 & 90.95 & 9.05 & 5.05 & 4.00 & 2.94 & 0.95 & Fine Sand \\
\hline UNH-13_139-141cm & 0.12 & 0.12 & 0.00 & 87.05 & 12.83 & 6.79 & 6.04 & 2.95 & 1.36 & $\begin{array}{l}\text { Slightly Pebbly Silty- } \\
\text { Clayey Fine Sand }\end{array}$ \\
\hline UNH-13_161-163cm & 0.00 & 0.00 & 0.00 & 20.74 & 79.26 & 36.30 & 42.96 & 7.44 & 3.61 & Very Fine Sandy Silt-Clay \\
\hline UNH-13_182-184cm & 0.25 & 0.00 & 0.25 & 43.47 & 56.28 & 32.91 & 23.37 & 5.74 & 3.32 & $\begin{array}{l}\text { Slightly Granuley Very } \\
\text { Fine Sandy Silt-Clay }\end{array}$ \\
\hline UNH-13_252-254cm & 0.59 & 0.00 & 0.59 & 11.41 & 88.00 & 40.78 & 47.22 & 8.03 & 3.47 & $\begin{array}{l}\text { Slightly Granuley Very } \\
\text { Fine Sandy Silt-Clay }\end{array}$ \\
\hline UNH-13_286-288cm & 1.05 & 0.90 & 0.15 & 75.75 & 23.20 & 12.84 & 10.36 & 3.74 & 2.25 & $\begin{array}{l}\text { Slightly Pebbly Silty- } \\
\text { Clayey Fine Sand }\end{array}$ \\
\hline UNH-13_316-318cm & 0.00 & 0.00 & 0.00 & 25.33 & 74.67 & 36.67 & 38.00 & 7.08 & 3.66 & Very Fine Sandy Silt-Clay \\
\hline UNH-13_423-425cm & 0.00 & 0.00 & 0.00 & 7.30 & 92.70 & 41.16 & 51.54 & 8.37 & 3.23 & Silt-Clay \\
\hline UNH-13_573-575cm & 0.00 & 0.00 & 0.00 & 9.60 & 90.40 & 35.57 & 54.83 & 8.60 & 3.36 & Silt-Clay \\
\hline
\end{tabular}




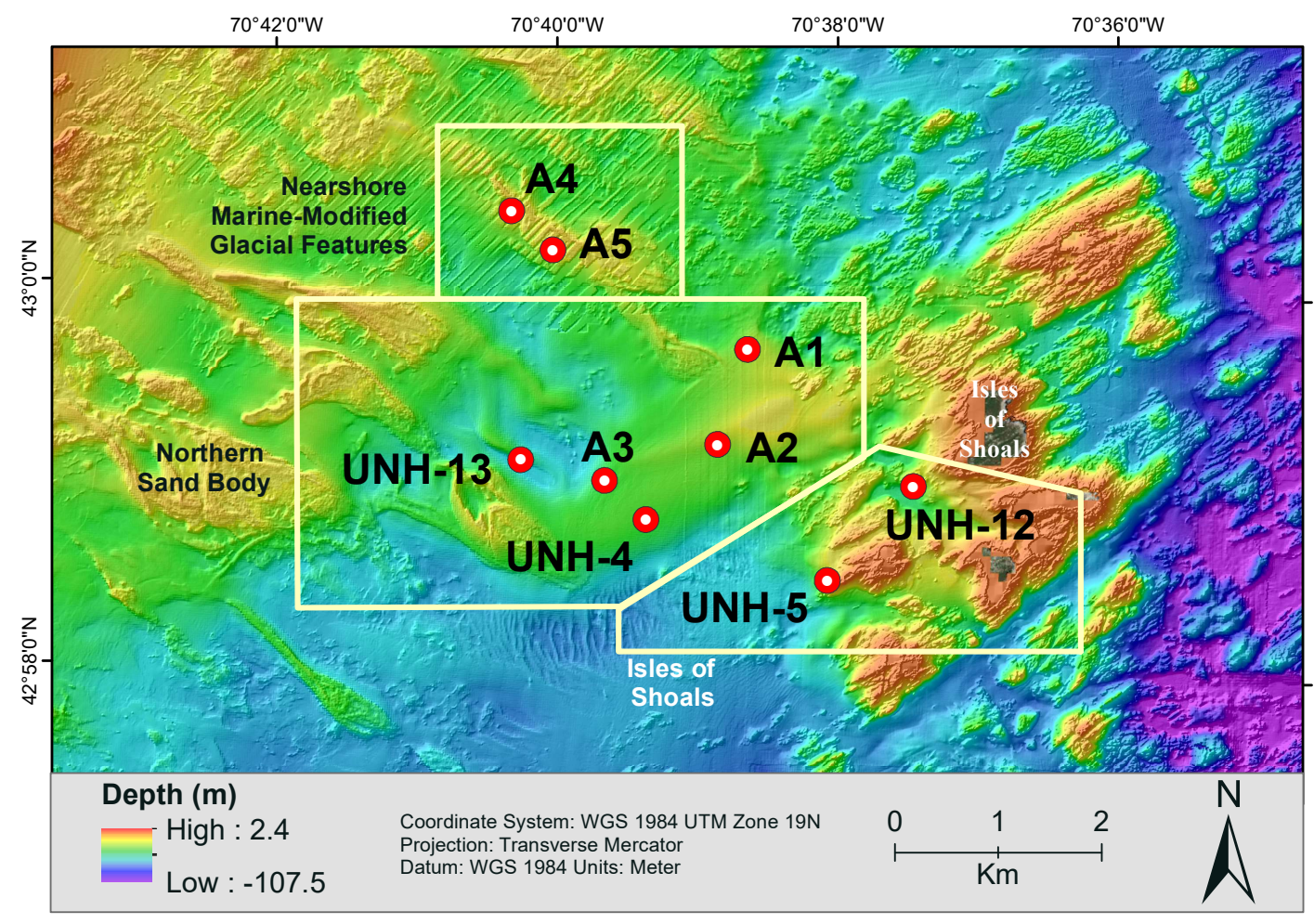

Figure 15. Bathymetric map and location of the vibracores taken in and around the Northern Sand Body (UNH-4, UNH-13, A1, A2, and A3). Vibracores taken in the Nearshore Marine-Modified Glacial Features (Eskers and Drumlins) (A4 and A5) and around the Isles of Shoals (UNH-5 and UNH-12), discussed below, are also shown. Map is shown at a scale of 1:50,000. 

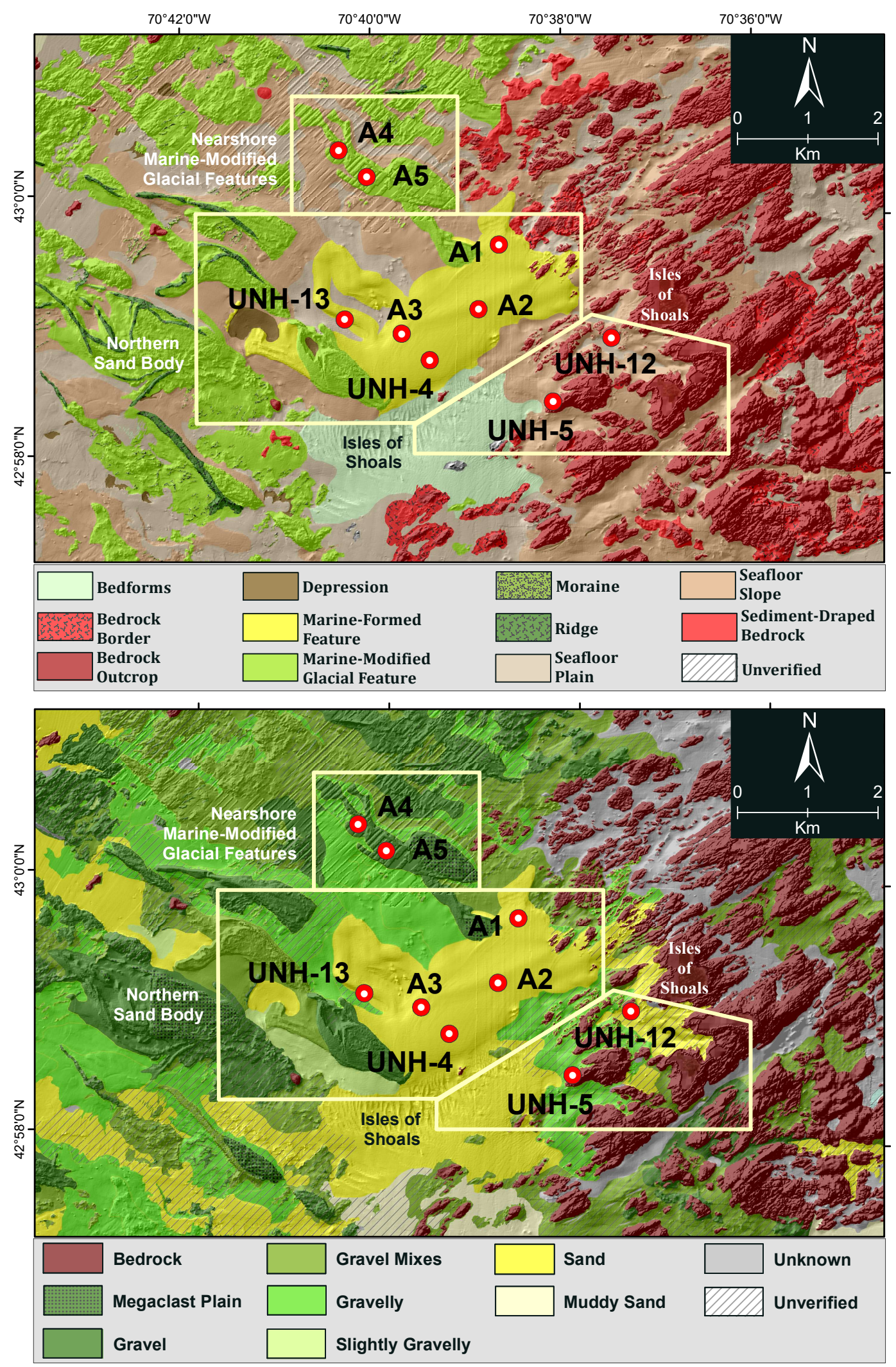

Figure 16. Major geoforms (physiographic features; top) and surficial sediment map (substrate classes; bottom) of the vibracores taken in and around the Northern Sand Body (outlined). Vibracores taken in the Nearshore MarineModified Glacial Features (Eskers and Drumlins) and around the Isles of Shoals, discussed in the next section. 


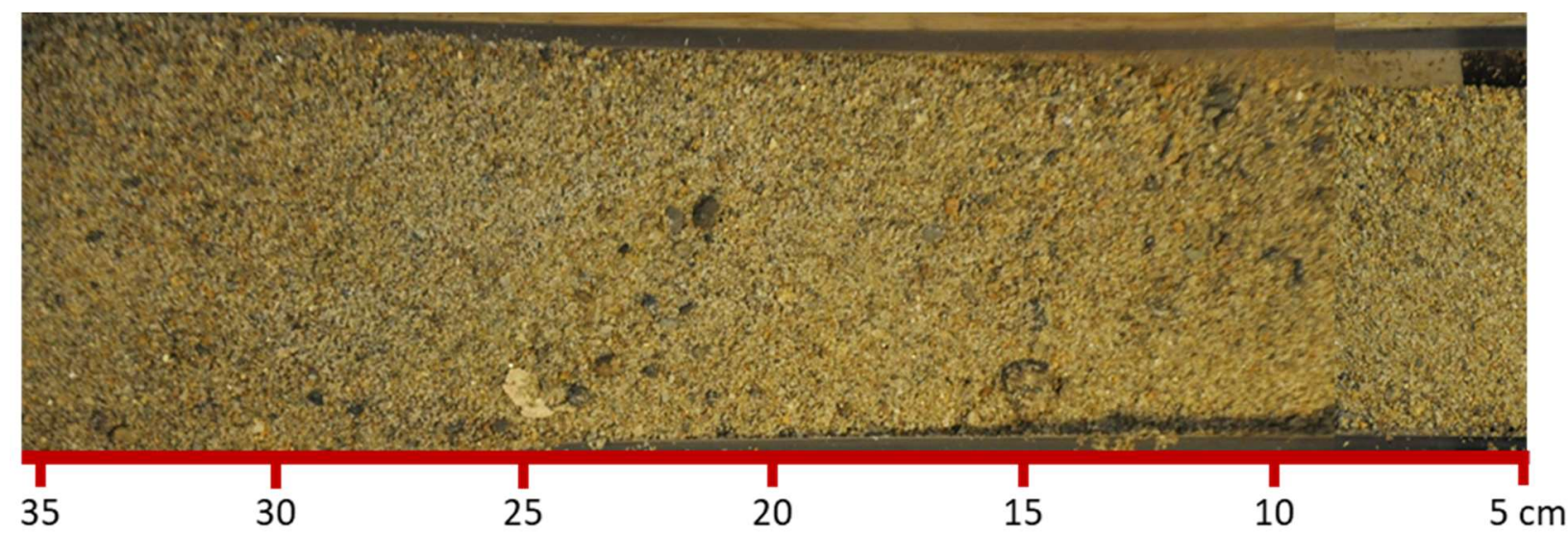

Figure 17. Photograph of vibracore A1 from $\sim 0.05$ to $0.35 \mathrm{~m}$. The top of core is to the right.

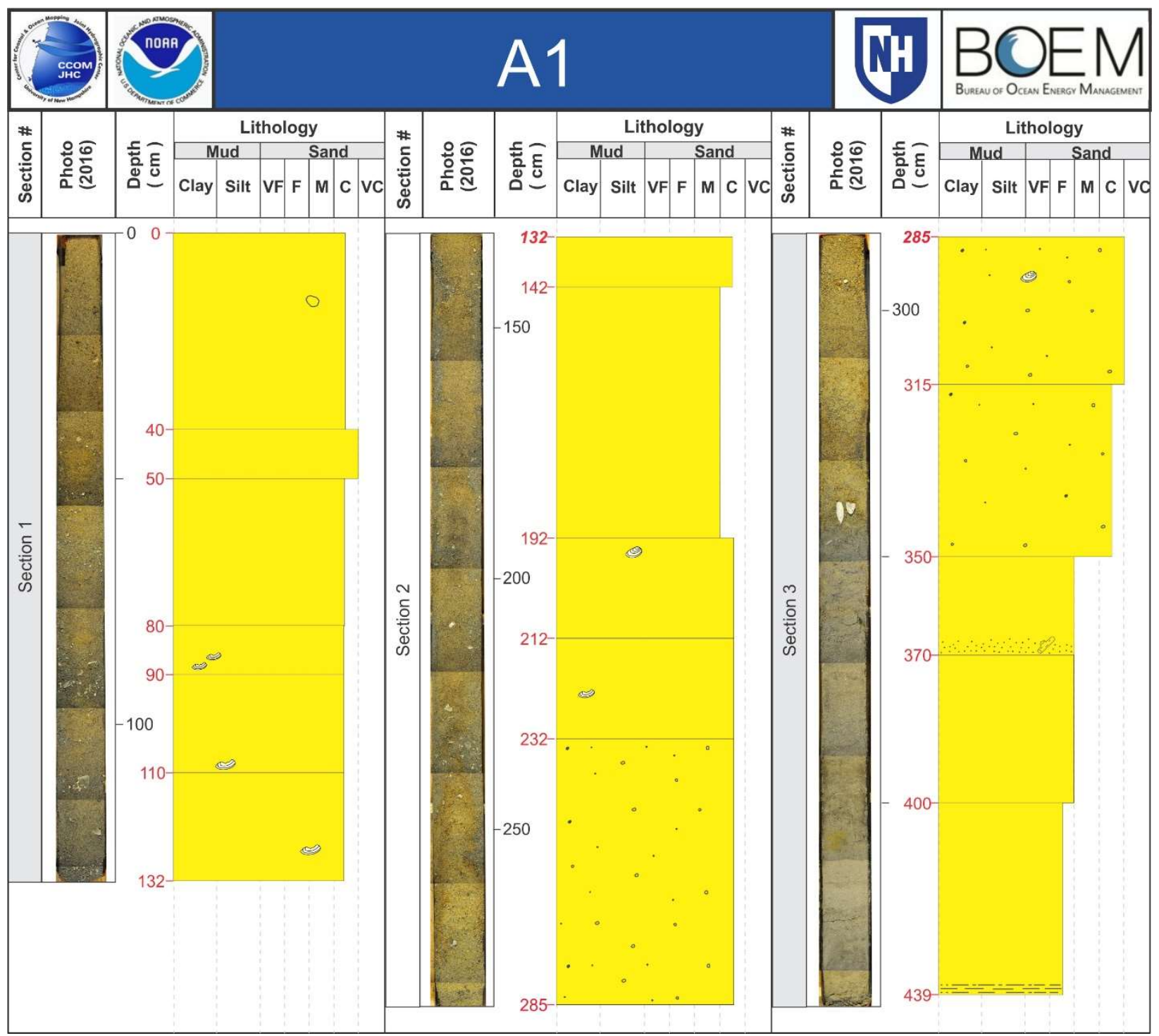

Figure 18. Log for vibracore A1. The location of the core is given in Figures 6, 15, and 16. A photograph of the surface is shown in Figure 17. A full description of the core is given in Appendix A. 


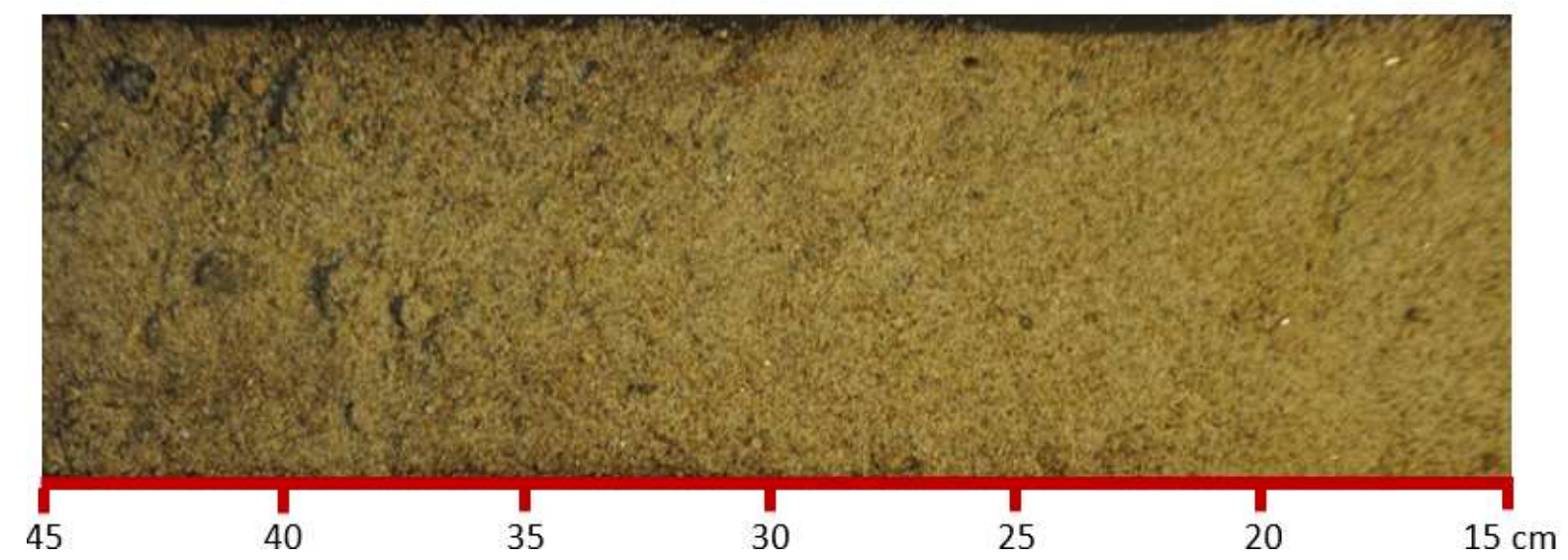

Figure 19. Photograph of vibracore A2 from $\sim 0.15$ to $0.45 \mathrm{~m}$.

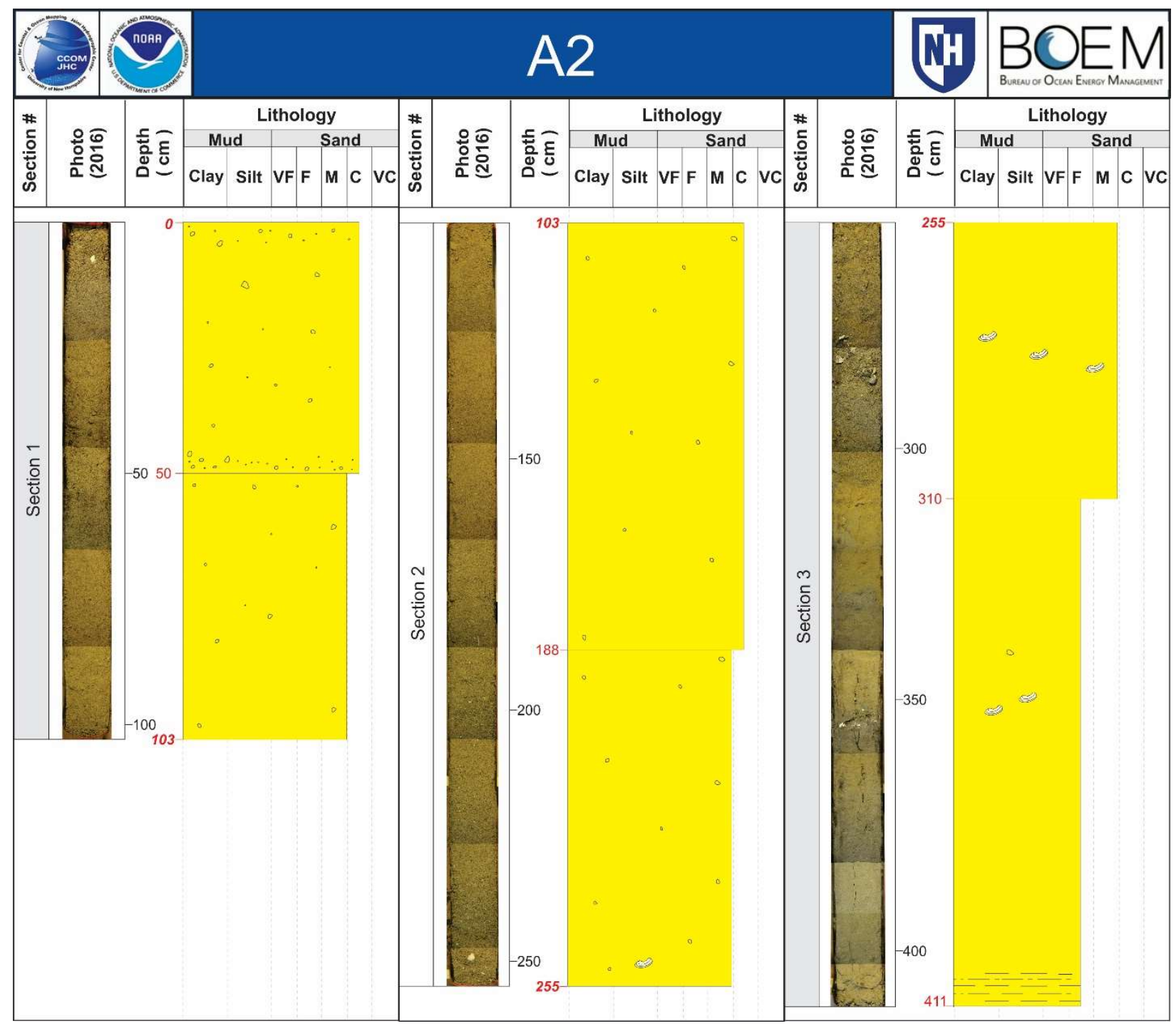

Figure 20a. Core log for A2 for the upper 4.11m (the core from 4.11 to $7.13 \mathrm{~m}$ is shown in Figure 20b). The location of the vibracore is shown in Figures 6, 15, and 16. A photograph of the top of the vibracore is shown in Figure 19. The full core log with greater detail is given in Appendix $A$. 


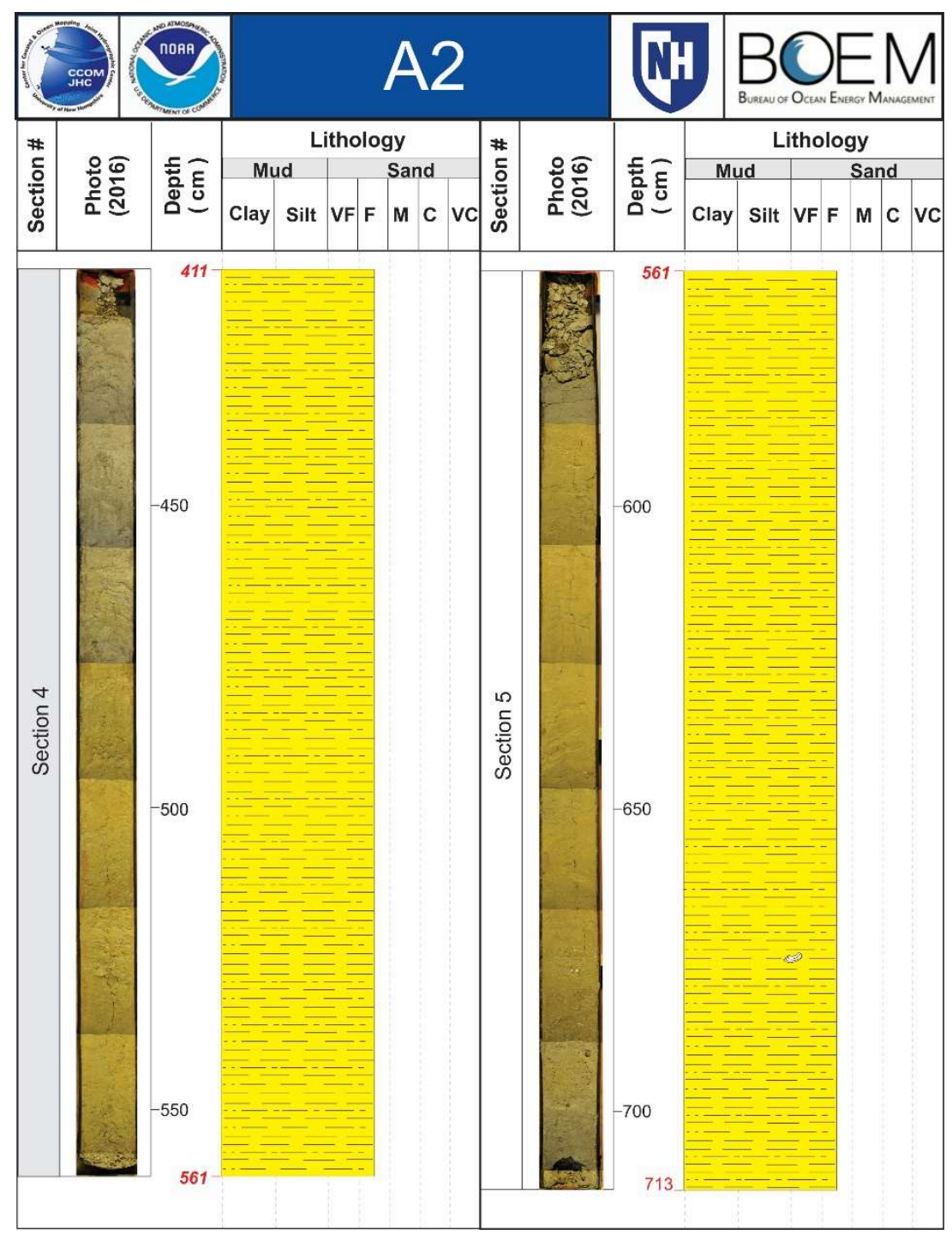

Figure 20b. Log for the lower portion of vibracore A2 from 4.11 to $7.13 \mathrm{~m}$. The location of the vibracore is shown in Figures 6, 15, and 16. The upper 4.11m is shown in Figure 20 a above.

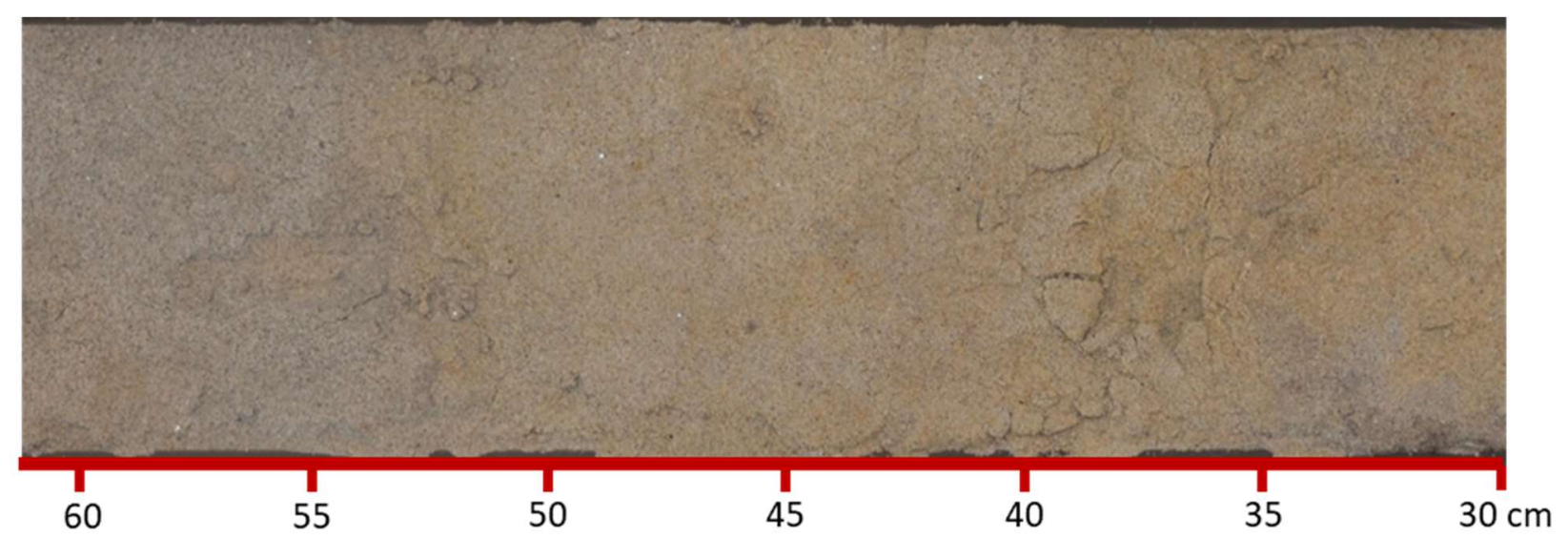

Figure 21. Photograph of vibracore A3 from 0.30 to $0.61 \mathrm{~m}$. Core log for vibracore A3 is shown in Figure 22 (below). 


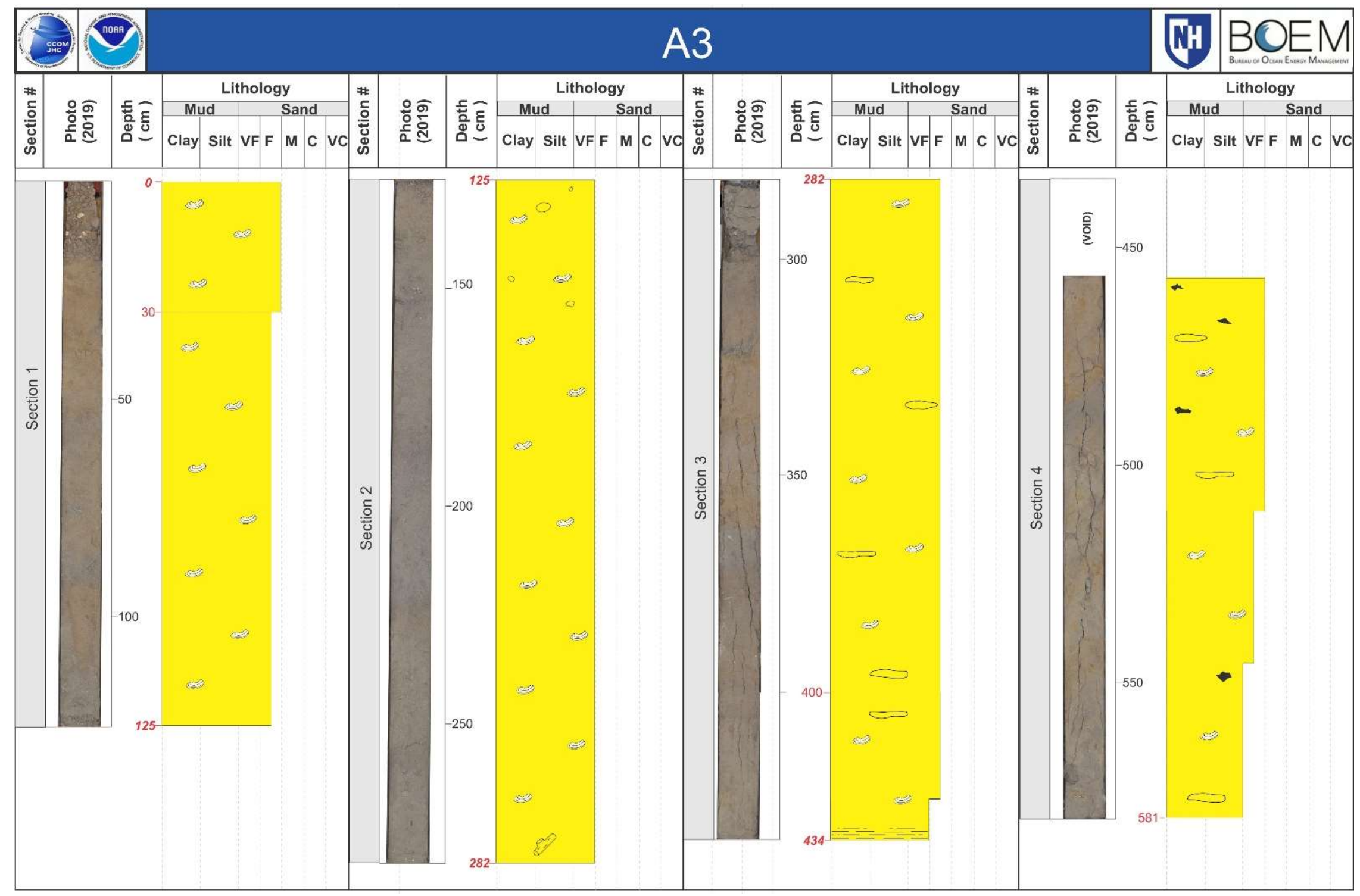

Figure 22. Core log for A3. The location of the core is given in Figures 6, 15, and 16. A photograph of the surface is shown in Figure 21 (above). A full description of the core is given in Appendix A. 


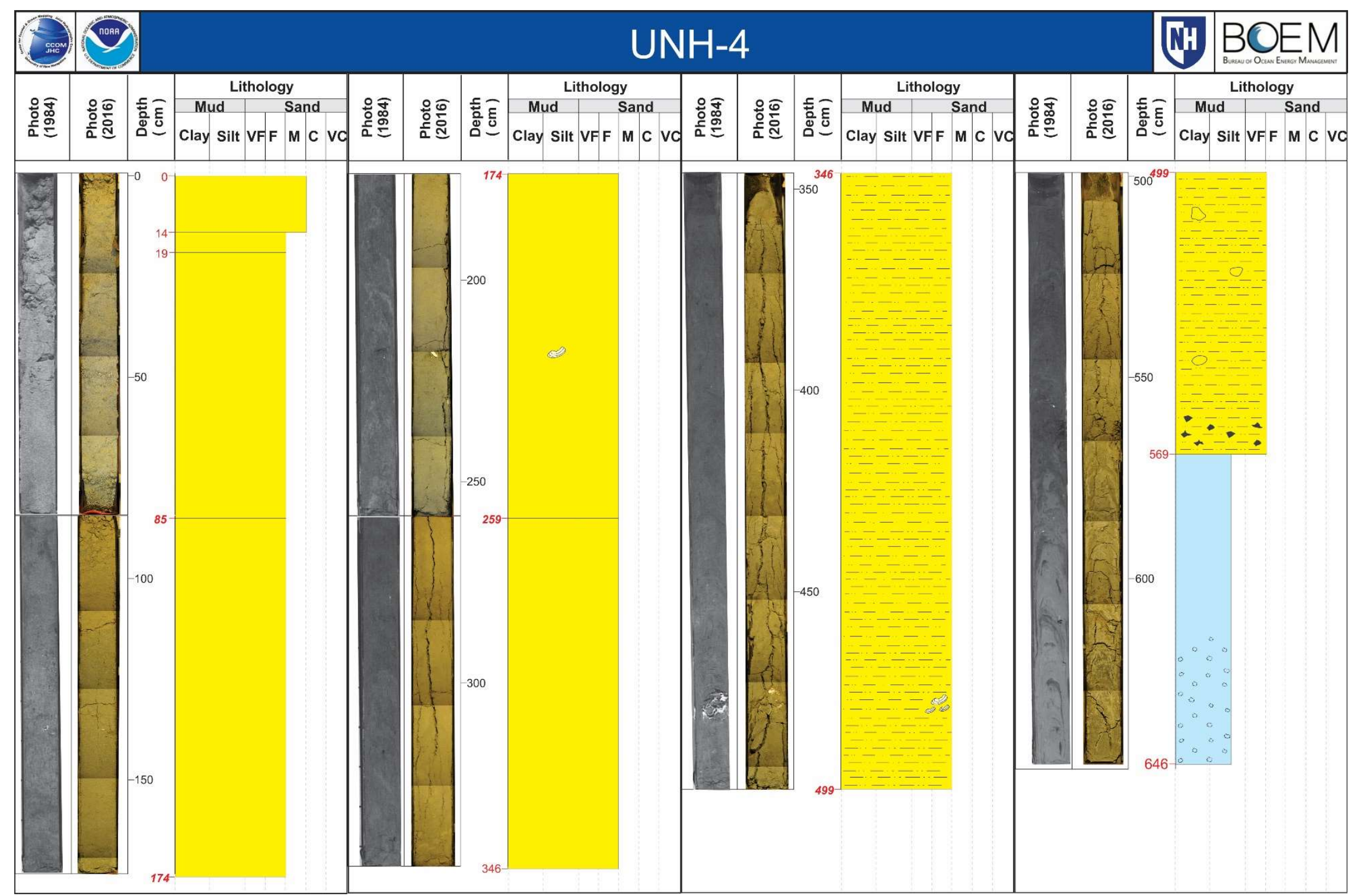

Figure 23. Log for vibracore UNH-4. The location of the core is given in Figures 6, 15, and 16. A photograph of the surface is shown in Figure 24 (below). A full description of the core is given in Appendix A. 


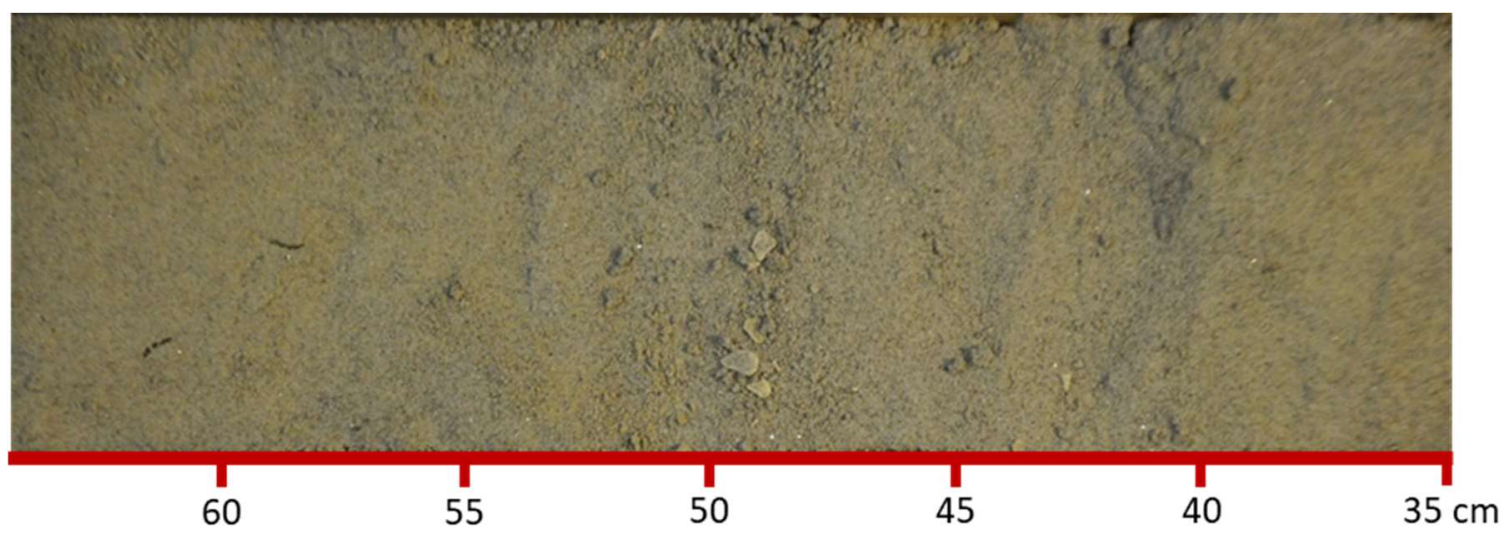

Figure 24. Photograph of vibracore UNH-4 from 0.35 to $0.64 m$. Core log for UNH-4 is shown above in Figure 23.

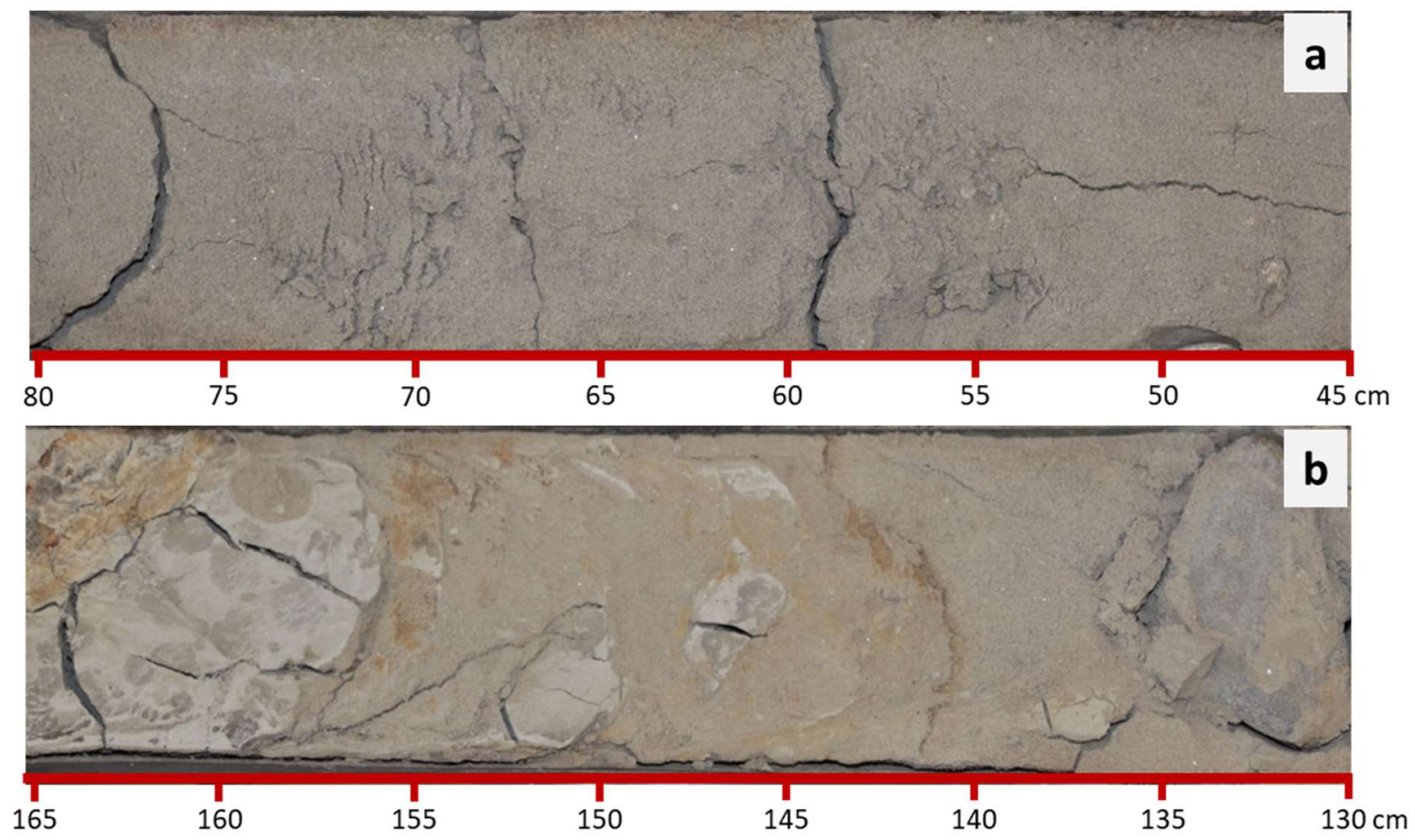

Figure 25. Photographs of vibracore UNH-13. Top photo (a) is from the upper core from 0.45 to $0.80 \mathrm{~m} ;$ bottom photo (b) is from 1.30 to $1.65 \mathrm{~m}$. In bottom photo (b) note rip up clasts and large dropstone. Core log for UNH-13 is shown below in Figure 26. 


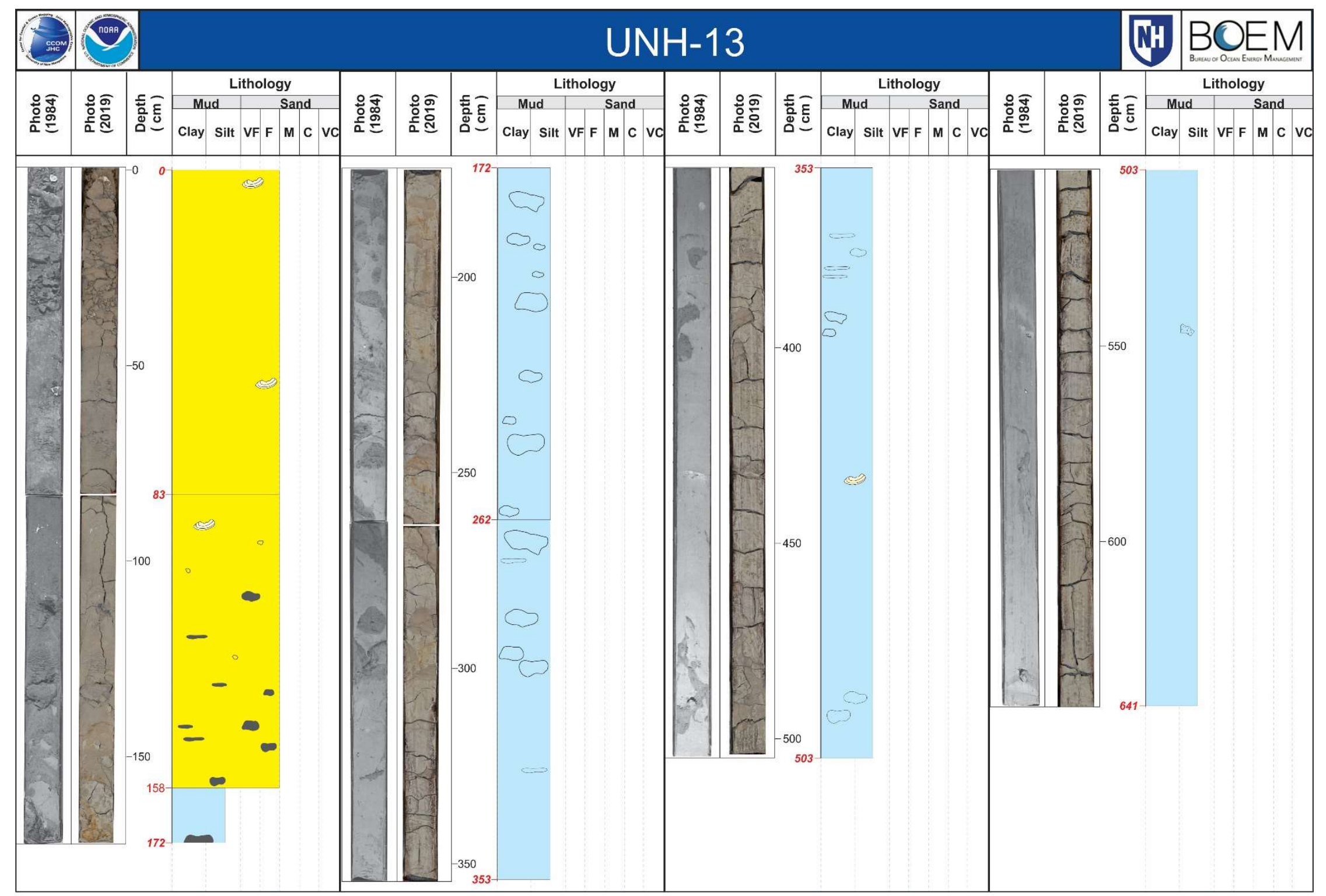

Figure 26. Core log for UNH-13. The location of the core is given in Figures 6, 15, and 16. Two photographs of the core are shown above in Figure 25 (above). A full description of the core is given in Appendix A. 


\section{Isles of Shoals}

Two vibracores were taken seaward of the Northern Sand Body close to the Isles of Shoals in relatively shallow water (UNH-5 and UNH-12) (Figures 6, 15, and 16). These vibracores represent nearshore deposits that were subaerially exposed during the early Holocene sea-level lowstand 12,000 yrs B.P. (Figure 2). As a result, the seafloor and the vibracores were subjected to shallow water and intertidal wave and current processes during the late Pleistocene regression and ensuing transgression (reviewed in Ward et al., 2021b). This is apparent when examining core UNH-5 which has a $3.2 \mathrm{~m}$ shell hash layer at the surface.

\section{Vibracore UNH-5}

UNH-5 is a long core $(7.13 \mathrm{~m})$ recovered near the Isles of Shoals in $\sim 22 \mathrm{~m}$ water depth and close to bedrock outcrops. The first $\sim 3.2 \mathrm{~m}$ of the core is completely composed of shell hash with scattered shell and rock fragments (Figures 27 and 28). The shell hash fines downward, beginning with coarse shell hash for the first $\sim 1 \mathrm{~m}$ and progressively becoming finer with depth. No grain size analyses were performed on this section of the core. Below the shell hash, the core is predominantly a pebbly silty fine sand from $3.22 \mathrm{~m}$ to the base at $7.64 \mathrm{~m}$ (Table 7). The exception is a small shell hash layer from $\sim 3.67$ to $3.78 \mathrm{~m}$ depth. A sediment sample from $4.05-4.07 \mathrm{~m}$ is $\sim 9 \%$ gravel (shells), $68 \%$ sand, and $23 \%$ mud with a mean grain size of $2.58 \phi(0.167 \mathrm{~mm})$. A sample taken near the base at $7.00-7.02 \mathrm{~m}$ is $\sim 8 \%$ gravel (shells), $62 \%$ sand, and $31 \%$ mud with a mean grain size of $3.04 \phi(0.122 \mathrm{~mm})$.

The thick shell hash layer in the upper $3.2 \mathrm{~m}$ of the vibracore is believed to have formed during the late Pleistocene regression and early Holocene transgression. Waves and shallow water currents likely eroded calcareous bivalves and other encrusting organisms that grew on the nearby bedrock outcrops and megaclast platforms by the Isles of Shoals and deposited them in deeper depressions. Once deposited in deeper water, the shell hash was preserved.

\section{Vibracore UNH-12}

UNH-12 was taken close to the Isles of Shoals $(\sim 0.5 \mathrm{~km})$ in $\sim 28 \mathrm{~m}$ of water. The location is in the middle of bedrock outcrops. The core is $2.44 \mathrm{~m}$ in length. The upper $0.33 \mathrm{~m}$ is comprised of fine to medium sand with some rock fragments (Figure 29). The sand fines downward transitioning into clayey silt with numerous sand lenses and shell hash pods which extends down to $\sim 1.9 \mathrm{~m}$. This section is likely the glacial marine clay of the Presumpscot Formation. The core ends in a fine to medium sand from $\sim 1.9 \mathrm{~m}$ to the base at $\sim 2.4 \mathrm{~m}$, with numerous rock fragments.

The upper sand layer is likely a shallow water deposit eroded into the underlying glacial marine muds (Presumpscot Formation). The lower sand layer was interpreted as lodgement till by Birch (1984). However, the lack of fines indicates it must have been winnowed at the sea-level lowstand. No subsamples were taken for grain size analysis. 
Table 7. Grain size data for vibracore UNH-5 taken near the Isles of Shoals (Figure 15). The top three meters of core is shell hash. Complete grain size classifications and statistics are given in Appendix $B$.

\begin{tabular}{|c|c|c|c|c|c|c|c|c|c|c|}
\hline UNH Sample ID & $\begin{array}{l}\text { Gravel } \\
\%\end{array}$ & $\begin{array}{l}\text { Pebble } \\
\%\end{array}$ & $\begin{array}{l}\text { Granule } \\
\%\end{array}$ & $\begin{array}{l}\text { Sand } \\
\%\end{array}$ & $\begin{array}{l}\text { Mud } \\
\%\end{array}$ & $\begin{array}{l}\text { Silt } \\
\%\end{array}$ & $\begin{array}{l}\text { Clay } \\
\%\end{array}$ & $\begin{array}{l}\text { Mean Size } \\
\text { (phi) }\end{array}$ & $\begin{array}{l}\text { Sorting } \\
\text { (phi) }\end{array}$ & $\begin{array}{l}\text { CMECS (FGDC 2012) } \\
\text { Substrate Component } \\
\text { Subgroup (Specific) } \\
\end{array}$ \\
\hline UNH-5_331-333cm & 14.23 & 8.59 & 5.64 & 77.79 & 7.98 & 5.45 & 2.53 & 1.81 & 2.25 & Granuley Very Fine Sand \\
\hline UNH-5_405-407cm & 9.19 & 4.94 & 4.26 & 67.48 & 23.33 & 17.74 & 5.59 & 2.58 & 2.73 & $\begin{array}{l}\text { Pebbly Silty Very Fine } \\
\text { Sand }\end{array}$ \\
\hline UNH-5_446-448cm & 7.79 & 5.55 & 2.24 & 70.11 & 22.10 & 16.73 & 5.37 & 2.61 & 2.64 & $\begin{array}{l}\text { Pebbly Silty Very Fine } \\
\text { Sand }\end{array}$ \\
\hline UNH-5_556-558cm & 7.17 & 4.62 & 2.54 & 73.02 & 19.81 & 16.06 & 3.75 & 2.60 & 2.29 & $\begin{array}{l}\text { Pebbly Silty Very Fine } \\
\text { Sand }\end{array}$ \\
\hline UNH-5_588-590cm & 22.53 & 18.96 & 3.56 & 49.93 & 27.54 & 21.77 & 5.77 & 1.49 & 3.98 & $\begin{array}{l}\text { Pebbly Silty Very Fine } \\
\text { Sand }\end{array}$ \\
\hline UNH-5_700-702cm & 7.64 & 4.18 & 3.46 & 61.91 & 30.45 & 21.56 & 8.89 & 3.04 & 3.23 & Pebbly Silty Fine Sand \\
\hline
\end{tabular}




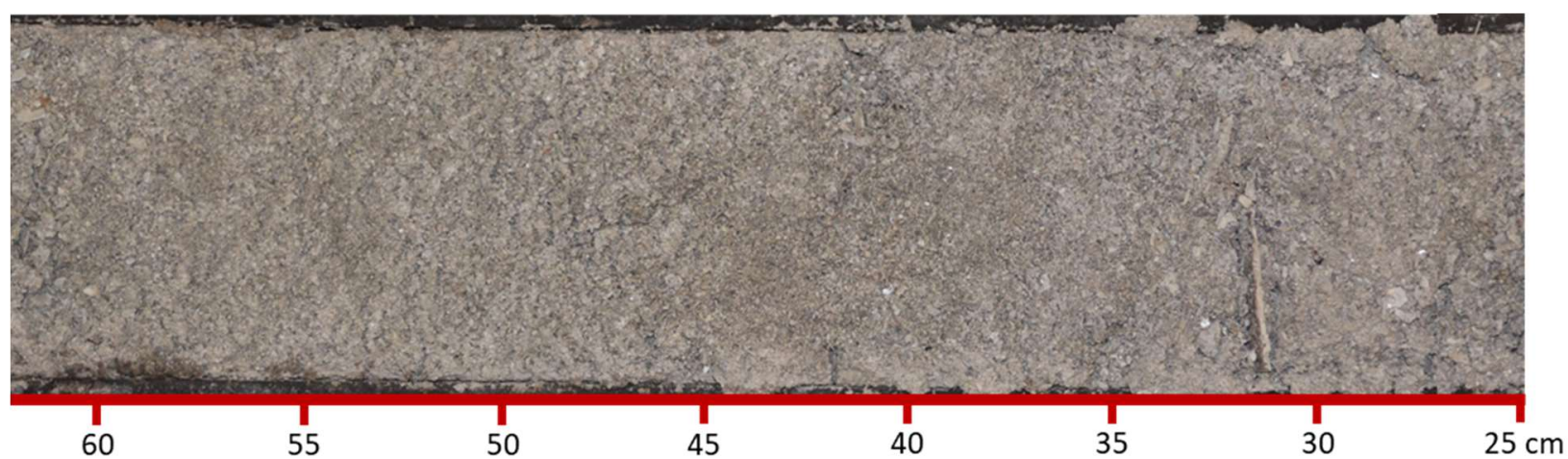

Figure 27. Photograph of vibracore UNH-5 from 0.25 to $0.62 \mathrm{~m}$. The upper $3.22 \mathrm{~m}$ of the vibracore is almost entirely composed of shell hash. The top of the core is to the right.

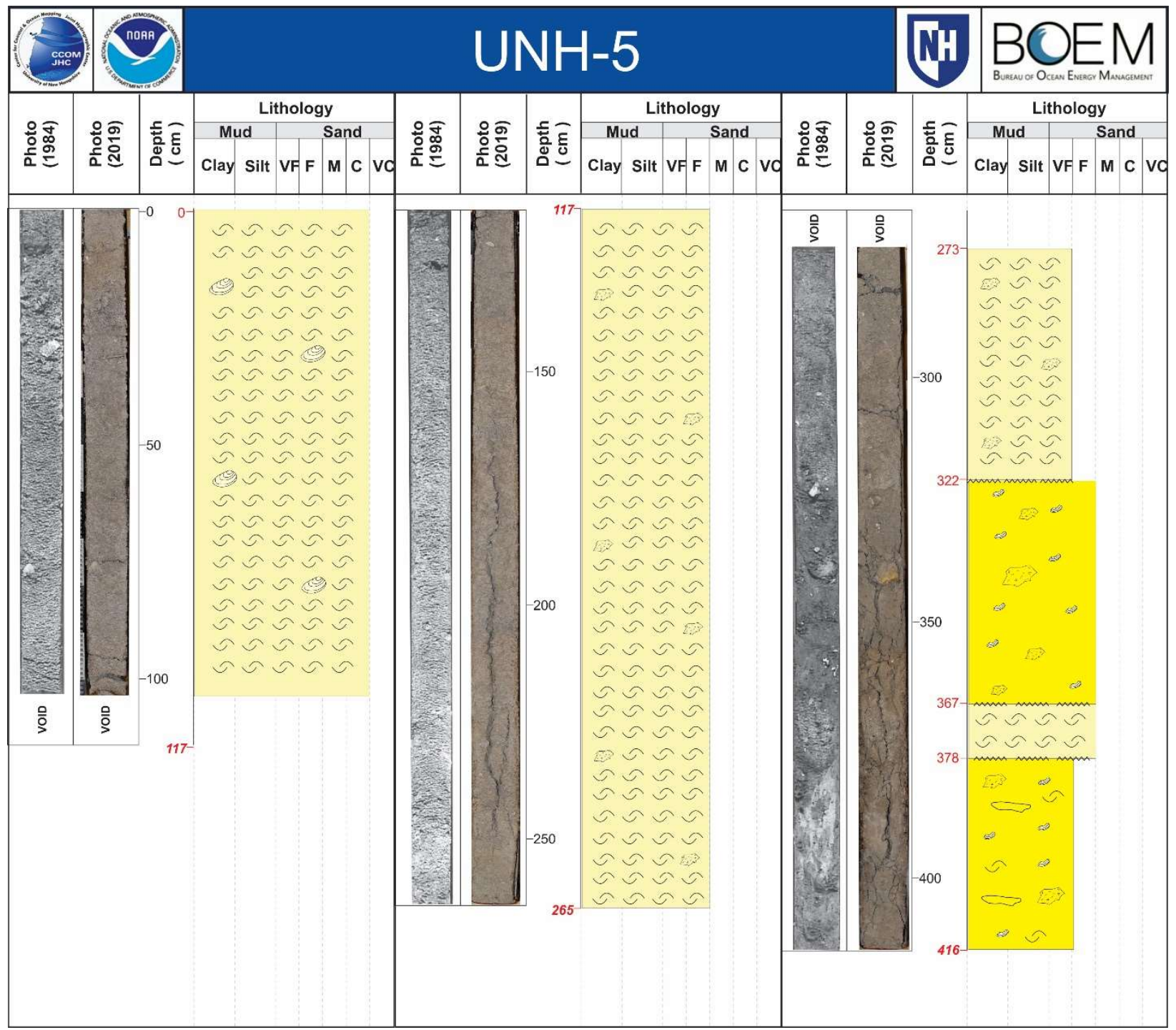

Figure 28a. Core log of the upper $4.15 \mathrm{~m}$ of $A 2$. The lower core log (4.26 to $7.13 \mathrm{~m} ; 4.11$ to $4.26 \mathrm{~m}$ is missing) is shown in Figure 28b. The location of the vibracore is shown in Figures 6, 15, and 16. A photograph of the top of the vibracore is shown in Figure 27. The full core log with greater detail is given in Appendix A. 


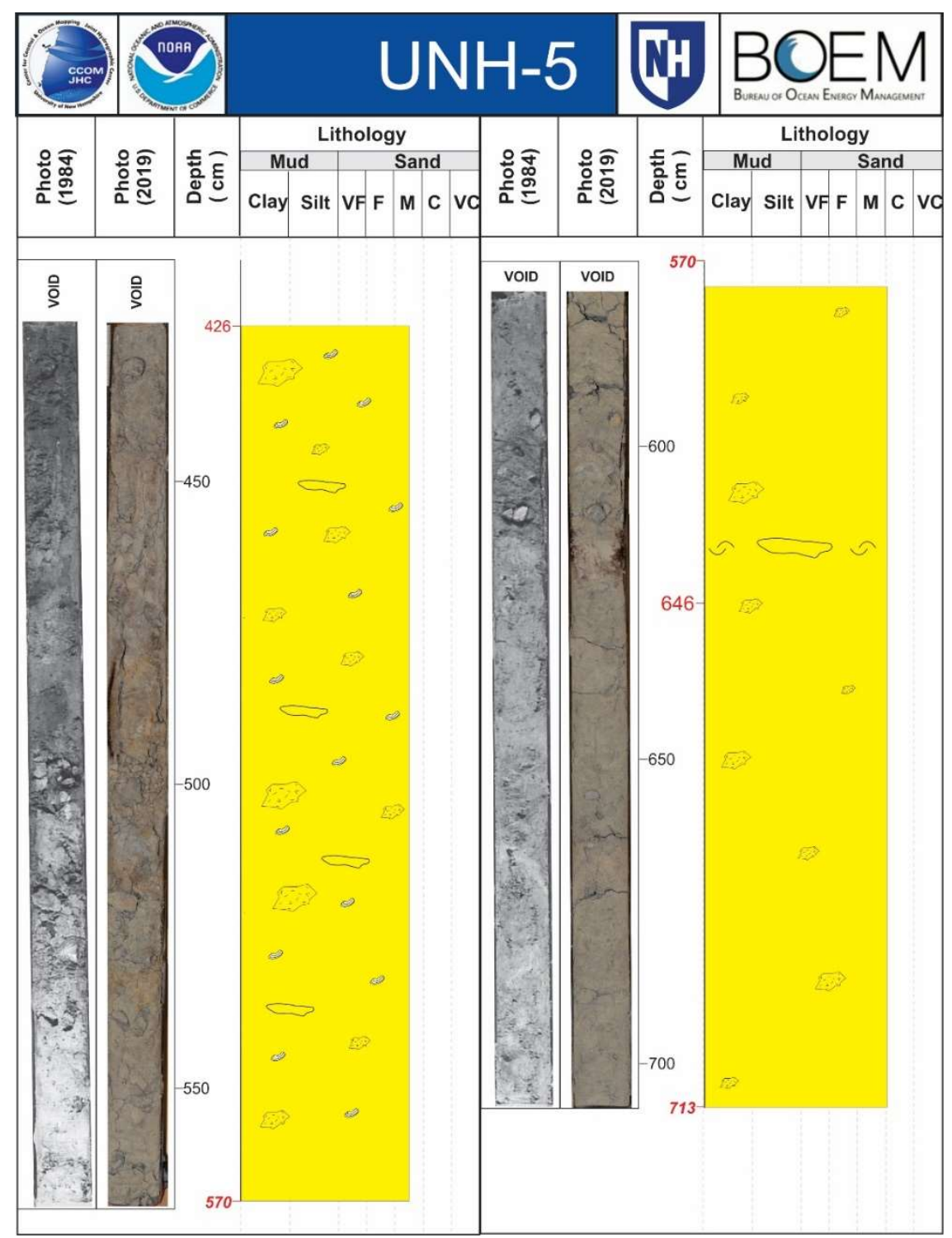

Figure 28b. UNH-5 core log for the lower section (4.26 to 7.13m). The upper $4.15 \mathrm{~m}$ is shown in Figure $28 \mathrm{a}$. 


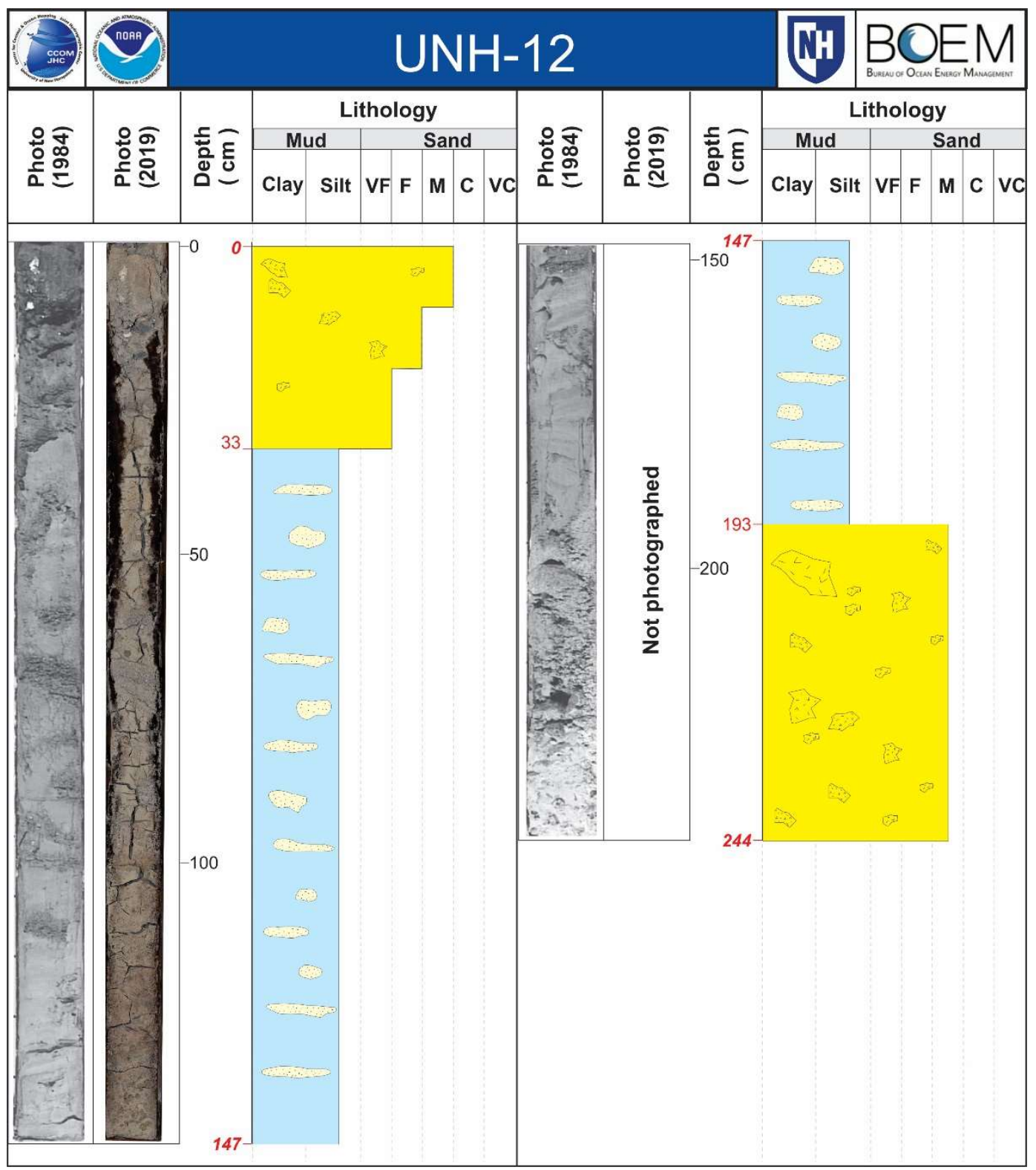

Figure 29. Core log UNH-12. The location of the core is given in Figures 6, 15, 16. A full description of the core is given in Appendix A. 


\section{Nearshore Marine-Modified Glacial Features (Eskers and Drumlins)}

Note: These features were referred to in earlier reports as the Northern Sand Body Extended (NSBE) (see Ward et al., 2021a).

Many of the depositional features found landward of the Isles of Shoals and south of Portsmouth Harbor appear to be glacial in origin, which have been significantly modified by marine processes as sea level fluctuated since the end of the last major glaciation (Figure 2). Included are megaclast platforms that appear to be the base of eroded drumlins (Figures 6, 15, and 16). Associated shoals are hypothesized to be sediment-derived from the eroded drumlin, transported by wave action as sea level rose and transgressed as discussed in Carter and Orford (1988). Several linear ridges hundreds of meters in length, many oriented northeast-southwest or relatively perpendicular to the $\mathrm{NH}$ shoreline, also occur landward of the Isles of Shoals. These features have been hypothesized by Ward et al. (2021a) to be glacial in origin, most likely eskers, that have been modified by marine processes. The esker-like feature where vibracores A4 and A5 were taken was exposed during the last sea-level lowstand, subjecting the glacial feature to waves and nearshore process during the Holocene transgression (Figure 2). Seafloor photographs show the surficial sediments are pebble and megaclast deposits that appear to overlay sand and gravel (Ward et al., 2021b). However, the feature has a broad megaclast platform on the seaward side that appears to be the base of an eroded drumlin. Presently, the origin of this esker-like feature is not clear.

Vibracores A4 and A5 were taken on one of the presumably modified eskers (Figure 6 and 16). The linear ridge is $\sim 1.6 \mathrm{~km}$ in length and $\sim 0.2 \mathrm{~km}$ in width. However, it appears to extend from a megaclast platform measuring $\sim 1.0$ by $0.6 \mathrm{~km}$.

\section{Vibracore A4}

A4 was taken at a depth of $\sim 20 \mathrm{~m}$ (estimated from a high-resolution bathymetry map) $\sim 100 \mathrm{~m}$ from the crest of the ridge of a marine-modified glacial deposit (Figures 6, 15, and 16). It is hypothesized here that the area where the vibracore was collected is a shoal which was eroded from the adjacent esker during the last transgression. A4 is $5.75 \mathrm{~m}$ in length and is primarily composed of very coarse sand to gravelly sediments with shell fragments, pebbles, and cobbles in the upper $\sim 2.5 \mathrm{~m}$ (Figures 30 and 31).

Grain size analysis of subsamples from the upper $\sim 2.0 \mathrm{~m}$ of the core show high gravel content ranging from $\sim 22 \%$ at $0.08-0.12 \mathrm{~m}$ up to $\sim 66 \%$ at $0.90-0.95 \mathrm{~m}$ (Table 8 ). However, the largest clasts are not sampled, so the analyses represent the matrix. The matrix samples range from granuley coarse sand to sandy granule gravel. From $\sim 2.00$ to $2.54 \mathrm{~m}$ the large pebble and cobble content decreases and the sediment becomes sandier. Below $\sim 2.54 \mathrm{~m}$ down to $4.28 \mathrm{~m}$ the sediments range from slightly granuley medium sand to slightly granuley coarse sand with scattered small pebbles. Sand content varies from $\sim 90$ to $96 \%$. Mean grain sizes range from $0.95 \phi(0.518 \mathrm{~mm})$ at $2.48-2.53 \mathrm{~m}$ down to $1.61 \phi(0.328 \mathrm{~mm})$ at $4.08-4.10 \mathrm{~m}$.

The section below $4.28 \mathrm{~m}$ to the base of the core at $5.75 \mathrm{~m}$ is somewhat confusing as an unexpected mud layer occurs from 4.28 to $4.73 \mathrm{~m}$ that appears to be a glacial marine mud associated with the Presumpscot Formation. A subsample taken from this muddy layer at $4.44-4.46 \mathrm{~m}$ is a very fine sandy silt, with a mud content of $\sim 84 \%$ and a mean grain size of $6.11 \phi(0.014 \mathrm{~mm})$, which is consistent with the Presumpscot Formation distal facies. Also, the upper part of the sandy mud has shell hash and a wood fragment suggesting that the contact is an erosional unconformity developed during the last sea-level transgression. However, what is unexpected is the transition to a muddy sand below the mud layer beginning at $4.73 \mathrm{~m}$, which coarsens downward to a very coarse sand to a gravelly layer at the base of the core at $5.75 \mathrm{~m}$. It is possible that the coarser sediment at the base of the vibracore is a proximal deposit of the receding ice front that was then draped by the more distal glacial muds as the ice front moved further inland. An alternative is that the sediment is lodgement till that has been winnowed. 


\section{Vibracore A5}

Vibracore A5 was taken at a water depth of $\sim 19 \mathrm{~m}$ (estimated from a high-resolution bathymetry map) $\sim 175 \mathrm{~m}$ away from the crest of the linear feature or marine-modified glacial deposit (Figures 6, 15, and 16). At present, it is hypothesized here that the ridge is the remnant of an eroded esker and that the area where the vibracore was collected is a shoal that was eroded from the adjacent ridge during the last transgression.

Although core A5 is shorter than A4 at $3.36 \mathrm{~m}$, it shows similar stratigraphy. The upper $1.52 \mathrm{~m}$ is comprised of a coarse to very coarse sand matrix or granule gravel with pebbles and cobbles (Figures 32 and 33). Three samples taken for grain size analysis in this upper part of the core are sandy pebble gravels with gravel contents ranging from $\sim 59$ to $71 \%$ (Table 8 ). Mean grain size ranges from $-1.58 \phi(2.99 \mathrm{~mm})$ to $-2.84 \phi(7.16 \mathrm{~mm})$. From $\sim 1.52$ to $1.67 \mathrm{~m}$ the composition changes but is still a sandy pebble gravel. From $\sim 1.67$ to $2.31 \mathrm{~m}$ the sediment becomes significantly finer. A sample from $2.05-2.07 \mathrm{~m}$ is a slightly pebbly very fine sandy silt with $\sim 34 \%$ sand and $65 \%$ mud and a mean grain size of $4.47 \phi(0.045 \mathrm{~mm})$. A sample from $2.21-2.23 \mathrm{~m}$ is a very fine sandy silt with $\sim 43 \%$ sand and $57 \%$ mud and a mean grain size of $4.60 \phi$ $(0.041 \mathrm{~mm})$. The contact between the overlying gravel and the muddy sediments is sharp suggesting an erosional contact. It is presumed the mud is a glacial marine sediment or the Presumpscot Formation distal facies which is Pleistocene in age. From $\sim 2.3 \mathrm{~m}$ to the base of the core, the sediments are composed of slightly granuley medium sand or pebbly medium sand. The coarse sediment underlying the glacial marine mud is similar to that in core A4 and is presumed to be either proximal glacial marine sediment or lodgement till. 
Table 8. Grain size data for vibracores taken in the Nearshore Marine-Modified Glacial Features (Eskers and Drumlins): A4 and A5 (Figures 6 and 16). Complete grain size classifications and statistics are given in Appendix B.

\begin{tabular}{|c|c|c|c|c|c|c|c|c|c|c|}
\hline UNH Sample ID & $\begin{array}{l}\text { Gravel } \\
\%\end{array}$ & $\begin{array}{l}\text { Pebble } \\
\%\end{array}$ & $\begin{array}{l}\text { Granule } \\
\%\end{array}$ & $\begin{array}{l}\text { Sand } \\
\%\end{array}$ & $\begin{array}{l}\text { Mud } \\
\%\end{array}$ & $\begin{array}{l}\text { Silt } \\
\%\end{array}$ & $\begin{array}{l}\text { Clay } \\
\%\end{array}$ & $\begin{array}{l}\text { Mean Size } \\
\text { (phi) }\end{array}$ & $\begin{array}{l}\text { Sorting } \\
\text { (phi) }\end{array}$ & $\begin{array}{l}\text { CMECS (FGDC 2012) } \\
\text { Substrate Component } \\
\text { Subgroup (Specific) }\end{array}$ \\
\hline A4_8-12cm & 22.14 & 5.76 & 16.38 & 74.30 & 3.56 & NA & NA & 0.32 & 1.68 & Granuley Coarse Sand \\
\hline A4_30-32cm & 45.10 & 28.30 & 16.80 & 53.81 & 1.09 & NA & NA & -0.94 & 1.70 & Sandy Granule Gravel \\
\hline A4_90-95cm & 65.96 & 54.75 & 11.21 & 32.30 & 1.74 & NA & NA & -2.02 & 2.39 & Sandy Pebble Gravel \\
\hline A4_143-153cm & 48.78 & 35.05 & 13.73 & 48.09 & 3.13 & NA & NA & -1.13 & 2.31 & Sandy Granule Gravel \\
\hline A4_213-216cm & 3.33 & 0.57 & 2.76 & 91.53 & 5.14 & 3.76 & 1.38 & 1.21 & 1.27 & $\begin{array}{l}\text { Slightly Granuley Medium } \\
\text { Sand }\end{array}$ \\
\hline A4_248-253cm & 4.71 & 1.71 & 3.00 & 91.09 & 4.20 & NA & NA & 0.95 & 1.09 & $\begin{array}{l}\text { Slightly Granuley Coarse } \\
\text { Sand }\end{array}$ \\
\hline A4_288-290cm & 0.40 & 0.00 & 0.40 & 90.72 & 8.88 & 5.60 & 3.28 & 1.88 & 1.29 & $\begin{array}{l}\text { Slightly Granuley Medium } \\
\text { Sand }\end{array}$ \\
\hline A4_326-328cm & 7.72 & 3.59 & 4.13 & 89.48 & 2.80 & NA & NA & 1.03 & 1.13 & Granular Medium Sand \\
\hline A4_358-360cm & 1.03 & 0.42 & 0.61 & 95.99 & 2.98 & NA & NA & 1.37 & 0.69 & $\begin{array}{l}\text { Slightly Granuley Medium } \\
\text { Sand }\end{array}$ \\
\hline A4_408-410cm & 0.08 & 0.00 & 0.08 & 95.59 & 4.33 & NA & NA & 1.61 & 0.70 & $\begin{array}{l}\text { Slightly Granuley Medium } \\
\text { Sand }\end{array}$ \\
\hline A4_444-446cm & 0.00 & 0.00 & 0.00 & 15.96 & 84.04 & 63.12 & 20.92 & 6.11 & 2.85 & Very Fine Sandy Silt \\
\hline A4_491-495cm & 0.00 & 0.00 & 0.00 & 40.06 & 59.94 & 46.82 & 13.12 & 4.84 & 2.25 & Very Fine Sandy Silt \\
\hline A4_536-539cm & 1.13 & 0.00 & 1.13 & 97.72 & 1.15 & NA & NA & 0.99 & 0.68 & $\begin{array}{l}\text { Slightly Granuley Medium } \\
\text { Sand }\end{array}$ \\
\hline A4_575-577cm & 33.65 & 24.52 & 9.13 & 62.48 & 3.87 & NA & NA & -0.72 & 2.41 & Sandy Pebble Gravel \\
\hline A5_20-22cm & 58.90 & 47.77 & 11.13 & 38.04 & 3.06 & NA & NA & -1.58 & 2.33 & Sandy Pebble Gravel \\
\hline A5_80-82cm & 66.65 & 54.26 & 12.39 & 30.55 & 2.80 & NA & NA & -2.11 & 2.10 & Sandy Pebble Gravel \\
\hline A5_121-123cm & 71.31 & 65.52 & 5.79 & 26.42 & 2.27 & NA & NA & -2.84 & 2.24 & Sandy Pebble Gravel \\
\hline A5_163-167cm & 32.91 & 31.91 & 1.00 & 61.88 & 5.21 & 4.43 & 0.78 & -0.23 & 2.86 & Sandy Pebble Gravel \\
\hline A5_171-173cm & 0.00 & 0.00 & 0.00 & 61.68 & 38.32 & 31.21 & 7.11 & 3.65 & 2.18 & Silty Very Fine Sand \\
\hline A5_205-207cm & 1.03 & 1.03 & 0.00 & 33.93 & 65.04 & 56.91 & 8.13 & 4.47 & 1.98 & $\begin{array}{l}\text { Slightly Pebbly Very Fine } \\
\text { Sandy Silt }\end{array}$ \\
\hline A5_221-223cm & 0.00 & 0.00 & 0.00 & 42.81 & 57.19 & 45.68 & 11.51 & 4.60 & 2.43 & Very Fine Sandy Silt \\
\hline A5_271-273cm & 1.79 & 0.00 & 1.79 & 93.00 & 5.21 & 4.84 & 0.37 & 1.66 & 1.14 & $\begin{array}{l}\text { Slightly Granuley Medium } \\
\text { Sand }\end{array}$ \\
\hline A5_331-333cm & 6.01 & 4.20 & 1.81 & 88.67 & 5.32 & 4.48 & 0.84 & 1.58 & 1.34 & Pebbly Medium Sand \\
\hline
\end{tabular}




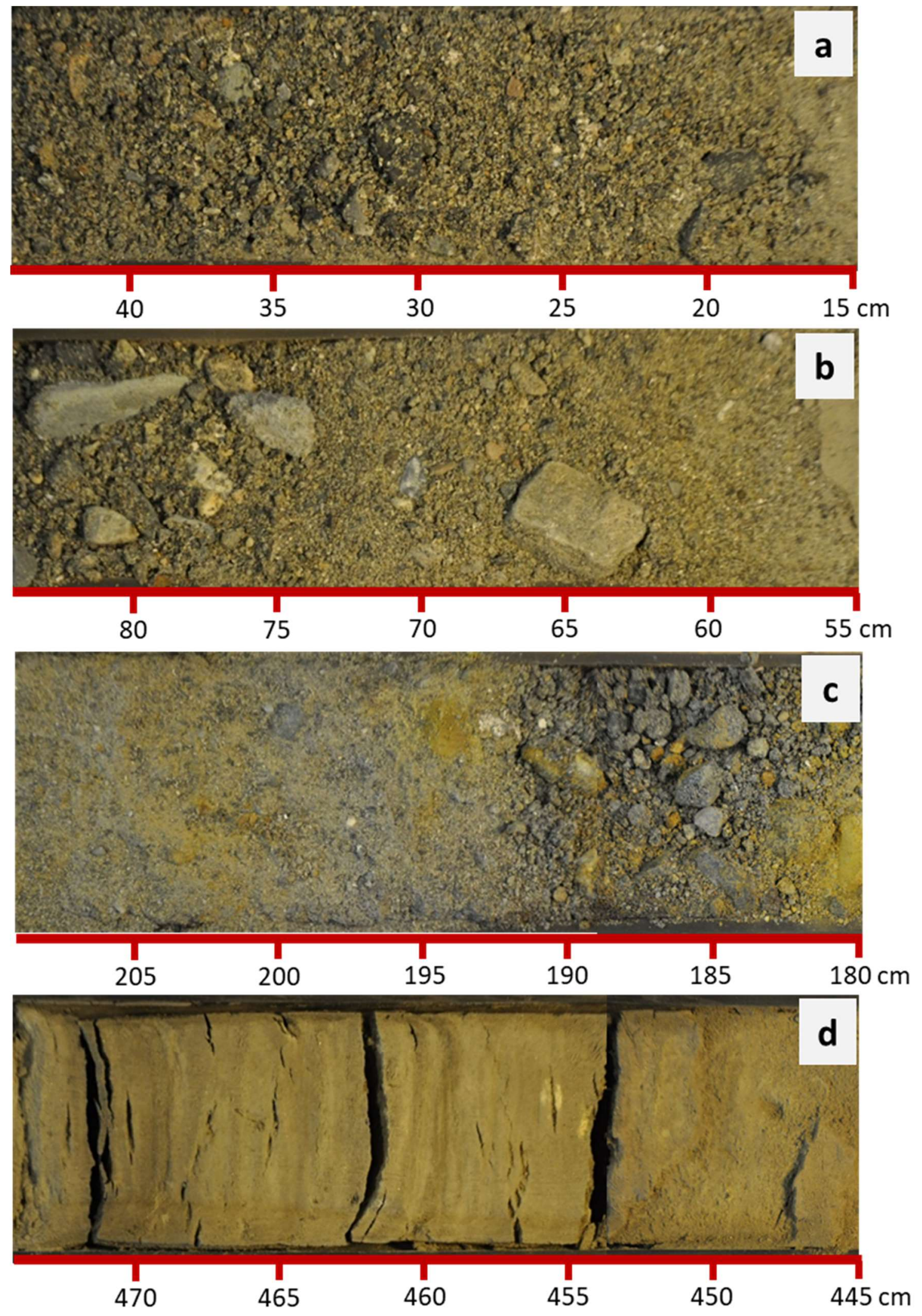

Figure $30(a, b, c, d)$. Photographs of vibracore A4 from 0.15 to $0.44 m(a)$, from $\sim 0.5 m$ to $0.84 m(b)$, from $\sim 1.80$ to $2.09 \mathrm{~m}(c)$, and from $\sim 4.45$ to $4.75 \mathrm{~m}(\mathrm{~d})$. 


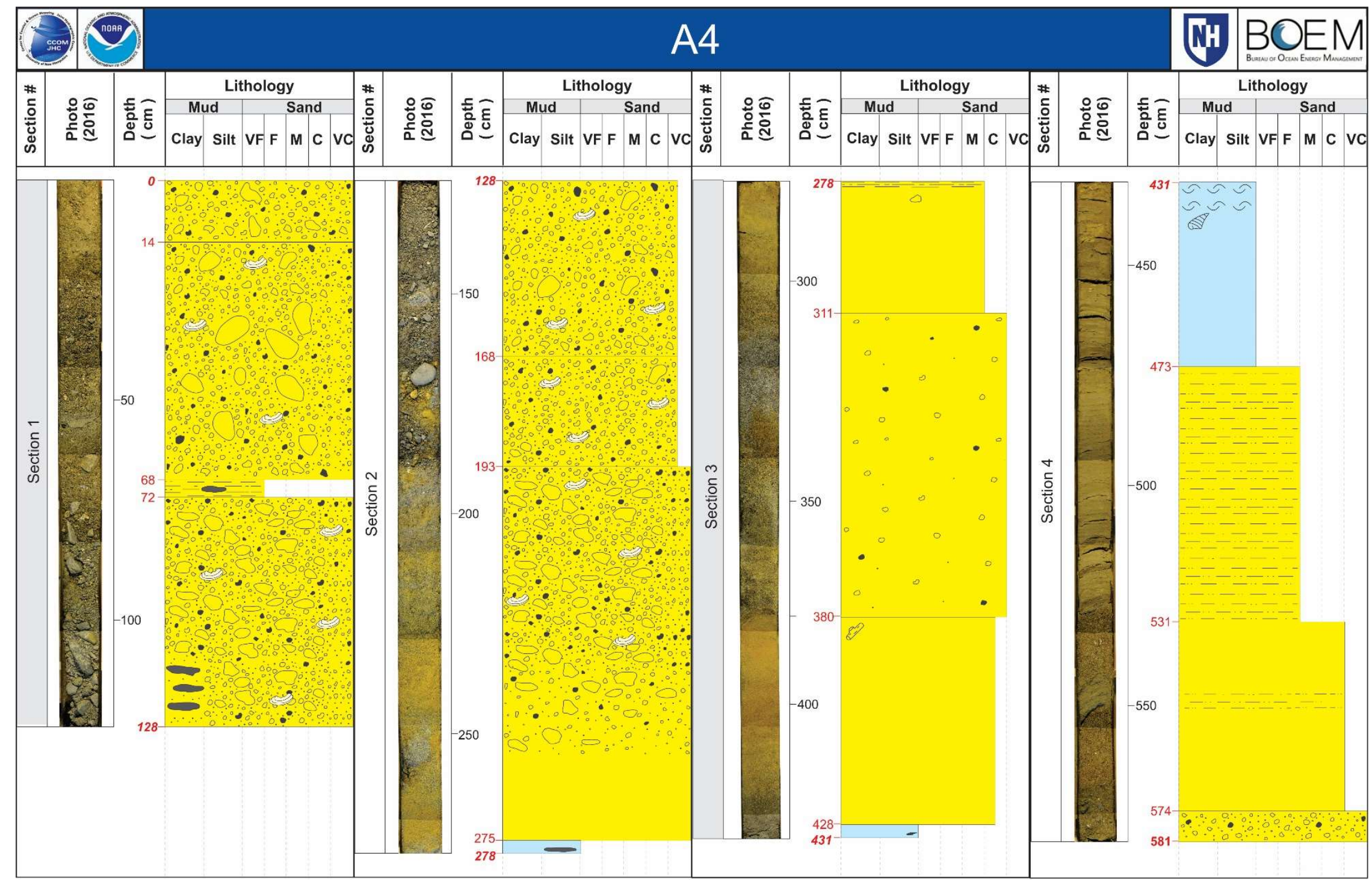

Figure 31. Log for vibracore A4. The location of the core is given in Figures 6, 15, and 16. Photographs of the core are shown in Figure 30. A full description of the core is given in Appendix A. 

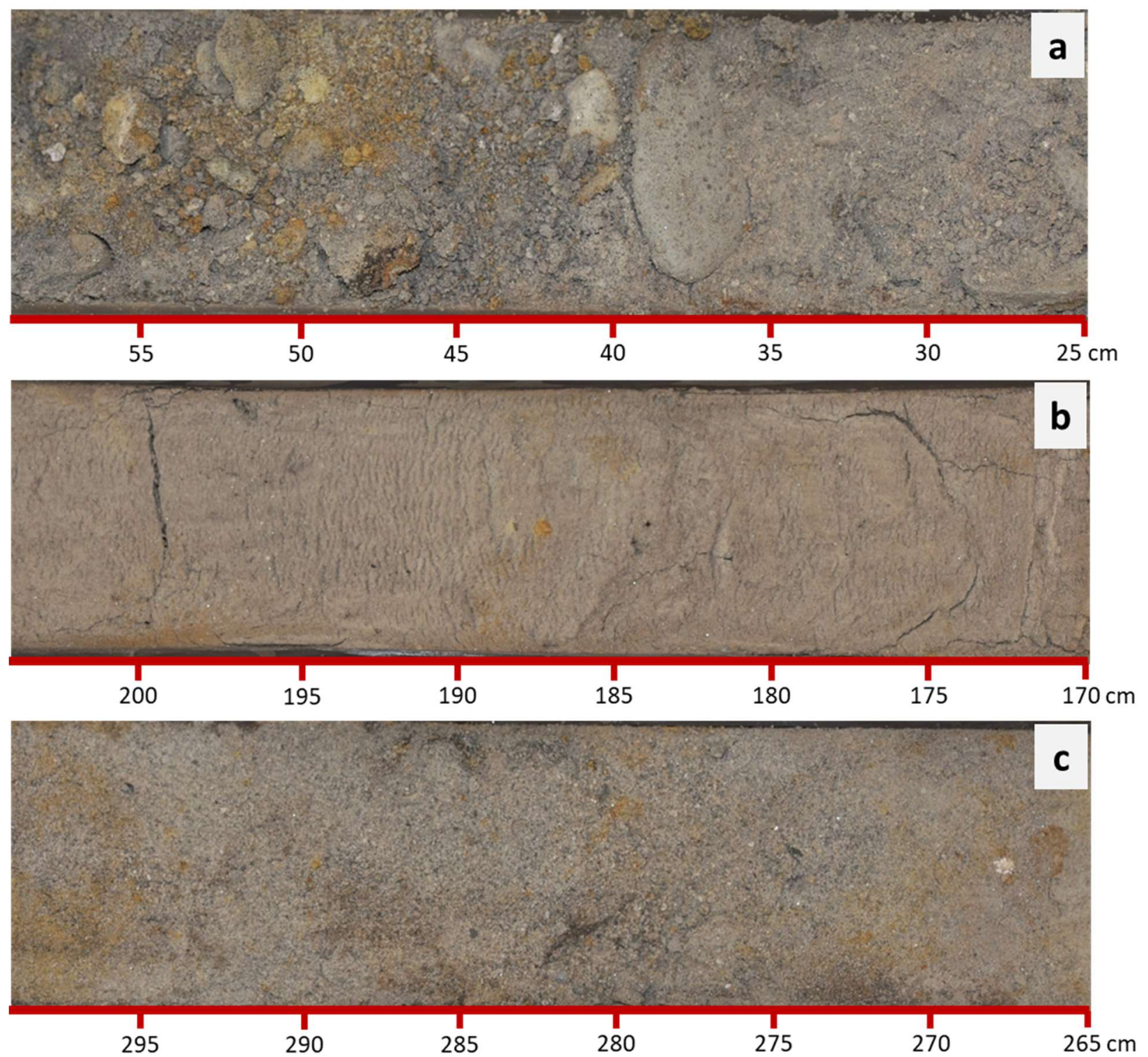

Figure $32(a, b, c)$. Photographs of vibracore A5 from $\sim 0.25$ to $0.59 \mathrm{~m}(a)$, from $\sim 1.70$ to $2.04 \mathrm{~m}(b)$, and from $\sim 2.65$ to $2.99 m(c)$. 


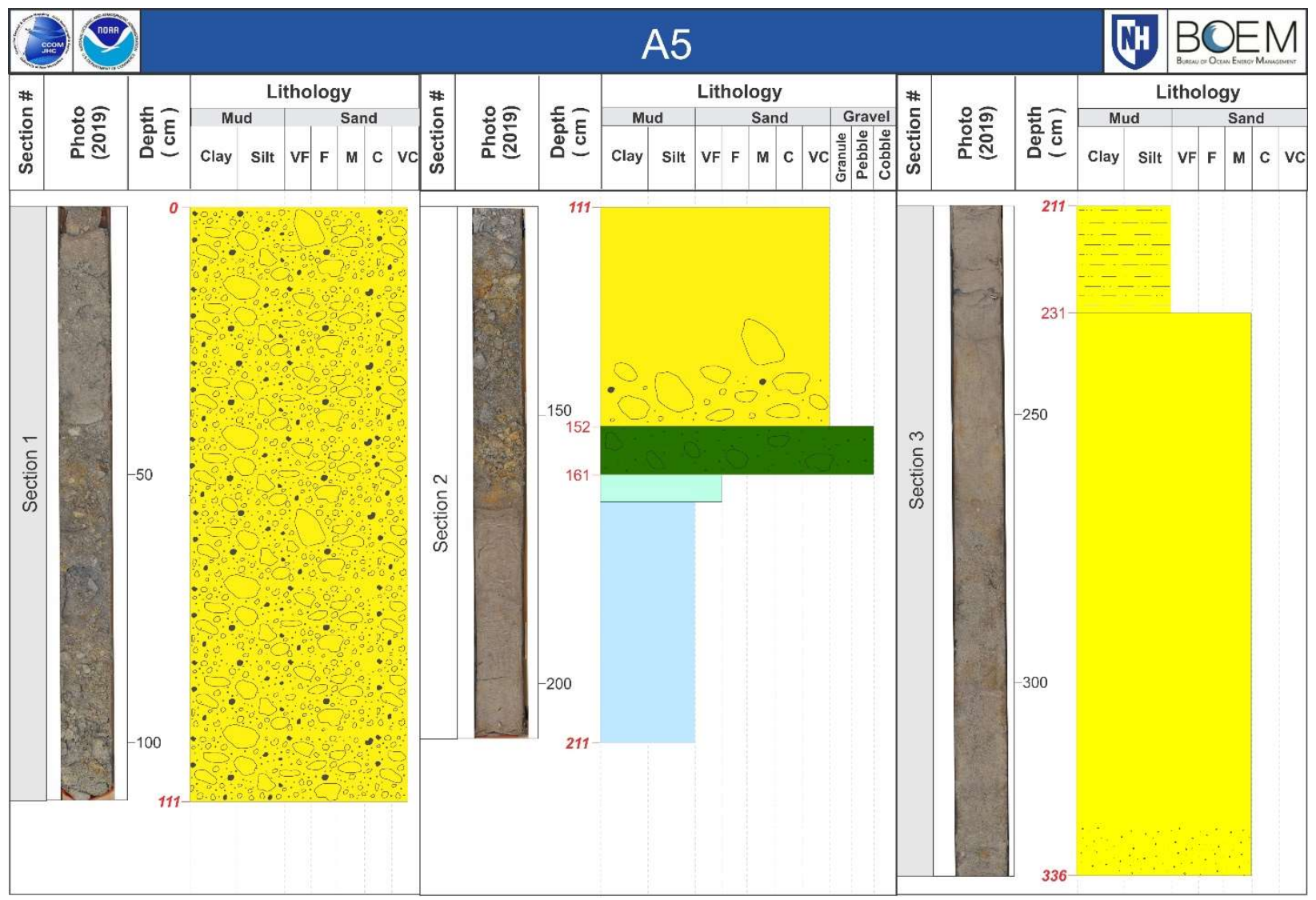

Figure 33. Log for vibracore A5. The location of the core is given in Figures 6, 15, and 16. Photographs of the core are shown in Figure 32. A full description of the core is given in Appendix A. 


\section{Nearshore Sheet Sand}

Note: the Nearshore Sheet Sand deposits were formerly referred to as the Southern Sand Body in earlier reports (Ward et al., 2021a).

The NH continental shelf landward of the Isles of Shoals is dominated by bedrock outcrops and marinemodified glacial deposits. One of the major physiographic features appear to be eroded drumlins and eskers that left behind megaclast platforms and gravel ridges (Figures 6 and 34) (Ward et al., 2021b). The surficial sediment map indicates that the bottom sediment in this region ranges from gravel to megaclasts (cobbles and boulders), gravel mixes, and sand (Figure 35). However, an area of continuous sand and gravel is found $\sim 2$ to $4 \mathrm{~km}$ offshore from Little Boars Head and southward to Great Boars Head in water depths between 20 and 35m (Figures 34 and 35). Based on subbottom seismic surveys, Birch (1984; 1986b) mapped this area, which he referred to as the Southern Sand Body, and estimated 16.4 million $^{3}$ of sand and gravel was present (summarized in Ward et al., 2021a). Here, we refer to this area previously mapped by Birch as the Nearshore Sheet Sand.

The origin and source of the Nearshore Sheet Sand deposits are not clear. Unlike the Northern Sand Body located further offshore just landward of the Isles of Shoals (described previously), which has significant positive relief, the Nearshore Sheet Sand deposits are relatively flat-lying layers of sand and gravel. They frequently overlie (often unconformably) glacial marine sandy mud associated with the Presumpscot Formation distal facies. Examination of the surficial geology of the upland adjacent to the coast provides important insights into the possible origin of the sediment for the sheet sand (Birch, 1984).

Common to the $\mathrm{NH}$ seacoast are glacial marine sediments including wave-modified marine deltas or outwash deposits (stratified sand and gravel), the sandy facies of the Presumpscot Formation, and tills. These glacial marine deposits are primarily composed of or contain substantial amounts of sand and gravel. It is reasonable to assume that the deposits common to the upland along the NH seacoast are also present on the nearby inner $\mathrm{NH}$ continental shelf. However, the inner shelf deposits were highly modified and redistributed by wave action during the last sea-level transgression (Figure 2), creating sheet sands as well as filling in shallow basins. Therefore, it is hypothesized that the Nearshore Sheet Sand deposits were formed from reworked glacial marine sediment during the last transgression, especially wavemodified marine deltas or outwash. In addition, the deposits are likely part of the nearshore sand ramp extending from the beaches in southern NH. The nearshore ramps are a seaward extension of the beaches and likely exchange sediment with the nearshore.

To characterize the Nearshore Sheet Sand Deposits, nine vibracores (UNH-6, UNH-6a, UNH-14, A6(1), $A 6(2), A 6(3), A 7(1), A 7(2)$, and $A 8$ ) from 5 different locations (3 sites were cored multiple times) were taken in the area in 1984 and 1988 under the direction of Birch (1986a; 1986b; 1988) (Figures 6 and 35). Vibracore $\mathrm{A} 8$ was taken in an area mapped as a marine-modified glacial deposit with surficial sediments composed of gravel mixes. The remaining vibracores are from areas mapped as a seafloor plain with sand being the dominant surficial sediment. Grain size data (Tables 9 and 10) and abbreviated cores are presented here and in more detail in Appendices $A$ and $B$.

\section{Vibracores A6(1), $A 6(2)$, and $A 6(3)$}

Cores $A 6(1), A 6(2)$, and $A 6(3)$ are located at the southern extent of the Nearshore Sheet Sand deposits in $\sim 21$ to $22 \mathrm{~m}$ of water (Figures 6,34 , and 35). Cores $A 6(1)$ and $A 6(2)$ are short, with lengths of 2.27 and $1.62 \mathrm{~m}$, respectively, and are composed of fine to medium sand with scattered shell fragments (Figures $36,37,38,39$, and 40 ). Core $A 6(1)$ has an organic-rich lense at $\sim 1.8 \mathrm{~m}$ below the top of the core (Figure 36). The sand content measured from grain size analyses of subsamples (Table 9) from A6(1) and A6(2) are all greater than $93 \%$ (most are close to $99 \%$ ) except for one sample at the top of $A 6(1)$ where a few 
pebbles were present which increased the gravel content. All the sediment samples taken from A6(1) and A6(2) are fine to medium sand with some granules or pebbles. Both cores terminated in sand (Figures 36 and 38 ). Core $A 6(3)$ is $5.92 \mathrm{~m}$ in length and is predominately medium sand or slightly granuley medium sand from the surface to $3.89 \mathrm{~m}$ (Figure 40 ). The sand content is $\sim 98$ to $99 \%$ and mean grain size is 1.38 to $1.91 \phi(0.384$ to $0.266 \mathrm{~mm})$ for the samples above $3.89 \mathrm{~m}$. Below $3.89 \mathrm{~m}$, the sediment rapidly transitions to slightly pebbly very fine sandy silt to very fine sandy silt-clay with mean grain sizes between 5.56 and $6.23 \phi(0.021$ to $0.013 \mathrm{~mm})$ based on the samples below the transition. The muddy sediments below $3.89 \mathrm{~m}$ in core A6(3) are likely the distal facies of the glacial marine deposits or the Presumpscot Formation. A6(1) and $A 6(2)$ also likely unconformably overlay the Presumpscot Formation, but the cores were not long enough to penetrate the glacial marine muds.

\section{Vibracores $A 7(1)$ and $A 7(2)$}

The northernmost vibracores taken from the Nearshore Sheet Sand deposits are relatively short, with $A 7(1)$ measuring $1.32 \mathrm{~m}$ and $A 7(2)$ measuring $2.05 \mathrm{~m}$. Cores $A 7(1)$ and $A 7(2)$ were taken in water depths of $\sim 24$ and $\sim 25 \mathrm{~m}$, respectively. Both cores are largely coarse to very coarse sand or granule and contain extensive pebbles and some cobbles throughout except in the upper layer, which is a coarse sand (Figures 41,42 , and 43). The base of both cores appears to be a reworked till or glacial marine proximal facies (sandy).

In core $A 7(1)$ the upper $0.12 \mathrm{~m}$ is a slightly granuley medium to coarse sand (Figure 42). A sample from $0.10-0.12 \mathrm{~m}$ has $\sim 3 \%$ gravel, $92 \%$ sand, $5 \%$ mud and a mean grain size of $1.62 \phi(0.325 \mathrm{~mm})$. Below this is a medium sand from $\sim 0.12$ to $0.52 \mathrm{~m}$. Below the sand is a pebble gravel extending to at least $1.0 \mathrm{~m}$ depth. A sediment sample from $0.60-0.64 \mathrm{~m}$ has $~ 85 \%$ gravel, $10 \%$ sand, $5 \%$ mud and a mean grain size of $-3.04 \phi$ $(8.23 \mathrm{~mm})$, which excludes some of the largest clasts (Table 9).

A $0.16 \mathrm{~m}$ section of the core is missing directly under the gravels, which is undoubtedly due to sediment slipping down the core liner. Upon recovery this void had been distinct, whereas in 2019 when the core was re-evaluated this section appeared to have slumped in storage. The lower unit appears to be sand overlying a sandy mud of the Presumpscot Formation distal facies (Figure 41). A sample from 1.20-1.22m is a silty sandy pebble gravel with $\sim 45 \%$ gravel, $\sim 41 \%$ sand, $\sim 14 \%$ mud, and a mean grain size of $0.02 \phi$ (0.99mm).

Core $A 7(2)$ apparently slipped downward $0.26 \mathrm{~m}$ in the core lining. Therefore, the top of the core starts at $0.26 \mathrm{~m}$ (Figure 45 ). Similar to $A 7(1)$, the void had been distinct during recovery, but slumped in storage. The top of the core from 0.26 to $0.45 \mathrm{~m}$ is a slightly granular coarse sand. A sample from $0.28-0.30 \mathrm{~m}$ is $\sim 4 \%$ granule, $93 \%$ sand and $3 \%$ mud with a mean grain size of $0.84 \phi(0.559 \mathrm{~mm})$. A granular coarse sand to sandy pebble gravel extends from $\sim 0.45$ to $1.12 \mathrm{~m}$. A sample from $0.52-0.56 \mathrm{~m}$ has $\sim 68 \%$ gravel, whereas a sample from $0.90-0.94 \mathrm{~m}$ has $\sim 21 \%$ gravel, causing a shift between the coarse sand to the gravel. Below $\sim 1.12 \mathrm{~m}$ down to $1.53 \mathrm{~m}$ the core is consistently a sandy pebble gravel. A sample from $1.34-1.38 \mathrm{~m}$ is a pebble gravel with $70 \%$ gravel, $28 \%$ sand, $2 \%$ mud and a mean grain size of $-1.95 \phi(3.864 \mathrm{~mm})$. Below this gravel layer to the base of the core the sediment remains a gravel or contains gravel-sized clasts but has a higher sand and mud content. For example, a sample from $1.60-1.62 \mathrm{~m}$ is a silty sandy pebble gravel and has $\sim 35 \%$ gravel, $47 \%$ sand, $18 \%$ mud and a mean grain size of $0.74 \phi(0.599 \mathrm{~mm})$.

\section{Vibracore $A 8$}

Core A8 was taken in a water depth of $\sim 25 \mathrm{~m}$ adjacent to what is mapped as a marine-modified glacial deposit (due to the coarse gravels and rough texture of the seafloor) (Ward et al., 2021b). The core is $4.04 \mathrm{~m}$ in length. The upper part of the core (surface to $0.55 \mathrm{~m}$ ) is coarse to very coarse sand with pebbles and a cobble (Figure 44). A subsample taken at $0.20-0.22 \mathrm{~m}$ which represents the matrix is a sandy pebble 
gravel with $\sim 40 \%$ gravel, $56 \%$ sand, and a mean grain size of $-0.66 \phi(1.58 \mathrm{~mm})$ (Table 9). Separated from the units above and below, muddy sandy sediments with numerous pebbles and cobbles and a high mud content occurs from $\sim 0.55$ to $0.95 \mathrm{~m}$. A sample from $0.88-0.90 \mathrm{~m}$ is a silty sandy pebble gravel with $\sim 33 \%$ gravel, $35 \%$ sand, $32 \%$ mud and a mean grain size of $1.38 \phi(0.38 \mathrm{~mm})$. At the base of the silty sandy pebble gravel, a coarse sand layer with pebbles and cobbles occurs from $\sim 0.95$ to $1.05 \mathrm{~m}$. The sediment samples from $1.01 \mathrm{~m}$ to the base of the core at $4.04 \mathrm{~m}$ include a pebbly silty-clayey fine sand at $1.19-1.21 \mathrm{~m}$, a siltyclayey pebble gravel at $2.02-2.04 \mathrm{~m}$, and a pebbly silt at $3.84-3.86 \mathrm{~m}$.

The mixture of sizes indicates a reworked till deposit or a proximal glacial marine deposit overlying the distal facies of the Presumpscot Formation.

\section{Vibracores UNH-6 and UNH-6a}

UNH-6 and UNH-6a are located seaward of all the vibracores taken in the Nearshore Sheet Sand deposits, collected $\sim 3.7 \mathrm{~km}$ from shore and in $\sim 30 \mathrm{~m}$ of water (Figures 6,34 , and 35). UNH-6 (Figures 45 and 46 ) and UNH-6a (Figures 47 and 48) are significantly longer than the previous cores for the Nearshore Sheet Sand deposits at 8.51 and $8.32 \mathrm{~m}$, respectively. However, only the upper $\sim 1.5 \mathrm{~m}$ of UNH-6 and $\sim 3.0 \mathrm{~m}$ of UNH-6a is sandy (very fine to fine sand). Both these sandy sections also have a significant mud content along with biotite-rich lenses. Below the sand, both cores transition to silt and clay for the rest of length of the cores, with scattered shell fragments and multiple sand lenses. The muddy sediments are likely the distal facies of the glacial marine deposits (Presumpscot Formation). Vibracores were likely taken at the seaward extent of, or more likely seaward of, the Nearshore Sheet Sands.

UNH-6 transitions from a slightly granuley very fine sand at the surface to a very fine sand near the base of the sand layer (surface to $1.54 \mathrm{~m}$ ). The mean grain size of the four samples from the interval range from 3.03 to $3.67 \phi(0.122$ to $0.079 \mathrm{~mm}$ ) (Table 10$)$. The transition from very fine sand to mud is quite abrupt. In core UNH-6, a subsample at $1.52-1.54 \mathrm{~m}$ is $~ 92 \%$ sand and $8 \%$ mud (mostly silt) with a mean grain size of $3.11 \phi(0.116 \mathrm{~mm})$. A sample from $1.76-1.78 \mathrm{~m}$ is almost entirely mud ( 99\%) with a mean grain size of $9.57 \phi(0.001 \mathrm{~mm})$. UNH-6a also transitions relatively rapidly from sand to mud. The sediment from the surface to $3.02 \mathrm{~m}$ transitions from slightly granuley fine sand to silty very fine sand with sand contents between $\sim 93$ and $98 \%$ with one exception $(\sim 81 \%$ at $2.98-3.00 \mathrm{~m})$. The mean grain size for the samples range from 2.69 to $3.58 \phi(0.155$ to $0.089 \mathrm{~mm})$, with a steady increase with depth. Below $3.02 \mathrm{~m}$ to the base at $8.32 \mathrm{~m}$ the sediment is mud. A sample taken at $3.05-3.07 \mathrm{~m}$ is a silt-clay with $\sim 98 \%$ mud and a mean grain size of $9.01 \phi(0.002 \mathrm{~mm})$.

\section{Vibracore UNH-14}

Core UNH-14 was taken $\sim 3.0 \mathrm{~km}$ from shore relatively close to A6 ( 0.6km seaward and to the southeast) (Figures 6, 34, and 35). UNH-14 is a long core measuring $7.87 \mathrm{~m}$ and was taken in a water depth of $\sim 23 \mathrm{~m}$. The upper $0.62 \mathrm{~m}$ of the core is a fine sand which grades into a siltier very fine sand from 0.62 to $1.38 \mathrm{~m}$ (Figure 49). From 1.38 to $2.36 \mathrm{~m}$ the sediment becomes slightly coarser ranging from slightly pebbly fine sand to fine sand (Table 10). All of the samples taken from this entire interval have sand contents between $\sim 93$ and $99 \%$ with the exception of the sample taken at $0.72-0.74 \mathrm{~m}$ which has a sand content of $\sim 67 \%$ and a mud content of $\sim 36 \%$. The mean grain sizes are between 2.55 and $2.84 \phi(0.171$ to $0.140 \mathrm{~mm})$ with the exception of the sample from $0.72-0.74 \mathrm{~m}$ which has a mean grain size of $3.88 \phi(0.068 \mathrm{~mm})$. Below $2.36 \mathrm{~m}$ to the base of the core is a mud. A sample from this interval was a very fine sandy silt-clay with a sand content of $\sim 10 \%$, a mud content of $\sim 90 \%$, and a mean grain size of $7.64 \phi(0.005 \mathrm{~mm})$. Once again, the mud deposit is likely fine-grained glacial marine sediment associated with the highstand, with a slightly winnowed surface. 
Table 9. Grain size data for the vibracores taken in the Nearshore Sheet Sand Deposits including A6(1), A6(2), A6(3), $A 7(1), A 7(2)$, and A8 (Figure 34). Complete grain size classifications and statistics are given in Appendix $B$.

\begin{tabular}{|c|c|c|c|c|c|c|c|c|c|c|}
\hline UNH Sample ID & $\begin{array}{l}\text { Gravel } \\
\%\end{array}$ & $\begin{array}{l}\text { Pebble } \\
\%\end{array}$ & $\begin{array}{l}\text { Granule } \\
\%\end{array}$ & $\begin{array}{l}\text { Sand } \\
\%\end{array}$ & $\begin{array}{l}\text { Mud } \\
\%\end{array}$ & $\begin{array}{l}\text { Silt } \\
\%\end{array}$ & $\begin{array}{l}\text { Clay } \\
\%\end{array}$ & $\begin{array}{l}\text { Mean Size } \\
\text { (phi) }\end{array}$ & $\begin{array}{l}\text { Sorting } \\
\text { (phi) }\end{array}$ & $\begin{array}{l}\text { CMECS (FGDC 2012) } \\
\text { Substrate Component } \\
\text { Subgroup (Specific) }\end{array}$ \\
\hline A6(1)_58-60cm & 22.42 & 20.15 & 2.26 & 76.82 & 0.76 & NA & NA & 0.42 & 2.19 & Pebbly Medium Sand \\
\hline A6(1)_110-112cm & 0.00 & 0.00 & 0.00 & 99.41 & 0.59 & NA & NA & 2.22 & 0.48 & Fine Sand \\
\hline A6(1)-2_148-150cm & 0.00 & 0.00 & 0.00 & 99.34 & 0.66 & NA & NA & 2.48 & 0.43 & Fine Sand \\
\hline A6(1)-2_198-200cm & 0.00 & 0.00 & 0.00 & 99.35 & 0.65 & NA & NA & 2.49 & 0.40 & Fine Sand \\
\hline A6(2)_10-12cm & 0.86 & 0.00 & 0.86 & 97.19 & 1.95 & $\mathrm{NA}$ & NA & 2.18 & 1.11 & $\begin{array}{l}\text { Slightly Granuley Fine } \\
\text { Sand }\end{array}$ \\
\hline A6(2)_32-34cm & 0.85 & 0.00 & 0.85 & 93.06 & 6.09 & 5.23 & 0.86 & 2.67 & 1.14 & $\begin{array}{l}\text { Slightly Granuley Very } \\
\text { Fine Sand }\end{array}$ \\
\hline $\mathrm{A} 6(2) \_48-50 \mathrm{~cm}$ & 0.00 & 0.00 & 0.00 & 99.56 & 0.44 & NA & NA & 1.94 & 0.42 & Medium Sand \\
\hline A6(2)_148-150cm & 0.00 & 0.00 & 0.00 & 99.42 & 0.58 & NA & NA & 2.57 & 0.39 & Fine Sand \\
\hline A6(3)_30-32cm & 0.00 & 0.00 & 0.00 & 99.85 & 0.15 & NA & NA & 1.64 & 0.40 & Medium Sand \\
\hline A6(3)_123-125cm & 0.00 & 0.00 & 0.00 & 99.79 & 0.21 & NA & NA & 1.79 & 0.45 & Medium Sand \\
\hline A6(3)_183-185cm & 0.00 & 0.00 & 0.00 & 99.78 & 0.22 & NA & NA & 1.91 & 0.41 & Medium Sand \\
\hline A6(3)_281-283cm & 0.13 & 0.00 & 0.13 & 99.37 & 0.50 & NA & NA & 1.66 & 0.71 & $\begin{array}{l}\text { Slightly Granuley Medium } \\
\text { Sand }\end{array}$ \\
\hline A6(3)_337-339cm & 1.01 & 0.07 & 0.94 & 97.94 & 1.05 & NA & NA & 1.38 & 0.87 & $\begin{array}{l}\text { Slightly Granuley Medium } \\
\text { Sand }\end{array}$ \\
\hline A6(3)_417-419cm & 2.59 & 1.82 & 0.78 & 20.89 & 76.52 & 59.80 & 16.72 & 5.56 & 2.62 & $\begin{array}{l}\text { Slightly Pebbly Very Fine } \\
\text { Sandy Silt }\end{array}$ \\
\hline A6(3)_485-487cm & 0.09 & 0.00 & 0.09 & 11.18 & 88.73 & 46.63 & 42.10 & 7.96 & 3.26 & $\begin{array}{l}\text { Slightly Granuley Medium } \\
\text { Sandy Silt-Clay }\end{array}$ \\
\hline A6(3)_560-563cm & 0.00 & 0.00 & 0.00 & 24.49 & 75.51 & 49.88 & 25.63 & 6.23 & 3.06 & Very Fine Sandy Silt-Clay \\
\hline$A 7(1) \_10-12 \mathrm{~cm}$ & 3.37 & 0.18 & 3.19 & 91.74 & 4.89 & 3.75 & 1.14 & 1.62 & 1.38 & $\begin{array}{l}\text { Slightly Granuley Medium } \\
\text { Sand }\end{array}$ \\
\hline A7(1)_60-64cm & 84.80 & 81.02 & 3.78 & 9.98 & 5.22 & 4.75 & 0.47 & -3.04 & 2.05 & Pebble Gravel \\
\hline A7(1)_120-122cm & 45.48 & 28.49 & 16.99 & 40.54 & 13.99 & 11.88 & 2.11 & 0.02 & 3.13 & Silty Sandy Granule Gravel \\
\hline A7(2)_28-30cm & 4.19 & 0.00 & 4.19 & 92.70 & 3.11 & NA & NA & 0.84 & 1.26 & $\begin{array}{l}\text { Slightly Granuley Coarse } \\
\text { Sand }\end{array}$ \\
\hline A7(2)_52-56cm & 68.36 & 60.70 & 7.66 & 29.52 & 2.12 & NA & NA & -2.50 & 2.79 & Sandy Pebble Gravel \\
\hline A7(2)_90-94cm & 21.16 & 10.22 & 10.94 & 77.84 & 1.00 & NA & NA & 0.17 & 1.61 & Granular Coarse Sand \\
\hline A7(2)_134-138cm & 69.54 & 58.68 & 10.86 & 28.23 & 2.23 & NA & NA & -1.95 & 2.79 & Sandy Pebble Gravel \\
\hline A7(2)_160-162cm & 34.60 & 25.16 & 9.43 & 47.40 & 18.00 & 15.24 & 2.76 & 0.74 & 3.41 & Silty Sandy Pebble Gravel \\
\hline A8_20-22cm & 40.78 & 35.54 & 5.24 & 55.50 & 3.72 & NA & NA & -0.66 & 2.35 & Sandy Pebble Gravel \\
\hline A8_88-90cm & 32.95 & 30.32 & 2.63 & 35.35 & 31.70 & 22.29 & 9.41 & 1.38 & 4.85 & Silty Sandy Pebble Gravel \\
\hline A8_119-121cm & 17.32 & 11.39 & 5.93 & 47.60 & 35.08 & 23.41 & 11.67 & 2.75 & 4.16 & $\begin{array}{l}\text { Pebbly Silty-Clayey Fine } \\
\text { Sand }\end{array}$ \\
\hline A8_202-204cm & 34.22 & 32.05 & 2.17 & 30.30 & 35.48 & 23.37 & 12.11 & 1.69 & 5.17 & Silty-Clayey Pebble Gravel \\
\hline A8_ $282-284 \mathrm{~cm}$ & 34.56 & 30.16 & 4.40 & 37.93 & 27.51 & 18.85 & 8.66 & 1.08 & 4.64 & Silty Sandy Pebble Gravel \\
\hline A8_384-386cm & 27.44 & 24.38 & 3.06 & 32.29 & 40.27 & 28.99 & 11.28 & 1.98 & 5.06 & Pebbly Silt \\
\hline
\end{tabular}


Table 10. Grain size data for the vibracores taken in the Nearshore Sheet Sand Deposits including UNH-6, UNH-6a, and UNH-14 (Figure 34). Complete grain size classifications and statistics are given in Appendix B.

\begin{tabular}{|c|c|c|c|c|c|c|c|c|c|c|}
\hline UNH Sample ID & $\begin{array}{l}\text { Gravel } \\
\%\end{array}$ & $\begin{array}{l}\text { Pebble } \\
\%\end{array}$ & $\begin{array}{l}\text { Granule } \\
\%\end{array}$ & $\begin{array}{l}\text { Sand } \\
\%\end{array}$ & $\begin{array}{l}\text { Mud } \\
\%\end{array}$ & $\begin{array}{l}\text { Silt } \\
\%\end{array}$ & $\begin{array}{l}\text { Clay } \\
\%\end{array}$ & $\begin{array}{l}\text { Mean Size } \\
\text { (phi) }\end{array}$ & $\begin{array}{l}\text { Sorting } \\
\text { (phi) }\end{array}$ & $\begin{array}{l}\text { CMECS (FGDC 2012) } \\
\text { Substrate Component } \\
\text { Subgroup (Specific) }\end{array}$ \\
\hline UNH-6_16-18cm & 0.53 & 0.00 & 0.53 & 96.80 & 2.67 & NA & NA & 3.03 & 0.49 & $\begin{array}{l}\text { Slightly Granuley Very } \\
\text { Fine Sand }\end{array}$ \\
\hline UNH-6_96-98cm & 0.00 & 0.00 & 0.00 & 91.42 & 8.58 & 8.28 & 0.30 & 3.34 & 0.53 & Very Fine Sand \\
\hline UNH-6_124-126cm & 0.00 & 0.00 & 0.00 & 77.24 & 22.76 & 22.25 & 0.51 & 3.67 & 0.62 & Silty Very Fine Sand \\
\hline UNH-6_152-154cm & 0.00 & 0.00 & 0.00 & 91.66 & 8.34 & 8.12 & 0.22 & 3.11 & 0.84 & Very Fine Sand \\
\hline UNH-6_176-178cm & 0.00 & 0.00 & 0.00 & 1.13 & 98.87 & 30.58 & 68.29 & 9.57 & 2.73 & Clay \\
\hline UNH-6A_20-22cm & 0.66 & 0.23 & 0.43 & 98.18 & 1.16 & NA & NA & 2.69 & 0.62 & $\begin{array}{l}\text { Slightly Granuley Fine } \\
\text { Sand }\end{array}$ \\
\hline UNH-6A_80-82cm & 0.00 & 0.00 & 0.00 & 95.29 & 4.71 & NA & NA & 2.91 & 0.51 & Fine Sand \\
\hline UNH-6A_122-124cm & 0.00 & 0.00 & 0.00 & 94.15 & 5.85 & 4.72 & 1.13 & 2.94 & 0.53 & Fine Sand \\
\hline UNH-6A_192-194cm & 0.00 & 0.00 & 0.00 & 93.42 & 6.58 & 6.13 & 0.45 & 3.08 & 0.55 & Very Fine Sand \\
\hline UNH-6A_235-237cm & 0.00 & 0.00 & 0.00 & 95.37 & 4.63 & 4.32 & 0.31 & 3.18 & 0.49 & Very Fine Sand \\
\hline UNH-6A_298-300cm & 0.00 & 0.00 & 0.00 & 80.78 & 19.22 & 18.60 & 0.62 & 3.58 & 0.70 & Silty Very Fine Sand \\
\hline UNH-6A_305-307cm & 0.00 & 0.00 & 0.00 & 2.42 & 97.58 & 37.27 & 60.31 & 9.01 & 3.03 & Silt-Clay \\
\hline UNH-14_8-10cm & 0.00 & 0.00 & 0.00 & 98.84 & 1.16 & NA & NA & 2.63 & 0.65 & Fine Sand \\
\hline UNH-14_54-56cm & 0.00 & 0.00 & 0.00 & 97.20 & 2.80 & NA & NA & 2.75 & 0.44 & Fine Sand \\
\hline UNH-14_72-74cm & 0.00 & 0.00 & 0.00 & 64.64 & 35.36 & 30.70 & 4.66 & 3.88 & 1.62 & Silty Very Fine Sand \\
\hline UNH-14_115-117cm & 0.00 & 0.00 & 0.00 & 93.12 & 6.88 & 6.32 & 0.56 & 2.84 & 0.62 & Fine Sand \\
\hline UNH-14_183-185cm & 0.44 & 0.44 & 0.00 & 96.41 & 3.15 & NA & NA & 2.63 & 0.42 & Slightly Pebbly Fine Sand \\
\hline UNH-14_196-198cm & 0.00 & 0.00 & 0.00 & 98.26 & 1.74 & NA & NA & 2.51 & 0.47 & Fine Sand \\
\hline UNH-14_232-234cm & 0.12 & 0.00 & 0.12 & 96.90 & 2.98 & NA & NA & 2.55 & 0.42 & $\begin{array}{l}\text { Slightly Granuley Fine } \\
\text { Sand }\end{array}$ \\
\hline UNH-14_248-250cm & 0.00 & 0.00 & 0.00 & 10.02 & 89.98 & 49.32 & 40.66 & 7.64 & 3.21 & Very Fine Sandy Silt-Clay \\
\hline
\end{tabular}




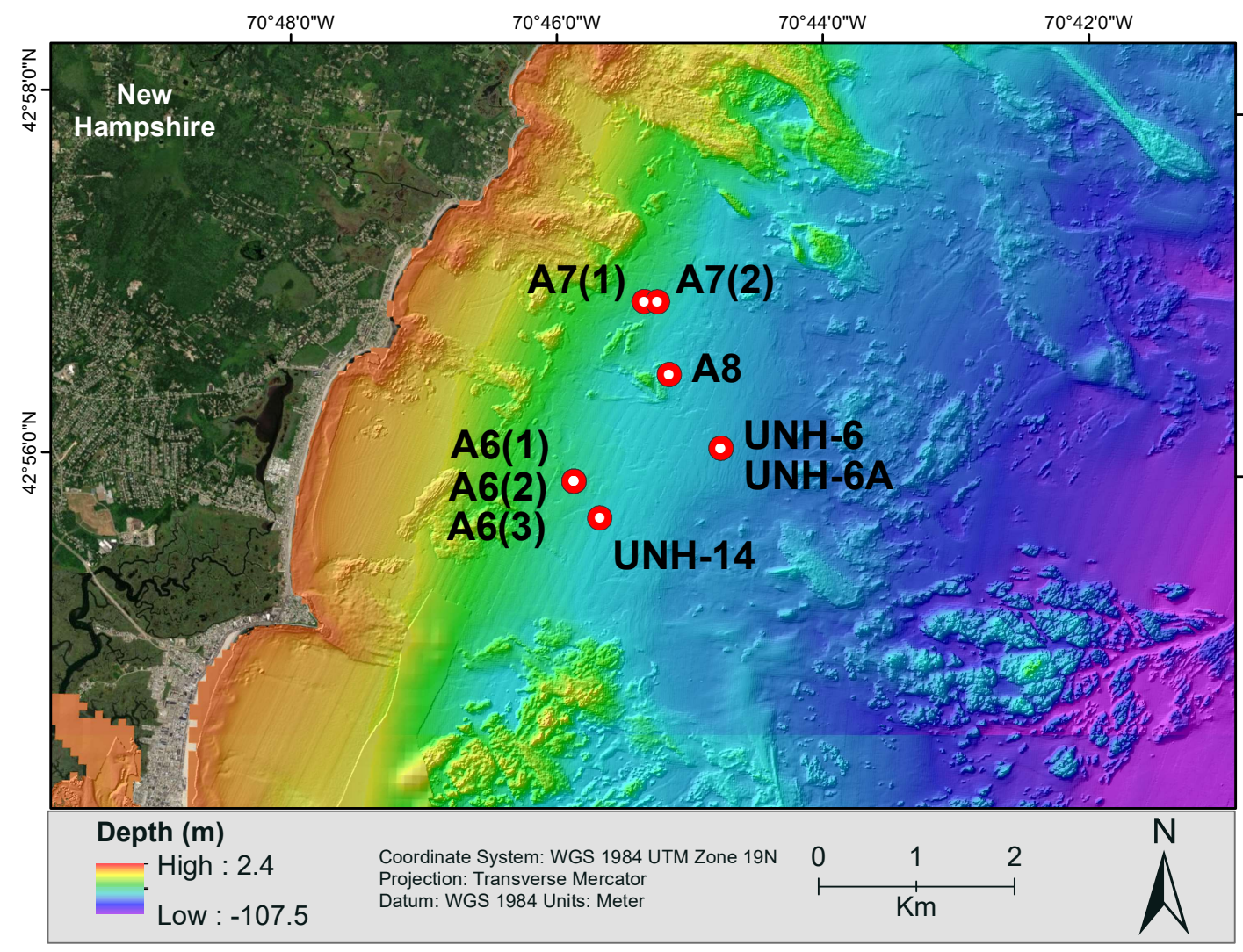

Figure 34. Bathymetric map of the vibracores taken in the Nearshore Sheet Sand Deposits. Map is shown at a scale of 1:50,000. 

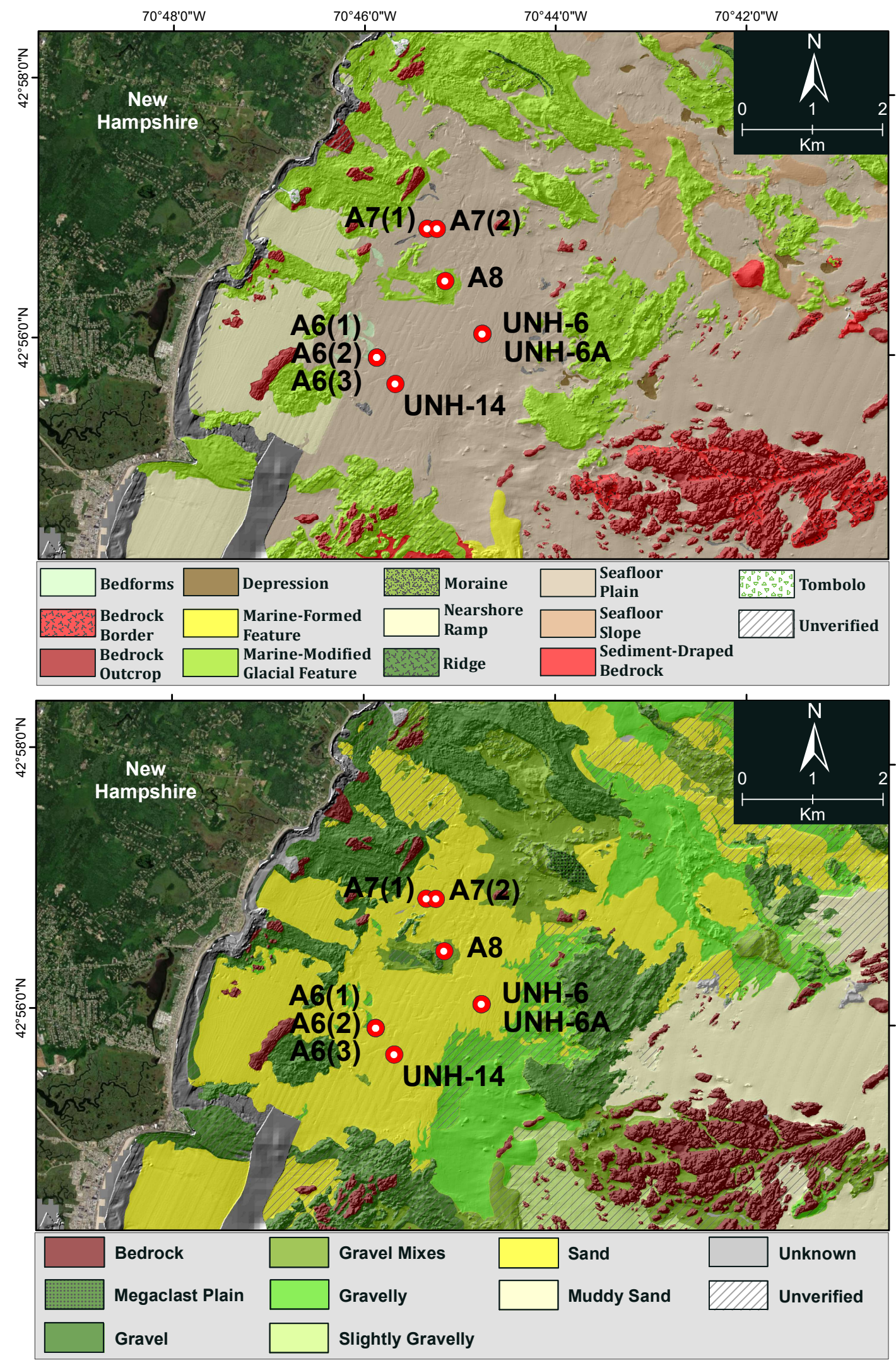

Figure 35. Major geoforms (physiographic features; top) and surficial sediment map (substrate classes; bottom) of the vibracores taken in the Nearshore Sheet Sand Deposits. Map is shown at a scale of 1:50,000. 


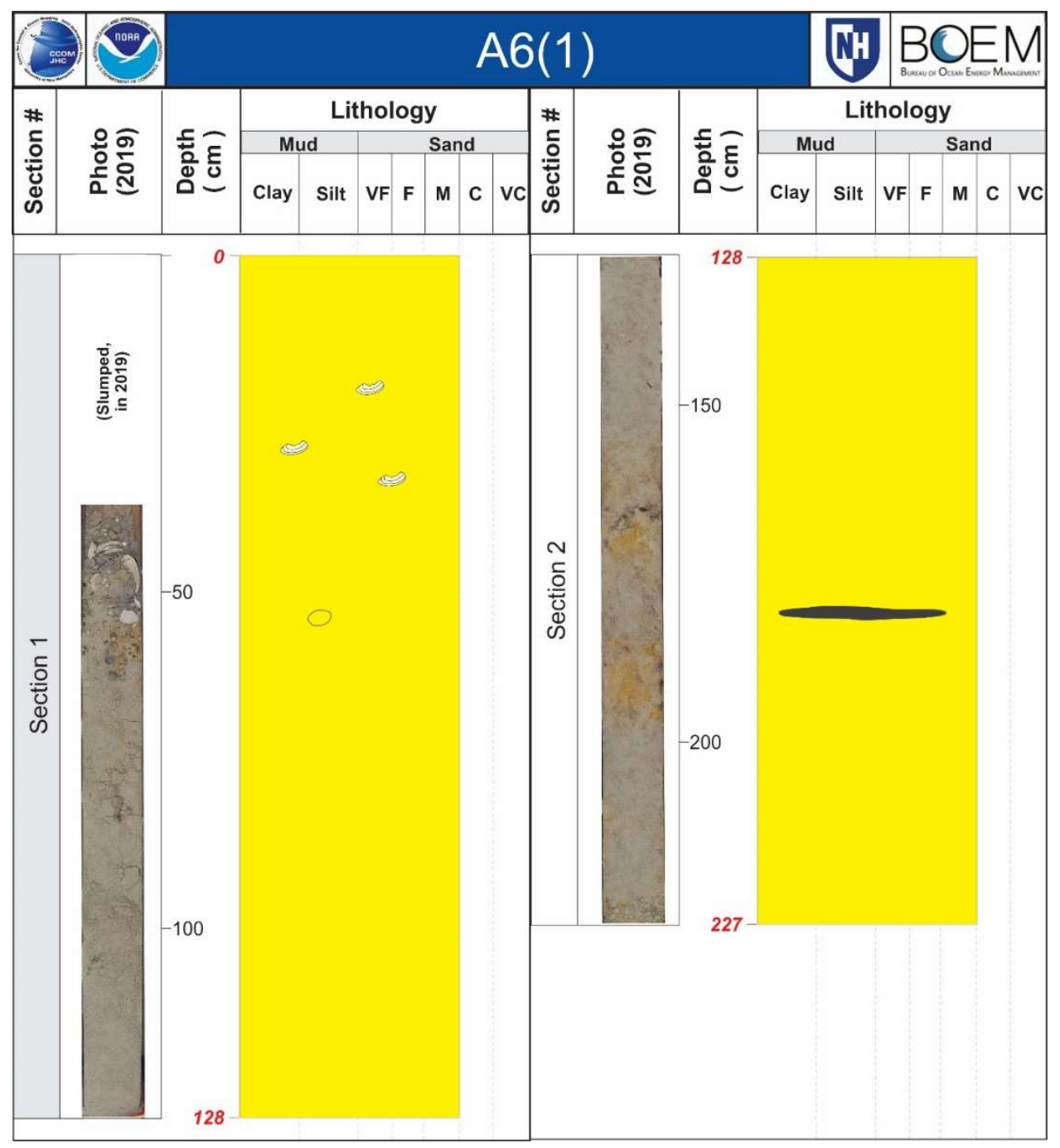

Figure 36. Core log for A6(1). The location of the core is given in Figures 6, 34, and 35. A full description of the core is given in Appendix $A$. 

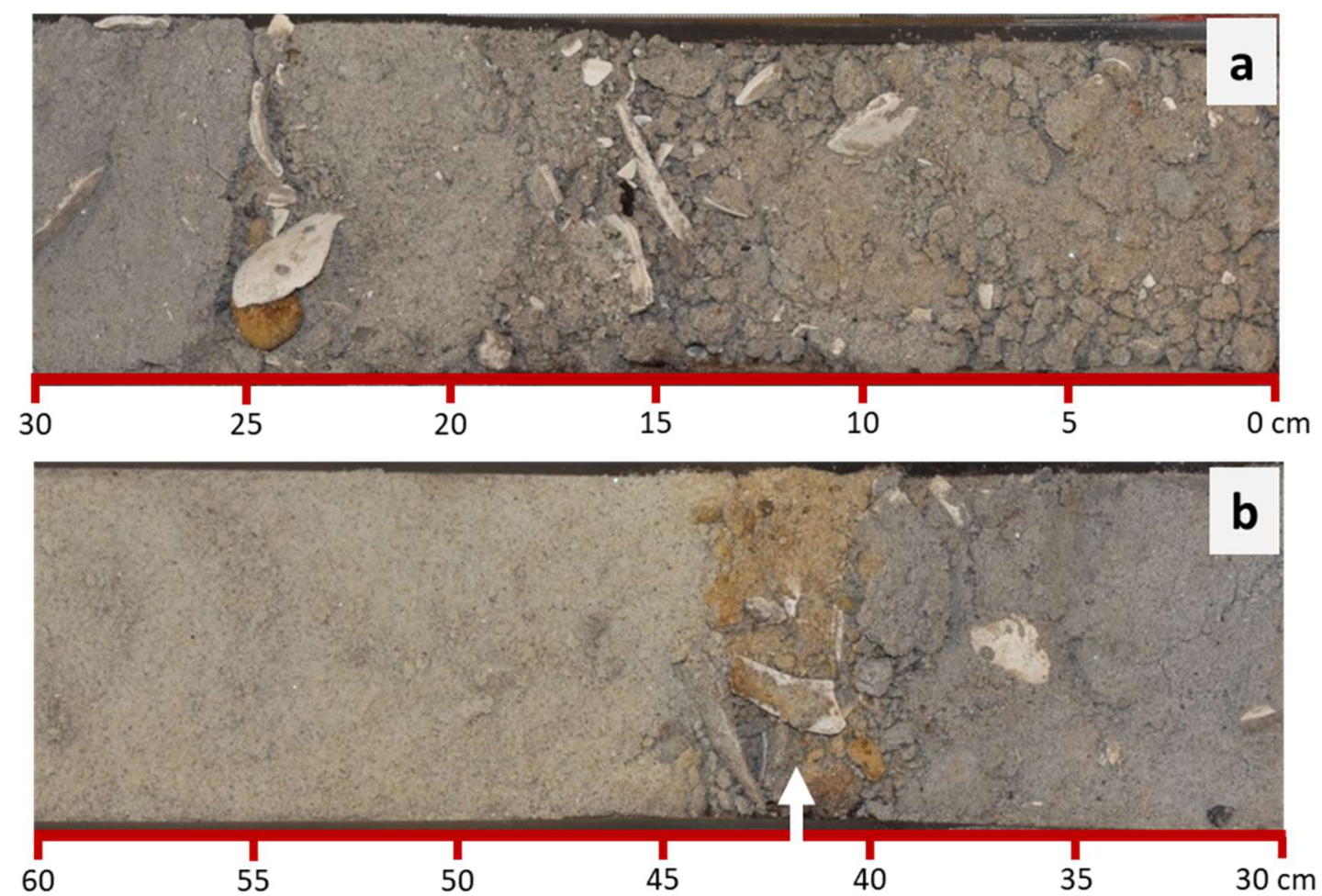

Figure $37(a, b)$. Photographs of Core A6(2). The top photograph (a) shows the core from the surface to $\sim 0.30 \mathrm{~m}$. The upper $\sim 0.20 \mathrm{~m}$ is a shell and sand lag deposit. The bottom photograph (b) shows the core from $\sim 0.30$ to $0.60 \mathrm{~m}$ and the contact with underlying sand deposit at $\sim 0.40$ to $0.44 \mathrm{~m}$ (white arrow). The top of the core is to the right.

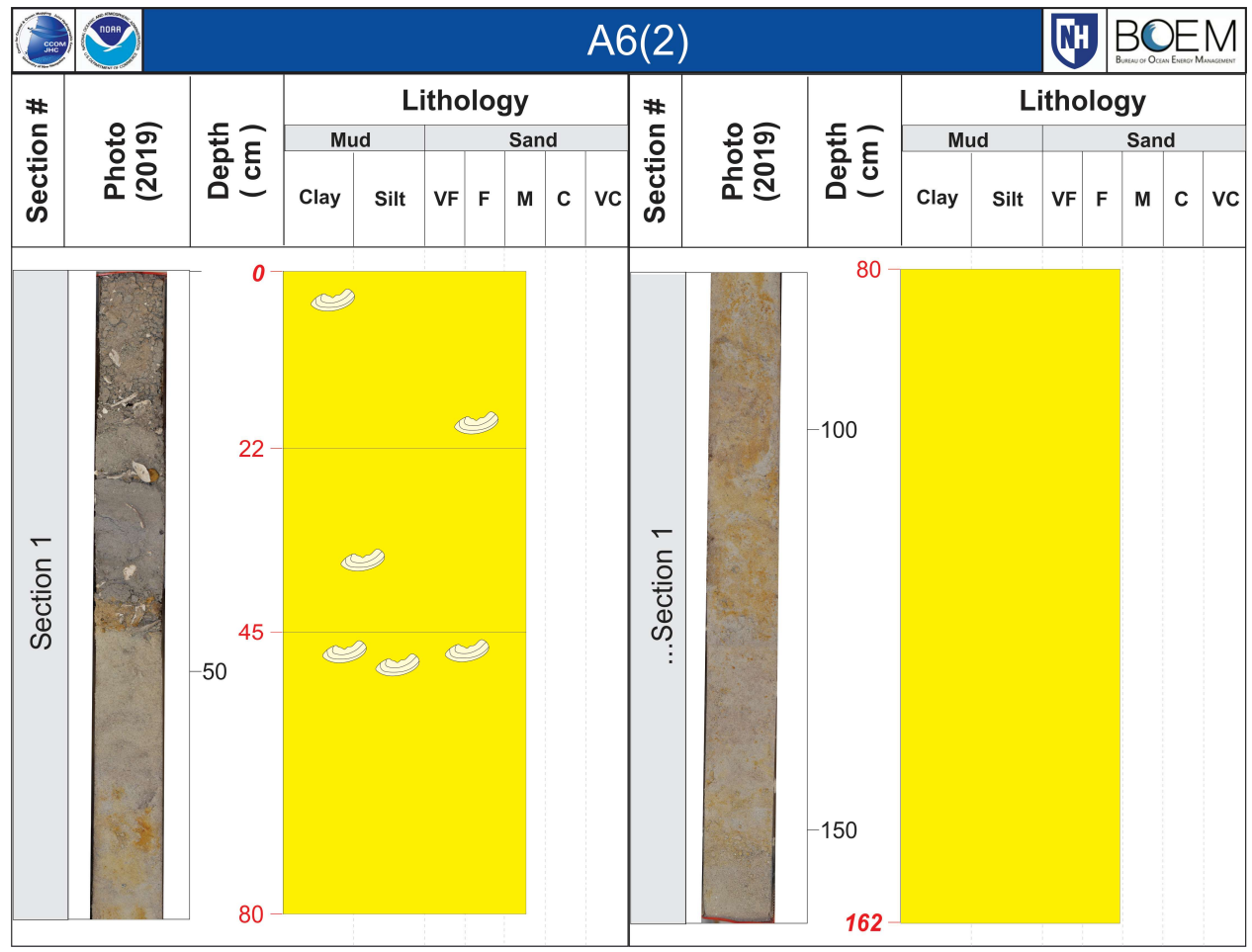

Figure 38. Log for vibracore A6(2). The location of the core is given in Figures 6, 34, and 35. Photographs of the core are shown in Figure 37. A full description of the core is given in Appendix A. 

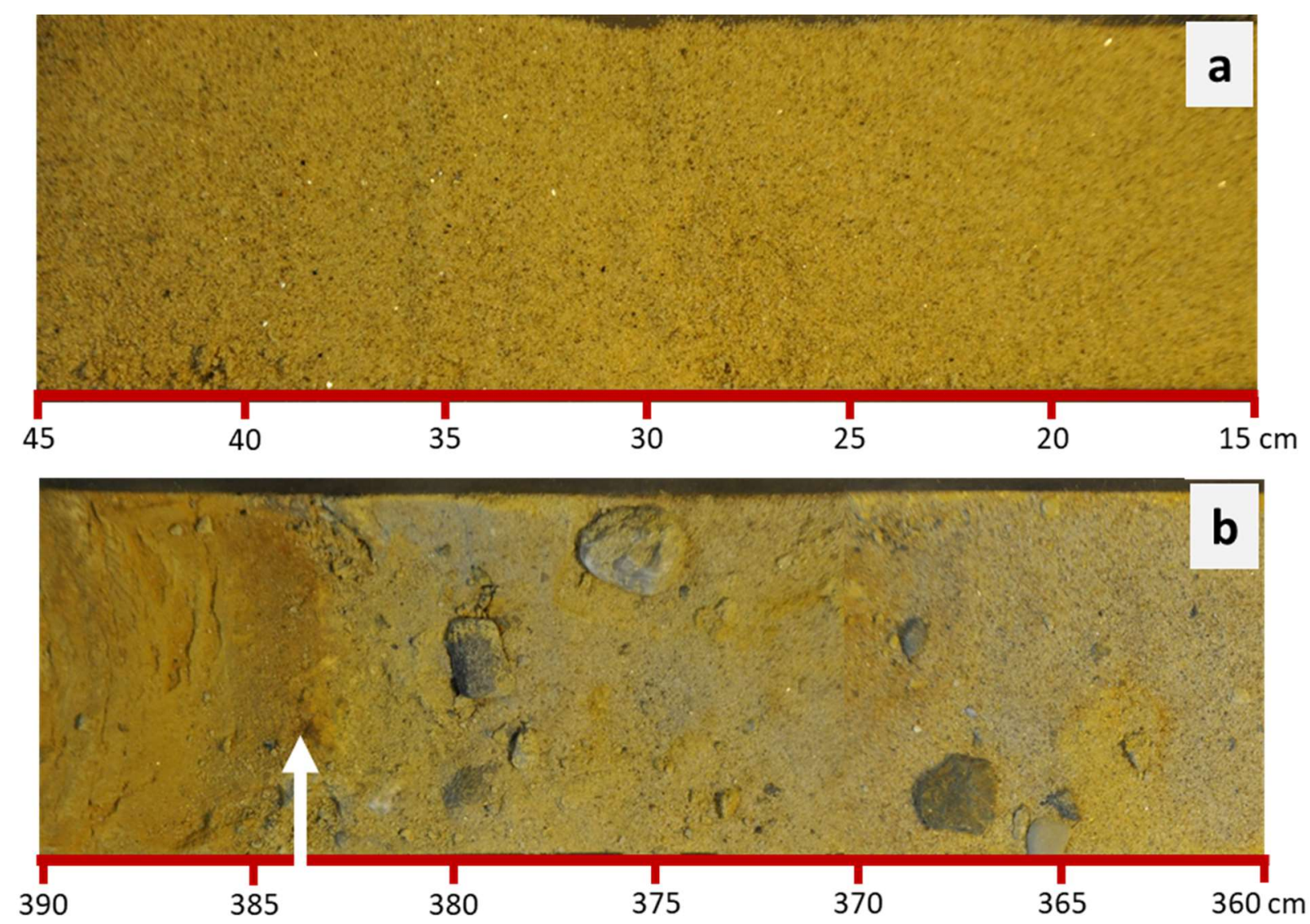

Figure $39(a, b)$. Photographs of Core A6(3). The top photograph (a) shows the core from 0.15 to $0.45 \mathrm{~m}$ composed of medium sand. The bottom photograph (b) shows the core from $\sim 3.60$ to $3.90 \mathrm{~m}$ and the contact with underlying glacial marine muds at $3.84 m$ (white arrow). 


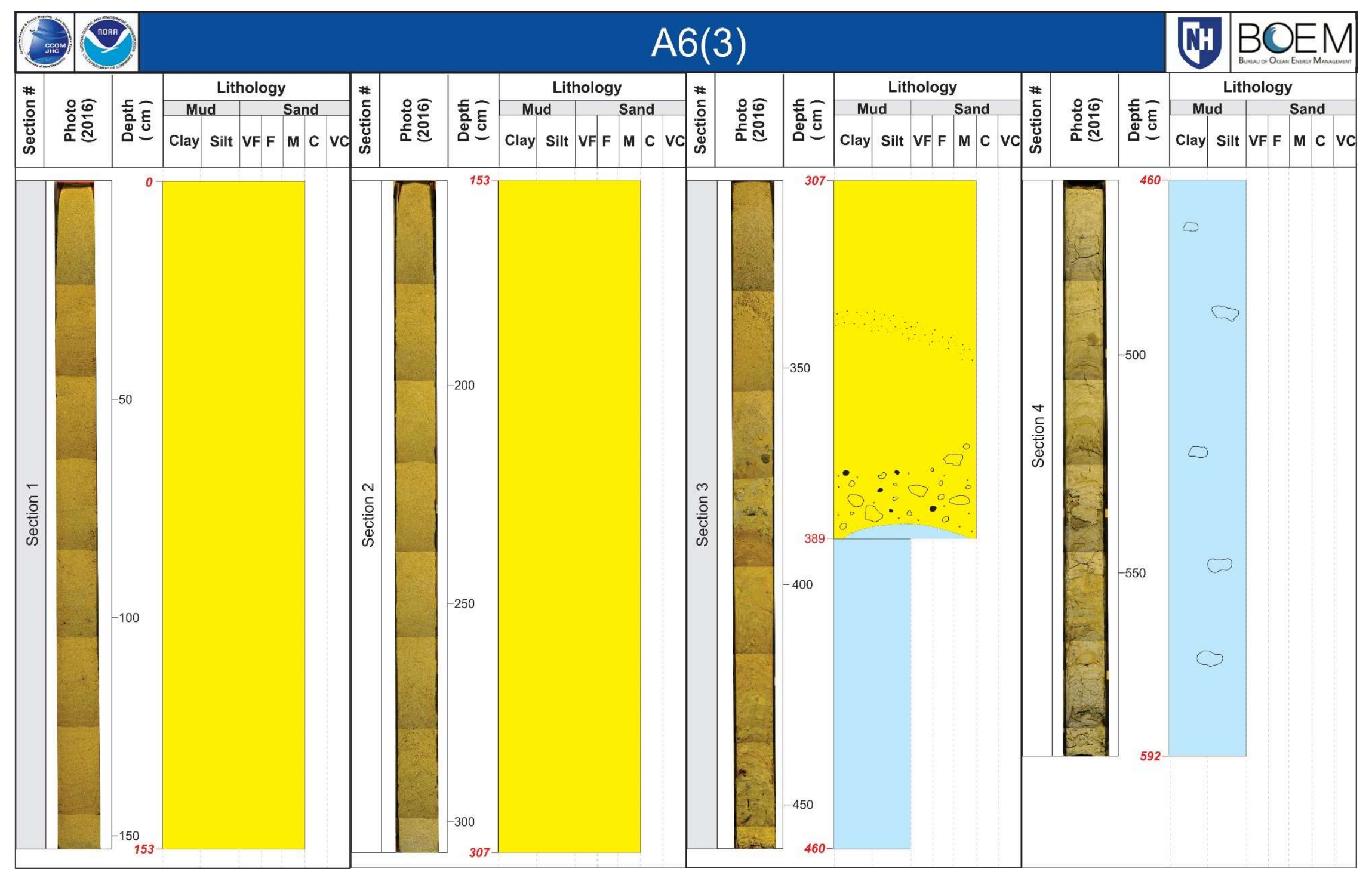

Figure 40. Core log for A6(3). The location of the core is given in Figures 6, 34, and 35. Photographs of the core are shown in Figure 39 (above). A full description of the core is given in Appendix A. 

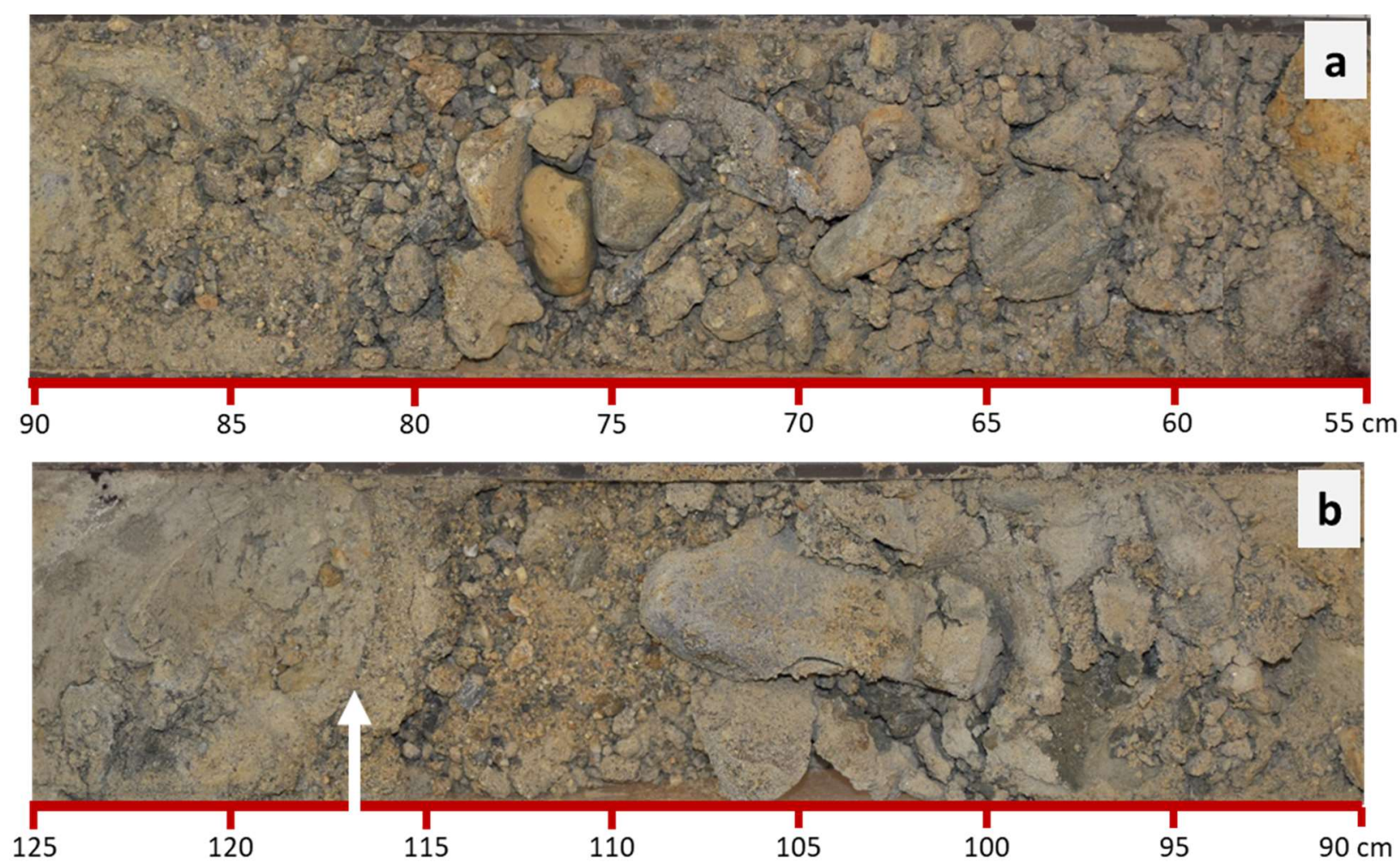

Figure 41 ( $a, b)$; Above. Photographs of Core A7(1). The top photograph (a) shows the core from $\sim 0.55$ to $0.90 \mathrm{~m}$ and is composed of pebble gravel. The bottom photograph (b) shows the core from $\sim 0.90$ to $1.25 \mathrm{~m}$ and the contact with the underlying very fine sand and marine muds (Presumpscot Formation distal facies) at $\sim 1.17 \mathrm{~m}$ (white arrow). 


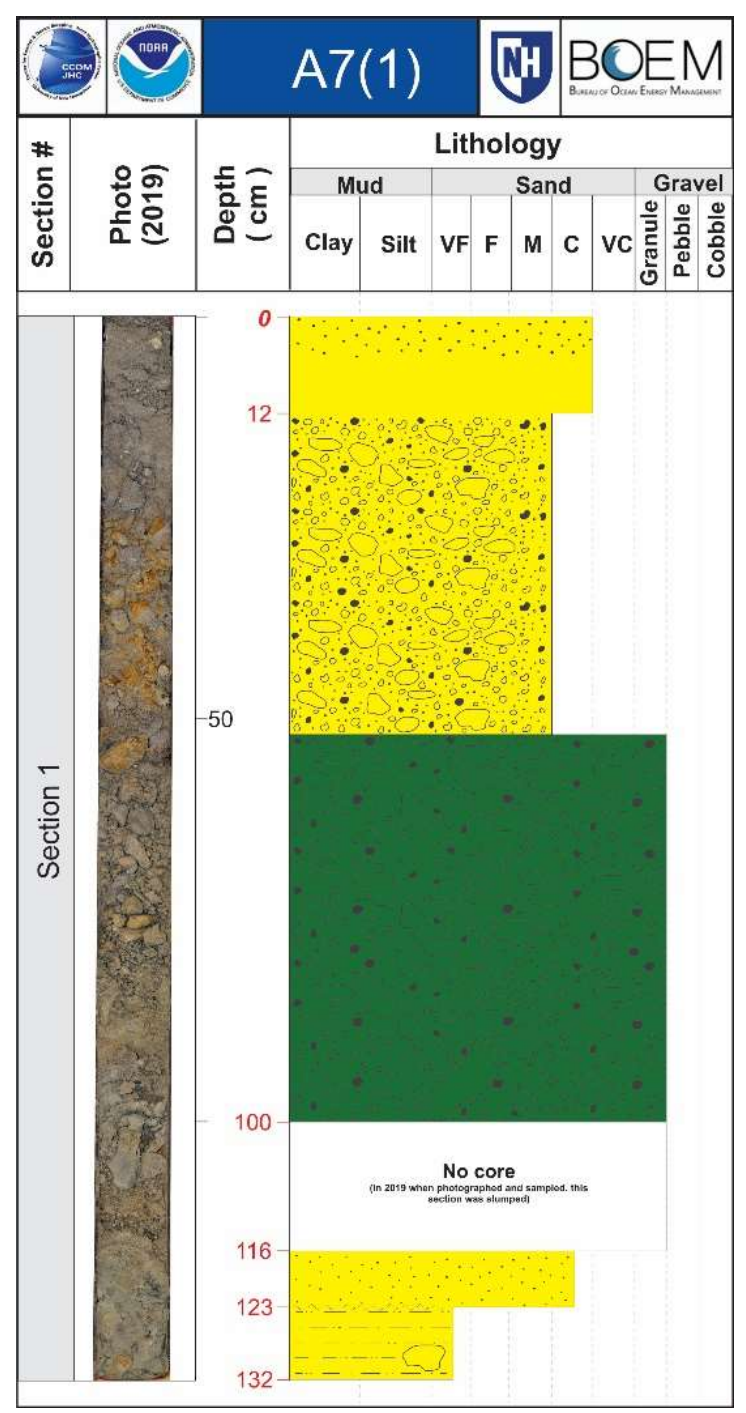

Figure 42; Left. Log for A7(1). The location of the core is given in Figures 6, 34, and 35. Photographs of the core are shown in Figure 41. A full description of the core is given in Appendix A. 


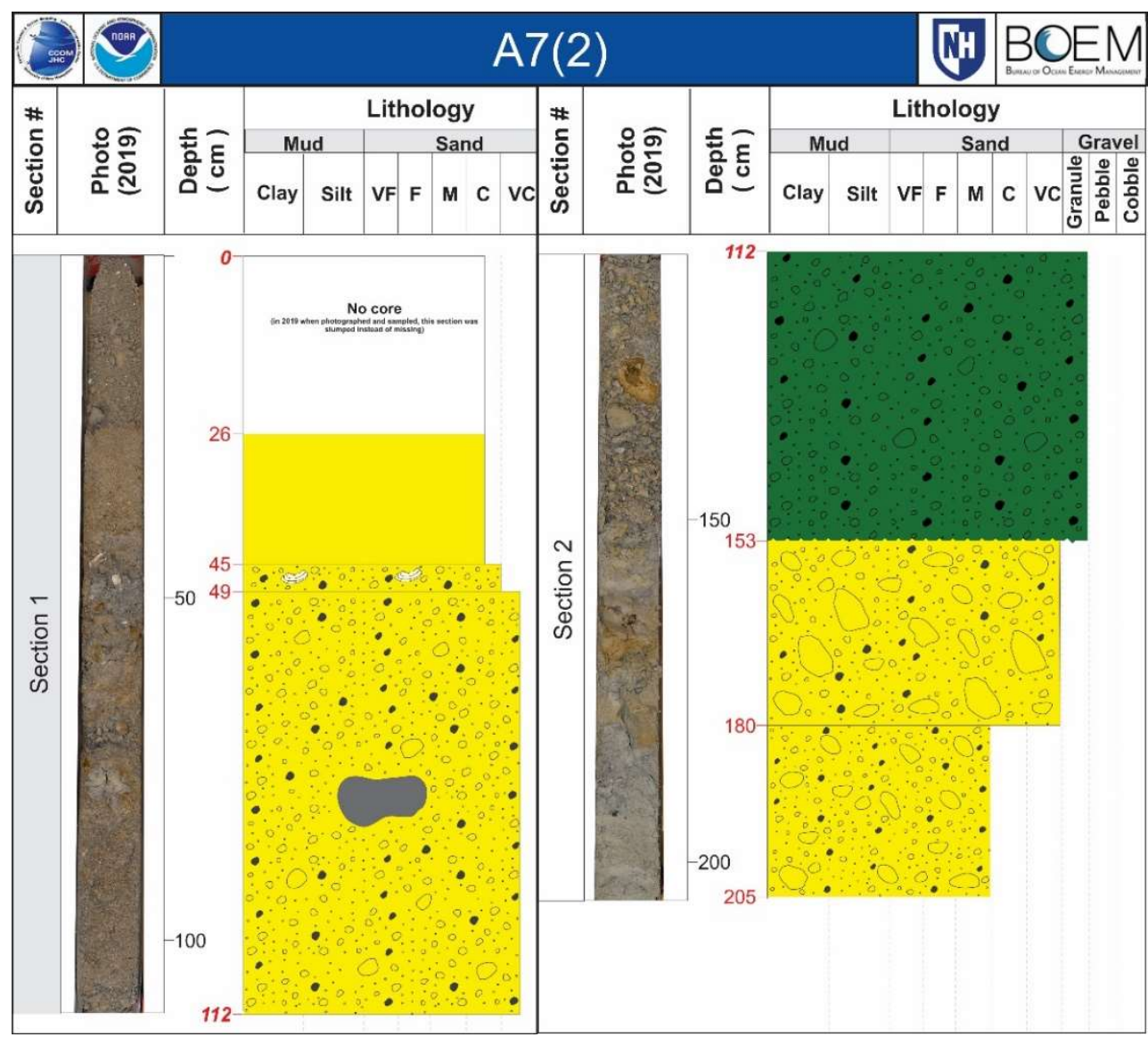

Figure 43. Log for vibracore A7(2) taken in 1988. The location of the core is given in Figures 6, 34, and 35. A full description of the core is given in Appendix A. 


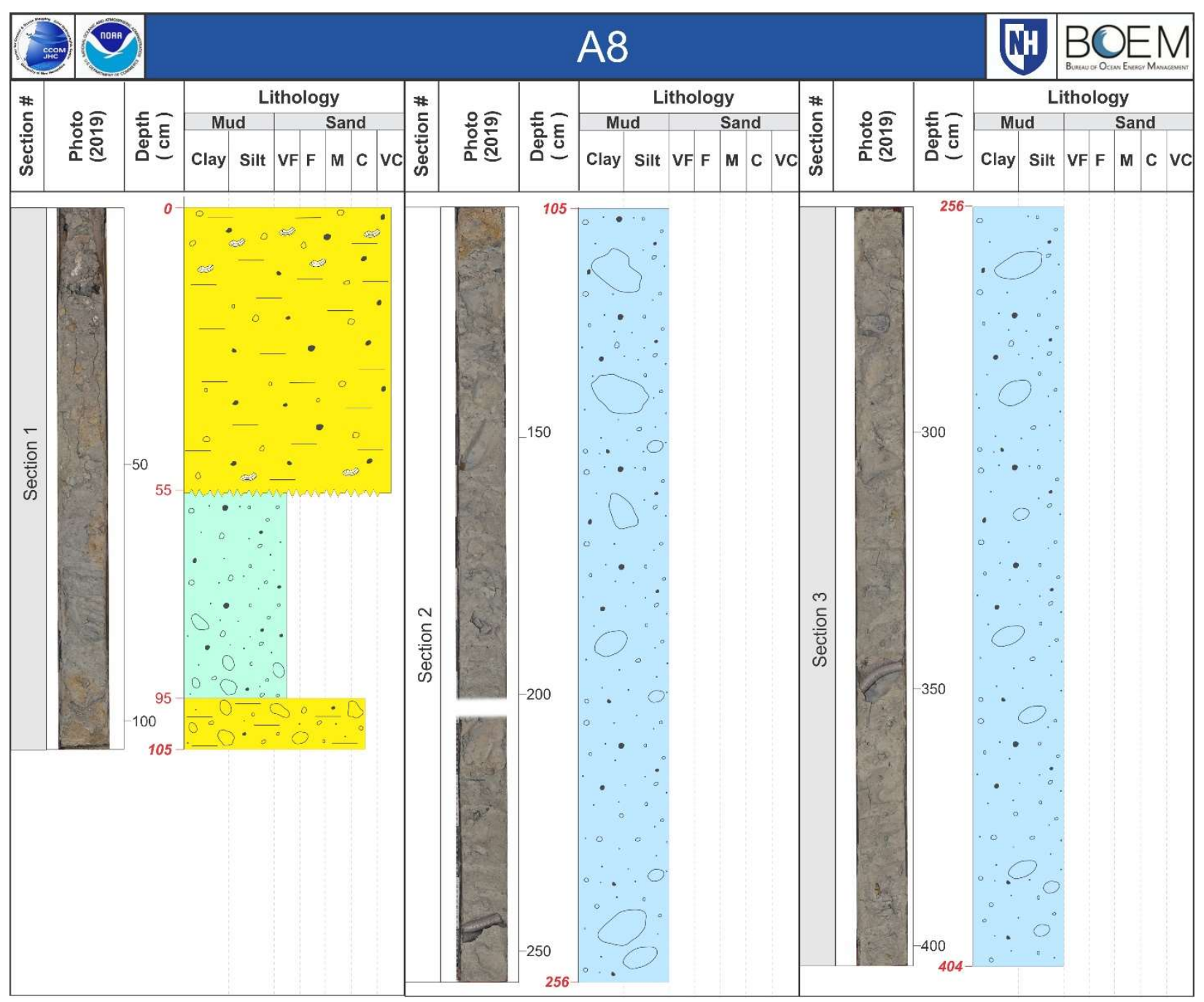

Figure 44. Log for vibracore A8. The location of the core is given in Figures 6, 34, and 35. A full description of the core is given in Appendix $A$. 


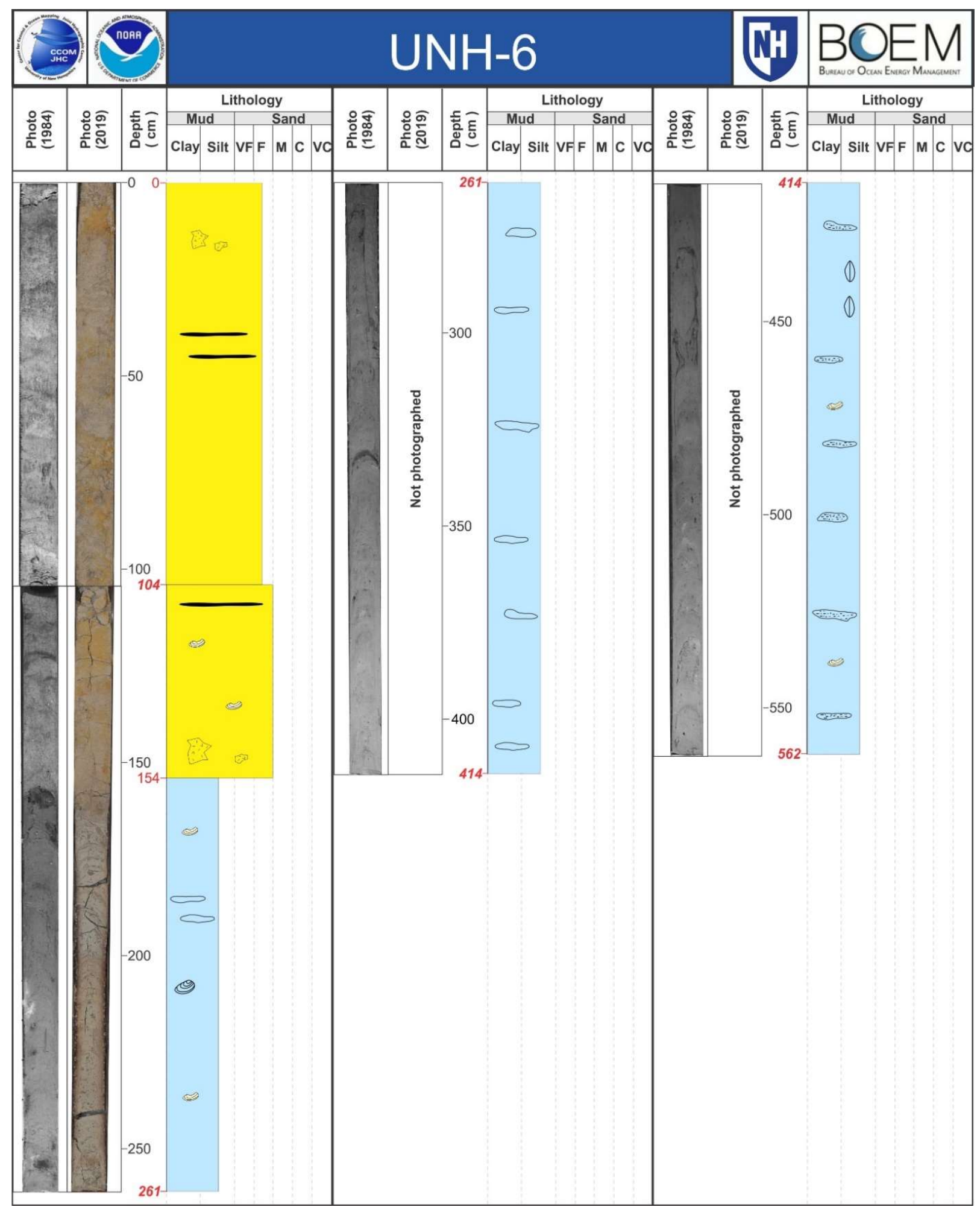

Figure 45a. Core log for the upper $5.62 \mathrm{~m}$ of UNH-6. The lower core log $(5.62-8.51 \mathrm{~m})$ is given in Figure $45 b$ (below). The location of the core is given in Figures 6, 34, and 35. Photographs of the core are shown in Figure 46 (below). A full description of the core is given in Appendix $A$. 


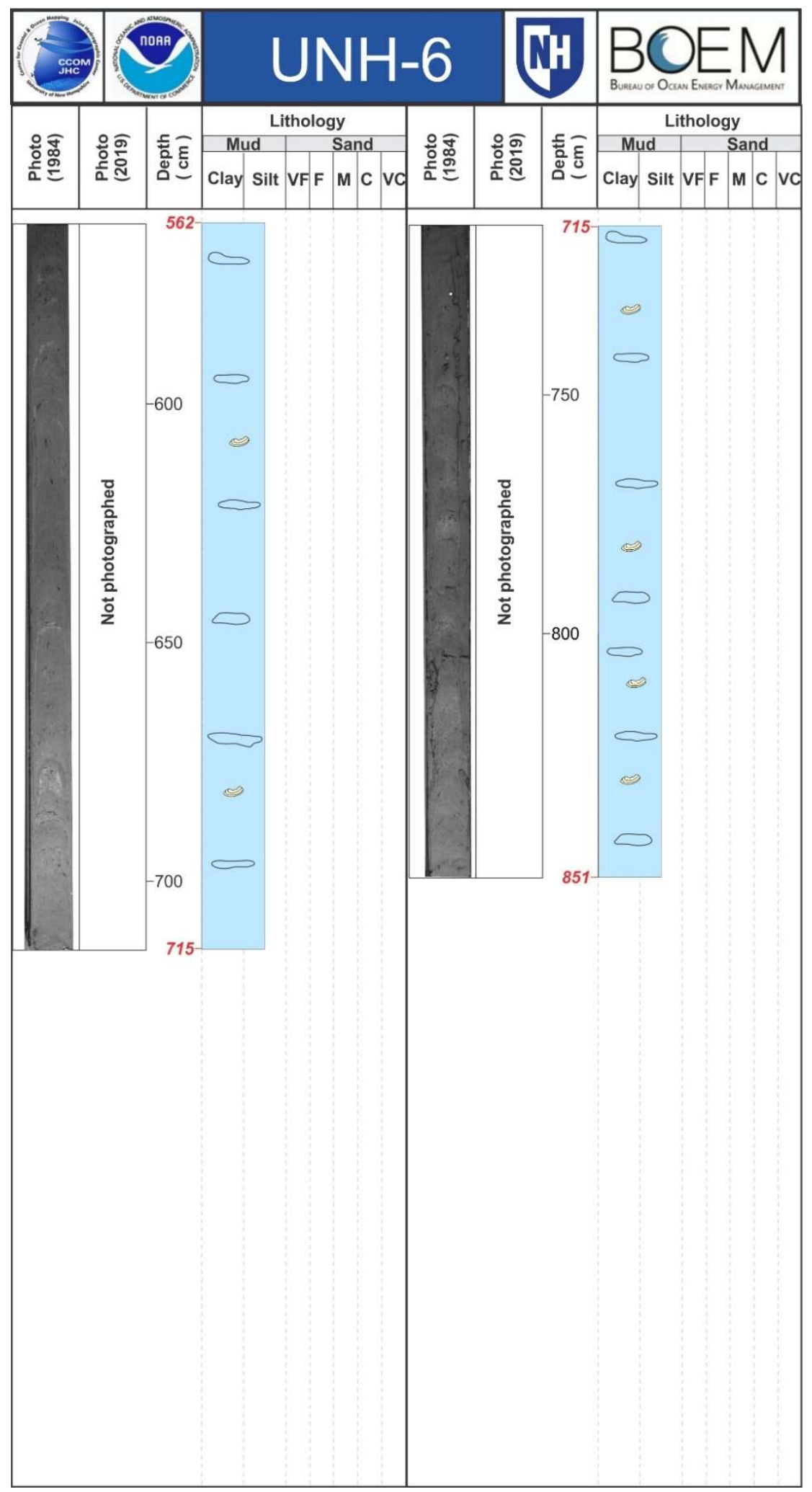

Figure 45b. Log for the lower part of UNH-6 (5.62 - 8.51m). The upper $5.62 \mathrm{~m}$ is shown in Figure 45a (above). 


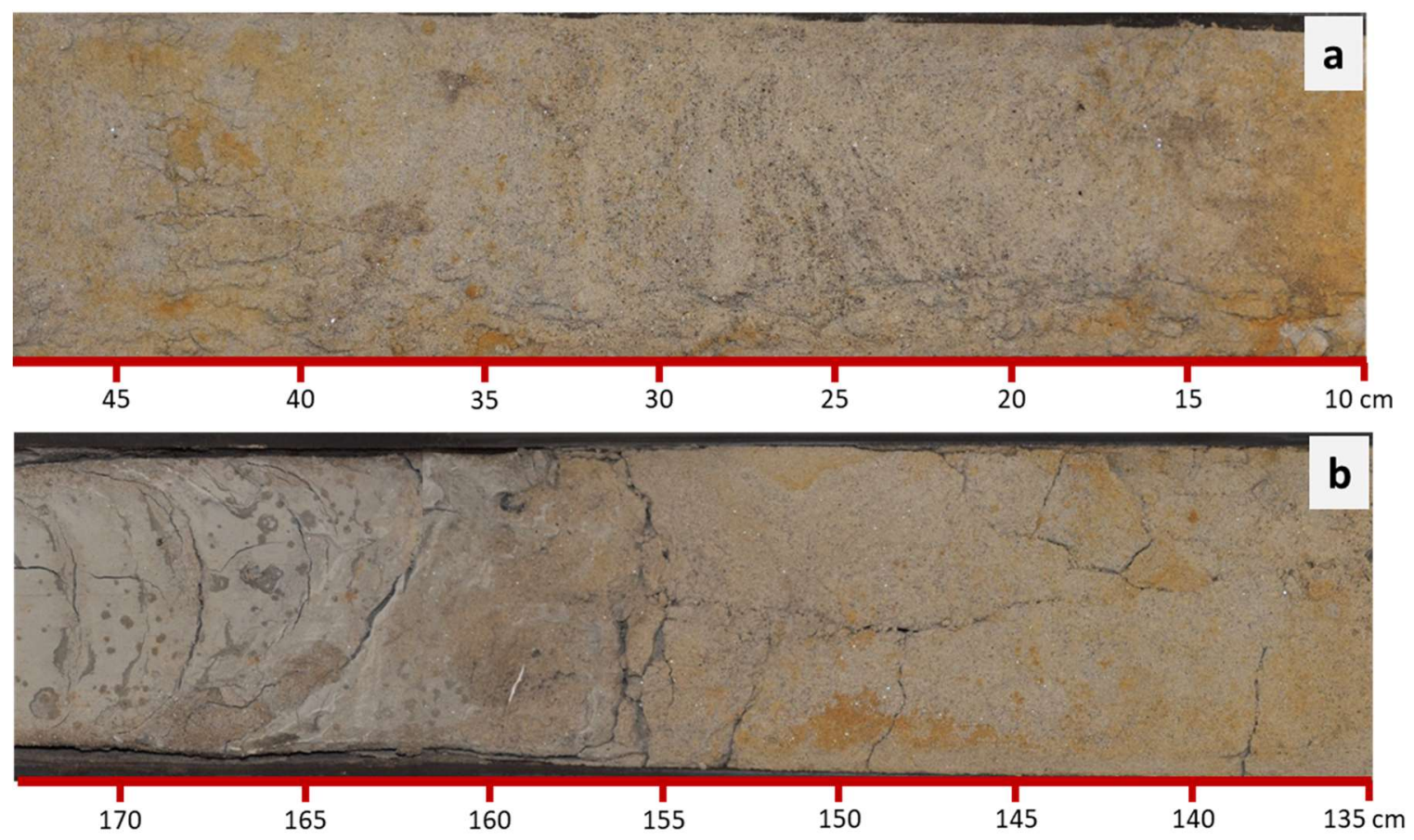

Figure 46 ( $a, b)$. Photographs of Core UNH-6. The upper core (a) from $\sim 0.10$ to $0.48 m$ is composed of fine to medium sand. The contact between fine sand and marine muds (Presumpscot Formation distal facies) is shown in lower photograph at $1.60 \mathrm{~m}$ (b). The core log for UNH-6 is shown in Figure 45 (above).
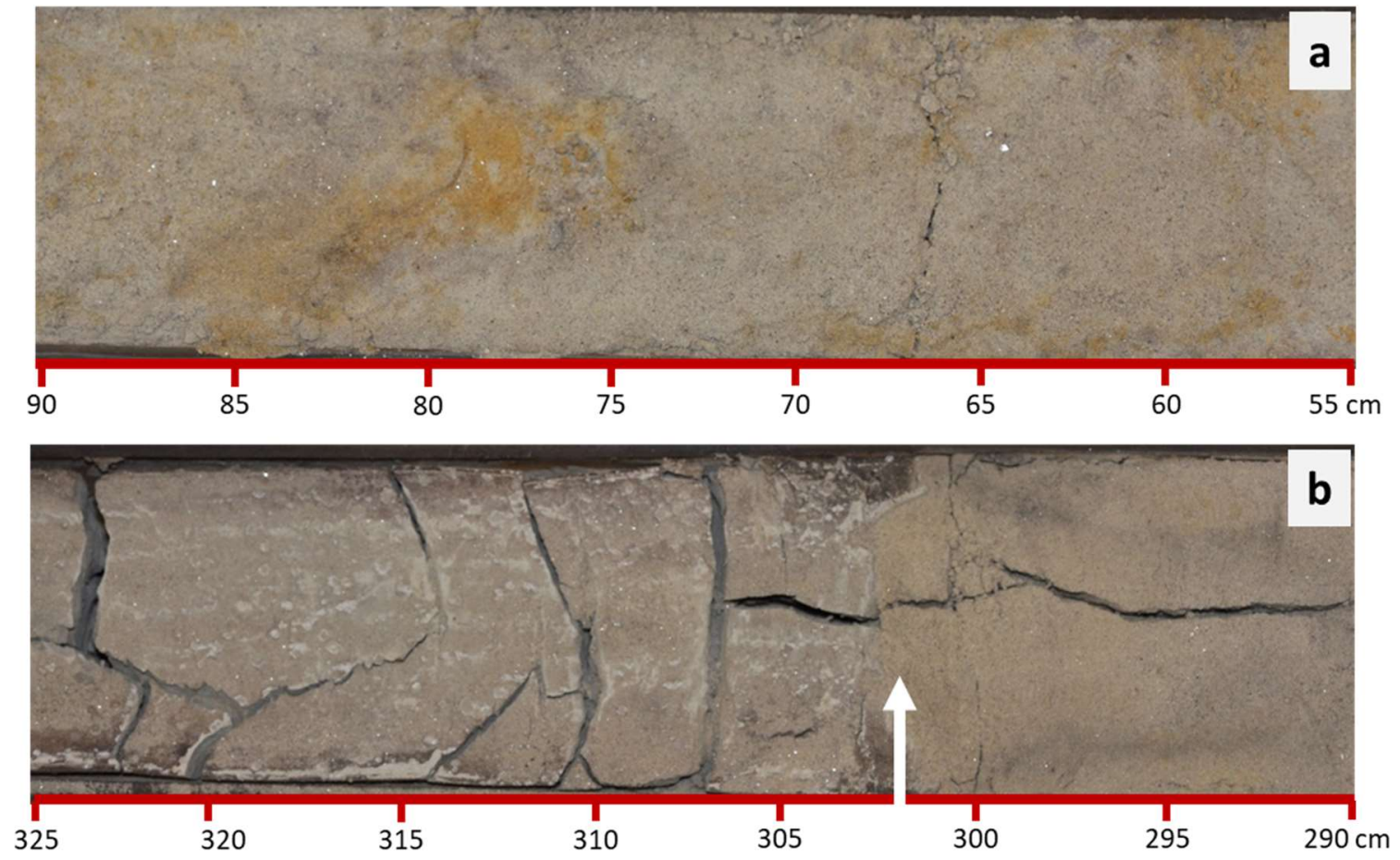

Figure $47(a, b)$. Photographs of Core UNH-6a. The top photograph (a) shows the core from 0.55 to $0.90 m$ composed of fine sand. The bottom photograph (b) shows the core from $\sim 2.90$ to $3.25 \mathrm{~m}$ and the contact with fine sand and marine muds (Presumpscot Formation distal facies) at $3.02 m$ (white arrow). 


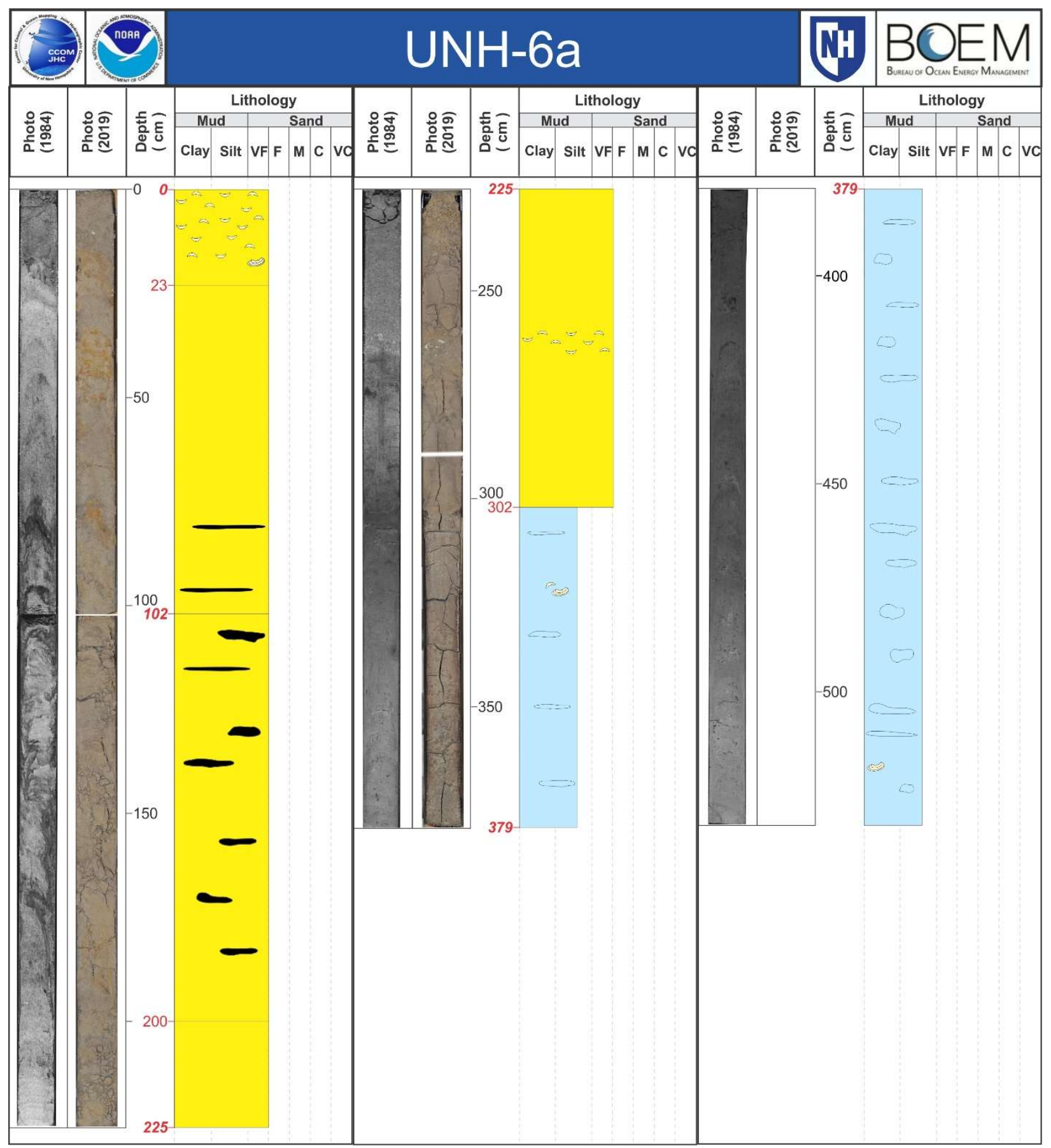

Figure 48a. Core log for the upper $5.32 \mathrm{~m}$ of UNH-6a. The lower core log $(5.32-8.32 \mathrm{~m})$ is given in Figure $48 b$ (below). The location of the core is given in Figures 6, 34, and 35. Photographs of the core are shown in Figure 47 (above). A full description of the core is given in Appendix A. 


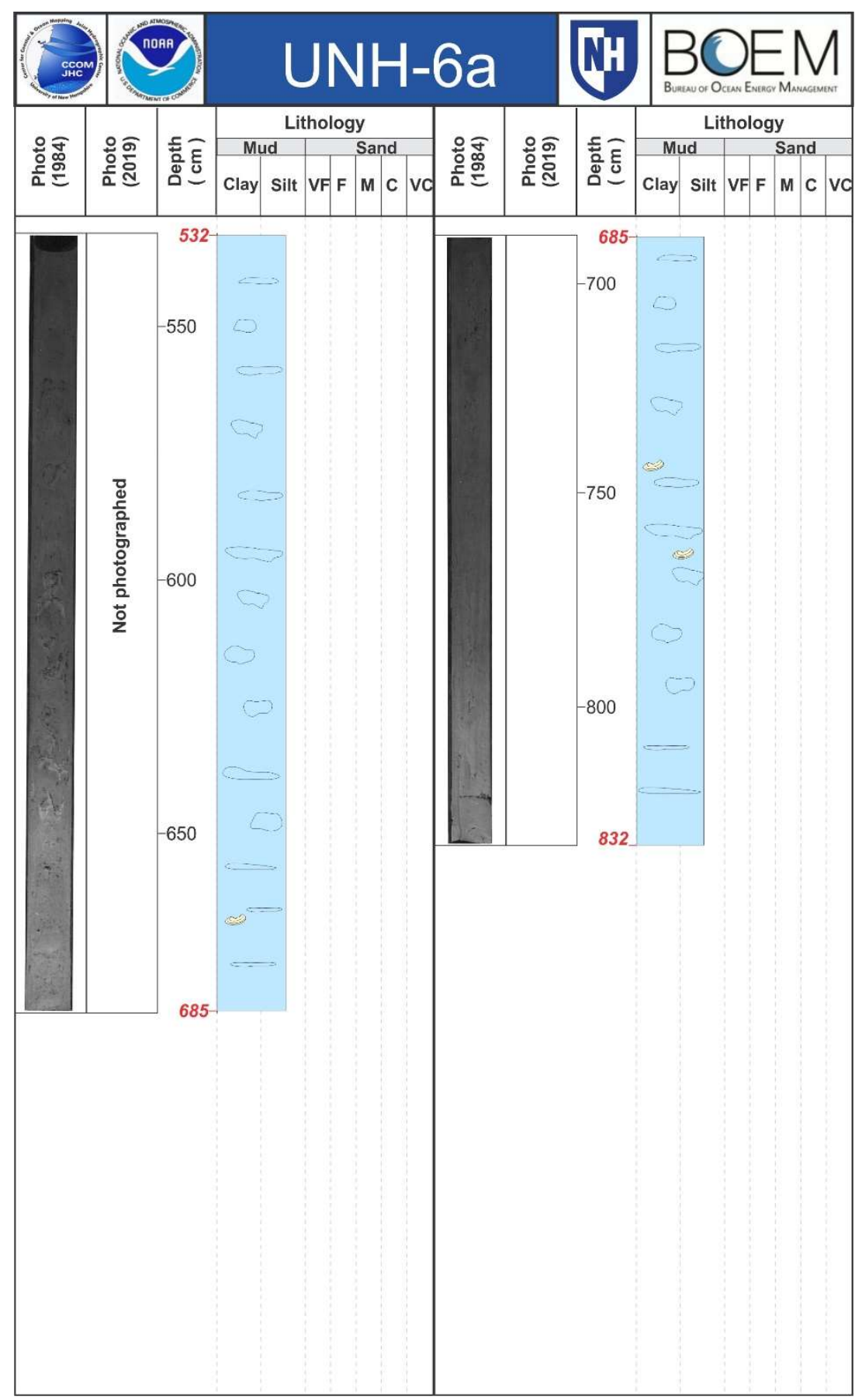

Figure 48b. Core log for the lower part of UNH-6a (5.32 - 8.32m). The upper $5.32 \mathrm{~m}$ is shown in Figure 48 a (above). 


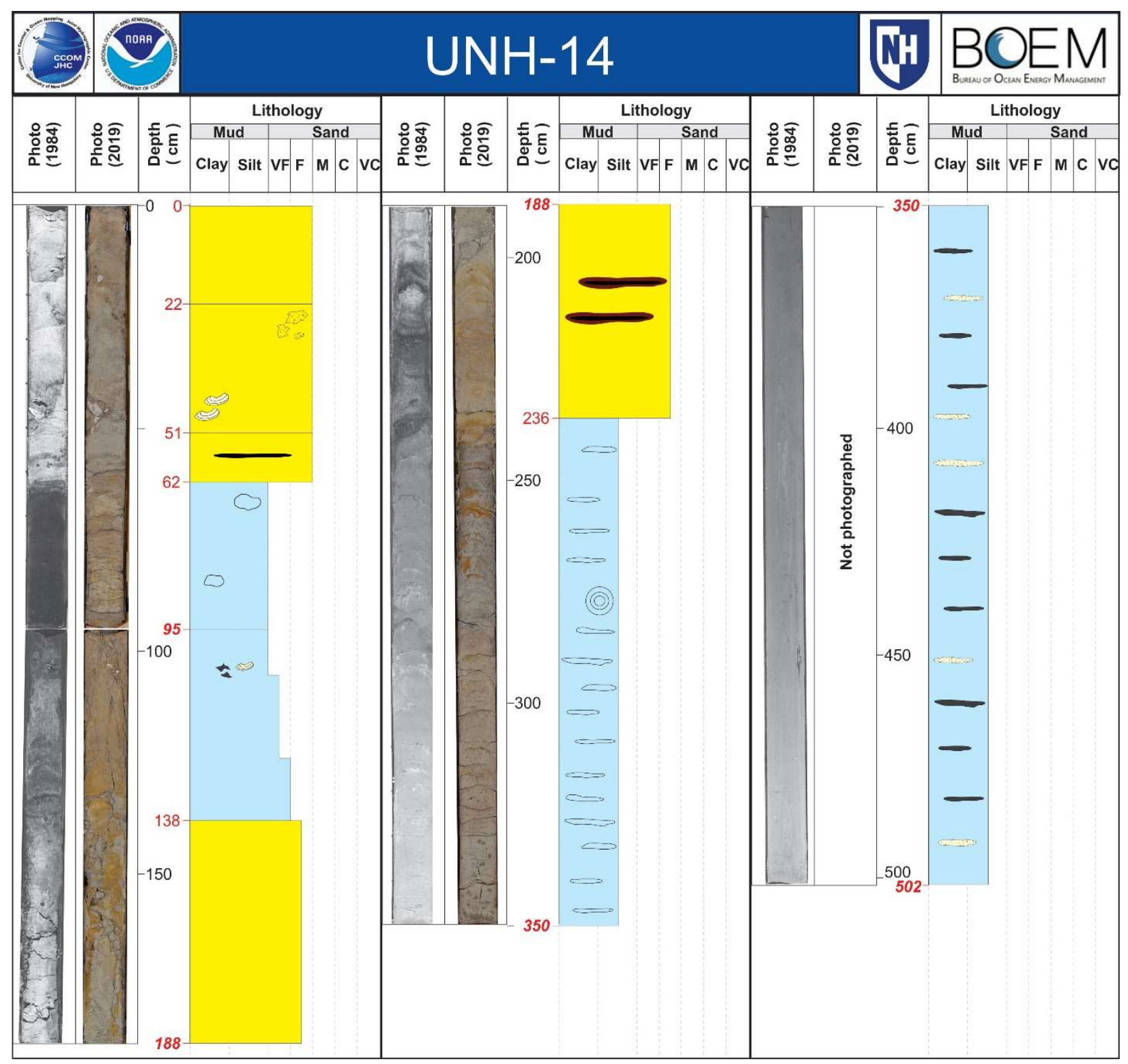

Figure 49a. Log of UNH-14 showing the upper 5.02m. The lower core log (5.02- $7.87 \mathrm{~m}$ ) is shown in Figure $49 \mathrm{~b}$ (below). The location of the core is given in Figures 6, 34, and 35. A full description of the core is given in Appendix A. 


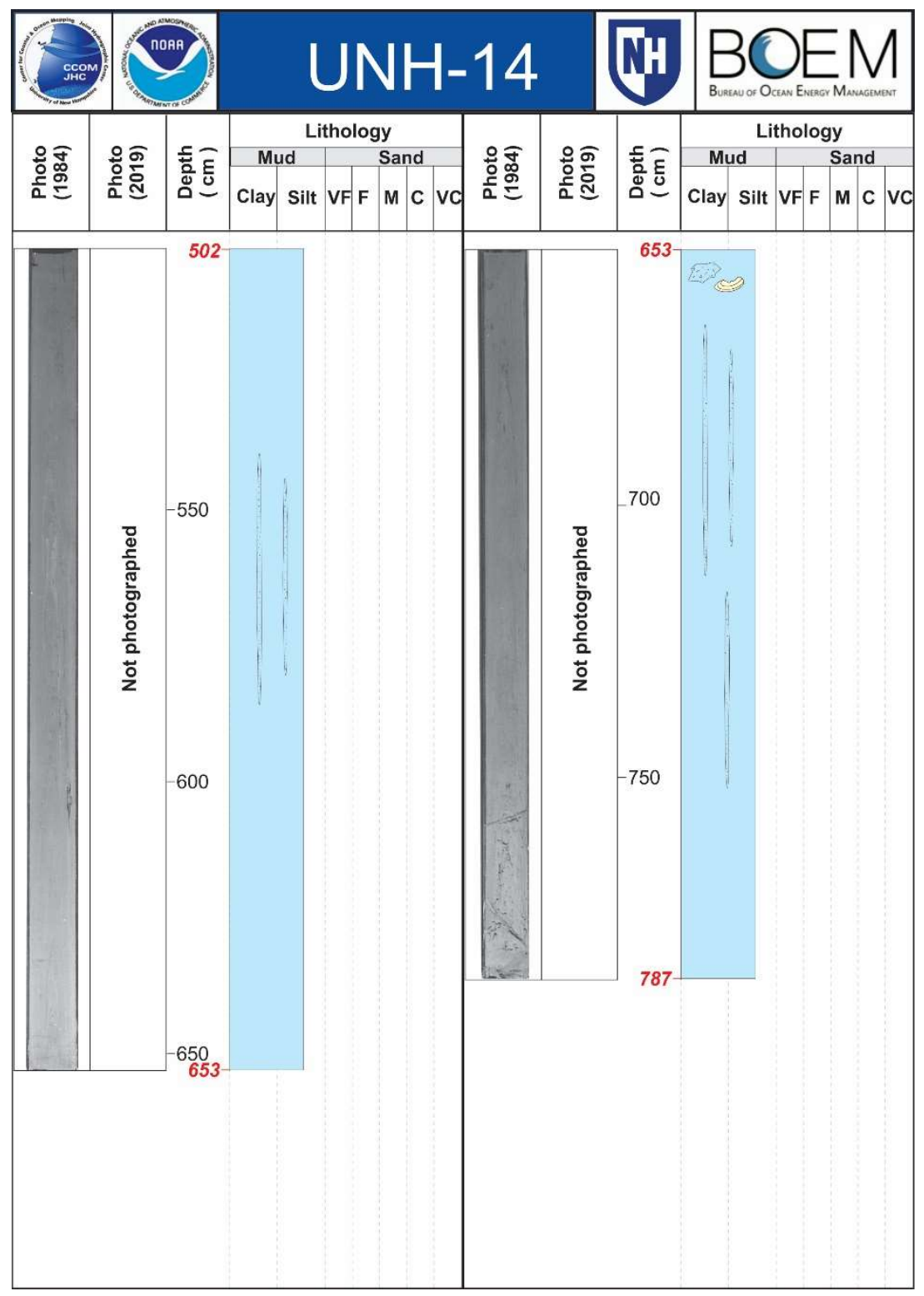

Figure 49b. Core log for the lower portion (5.02 - 7.87m) of UNH-14. The upper 5.02m is shown in Figure 49a (above). 


\section{Offshore Seafloor Plain}

Two vibracores (UNH-9 and UNH-10) were located offshore in an area characterized by bedrock outcrops separated by seafloor plains (Figures 6,50 , and 51 ). The seafloor plain is presumably characterized by distal glacial marine sediment (Presumpscot Formation).

\section{Vibracore UNH-9}

UNH-9 was collected $\sim 12.5 \mathrm{~km}$ offshore in $\sim 61 \mathrm{~m}$ water depth. It is $8.39 \mathrm{~m}$ in length and is composed of very fine sand to silt and clay (Figure 52). A sample from $0.06-0.08 \mathrm{~m}$ is a slightly granuley silty-clayey very fine sand with $\sim 52 \%$ sand, $48 \%$ mud, and a mean grain size of $5.20 \phi(0.027 \mathrm{~mm})$ (Table 11). A sample from $0.19-0.21 \mathrm{~m}$ is a very fine sandy silt-clay with $\sim 18 \%$ sand, $82 \%$ mud and a mean grain size of $7.90 \phi$ $(0.004 \mathrm{~mm})$. The upper $\sim 1.5 \mathrm{~m}$ contain numerous centimeter-scale clayey silt lenses and pods. From $\sim 1.5$ to $3.9 \mathrm{~m}$ there are fewer pods, but a greater number of thin laminae made up of clayey silt and sand. This sequence of sediment is typical of the distal facies of the glacial marine muds.

\section{Vibracore UNH-10}

UNH-10 is located $\sim 15.6 \mathrm{~km}$ offshore in $\sim 70 \mathrm{~m}$ of water. The core is $7.40 \mathrm{~m}$ in length and is comprised completely of silt-clay characteristic of the distal facies of the Presumpscot Formation (Figure 53). It was taken approximately $6 \mathrm{~km}$ to the northeast of vibracore UNH-9 in an area surrounded by bedrock (Figure 51). Frequent thin silty layers and sandy laminae were observed in the upper core along with mottling and shell fragments. Throughout the remainder of the core some clay-rich laminae and additional shell fragments were observed. Similar to UNH-9, grain size analyses (Table 11) show higher sand fractions at the top of the core (e.g. from $0.24-0.26 \mathrm{~m}$ the sand content is $\sim 22 \%$ ), but the remainder of the core has very high mud fractions, all greater than $94 \%$.

Table 11. Grain size data for vibracores taken in the Offshore Seafloor Plain: UNH-9 and UNH-10. Complete grain size classifications and statistics are given in Appendix $B$.

\begin{tabular}{|c|c|c|c|c|c|c|c|c|c|c|}
\hline UNH Sample ID & $\begin{array}{l}\text { Gravel } \\
\%\end{array}$ & $\begin{array}{l}\text { Pebble } \\
\%\end{array}$ & $\begin{array}{l}\text { Granule } \\
\%\end{array}$ & $\begin{array}{l}\text { Sand } \\
\%\end{array}$ & $\begin{array}{l}\text { Mud } \\
\%\end{array}$ & $\begin{array}{l}\text { Silt } \\
\%\end{array}$ & $\begin{array}{l}\text { Clay } \\
\%\end{array}$ & $\begin{array}{l}\text { Mean Size } \\
\text { (phi) }\end{array}$ & $\begin{array}{l}\text { Sorting } \\
\text { (phi) }\end{array}$ & $\begin{array}{l}\text { CMECS (FGDC 2012) } \\
\text { Substrate Component } \\
\text { Subgroup (Specific) }\end{array}$ \\
\hline UNH-9_6-8cm & 0.06 & 0.00 & 0.06 & 51.76 & 48.18 & 31.57 & 16.61 & 5.20 & 2.61 & $\begin{array}{l}\text { Slightly Granuley Silty- } \\
\text { Clayey Very Fine Sand }\end{array}$ \\
\hline UNH-9_19-21cm & 0.00 & 0.00 & 0.00 & 17.67 & 82.33 & 34.33 & 48.00 & 7.90 & 3.56 & Very Fine Sandy Silt-Clay \\
\hline UNH-9_37-39cm & 0.00 & 0.00 & 0.00 & 65.99 & 34.01 & 23.19 & 10.82 & 4.27 & 1.91 & Silty Very Fine Sand \\
\hline UNH-9_48-50cm & 0.00 & 0.00 & 0.00 & 9.01 & 90.99 & 44.28 & 46.71 & 8.06 & 3.33 & Silt-Clay \\
\hline UNH-9_88-90cm & 0.00 & 0.00 & 0.00 & 5.66 & 94.34 & 35.85 & 58.49 & 8.87 & 3.27 & Silt-Clay \\
\hline UNH-9_181-183cm & 0.14 & 0.00 & 0.14 & 60.67 & 39.19 & 28.22 & 10.97 & 4.37 & 2.04 & $\begin{array}{l}\text { Slightly Granuley Silty } \\
\text { Very Fine Sand }\end{array}$ \\
\hline UNH-9_198-200cm & 0.00 & 0.00 & 0.00 & 7.98 & 92.02 & 48.11 & 43.91 & 7.81 & 3.32 & Silt-Clay \\
\hline UNH-10_24-26cm & 0.00 & 0.00 & 0.00 & 21.86 & 78.14 & 29.97 & 48.17 & 7.89 & 3.61 & Very Fine Sandy Silt-Clay \\
\hline UNH-10_120-122cm & 0.00 & 0.00 & 0.00 & 4.44 & 95.56 & 59.14 & 36.42 & 7.38 & 3.12 & Silt-Clay \\
\hline UNH-10_152-154cm & 0.00 & 0.00 & 0.00 & 5.32 & 94.68 & 38.88 & 55.80 & 8.59 & 3.30 & Silt-Clay \\
\hline UNH-10_268-270cm & 0.00 & 0.00 & 0.00 & 2.53 & 97.47 & 39.48 & 57.99 & 8.84 & 3.12 & Silt-Clay \\
\hline
\end{tabular}




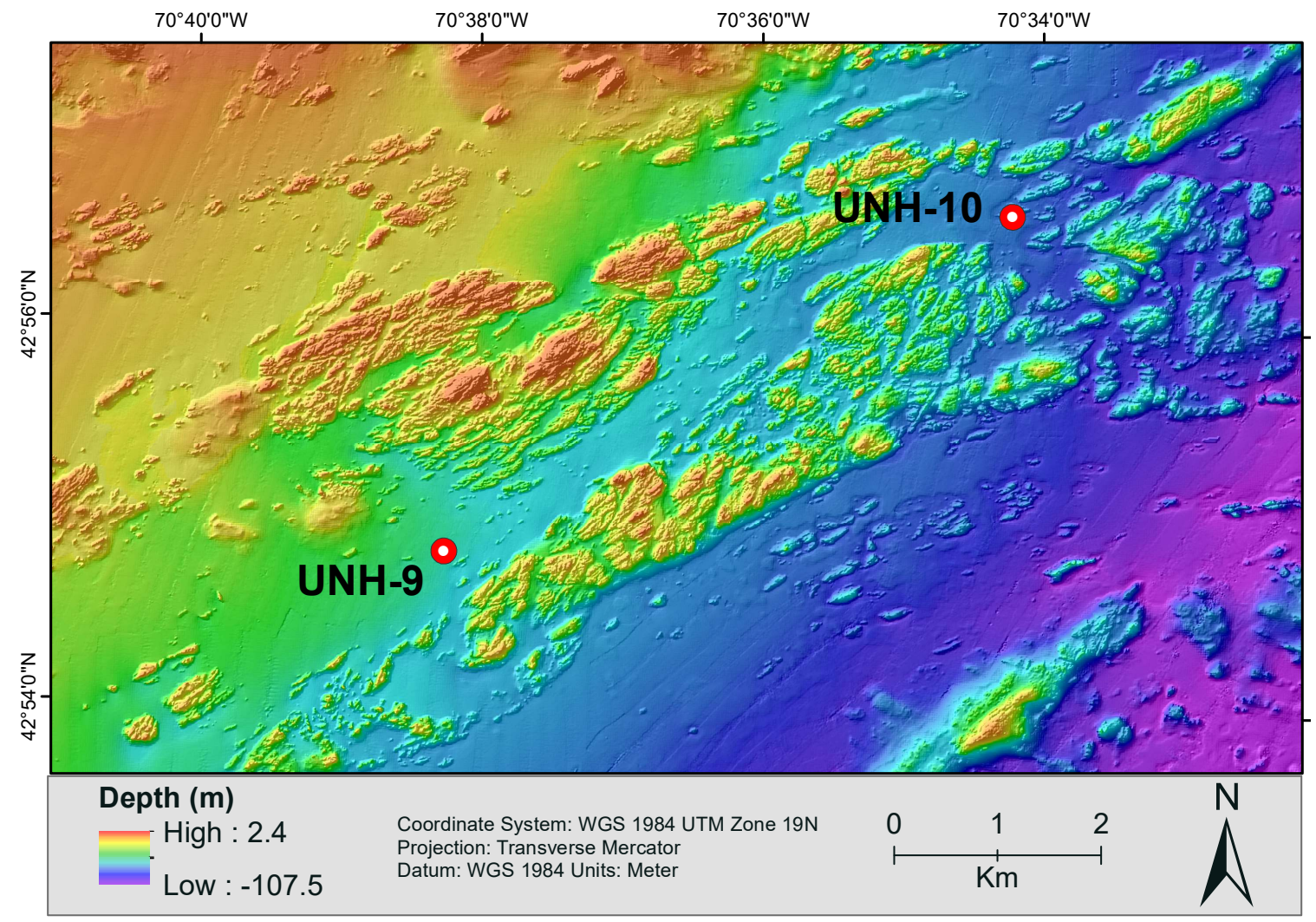

Figure 50. Bathymetric map of the vibracores taken in the Offshore Seafloor Plain. Map is shown at a scale of 1:50,000. 

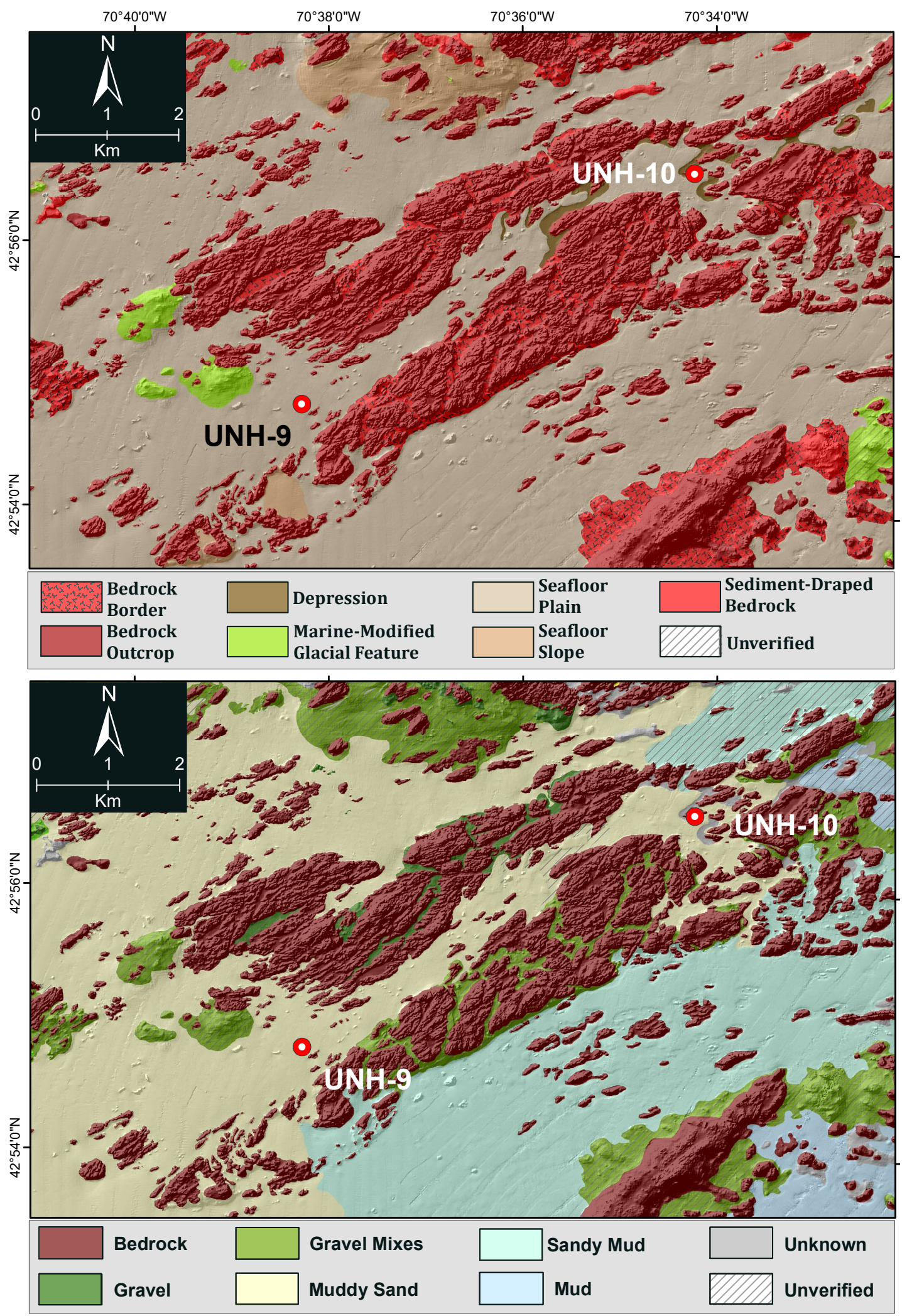

Figure 51. Major geoforms (physiographic features; top) and surficial sediment map (substrate classes; bottom) of the vibracores taken in the Offshore Seafloor Plain. Map is shown at a scale of 1:50,000. 


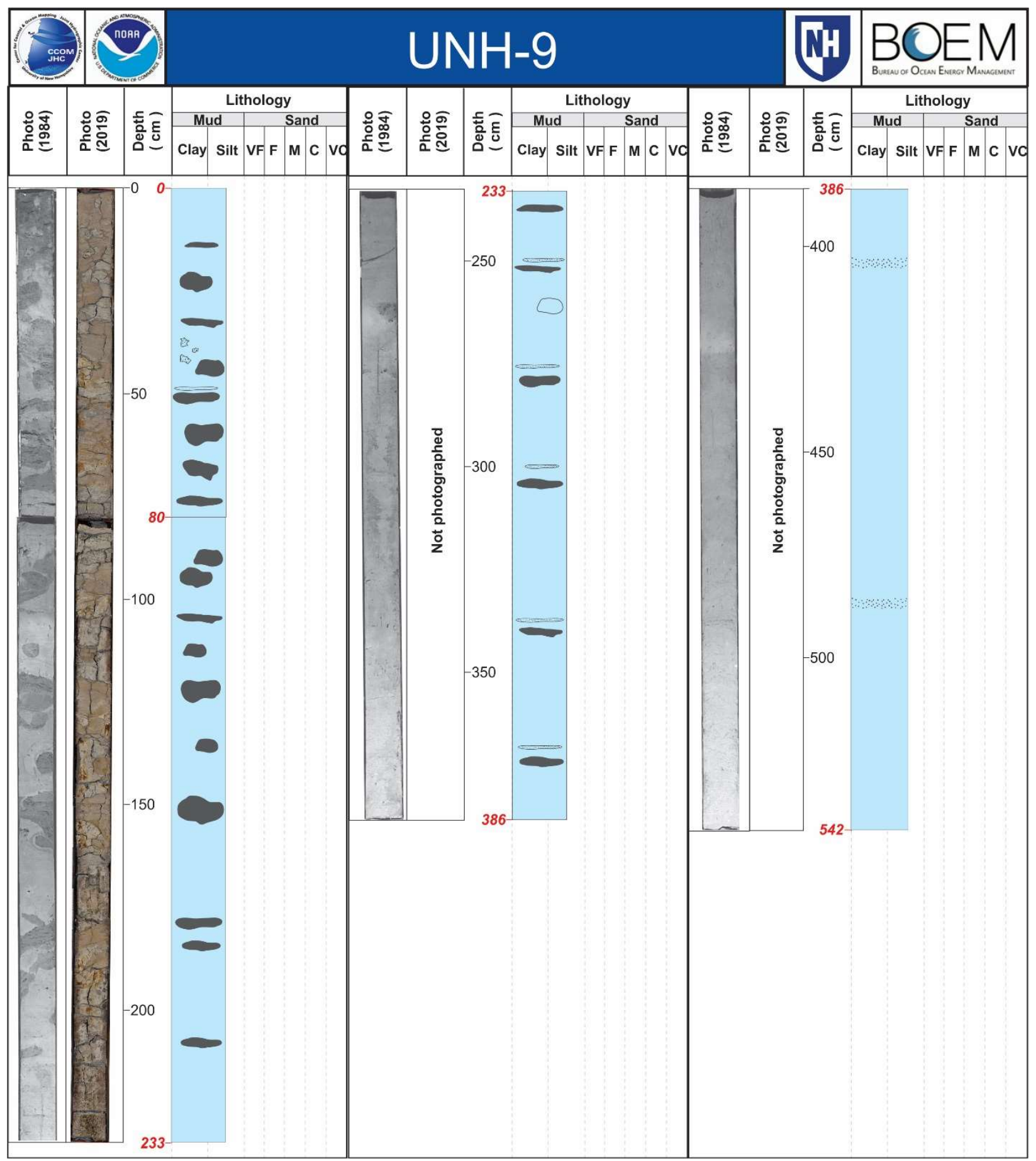

Figure 52a. Core log for upper $5.42 m$ of UNH-9. The lower core $(5.42 m-8.39 m)$ is shown in Figure $52 b$ (below). The location of the core is given in Figures 6, 50, and 51. A full description of the core is given in Appendix A. 


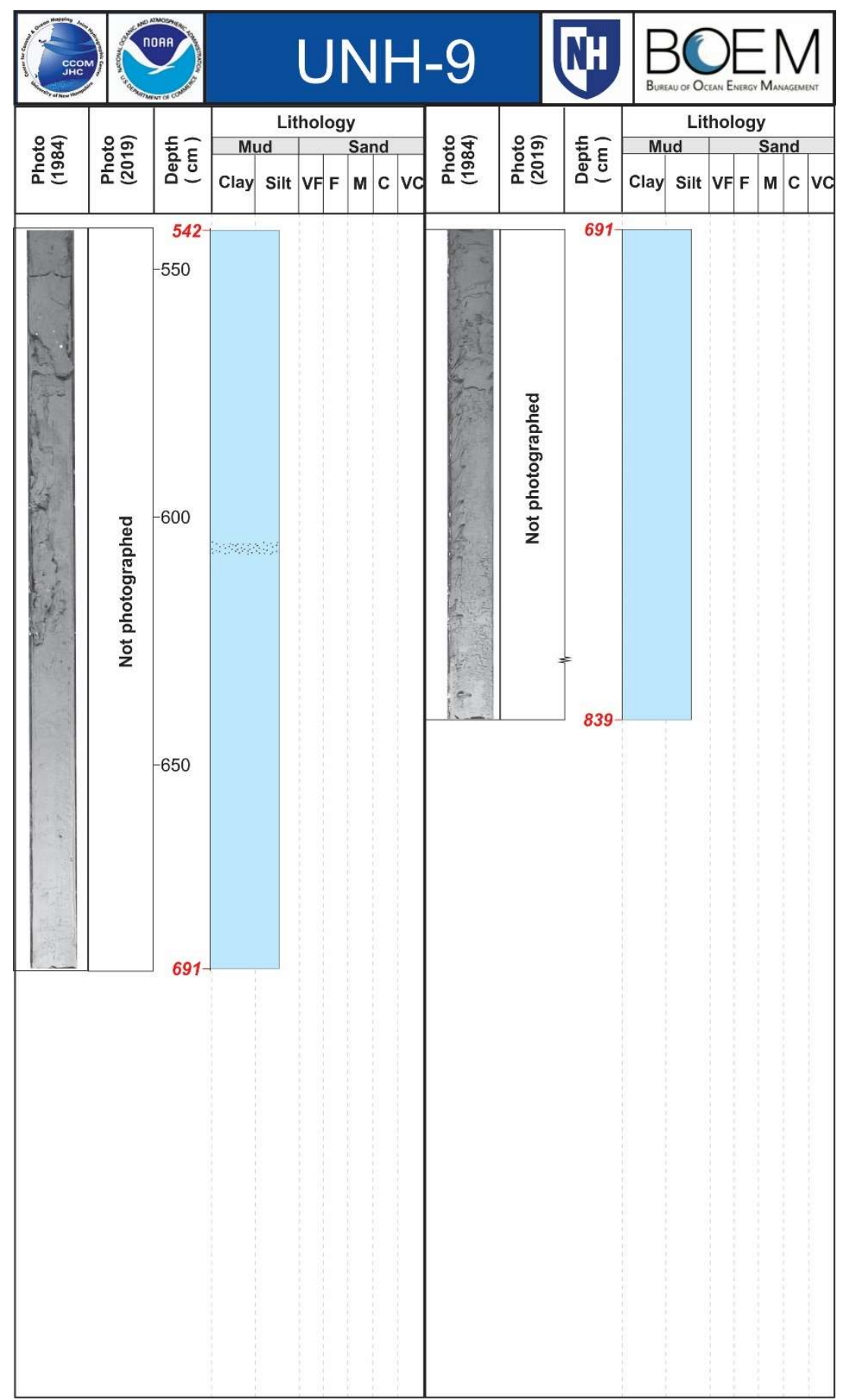

Figure 52b. Core log for the lower portion of UNH-9 (5.42-8.39mn). The upper $5.42 \mathrm{~m}$ is shown in Figure $52 a$ (above). 


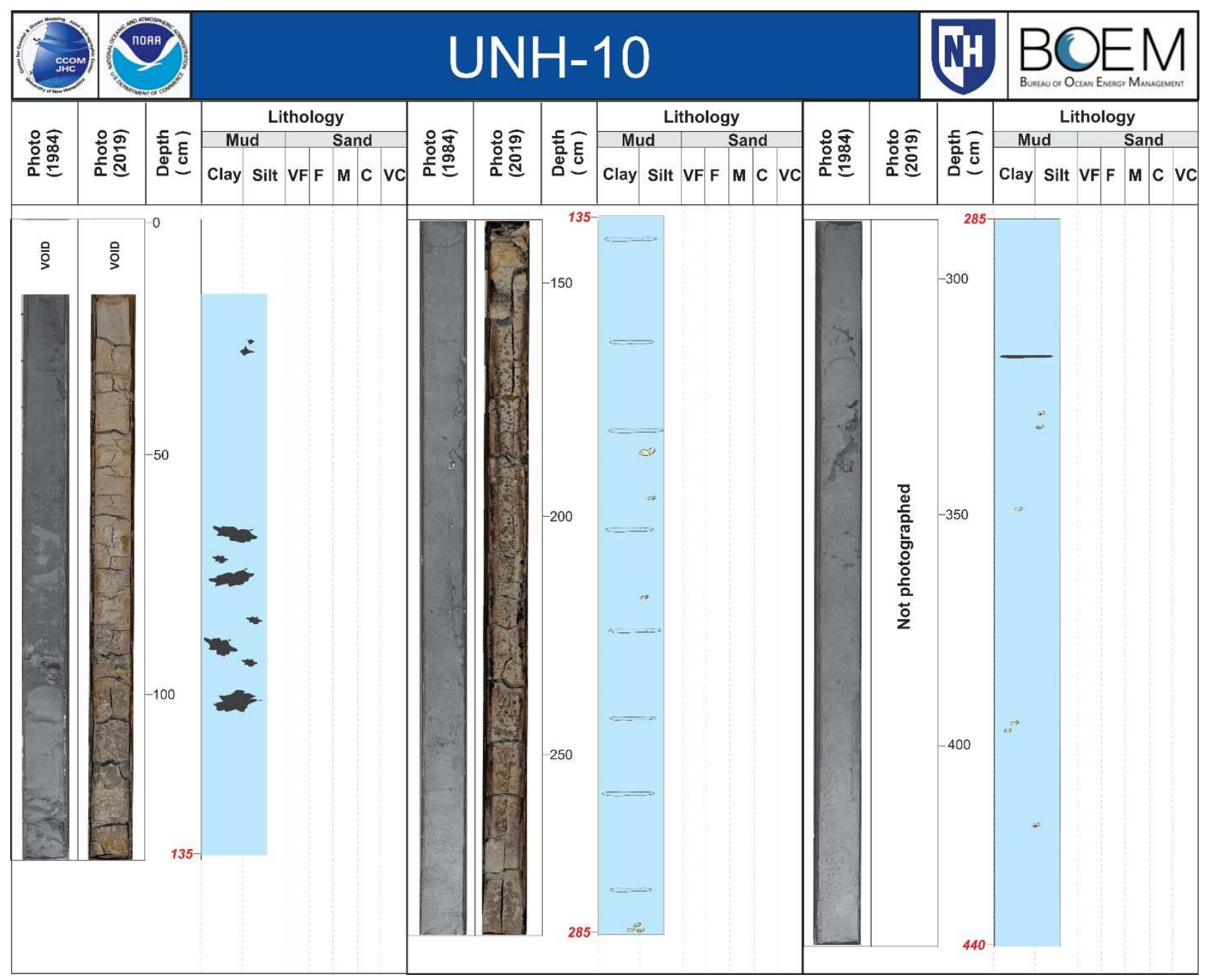

Figure 53a. Core log for the upper $4.40 \mathrm{~m}$ of UNH-10. The lower core (4.40-7.40m) is shown in Figure 53b (below). The location of the core is given in Figures 6, 50, and 51. A full description of the core is given in Appendix A. 


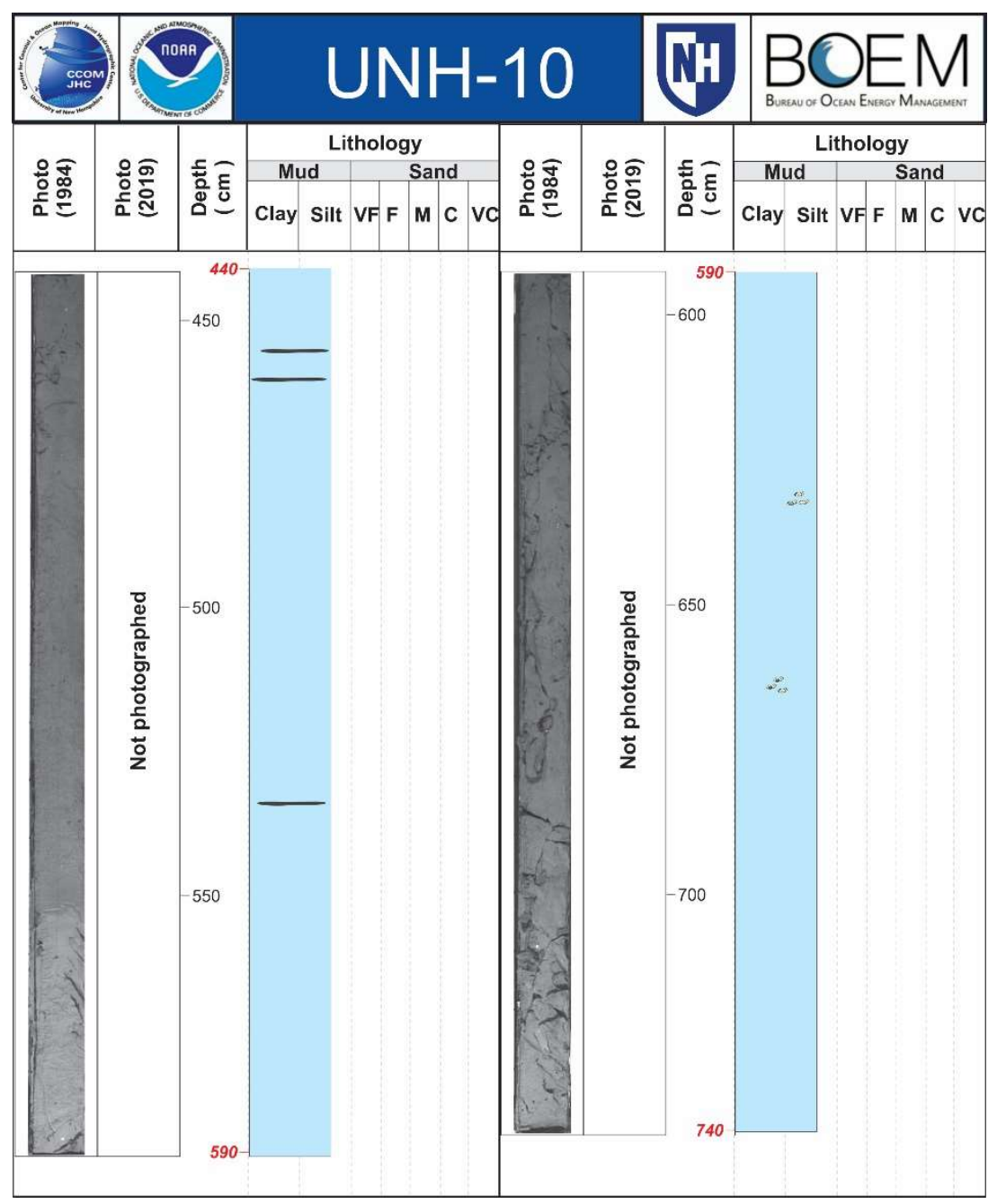

Figure 53b. Core log for the lower portion of UNH-10 (4.0-7.40m). The upper 4.40m is shown in Figure 53a (above). 


\section{Summary}

Twenty-three vibracores were taken on the NH continental shelf in 1984 and 1988 to describe the major sedimentary units and to gain a better understanding of potential sand and gravel resources (Figures 1 and 6). During this study, the vibracores were re-examined in order to verify and expand the original descriptions and to obtain more comprehensive grain size data. The additional analyses and descriptions are important because the 1984 and 1988 vibracores are the only subsurface samples to date on the $\mathrm{NH}$ continental shelf (to the knowledge of the authors). The vibracores are grouped by location with respect to major physiographic features (geoforms) or surficial sediment type (Figures 7 and 8) including Offshore Marine-Modified Glacial Features (Drumlins and Lodgement Till Deposits), Northern Sand Body, Nearshore Marine-Modified Glacial Features (Eskers and Drumlins), Isles of Shoals, Nearshore Sheet Sand, and Offshore Seafloor Plain (Table 12).

Three vibracores were collected in the Offshore Marine-Modified Glacial Features (Drumlins and Lodgement Till Deposits) located $\sim 23$ to $27 \mathrm{~km}$ offshore. The offshore drumlins have not been well sampled and the composition is unknown beyond the three vibracores described here. However, one of the vibracores has $\sim 5.28 \mathrm{~m}$ of medium to coarse sand at the surface overlying silty very fine sand to silt deposits (Table 12). This thick sequence of sand indicates the potential erosion of the drumlin surface and the formation of a shallow water shoal deposit during the early Holocene sea-level lowstand at 12,500 yrs B.P. The surfaces of the drumlins were likely exposed to wave action resulting in winnowing and a redistribution of the surficial sediments. The other offshore drumlins cored do not have high concentrations of sand and gravel. Likely they were too deep to have been eroded during the sea-level lowstand.

The Northern Sand Body (NSB), which is located $\sim 10 \mathrm{~km}$ offshore near the Isles of Shoals, has an estimated sand volume of $\sim 17$ million $\mathrm{m}^{3}$, but this remains to be verified. However, two of the five vibracores had up to $3.60 \mathrm{~m}$ of medium to coarse sand (>90\%); the other three cores had between 0.95 and $3.04 \mathrm{~m}$ of fine sand (>90\%). Greater than $75 \%$ fine sand extended down to $4.39 \mathrm{~m}$ in core A1 (Table 12 ). The origin of the NSB is not clear, but the sand body likely formed from deposits that were originally either a marine glacial delta, a subaqueous delta, or a sandy outwash that were heavily modified by marine processes. The NSB has relatively thick sand over a large area.

The Nearshore Marine-Modified Glacial Features (Eskers and Drumlins) include several linear ridges, largely oriented northeast-southwest or relatively perpendicular the $\mathrm{NH}$ shoreline, that are hundreds of meters in length. These features are hypothesized here to be of glacial origin, most likely eskers, that have been modified by marine processes. The esker-like features were exposed during the last sea-level lowstand and exposed to shallow water waves and nearshore process during the Holocene transgression. Two vibracores taken near a ridge had 5.81 and $3.36 \mathrm{~m}$ of medium to coarse sand along with pebble gravel (Table 12).

The Nearshore Sheet Sand deposits are relatively flat-lying layers of sand and gravel. They frequently overlie (often unconformably) glacial marine sandy mud associated with the Presumpscot Formation distal facies. It is hypothesized that the Nearshore Sheet Sand deposits were formed from reworked glacial marine sediment during the last transgression, especially wave-modified marine deltas or outwash. In addition, the deposits are likely part of the nearshore sand ramp extending from the beaches in southern $\mathrm{NH}$. The vibracores taken in the Nearshore Sheet Sand had variable thicknesses of sand and gravel but were generally less than $\sim 2.5 \mathrm{~m}$. However, one site had $3.89 \mathrm{~m}$ of medium sand. 
Except for the Northern Sandy Body and potentially the offshore drumlin, all of the features where vibracores were taken are relatively small in aerial extent. Further high-resolution subbottom seismic reflection surveys are needed and additional vibracores are required to map potential sand and gravel resources. Presently, the extent and characteristics of the sand and gravel deposits on the NH continental shelf are not clear.

Table 12. Sand and gravel thicknesses in the vibracores taken on the NH continental shelf (Figure 6) in 1984 ("UNH" series) and 1988 ("A" series). The thicknesses of the layers were determined from the vibracore logs (Appendix A) and the grain size data from new vibracore samples acquired in 2016 and 2019 (Appendix B). Small layers (less than 25 $\mathrm{cm}$ thick) were ignored. Thicknesses and depths are best estimates. The sediment size classification is based on the mean grain size using the Wentworth (1922) scale. The following abbreviations are used: PG - pebble gravel, CS coarse sand, MS - medium sand, FS - fine sand, and VFS - very fine sand.

\begin{tabular}{|c|c|c|c|c|c|}
\hline Location & $\begin{array}{l}\text { Vibracore } \\
\text { Number }\end{array}$ & $\begin{array}{c}\text { Sand and Gravel } \\
>90 \%\end{array}$ & $\begin{array}{c}\text { Sediment } \\
\text { Classification }\end{array}$ & $\begin{array}{c}\text { Sand and Gravel } \\
>75 \%\end{array}$ & $\begin{array}{c}\text { Sediment } \\
\text { Classification }\end{array}$ \\
\hline \multirow{3}{*}{$\begin{array}{l}\text { Offshore Marine-Modified } \\
\text { Glacial Deposits }\end{array}$} & UNH-1 & ----- & ----- & ----- & ----- \\
\hline & UNH-2 & ----- & ----- & ----- & ----- \\
\hline & UNH-3 & $0.00 m-4.73 m$ & MS-CS & $4.73 m-5.28 m$ & FS \\
\hline \multirow{5}{*}{ Northern Sand Body } & $\mathrm{A} 1$ & $0.00 m-3.60 m$ & MS-CS & $3.60 m-4.39 m$ & FS \\
\hline & $\mathrm{A} 2$ & $0.00 m-3.10 m$ & MS & $3.10 m-5.21 m$ & VFS \\
\hline & A3 & $0.00 m-3.04 m$ & FS & $3.04 m-4.34 m$ & VFS-FS \\
\hline & UNH-4 & $0.00 m-1.45 m$ & FS & $1.45 m-1.94 m$ & VFS \\
\hline & UNH-13 & $0.00 m-0.95 m$ & FS & $0.95 m-1.58 m$ & $\mathrm{FS}$ \\
\hline \multirow{5}{*}{$\begin{array}{c}\text { Nearshore Marine-Modified } \\
\text { Glacial Features }\end{array}$} & \multirow{3}{*}{ A4 } & $0.00 m-2.50 m$ & CS-PG & ----- & ----- \\
\hline & & $2.50 m-4.28 m$ & MS-CS & ----- & ----- \\
\hline & & $5.31 m-5.81 m$ & MS-PG & ----- & ----- \\
\hline & \multirow{2}{*}{ A5 } & $0.00 m-1.67 m$ & $P G$ & ----- & ----- \\
\hline & & $2.71 m-3.36 m$ & MS & ----- & ----- \\
\hline \multirow{16}{*}{ Nearshore Sheet Sands } & \multirow{2}{*}{$A 6(1)$} & $0.00 m-0.60 m$ & MS & ----- & ----- \\
\hline & & $0.60 m-2.27 m$ & FS & ----- & ----- \\
\hline & $A 6(2)$ & $0.00 m-1.62 m$ & FS & ----- & ----- \\
\hline & $\mathrm{A} 6(3)$ & $0.00 m-3.89 m$ & MS & ----- & ----- \\
\hline & \multirow{2}{*}{$A 7(1)$} & $0.00 m-0.12 m$ & MS & ----- & ----- \\
\hline & & $0.12 m-1.23 m$ & $P G$ & ----- & ----- \\
\hline & \multirow{5}{*}{$A 7(2)$} & $0.00 m-0.45 m$ & $\mathrm{CS}$ & ----- & ----- \\
\hline & & $0.45 m-1.12 m$ & CS-PG & ----- & ----- \\
\hline & & $1.12 m-1.53 m$ & $P G$ & ----- & ----- \\
\hline & & $1.53 m-1.80 m$ & $\mathrm{CS}$ & ----- & ----- \\
\hline & & $1.80 m-2.05 m$ & MS & ----- & ----- \\
\hline & A8 & $0.00 m-0.55 m$ & CS-SPG & ----- & ----- \\
\hline & UNH-6 & $0.00 m-1.54 m$ & VFS & ----- & ----- \\
\hline & UNH-6A & $0.00 m-2.37 m$ & VFS-FS & $2.37 m-3.02 m$ & VFS-FS \\
\hline & \multirow{2}{*}{ UNH-14 } & $0.00 m-0.82 m$ & FS & ----- & ----- \\
\hline & & $1.38 m-2.36 m$ & FS & $\begin{array}{ll}---- \\
\end{array}$ & $\begin{array}{ll}---- \\
\end{array}$ \\
\hline \multirow{3}{*}{ Isles of Shoals } & \multirow{2}{*}{ UNH-5 } & $0.00 m-3.22 m$ & Shell Hash & ----- & ----- \\
\hline & & $3.22 m-3.67 m$ & MS & $3.67 m-5.70 m$ & $\mathrm{FS}$ \\
\hline & UNH-12 & \multicolumn{4}{|c|}{ No Sediment Samples } \\
\hline \multirow{2}{*}{ Seafloor Plain } & UNH-9 & ----- & ----- & ----- & ----- \\
\hline & UNH-10 & ----- & ----- & ----- & $\begin{array}{ll}---- \\
\end{array}$ \\
\hline
\end{tabular}




\section{References}

Barnhardt, W.A., Andrews, B.D., Ackerman, S.D., Baldwin, W.E., and Hein, C.J., 2007: High-resolution geologic mapping of the inner continental shelf: Cape Ann to Salisbury Beach, Massachusetts: U.S. Geological Survey Open-file Report 2007-1373, variously paged, available online at http://pubs.usgs.gov/of/2007/1373/.

Birch, F.S., 1984, A geophysical study of sedimentary deposits on the inner continental shelf of New Hampshire: Northeastern Geology, volume 6, number 4, pp. 207-221.

Birch, F.S., 1986a, Evaluation of sand and gravel on the inner continental shelf of New Hampshire: Final Report for the Cooperative Agreement (14-12-0001-30115) between the University of New Hampshire and the U.S. Department of Interior, Minerals Management Service, Herndon, Virginia, $14 \mathrm{pp}$.

Birch, F.S., 1986b, Vibracores from the inner continental shelf of New Hampshire: Final Report for the Cooperative Agreement (14-12-0001-30115) between the University of New Hampshire and the U.S. Department of Interior, Minerals Management Service, Herndon, Virginia, 54 pp.

Birch, F.S., 1988, Sediments of the inner continental shelf: first- and second-year projects in New Hampshire. In: M.C. Hunt, D.C. Radcliff, S. Doenges and C. Condon (eds.), Proceedings of the First Symposium on the Studies Related to Continental Margins - A Summary of Year-One and Year-Two Activities, p. 242-251. U.S. Department of Interior, Minerals Management Service Continental Margins Program and Association of American State Geologists Continental Margins Committee.

Birch, F.S., 1989, Sediments of the inner continental shelf: a progress report on projects in New Hampshire: Marine Geology, volume 90, pp. 131-137.

Blott, S.J., and Pye, K., 2001, Gradistat: A grain size distribution and statistics package for the analysis of unconsolidated sediments: Earth Surface Processes and Landforms, v. 26, no. 11, p. 1237-1248. DOI: 10.1002/esp.261, Accessed March 1, 2020: http://www.kpal.co.uk/gradistat.html

Carter, R.W.G. and Orford, J.D., 1988, Conceptual model of coarse clastic barrier formation from multiple sediment sources: The Geographical Review, volume. 78, pp. 221-239.

FGDC, 2012, Federal Geographic Data Committee, Marine and Coastal Spatial Data Subcommittee, Coastal and estuarine ecological classification standard, FGDC-STD-018-2012, 343 pp., https://www.fgdc.gov/standards/projects/cmecs-folder/CMECS_Version_06-2012_FINAL.pdf; accessed April 30, 2020.

Folk, R.L., 1954, The distinction between grain size and mineral composition in sedimentary-rock nomenclature: The Journal of Geology, volume 62, number 4, pp. 344-359.

Folk, R.L., 1980, Petrology of Sedimentary Rocks: Hemphill Publishing Company, Austin, TX. 182 pp.

Geological Society of America and Munsell Color, 2009, Geological Rock-Color Chart with Genuine Munsell Color Chips: 2009 Year Revised.

Kelley, J.T., Belknap, D.F., and Claesson, S., 2010, Drowned coastal deposits with associated archaeological remains from a sea-level "slowstand": Northwestern Gulf of Maine, USA: Geology, 38 (8): 695-698. DOI: 10.1130/G31002.1 
Ward, L.G., 1989, Sedimentological characteristics of vibracores taken in sand and gravel deposits on the inner continental shelf of New Hampshire: Final Report for the Cooperative Agreement (14-120001-30316) between the University of New Hampshire and the U.S. Department of Interior, Minerals Management Service, Herndon, Virginia., $22 \mathrm{pp}$.

Ward, L.G., 2007, Assessment of sand resources and the geological environment of the New Hampshire inner continental shelf: Final Report for the Cooperative Agreement (0104CA34383) Between the University of New Hampshire and the U.S. Department of Interior, Minerals Management Service, Herndon, Virginia, 58 pp. plus ArcGIS Projects.

Ward, L.G., McAvoy, Z.S., and Vallee-Anziani, M., 2021a, New Hampshire and Vicinity Continental Shelf: Sand and Gravel Resources: BOEM/New Hampshire Cooperative Agreement (Contract M14ACO0010) Technical Report, Department of Interior, Bureau of Ocean Energy Management, Marine Minerals Division, 45600 Woodland Road, Sterling, VA, 20166, 113 pp. https://dx.doi.org/10.34051/p/2021.30

Ward, L.G., McAvoy, Z.S., Vallee-Anziani, M., and Morrison, R., 2021b, Surficial Geology of the Continental Shelf off New Hampshire: Morphologic Features and Surficial Sediments: BOEM/New Hampshire Cooperative Agreement (Contract M14AC00010) Technical Report, Department of Interior, Bureau of Ocean Energy Management, Marine Minerals Division, 45600 Woodland Road, Sterling, VA, 20166, 182 pp. https://dx.doi.org/10.34051/p/2021.31

Ward, L.G., Morrison, R.C., McAvoy, Z.S., and Vallee-Anziani, M., 2021c, New Hampshire Continental Shelf Geophysical Database: Vibracore Logs and Sediment Data. University of New Hampshire Center for Coastal and Ocean Mapping/Joint Hydrographic Center (CCOM/JHC), 24 Colovos Road, Durham, NH 03824. UNH Scholars Repository https://dx.doi.org/10.34051/d/2021.4

Wentworth, C.K., 1922, A scale of grade and class terms for clastic sediments: The Journal of Geology, volume 30 , number 5, pp. 377-392. 


\section{Appendix A: Vibracore Logs}

The logs for the vibracores taken on the New Hampshire continental shelf in 1984 (Birch, 1986b) and 1988 (Ward, 1989) are presented in this appendix. The vibracores logs are shown in numerical order with the 1984 cores ("UNH" series) presented first followed by the 1988 cores ("A" series). Abbreviated vibracore logs can be found in the Results and Discussion section of this report along with the core descriptions. Each vibracore log presented in this appendix includes the following: photographs taken during the original examinations (only available for the UNH series taken in 1984) and more recent photographs taken during this study in 2016 and 2019; the lithology and sediment descriptions of the cores based on Birch (1986a; 1986b; 1988), Ward (1989; 2007), and this study; Munsell colors; grain size data; and depositional environments and seismic units from Birch (1984; 1986b). The core log template is shown in Figure Appendix-1 and the symbology used in the core logs is shown in Figure Appendix-2. The color assignments presented here use the Munsell Rock-Color Chart (Geological Society of America and Munsell Color, 2009). The original core descriptions used a combination of the Munsell Soil-Color Chart and the Geological Society of America (GSA) Rock-Color Chart. In order to make color names, hues, values, and chromas consistent and comparable, all Soil-Colors were converted to the Rock-Color Chart for this report. The closest equivalent colors were chosen where necessary (Figure Appendix-2). The grain size data from this study are reported as $\% \mathrm{G}, \% \mathrm{~S}, \% \mathrm{M}$ and mean grain size $(\phi)$ and sorting $(\phi)$ for the entire sample. Grain size data from Ward (1989) are presented as \%G, \%S, \%M and mean grain size $(\phi)$ and sorting $(\phi)$ for sand fraction only. Grain size data from Birch (1986b) only provide the \%G, \%S, and \%M for the predominantly sand and mud samples (\%G <0.9\%) due to a difference in analytical methods. The grain size procedures are described in detail in the Methods section of this report.

Note: The full logs presented here were made in CorelDraw 7x (64 bit), and are best viewed digitally and at $125-150 \%$.

The vibracore logs can also be downloaded at Ward et al. (2021c) (https://dx.doi.org/10.34051/d/2021.4). 


\begin{tabular}{|c|c|c|c|c|c|c|c|c|c|c|c|c|c|c|c|c|c|c|c|c|c|c|}
\hline \multirow{2}{*}{ 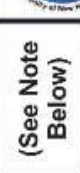 } & \multirow[b]{2}{*}{$\frac{}{\frac{0}{0}}$} & \multirow[b]{2}{*}{ 흠 } & \multicolumn{5}{|c|}{ Lithology } & \multirow[b]{2}{*}{ DESCRIPTION } & \multirow[b]{2}{*}{ 흥 } & \multirow{2}{*}{ 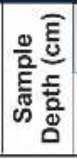 } & \multicolumn{3}{|c|}{$\operatorname{GSM}(\%)$} & \multicolumn{2}{|c|}{$\begin{array}{l}\text { Sand Fraction } \\
\text { Only }\end{array}$} & \multicolumn{3}{|c|}{$\operatorname{GSM}(\%)$} & \multicolumn{2}{|c|}{$\begin{array}{l}\text { Whole } \\
\text { Sample }\end{array}$} & \multirow[b]{2}{*}{$\begin{array}{l}\text { Depositional } \\
\text { Environment }\end{array}$} & \multirow[b]{2}{*}{$\begin{array}{c}\text { Seismic } \\
\text { Unit }\end{array}$} \\
\hline & & & Clay & ud & VF F & Man & 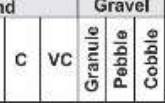 & & & & 爱 & $\begin{array}{l}\text { 䓌 } \\
\text { 至 }\end{array}$ & 总 & 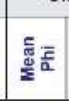 & 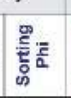 & 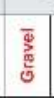 & \begin{tabular}{|l} 
हूँ \\
का
\end{tabular} & है & 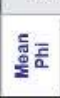 & 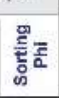 & & \\
\hline 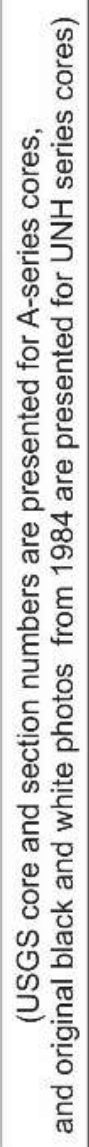 & 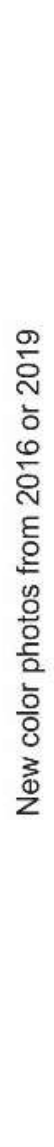 & & & $\begin{array}{l}\text { timat } \\
\text { visu } \\
\text { orig }\end{array}$ & $\begin{array}{l}\text { ted gr } \\
\text { ual de } \\
\text { ginal }\end{array}$ & $\begin{array}{l}\text { rrain } \\
\text { esc } \\
\text { refe }\end{array}$ & $\begin{array}{l}\text { size based } \\
\text { ription from } \\
\text { arences. }\end{array}$ & $\begin{array}{l}\text { The core description was } \\
\text { primarily based on Birch } \\
\text { (1986b), Ward (1989), Ward } \\
\text { (2007), and expanded here. } \\
\text { Birch, F.S., 1986b, Vibracores from the inner } \\
\text { continental shelf of New Hampshire: Final } \\
\text { Report for the Cooperative Agreement (14- } \\
\text { 12-0001-30115) between the University of } \\
\text { New Hampshire and the U.S. Department of } \\
\text { Interior, Minerals Management Service, } \\
\text { Herndon, Virginia, } 54 \text { pp. } \\
\text { Ward, L.G., 1989, Sedimentological } \\
\text { characteristics of vibracores taken in sand } \\
\text { and gravel deposits on the inner continental } \\
\text { shelf of New Hampshire: Final Report for } \\
\text { the Cooperative Agreement (14-12-0001- } \\
\text { 30316) between the University of New } \\
\text { Hampshire and the U.S. Department of } \\
\text { Interior, Minerals Management Service, } \\
\text { Herndon, Virginia., } 22 \text { pp. } \\
\text { Ward, L.G., 2007, Assessment of sand } \\
\text { resources and the geological environment of } \\
\text { the New Hampshire inner continental shelf: } \\
\text { Final Report for the Cooperative Agrement } \\
\text { (0104CA34383) Between the University of } \\
\text { New Hampshire and the U.S. Department of } \\
\text { Interior, Minerals Management Service, } \\
\text { Herndon, Virginia, } 58 \text { pp. plus ArcGIS } \\
\text { Projects. }\end{array}$ & 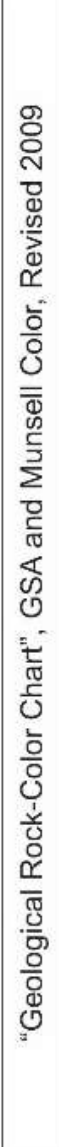 & & & & & & 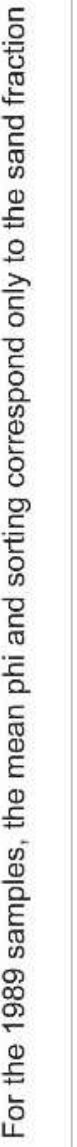 & & 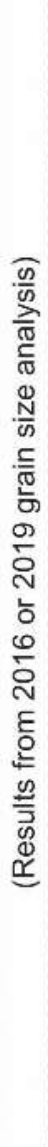 & & & & $\begin{array}{r}\text { The dep } \\
\text { environn } \\
\text { seismi } \\
\text { descriptic } \\
\text { based on B } \\
\text { and Birch } \\
\\
\text { Birch, F.S., 1984, } \\
\text { study of sedimente } \\
\text { the inner continen } \\
\text { Hampshire: North } \\
\text { volume 6, number } \\
\text { Birch, F.S., 1986b, } \\
\text { the inner continen } \\
\text { Hampshire: Final } \\
\text { Cooperative Agree } \\
\text { o001-30115) betw } \\
\text { of New Hampshire } \\
\text { Department of Inte } \\
\text { Management Serv } \\
\text { Virginia, } 54 \text { pp. }\end{array}$ & $\begin{array}{l}\text { sitional } \\
\text { ent and } \\
\text { units } \\
\text { 1s were } \\
\text { ch (1984) } \\
\text { (1986b). } \\
\\
\text { geophysical } \\
\text { deposits on } \\
\text { shelf of New } \\
\text { stern Geology, } \\
\text { pp. 207-221. } \\
\text { ibracores from } \\
\text { shelf of New } \\
\text { port for the } \\
\text { lent (14-12- } \\
\text { nthe University } \\
\text { ind the U.S. } \\
\text { or, Minerals } \\
\text { e, Herndon, }\end{array}$ \\
\hline
\end{tabular}

Figure Appendix-1. Complete core log description template. 


Lithological Patterns
Muddy Sand
Sandy Mud
Mud Savel

Figure Appendix-2(a). Complete core log symbol, pattern, and color key. 


\section{Munsell Color Patterns}

\begin{tabular}{|c|c|c|c|}
\hline Olive black (5Y2/1) & Brownish gray (5YR4/1) & Grayish olive green (5GY3/2) & Grayish black (N2) \\
\hline Olive gray $(5 Y 3 / 2)$ & Moderate brown (5YR4/4) & Dusky yellow green (5GY5/2) & Dark gray (N3) \\
\hline Olive gray $(5 Y 4 / 1)$ & Light brownish gray (5YR6/1) & Greenish gray (5GY6/1) & Medium dark gray (N4) \\
\hline Light olive gray $(5 Y 5 / 2)$ & Dusky yellowish brown (10YR 2/2) & Grayish green (10G4/2) & Medium gray (N5) \\
\hline Light olive brown $(5 Y 5 / 6)$ & Dark yellowish brown (10YR4/2) & & Light gray (N7) \\
\hline Light olive gray $(5 Y 6 / 1)$ & Moderate yellowish brown (10YR5/4) & & \\
\hline Yellowish gray $(5 Y 7 / 2)$ & Dark yellowish orange (10YR 6/6) & & \\
\hline Grayish olive (10Y4/2) & Grayish orange (10YR7/4) & & \\
\hline
\end{tabular}

Figure Appendix-2(b). Complete core log Munsell color key. 
Full Vibracore Logs from 1984 (UNH series) 


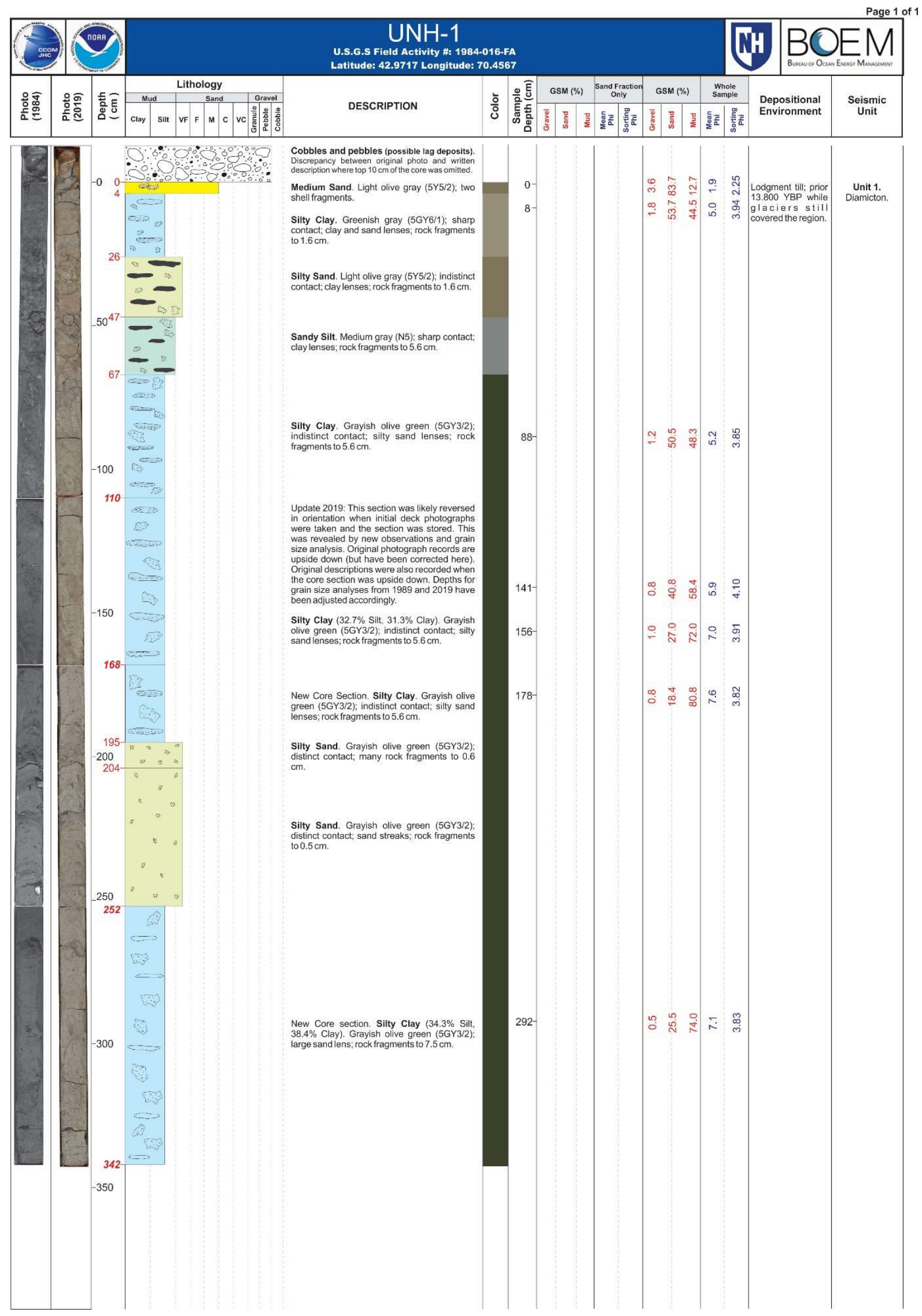




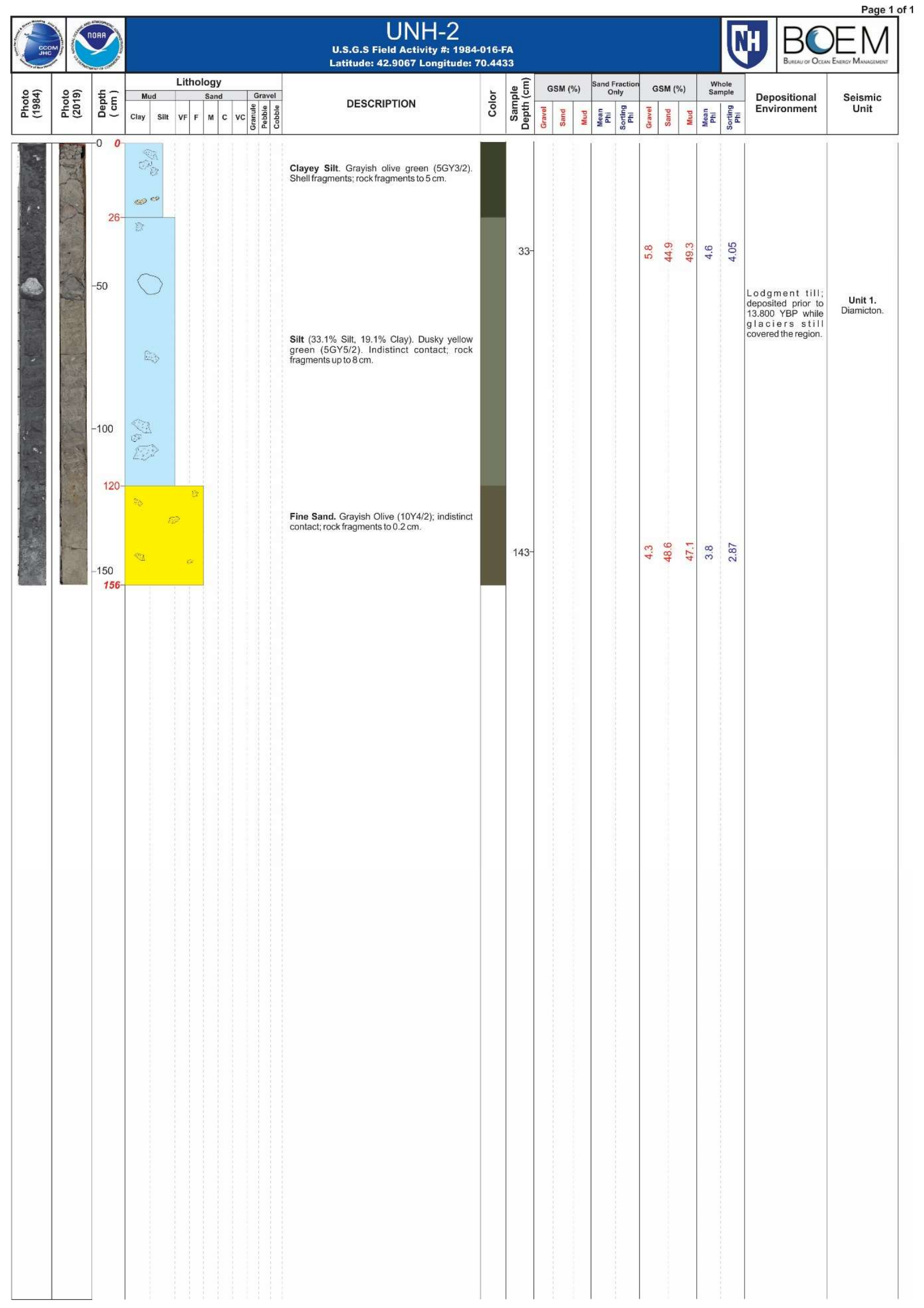




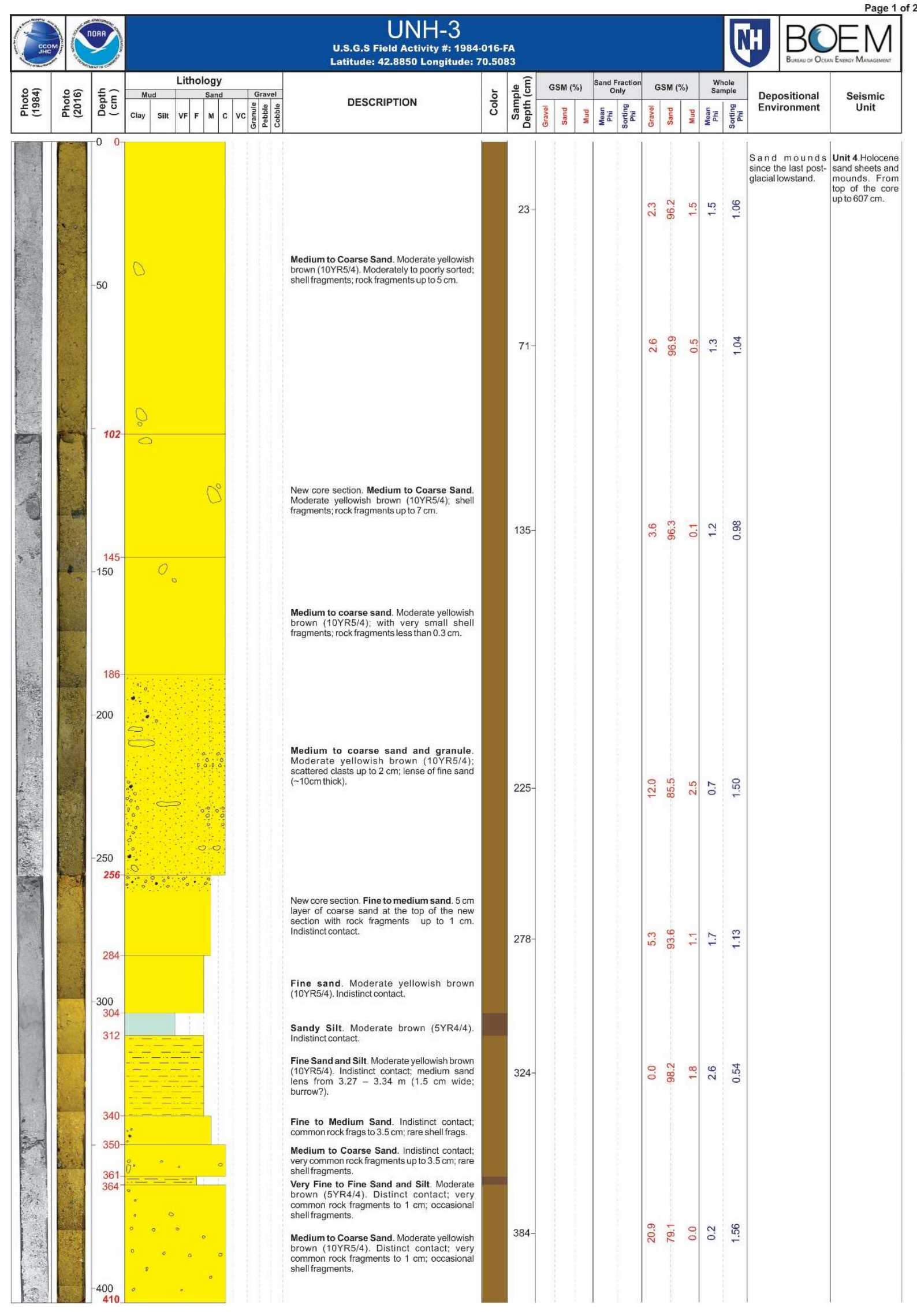




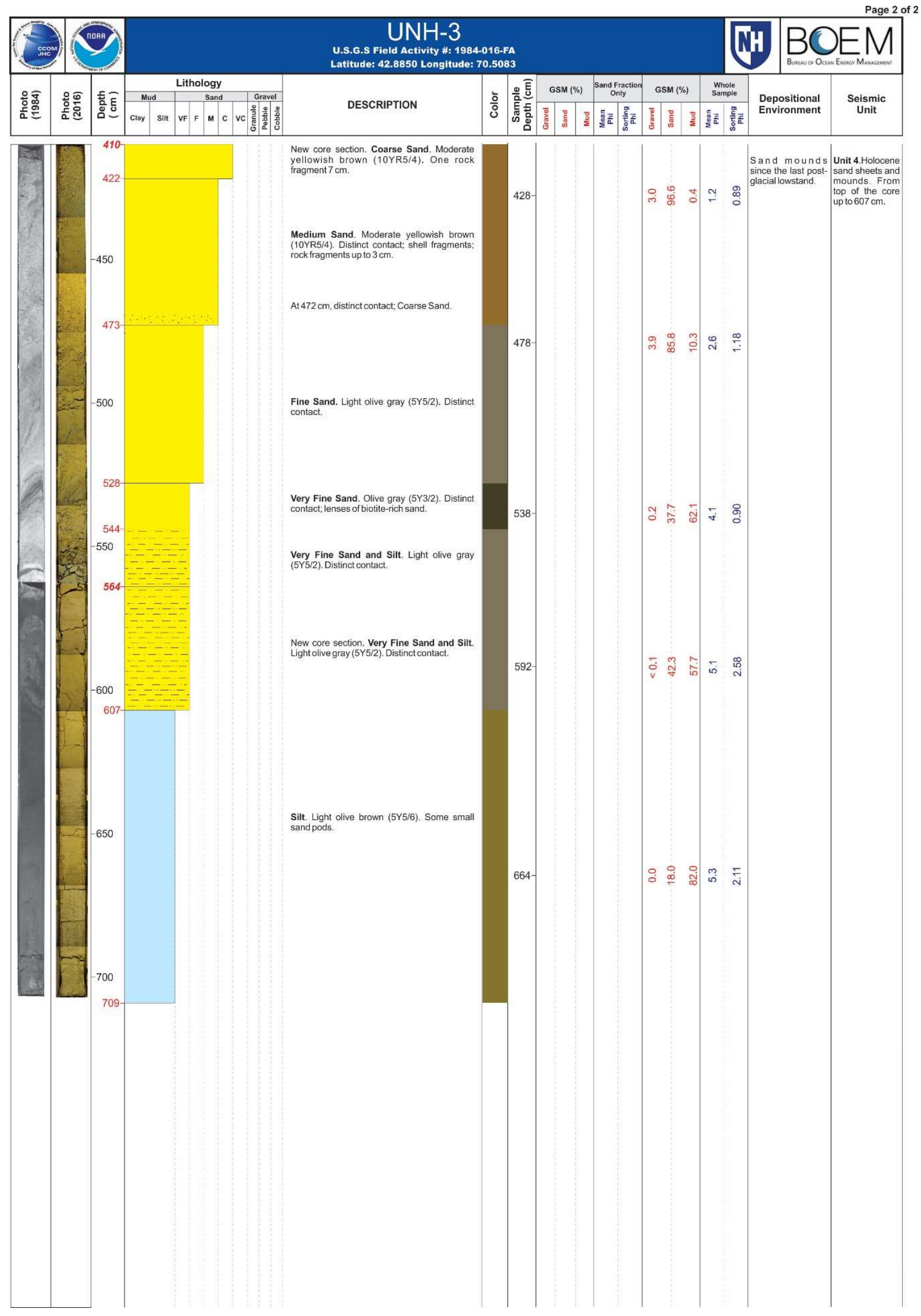




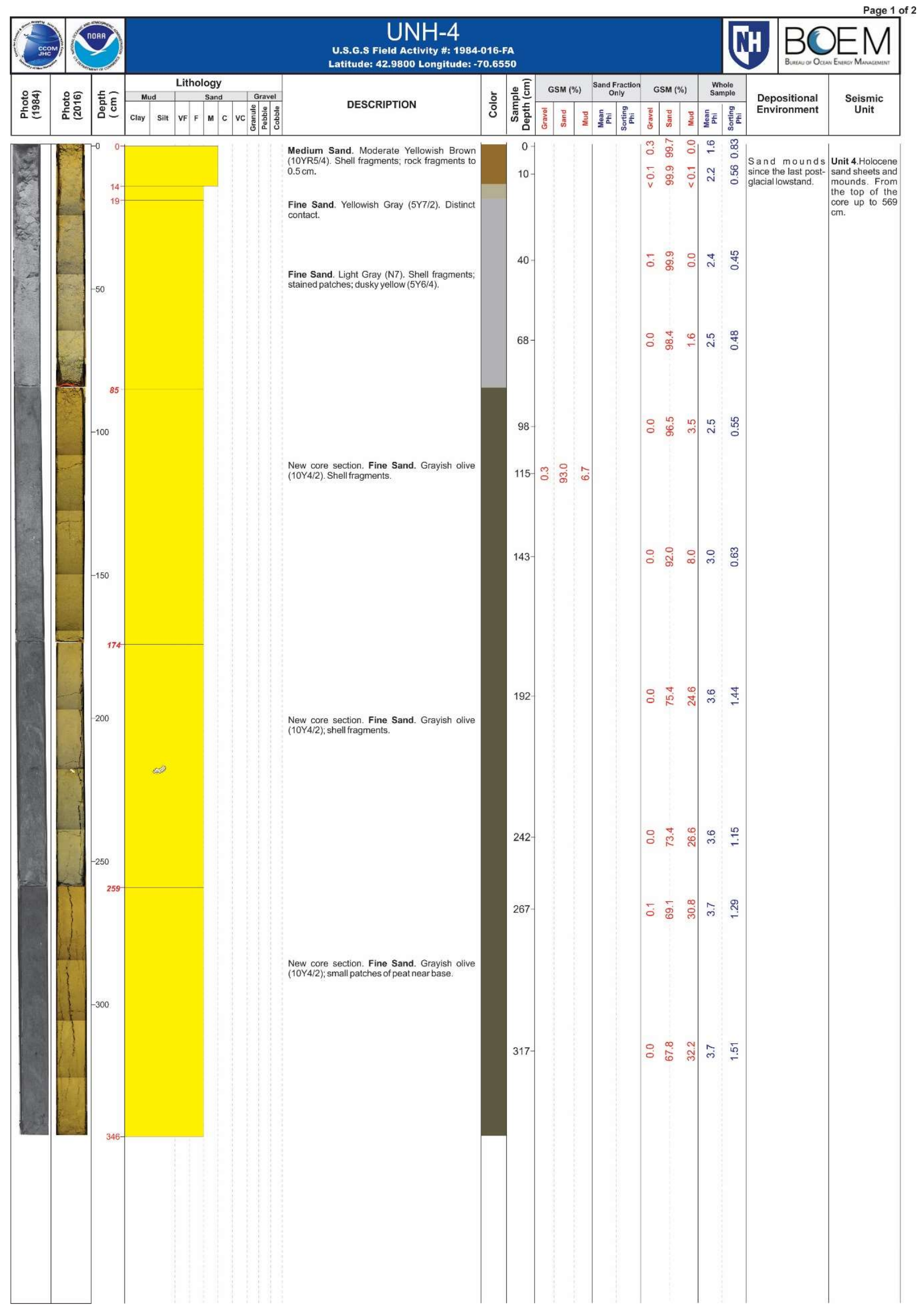




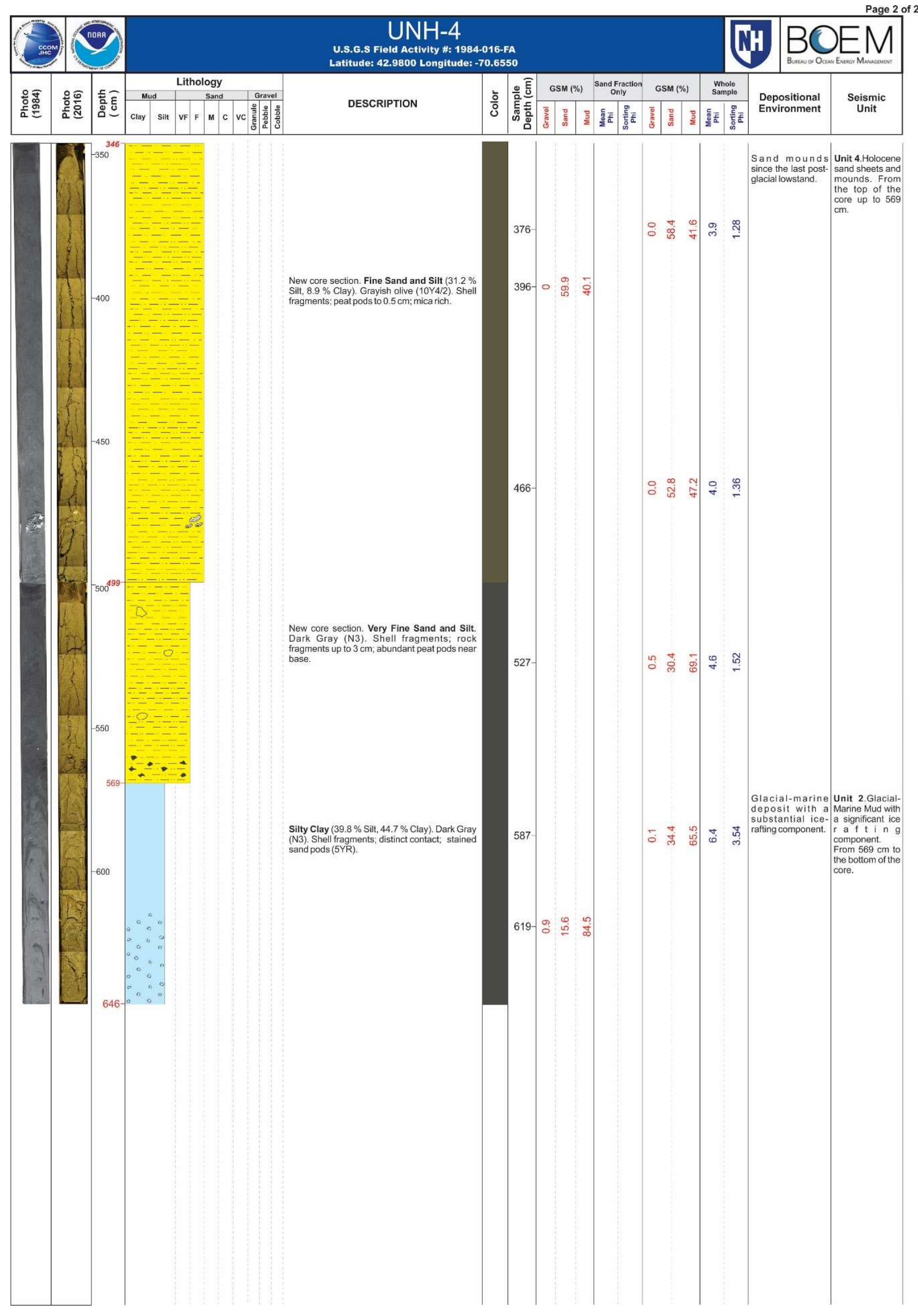




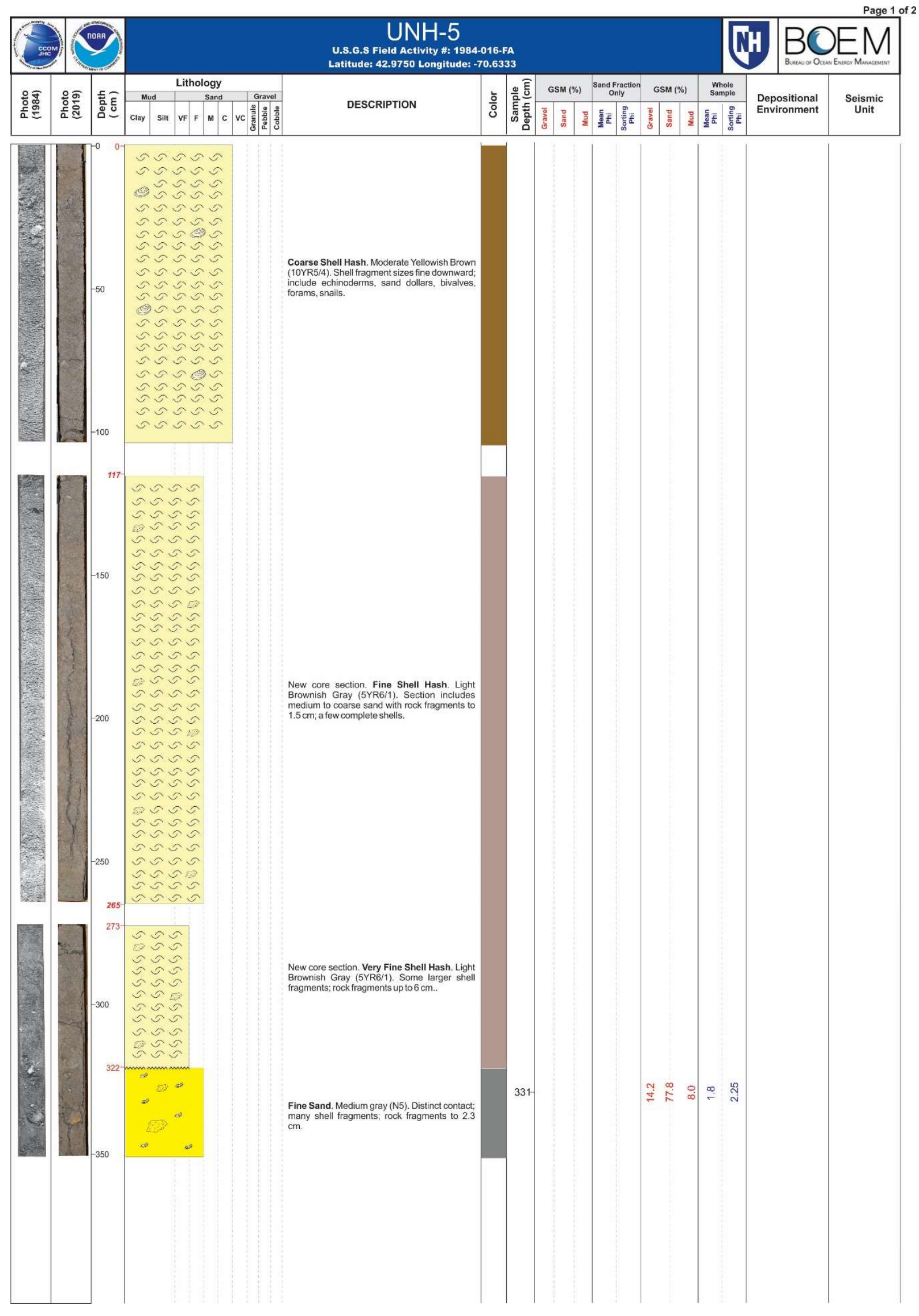




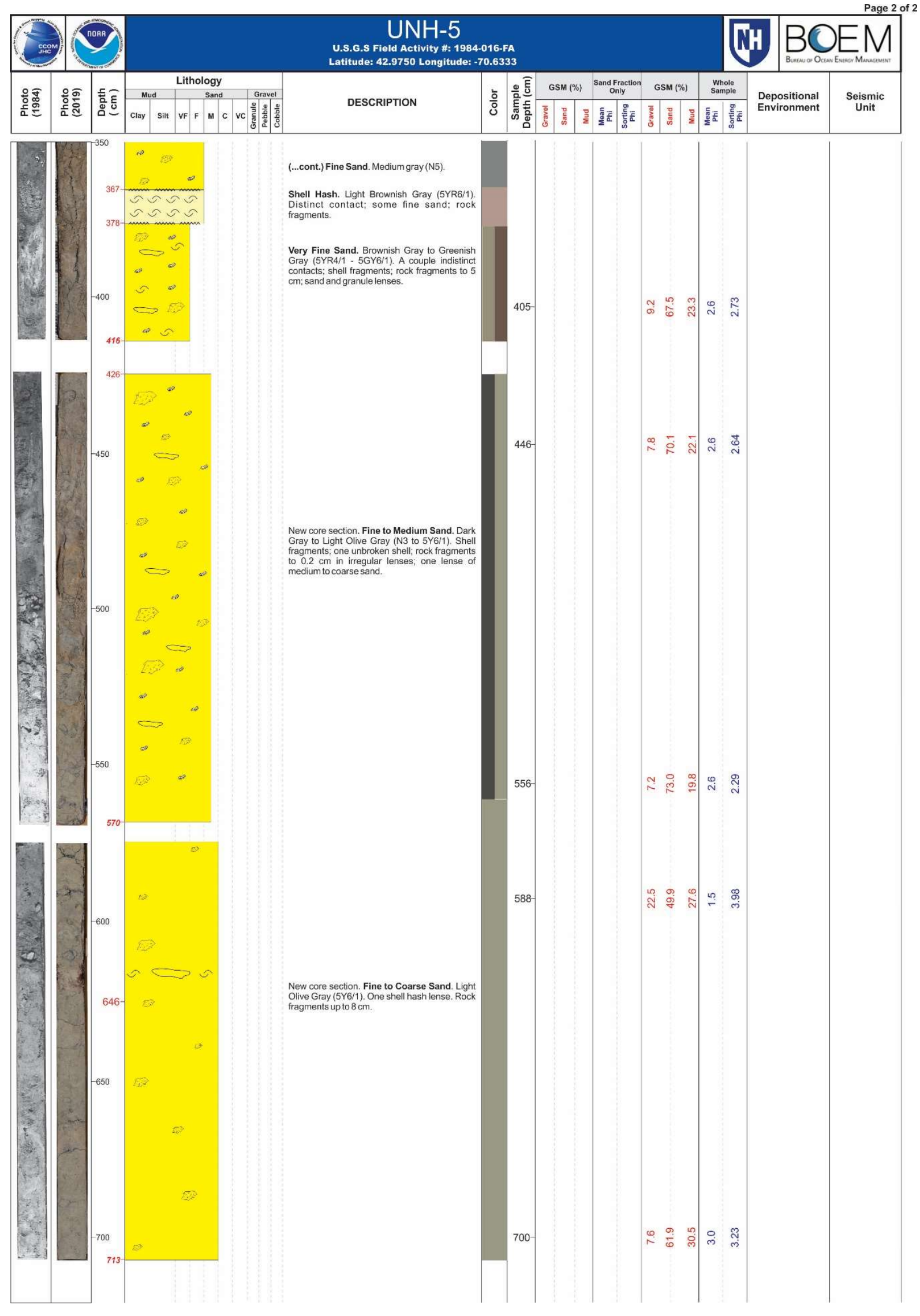




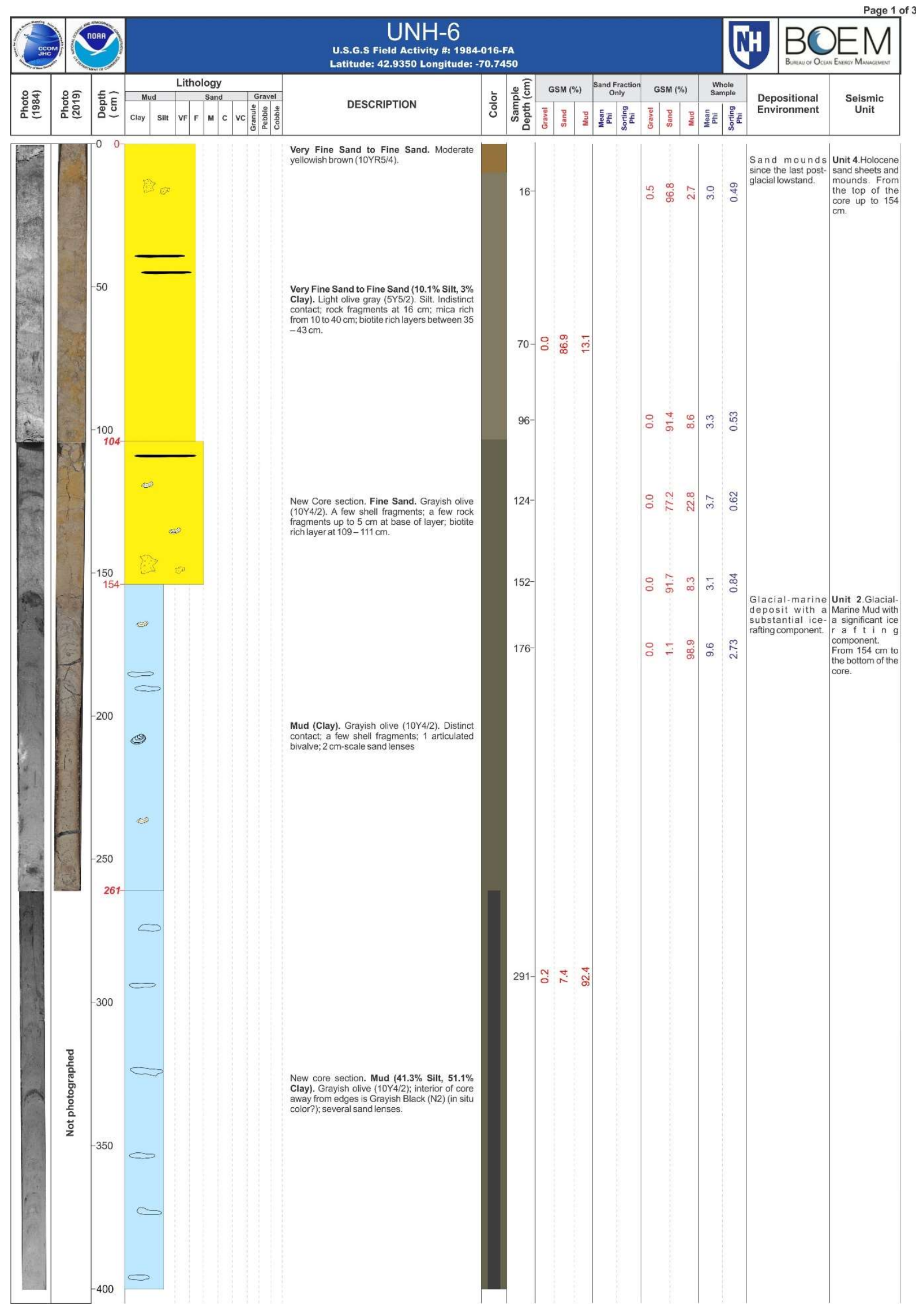




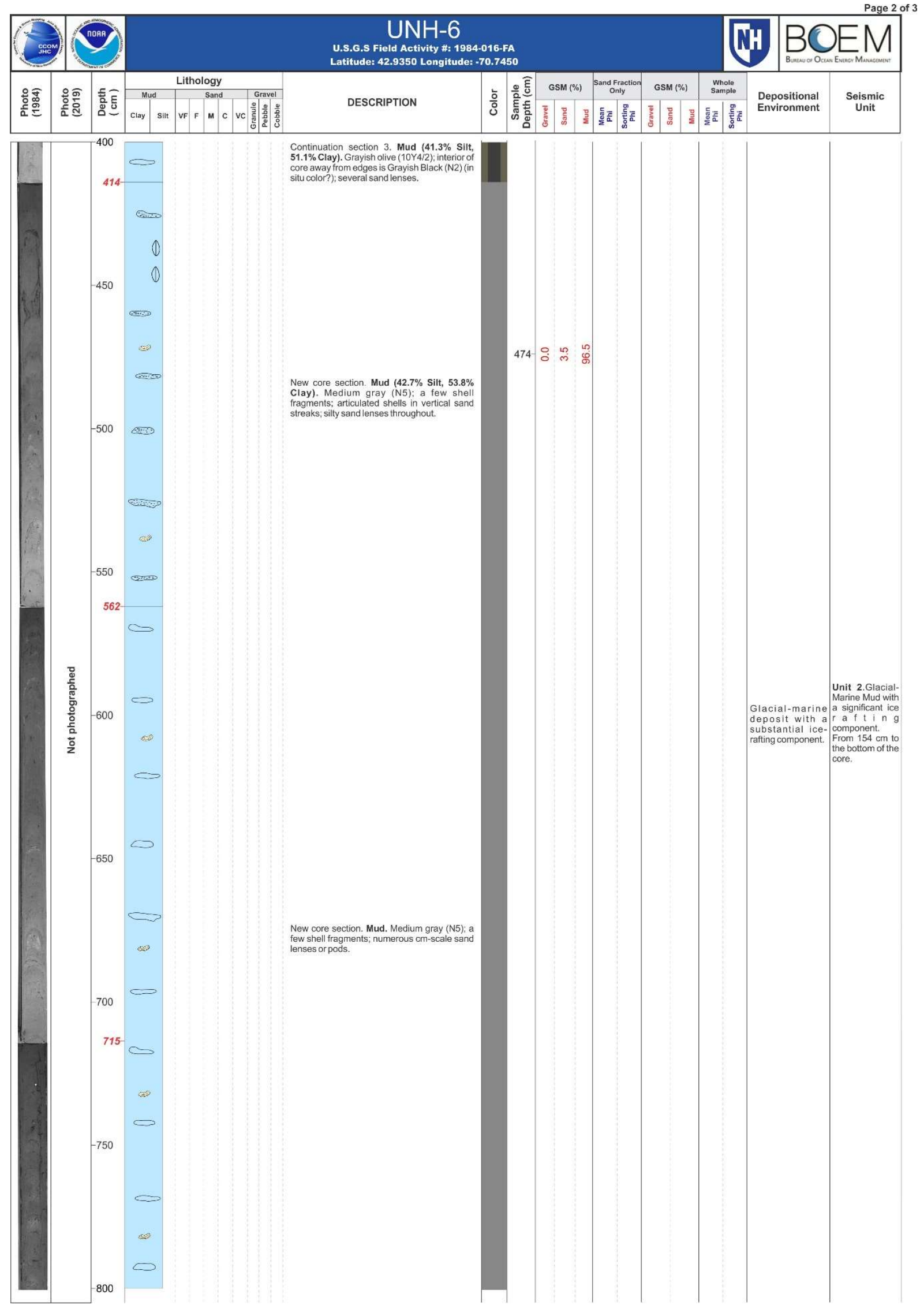




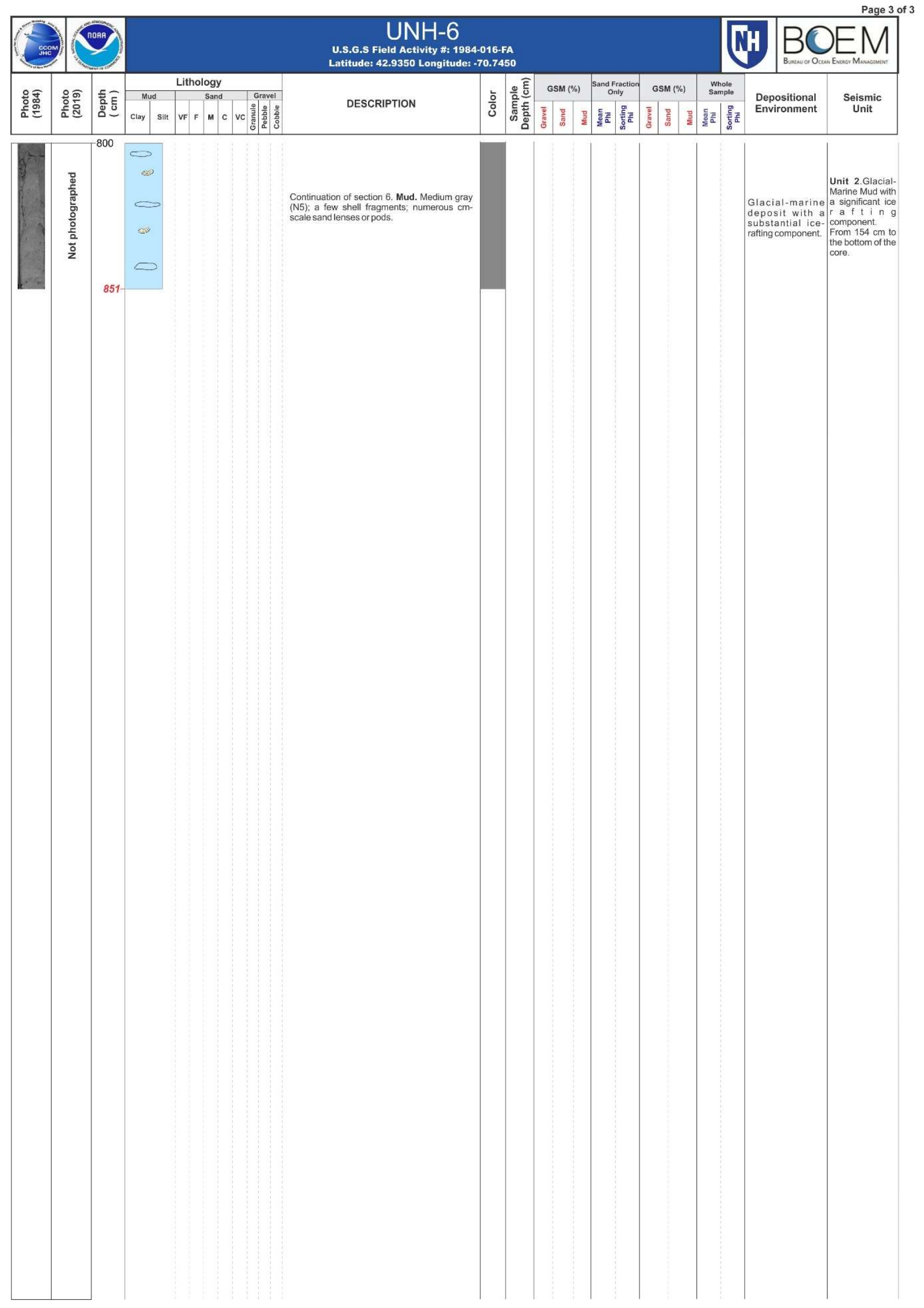




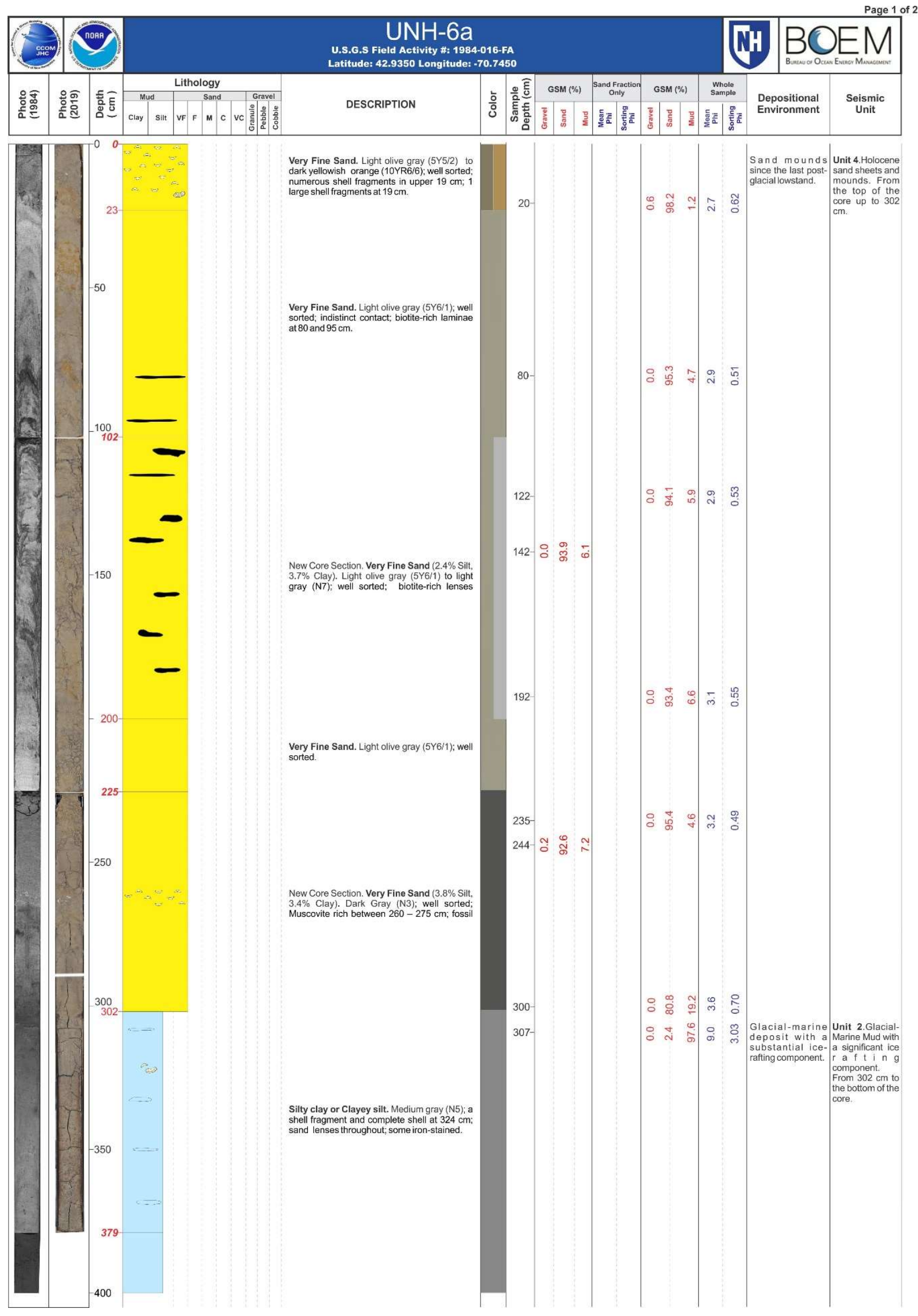




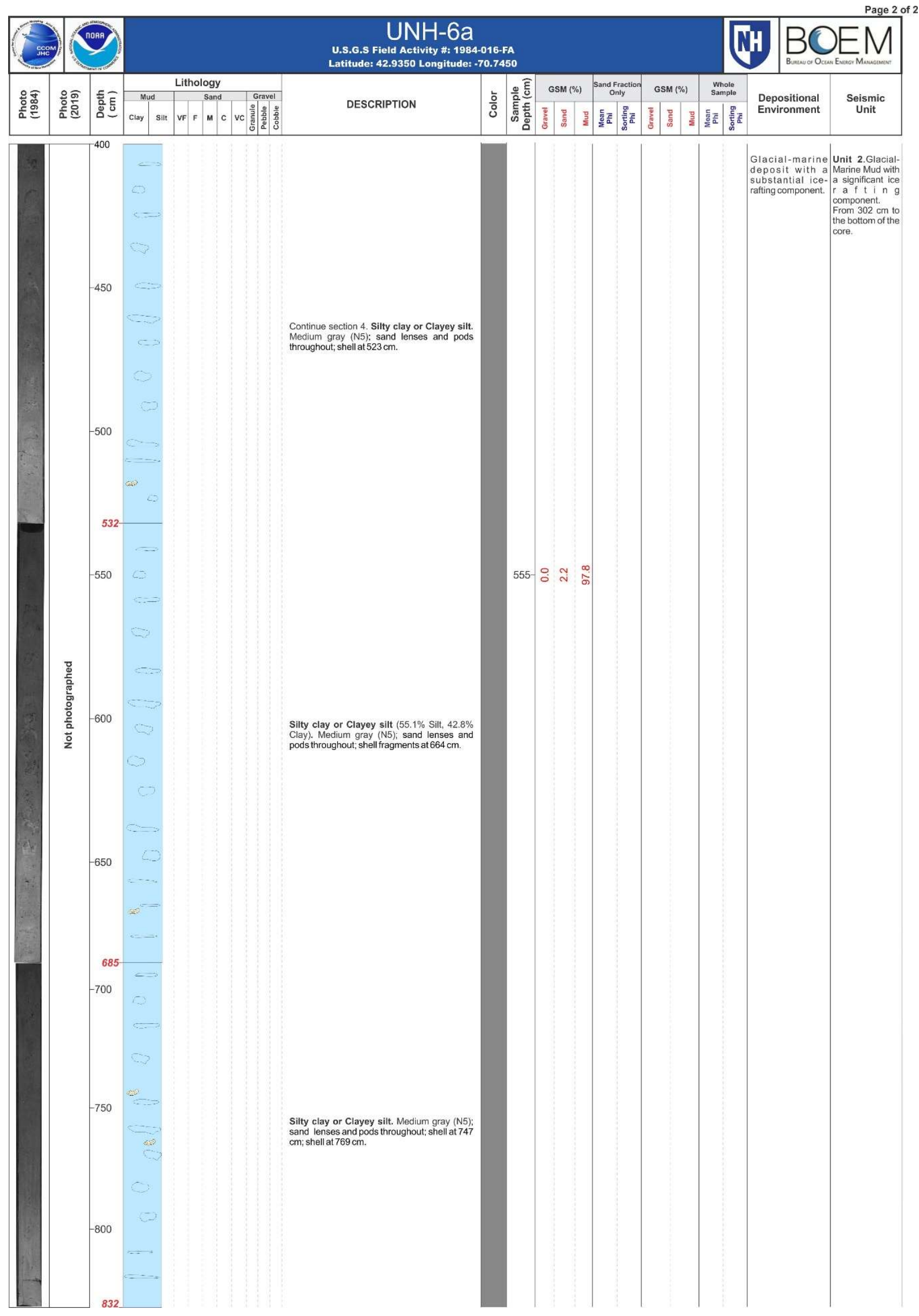




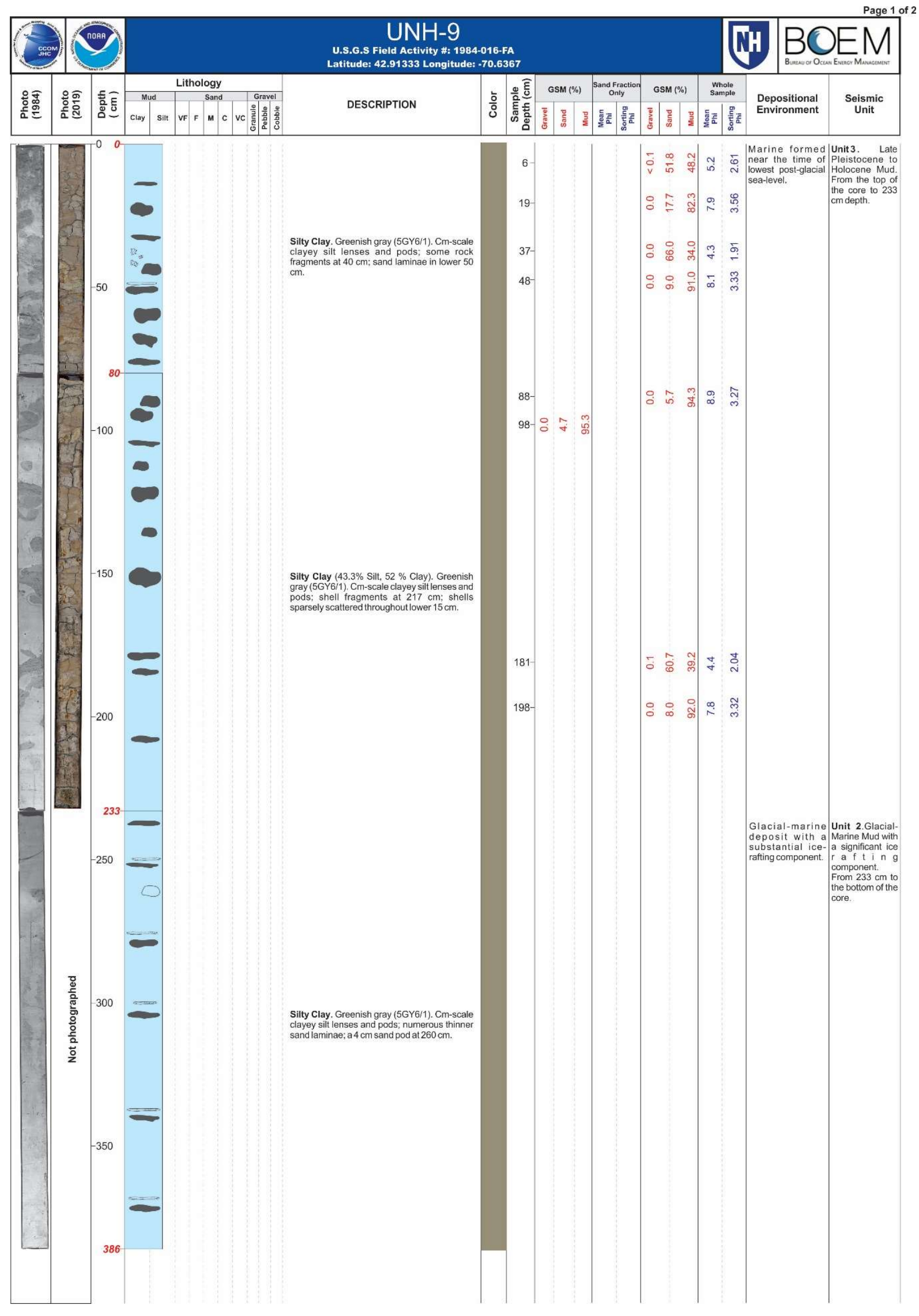




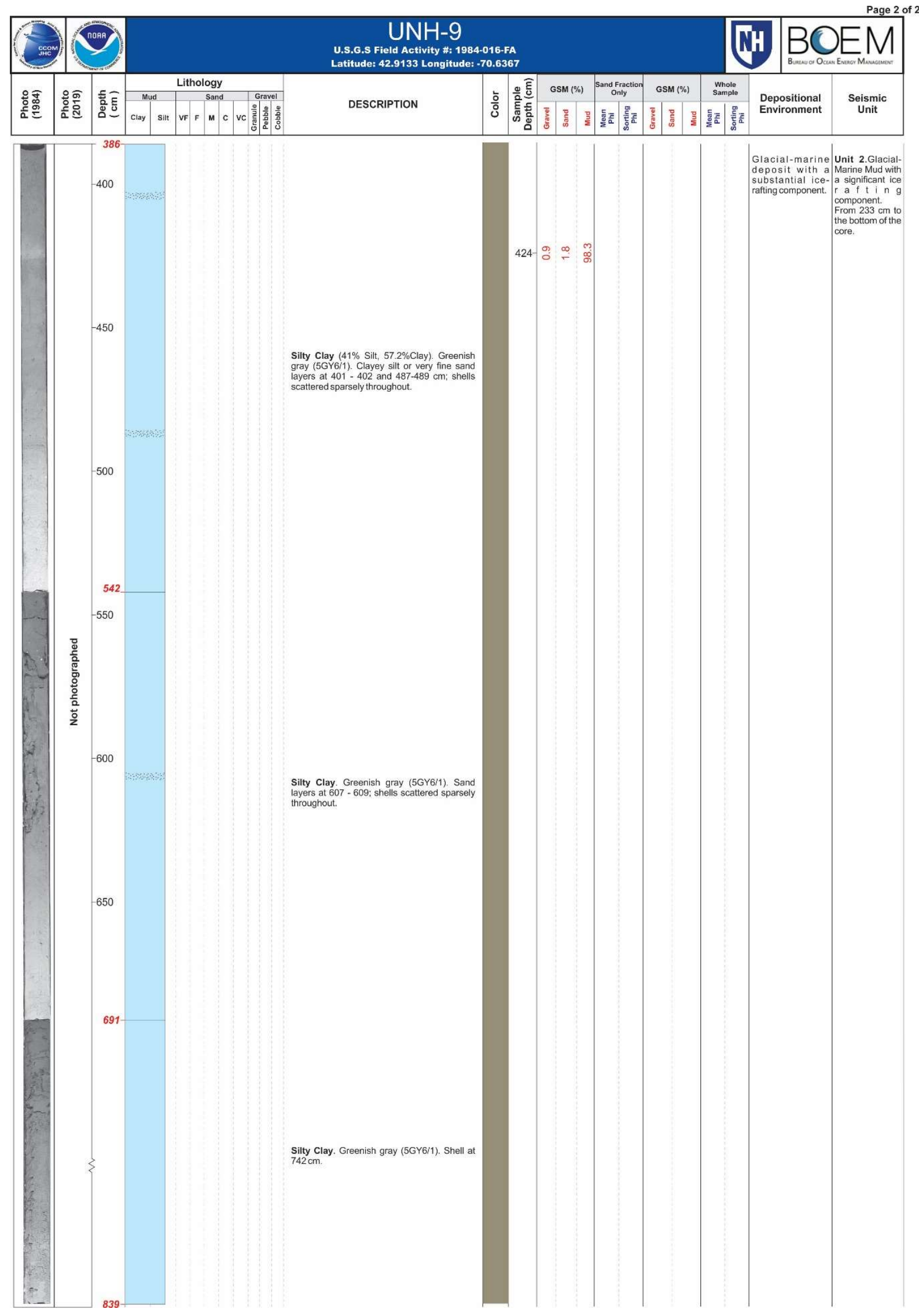




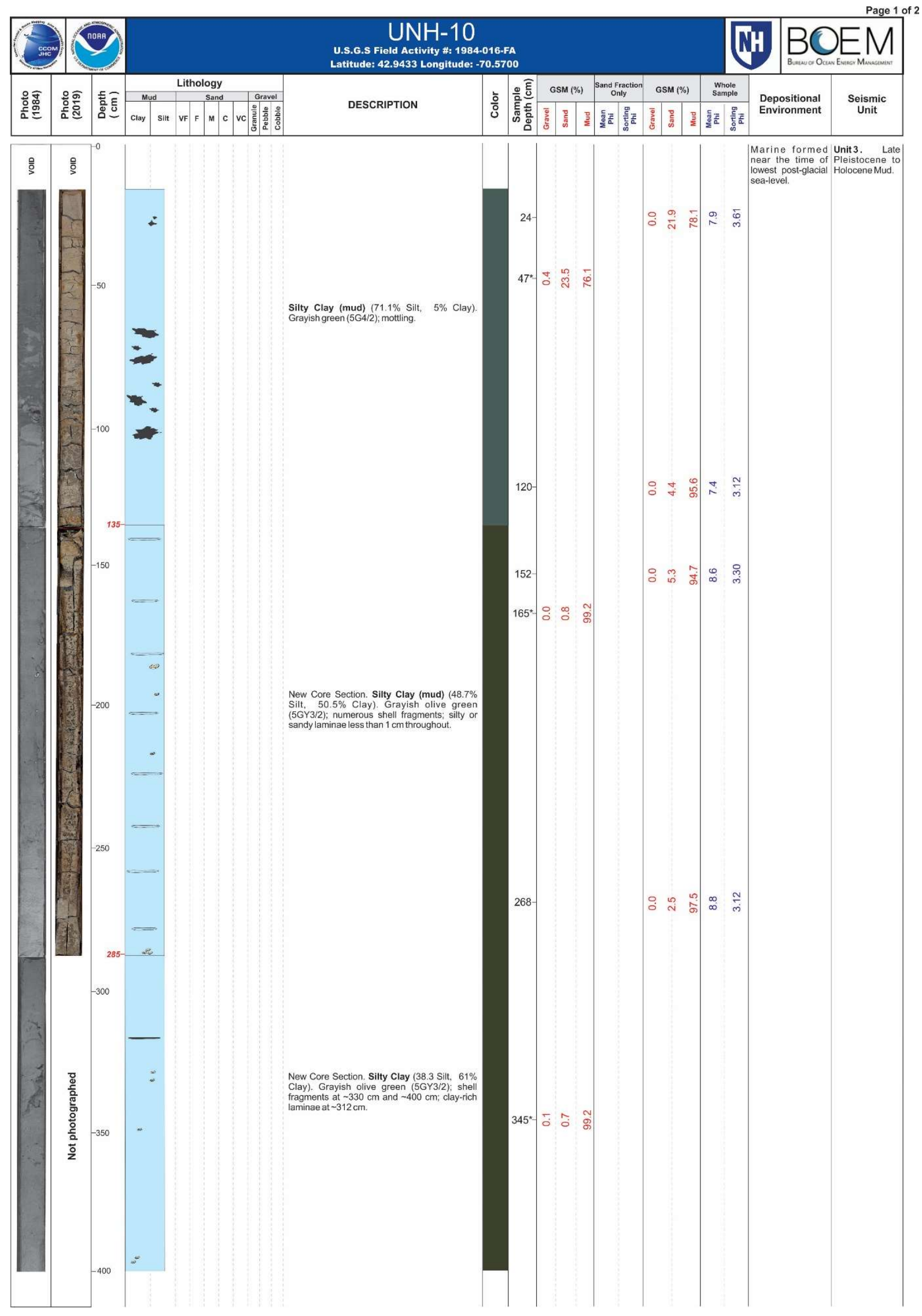




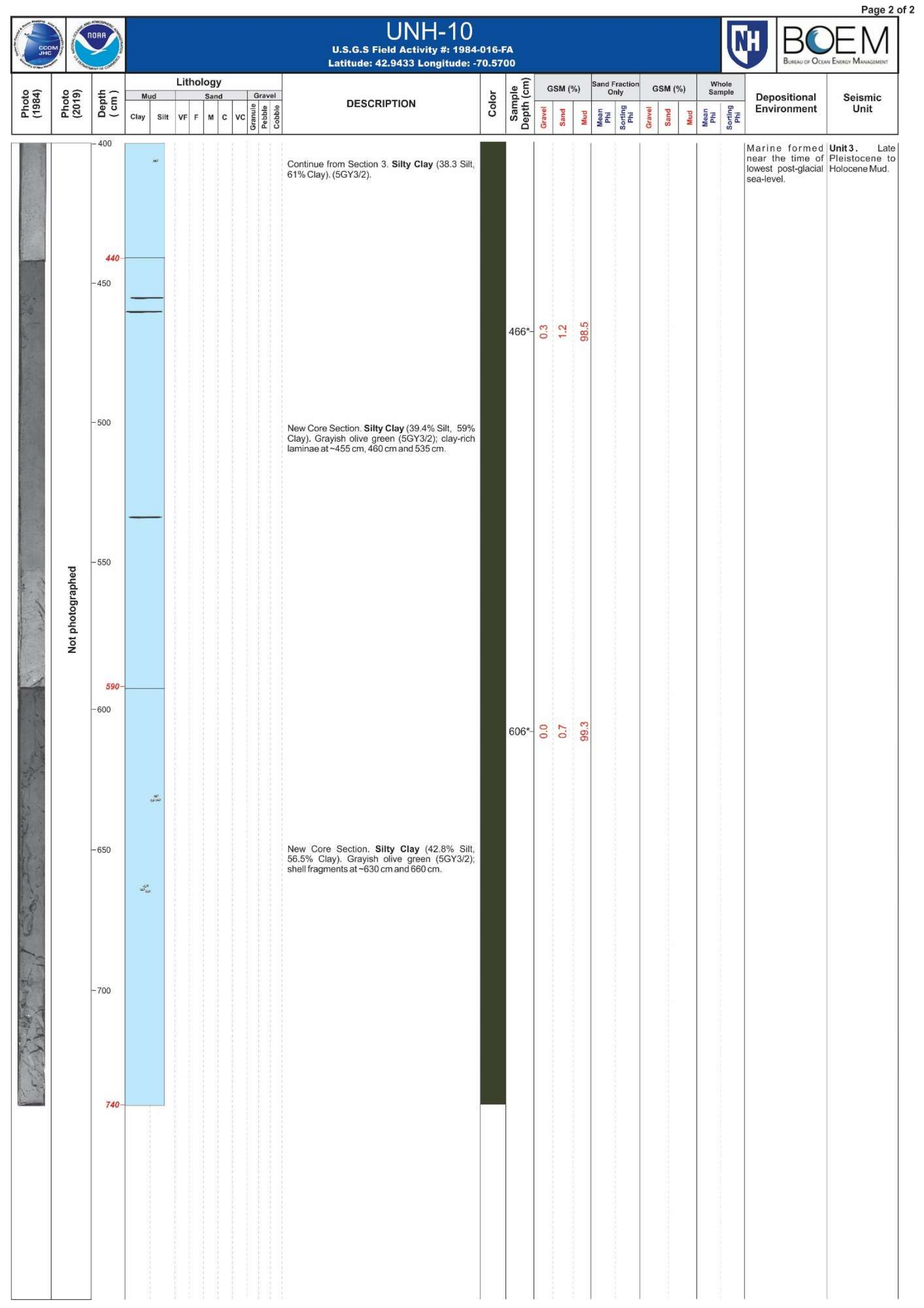




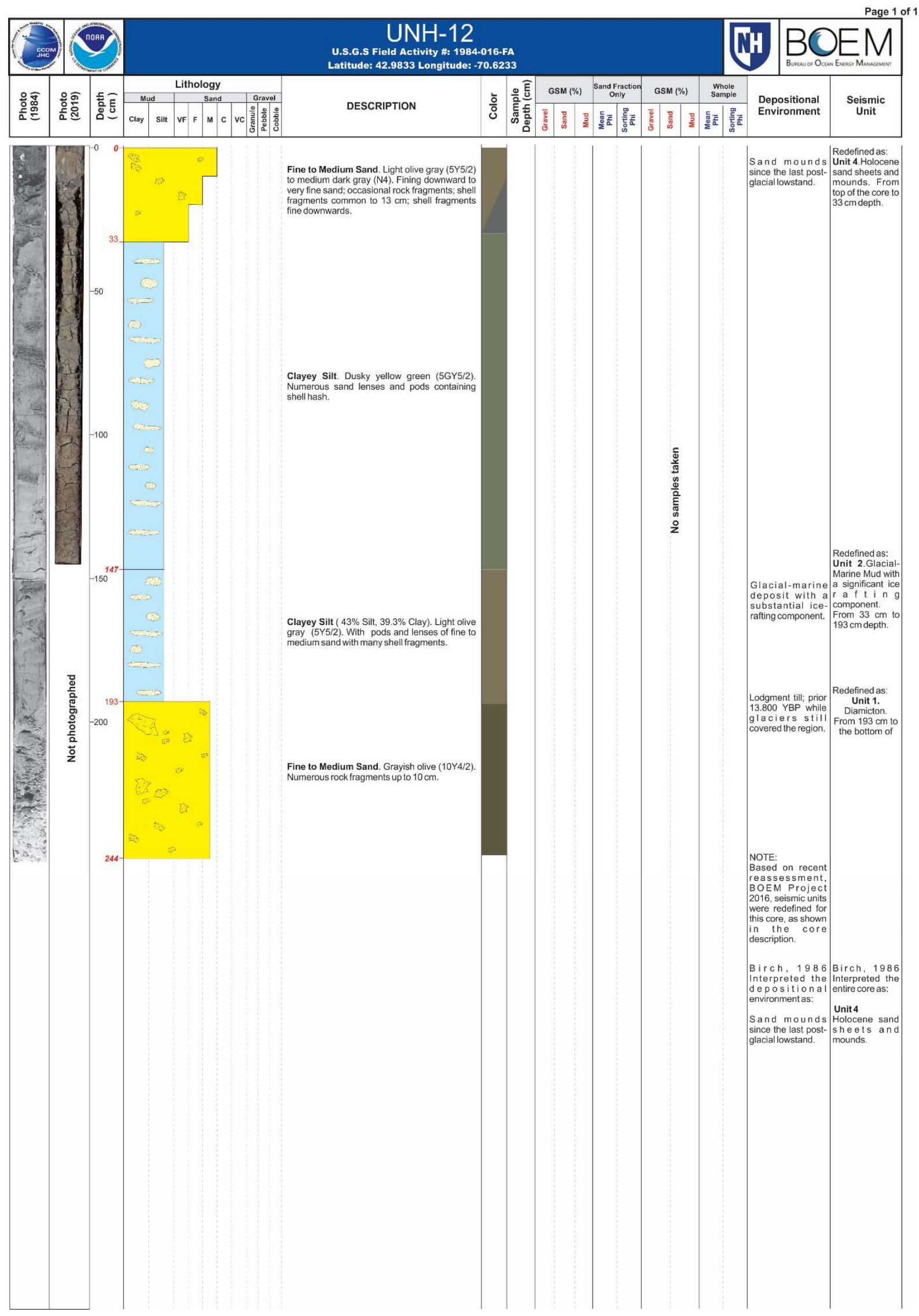




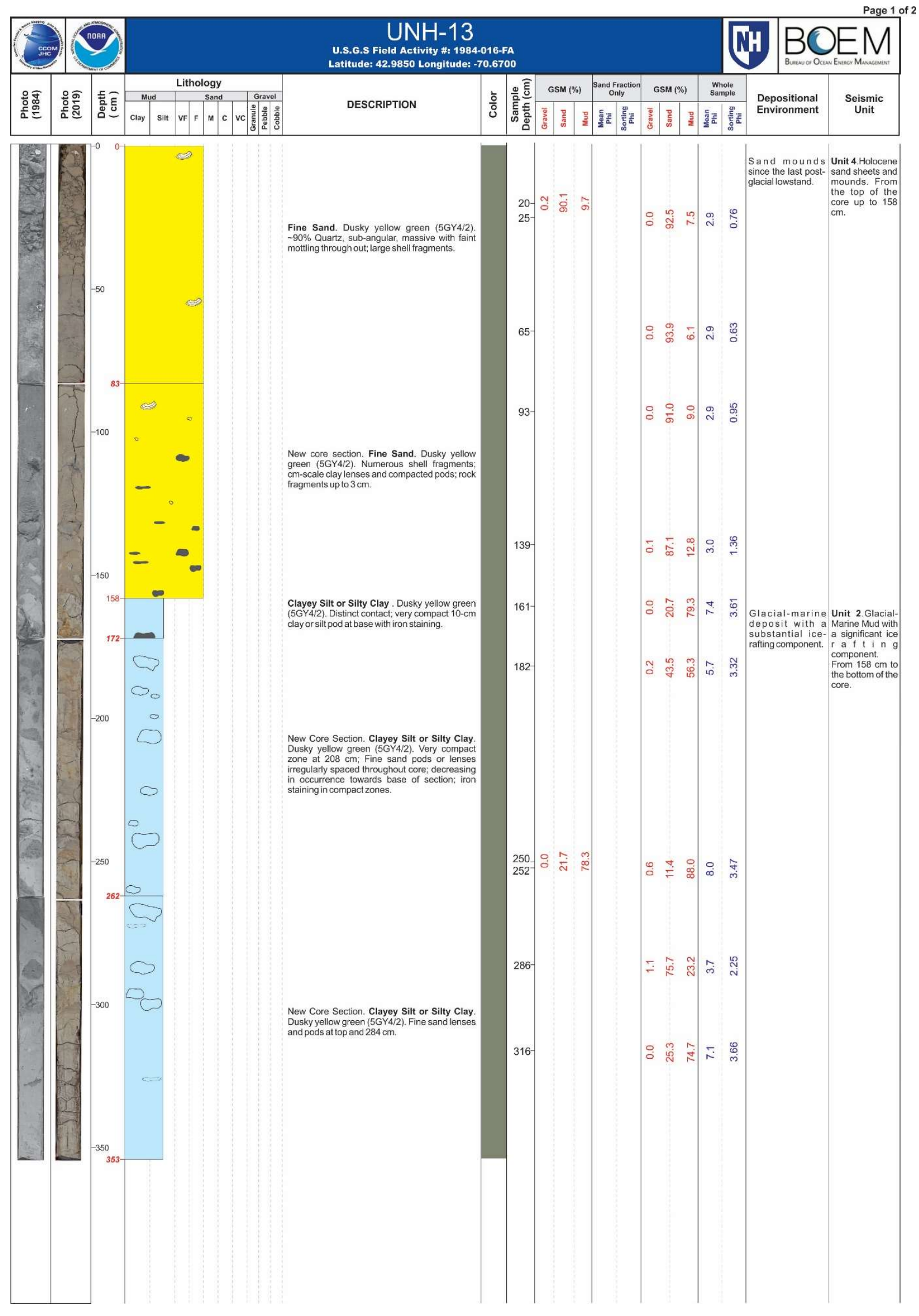




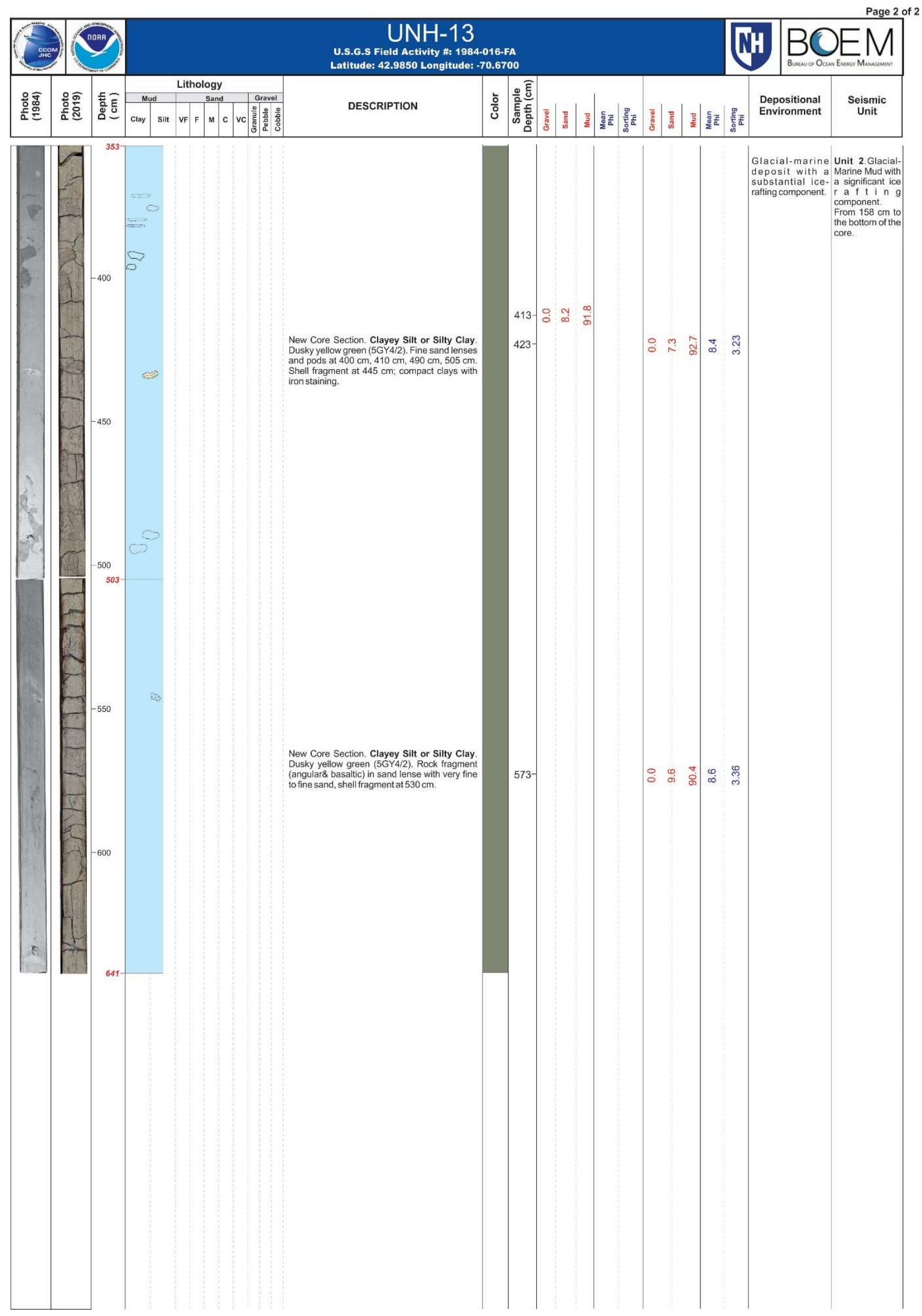




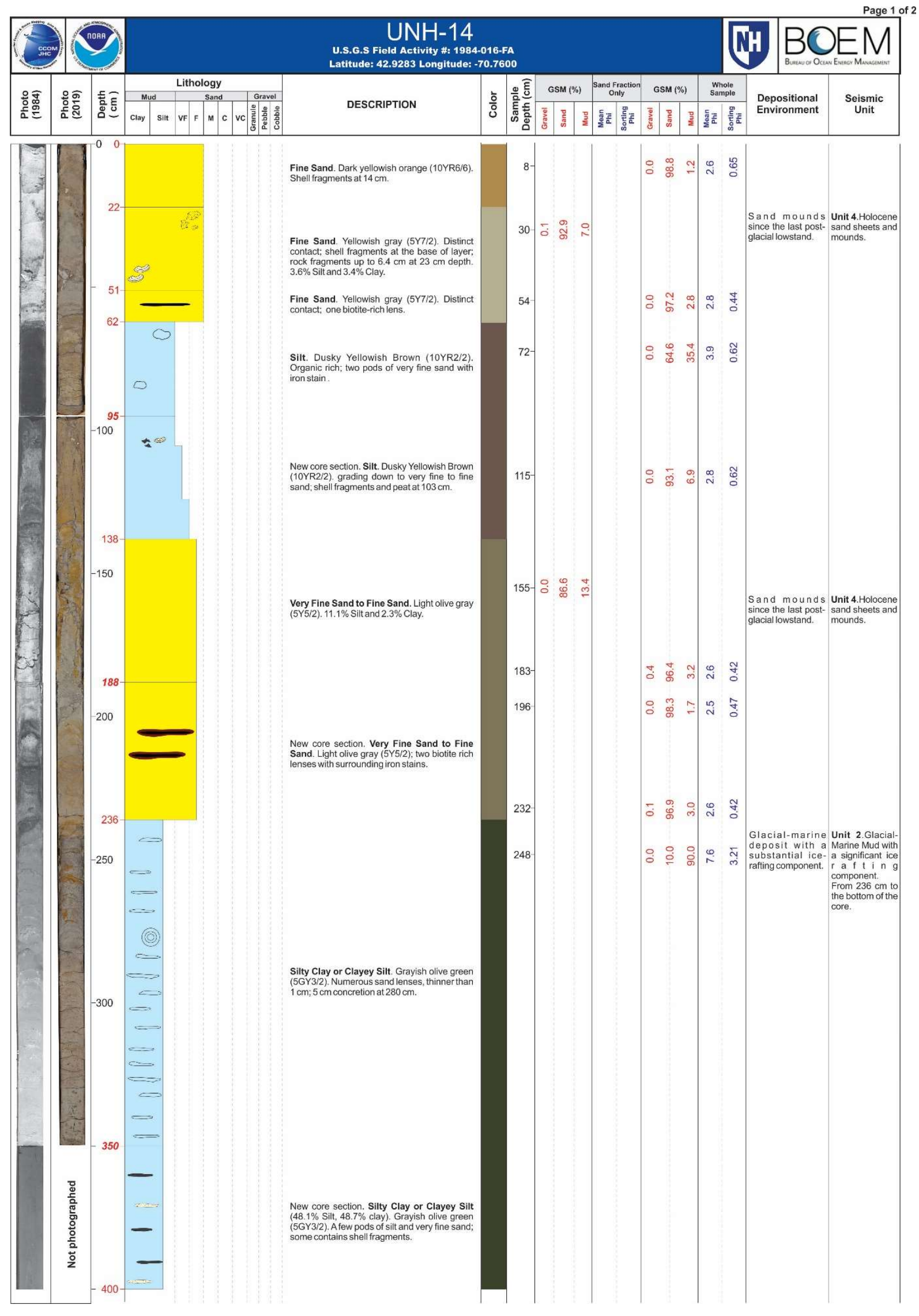




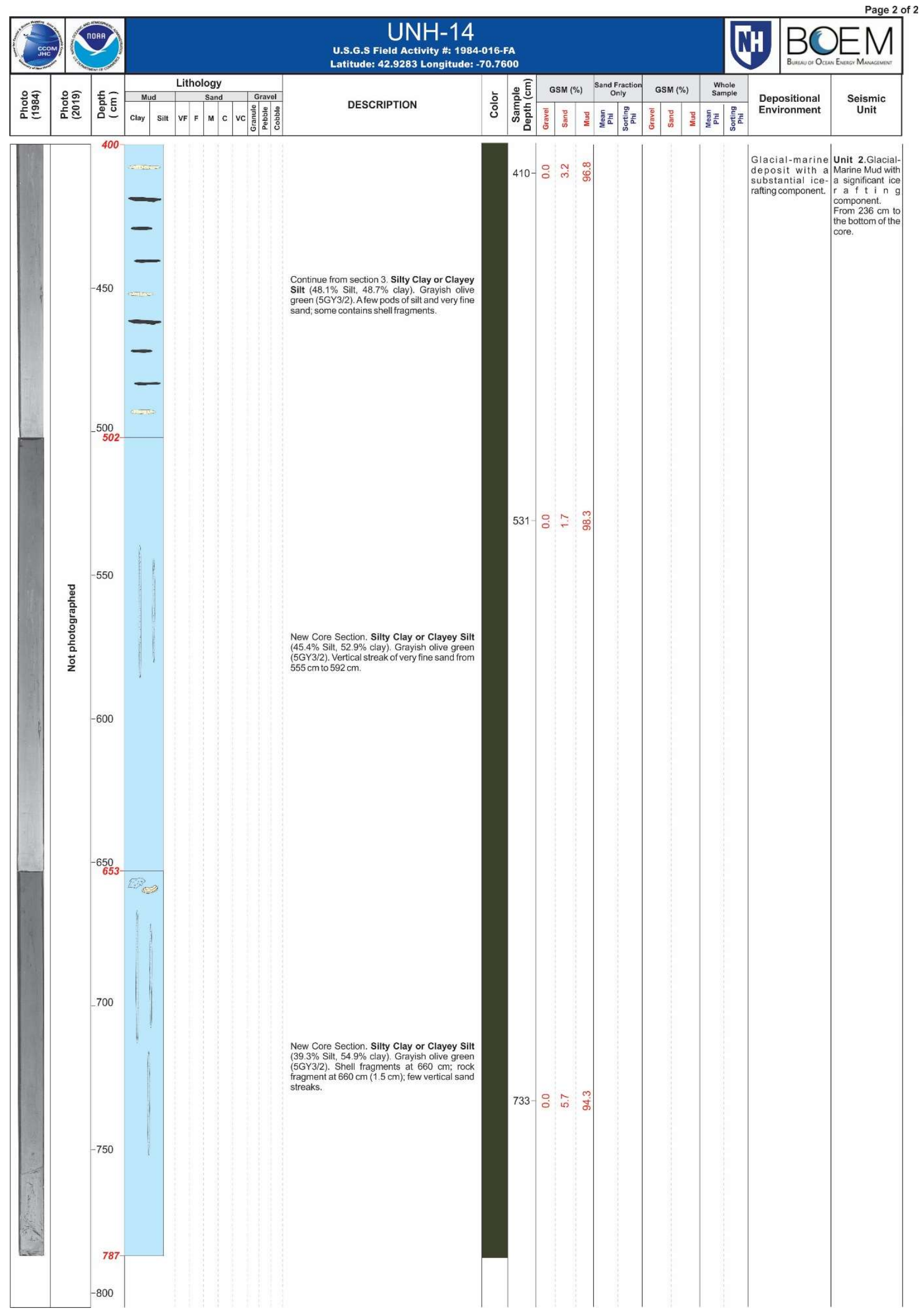


Full Vibracore Logs from 1988 (A series) 


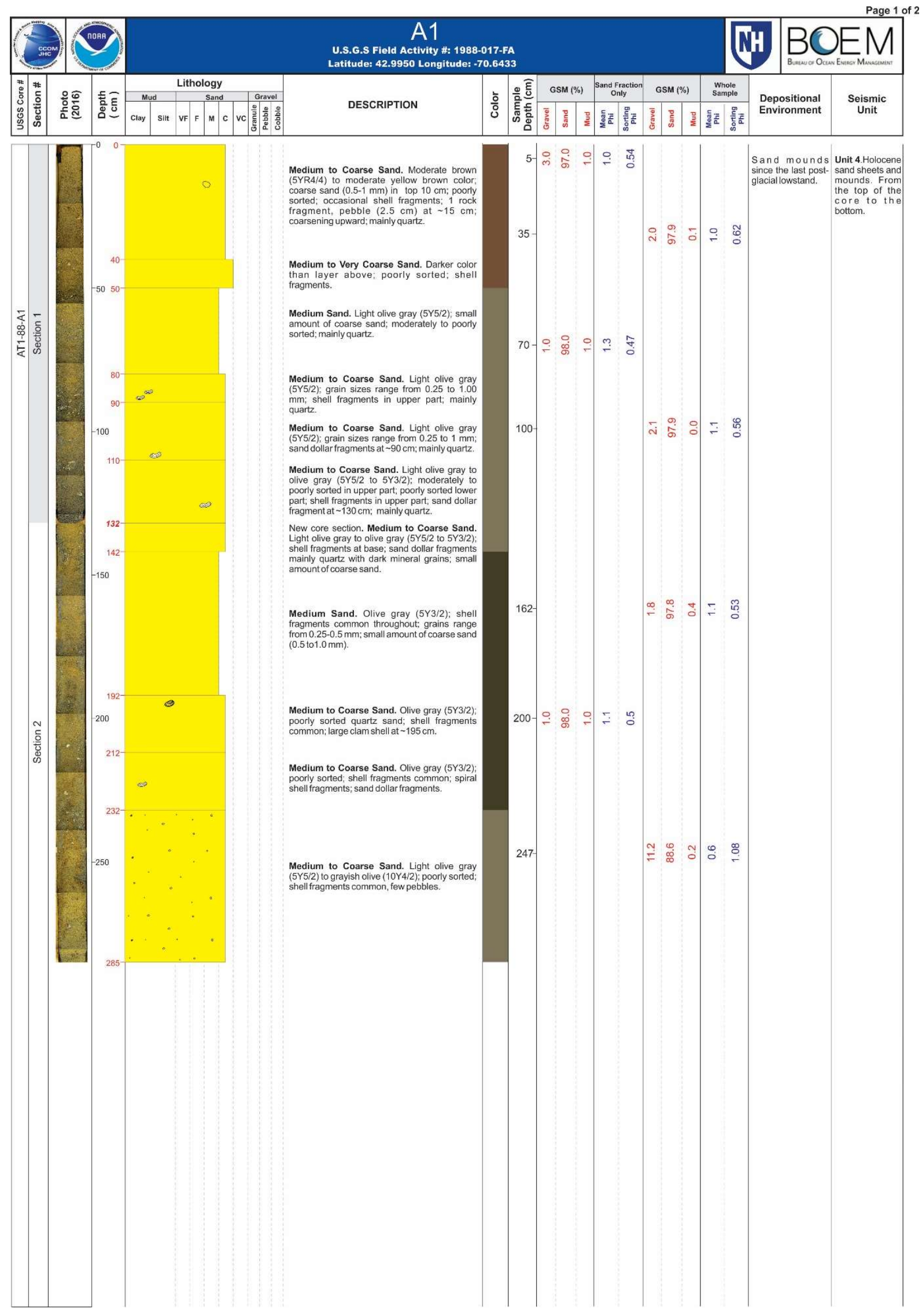




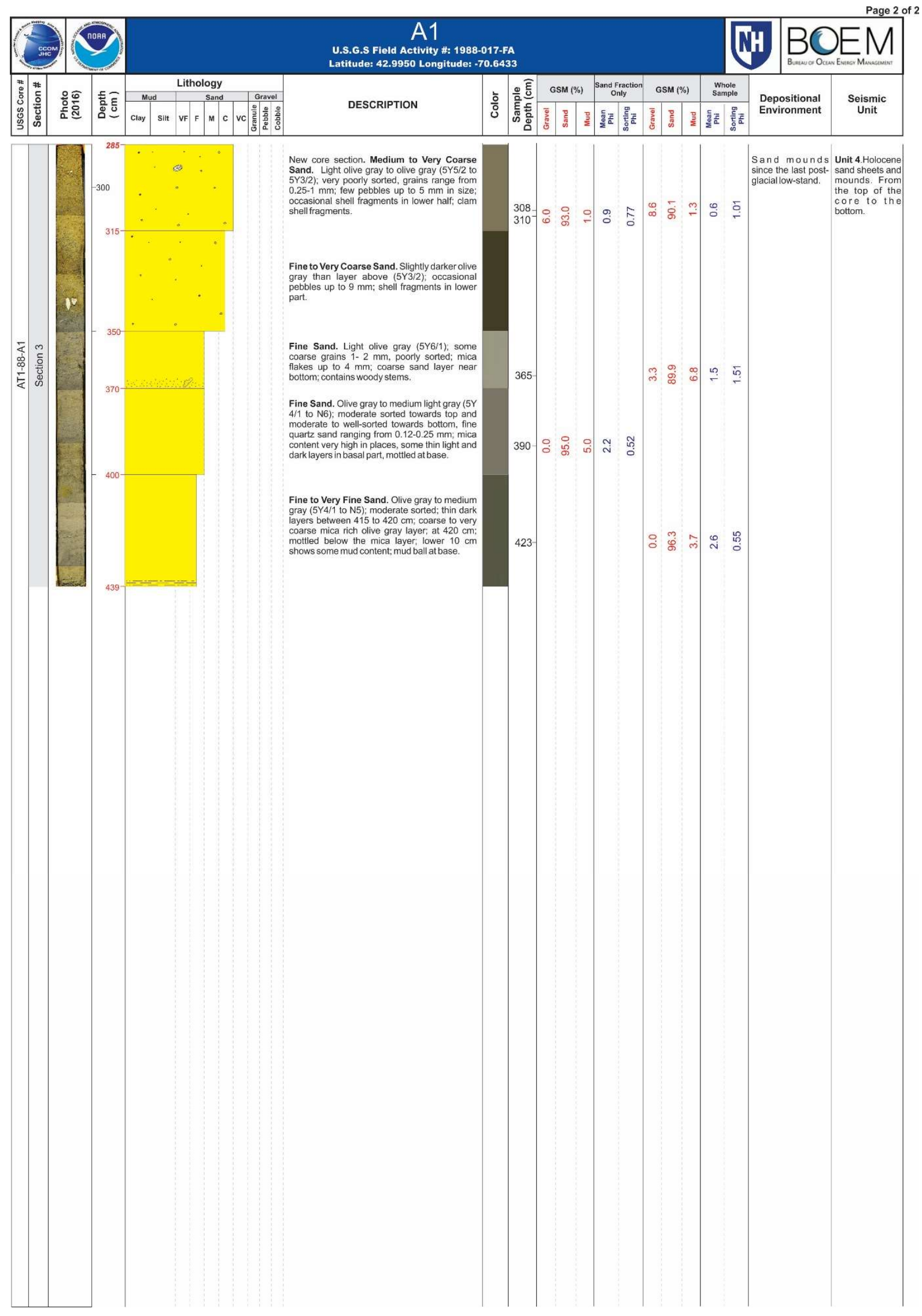




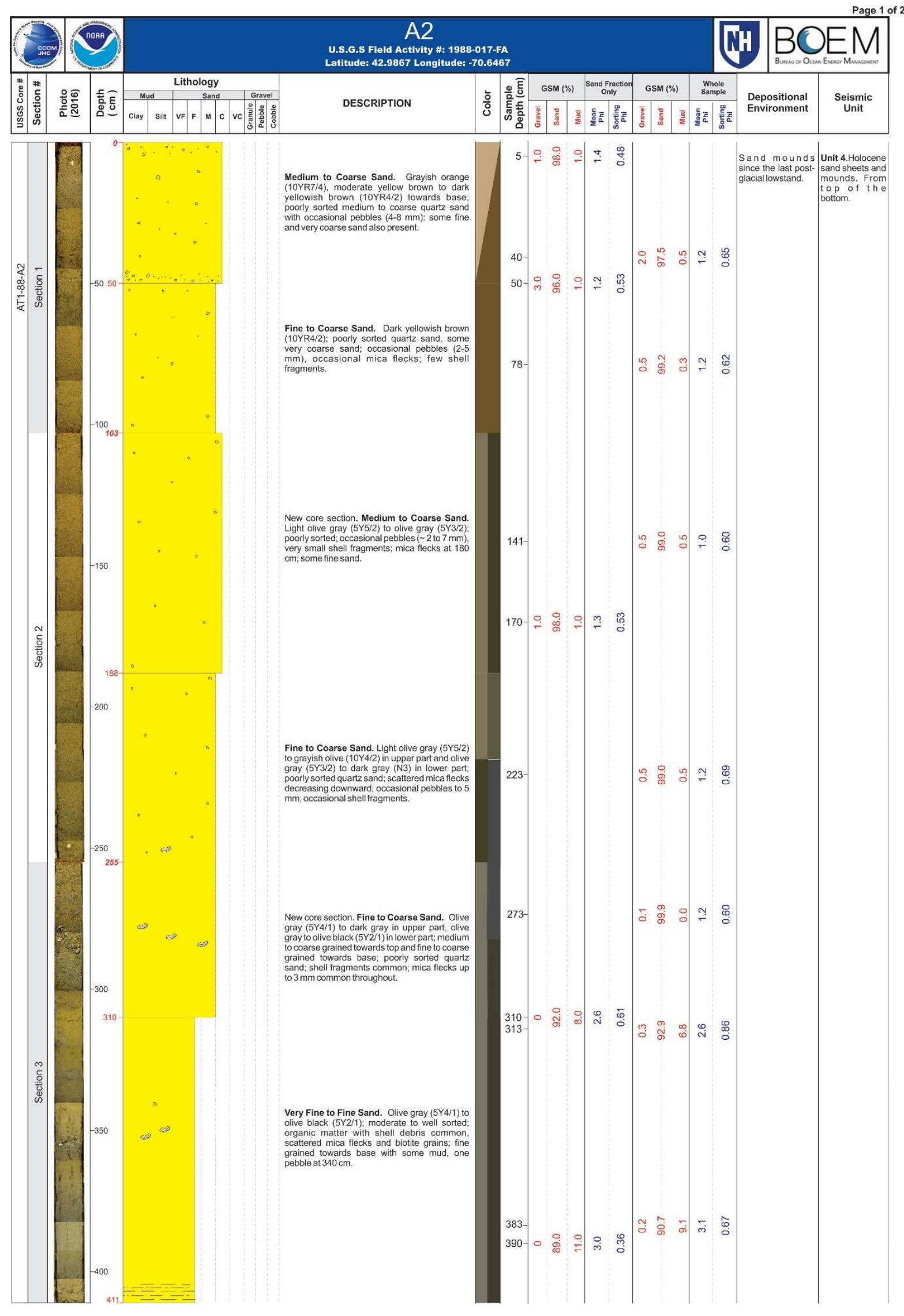




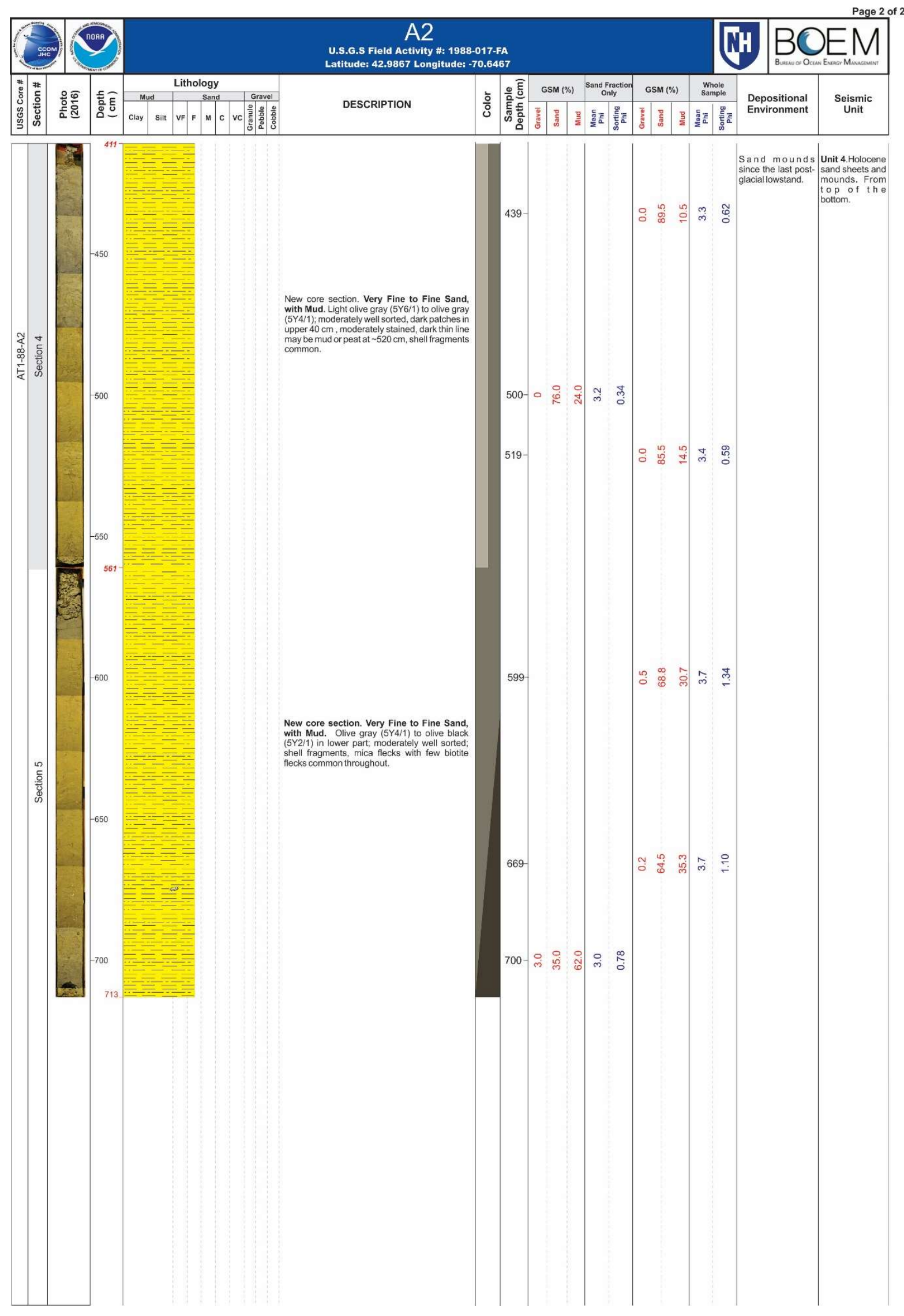




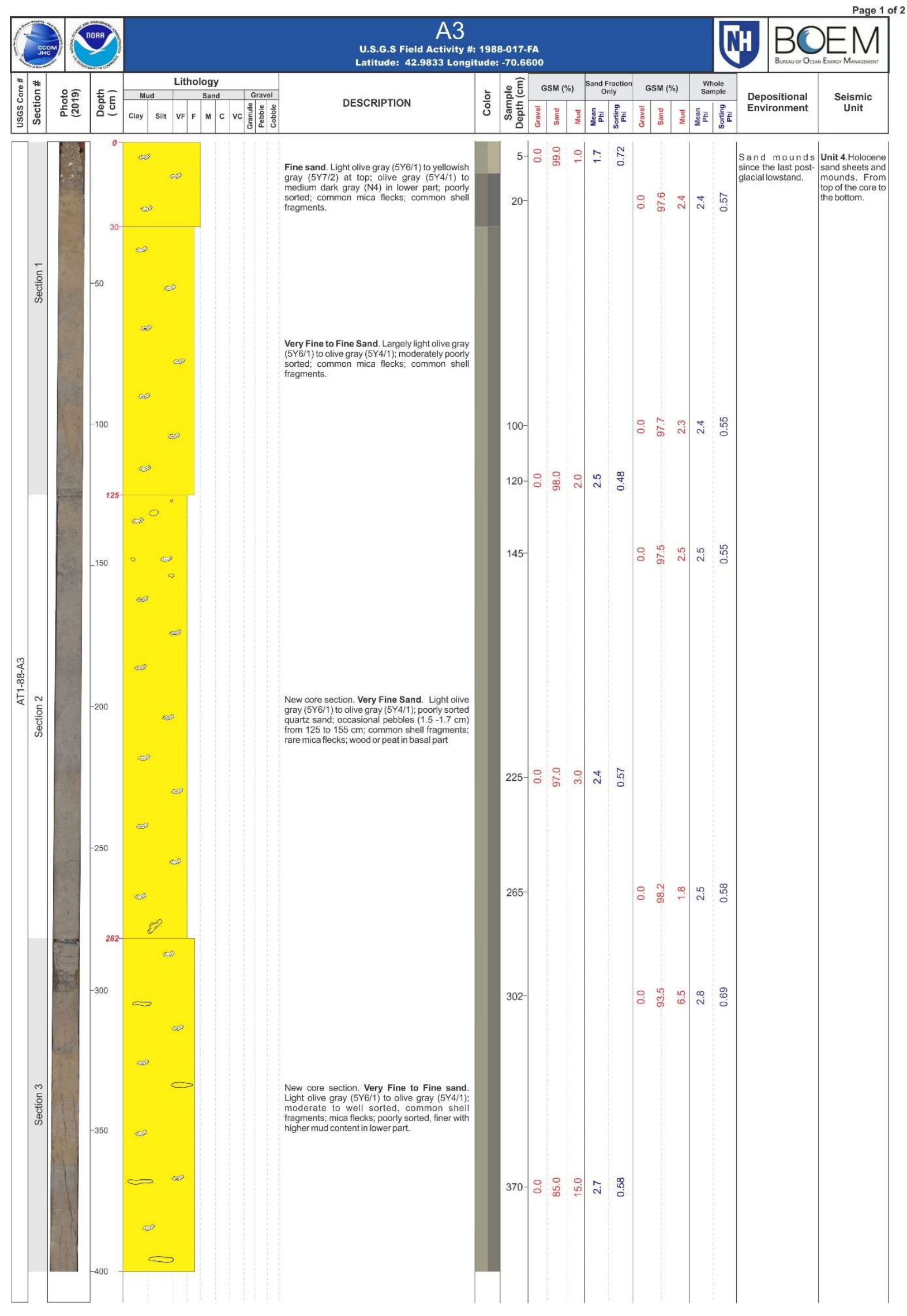




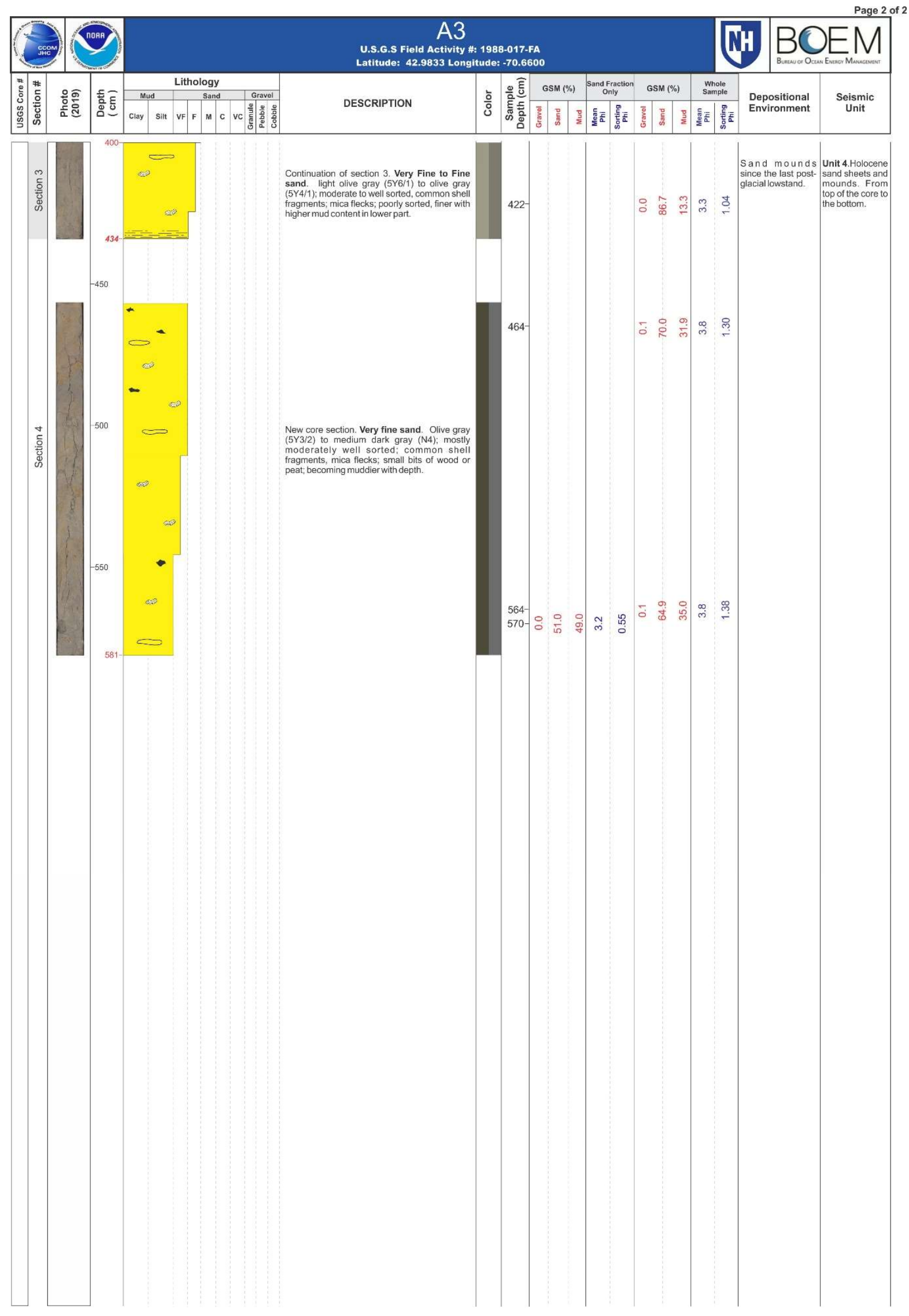




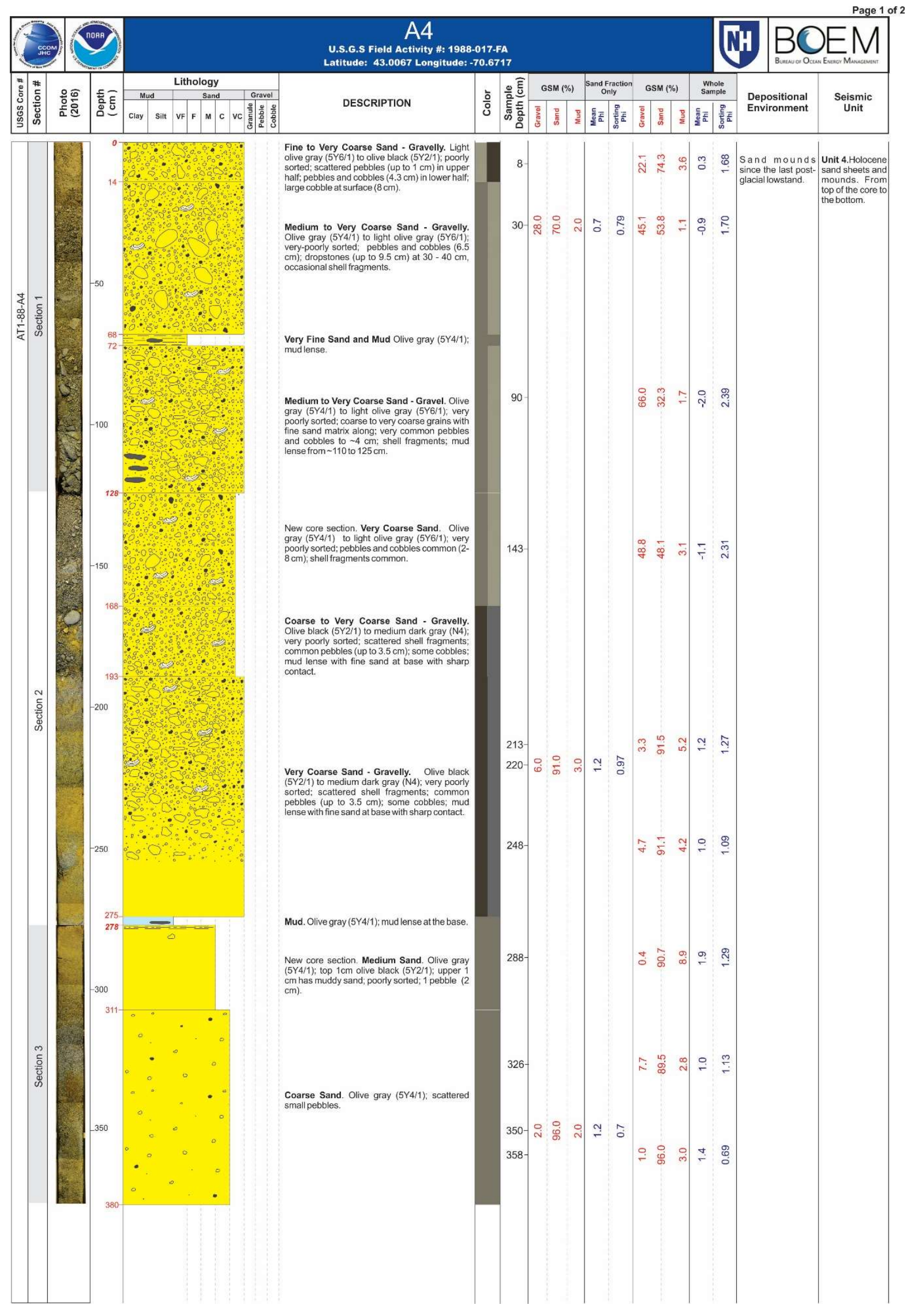




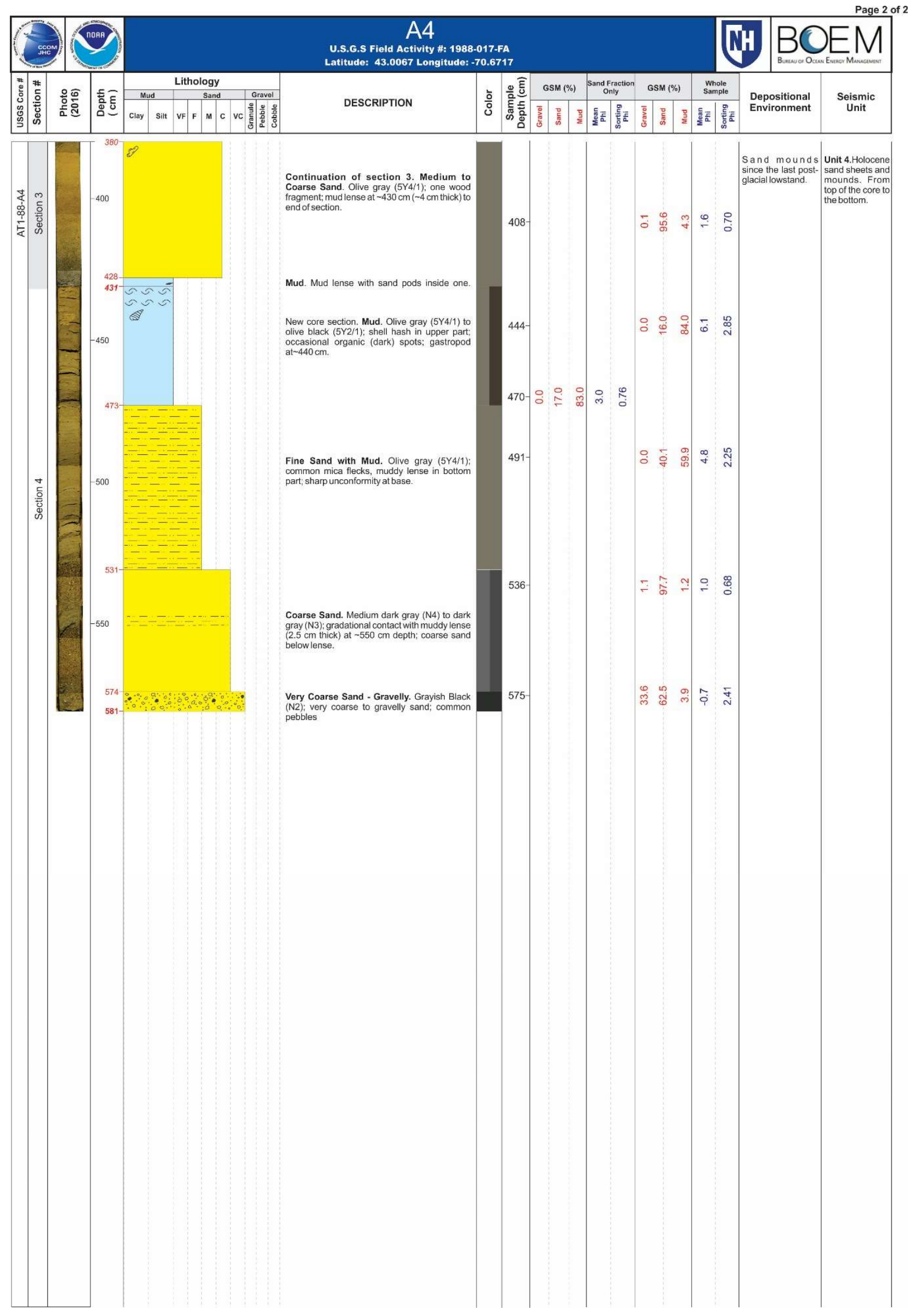




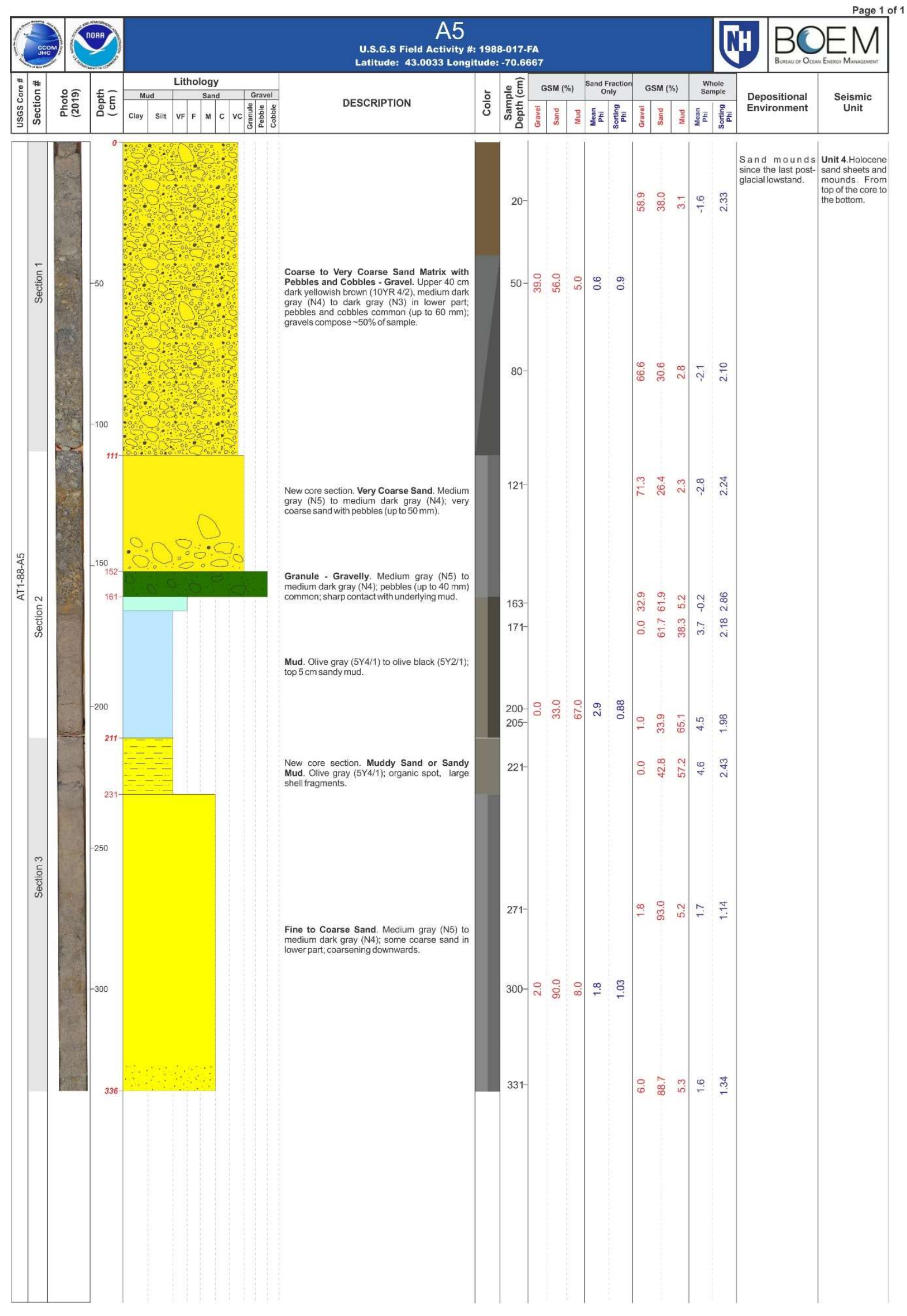




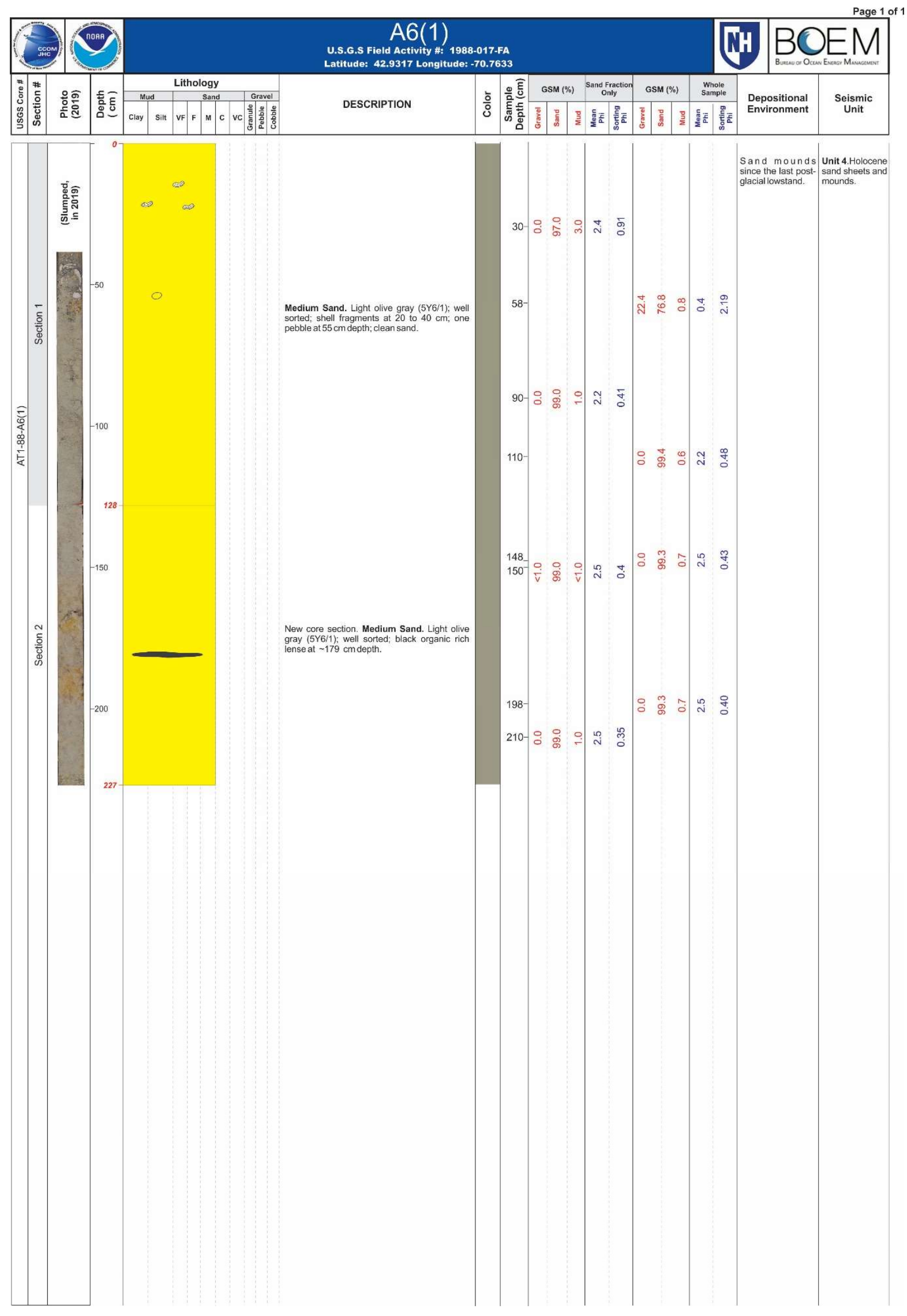




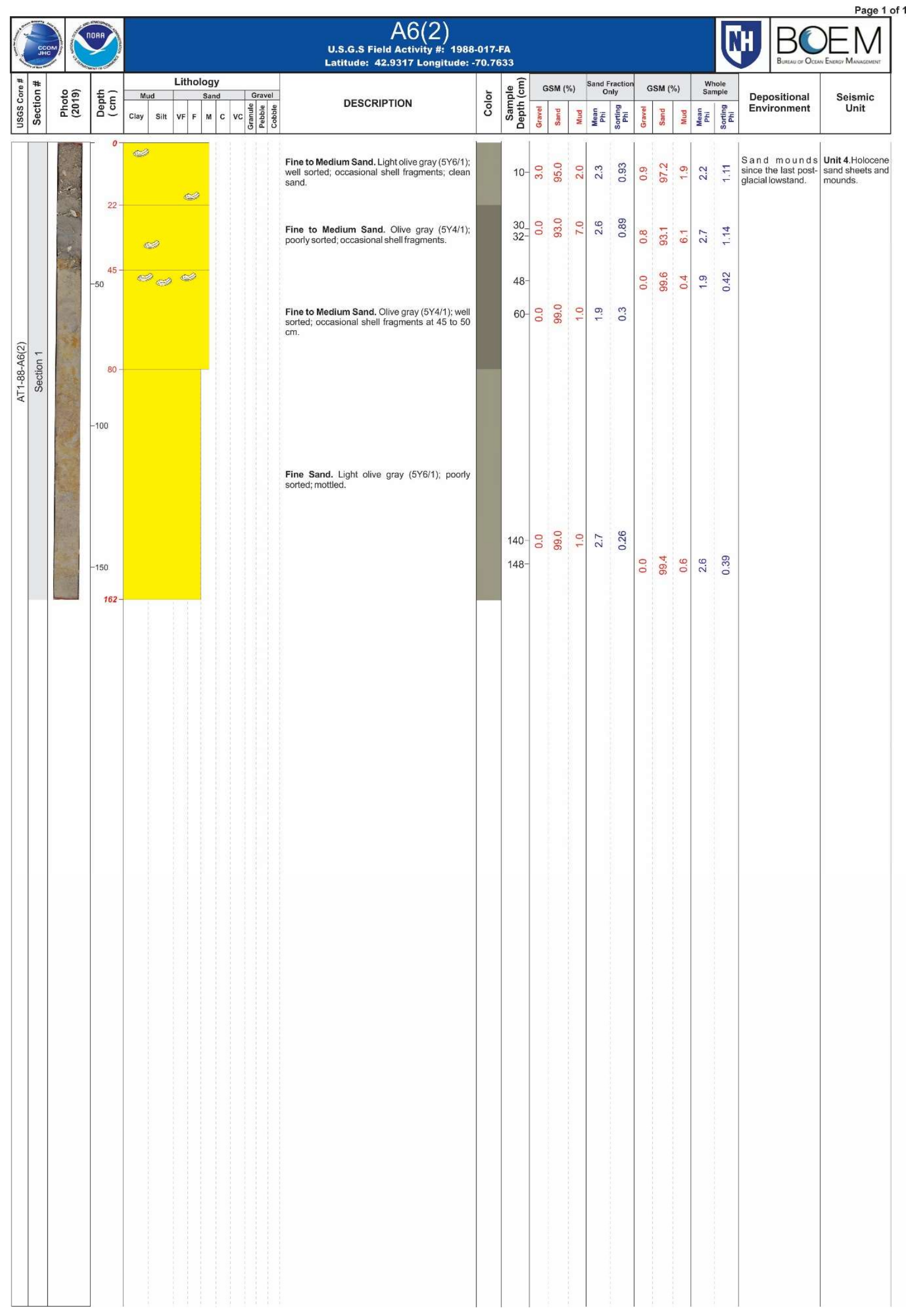




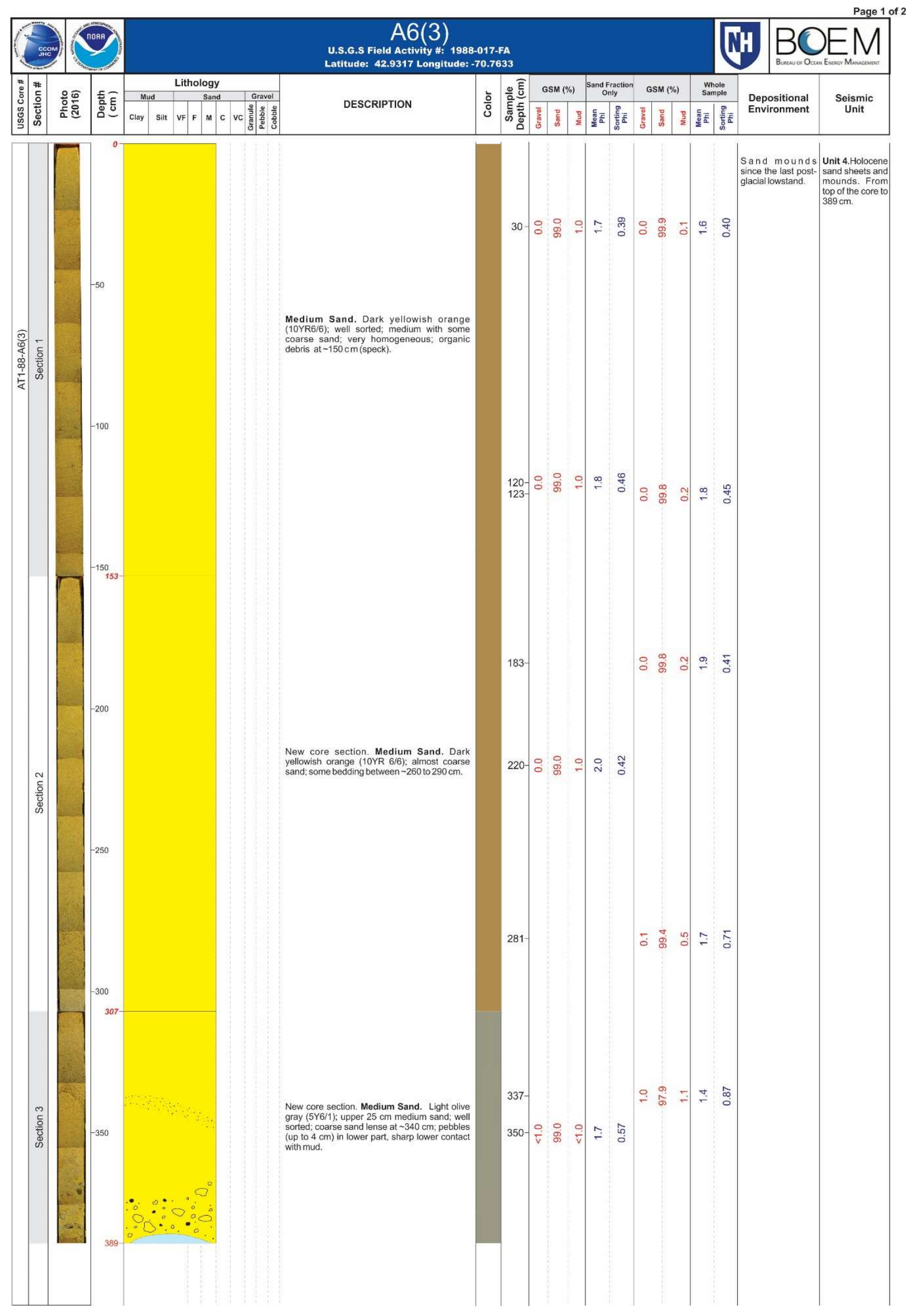




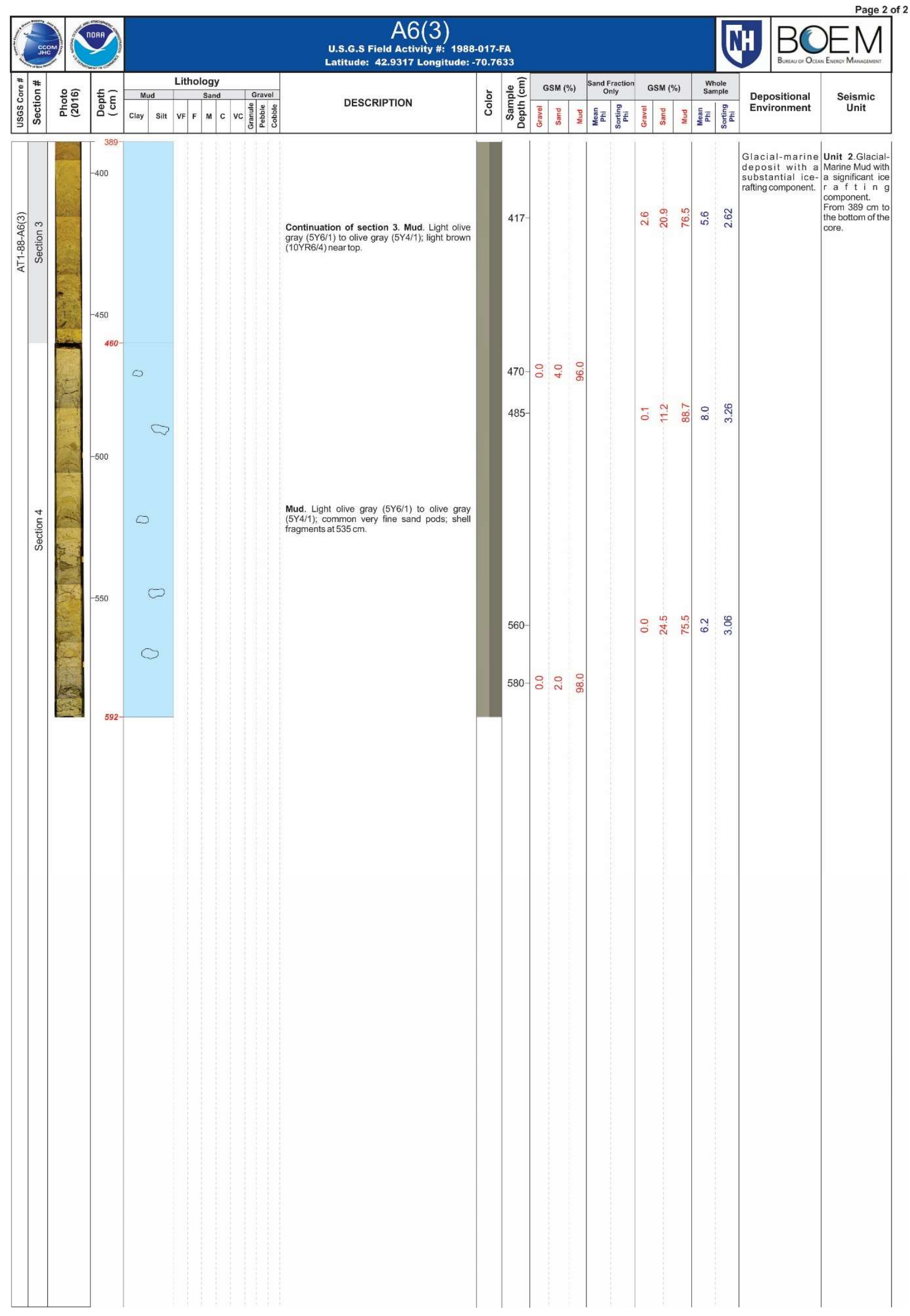




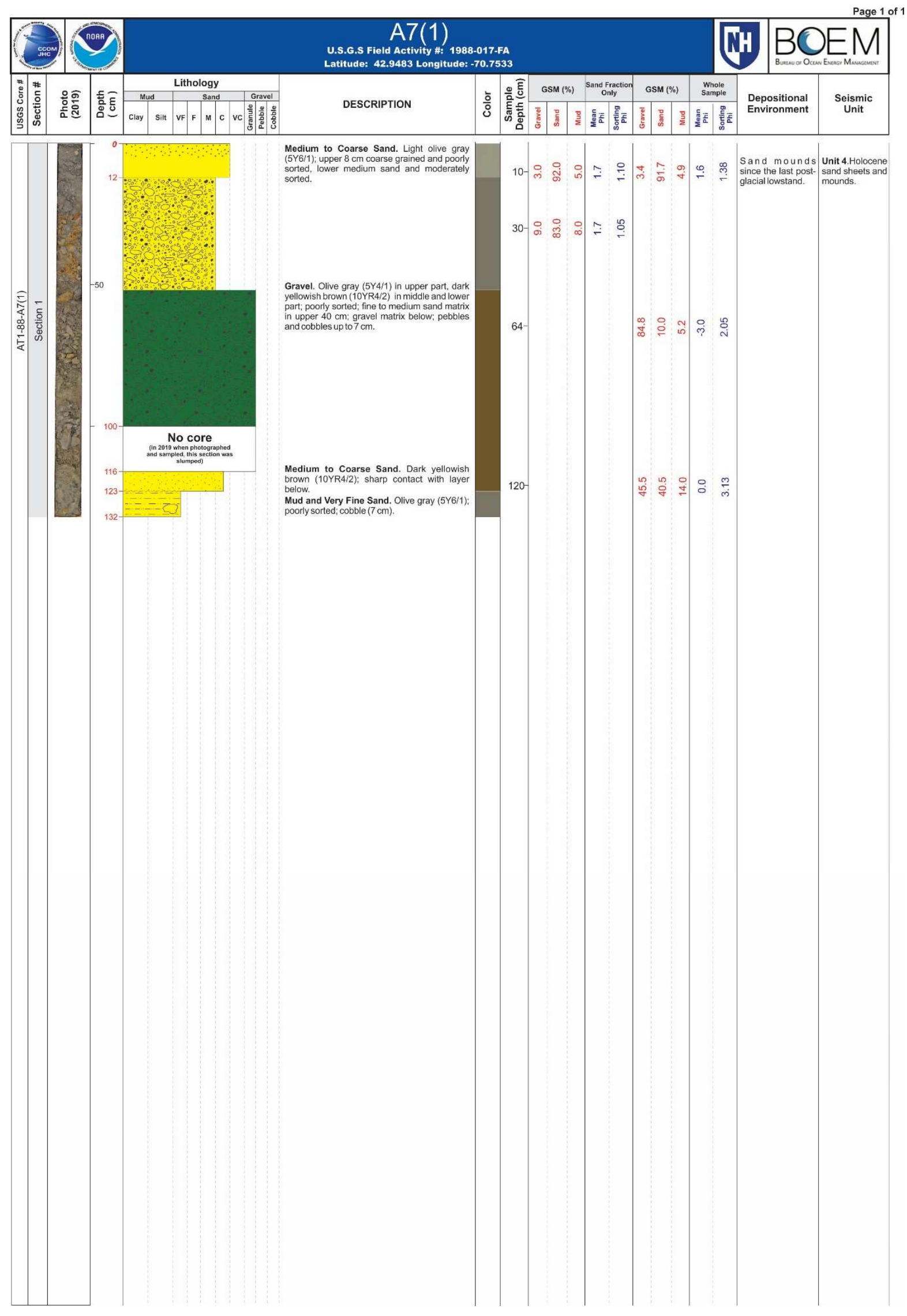




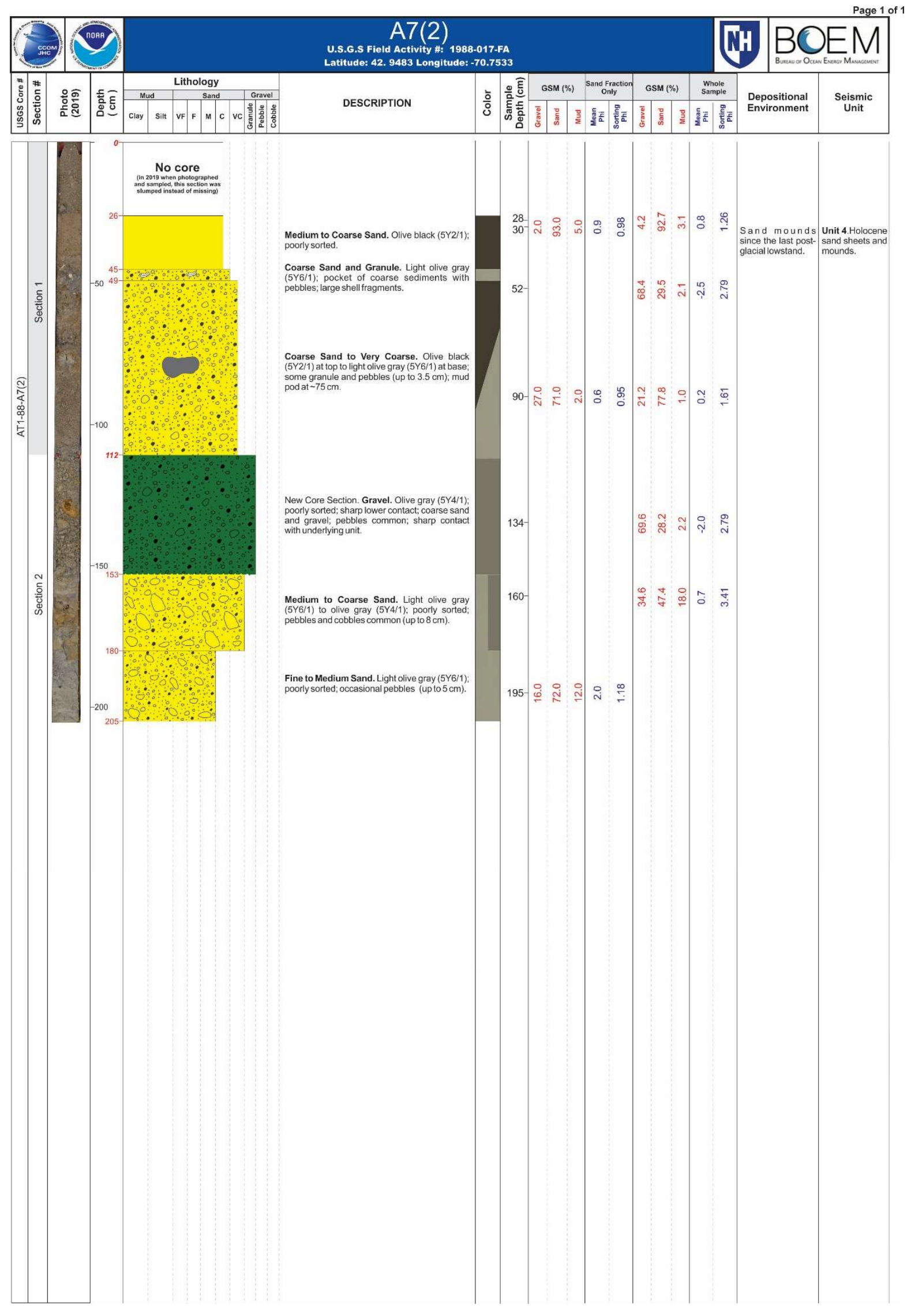




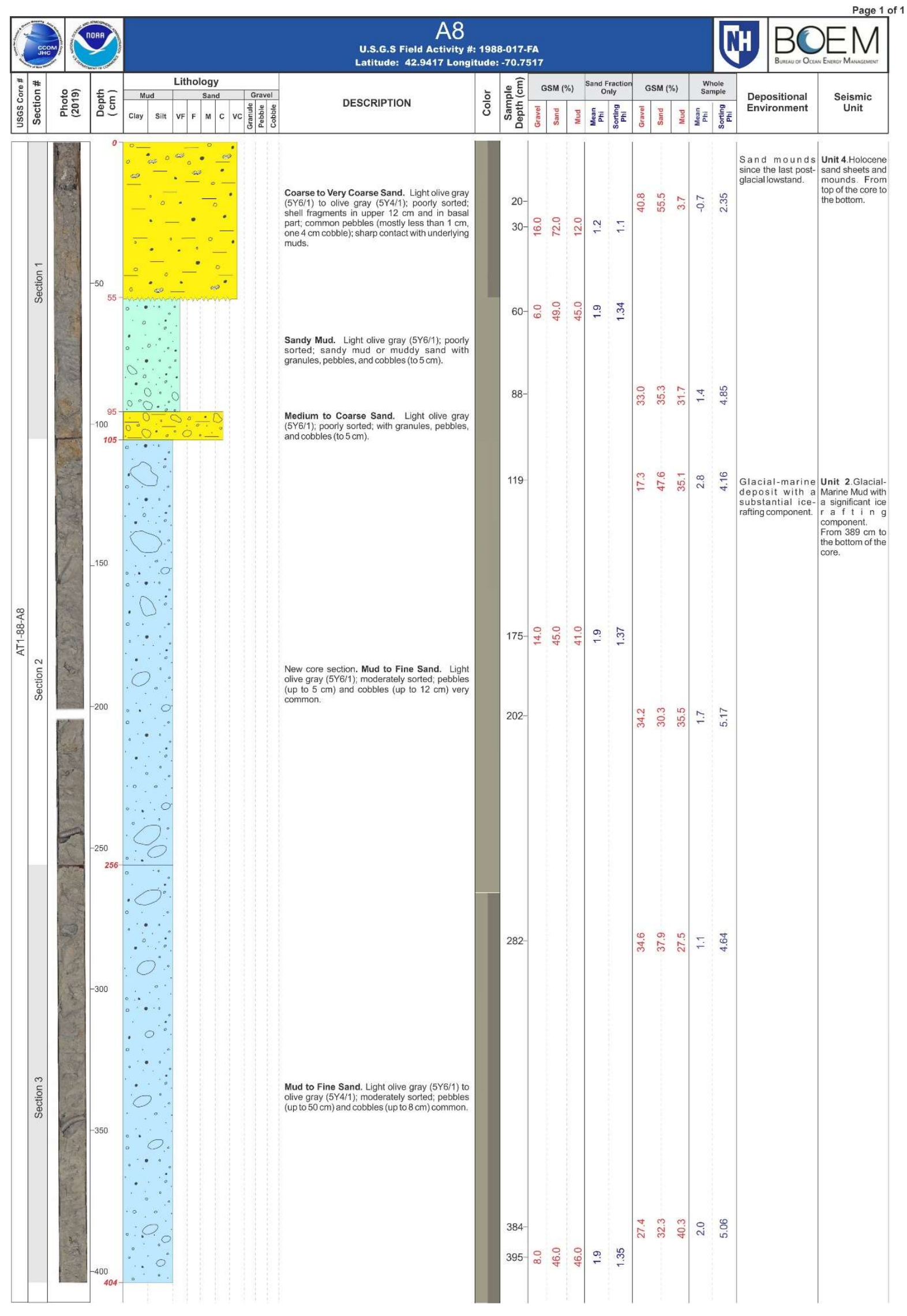




\section{Appendix B: Complete Grain Size Data for Vibracore Sediment Samples}

Each vibracore collected on the New Hampshire continental shelf in 1984 and 1988 was subsampled in 2016 and 2019 during this study. In total, 162 sediment samples were taken from the archived cores and grain size analysis conducted. This appendix provides complete descriptions for each sample including identification (UNH and BOEM numbering), core characteristics, sample characteristics, sediment classifications, grain size statistics, and grain size distribution. The methods used for extracting the samples and grain size analyses are given in this report in the Methods section. The sediment grain size classifications used here include: CMECS (Coastal and Marine Ecological Classification Standard; FGDC, 2012); Gradistat (Blot and Pye, 2001); and Wentworth (Wentworth, 1922; described in Folk, 1954, 1980). Statistics are based on the phi scale and include the graphic mean, sorting, skewness, and kurtosis (Folk, 1980). Grain size data for the vibracores are grouped with the results for two to four vibracores presented in each section. This was done to simplify the appendix. Data for each sample is spread across four pages, with each sample identified in the first column by the University of New Hampshire label. The results of the grain size analyses for the vibracores collected in 1984 (UNH series) are presented in Sections 1 through 4 and the results for the vibracores collected in 1988 (A series) are in Sections 5 through 8.

The vibracore sediment data can also be downloaded at Ward et al. (2021c): https://dx.doi.org/10.34051/d/2021.4). 
Section 1: Vibracores UNH-1, UNH-2, and UNH-3 


\section{Vibracores UNH-1, UNH-2, and UNH-3: Identification, Location, and Description}

\begin{tabular}{|c|c|c|c|c|c|c|c|c|c|c|c|c|c|c|}
\hline UNH Sample ID & $\begin{array}{c}\text { Global Core } \\
\text { Link ID } \\
\end{array}$ & BOEM Global Sample ID & $\begin{array}{c}\text { Latitude } \\
\text { NAD83 } \\
\end{array}$ & $\begin{array}{c}\text { Longitude } \\
\text { NAD83 } \\
\end{array}$ & $\begin{array}{c}\text { Position } \\
\text { Uncertainty }\end{array}$ & $\begin{array}{c}\begin{array}{c}\text { Water } \\
\text { Depth }(\mathrm{m})\end{array} \\
\end{array}$ & $\begin{array}{c}\text { Diameter } \\
(\mathrm{cm})\end{array}$ & $\begin{array}{c}\text { Core Length } \\
\text { (m) }\end{array}$ & $\begin{array}{l}\text { Vibracore } \\
\text { Collected } \\
\end{array}$ & $\begin{array}{c}\text { Sample } \\
\text { Depth } \\
(\mathrm{cm}) \\
\end{array}$ & $\begin{array}{c}\text { Total Wt } \\
\text { (gm) }\end{array}$ & $\begin{array}{c}\text { Munsell } \\
\text { Hue }\end{array}$ & $\begin{array}{c}\text { Munsell } \\
\text { Value }\end{array}$ & $\begin{array}{l}\text { Munsell } \\
\text { Chroma }\end{array}$ \\
\hline UNH-1_0-1cm & ATTW84-UNH-1 & ATTW84-UNH-1_0-1cm_D19841011 & 42.9717 & -70.4567 & $250 \mathrm{~m}$ & 57.0 & 8.9 & 3.42 & $10 / 11 / 1984$ & $0-1$ & 49.53 & $5 \mathrm{Y}$ & 5 & 2 \\
\hline UNH-1 $8-10 \mathrm{~cm}$ & ATTW84-UNH-1 & ATTW84-UNH-1_8-10cm_D19841011 & 42.9717 & -70.4567 & $250 \mathrm{~m}$ & 57.0 & 8.9 & 3.42 & $10 / 11 / 1984$ & $8-10$ & 77.79 & $5 \mathrm{GY}$ & 6 & 1 \\
\hline UNH-1_88-90cm & ATTW84-UNH-1 & ATTW84-UNH-1_88-90cm_D19841011 & 42.9717 & -70.4567 & $250 \mathrm{~m}$ & 57.0 & 8.9 & 3.42 & $10 / 11 / 1984$ & $88-90$ & 19.42 & $5 \mathrm{GY}$ & 3 & 2 \\
\hline UNH-1_141-143cm & ATTW84-UNH-1 & ATTW84-UNH-1_141-143cm_D19841011 & 42.9717 & -70.4567 & $250 \mathrm{~m}$ & 57.0 & 8.9 & 3.42 & $10 / 11 / 1984$ & $141-143$ & 41.51 & $5 \mathrm{GY}$ & 3 & 2 \\
\hline UNH-1_156-158cm & ATTW84-UNH-1 & ATTW84-UNH-1_156-158cm_D19841011 & 42.9717 & -70.4567 & $250 \mathrm{~m}$ & 57.0 & 8.9 & 3.42 & $10 / 11 / 1984$ & $156-158$ & 43.77 & $5 \mathrm{GY}$ & 3 & 2 \\
\hline UNH-1_178-180cm & ATTW84-UNH-1 & ATTW84-UNH-1_178-180cm_D19841011 & 42.9717 & -70.4567 & $250 \mathrm{~m}$ & 57.0 & 8.9 & 3.42 & $10 / 11 / 1984$ & $178-180$ & 36.30 & $5 \mathrm{GY}$ & 3 & 2 \\
\hline UNH-1_292-294cm & ATTW84-UNH-1 & ATTW84-UNH-1_292-294cm_D19841011 & 42.9717 & -70.4567 & $250 \mathrm{~m}$ & 57.0 & 8.9 & 3.42 & $10 / 11 / 1984$ & 292-294 & 3.36 & $5 \mathrm{GY}$ & 3 & 2 \\
\hline UNH-2 $-33-35 \mathrm{~cm}$ & ATTW84-UNH-2 & ATTW84-UNH-2_33-35cm_D19841011 & 42.9067 & -70.4433 & $250 \mathrm{~m}$ & 76.0 & 8.9 & 1.56 & 10/11/1984 & 33-35 & 59.12 & $5 G Y$ & 5 & 2 \\
\hline UNH-2_143-145cm & ATTW84-UNH-2 & ATTW84-UNH-2_143-145cm_D19841011 & 42.9067 & -70.4433 & $250 \mathrm{~m}$ & 76.0 & 8.9 & 1.56 & $10 / 11 / 1984$ & $143-145$ & 52.04 & $10 Y$ & 4 & 2 \\
\hline UNH $-3,23-25 \mathrm{~cm}$ & ATTW84-UNH-3 & ATTW84-UNH-3_23-25cm_D19841011 & 42.8850 & -70.5083 & $250 \mathrm{~m}$ & 57.0 & 8.9 & 7.09 & 10/11/1984 & $23-25$ & 51.95 & $10 \mathrm{Y}$ & 5 & 4 \\
\hline UNH-3_-71-73cm & ATTW84-UNH-3 & ATTW84-UNH-3_71-73cm_D19841011 & 42.8850 & -70.5083 & $250 \mathrm{~m}$ & 57.0 & 8.9 & 7.09 & $10 / 11 / 1984$ & 71-73 & 40.52 & $10 \mathrm{Y}$ & 5 & 4 \\
\hline UNH-3 $135-137 \mathrm{~cm}$ & ATTW84-UNH-3 & ATTW84-UNH-3 $135-137 \mathrm{~cm}$ DD19841011 & 42.8850 & -70.5083 & $250 \mathrm{~m}$ & 57.0 & 8.9 & 7.09 & 10/11/1984 & $135-137$ & 50.58 & $10 \mathrm{Y}$ & 5 & 4 \\
\hline UNH-3 $225-227 \mathrm{~cm}$ & ATTW84-UNH-3 & ATTW84-UNH-3_225-227cm_D19841011 & 42.8850 & -70.5083 & $250 \mathrm{~m}$ & 57.0 & 8.9 & 7.09 & $10 / 11 / 1984$ & $225-227$ & 52.42 & $10 \mathrm{Y}$ & 5 & 4 \\
\hline UNH-3_278-281cm & ATTW84-UNH-3 & ATTW84-UNH-3_278-281cm_D19841011 & 42.8850 & -70.5083 & $250 \mathrm{~m}$ & 57.0 & 8.9 & 7.09 & $10 / 11 / 1984$ & 278-281 & 52.87 & $10 \mathrm{Y}$ & 5 & 4 \\
\hline UNH-3 $324-326 \mathrm{~cm}$ & ATTW84-UNH-3 & ATTW84-UNH-3_324-326cm_D19841011 & 42.8850 & -70.5083 & $250 \mathrm{~m}$ & 57.0 & 8.9 & 7.09 & $10 / 11 / 1984$ & $324-326$ & 34.46 & $10 \mathrm{Y}$ & 5 & 4 \\
\hline UNH-3 $384-386 \mathrm{~cm}$ & ATTW84-UNH-3 & ATTW84-UNH-3_384-386cm_D19841011 & 42.8850 & -70.5083 & $250 \mathrm{~m}$ & 57.0 & 8.9 & 7.09 & $10 / 11 / 1984$ & $384-386$ & 40.49 & $10 \mathrm{Y}$ & 5 & 4 \\
\hline UNH-3 $3428-430 \mathrm{~cm}$ & ATTW84-UNH-3 & ATTW84-UNH-3 $428-430 \mathrm{~cm}$ D19841011 & 42.8850 & -70.5083 & $250 \mathrm{~m}$ & 57.0 & 8.9 & 7.09 & $10 / 11 / 1984$ & $428-430$ & 50.60 & $10 \mathrm{Y}$ & 5 & 4 \\
\hline UNH-3 $3478-480 \mathrm{~cm}$ & ATTW84-UNH-3 & ATTW84-UNH-3 $478-480 \mathrm{~cm}$ D19841011 & 42.8850 & -70.5083 & $250 \mathrm{~m}$ & 57.0 & 8.9 & 7.09 & $10 / 11 / 1984$ & $478-480$ & 44.65 & $5 Y$ & 5 & 2 \\
\hline UNH-3_538-540cm & ATTW84-UNH-3 & ATTW84-UNH-3_538-540cm_D19841011 & 42.8850 & -70.5083 & $250 \mathrm{~m}$ & 57.0 & 8.9 & 7.09 & $10 / 11 / 1984$ & $538-540$ & 37.35 & $5 Y$ & 3 & 2 \\
\hline UNH-3 $592-594 \mathrm{~cm}$ & ATTW84-UNH-3 & ATTW84-UNH-3 592-594cm_D19841011 & 42.8850 & -70.5083 & $250 \mathrm{~m}$ & 57.0 & 8.9 & 7.09 & $10 / 11 / 1984$ & 592-594 & 81.13 & $5 Y$ & 5 & 2 \\
\hline UNH-3_664-666cm & ATTW84-UNH-3 & ATTW84-UNH-3_664-666cm_D19841011 & 42.8850 & -70.5083 & $250 \mathrm{~m}$ & 57.0 & 8.9 & 7.09 & $10 / 11 / 1984$ & $664-666$ & 31.22 & $5 Y$ & 5 & 6 \\
\hline
\end{tabular}




\section{Vibracores UNH-1, UNH-2, and UNH-3: Sediment Classifications}

\begin{tabular}{|c|c|c|c|c|c|c|c|c|c|}
\hline UNH Sample ID & $\begin{array}{l}\text { CMECS Substrate } \\
\text { Component Group } \\
\text { (Specific) }\end{array}$ & $\begin{array}{l}\text { CMECS Substrate } \\
\text { Component Subgroup } \\
\text { (Specific) }\end{array}$ & $\begin{array}{l}\text { Textural Group from } \\
\% \text { GSM (Gradistat) }\end{array}$ & $\begin{array}{l}\text { Textural Group } \\
\text { from } \% \text { SZC } \\
\text { (Gradistat) } \\
\text { Ignores Gravel }\end{array}$ & $\begin{array}{l}\text { Sediment Name from \%GSM } \\
\text { and Mode (Gradistat) }\end{array}$ & $\begin{array}{l}\text { Sediment Name from \%GSM } \\
\text { and Mode (Wentworth Scale) }\end{array}$ & $\begin{array}{l}\text { Sediment } \\
\text { Classification } \\
\text { from Mean Phi } \\
\text { (Gradistat) }\end{array}$ & $\begin{array}{l}\text { Sediment } \\
\text { Classification } \\
\text { from Mean Phi } \\
\text { (Wentworth) }\end{array}$ & Sorting (Gradistat) \\
\hline UNH-1_0-1cm & Slightly Granuley & $\begin{array}{l}\text { Slightly Granuley Silty- } \\
\text { Clayey Medium Sand }\end{array}$ & $\begin{array}{l}\text { Slightly Gravelly } \\
\text { Muddy Sand }\end{array}$ & Muddy Sand & $\begin{array}{l}\text { Slightly Very Fine Gravelly Muddy } \\
\text { Medium Sand }\end{array}$ & $\begin{array}{l}\text { Slightly Granular Muddy } \\
\text { Medium Sand }\end{array}$ & Medium Sand & Medium Sand & Very Poorly Sorted \\
\hline UNH-1_8-10cm & Slightly Granuley & $\begin{array}{l}\text { Slightly Granuley Silty- } \\
\text { Clayey Fine Sand }\end{array}$ & $\begin{array}{l}\text { Slightly Gravelly } \\
\text { Muddy Sand }\end{array}$ & Muddy Sand & $\begin{array}{l}\text { Slightly Very Fine Gravelly Muddy } \\
\text { Fine Sand }\end{array}$ & $\begin{array}{l}\text { Slightly Granular Muddy Fine } \\
\text { Sand }\end{array}$ & Very Coarse Silt & Very Coarse Silt & Very Poorly Sorted \\
\hline UNH-1_88-90 cm & Slightly Granuley & $\begin{array}{l}\text { Slightly Granuley Silty- } \\
\text { Clayey Fine Sand }\end{array}$ & $\begin{array}{l}\text { Slightly Gravelly } \\
\text { Muddy Sand }\end{array}$ & Muddy Sand & $\begin{array}{l}\text { Slightly Very Fine Gravelly Muddy } \\
\text { Fine Sand }\end{array}$ & $\begin{array}{l}\text { Slightly Granular Muddy Fine } \\
\text { Sand }\end{array}$ & Coarse Silt & Coarse Silt & Very Poorly Sorted \\
\hline UNH-1_141-143cm & Slightly Granuley & $\begin{array}{l}\text { Slightly Granuley Very Fine } \\
\text { Sandy Silt-Clay }\end{array}$ & $\begin{array}{l}\text { Slightly Gravelly } \\
\text { Sandy Mud }\end{array}$ & Sandy Mud & $\begin{array}{l}\text { Slightly Very Fine Gravelly Very } \\
\text { Fine Sandy Mud }\end{array}$ & $\begin{array}{l}\text { Slightly Granular Very Fine } \\
\text { Sandy Mud }\end{array}$ & Coarse Silt & Coarse Silt & $\begin{array}{l}\text { Extremely Poorly } \\
\text { Sorted }\end{array}$ \\
\hline UNH-1_156-158cm & Slightly Granuley & $\begin{array}{l}\text { Slightly Granuley Very Fine } \\
\text { Sandy Silt-Clay }\end{array}$ & $\begin{array}{l}\text { Slightly Gravelly } \\
\text { Sandy Mud }\end{array}$ & Sandy Mud & $\begin{array}{l}\text { Slightly Very Fine Gravelly Very } \\
\text { Fine Sandy Mud }\end{array}$ & $\begin{array}{l}\text { Slightly Granular Very Fine } \\
\text { Sandy Mud }\end{array}$ & Fine Silt & Fine Silt & Very Poorly Sorted \\
\hline UNH-1_178-180cm & Slightly Granuley & $\begin{array}{l}\text { Slightly Granuley Very Fine } \\
\text { Sandy Silt-Clay }\end{array}$ & $\begin{array}{l}\text { Slightly Gravelly } \\
\text { Sandy Mud }\end{array}$ & Sandy Mud & $\begin{array}{l}\text { Slightly Very Fine Gravelly Very } \\
\text { Fine Sandy Mud }\end{array}$ & $\begin{array}{l}\text { Slightly Granular Very Fine } \\
\text { Sandy Mud }\end{array}$ & Fine Silt & Fine Silt & Very Poorly Sorted \\
\hline UNH-1_292-294cm & Slightly Granuley & $\begin{array}{l}\text { Slightly Granuley Very Fine } \\
\text { Sandy Silt-Clay } \\
\end{array}$ & $\begin{array}{l}\text { Slightly Gravelly } \\
\text { Sandy Mud }\end{array}$ & Sandy Mud & $\begin{array}{l}\text { Slightly Very Fine Gravelly Very } \\
\text { Fine Sandy Mud }\end{array}$ & $\begin{array}{l}\text { Slightly Granular Very Fine } \\
\text { Sandy Mud }\end{array}$ & Fine Silt & Fine Silt & Very Poorly Sorted \\
\hline UNH-2 $33-35 \mathrm{~cm}$ & Granuley & Granu & Grav & andy Silt & Very Fine Gravelly Coarse Silt & $\mathrm{G}$ & ilt & Very & $\begin{array}{l}\text { Extremely Poorly } \\
\text { Sorted }\end{array}$ \\
\hline UNH-2_143-145cm & Slightly Granuley & $\begin{array}{l}\text { Slightly Granuley Silty Very } \\
\text { Fine Sand }\end{array}$ & $\begin{array}{l}\text { Slightly Gravelly } \\
\text { Muddy Sand } \\
\end{array}$ & Silty Sand & $\begin{array}{l}\text { Slightly Very Fine Gravelly Very } \\
\text { Coarse Silty Very Fine Sand }\end{array}$ & $\begin{array}{l}\text { Slightly Granular Very Coarse } \\
\text { Silty Very Fine Sand }\end{array}$ & Very Fine Sand & Very & Very Poorly Sorted \\
\hline UNH-3 $23-25 \mathrm{~cm}$ & Slightly Granuley & $\begin{array}{l}\text { Slightly Granuley Medium } \\
\text { Sand }\end{array}$ & Slightly Gravelly & Sand & $\begin{array}{l}\text { Slightly Very Fine Gravelly } \\
\text { Medium Sand }\end{array}$ & $\begin{array}{l}\text { Slightly Granular Medium } \\
\text { Sand }\end{array}$ & Medium Sand & Medium Sand & Poorly Sorted \\
\hline UNH-3_-71-73cm & Slightly Granuley & $\begin{array}{l}\text { Slightly Granuley Medium } \\
\text { Sand }\end{array}$ & Slightly Gravelly Sand & Sand & $\begin{array}{l}\text { Slightly Very Fine Gravelly } \\
\text { Medium Sand }\end{array}$ & $\begin{array}{l}\text { Slightly Granular Medium } \\
\text { Sand }\end{array}$ & Medium Sand & Medium Sand & Poorly Sorted \\
\hline UNH-3_135-137cm & Slightly Granuley & $\begin{array}{l}\text { Slightly Granuley Medium } \\
\text { Sand }\end{array}$ & Slightly Gravelly Sand & Sand & $\begin{array}{l}\text { Slightly Very Fine Gravelly } \\
\text { Medium Sand }\end{array}$ & $\begin{array}{l}\text { Slightly Granular Medium } \\
\text { Sand }\end{array}$ & Medium Sand & Medium Sand & Moderately Sorted \\
\hline $\mathrm{JNH}-3 \quad 225-227 \mathrm{~cm}$ & Granuley & Granuley Coarse Sand & Gravelly Sand & Sand & Very Fine Gravelly Coarse Sand & Granular Coarse Sand & Coarse Sand & Coarse Sand & Poorly Sorted \\
\hline UNH-3_278-281cm & Pebbly & Pebbly Medium Sand & Gravelly Sand & Sand & Medium Gravelly Medium Sand & Pebbly Medium Sand & Medium Sand & Medium Sand & Poorly Sorted \\
\hline UNH-3 $324-326 \mathrm{~cm}$ & Sand & Fine Sand & Sand & Sand & Moderately Well Sorted Fine Sand & Fine Sand & Fine Sand & Fine Sand & $\begin{array}{l}\text { Moderately Well } \\
\text { Sorted }\end{array}$ \\
\hline UNH-3 $384-386 \mathrm{~cm}$ & Granuley & $\mathrm{Gra}$ & Gravelly Sand & Sand & and & Granular Coar & Sand & e Sand & Poorly Sorted \\
\hline UNH-3_428-430cm & Slightly Pebbly & $\begin{array}{l}\text { Slightly Pebbly Medium } \\
\text { Sand }\end{array}$ & Slightly Gravelly Sand & Sand & $\begin{array}{l}\text { Slightly Fine Gravelly Medium } \\
\text { Sand }\end{array}$ & Slightly Pebbly Medium Sand & Medium Sand & Medium Sand & Moderately Sorted \\
\hline UNH-3 $3478-480 \mathrm{~cm}$ & Slightly Pe & $\begin{array}{l}\text { Slightly Pebbly Silty Fine } \\
\text { Sand }\end{array}$ & $\begin{array}{l}\text { Slightly Gravelly } \\
\text { Muddy Sand }\end{array}$ & Silty Sand & $\begin{array}{l}\text { Slightly Medium Gravelly Very } \\
\text { Coarse Silty Fine Sand }\end{array}$ & $\begin{array}{l}\text { Slightly Pebbly Very Coarse } \\
\text { Silty Fine Sand }\end{array}$ & Fine Sand & Fine Sand & Poorly Sorted \\
\hline UNH-3 $538-540 \mathrm{~cm}$ & Slightly Gr & $\begin{array}{l}\text { Slightly Granuley Very Fine } \\
\text { Sandy Silt }\end{array}$ & $\begin{array}{l}\text { Slightly Gravelly } \\
\text { Sandy Mud }\end{array}$ & Sandy Silt & $\begin{array}{l}\text { Slightly Very Fine Gravelly Very } \\
\text { Fine Sandy Very Coarse Silt }\end{array}$ & $\begin{array}{l}\text { Slightly Granular Very Fine } \\
\text { Sandy Very Coarse Silt }\end{array}$ & Very Coarse Silt & Very Coarse Silt & Moderately Sorted \\
\hline UNH-3 $392-594 \mathrm{~cm}$ & Slightly Gra & $\begin{array}{l}\text { Slightly Granuley Very Fine } \\
\text { Sandy Silt }\end{array}$ & $\begin{array}{l}\text { Slightly Gravelly } \\
\text { Sandy Mud }\end{array}$ & Sandy Silt & $\begin{array}{l}\text { Slightly Very Fine Gravelly Very } \\
\text { Fine Sandy Very Coarse Silt }\end{array}$ & $\begin{array}{l}\text { Slightly Granular Very Fine } \\
\text { Sandy Very Coarse Silt }\end{array}$ & Coarse Silt & Coarse Silt & Very Poorly Sorted \\
\hline UNH-3_664-666cm & & Very Fine Sandy Silt & Sandy Mud & & Very Fine Sandy Very Coarse Silt & $\begin{array}{l}\text { Very Fine Sandy Very Coarse } \\
\text { Silt }\end{array}$ & Coarse Silt & & \\
\hline
\end{tabular}




\section{Vibracores UNH-1, UNH-2, and UNH-3: Grain Size Statistics}

\begin{tabular}{|c|c|c|c|c|c|c|c|c|c|c|c|c|c|c|c|c|c|c|c|c|}
\hline UNH Sample ID & Gravel \% & Pebble \% & Granule \% & Sand $\%$ & Mud \% & Silt \% & Clay $\%$ & Modes & $\begin{array}{c}\text { Mode } 1 \\
\text { (phi) }\end{array}$ & $\begin{array}{c}\text { Mode } 2 \\
\text { (phi) }\end{array}$ & $\begin{array}{c}\text { Mode } 3 \\
\text { (phi) }\end{array}$ & $\begin{array}{c}D_{10} \\
\text { (phi) }\end{array}$ & $\begin{array}{c}D_{10} \\
(\mathrm{~mm})\end{array}$ & $\begin{array}{c}D_{50} \\
\text { (phi) }\end{array}$ & $\begin{array}{c}D_{50} \\
(\mathrm{~mm})\end{array}$ & $\begin{array}{c}\text { Mean } \\
\text { Size } \\
\text { (phi) }\end{array}$ & $\begin{array}{c}\text { Mean } \\
\text { Size } \\
(\mathrm{mm})\end{array}$ & $\begin{array}{c}\text { Sorting } \\
\text { (phi) }\end{array}$ & Skewness & Kurtosis \\
\hline UNH-1_0-1cm & 3.65 & 1.56 & 2.09 & 83.67 & 12.68 & 6.67 & 6.01 & $u$ & 1.75 & NA & NA & -0.17 & 1.12 & 1.87 & 0.27 & 1.90 & 0.27 & 2.25 & 0.24 & 1.99 \\
\hline UNH-1_8-10cm & 1.81 & 0.32 & 1.49 & 53.71 & 44.48 & 21.96 & 22.52 & $u$ & 2.74 & NA & NA & 1.07 & 0.48 & 3.57 & 0.08 & 4.98 & 0.03 & 3.94 & 0.49 & 0.97 \\
\hline UNH-1_88-90cm & 1.15 & 0.00 & 1.15 & 50.54 & 48.31 & 24.23 & 24.08 & $u$ & 2.74 & NA & NA & 1.43 & 0.37 & 3.87 & 0.07 & 5.24 & 0.03 & 3.85 & 0.49 & 0.92 \\
\hline UNH-1 $141-143 \mathrm{~cm}$ & 0.74 & 0.00 & 0.74 & 40.83 & 58.43 & 27.22 & 31.21 & $u$ & 3.24 & NA & NA & 1.49 & 0.36 & 4.79 & 0.04 & 5.92 & 0.02 & 4.10 & 0.36 & 0.79 \\
\hline UNH-1 $156-158 \mathrm{~cm}$ & 0.97 & 0.68 & 0.30 & 27.02 & 72.01 & 33.04 & 38.97 & $u$ & 3.73 & NA & NA & 2.45 & 0.18 & 6.31 & 0.01 & 7.01 & 0.01 & 3.91 & 0.22 & 0.74 \\
\hline UNH-1_178-180cm & 0.80 & 0.00 & 0.80 & 18.42 & 80.78 & 36.39 & 44.39 & $u$ & 4.50 & NA & NA & 3.00 & 0.12 & 7.27 & 0.01 & 7.63 & 0.01 & 3.82 & 0.09 & 0.76 \\
\hline UNH-1_292-294cm & 0.48 & 0.00 & 0.48 & 25.47 & 74.05 & 33.67 & 40.38 & $u$ & 3.73 & $\mathrm{NA}$ & $\mathrm{NA}$ & 2.53 & 0.17 & 6.53 & 0.01 & 7.07 & 0.01 & 3.83 & 0.18 & 0.78 \\
\hline UNH-2_33-35cm & 5.83 & 2.77 & 3.06 & 44.93 & 49.24 & 29.09 & 20.15 & $\mathrm{~B}$ & 2.74 & 5.51 & NA & 0.10 & 0.93 & 3.92 & 0.07 & 4.62 & 0.04 & 4.05 & 0.25 & 1.09 \\
\hline UNH-2_143-145cm & 4.33 & 1.78 & 2.55 & 48.57 & 47.10 & 39.10 & 8.00 & $u$ & 4.50 & NA & NA & 0.33 & 0.80 & 3.81 & 0.07 & 3.80 & 0.07 & 2.87 & 0.05 & 1.24 \\
\hline UNH-3 $23-25 \mathrm{~cm}$ & 2.32 & 0.39 & 1.93 & 96.22 & 1.46 & NA & NA & $u$ & 1.75 & NA & NA & 0.08 & 0.95 & 1.56 & 0.34 & 1.48 & 0.36 & 1.06 & -0.10 & 1.03 \\
\hline UNH-3_71-73cm & 2.60 & 0.66 & 1.94 & 96.89 & 0.51 & NA & NA & $u$ & 1.75 & NA & NA & -0.20 & 1.15 & 1.39 & 0.38 & 1.27 & 0.42 & 1.04 & -0.18 & 1.10 \\
\hline UNH-3 $135-137 \mathrm{~cm}$ & 3.62 & 0.30 & 3.32 & 96.29 & 0.09 & NA & NA & $u$ & 1.75 & NA & NA & -0.29 & 1.22 & 1.30 & 0.41 & 1.16 & 0.45 & 0.98 & -0.25 & 1.09 \\
\hline UNH-3_225-227cm & 11.97 & 5.80 & 6.18 & 85.47 & 2.56 & NA & NA & $u$ & 0.75 & NA & NA & -1.28 & 2.43 & 0.70 & 0.61 & 0.65 & 0.64 & 1.50 & -0.06 & 1.21 \\
\hline UNH-3_278-281cm & 5.30 & 4.03 & 1.27 & 93.57 & 1.13 & NA & NA & $u$ & 1.75 & NA & NA & 0.13 & 0.91 & 1.86 & 0.28 & 1.73 & 0.30 & 1.13 & -0.30 & 1.58 \\
\hline UNH-3_324-326cm & 0.00 & 0.00 & 0.00 & 98.19 & 1.81 & NA & NA & $u$ & 2.74 & NA & NA & 1.96 & 0.26 & 2.57 & 0.17 & 2.57 & 0.17 & 0.54 & 0.05 & 1.11 \\
\hline UNH-3 $384-386 \mathrm{~cm}$ & 20.87 & 11.46 & 9.41 & 79.13 & 0.00 & NA & NA & B & 0.75 & -3.24 & NA & -2.24 & 4.73 & 0.50 & 0.70 & 0.18 & 0.89 & 1.56 & -0.35 & 1.10 \\
\hline UNH-3 $\quad 428-430 \mathrm{~cm}$ & 2.96 & 1.83 & 1.13 & 96.64 & 0.40 & NA & NA & $u$ & 1.25 & NA & NA & 0.02 & 0.99 & 1.25 & 0.42 & 1.18 & 0.44 & 0.89 & -0.11 & 1.21 \\
\hline UNH-3_478-480cm & 3.95 & 3.67 & 0.28 & 85.78 & 10.27 & 10.25 & 0.02 & $B$ & 2.24 & -3.24 & NA & 1.23 & 0.43 & 2.53 & 0.17 & 2.59 & 0.17 & 1.18 & 0.01 & 1.45 \\
\hline UNH-3_538-540cm & 0.20 & 0.00 & 0.20 & 37.72 & 62.08 & 61.21 & 0.87 & $u$ & 4.50 & NA & NA & 2.86 & 0.14 & 4.22 & 0.05 & 4.11 & 0.06 & 0.90 & -0.16 & 1.20 \\
\hline UNH-3_592-594cm & 0.02 & 0.00 & 0.02 & 42.31 & 57.67 & 42.51 & 15.16 & $u$ & 3.73 & NA & NA & 2.84 & 0.14 & 4.29 & 0.05 & 5.05 & 0.03 & 2.58 & 0.56 & 1.71 \\
\hline UNH-3_664-666cm & 0.00 & 0.00 & 0.00 & 17.97 & 82.03 & 68.14 & 13.89 & $\mathrm{u}$ & 4.50 & NA & NA & 3.68 & 0.08 & 4.62 & 0.04 & 5.30 & 0.03 & 2.11 & 0.66 & 2.32 \\
\hline
\end{tabular}




\section{Vibracores UNH-1, UNH-2, and UNH-3: Grain Size Distribution}

\begin{tabular}{|c|c|c|c|c|c|c|c|c|c|c|c|c|c|c|c|c|c|c|c|c|c|c|c|c|}
\hline UNH Sample ID & $\begin{array}{c}\text { Class \% } \\
\text { phi } \\
-3.5\end{array}$ & $\begin{array}{c}\text { Class \% } \\
\text { phi } \\
-3.0\end{array}$ & $\begin{array}{c}\text { Class \% } \\
\text { phi } \\
-2.5\end{array}$ & $\begin{array}{c}\text { Class \% } \\
\text { phi } \\
-2.0\end{array}$ & $\begin{array}{c}\text { Class \% } \\
\text { phi } \\
-1.5\end{array}$ & $\begin{array}{c}\text { Class \% } \\
\text { phi } \\
-1.0\end{array}$ & $\begin{array}{c}\text { Class \% } \\
\text { phi } \\
-0.5\end{array}$ & $\begin{array}{c}\text { Class \% } \\
\text { phi } \\
0.0\end{array}$ & $\begin{array}{c}\text { Class \% } \\
\text { phi } \\
0.5\end{array}$ & $\begin{array}{c}\text { Class \% } \\
\text { phi } \\
1.0\end{array}$ & $\begin{array}{c}\text { Class \% } \\
\text { phi } \\
1.5\end{array}$ & $\begin{array}{c}\text { Class \% } \\
\text { phi } \\
2.0\end{array}$ & $\begin{array}{c}\text { Class \% } \\
\text { phi } \\
2.5\end{array}$ & $\begin{array}{c}\text { Class \% } \\
\text { phi } \\
3.0\end{array}$ & $\begin{array}{c}\text { Class \% } \\
\text { phi } \\
3.5\end{array}$ & $\begin{array}{c}\text { Class \% } \\
\text { phi } \\
4.0\end{array}$ & $\begin{array}{c}\text { Class \% } \\
\text { phi } \\
>4.0\end{array}$ & $\begin{array}{c}\text { Class \% } \\
\text { phi } \\
5.0\end{array}$ & $\begin{array}{c}\text { Class \% } \\
\text { phi } \\
6.0\end{array}$ & $\begin{array}{c}\text { Class \% } \\
\text { phi } \\
7.0\end{array}$ & $\begin{array}{c}\text { Class \% } \\
\text { phi } \\
8.0\end{array}$ & $\begin{array}{c}\text { Class \% } \\
\text { phi } \\
9.0\end{array}$ & $\begin{array}{c}\text { Class } \% \\
\text { phi } \\
10.0\end{array}$ & $\begin{array}{c}\text { Class \% } \\
\text { phi } \\
>10.0\end{array}$ \\
\hline UNH-1_0-1cm & 0.00 & 0.00 & 0.73 & 0.83 & 0.64 & 1.45 & 3.35 & 4.54 & 6.50 & 8.47 & 12.07 & 15.22 & 11.59 & 11.84 & 6.65 & 3.44 & NA & 2.67 & 1.53 & 1.29 & 1.17 & 1.14 & 1.10 & 3.77 \\
\hline UNH-1_8-10cm & 0.00 & 0.00 & 0.00 & 0.32 & 0.82 & 0.67 & 1.00 & 1.19 & 1.93 & 3.29 & 5.52 & 8.29 & 7.93 & 9.77 & 7.96 & 6.82 & NA & 9.55 & 4.43 & 4.06 & 3.93 & 3.77 & 3.41 & 15.34 \\
\hline UNH-1_88-90 $80 \mathrm{~cm}$ & 0.00 & 0.00 & 0.00 & 0.00 & 0.24 & 0.91 & 0.45 & 0.69 & 1.33 & 2.39 & 4.61 & 7.77 & 7.65 & 9.86 & 8.43 & 7.37 & NA & 9.61 & 5.59 & 4.94 & 4.09 & 4.22 & 3.86 & 15.99 \\
\hline UNH-1_141-143cm & 0.00 & 0.00 & 0.00 & 0.00 & 0.12 & 0.62 & 0.70 & 0.84 & 1.44 & 2.34 & 3.95 & 5.84 & 5.05 & 6.60 & 6.90 & 7.18 & $\mathrm{NA}$ & 10.76 & 5.78 & 5.68 & 5.00 & 5.13 & 5.05 & 21.03 \\
\hline UNH-1_156-158cm & 0.00 & 0.00 & 0.68 & 0.00 & 0.10 & 0.20 & 0.19 & 0.32 & 0.57 & 0.95 & 1.61 & 2.76 & 2.77 & 4.72 & 6.08 & 7.06 & NA & 12.28 & 7.71 & 6.55 & 6.50 & 6.60 & 5.63 & 26.73 \\
\hline UNH-1_178-180cm & 0.00 & 0.00 & 0.00 & 0.00 & 0.74 & 0.06 & 0.32 & 0.28 & 0.49 & 0.78 & 1.30 & 1.86 & 1.56 & 2.58 & 3.72 & 5.51 & NA & 12.51 & 8.03 & 8.15 & 7.70 & 7.23 & 6.63 & 30.54 \\
\hline UNH-1_292-294cm & 0.00 & 0.00 & 0.00 & 0.00 & 0.00 & 0.48 & 0.16 & 0.77 & 0.50 & 0.88 & 1.55 & 2.49 & 2.70 & 4.24 & 5.16 & 7.04 & NA & 12.22 & 8.19 & 6.85 & 6.41 & 7.45 & 7.60 & 25.33 \\
\hline UNH-2_33-35cm & 0.00 & 0.00 & 0.89 & 1.87 & 1.74 & 1.31 & 1.59 & 2.02 & 2.71 & 3.63 & 4.49 & 5.95 & 5.80 & 7.40 & 5.95 & 5.39 & NA & 8.18 & 8.36 & 7.47 & 5.07 & 4.42 & 3.12 & 12.60 \\
\hline UNH-2_143-145cm & 0.00 & 0.00 & 0.94 & 0.84 & 0.97 & 1.58 & 1.84 & 1.98 & 2.80 & 3.55 & 4.42 & 5.58 & 5.43 & 7.47 & 7.34 & 8.15 & NA & 16.93 & 11.36 & 6.84 & 3.97 & 2.27 & 1.44 & 4.30 \\
\hline UNH-3 $23-25 \mathrm{~cm}$ & 0.00 & 0.00 & 0.00 & 0.39 & 0.78 & 1.14 & 1.74 & 4.45 & 9.04 & 13.51 & 16.32 & 21.41 & 15.08 & 9.78 & 3.49 & 1.39 & 1.46 & NA & NA & NA & NA & NA & NA & $\mathrm{NA}$ \\
\hline UNH-3.71-73cm & 0.00 & 0.00 & 0.00 & 0.66 & 0.43 & 1.51 & 3.84 & 6.12 & 9.13 & 13.12 & 19.26 & 23.92 & 12.87 & 5.91 & 1.87 & 0.86 & 0.51 & NA & NA & $\mathrm{NA}$ & NA & NA & NA & NA \\
\hline UNH-3 $135-137 \mathrm{~cm}$ & 0.00 & 0.00 & 0.00 & 0.29 & 1.25 & 2.08 & 4.02 & 5.74 & 9.54 & 14.62 & 20.33 & 25.37 & 11.25 & 3.96 & 0.98 & 0.48 & 0.09 & NA & NA & NA & NA & NA & NA & $\mathrm{NA}$ \\
\hline UNH-3 $225-227 \mathrm{~cm}$ & 0.00 & 1.69 & 1.81 & 2.30 & 2.76 & 3.41 & 7.91 & 10.14 & 13.63 & 15.31 & 14.00 & 11.27 & 5.68 & 4.12 & 2.01 & 1.40 & 2.56 & NA & NA & $\mathrm{NA}$ & NA & NA & NA & NA \\
\hline UNH-3 $278-281 \mathrm{~cm}$ & 0.00 & 2.47 & 1.11 & 0.45 & 0.62 & 0.64 & 1.67 & 2.05 & 3.66 & 6.82 & 12.40 & 25.35 & 23.63 & 12.96 & 3.63 & 1.41 & 1.13 & NA & NA & NA & NA & NA & NA & $\mathrm{NA}$ \\
\hline UNH-3 $324-326 \mathrm{~cm}$ & 0.00 & 0.00 & 0.00 & 0.00 & 0.00 & 0.00 & 0.03 & 0.01 & 0.04 & 0.13 & 0.71 & 9.89 & 32.46 & 38.87 & 11.96 & 4.10 & 1.81 & NA & NA & NA & NA & NA & NA & NA \\
\hline UNH-3 $384-386 \mathrm{~cm}$ & 0.00 & 6.32 & 2.20 & 2.93 & 5.02 & 4.39 & 6.51 & 9.07 & 13.19 & 16.85 & 16.04 & 11.83 & 3.44 & 1.46 & 0.46 & 0.26 & 0.00 & NA & NA & NA & NA & NA & NA & NA \\
\hline UNH-3 $428-430 \mathrm{~cm}$ & 0.00 & 0.00 & 1.51 & 0.33 & 0.56 & 0.57 & 2.02 & 4.66 & 9.61 & 17.29 & 26.90 & 22.63 & 7.24 & 3.57 & 1.71 & 1.01 & 0.40 & NA & NA & NA & NA & NA & NA & NA \\
\hline UNH-3 $478-480 \mathrm{~cm}$ & 0.00 & 3.67 & 0.00 & 0.00 & 0.00 & 0.28 & 0.42 & 0.40 & 0.92 & 2.08 & 4.85 & 14.12 & 20.82 & 22.77 & 11.32 & 8.09 & NA & 8.96 & 0.77 & 0.28 & 0.24 & 0.02 & 0.00 & 0.00 \\
\hline UNH-3 $538-540 \mathrm{~cm}$ & 0.00 & 0.00 & 0.00 & 0.00 & 0.14 & 0.06 & 0.06 & 0.17 & 0.31 & 0.56 & 0.72 & 0.99 & 2.22 & 6.60 & 8.27 & 17.83 & NA & 52.95 & 6.64 & 1.19 & 0.43 & 0.07 & 0.33 & 0.47 \\
\hline UNH-3 $592-594 \mathrm{~cm}$ & 0.00 & 0.00 & 0.00 & 0.00 & 0.00 & 0.02 & 0.01 & 0.01 & 0.02 & 0.02 & 0.07 & 1.52 & 3.45 & 6.98 & 12.34 & 17.88 & NA & 26.27 & 8.50 & 4.79 & 2.95 & 2.85 & 2.71 & 9.61 \\
\hline UNH-3_664-666cm & 0.00 & 0.00 & 0.00 & 0.00 & 0.00 & 0.00 & 0.16 & 0.22 & 0.13 & 0.10 & 0.07 & 0.08 & 0.15 & 0.66 & 3.04 & 13.35 & NA & 52.03 & 8.73 & 4.04 & 3.35 & 2.95 & 2.34 & 8.60 \\
\hline
\end{tabular}


Section 2: Vibracores UNH-4 and UNH-5 


\section{Vibracores UNH-4 and UNH-5: Identification, Location, and Description}

\begin{tabular}{|c|c|c|c|c|c|c|c|c|c|c|c|c|c|c|}
\hline UNH Sample ID & $\begin{array}{l}\text { Global Core } \\
\text { Link ID }\end{array}$ & BOEM Global Sample ID & $\begin{array}{c}\text { Latitude } \\
\text { NAD83 }\end{array}$ & $\begin{array}{c}\text { Longitude } \\
\text { NAD83 }\end{array}$ & $\begin{array}{c}\text { Position } \\
\text { Uncertainty }\end{array}$ & $\begin{array}{c}\text { Water } \\
\text { Depth }(\mathrm{m})\end{array}$ & $\begin{array}{c}\text { Diameter } \\
(\mathrm{cm})\end{array}$ & $\begin{array}{l}\text { Core Length } \\
\text { (m) }\end{array}$ & $\begin{array}{l}\text { Vibracore } \\
\text { Collected }\end{array}$ & $\begin{array}{l}\text { Sample } \\
\text { Depth } \\
(\mathrm{cm})\end{array}$ & $\begin{array}{c}\text { Total Wt } \\
(\mathrm{gm})\end{array}$ & $\begin{array}{c}\begin{array}{c}\text { Munsell } \\
\text { Hue }\end{array} \\
\text {. }\end{array}$ & $\begin{array}{c}\text { Munsell } \\
\text { Value }\end{array}$ & $\begin{array}{l}\text { Munsell } \\
\text { Chroma }\end{array}$ \\
\hline UNH-4_0-4cm & ATTW84-UNH-4 & ATTW84-UNH-4_0-4cm_D19841011 & 42.9800 & -70.6550 & $250 \mathrm{~m}$ & 25.0 & 8.9 & 6.46 & $10 / 11 / 1984$ & $0-4$ & 59.85 & 10YR & 5 & 4 \\
\hline UNH-4_10-12cm & ATTW84-UNH-4 & ATTW84-UNH-4_10-12cm_D19841011 & 42.9800 & -70.6550 & $250 \mathrm{~m}$ & 25.0 & 8.9 & 6.46 & $10 / 11 / 1984$ & $10-12$ & 55.32 & $10 \mathrm{YR}$ & 5 & 4 \\
\hline UNH-4_40-42 cm & ATTW84-UNH-4 & ATTW84-UNH-4_40-42cm_D19841011 & 42.9800 & -70.6550 & $250 \mathrm{~m}$ & 25.0 & 8.9 & 6.46 & $10 / 11 / 1984$ & $40-42$ & 98.84 & N7 & NA & NA \\
\hline UNH-4 $68-70 \mathrm{~cm}$ & ATTW84-UNH-4 & ATTW84-UNH-4_68-70cm_D19841011 & 42.9800 & -70.6550 & $250 \mathrm{~m}$ & 25.0 & 8.9 & 6.46 & $10 / 11 / 1984$ & $68-70$ & 42.54 & N7 & NA & NA \\
\hline UNH-4 $98-100 \mathrm{~cm}$ & ATTW84-UNH-4 & ATTW84-UNH-4_98-100cm_D19841011 & 42.9800 & -70.6550 & $250 \mathrm{~m}$ & 25.0 & 8.9 & 6.46 & $10 / 11 / 1984$ & $98-100$ & 79.01 & $10 \mathrm{Y}$ & 4 & 2 \\
\hline UNH-4_143-145cm & ATTW84-UNH-4 & ATTW84-UNH-4_143-145cm_D19841011 & 42.9800 & -70.6550 & $250 \mathrm{~m}$ & 25.0 & 8.9 & 6.46 & $10 / 11 / 1984$ & $143-145$ & 52.56 & $10 Y$ & 4 & 2 \\
\hline UNH-4_192-194cm & ATTW84-UNH-4 & ATTW84-UNH-4_192-194cm D19841011 & 42.9800 & -70.6550 & $250 \mathrm{~m}$ & 25.0 & 8.9 & 6.46 & $10 / 11 / 1984$ & $192-194$ & 48.88 & $10 \mathrm{Y}$ & 4 & 2 \\
\hline UNH-4 $242-244 \mathrm{~cm}$ & ATTW84-UNH-4 & АТTW84-UNH-4_242-244cm_D19841011 & 42.9800 & -70.6550 & $250 \mathrm{~m}$ & 25.0 & 8.9 & 6.46 & $10 / 11 / 1984$ & $242-244$ & 56.08 & $10 \mathrm{r}$ & 4 & 2 \\
\hline UNH-4_267-269cm & ATTW84-UNH-4 & ATTW84-UNH-4_267-269cm_D19841011 & 42.9800 & -70.6550 & $250 \mathrm{~m}$ & 25.0 & 8.9 & 6.46 & $10 / 11 / 1984$ & $267-269$ & 48.75 & $10 \mathrm{Y}$ & 4 & 2 \\
\hline UNH-4 $317-319 \mathrm{~cm}$ & ATTW84-UNH-4 & ATTW84-UNH-4 317-319cm D19841011 & 42.9800 & -70.6550 & $250 \mathrm{~m}$ & 25.0 & 8.9 & 6.46 & $10 / 11 / 1984$ & $317-319$ & 56.02 & $10 \mathrm{Y}$ & 4 & 2 \\
\hline UNH-4_376-378cm & ATTW84-UNH-4 & ATTW84-UNH-4_376-378cm_D19841011 & 42.9800 & -70.6550 & $250 \mathrm{~m}$ & 25.0 & 8.9 & 6.46 & $10 / 11 / 1984$ & $376-378$ & 55.78 & $10 \mathrm{r}$ & 4 & 2 \\
\hline UNH-4 $466-468 \mathrm{~cm}$ & ATTW84-UNH-4 & ATTW84-UNH-4 466-468cm D19841011 & 42.9800 & -70.6550 & $250 \mathrm{~m}$ & 25.0 & 8.9 & 6.46 & $10 / 11 / 1984$ & $466-468$ & 78.44 & $10 Y$ & 4 & 2 \\
\hline UNH-4 $527-529 \mathrm{~cm}$ & ATTW84-UNH-4 & ATTW84-UNH-4_527-529cm_D19841011 & 42.9800 & -70.6550 & $250 \mathrm{~m}$ & 25.0 & 8.9 & 6.46 & $10 / 11 / 1984$ & $527-529$ & 88.70 & N3 & NA & NA \\
\hline UNH-4_587-589cm & ATTW84-UNH-4 & ATTW84-UNH-4 587-589cm_D19841011 & 42.9800 & -70.6550 & $250 \mathrm{~m}$ & 25.0 & 8.9 & 6.46 & $10 / 11 / 1984$ & $587-589$ & 33.61 & N3 & NA & NA \\
\hline UNH-5 $331-333 \mathrm{~cm}$ & ATTW84-UNH-5 & ATTW84-UNH-5 $331-333 \mathrm{~cm}$ D19841011 & 42.9750 & -70.6333 & $250 \mathrm{~m}$ & 22.0 & 8.9 & 7.13 & $10 / 11 / 1984$ & $331-333$ & 74.94 & N5 & NA & NA \\
\hline UNH-5 $405-407 \mathrm{~cm}$ & ATTW84-UNH-5 & ATTW84-UNH-5 405-407cm D19841011 & 42.9750 & -70.6333 & $250 \mathrm{~m}$ & 22.0 & 8.9 & 7.13 & $10 / 11 / 1984$ & $405-407$ & 36.48 & $5 Y R$ & 4 & 1 \\
\hline UNH-5 $446-448 \mathrm{~cm}$ & ATTW84-UNH-5 & ATTW84-UNH-5 446-448cm D19841011 & 42.9750 & -70.6333 & $250 \mathrm{~m}$ & 22.0 & 8.9 & 7.13 & $10 / 11 / 1984$ & $446-448$ & 51.65 & N3 & NA & NA \\
\hline UNH-5 $556-558 \mathrm{~cm}$ & ATTW84-UNH-5 & ATTW84-UNH-5 556-558cm D19841011 & 42.9750 & -70.6333 & $250 \mathrm{~m}$ & 22.0 & 8.9 & 7.13 & $10 / 11 / 1984$ & $556-558$ & 60.48 & N3 & NA & NA \\
\hline UNH-5_588-590cm & ATTW84-UNH-5 & ATTW84-UNH-5_588-590cm_D19841011 & 42.9750 & -70.6333 & $250 \mathrm{~m}$ & 22.0 & 8.9 & 7.13 & $10 / 11 / 1984$ & $588-590$ & 33.51 & $5 Y$ & 6 & 1 \\
\hline UNH-5_700-702cm & ATTW84-UNH-5 & ATTW84-UNH-5_700-702cm_D19841011 & 42.9750 & -70.6333 & $250 \mathrm{~m}$ & 22.0 & 8.9 & 7.13 & $10 / 11 / 1984$ & $700-702$ & 56.18 & $5 Y$ & 6 & 1 \\
\hline
\end{tabular}




\section{Vibracores UNH-4 and UNH-5: Sediment Classifications}

\begin{tabular}{|c|c|c|c|c|c|c|c|c|c|}
\hline UNH Sample ID & $\begin{array}{l}\text { CMECS Substrate } \\
\text { Component Group } \\
\text { (Specific) }\end{array}$ & $\begin{array}{l}\text { CMECS Substrate } \\
\text { Component Subgroup } \\
\text { (Specific) }\end{array}$ & $\begin{array}{l}\text { Textural Group from } \\
\% \text { GSM (Gradistat) }\end{array}$ & $\begin{array}{l}\text { Textural Group } \\
\text { from \% } \% \text { ZC } \\
\text { (Gradistat) } \\
\text { lgnores Gravel }\end{array}$ & $\begin{array}{l}\text { Sediment Name from \%GSM } \\
\text { and Mode (Gradistat) }\end{array}$ & $\begin{array}{l}\text { Sediment Name from \%GSM } \\
\text { and Mode (Wentworth Scale) }\end{array}$ & $\begin{array}{l}\text { Sediment } \\
\text { Classification } \\
\text { from Mean Phi } \\
\text { (Gradistat) }\end{array}$ & $\begin{array}{l}\text { Sediment } \\
\text { Classification } \\
\text { from Mean Phi } \\
\text { (Wentworth) }\end{array}$ & Sorting (Gradistat) \\
\hline UNH-4_0-4cm & Slightly Granuley & $\begin{array}{l}\text { Slightly Granuley Medium } \\
\text { Sand }\end{array}$ & Slightly Gravelly Sand & Sand & $\begin{array}{l}\text { Slightly Very Fine Gravelly } \\
\text { Medium Sand }\end{array}$ & $\begin{array}{l}\text { Slightly Granular Medium } \\
\text { Sand }\end{array}$ & Medium Sand & Medium Sand & Moderately Sorted \\
\hline UNH-4_10-12cm & Slightly Granuley & Slightly Granuley Fine Sand & Slightly Gravelly Sand & Sand & $\begin{array}{l}\text { Slightly Very Fine Gravelly Fine } \\
\text { Sand }\end{array}$ & Slightly Granular Fine Sand & Fine Sand & Fine Sand & $\begin{array}{l}\text { Moderately Well } \\
\text { Sorted }\end{array}$ \\
\hline UNH-4_40-42 cm & Slightly Granuley & Slightly Granuley Fine Sand & Slightly Gravelly Sand & Sand & $\begin{array}{l}\text { Slightly Very Fine Gravelly Fine } \\
\text { Sand }\end{array}$ & Slightly Granular Fine Sand & Fine Sand & Fine Sand & Well Sorted \\
\hline UNH-4_68-70 cm & Sand & Fine Sand & Sand & Sand & Well Sorted Fine Sand & Fine Sand & Fine Sand & Fine Sand & Well Sorted \\
\hline UNH-4_98-100cm & Sand & Fine Sand & Sand & Sand & Moderately Well Sorted Fine Sand & Fine Sand & Fine Sand & Fine Sand & $\begin{array}{l}\text { Moderately Well } \\
\text { Sorted }\end{array}$ \\
\hline UNH-4_143-145cm & Sand & Fine Sand & Sand & Sand & Moderately Well Sorted Fine Sand & Fine Sand & Fine Sand & Fine Sand & $\begin{array}{l}\text { Moderately Well } \\
\text { Sorted }\end{array}$ \\
\hline UNH-4_192-194cm & Muddy Sand & Silty Very Fine Sand & Muddy Sand & Silty S & Very Coarse Silty Very Fine Sand & $\begin{array}{l}\text { Very Coarse Silty Very Fine } \\
\text { Sand }\end{array}$ & ery $\mathrm{Fi}$ & Very & Poo \\
\hline UNH-4_242-244cm & Muddy Sand & Silty Very Fine Sand & Muddy Sand & Silty Sand & Very Coarse Silty Very Fine Sand & $\begin{array}{l}\text { Very Coarse Silty Very Fine } \\
\text { Sand }\end{array}$ & Very & Very & Poor \\
\hline UNH-4_267-269cm & Slightly Granuley & $\begin{array}{l}\text { Slightly Granuley Silty Very } \\
\text { Fine Sand }\end{array}$ & $\begin{array}{l}\text { Slightly Gravelly } \\
\text { Muddy Sand }\end{array}$ & Silty Sand & $\begin{array}{l}\text { Slightly Very Fine Gravelly Very } \\
\text { Coarse Silty Very Fine Sand }\end{array}$ & $\begin{array}{l}\text { Slightly Granular Very Coarse } \\
\text { Silty Very Fine Sand }\end{array}$ & Very Fine Sand & Very Fine Sand & Poorly Sorted \\
\hline UNH-4_317-319cm & Muddy Sand & Silty Very Fine Sand & Muddy Sand & Silty Sand & Very Coarse Silty Very Fine Sand & $\begin{array}{l}\text { Very Coarse Silty Very Fine } \\
\text { Sand }\end{array}$ & Very Fine Sand & Very Fine Sand & Poorly Sorted \\
\hline UNH-4_376-378cm & Muddy Sand & Silty Very Fine Sand & Muddy Sand & Silty Sand & Very Coarse Silty Very Fine Sand & $\begin{array}{l}\text { Very Coarse Silty Very Fine } \\
\text { Sand }\end{array}$ & Very Fine Sand & Very Fine Sand & Poorly Sorted \\
\hline UNH-4_466-468cm & Slightly Granuley & $\begin{array}{l}\text { Slightly Granuley Silty Very } \\
\text { Fine Sand }\end{array}$ & $\begin{array}{l}\text { Slightly Gravelly } \\
\text { Muddy Sand }\end{array}$ & Silty Sand & $\begin{array}{l}\text { Slightly Very Fine Gravelly Very } \\
\text { Coarse Silty Very Fine Sand }\end{array}$ & $\begin{array}{l}\text { Slightly Granular Very Coarse } \\
\text { Silty Very Fine Sand }\end{array}$ & Very Coarse Silt & Very Coarse Silt & Poorly Sorted \\
\hline UNH-4 $527-529 \mathrm{~cm}$ & Slightly Granuley & $\begin{array}{l}\text { Slightly Granuley Very Fine } \\
\text { Sandy Silt }\end{array}$ & $\begin{array}{l}\text { Slightly Gravelly } \\
\text { Sandy Mud }\end{array}$ & Sandy Silt & $\begin{array}{l}\text { Slightly Medium Gravelly Very } \\
\text { Fine Sandy Very Coarse Silt }\end{array}$ & $\begin{array}{l}\text { Slightly Granular Very Fine } \\
\text { Sandy Very Coarse Silt }\end{array}$ & Very Coarse Silt & Very Coarse Silt & Poorly Sorted \\
\hline UNH-4_587-589cm & Slightly Granuley & $\begin{array}{l}\text { Slightly Granuley Very Fine } \\
\text { Sandy Silt-Clay }\end{array}$ & $\begin{array}{l}\text { Slightly Gravelly } \\
\text { Sandy Mud } \\
\end{array}$ & Sandy Mud & $\begin{array}{l}\text { Slightly Very Fine Gravelly Very } \\
\text { Fine Sandy Mud }\end{array}$ & $\begin{array}{l}\text { Slightly Granular Very Fine } \\
\text { Sandy Mud }\end{array}$ & Medium Silt & Medium Silt & Very Poorly Sorted \\
\hline UNH-5 $331-333 \mathrm{~cm}$ & Granuley & Granuley Very Fine Sand & Gravelly Sand & Sand & Very Fine Gravelly Very Fine Sand & Granula & Medium Sand & Medium Sand & Very Poorly Sorted \\
\hline UNH-5_405-407cm & Pebbly & Pebbly Silty Very Fine Sand & Gravelly Muddy Sand & Silty Sand & $\begin{array}{l}\text { Fine Gravelly Very Coarse Silty } \\
\text { Very Fine Sand }\end{array}$ & $\begin{array}{l}\text { Pebbly Very Coarse Silty Very } \\
\text { Fine Sand }\end{array}$ & Fine Sand & Fine Sand & Very Poorly Sorted \\
\hline UNH-5_446-448cm & Pebbly & Pebbly Silty Very Fine Sand & Gravelly Muddy Sand & Silty Sand & $\begin{array}{l}\text { Medium Gravelly Very Coarse } \\
\text { Silty Very Fine Sand }\end{array}$ & $\begin{array}{l}\text { Pebbly Very Coarse Silty Very } \\
\text { Fine Sand }\end{array}$ & Fine Sand & Fine Sand & Very Poorly Sorted \\
\hline UNH-5 $556-558 \mathrm{~cm}$ & Pebbly & Pebbly Silty Very Fine Sand & Gravelly Muddy Sand & Silty Sand & $\begin{array}{l}\text { Medium Gravelly Very Coarse } \\
\text { Silty Very Fine Sand }\end{array}$ & $\begin{array}{l}\text { Pebbly Very Coarse Silty Very } \\
\text { Fine Sand }\end{array}$ & Fine Sand & Fine Sand & Very Poorly Sorted \\
\hline UNH-5_588-590cm & Pebbly & Pebbly Silty Very Fine Sand & Gravelly Muddy Sand & Silty Sand & $\begin{array}{l}\text { Medium Gravelly Very Coarse } \\
\text { Silty Very Fine Sand }\end{array}$ & $\begin{array}{l}\text { Pebbly Very Coarse Silty Very } \\
\text { Fine Sand }\end{array}$ & Medium Sand & Medium Sand & Very Poorly Sorted \\
\hline UNH-5_700-702cm & Pebbly & Pebbly Silty Fine Sand & Gravelly Muddy Sand & Silty Sand & $\begin{array}{l}\text { Fine Gravelly Very Coarse Silty } \\
\text { Fine Sand }\end{array}$ & $\begin{array}{l}\text { Pebbly Very Coarse Silty Fine } \\
\text { Sand }\end{array}$ & Very Fine Sand & Very Fine Sand & Very Poorly Sorted \\
\hline
\end{tabular}




\section{Vibracores UNH-4 and UNH-5: Grain Size Statistics}

\begin{tabular}{|c|c|c|c|c|c|c|c|c|c|c|c|c|c|c|c|c|c|c|c|c|}
\hline UNH Sample ID & Gravel \% & Pebble \% & Granule \% & Sand $\%$ & Mud $\%$ & Silt \% & Clay $\%$ & Modes & $\begin{array}{c}\text { Mode } 1 \\
\text { (phi) }\end{array}$ & $\begin{array}{c}\text { Mode } 2 \\
\text { (phi) }\end{array}$ & $\begin{array}{c}\text { Mode } 3 \\
\text { (phi) }\end{array}$ & $\begin{array}{c}\mathrm{D}_{10} \\
\text { (phi) }\end{array}$ & $\begin{array}{c}\mathrm{D}_{10} \\
(\mathrm{~mm})\end{array}$ & $\begin{array}{r}\begin{array}{c}D_{50} \\
\text { (phi) }\end{array} \\
\end{array}$ & $\begin{array}{c}D_{50} \\
(\mathrm{~mm})\end{array}$ & $\begin{array}{c}\text { Mean } \\
\text { Size } \\
\text { (phi) } \\
\end{array}$ & $\begin{array}{c}\text { Mean } \\
\text { Size } \\
(\mathrm{mm}) \\
\end{array}$ & $\begin{array}{c}\text { Sorting } \\
\text { (phi) }\end{array}$ & Skewness & Kurtosis \\
\hline UNH-4_0-4cm & 0.30 & 0.00 & 0.30 & 99.70 & 0.00 & $\mathrm{NA}$ & NA & $u$ & 1.75 & NA & NA & 0.41 & 0.75 & 1.68 & 0.31 & 1.57 & 0.34 & 0.83 & -0.18 & 0.92 \\
\hline UNH-4_10-12cm & 0.02 & 0.00 & 0.02 & 99.94 & 0.04 & NA & NA & $u$ & 2.24 & $\mathrm{NA}$ & NA & 1.54 & 0.34 & 2.26 & 0.21 & 2.24 & 0.21 & 0.56 & -0.14 & 1.14 \\
\hline UNH-4_40-42 cm & 0.05 & 0.01 & 0.05 & 99.95 & 0.00 & NA & NA & $u$ & 2.24 & NA & NA & 1.82 & 0.28 & 2.43 & 0.19 & 2.44 & 0.18 & 0.45 & 0.02 & 1.00 \\
\hline UNH-4_68-70 $6 \mathrm{~cm}$ & 0.00 & 0.00 & 0.00 & 98.39 & 1.61 & $\mathrm{NA}$ & $\mathrm{NA}$ & $u$ & 2.74 & NA & NA & 1.98 & 0.25 & 2.56 & 0.17 & 2.53 & 0.17 & 0.48 & -0.04 & 1.09 \\
\hline UNH-4 $-98-100 \mathrm{~cm}$ & 0.00 & 0.00 & 0.00 & 96.48 & 3.52 & NA & $\mathrm{NA}$ & $u$ & 2.74 & $\mathrm{NA}$ & $\mathrm{NA}$ & 1.82 & 0.28 & 2.56 & 0.17 & 2.52 & 0.17 & 0.55 & -0.02 & 1.20 \\
\hline UNH-4_143-145cm & 0.00 & 0.00 & 0.00 & 92.00 & 8.00 & 6.22 & 1.78 & $u$ & 2.74 & NA & $\mathrm{NA}$ & 2.38 & 0.19 & 2.89 & 0.13 & 2.95 & 0.13 & 0.63 & 0.31 & 1.60 \\
\hline UNH-4_192-194cm & 0.00 & 0.00 & 0.00 & 75.37 & 24.63 & 19.33 & 5.30 & $u$ & 3.24 & NA & NA & 2.56 & 0.17 & 3.31 & 0.10 & 3.62 & 0.08 & 1.44 & 0.56 & 2.18 \\
\hline UNH-4_242-244cm & 0.00 & 0.00 & 0.00 & 73.42 & 26.58 & 22.82 & 3.76 & $u$ & 3.24 & NA & NA & 2.59 & 0.17 & 3.37 & 0.10 & 3.59 & 0.08 & 1.15 & 0.46 & 1.57 \\
\hline UNH-4_267-269cm & 0.05 & 0.00 & 0.05 & 69.10 & 30.85 & 26.33 & 4.52 & $u$ & 3.24 & NA & NA & 2.64 & 0.16 & 3.47 & 0.09 & 3.70 & 0.08 & 1.29 & 0.48 & 1.63 \\
\hline UNH-4_317-319cm & 0.00 & 0.00 & 0.00 & 67.78 & 32.22 & 26.39 & 5.83 & $u$ & 3.24 & NA & NA & 2.61 & 0.16 & 3.47 & 0.09 & 3.72 & 0.08 & 1.51 & 0.52 & 1.85 \\
\hline UNH-4_376-378cm & 0.00 & 0.00 & 0.00 & 58.44 & 41.56 & 36.60 & 4.96 & $u$ & 3.73 & NA & NA & 2.87 & 0.14 & 3.81 & 0.07 & 3.94 & 0.07 & 1.28 & 0.39 & 1.64 \\
\hline UNH-4_466-468cm & 0.01 & 0.01 & 0.00 & 52.75 & 47.24 & 41.83 & 5.41 & $u$ & 3.73 & NA & NA & 3.00 & 0.12 & 3.93 & 0.07 & 4.04 & 0.06 & 1.36 & 0.38 & 1.75 \\
\hline UNH-4_527-529cm & 0.48 & 0.42 & 0.06 & 30.37 & 69.15 & 62.42 & 6.73 & $u$ & 4.50 & NA & NA & 3.38 & 0.10 & 4.42 & 0.05 & 4.56 & 0.04 & 1.52 & 0.40 & 2.37 \\
\hline UNH-4_587-589cm & 0.06 & 0.01 & 0.06 & 34.45 & 65.49 & 33.25 & 32.24 & $u$ & 3.24 & NA & NA & 2.79 & 0.14 & 5.25 & 0.03 & 6.41 & 0.01 & 3.54 & 0.46 & 0.76 \\
\hline UNH-5_331-333cm & 14.23 & 8.59 & 5.64 & 77.79 & 7.98 & 5.45 & 2.53 & B & 3.24 & -3.24 & NA & -1.79 & 3.45 & 2.57 & 0.17 & 1.81 & 0.29 & 2.25 & -0.45 & 1.30 \\
\hline UNH-5_405-407cm & 9.19 & 4.94 & 4.26 & 67.48 & 23.33 & 17.74 & 5.59 & B & 3.24 & -2.74 & $\mathrm{NA}$ & -0.83 & 1.78 & 2.77 & 0.15 & 2.58 & 0.17 & 2.73 & -0.02 & 1.61 \\
\hline UNH-5 $446-448 \mathrm{~cm}$ & 7.79 & 5.55 & 2.24 & 70.11 & 22.10 & 16.73 & 5.37 & $B$ & 3.24 & -3.24 & NA & -0.52 & 1.43 & 2.72 & 0.15 & 2.61 & 0.16 & 2.64 & -0.01 & 1.72 \\
\hline UNH-5 $556-558 \mathrm{~cm}$ & 7.17 & 4.62 & 2.54 & 73.02 & 19.81 & 16.06 & 3.75 & B & 2.74 & -3.24 & $\mathrm{NA}$ & -0.27 & 1.21 & 2.78 & 0.15 & 2.60 & 0.16 & 2.29 & -0.10 & 1.71 \\
\hline UNH-5_588-590cm & 22.53 & 18.96 & 3.56 & 49.93 & 27.54 & 21.77 & 5.77 & B & 3.24 & -3.74 & $\mathrm{NA}$ & -3.64 & 12.42 & 2.63 & 0.16 & 1.49 & 0.36 & 3.98 & -0.22 & 1.12 \\
\hline UNH-5_700-702 cm & 7.64 & 4.18 & 3.46 & 61.91 & 30.45 & 21.56 & 8.89 & $\mathrm{~B}$ & 2.74 & -2.24 & NA & -0.54 & 2.83 & 2.83 & 0.14 & 3.04 & 0.12 & 3.23 & 0.18 & 1.45 \\
\hline
\end{tabular}




\section{Vibracores UNH-4 and UNH-5: Grain Size Distribution}

\begin{tabular}{|c|c|c|c|c|c|c|c|c|c|c|c|c|c|c|c|c|c|c|c|c|c|c|c|c|}
\hline UNH Sample ID & $\begin{array}{c}\text { Class \% } \\
\text { phi } \\
-3.5 \\
\end{array}$ & $\begin{array}{c}\text { Class \% } \\
\text { phi } \\
-3.0 \\
\end{array}$ & $\begin{array}{c}\text { Class \% } \\
\text { phi } \\
-2.5 \\
\end{array}$ & $\begin{array}{c}\text { Class \% } \\
\text { phi } \\
-2.0 \\
\end{array}$ & $\begin{array}{c}\text { Class \% } \\
\text { phi } \\
-1.5 \\
\end{array}$ & $\begin{array}{c}\text { Class \% } \\
\text { phi } \\
-1.0 \\
\end{array}$ & $\begin{array}{c}\text { Class \% } \\
\text { phi } \\
-0.5 \\
\end{array}$ & $\begin{array}{c}\text { Class \% } \\
\text { phi } \\
0.0 \\
\end{array}$ & $\begin{array}{c}\text { Class \% } \\
\text { phi } \\
0.5 \\
\end{array}$ & $\begin{array}{c}\text { Class \% } \\
\text { phi } \\
1.0 \\
\end{array}$ & $\begin{array}{c}\text { Class \% } \\
\text { phi } \\
1.5 \\
\end{array}$ & $\begin{array}{c}\text { Class \% } \\
\text { phi } \\
2.0 \\
\end{array}$ & $\begin{array}{c}\text { Class \% } \\
\text { phi } \\
2.5 \\
\end{array}$ & $\begin{array}{c}\text { Class \% } \\
\text { phi } \\
3.0 \\
\end{array}$ & $\begin{array}{c}\text { Class \% } \\
\text { phi } \\
3.5 \\
\end{array}$ & $\begin{array}{c}\text { Class \% } \\
\text { phi } \\
4.0 \\
\end{array}$ & $\begin{array}{c}\text { Class } \% \\
\text { phi } \\
>4.0 \\
\end{array}$ & $\begin{array}{c}\text { Class \% } \\
\text { phi } \\
5.0 \\
\end{array}$ & $\begin{array}{c}\text { Class \% } \\
\text { phi } \\
6.0 \\
\end{array}$ & $\begin{array}{c}\text { Class \% } \\
\text { phi } \\
7.0 \\
\end{array}$ & $\begin{array}{c}\text { Class \% } \\
\text { phi } \\
8.0 \\
\end{array}$ & $\begin{array}{c}\text { Class \% } \\
\text { phi } \\
9.0 \\
\end{array}$ & $\begin{array}{c}\text { Class \% } \\
\text { phi } \\
10.0 \\
\end{array}$ & $\begin{array}{c}\text { Class } \% \\
\text { phi } \\
>10.0\end{array}$ \\
\hline UNH-4_0-4cm & 0.00 & 0.00 & 0.00 & 0.00 & 0.16 & 0.13 & 0.30 & 1.88 & 9.01 & 14.33 & 13.91 & 27.93 & 21.34 & 9.71 & 1.09 & 0.20 & 0.00 & NA & NA & NA & NA & NA & NA & NA \\
\hline UNH-4_10-12cm & 0.00 & 0.00 & 0.00 & 0.00 & 0.00 & 0.02 & 0.07 & 0.32 & 1.51 & 2.45 & 3.71 & 20.16 & 39.93 & 27.22 & 3.95 & 0.63 & 0.04 & NA & NA & NA & NA & NA & NA & NA \\
\hline UNH-4 $40-42 \mathrm{~cm}$ & 0.00 & 0.00 & 0.00 & 0.00 & 0.00 & 0.05 & 0.00 & 0.01 & 0.03 & 0.12 & 1.02 & 13.56 & 39.18 & 38.71 & 5.94 & 1.39 & 0.00 & NA & NA & NA & NA & NA & NA & NA \\
\hline UNH-4 $68-70 \mathrm{~cm}$ & 0.00 & 0.00 & 0.00 & 0.00 & 0.00 & 0.00 & 0.00 & 0.00 & 0.02 & 0.09 & 0.79 & 9.46 & 32.78 & 44.34 & 8.67 & 2.24 & 1.61 & NA & NA & NA & NA & NA & NA & NA \\
\hline UNH-4 $98-100 \mathrm{~cm}$ & 0.00 & 0.00 & 0.00 & 0.00 & 0.00 & 0.00 & 0.00 & 0.02 & 0.08 & 0.35 & 1.99 & 11.80 & 29.28 & 41.90 & 8.94 & 2.13 & 3.52 & NA & NA & NA & NA & NA & NA & NA \\
\hline UNH-4_143-145cm & 0.00 & 0.00 & 0.00 & 0.00 & 0.00 & 0.00 & 0.00 & 0.01 & 0.05 & 0.11 & 0.30 & 1.55 & 9.96 & 47.83 & 25.54 & 6.65 & NA & 4.09 & 1.01 & 0.59 & 0.53 & 0.25 & 0.28 & 1.26 \\
\hline UNH-4_192-194cm & 0.00 & 0.00 & 0.00 & 0.00 & 0.00 & 0.00 & 0.00 & 0.02 & 0.03 & 0.08 & 0.21 & 0.76 & 4.78 & 25.25 & 28.98 & 15.25 & NA & 9.97 & 5.71 & 2.16 & 1.49 & 1.14 & 0.98 & 3.18 \\
\hline UNH-4_242-244cm & 0.00 & 0.00 & 0.00 & 0.00 & 0.00 & 0.00 & 0.03 & 0.02 & 0.05 & 0.09 & 0.20 & 0.68 & 3.79 & 22.63 & 28.54 & 17.37 & NA & 16.06 & 3.67 & 2.15 & 0.95 & 1.01 & 0.50 & 2.26 \\
\hline UNH-4_267-269cm & 0.00 & 0.00 & 0.00 & 0.00 & 0.00 & 0.05 & 0.01 & 0.02 & 0.05 & 0.09 & 0.19 & 0.63 & 3.03 & 19.25 & 26.93 & 18.89 & NA & 18.06 & 4.64 & 2.35 & 1.28 & 0.77 & 0.86 & 2.89 \\
\hline UNH-4 $317-319 \mathrm{~cm}$ & 0.00 & 0.00 & 0.00 & 0.00 & 0.00 & 0.00 & 0.00 & 0.02 & 0.03 & 0.07 & 0.17 & 0.69 & 3.77 & 20.62 & 24.83 & 17.59 & NA & 17.72 & 4.95 & 3.32 & 0.40 & 0.92 & 0.93 & 3.98 \\
\hline UNH-4_376-378cm & 0.00 & 0.00 & 0.00 & 0.00 & 0.00 & 0.00 & 0.00 & 0.01 & 0.03 & 0.05 & 0.12 & 0.38 & 1.40 & 10.64 & 21.94 & 23.87 & NA & 27.65 & 5.39 & 2.11 & 1.45 & 0.71 & 0.87 & 3.38 \\
\hline UNH-4_466-468cm & 0.00 & 0.00 & 0.00 & 0.00 & 0.00 & 0.01 & 0.01 & 0.02 & 0.06 & 0 & 0.12 & 0.33 & 0.93 & 8.30 & 19.75 & 23.14 & NA & 30.96 & 6.80 & 2.50 & 1.57 & 0.79 & 0.95 & 3.67 \\
\hline UNH-4_527-529cm & 0.00 & 0.42 & 0.00 & 0.00 & 0.00 & 0.06 & 0.07 & 0.13 & 0.10 & 0.11 & 0.18 & 0.37 & 0.69 & 2.19 & 7.03 & 19.50 & NA & 45.63 & 11.36 & 3.87 & 1.56 & 0.96 & 1.14 & 4.63 \\
\hline UNH-4_587-589cm & 0.00 & 0.00 & 0.00 & 0.00 & 0.00 & 0.06 & 0.07 & 0.15 & 0.21 & 0.24 & 0.34 & 0.86 & 2.62 & 8.95 & 10.38 & 10.63 & NA & 13.85 & 6.89 & 6.99 & 5.52 & 5.86 & 5.94 & 20.44 \\
\hline UNH-5 $331-333 \mathrm{~cm}$ & 0.00 & 3.91 & 2.99 & 1.68 & 3.42 & 2.22 & 2.60 & 2.83 & 3.23 & 3.92 & 5.13 & 7.57 & 7.81 & 15.32 & 20.77 & 8.60 & NA & 2.82 & 0.97 & 0.65 & 1.01 & 1.02 & 1.11 & 0.39 \\
\hline UNH-5_405-407cm & 0.00 & 0.00 & 3.64 & 1.29 & 2.13 & 2.13 & 2.46 & 2.67 & 3.57 & 4.55 & 6.16 & 8.26 & 7.44 & 9.97 & 11.32 & 11.08 & $\mathrm{NA}$ & 10.22 & 4.02 & 2.26 & 1.23 & 0.92 & 1.00 & 3.67 \\
\hline UNH-5_446-448cm & 0.00 & 3.39 & 0.55 & 1.61 & 0.62 & 1.63 & 2.35 & 2.86 & 3.33 & 4.50 & 6.16 & 8.80 & 8.51 & 12.07 & 12.24 & 9.31 & NA & 9.28 & 3.76 & 2.24 & 1.45 & 1.14 & 0.93 & 3.30 \\
\hline UNH-5_556-558cm & 0.00 & 2.88 & 0.00 & 1.74 & 1.26 & 1.28 & 1.66 & 2.69 & 3.54 & 4.00 & 4.61 & 7.06 & 9.46 & 16.74 & 13.65 & 9.60 & NA & 9.23 & 3.75 & 1.85 & 1.22 & 0.95 & 0.70 & 2.10 \\
\hline UNH-5_588-590cm & 14.11 & 4.34 & 0.00 & 0.51 & 2.13 & 1.43 & 1.73 & 2.09 & 2.24 & 2.71 & 3.86 & 5.83 & 6.20 & 32 & 8.51 & 7.43 & NA & 10.91 & 5.83 & 3.33 & 1.70 & 1.21 & 1.13 & 3.43 \\
\hline UNH-5_700- & 0.00 & 0.00 & 1.31 & 2.86 & 1.57 & 1.89 & 2.62 & 2.79 & 4.03 & 4.92 & 6.10 & 7.71 & 7.34 & 10.07 & 8.76 & 7.58 & NA & 8.39 & 6.48 & 4.21 & 2.47 & 1.86 & 1.53 & 5.50 \\
\hline
\end{tabular}


Section 3: Vibracores UNH-6, UNH-6A and UNH-9 


\section{Vibracores UNH-6, UNH-6a, and UNH-9: Identification, Location, and Description}

\begin{tabular}{|c|c|c|c|c|c|c|c|c|c|c|c|c|c|c|}
\hline UNH Sample ID & $\begin{array}{c}\text { Global Core } \\
\text { Link ID } \\
\end{array}$ & BOEM Global Sample ID & $\begin{array}{r}\text { Latitude } \\
\text { NAD83 } \\
\end{array}$ & $\begin{array}{c}\text { Longitude } \\
\text { NAD83 } \\
\end{array}$ & $\begin{array}{c}\text { Position } \\
\text { Uncertainty }\end{array}$ & $\begin{array}{c}\begin{array}{c}\text { Water } \\
\text { Depth }(\mathrm{m})\end{array} \\
\end{array}$ & $\begin{array}{c}\text { Diameter } \\
(\mathrm{cm})\end{array}$ & $\begin{array}{c}\text { Core Length } \\
(\mathrm{m})\end{array}$ & $\begin{array}{l}\text { Vibracore } \\
\text { Collected } \\
\end{array}$ & $\begin{array}{c}\text { Sample } \\
\text { Depth } \\
(\mathrm{cm}) \\
\end{array}$ & $\begin{array}{c}\text { Total Wt } \\
(\mathrm{gm})\end{array}$ & $\begin{array}{c}\text { Munsell } \\
\text { Hue }\end{array}$ & $\begin{array}{c}\text { Munsell } \\
\text { Value }\end{array}$ & $\begin{array}{l}\text { Munsell } \\
\text { Chroma }\end{array}$ \\
\hline UNH-6_16-18cm & ATTW84-UNH-6 & ATTW84-UNH-6_16-18cm_D19841011 & 42.9350 & -70.7450 & $250 \mathrm{~m}$ & 30.0 & 8.9 & 8.50 & $10 / 11 / 1984$ & $16-18$ & 57.06 & $5 Y$ & 5 & 2 \\
\hline UNH-6 $-96-98 \mathrm{~cm}$ & ATTW84-UNH-6 & ATTW84-UNH-6_96-98cm_D19841011 & 42.9350 & -70.7450 & $250 \mathrm{~m}$ & 30.0 & 8.9 & 8.50 & $10 / 11 / 1984$ & $96-98$ & 49.61 & $5 Y$ & 5 & 2 \\
\hline UNH-6_124-126cm & ATTW84-UNH-6 & ATTW84-UNH-6_124-126cm_D19841011 & 42.9350 & -70.7450 & $250 \mathrm{~m}$ & 30.0 & 8.9 & 8.50 & $10 / 11 / 1984$ & $124-126$ & 42.88 & $10 Y$ & 4 & 2 \\
\hline UNH-6_152-154cm & ATTW84-UNH-6 & ATTW84-UNH-6_152-154cm_D19841011 & 42.9350 & -70.7450 & $250 \mathrm{~m}$ & 30.0 & 8.9 & 8.50 & $10 / 11 / 1984$ & $152-154$ & 47.52 & $10 \mathrm{Y}$ & 4 & 2 \\
\hline UNH-6_176-178cm & ATTW84-UNH-6 & ATTW84-UNH-6_176-178cm_D19841011 & 42.9350 & -70.7450 & $250 \mathrm{~m}$ & 30.0 & 8.9 & 8.50 & $10 / 11 / 1984$ & $176-178$ & 28.78 & $10 \mathrm{r}$ & 4 & 2 \\
\hline UNH-6A_20-22cm & ATTW84-UNH-6A & ATTW84-UNH-6A_20-22cm_D19841011 & 42.9350 & -70.7450 & $250 \mathrm{~m}$ & 30.0 & 8.9 & 8.32 & $10 / 11 / 1984$ & $20-22$ & 68.61 & $5 Y$ & 5 & 2 \\
\hline UNH-6A $80-82 \mathrm{~cm}$ & ATTW84-UNH-6A & ATTW84-UNH-6A_80-82cm_D19841011 & 42.9350 & -70.7450 & $250 \mathrm{~m}$ & 30.0 & 8.9 & 8.32 & $10 / 11 / 1984$ & $80-82$ & 62.78 & $5 Y$ & 6 & 1 \\
\hline UNH-6A_122-124cm & ATTW84-UNH-6A & ATTW84-UNH-6A_122-124cm_D19841011 & 42.9350 & -70.7450 & $250 \mathrm{~m}$ & 30.0 & 8.9 & 8.32 & $10 / 11 / 1984$ & $122-124$ & 82.91 & $5 Y$ & 6 & 1 \\
\hline UNH-6A_192-194cm & ATTW84-UNH-6A & ATTW84-UNH-6A_192-194cm_D19841011 & 42.9350 & -70.7450 & $250 \mathrm{~m}$ & 30.0 & 8.9 & 8.32 & $10 / 11 / 1984$ & 192-194 & 69.24 & $5 Y$ & 6 & 1 \\
\hline UNH-6A_235-237cm & ATTW84-UNH-6A & ATTW84-UNH-6A_235-237cm_D19841011 & 42.9350 & -70.7450 & $250 \mathrm{~m}$ & 30.0 & 8.9 & 8.32 & $10 / 11 / 1984$ & $235-237$ & 76.89 & N3 & NA & $\mathrm{NA}$ \\
\hline UNH-6A_298-300 cm & ATTW84-UNH-6A & ATTW84-UNH-6A_298-300cm_D19841011 & 42.9350 & -70.7450 & $250 \mathrm{~m}$ & 30.0 & 8.9 & 8.32 & $10 / 11 / 1984$ & $298-300$ & 51.26 & N3 & NA & NA \\
\hline UNH-6A_305-307cm & ATTW84-UNH-6A & ATTW84-UNH-6A_305-307cm_D19841011 & 42.9350 & -70.7450 & $250 \mathrm{~m}$ & 30.0 & 8.9 & 8.32 & $10 / 11 / 1984$ & 305-307 & 36.43 & N5 & NA & NA \\
\hline UNH-9_6-8cm & ATTW84-UNH-9 & ATTW84-UNH-9_6-8cm_D19841011 & 42.9133 & -70.6367 & $250 \mathrm{~m}$ & 61.0 & 8.9 & 8.39 & $10 / 11 / 1984$ & $6-8$ & 41.21 & $5 G Y$ & 6 & 1 \\
\hline UNH-9_19-21cm & ATTW84-UNH-9 & ATTW84-UNH-9_19-21cm_D19841011 & 42.9133 & -70.6367 & $250 \mathrm{~m}$ & 61.0 & 8.9 & 8.39 & $10 / 11 / 1984$ & $19-21$ & 18.66 & $5 G Y$ & 6 & 1 \\
\hline UNH-9.37-39cm & ATTW84-UNH-9 & ATTW84-UNH-9_37-39cm_D19841011 & 42.9133 & -70.6367 & $250 \mathrm{~m}$ & 61.0 & 8.9 & 8.39 & $10 / 11 / 1984$ & $37-39$ & 24.77 & $5 \mathrm{GY}$ & 6 & 1 \\
\hline UNH-9_48-50cm & ATTW84-UNH-9 & ATTW84-UNH-9_48-50cm_D19841011 & 42.9133 & -70.6367 & $250 \mathrm{~m}$ & 61.0 & 8.9 & 8.39 & $10 / 11 / 1984$ & $48-50$ & 26.92 & $5 G Y$ & 6 & 1 \\
\hline UNH-9.88-90cm & ATTW84-UNH-9 & ATTW84-UNH-9_88-90cm_D19841011 & 42.9133 & -70.6367 & $250 \mathrm{~m}$ & 61.0 & 8.9 & 8.39 & $10 / 11 / 1984$ & $88-90$ & 29.35 & $5 \mathrm{GY}$ & 6 & 1 \\
\hline UNH-9_181-183cm & ATTW84-UNH-9 & ATTW84-UNH-9_181-183cm_D19841011 & 42.9133 & -70.6367 & $250 \mathrm{~m}$ & 61.0 & 8.9 & 8.39 & $10 / 11 / 1984$ & $181-183$ & 21.56 & $5 \mathrm{GY}$ & 6 & 1 \\
\hline UNH-9_198-200cm & ATTW84-UNH-9 & ATTW84-UNH-9_198-200cm_D19841011 & 42.9133 & -70.6367 & $250 \mathrm{~m}$ & 61.0 & 8.9 & 8.39 & $10 / 11 / 1984$ & $198-200$ & 31.11 & $5 \mathrm{GY}$ & 6 & 1 \\
\hline
\end{tabular}




\section{Vibracores UNH-6, UNH-6a, and UNH-9: Sediment Classifications}

\begin{tabular}{|c|c|c|c|c|c|c|c|c|c|}
\hline UNH Sample ID & $\begin{array}{l}\text { CMECS Substrate } \\
\text { Component Group } \\
\text { (Specific) }\end{array}$ & $\begin{array}{l}\text { CMECS Substrate } \\
\text { Component Subgroup } \\
\text { (Specific) }\end{array}$ & $\begin{array}{l}\text { Textural Group from } \\
\% \text { GSM (Gradistat) }\end{array}$ & $\begin{array}{l}\text { Textural Group } \\
\text { from \% } \% \text { ZC } \\
\text { (Gradistat) } \\
\text { lgnores Gravel }\end{array}$ & $\begin{array}{l}\text { Sediment Name from \%GSM } \\
\text { and Mode (Gradistat) }\end{array}$ & $\begin{array}{l}\text { Sediment Name from \%GSM } \\
\text { and Mode (Wentworth Scale) }\end{array}$ & $\begin{array}{l}\text { Sediment } \\
\text { Classification } \\
\text { from Mean Phi } \\
\text { (Gradistat) } \\
\end{array}$ & $\begin{array}{l}\text { Sediment } \\
\text { Classification } \\
\text { from Mean Phi } \\
\text { (Wentworth) }\end{array}$ & Sorting (Gradistat) \\
\hline UNH-6_16-18cm & Slightly Granuley & $\begin{array}{l}\text { Slightly Granuley Very Fine } \\
\text { Sand }\end{array}$ & Slightly Gravelly Sand & Sand & $\begin{array}{l}\text { Slightly Very Fine Gravelly Very } \\
\text { Fine Sand }\end{array}$ & $\begin{array}{l}\text { Slightly Granular Very Fine } \\
\text { Sand }\end{array}$ & Very Fine Sand & Very Fine Sand & Well Sorted \\
\hline UNH-6_96-98cm & Sand & Very Fine Sand & Sand & Sand & $\begin{array}{l}\text { Moderately Well Sorted Very Fine } \\
\text { Sand }\end{array}$ & Very Fine Sand & Very Fine Sand & Very Fine Sand & $\begin{array}{l}\text { Moderately Well } \\
\text { Sorted }\end{array}$ \\
\hline UNH-6_124-126cm & Muddy Sand & Silty Very Fine Sand & Muddy Sand & Silty Sand & Very Coarse Silty Very Fine Sand & $\begin{array}{l}\text { Very Coarse Silty Very Fine } \\
\text { Sand }\end{array}$ & Very Fine Sand & Very Fine Sand & $\begin{array}{l}\text { Moderately Well } \\
\text { Sorted }\end{array}$ \\
\hline UNH-6_152-154cm & Sand & Very Fine Sand & Sand & Sand & Moderately Sorted Very Fine Sand & Very Fine Sand & Very Fine Sand & Very Fine Sand & Moderately Sorted \\
\hline UNH-6_176-178cm & Mud & Clay & Mud & Mud & Mud & Mud & Clay & Clay & Very Poorly Sorted \\
\hline UNH-6A_20-22cm & Slightly Granuley & Slightly Granuley Fine Sand & Slightly Gravelly Sand & Sand & $\begin{array}{l}\text { Slightly Very Fine Gravelly Fine } \\
\text { Sand }\end{array}$ & Slightly Granular Fine Sand & Fine Sand & Fine Sand & $\begin{array}{l}\text { Moderately Well } \\
\text { Sorted }\end{array}$ \\
\hline UNH-6A_80-82cm & Sand & Fine Sand & Sand & Sand & Moderately Well Sorted Fine Sand & Fine Sand & Fine Sand & Fine Sand & $\begin{array}{l}\text { Moderately Well } \\
\text { Sorted }\end{array}$ \\
\hline UNH-6A_122-124cm & Sand & Fine Sand & Sand & Sand & Moderately Well Sorted Fine Sand & Fine Sand & Fine Sand & Fine Sand & $\begin{array}{l}\text { Moderately Well } \\
\text { Sorted }\end{array}$ \\
\hline UNH-6A_192-194cm & Sand & Very Fine Sand & Sand & Sand & $\begin{array}{l}\text { Moderately Well Sorted Very Fine } \\
\text { Sand }\end{array}$ & Very Fine Sand & Very Fine Sand & Very Fine Sand & $\begin{array}{l}\text { Moderately Well } \\
\text { Sorted }\end{array}$ \\
\hline UNH-6A_235-237cm & Sand & Very Fine Sand & Sand & Sand & Well Sorted Very Fine Sand & Very Fine Sand & Very Fine Sand & Very Fine Sand & Well Sorted \\
\hline UNH-6A_298-300cm & Muddy Sand & Silty Very Fine Sand & Muddy Sand & Silty Sand & Very Coarse Silty Very Fine Sand & $\begin{array}{l}\text { Very Coarse Silty Very Fine } \\
\text { Sand }\end{array}$ & Very Fine Sand & Very Fine Sand & Moderately Sorted \\
\hline UNH-6A_305-307cm & Mud & Silt-Clay & Mud & Mud & Mud & Mud & Clay & Clay & Very Poorly Sorted \\
\hline UNH-9_6-8cm & Slightly Granuley & $\begin{array}{l}\text { Slightly Granuley Silty- } \\
\text { Clayey Very Fine Sand }\end{array}$ & $\begin{array}{l}\text { Slightly Gravelly } \\
\text { Muddy Sand }\end{array}$ & Silty Sand & $\begin{array}{l}\text { Slightly Very Fine Gravelly Very } \\
\text { Coarse Silty Very Fine Sand }\end{array}$ & $\begin{array}{l}\text { Slightly Granular Very Coarse } \\
\text { Silty Very Fine Sand }\end{array}$ & Coarse Silt & Coarse Silt & Very Poorly Sorted \\
\hline UNH-9_19-21cm & Sandy Mud & Very Fine Sandy Silt-Clay & Sandy Mud & Sandy Mud & Very Fine Sandy Mud & Very Fine Sandy Mud & Fine Silt & Fine Silt & Very Poorly Sorted \\
\hline UNH-9 $37-39 \mathrm{~cm}$ & Muddy Sand & Silty Very Fine Sand & Muddy Sand & Silty Sand & Very Coarse Silty Very Fine Sand & $\begin{array}{l}\text { Very Coarse Silty Very Fine } \\
\text { Sand }\end{array}$ & Very Coarse Silt & Very Coarse Silt & Poorly Sorted \\
\hline UNH-9_48-50cm & Mud & Silt-Clay & Mud & Mud & Mud & Mud & Very Fine Silt & Very Fine Silt & Very Poorly Sorted \\
\hline UNH-9_88-90cm & Mud & Silt-Clay & Mud & Mud & Mud & Mud & Very Fine Silt & Very Fine Silt & Very Poorly Sorted \\
\hline UNH-9_181-183cm & Slightly Granuley & $\begin{array}{l}\text { Slightly Granuley Silty Very } \\
\text { Fine Sand }\end{array}$ & $\begin{array}{l}\text { Slightly Gravelly } \\
\text { Muddy Sand }\end{array}$ & Silty Sand & $\begin{array}{l}\text { Slightly Very Fine Gravelly Very } \\
\text { Coarse Silty Very Fine Sand }\end{array}$ & $\begin{array}{l}\text { Slightly Granular Very Coarse } \\
\text { Silty Very Fine Sand }\end{array}$ & Very Coarse Silt & Very Coarse Silt & Very Poorly Sorted \\
\hline UNH-9_198-200cm & Mud & Silt-Clay & Mud & Mud & Mud & Mud & Fine Silt & Fine Silt & Very Poorly Sorted \\
\hline
\end{tabular}




\section{Vibracores UNH-6, UNH-6a, and UNH-9: Grain Size Statistics}

\begin{tabular}{|c|c|c|c|c|c|c|c|c|c|c|c|c|c|c|c|c|c|c|c|c|}
\hline UNH Sample ID & Gravel \% & Pebble \% & Granule \% & Sand $\%$ & Mud \% & Silt \% & Clay $\%$ & Modes & $\begin{array}{c}\text { Mode } 1 \\
\text { (phi) }\end{array}$ & $\begin{array}{c}\text { Mode } 2 \\
\text { (phi) }\end{array}$ & $\begin{array}{c}\text { Mode } 3 \\
\text { (phi) }\end{array}$ & $\begin{array}{c}\mathrm{D}_{10} \\
\text { (phi) }\end{array}$ & $\begin{array}{c}D_{10} \\
(\mathrm{~mm})\end{array}$ & $\begin{array}{c}D_{50} \\
\text { (phi) }\end{array}$ & $\begin{array}{c}D_{50} \\
(\mathrm{~mm})\end{array}$ & $\begin{array}{c}\text { Mean } \\
\text { Size } \\
\text { (phi) }\end{array}$ & $\begin{array}{c}\text { Mean } \\
\text { Size } \\
(\mathrm{mm})\end{array}$ & $\begin{array}{c}\text { Sorting } \\
\text { (phi) }\end{array}$ & Skewness & Kurtosis \\
\hline UNH-6_16-18cm & 0.53 & 0.00 & 0.53 & 96.80 & 2.67 & NA & NA & $u$ & 3.24 & NA & NA & 2.49 & 0.18 & 3.08 & 0.12 & 3.03 & 0.12 & 0.49 & -0.17 & 1.24 \\
\hline UNH-6_96-98cm & 0.00 & 0.00 & 0.00 & 91.42 & 8.58 & 8.28 & 0.30 & $u$ & 3.24 & NA & NA & 2.69 & 0.16 & 3.31 & 0.10 & 3.34 & 0.10 & 0.53 & 0.16 & 1.37 \\
\hline UNH-6_124-126cm & 0.00 & 0.00 & 0.00 & 77.24 & 22.76 & 22.25 & 0.51 & $u$ & 3.24 & NA & NA & 3.04 & 0.12 & 3.58 & 0.08 & 3.67 & 0.08 & 0.62 & 0.24 & 1.19 \\
\hline UNH-6 $\quad 152-154 \mathrm{~cm}$ & 0.00 & 0.00 & 0.00 & 91.66 & 8.34 & 8.12 & 0.22 & $u$ & 3.24 & NA & NA & 1.93 & 0.26 & 3.28 & 0.10 & 3.11 & 0.12 & 0.84 & -0.23 & 1.06 \\
\hline UNH-6_176-178cm & 0.00 & 0.00 & 0.00 & 1.13 & 98.87 & 30.58 & 68.29 & $u$ & 8.48 & NA & NA & 6.12 & 0.01 & 9.44 & 0.00 & 9.57 & 0.03 & 2.73 & 0.03 & 0.80 \\
\hline UNH-6A_20-22cm & 0.66 & 0.23 & 0.43 & 98.18 & 1.16 & NA & NA & $u$ & 2.74 & NA & NA & 1.90 & 0.27 & 2.72 & 0.15 & 2.69 & 0.16 & 0.62 & -0.24 & 1.67 \\
\hline UNH-6A_80-82 cm & 0.00 & 0.00 & 0.00 & 95.29 & 4.71 & NA & NA & $u$ & 2.74 & NA & NA & 2.28 & 0.21 & 2.86 & 0.14 & 2.91 & 0.13 & 0.51 & 0.18 & 1.19 \\
\hline UNH-6A_122-124cm & 0.00 & 0.00 & 0.00 & 94.15 & 5.85 & 4.72 & 1.13 & $u$ & 2.74 & NA & NA & 2.50 & 0.18 & 2.88 & 0.14 & 2.94 & 0.13 & 0.53 & 0.33 & 1.48 \\
\hline UNH-6A_192-194cm & 0.00 & 0.00 & 0.00 & 93.42 & 6.58 & 6.13 & 0.45 & $u$ & 2.74 & NA & NA & 2.52 & 0.17 & 3.05 & 0.12 & 3.08 & 0.12 & 0.55 & 0.19 & 1.20 \\
\hline UNH-6A_235-237cm & 0.00 & 0.00 & 0.00 & 95.37 & 4.63 & 4.32 & 0.31 & $u$ & 3.24 & NA & NA & 2.56 & 0.17 & 3.19 & 0.11 & 3.18 & 0.11 & 0.49 & -0.02 & 1.11 \\
\hline UNH-6A_298-300cm & 0.00 & 0.00 & 0.00 & 80.78 & 19.22 & 18.60 & 0.62 & $u$ & 3.73 & NA & NA & 2.66 & 0.16 & 3.54 & 0.09 & 3.58 & 0.08 & 0.70 & 0.06 & 1.48 \\
\hline UNH-6A_305-307cm & 0.00 & 0.00 & 0.00 & 2.42 & 97.58 & 37.27 & 60.31 & $u$ & 8.48 & NA & NA & 5.01 & 0.03 & 8.85 & 0.00 & 9.01 & 0.00 & 3.03 & 0.04 & 0.79 \\
\hline UNH-9_6-8cm & 0.06 & 0.00 & 0.06 & 51.76 & 48.18 & 31.57 & 16.61 & $u$ & 3.73 & NA & NA & 3.19 & 0.11 & 3.96 & 0.06 & 5.20 & 0.03 & 2.61 & 0.78 & 1.77 \\
\hline UNH-9_19-21cm & 0.00 & 0.00 & 0.00 & 17.67 & 82.33 & 34.33 & 48.00 & $u$ & 3.73 & NA & NA & 3.64 & 0.08 & 7.76 & 0.00 & 7.90 & 0.00 & 3.56 & 0.09 & 0.67 \\
\hline UNH-9_37-39cm & 0.00 & 0.00 & 0.00 & 65.99 & 34.01 & 23.19 & 10.82 & $u$ & 3.73 & NA & NA & 3.10 & 0.12 & 3.79 & 0.07 & 4.27 & 0.05 & 1.91 & 0.66 & 3.15 \\
\hline UNH-9.48-50cm & 0.00 & 0.00 & 0.00 & 9.01 & 90.99 & 44.28 & 46.71 & $u$ & 5.51 & NA & NA & 4.07 & 0.06 & 7.62 & 0.01 & 8.06 & 0.00 & 3.33 & 0.18 & 0.72 \\
\hline UNH-9_88-90cm & 0.00 & 0.00 & 0.00 & 5.66 & 94.34 & 35.85 & 58.49 & $u$ & 12.52 & NA & NA & 4.53 & 0.04 & 8.92 & 0.00 & 8.87 & 0.00 & 3.27 & -0.03 & 0.73 \\
\hline UNH-9_181-183cm & 0.14 & 0.00 & 0.14 & 60.67 & 39.19 & 28.22 & 10.97 & $u$ & 3.73 & NA & NA & 3.07 & 0.12 & 3.85 & 0.07 & 4.37 & 0.05 & 2.04 & 0.61 & 2.97 \\
\hline UNH-9_198-200cm & 0.00 & 0.00 & 0.00 & 7.98 & 92.02 & 48.11 & 43.91 & $u$ & 4.50 & NA & NA & 4.10 & 0.06 & 7.16 & 0.01 & 7.81 & 0.00 & 3.32 & 0.27 & 0.69 \\
\hline
\end{tabular}




\section{Vibracores UNH-6, UNH-6a, and UNH-9: Grain Size Distribution}

\begin{tabular}{|c|c|c|c|c|c|c|c|c|c|c|c|c|c|c|c|c|c|c|c|c|c|c|c|c|}
\hline UNH Sample ID & $\begin{array}{c}\text { Class \% } \\
\text { phi } \\
-3.5\end{array}$ & $\begin{array}{c}\text { Class \% } \\
\text { phi } \\
-3.0\end{array}$ & $\begin{array}{c}\text { Class \% } \\
\text { phi } \\
-2.5\end{array}$ & $\begin{array}{c}\text { Class \% } \\
\text { phi } \\
-2.0\end{array}$ & $\begin{array}{c}\text { Class \% } \\
\text { phi } \\
-1.5\end{array}$ & $\begin{array}{c}\text { Class \% } \\
\text { phi } \\
-1.0\end{array}$ & $\begin{array}{c}\text { Class \% } \\
\text { phi } \\
-0.5\end{array}$ & $\begin{array}{c}\text { Class \% } \\
\text { phi } \\
0.0\end{array}$ & $\begin{array}{c}\text { Class \% } \\
\text { phi } \\
0.5\end{array}$ & $\begin{array}{c}\text { Class \% } \\
\text { phi } \\
1.0\end{array}$ & $\begin{array}{c}\text { Class \% } \\
\text { phi } \\
1.5\end{array}$ & $\begin{array}{c}\text { Class \% } \\
\text { phi } \\
2.0\end{array}$ & $\begin{array}{c}\text { Class \% } \\
\text { phi } \\
2.5\end{array}$ & $\begin{array}{c}\text { Class \% } \\
\text { phi } \\
3.0\end{array}$ & $\begin{array}{c}\text { Class \% } \\
\text { phi } \\
3.5\end{array}$ & $\begin{array}{c}\text { Class \% } \\
\text { phi } \\
4.0 \\
\end{array}$ & $\begin{array}{c}\text { Class } \% \\
\text { phi } \\
>4.0\end{array}$ & $\begin{array}{c}\text { Class \% } \\
\text { phi } \\
5.0\end{array}$ & $\begin{array}{c}\text { Class \% } \\
\text { phi } \\
6.0\end{array}$ & $\begin{array}{c}\text { Class \% } \\
\text { phi } \\
7.0\end{array}$ & $\begin{array}{c}\text { Class \% } \\
\text { phi } \\
8.0 \\
\end{array}$ & $\begin{array}{c}\text { Class \% } \\
\text { phi } \\
9.0\end{array}$ & $\begin{array}{c}\text { Class \% } \\
\text { phi } \\
10.0\end{array}$ & $\begin{array}{c}\text { Class \% } \\
\text { phi } \\
>10.0\end{array}$ \\
\hline UNH-6_16-18cm & 0.00 & 0.00 & 0.00 & 0.00 & 0.45 & 0.08 & 0.09 & 0.10 & 0.22 & 0.49 & 1.15 & 2.24 & 4.14 & 32.93 & 46.18 & 9.27 & NA & 2.67 & 0.00 & 0.00 & 0.00 & 0.00 & 0.00 & 0.00 \\
\hline UNH-6_96-98cm & 0.00 & 0.00 & 0.00 & 0.00 & 0.00 & 0.00 & 0.02 & 0.01 & 0.06 & 0.16 & 0.38 & 1.04 & 2.07 & 15.39 & 47.88 & 24.40 & NA & 7.69 & 0.34 & 0.19 & 0.06 & 0.02 & 0.04 & 0.24 \\
\hline UNH-6_124-126cm & 0.00 & 0.00 & 0.00 & 0.00 & 0.00 & 0.00 & 0.00 & 0.05 & 0.02 & 0.06 & 0.14 & 0.42 & 0.90 & 5.70 & 35.65 & 34.30 & NA & 20.41 & 1.31 & 0.40 & 0.14 & 0.08 & 0.07 & 0.36 \\
\hline UNH-6_152-154cm & 0.00 & 0.00 & 0.00 & 0.00 & 0.00 & 0.00 & 0.04 & 0.09 & 0.10 & 0.37 & 1.79 & 8.93 & 10.97 & 10.61 & 29.29 & 29.48 & NA & 7.23 & 0.67 & 0.14 & 0.08 & 0.05 & 0.03 & 0.14 \\
\hline UNH-6_176-178cm & 0.00 & 0.00 & 0.00 & 0.00 & 0.00 & 0.00 & 0.00 & 0.00 & 0.00 & 0.01 & 0.03 & 0.12 & 0.19 & 0.22 & 0.19 & 0.37 & NA & 2.59 & 5.11 & 10.27 & 12.61 & 13.08 & 11.24 & 43.97 \\
\hline UNH-6A_20-22cm & 0.00 & 0.00 & 0.00 & 0.23 & 0.11 & 0.31 & 0.45 & 0.71 & 1.21 & 1.56 & 1.92 & 4.32 & 16.19 & 48.81 & 20.25 & 2.76 & 1.16 & NA & NA & NA & NA & NA & NA & $\mathrm{NA}$ \\
\hline UNH-6A_80-82cm & 0.00 & 0.00 & 0.00 & 0.00 & 0.00 & 0.00 & 0.01 & 0.00 & 0.02 & 0.07 & 0.25 & 2.00 & 12.83 & 47.44 & 26.16 & 6.52 & 4.71 & NA & NA & NA & NA & NA & NA & NA \\
\hline UNH-6A_122-124cm & 0.00 & 0.00 & 0.00 & 0.00 & 0.00 & 0.00 & 0.00 & 0.01 & 0.02 & 0.07 & 0.20 & 0.81 & 34 & 1.76 & 26.78 & 5.15 & NA & 2.10 & 1.06 & 0.90 & 0.66 & 0.48 & 0.27 & 0.39 \\
\hline UNH-6A_192-194cm & 0.00 & 0.00 & 0.00 & 0.00 & 0.00 & 0.00 & 0.02 & 0.01 & 0.02 & 0.0 & 0.18 & 0. & 5.7 & .75 & 34.08 & 12.71 & $\mathrm{~N}$ & 5.08 & 0.66 & 0.39 & .08 & 0.17 & 0.04 & 0.16 \\
\hline UNH-6A_235-237cm & 0.00 & 0.00 & 0.00 & 0.00 & 0.00 & 0.00 & 0.0 & 0.01 & 0.03 & 0.1 & 0. & 1. & 3.68 & 25.80 & 45.25 & 18.61 & $\mathrm{NA}$ & 3.86 & 30 & 0.11 & .05 & 0.10 & 0.03 & 0.18 \\
\hline UNH-6A_298-300 cm & 0.00 & 0.00 & 0.00 & 0.00 & 0.00 & 0.00 & 0.0 & 0.02 & 0. & 0.1 & 0. & 2.56 & 4.01 & 56 & 0.77 & 35.11 & NA & 16.00 & 1.96 & 45 & .20 & 0.10 & 0.24 & 0.28 \\
\hline UNH-6A_305-307cm & 0.00 & 0.00 & 0.00 & 0.00 & 0.00 & 0.00 & 0.00 & 0.00 & 0.00 & 0.0 & 0. & 0. & 0.16 & 0 & 0.40 & 1.58 & NA & 7.62 & 7.45 & 11.20 & 11.00 & 11.72 & 9.80 & 38.79 \\
\hline UNH-9.6-8cm & 0.00 & 0.00 & 0.00 & 0.00 & 0.00 & 0.06 & 0.02 & 0.10 & 0.10 & 0.23 & 0.54 & 1.11 & 1.16 & 1.56 & 12.73 & 34.21 & $\mathrm{NA}$ & 18.75 & 6.02 & 4.04 & 2.77 & 2.71 & 2.35 & 11.55 \\
\hline UNH-9_19-21cm & 0.00 & 0.00 & 0.00 & 0.00 & .00 & 0.00 & 0.04 & 0.04 & 05 & 0.06 & 0.16 & 42 & 13 & 63 & .69 & 1.16 & Ne & 0.88 & 29 & 7.88 & 8.28 & 8.71 & 7.29 & 32.00 \\
\hline UNH-9 $37-39 \mathrm{~cm}$ & 0.00 & 0.00 & 0.00 & 0.00 & 0.00 & 0.00 & 0.00 & 0.05 & 0.18 & 0.30 & 0.68 & 1.47 & 1.47 & 2.00 & 17.65 & 42.19 & NA & 15.28 & 3.65 & 2.30 & 1.96 & 1.86 & 1.90 & 7.06 \\
\hline UNH-9.48-50cm & 0.00 & 0.00 & 0.00 & 0.00 & 0.00 & 0.00 & 0.00 & 0.02 & 0.07 & 0.13 & 0.20 & 0.31 & 0.23 & 0.44 & 1.92 & 5.70 & NA & 12.04 & 14.75 & 9.01 & 8.49 & 8.08 & 7.13 & 31.50 \\
\hline UNH-9 $88-90 \mathrm{~cm}$ & 0.00 & 0.00 & 0.00 & 0.00 & 0.00 & 0.00 & 0.00 & 0.01 & 0.01 & 0.01 & 0.03 & 0.06 & 0.08 & 0.21 & 1.35 & 3.90 & NA & 8.26 & 9.71 & 8.79 & 9.08 & 8.91 & 8.21 & 41.37 \\
\hline UNH-9 $181-183 \mathrm{~cm}$ & 0.00 & 0.00 & 0.00 & 0.00 & 0.00 & 0.14 & 0.07 & 0.05 & 0.13 & 0.37 & 1.05 & 2.20 & 1.94 & 2.09 & 13.53 & 39.24 & $\mathrm{NA}$ & 18.71 & 4.59 & 2.90 & 2.02 & 1.79 & 1.90 & 7.28 \\
\hline UNH-9_198-200cm & 0.00 & 0.00 & 0.00 & 0.00 & 0.00 & 0.00 & 0.00 & 0.01 & 0.01 & 0.05 & 0.07 & 0.14 & 0.15 & 0.42 & 1.23 & 5.90 & NA & 19.25 & 13.32 & 8.28 & 7.25 & 7.67 & 6.56 & 29.69 \\
\hline
\end{tabular}


Section 4: Vibracores UNH-10, UNH-13 and UNH-14 
Vibracores UNH-10, UNH-13, and UNH-14: Identification, Location, and Description

\begin{tabular}{|c|c|c|c|c|c|c|c|c|c|c|c|c|c|c|}
\hline UNH Sample ID & $\begin{array}{l}\text { Global Core } \\
\text { Link ID }\end{array}$ & BOEM Global Sample ID & $\begin{array}{c}\text { Latitude } \\
\text { NAD83 }\end{array}$ & $\begin{array}{c}\text { Longitude } \\
\text { NAD83 }\end{array}$ & $\begin{array}{c}\text { Position } \\
\text { Uncertainty }\end{array}$ & $\begin{array}{c}\text { Water } \\
\text { Depth }(\mathrm{m})\end{array}$ & $\begin{array}{l}\text { Diameter } \\
(\mathrm{cm})\end{array}$ & $\begin{array}{l}\text { Core Length } \\
\text { (m) }\end{array}$ & $\begin{array}{l}\text { Vibracore } \\
\text { Collected }\end{array}$ & $\begin{array}{l}\text { Sample } \\
\text { Depth } \\
\text { (cm) }\end{array}$ & $\begin{array}{c}\text { Total Wt } \\
(\mathrm{gm})\end{array}$ & $\begin{array}{c}\text { Munsell } \\
\text { Hue }\end{array}$ & $\begin{array}{c}\text { Munsell } \\
\text { Value }\end{array}$ & $\begin{array}{l}\text { Munsell } \\
\text { Chroma }\end{array}$ \\
\hline UNH-10_24-26cm & ATTW84-UNH-10 & ATTW84-UNH-10_24-26cm_D19841011 & 42.9433 & -70.5700 & $250 \mathrm{~m}$ & 70.0 & 8.9 & 7.40 & $10 / 11 / 1984$ & $24-26$ & 23.62 & $5 \mathrm{G}$ & 4 & 2 \\
\hline UNH-10_120-122cm & ATTW84-UNH-10 & ATTW84-UNH-10_120-122cm_D19841011 & 42.9433 & -70.5700 & $250 \mathrm{~m}$ & 70.0 & 8.9 & 7.40 & $10 / 11 / 1984$ & $120-122$ & 12.81 & $5 G$ & 4 & 2 \\
\hline UNH-10_152-154cm & ATTW84-UNH-10 & ATTW84-UNH-10_152-154cm_D19841011 & 42.9433 & -70.5700 & $250 \mathrm{~m}$ & 70.0 & 8.9 & 7.40 & $10 / 11 / 1984$ & $152-154$ & 21.75 & $5 G Y$ & 3 & 2 \\
\hline UNH-10_268-270cm & ATTW84-UNH-10 & ATTW84-UNH-10_268-270cm_D19841011 & 42.9433 & -70.5700 & $250 \mathrm{~m}$ & 70.0 & 8.9 & 7.40 & $10 / 11 / 1984$ & $268-270$ & 18.92 & $5 \mathrm{GY}$ & 3 & 2 \\
\hline UNH-13 $25-27 \mathrm{~cm}$ & ATTW84-UNH-13 & ATTW84-UNH-13_25-27cm_D19841011 & 42.9850 & -70.6700 & $250 \mathrm{~m}$ & 28.0 & 8.9 & 6.41 & $10 / 12 / 1984$ & $25-27$ & 84.78 & $5 \mathrm{GY}$ & 4 & 2 \\
\hline UNH-13_65-67cm & ATTW84-UNH-13 & ATTW84-UNH-13_65-67cm_D19841011 & 42.9850 & -70.6700 & $250 \mathrm{~m}$ & 28.0 & 8.9 & 6.41 & $10 / 12 / 1984$ & $65-67$ & 109.67 & $5 G Y$ & 4 & 2 \\
\hline UNH-13_93-95cm & ATTW84-UNH-13 & ATTW84-UNH-13_93-95cm_D19841011 & 42.9850 & -70.6700 & $250 \mathrm{~m}$ & 28.0 & 8.9 & 6.41 & $10 / 12 / 1984$ & $93-95$ & 49.38 & $5 \mathrm{GY}$ & 4 & 2 \\
\hline UNH-13_139-141cm & ATTW84-UNH-13 & ATTW84-UNH-13_139-141cm_D19841011 & 42.9850 & -70.6700 & $250 \mathrm{~m}$ & 28.0 & 8.9 & 6.41 & $10 / 12 / 1984$ & $139-141$ & 53.31 & $5 G Y$ & 4 & 2 \\
\hline UNH-13 $161-163 \mathrm{~cm}$ & ATTW84-UNH-13 & ATTW84-UNH-13_161-163cm_D19841011 & 42.9850 & -70.6700 & $250 \mathrm{~m}$ & 28.0 & 8.9 & 6.41 & $10 / 12 / 1984$ & $161-163$ & 13.21 & $5 \mathrm{GY}$ & 4 & 2 \\
\hline UNH-13_182-184cm & ATTW84-UNH-13 & ATTW84-UNH-13_182-184cm_D19841011 & 42.9850 & -70.6700 & $250 \mathrm{~m}$ & 28.0 & 8.9 & 6.41 & $10 / 12 / 1984$ & $182-184$ & 25.51 & $5 \mathrm{GY}$ & 4 & 2 \\
\hline UNH-13_252-254cm & ATTW84-UNH-13 & ATTW84-UNH-13_252-254cm_D19841011 & 42.9850 & -70.6700 & $250 \mathrm{~m}$ & 28.0 & 8.9 & 6.41 & $10 / 12 / 1984$ & $252-254$ & 29.71 & $5 \mathrm{GY}$ & 4 & 2 \\
\hline UNH-13_286-288cm & ATTW84-UNH-13 & ATTW84-UNH-13_286-288cm_D19841011 & 42.9850 & -70.6700 & $250 \mathrm{~m}$ & 28.0 & 8.9 & 6.41 & $10 / 12 / 1984$ & $286-288$ & 35.20 & $5 G Y$ & 4 & 2 \\
\hline UNH-13_316-318cm & ATTW84-UNH-13 & ATTW84-UNH-13_316-318cm_D19841011 & 42.9850 & -70.6700 & $250 \mathrm{~m}$ & 28.0 & 8.9 & 6.41 & $10 / 12 / 1984$ & 316-318 & 11.70 & $5 \mathrm{GY}$ & 4 & 2 \\
\hline UNH-13 $423-425 \mathrm{~cm}$ & ATTW84-UNH-13 & ATTW84-UNH-13_423-425cm_D19841011 & 42.9850 & -70.6700 & $250 \mathrm{~m}$ & 28.0 & 8.9 & 6.41 & $10 / 12 / 1984$ & $423-425$ & 34.84 & $5 G Y$ & 4 & 2 \\
\hline UNH-13_573-575cm & ATTW84-UNH-13 & ATTW84-UNH-13_573-575cm_D19841011 & 42.9850 & -70.6700 & $250 \mathrm{~m}$ & 28.0 & 8.9 & 6.41 & $10 / 12 / 1984$ & 573-575 & 11.43 & $5 G Y$ & 4 & 2 \\
\hline UNH-14_8-10 cm & ATTW84-UNH-14 & ATTW84-UNH-14_8-10cm_D19841011 & 42.9283 & -70.7600 & $250 \mathrm{~m}$ & 23.0 & 8.9 & 7.87 & $10 / 12 / 1984$ & $8-10$ & 59.20 & $10 Y R$ & 6 & 6 \\
\hline UNH-14_54-56cm & ATTW84-UNH-14 & ATTW84-UNH-14_54-56cm_D19841011 & 42.9283 & -70.7600 & $250 \mathrm{~m}$ & 23.0 & 8.9 & 7.87 & $10 / 12 / 1984$ & $54-56$ & 53.30 & $5 Y$ & 7 & 2 \\
\hline UNH-14_72-74 cm & ATTW84-UNH-14 & ATTW84-UNH-14_72-74cm_D19841011 & 42.9283 & -70.7600 & $250 \mathrm{~m}$ & 23.0 & 8.9 & 7.87 & $10 / 12 / 1984$ & 72-74 & 21.14 & $10 \mathrm{YR}$ & 2 & 2 \\
\hline UNH-14_115-117cm & ATTW84-UNH-14 & ATTW84-UNH-14_115-117cm_D19841011 & 42.9283 & -70.7600 & $250 \mathrm{~m}$ & 23.0 & 8.9 & 7.87 & $10 / 12 / 1984$ & $115-117$ & 46.59 & $10 \mathrm{YR}$ & 2 & 2 \\
\hline UNH-14_183-185cm & ATTW84-UNH-14 & ATTW84-UNH-14_183-185cm_D19841011 & 42.9283 & -70.7600 & $250 \mathrm{~m}$ & 23.0 & 8.9 & 7.87 & $10 / 12 / 1984$ & 183-185 & 67.09 & $5 Y$ & 5 & 2 \\
\hline UNH-14_196-198cm & ATTW84-UNH-14 & ATTW84-UNH-14_196-198cm_D19841011 & 42.9283 & -70.7600 & $250 \mathrm{~m}$ & 23.0 & 8.9 & 7.87 & $10 / 12 / 1984$ & 196-198 & 39.61 & $5 Y$ & 5 & 2 \\
\hline UNH-14_232-234cm & ATTW84-UNH-14 & ATTW84-UNH-14_232-234cm_D19841011 & 42.9283 & -70.7600 & $250 \mathrm{~m}$ & 23.0 & 8.9 & 7.87 & $10 / 12 / 1984$ & $232-234$ & 42.62 & $5 Y$ & 5 & 2 \\
\hline UNH-14_248-250cm & ATTW84-UNH-14 & ATTW84-UNH-14_248-250cm_D19841011 & 42.9283 & -70.7600 & $250 \mathrm{~m}$ & 23.0 & 8.9 & 7.87 & $10 / 12 / 1984$ & $248-250$ & 38.97 & $5 \mathrm{GY}$ & 3 & 2 \\
\hline
\end{tabular}




\section{Vibracores UNH-10, UNH-13, and UNH-14: Sediment Classifications}

\begin{tabular}{|c|c|c|c|c|c|c|c|c|c|}
\hline UNH Sample ID & $\begin{array}{l}\text { CMECS Substrate } \\
\text { Component Group } \\
\text { (Specific) }\end{array}$ & $\begin{array}{l}\text { CMECS Substrate } \\
\text { Component Subgroup } \\
\text { (Specific) }\end{array}$ & $\begin{array}{l}\text { Textural Group from } \\
\% G S M \text { (Gradistat) }\end{array}$ & $\begin{array}{l}\text { Textural Group } \\
\text { from } \% \text { SZC } \\
\text { (Gradistat) } \\
\text { Ignores Gravel }\end{array}$ & $\begin{array}{l}\text { Sediment Name from \%GSM } \\
\text { and Mode (Gradistat) }\end{array}$ & $\begin{array}{l}\text { Sediment Name from \%GSM } \\
\text { and Mode (Wentworth Scale) }\end{array}$ & $\begin{array}{l}\text { Sediment } \\
\text { Classification } \\
\text { from Mean Phi } \\
\text { (Gradistat) }\end{array}$ & $\begin{array}{l}\text { Sediment } \\
\text { Classification } \\
\text { from Mean Phi } \\
\text { (Wentworth) }\end{array}$ & Sorting (Gradistat) \\
\hline UNH-10_24-26cm & Sandy Mud & Very Fine Sandy Silt-Clay & Sandy Mud & Sandy Mud & Very Fine Sandy Mud & Very Fine Sandy Mud & Fine Silt & Fine Silt & Very Poorly Sorted \\
\hline UNH-10_120-122cm & Mud & Silt-Clay & Mud & Silt & Very Coarse Silt & Very Coarse Silt & Fine Silt & Fine Silt & Very Poorly Sorted \\
\hline UNH-10_152-154cm & Mud & Silt-Clay & Mud & Mud & Mud & Mud & Very Fine Silt & Very Fine Silt & Very Poorly Sorted \\
\hline UNH-10_268-270cm & Mud & Silt-Clay & Mud & Mud & Mud & Mud & Very Fine Silt & Very Fine Silt & Very Poorly Sorted \\
\hline UNH-13 $25-27 \mathrm{~cm}$ & Slightly Granuley & Slightly Granuley Fine Sand & Slightly Gravelly Sand & Sand & $\begin{array}{l}\text { Slightly Very Fine Gravelly Fine } \\
\text { Sand }\end{array}$ & Slightly Granular Fine Sand & Fine Sand & Fine Sand & Moderately Sorted \\
\hline UNH-13_65-67cm & Sand & Fine Sand & Sand & Sand & Moderately Well Sorted Fine Sand & Fine Sand & Fine Sand & Fine Sand & $\begin{array}{l}\text { Moderately Well } \\
\text { Sorted }\end{array}$ \\
\hline UNH-13_93-95cm & Sand & Fine Sand & Sand & Sand & Moderately Sorted Fine Sand & Fine Sand & Fine Sand & Fine Sand & Moderately Sorted \\
\hline UNH-13 $139-141 \mathrm{~cm}$ & Slightly Pebbly & $\begin{array}{l}\text { Slightly Pebbly Silty-Clayey } \\
\text { Fine Sand }\end{array}$ & $\begin{array}{l}\text { Slightly Gravelly } \\
\text { Muddy Sand }\end{array}$ & Muddy Sand & $\begin{array}{l}\text { Slightly Fine Gravelly Muddy Fine } \\
\text { Sand }\end{array}$ & $\begin{array}{l}\text { Slightly Pebbly Muddy Fine } \\
\text { Sand }\end{array}$ & Fine Sand & Fine Sand & Poorly Sorted \\
\hline UNH-13 $161-163 \mathrm{~cm}$ & Sandy Mud & Very Fine Sandy Silt-Clay & Sandy Mud & Sandy Mud & Very Fine Sandy Mud & Very Fine Sandy Mud & Fine Silt & Fine Silt & Very Poorly Sorted \\
\hline UNH-13_182-184cm & Sligh & $\begin{array}{l}\text { Slightly Granuley Very Fine } \\
\text { Sandy Silt-Clay }\end{array}$ & $\begin{array}{l}\text { Slightly Gravelly } \\
\text { Sandy Mud }\end{array}$ & Sandy Mud & $\begin{array}{l}\text { Slightly Very Fine Gravelly Very } \\
\text { Fine Sandy Mud }\end{array}$ & $\begin{array}{l}\text { Slightly Granular Very Fine } \\
\text { Sandy Mud }\end{array}$ & Coarse Silt & Coarse Silt & Very Poorly Sorted \\
\hline UNH-13 $252-254 \mathrm{~cm}$ & Slightly Granuley & $\begin{array}{l}\text { Slightly Granuley Very Fine } \\
\text { Sandy Silt-Clay }\end{array}$ & $\begin{array}{l}\text { Slightly Gravelly } \\
\text { Sandy Mud }\end{array}$ & Sandy Mud & $\begin{array}{l}\text { Slightly Very Fine Gravelly Very } \\
\text { Fine Sandy Mud }\end{array}$ & $\begin{array}{l}\text { Slightly Granular Very Fine } \\
\text { Sandy Mud }\end{array}$ & Very Fine Silt & Very Fine Silt & Very Poorly Sorted \\
\hline UNH-13_286-288cm & Slightly Pebbly & $\begin{array}{l}\text { Slightly Pebbly Silty-Clayey } \\
\text { Fine Sand }\end{array}$ & $\begin{array}{l}\text { Slightly Gravelly } \\
\text { Muddy Sand }\end{array}$ & Muddy Sand & $\begin{array}{l}\text { Slightly Fine Gravelly Muddy Fine } \\
\text { Sand }\end{array}$ & $\begin{array}{l}\text { Slightly Pebbly Muddy Fine } \\
\text { Sand }\end{array}$ & Very Fine Sand & Very Fine Sand & Very Poorly Sorted \\
\hline UNH-13_316-318cm & Sandy Mud & Very Fine Sandy Silt-Clay & Sandy Mud & Sandy Mud & Very Fine Sandy Mud & Very Fine Sandy Mud & Fine Silt & Fine Silt & Very Poorly Sorted \\
\hline UNH-13_423-425cm & Mud & Silt-Clay & Mud & Mud & Mud & Mud & Very Fine Silt & Very Fine Silt & Very Poorly Sorted \\
\hline UNH-13_573-575cm & Mud & Silt-Clay & Mud & Mud & Mud & Mud & Very Fine Silt & Very Fine Silt & Very Poorly Sorted \\
\hline UNH-14_8-10cm & Sand & Fine Sand & Sand & Sand & Moderately Well Sorted Fine Sand & Fine Sand & Fine Sand & Fine Sand & $\begin{array}{l}\text { Moderately Well } \\
\text { Sorted }\end{array}$ \\
\hline UNH-14_54-56cm & Sand & Fine Sand & Sand & Sand & Well Sorted Fine Sand & Fine Sand & Fine Sand & Fine Sand & Well Sorted \\
\hline UNH-14_72-74cm & Muddy Sand & Silty Very Fine Sand & Muddy Sand & Silty Sand & Very Coarse Silty Very Fine Sand & $\begin{array}{l}\text { Very Coarse Silty Very Fine } \\
\text { Sand }\end{array}$ & Very Fine Sand & Very Fine Sand & Poorly Sorted \\
\hline UNH-14_115-117cm & Sand & Fine Sand & Sand & Sand & Moderately Well Sorted Fine Sand & Fine Sand & Fine Sand & Fine Sand & $\begin{array}{l}\text { Moderately Well } \\
\text { Sorted }\end{array}$ \\
\hline UNH-14_183-185cm & Slightly Pebbly & Slightly Pebbly Fine Sand & Slightly Gravelly Sand & Sand & Slightly Fine Gravelly Fine Sand & Slightly Pebbly Fine Sand & Fine Sand & Fine Sand & Well Sorted \\
\hline UNH-14_196-198cm & Sand & Fine Sand & Sand & Sand & Well Sorted Fine Sand & Fine Sand & Fine Sand & Fine Sand & Well Sorted \\
\hline UNH-14_232-234cm & Slightly Granuley & Slightly Granuley Fine Sand & Slightly Gravelly Sand & Sand & $\begin{array}{l}\text { Slightly Very Fine Gravelly Fine } \\
\text { Sand }\end{array}$ & Slightly Granular Fine Sand & Fine Sand & Fine Sand & Well Sorted \\
\hline UNH-14_248-250cm & & Very Fine Sandy Silt-Clay & Sandy Mud & Sandy Mud & Very Fine Sandy Mud & Very Fine Sandy Mud & Fine Silt & Fine Silt & Very Poorly Sorted \\
\hline
\end{tabular}




\section{Vibracores UNH-10, UNH-13, and UNH-14: Grain Size Statistics}

\begin{tabular}{|c|c|c|c|c|c|c|c|c|c|c|c|c|c|c|c|c|c|c|c|c|}
\hline UNH Sample ID & Gravel\% & Pebble \% & Granule \% & Sand \% & Mud \% & Silt \% & Clay \% & Modes & $\begin{array}{c}\text { Mode } 1 \\
\text { (phi) }\end{array}$ & $\begin{array}{c}\text { Mode } 2 \\
\text { (phi) }\end{array}$ & $\begin{array}{c}\text { Mode } 3 \\
\text { (phi) }\end{array}$ & $\begin{array}{c}\mathrm{D}_{10} \\
\text { (phi) }\end{array}$ & $\begin{array}{c}D_{10} \\
(\mathrm{~mm})\end{array}$ & $\begin{array}{c}\text { D }_{50} \\
\text { (phi) }\end{array}$ & $\begin{array}{c}D_{50} \\
(\mathrm{~mm})\end{array}$ & $\begin{array}{c}\text { Mean } \\
\text { Size } \\
(\mathrm{phi})\end{array}$ & $\begin{array}{c}\text { Mean } \\
\text { Size } \\
(\mathrm{mm})\end{array}$ & $\begin{array}{c}\text { Sorting } \\
\text { (phi) }\end{array}$ & Skewness & Kurtosis \\
\hline UNH-10_24-26cm & 0.00 & 0.00 & 0.00 & 21.86 & 78.14 & 29.97 & 48.17 & u & 3.73 & NA & NA & 3.57 & 0.08 & 7.80 & 0.00 & 7.89 & 0.00 & 3.61 & 0.07 & 0.64 \\
\hline UNH-10_120-122cm & 0.00 & 0.00 & 0.00 & 4.44 & 95.56 & 59.14 & 36.42 & $u$ & 4.50 & NA & NA & 4.19 & 0.05 & 6.39 & 0.01 & 7.38 & 0.01 & 3.12 & 0.45 & 0.75 \\
\hline UNH-10_152-154cm & 0.00 & 0.00 & 0.00 & 5.32 & 94.68 & 38.88 & 55.80 & $u$ & 4.50 & 8.48 & NA & 4.40 & 0.05 & 8.54 & 0.00 & 8.59 & 0.00 & 3.30 & 0.03 & 0.71 \\
\hline UNH-10_268-270cm & 0.00 & 0.00 & 0.00 & 2.53 & 97.47 & 39.48 & 57.99 & $u$ & 7.50 & NA & NA & 4.78 & 0.04 & 8.76 & 0.00 & 8.84 & 0.00 & 3.12 & 0.03 & 0.77 \\
\hline UNH-13 $25-27 \mathrm{~cm}$ & 0.02 & 0.00 & 0.02 & 92.44 & 7.54 & 5.06 & 2.48 & $u$ & 2.74 & NA & NA & 2.21 & 0.22 & 2.80 & 0.14 & 2.87 & 0.14 & 0.76 & 0.39 & 2.65 \\
\hline UNH-13_65-67cm & 0.00 & 0.00 & 0.00 & 93.90 & 6.10 & 3.08 & 3.02 & $u$ & 2.74 & NA & NA & 2.26 & 0.21 & 2.79 & 0.14 & 2.86 & 0.14 & 0.63 & 0.34 & 2.36 \\
\hline UNH-13_93-95cm & 0.00 & 0.00 & 0.00 & 90.95 & 9.05 & 5.05 & 4.00 & $u$ & 2.74 & NA & NA & 2.28 & 0.21 & 2.88 & 0.14 & 2.94 & 0.13 & 0.95 & 0.41 & 2.90 \\
\hline UNH-13_139-141cm & 0.12 & 0.12 & 0.00 & 87.05 & 12.83 & 6.79 & 6.04 & $u$ & 2.74 & NA & NA & 2.17 & 0.22 & 2.85 & 0.14 & 2.95 & 0.13 & 1.36 & 0.50 & 4.19 \\
\hline UNH-13_161-163cm & 0.00 & 0.00 & 0.00 & 20.74 & 79.26 & 36.30 & 42.96 & $u$ & 3.73 & NA & NA & 3.27 & 0.10 & 6.85 & 0.01 & 7.44 & 0.01 & 3.61 & 0.23 & 0.69 \\
\hline UNH-13 $182-184 \mathrm{~cm}$ & 0.25 & 0.00 & 0.25 & 43.47 & 56.28 & 32.91 & 23.37 & $u$ & 3.24 & NA & NA & 2.66 & 0.16 & 4.40 & 0.05 & 5.74 & 0.02 & 3.32 & 0.58 & 0.98 \\
\hline UNH-13_252-254cm & 0.59 & 0.00 & 0.59 & 11.41 & 88.00 & 40.78 & 47.22 & $u$ & 5.51 & NA & NA & 3.78 & 0.07 & 7.69 & 0.00 & 8.03 & 0.00 & 3.47 & 0.13 & 0.73 \\
\hline UNH-13_286-288cm & 1.05 & 0.90 & 0.15 & 75.75 & 23.20 & 12.84 & 10.36 & $u$ & 2.74 & NA & NA & 2.06 & 0.24 & 3.03 & 0.12 & 3.74 & 0.08 & 2.25 & 0.67 & 3.19 \\
\hline UNH-13_316-318cm & 0.00 & 0.00 & 0.00 & 25.33 & 74.67 & 36.67 & 38.00 & $u$ & 3.73 & NA & NA & 2.87 & 0.14 & 6.44 & 0.01 & 7.08 & 0.01 & 3.66 & 0.25 & 0.73 \\
\hline UNH-13_423-425cm & 0.00 & 0.00 & 0.00 & 7.30 & 92.70 & 41.16 & 51.54 & $u$ & 8.48 & NA & NA & 4.32 & 0.05 & 8.13 & 0.00 & 8.37 & 0.00 & 3.23 & 0.08 & 0.82 \\
\hline UNH-13_573-575cm & 0.00 & 0.00 & 0.00 & 9.60 & 90.40 & 35.57 & 54.83 & $u$ & 7.50 & 2.74 & NA & 4.08 & 0.06 & 8.44 & 0.00 & 8.60 & 0.00 & 3.36 & 0.00 & 0.88 \\
\hline UNH-14_8-10cm & 0.00 & 0.00 & 0.00 & 98.84 & 1.16 & NA & NA & $u$ & 2.74 & NA & NA & 1.70 & 0.31 & 2.66 & 0.16 & 2.63 & 0.16 & 0.65 & -0.09 & 1.06 \\
\hline UNH-14_54-56cm & 0.00 & 0.00 & 0.00 & 97.20 & 2.80 & NA & NA & $u$ & 2.74 & NA & NA & 2.18 & 0.22 & 2.74 & 0.15 & 2.75 & 0.15 & 0.44 & 0.07 & 1.38 \\
\hline UNH-14_72-74cm & 0.00 & 0.00 & 0.00 & 64.64 & 35.36 & 30.70 & 4.66 & $u$ & 3.24 & NA & NA & 2.38 & 0.19 & 3.51 & 0.09 & 3.88 & 0.07 & 1.62 & 0.43 & 1.27 \\
\hline UNH-14_115-117cm & 0.00 & 0.00 & 0.00 & 93.12 & 6.88 & 6.32 & 0.56 & $u$ & 2.74 & NA & NA & 2.19 & 0.22 & 2.79 & 0.14 & 2.84 & 0.14 & 0.62 & 0.26 & 1.60 \\
\hline UNH-14_183-185cm & 0.44 & 0.44 & 0.00 & 96.41 & 3.15 & NA & NA & $u$ & 2.74 & NA & NA & 2.10 & 0.23 & 2.67 & 0.16 & 2.63 & 0.16 & 0.42 & -0.04 & 1.12 \\
\hline UNH-14_196-198cm & 0.00 & 0.00 & 0.00 & 98.26 & 1.74 & NA & NA & $u$ & 2.74 & NA & NA & 1.95 & 0.26 & 2.53 & 0.17 & 2.51 & 0.18 & 0.47 & -0.08 & 1.12 \\
\hline UNH-14 $232-234 \mathrm{~cm}$ & 0.12 & 0.00 & 0.12 & 96.90 & 2.98 & NA & NA & $u$ & 2.74 & NA & NA & 2.05 & 0.24 & 2.60 & 0.17 & 2.55 & 0.17 & 0.42 & -0.12 & 1.10 \\
\hline UNH-14_248-250cm & 0.00 & 0.00 & 0.00 & 10.02 & 89.98 & 49.32 & 40.66 & $u$ & 5.51 & NA & NA & 3.99 & 0.06 & 7.19 & 0.01 & 7.64 & 0.01 & 3.21 & 0.18 & 0.98 \\
\hline
\end{tabular}




\section{Vibracores UNH-10, UNH-13, and UNH-14: Grain Size Distribution}

\begin{tabular}{|c|c|c|c|c|c|c|c|c|c|c|c|c|c|c|c|c|c|c|c|c|c|c|c|c|}
\hline UNH Sample ID & $\begin{array}{c}\text { Class \% } \\
\text { phi } \\
-3.5 \\
\end{array}$ & $\begin{array}{c}\text { Class \% } \\
\text { phi } \\
-3.0 \\
\end{array}$ & $\begin{array}{c}\text { Class \% } \\
\text { phi } \\
-2.5 \\
\end{array}$ & $\begin{array}{c}\text { Class \% } \\
\text { phi } \\
-2.0 \\
\end{array}$ & $\begin{array}{c}\text { Class \% } \\
\text { phi } \\
-1.5 \\
\end{array}$ & $\begin{array}{c}\text { Class \% } \\
\text { phi } \\
-1.0 \\
\end{array}$ & $\begin{array}{c}\text { Class \% } \\
\text { phi } \\
-0.5 \\
\end{array}$ & $\begin{array}{c}\text { Class \% } \\
\text { phi } \\
0.0 \\
\end{array}$ & $\begin{array}{c}\text { Class \% } \\
\text { phi } \\
0.5 \\
\end{array}$ & $\begin{array}{c}\text { Class \% } \\
\text { phi } \\
1.0 \\
\end{array}$ & $\begin{array}{c}\text { Class \% } \\
\text { phi } \\
1.5 \\
\end{array}$ & $\begin{array}{c}\text { Class \% } \\
\text { phi } \\
2.0 \\
\end{array}$ & $\begin{array}{c}\text { Class \% } \\
\text { phi } \\
2.5 \\
\end{array}$ & $\begin{array}{c}\text { Class \% } \\
\text { phi } \\
3.0 \\
\end{array}$ & $\begin{array}{c}\text { Class \% } \\
\text { phi } \\
3.5 \\
\end{array}$ & $\begin{array}{c}\text { Class \% } \\
\text { phi } \\
4.0 \\
\end{array}$ & $\begin{array}{c}\text { Class \% } \\
\text { phi } \\
>4.0 \\
\end{array}$ & $\begin{array}{c}\text { Class \% } \\
\text { phi } \\
5.0 \\
\end{array}$ & $\begin{array}{c}\text { Class \% } \\
\text { phi } \\
6.0 \\
\end{array}$ & $\begin{array}{c}\text { Class \% } \\
\text { phi } \\
7.0 \\
\end{array}$ & $\begin{array}{c}\text { Class \% } \\
\text { phi } \\
8.0 \\
\end{array}$ & $\begin{array}{c}\text { Class \% } \\
\text { phi } \\
9.0 \\
\end{array}$ & $\begin{array}{c}\text { Class \% } \\
\text { phi } \\
10.0 \\
\end{array}$ & 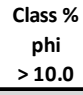 \\
\hline UNH-10_24-26cm & 0.00 & 0.00 & 0.00 & 0.00 & 0.00 & 0.00 & 0.00 & 0.01 & 0.03 & 0.04 & 0.05 & 0.13 & 0.19 & 0.92 & 5.84 & 14.65 & NA & 5.99 & 6.98 & 7.96 & 9.04 & 7.87 & 7.09 & 33.21 \\
\hline UNH-10_120-122cm & 0.00 & 0.00 & 0.00 & 0.00 & 0.00 & 0.00 & 0.00 & 0.02 & 0.02 & 0.02 & 0.04 & 0.08 & 0.10 & 0.26 & 0.92 & 2.98 & NA & 28.30 & 13.58 & 9.41 & 7.85 & 7.10 & 5.43 & 23.89 \\
\hline UNH-10_152-154cm & 0.00 & 0.00 & 0.00 & 0.00 & 0.00 & 0.00 & 0.00 & 0.00 & 0.01 & 0.01 & 0.02 & 0.05 & 0.09 & 0.71 & 1.40 & 3.04 & NA & 11.77 & 9.47 & 7.93 & 9.70 & 10.44 & 7.93 & 37.43 \\
\hline UNH-10_268-270cm & 0.00 & 0.00 & 0.00 & 0.00 & 0.00 & 0.00 & 0.00 & 0.00 & 0.00 & 0.00 & 0.01 & 0.03 & 0.04 & 0.14 & 0.42 & 1.89 & NA & 9.65 & 8.93 & 9.46 & 11.44 & 10.10 & 10.60 & 37.29 \\
\hline UNH-13 $25-27 \mathrm{~cm}$ & 0.00 & 0.00 & 0.00 & 0.00 & 0.00 & 0.02 & 0.02 & 0.03 & 0.06 & 0.09 & 0.45 & 4.31 & 11.31 & 54.20 & 19.21 & 2.77 & NA & 0.72 & 3.21 & 0.43 & 0.70 & 1.42 & 0.64 & 0.41 \\
\hline UNH-13 $65-67 \mathrm{~cm}$ & 0.00 & 0.00 & 0.00 & 0.00 & 0.00 & 0.00 & 0.03 & 0.03 & 0.04 & 0.08 & 0.43 & 3.82 & 10.33 & 58.17 & 18.22 & 2.74 & NA & 1.34 & 0.70 & 0.63 & 0.40 & 0.49 & 0.50 & 2.02 \\
\hline $\mathrm{UNH}-13.93-95 \mathrm{~cm}$ & 0.00 & 0.00 & 0.00 & 0.00 & 0.00 & 0.00 & 0.05 & 0.06 & 0.08 & 0.08 & 0.47 & 3.84 & 9.19 & 46.43 & 25.97 & 4.77 & NA & 2.17 & 1.15 & 0.98 & 0.75 & 0.81 & 0.60 & 2.59 \\
\hline UNH-13 $139-141 \mathrm{~cm}$ & 0.00 & 0.00 & 0.00 & 0.12 & 0.00 & 0.00 & 0.15 & 0.16 & 0.23 & 0.30 & 0.87 & 4.80 & 9.67 & 47.21 & 19.93 & 3.73 & NA & 2.79 & 1.64 & 1.34 & 1.02 & 1.00 & 0.93 & 4.11 \\
\hline UNH-13 $161-163 \mathrm{~cm}$ & 0.00 & 0.00 & 0.00 & 0.00 & 0.00 & 0.00 & 0.00 & 0.00 & 0.01 & 0.03 & 0.03 & 0.30 & 1.26 & 4.85 & 6.17 & 8.09 & NA & 14.04 & 8.59 & 7.83 & 5.83 & 7.30 & 7.04 & 28.61 \\
\hline UNH-13 $182-184 \mathrm{~cm}$ & 0.00 & 0.00 & 0.00 & 0.00 & 0.00 & 0.25 & 0.10 & 0.14 & 0.25 & 0.29 & 0.58 & 1.72 & 2.50 & 11.85 & 14.23 & 11.79 & NA & 15.51 & 8.37 & 4.86 & 4.18 & 4.02 & 3.78 & 15.57 \\
\hline UNH-13 $252-254 \mathrm{~cm}$ & 0.00 & 0.00 & 0.00 & 0.00 & 0.59 & 0.00 & 0.06 & 0.07 & 0.11 & 0.20 & 0.26 & 0.36 & 0.38 & 1.43 & 3.60 & 4.92 & NA & 11.14 & 11.16 & 9.69 & 8.79 & 7.89 & 6.93 & 32.40 \\
\hline UNH-13 $286-288 \mathrm{~cm}$ & 0.00 & 0.00 & 0.00 & 0.90 & 0.00 & 0.15 & 0.19 & 0.35 & 0.44 & 0.62 & 1.44 & 4.97 & 7.47 & 32.23 & 22.48 & 5.55 & NA & 4.67 & 3.42 & 2.68 & 2.06 & 1.88 & 1.80 & 6.68 \\
\hline UNH-13 $316-318 \mathrm{~cm}$ & 0.00 & 0.00 & 0.00 & 0.00 & 0.00 & 0.00 & 0.05 & 0.02 & 0.00 & 0.02 & 0.14 & 1.22 & 3.31 & 6.99 & 6.00 & 7.57 & NA & 11.33 & 9.79 & 8.08 & 7.48 & 6.75 & 6.16 & 25.09 \\
\hline UNH-13_423-425cm & 0.00 & 0.00 & 0.00 & 0.00 & 0.00 & 0.00 & 0.01 & 0.00 & 0.02 & 0.03 & 0.07 & 0.28 & 0.55 & 2.11 & 1.90 & 2.35 & NA & 8.41 & 11.12 & 11.07 & 10.56 & 11.25 & 9.40 & 30.89 \\
\hline UNH-13_573-575cm & 0.00 & 0.00 & 0.00 & 0.00 & 0.00 & 0.00 & 0.08 & 0.03 & 0.08 & 0.17 & 0.33 & 1.06 & 1.06 & 3.37 & 2.14 & 1.26 & NA & 4.77 & 9.06 & 9.98 & 11.77 & 10.55 & 9.80 & 34.48 \\
\hline UNH-14_8-10 cm & 0.00 & 0.00 & 0.00 & 0.00 & 0.00 & 0.00 & 0.01 & 0.05 & 0.19 & 0.96 & 4.12 & 11.29 & 20.84 & 36.19 & 19.56 & 5.64 & 1.16 & NA & NA & NA & NA & NA & NA & NA \\
\hline UNH-14_54-56cm & 0.00 & 0.00 & 0.00 & 0.00 & 0.00 & 0.00 & 0.00 & 0.01 & 0.02 & 0.10 & 0.34 & 2.78 & 17.48 & 57.61 & 16.03 & 2.83 & 2.80 & NA & NA & NA & NA & NA & NA & NA \\
\hline UNH-14_72-74cm & 0.00 & 0.00 & 0.00 & 0.00 & 0.00 & 0.00 & 0.00 & 0.05 & 0.06 & 0.31 & 0.95 & 3.32 & 6.69 & 19.46 & 18.04 & 15.78 & NA & 14.26 & 9.91 & 3.90 & 2.62 & 1.63 & 0.95 & 2.08 \\
\hline UNH-14_115-117cm & 0.00 & 0.00 & 0.00 & 0.00 & 0.00 & 0.00 & 0.02 & 0.01 & 0.03 & 0.12 & 0.41 & 2.63 & 16.94 & 49.30 & 18.58 & 5.07 & NA & 4.20 & 1.31 & 0.44 & 0.38 & 0.17 & 0.08 & 0.31 \\
\hline UNH-14_183-185cm & 0.00 & 0.00 & 0.44 & 0.00 & 0.00 & 0.00 & 0.01 & 0.02 & 0.05 & 0.12 & 0.42 & 3.89 & 24.59 & 54.23 & 11.92 & 1.15 & 3.15 & NA & NA & NA & NA & NA & NA & NA \\
\hline UNH-14_196-198cm & 0.00 & 0.00 & 0.00 & 0.00 & 0.00 & 0.00 & 0.02 & 0.06 & 0.22 & 0.70 & 2.14 & 7.56 & 34.13 & 45.33 & 7.06 & 1.04 & 1.74 & NA & NA & NA & NA & NA & NA & NA \\
\hline UNH-14_232-234cm & 0.00 & 0.00 & 0.00 & 0.00 & 0.12 & 0.00 & 0.10 & 0.13 & 0.16 & 0.33 & 0.88 & 5.26 & 29.98 & 55.90 & 3.63 & 0.52 & 2.98 & NA & NA & NA & NA & NA & NA & NA \\
\hline UNH-14_248-250c & 0 & 0.00 & 0.00 & 0.00 & 0.00 & 0.00 & 0.00 & 0.06 & 0.15 & 0.40 & 0.78 & 1.24 & 1.24 & 1.71 & 1.57 & 2.85 & NA & 10.50 & 13.83 & 13.52 & 11.47 & 10.11 & 8.08 & 22.47 \\
\hline
\end{tabular}


Section 5: Vibracores $A 1$ and $A 2$ 
Vibracores A1 and A2: Identification, Location, and Description

\begin{tabular}{|c|c|c|c|c|c|c|c|c|c|c|c|c|c|c|}
\hline UNH Sample ID & $\begin{array}{c}\text { Global Core } \\
\text { Link ID }\end{array}$ & BOEM Global Sample ID & $\begin{array}{r}\text { Latitude } \\
\text { NAD83 } \\
\end{array}$ & $\begin{array}{c}\text { Longitude } \\
\text { NAD83 } \\
\end{array}$ & $\begin{array}{c}\text { Position } \\
\text { Uncertainty }\end{array}$ & $\begin{array}{c}\text { Water } \\
\text { Depth }(\mathrm{m})\end{array}$ & $\begin{array}{c}\text { Diameter } \\
(\mathrm{cm})\end{array}$ & $\begin{array}{c}\text { Core Length } \\
\text { (m) }\end{array}$ & $\begin{array}{l}\text { Vibracore } \\
\text { Collected } \\
\end{array}$ & $\begin{array}{c}\text { Sample } \\
\text { Depth } \\
(\mathrm{cm})\end{array}$ & $\begin{array}{c}\text { Total Wt } \\
\text { (gm) }\end{array}$ & $\begin{array}{c}\text { Munsell } \\
\text { Hue }\end{array}$ & $\begin{array}{c}\text { Munsell } \\
\text { Value }\end{array}$ & $\begin{array}{l}\text { Munsell } \\
\text { Chroma }\end{array}$ \\
\hline A1_35-37cm & AT1-88-A1 & AT1-88-A1_35-37cm_D19880922 & 42.9950 & -70.6433 & $250 \mathrm{~m}$ & 21.0 & 8.9 & 4.39 & $09 / 22-25 / 1988$ & $35-37$ & 42.12 & $5 \mathrm{YR}$ & 4 & 4 \\
\hline A1_100-102cm & AT1-88-A1 & AT1-88-A1_100-102cm_D19880922 & 42.9950 & -70.6433 & $250 \mathrm{~m}$ & 21.0 & 8.9 & 4.39 & $09 / 22-25 / 1988$ & $100-102$ & 38.75 & $5 Y$ & 5 & 2 \\
\hline A1_162-164cm & AT1-88-A1 & AT1-88-A1_162-164cm_D19880922 & 42.9950 & -70.6433 & $250 \mathrm{~m}$ & 21.0 & 8.9 & 4.39 & $09 / 22-25 / 1988$ & $162-164$ & 44.08 & $5 Y$ & 3 & 2 \\
\hline A1_247-249cm & AT1-88-A1 & AT1-88-A1_247-249cm_D19880922 & 42.9950 & -70.6433 & $250 \mathrm{~m}$ & 21.0 & 8.9 & 4.39 & $09 / 22-25 / 1988$ & $247-249$ & 41.33 & $5 Y$ & 5 & 2 \\
\hline A1_ $308-310 \mathrm{~cm}$ & AT1-88-A1 & AT1-88-A1_308-310cm_D19880922 & 42.9950 & -70.6433 & $250 \mathrm{~m}$ & 21.0 & 8.9 & 4.39 & $09 / 22-25 / 1988$ & $308-310$ & 48.09 & $5 Y$ & 5 & 2 \\
\hline A1_365-367cm & AT1-88-A1 & AT1-88-A1_365-367cm_D19880922 & 42.9950 & -70.6433 & $250 \mathrm{~m}$ & 21.0 & 8.9 & 4.39 & $09 / 22-25 / 1988$ & $365-367$ & 47.35 & $5 Y$ & 6 & 1 \\
\hline A1_ $423-425 \mathrm{~cm}$ & AT1-88-A1 & AT1-88-A1_423-425cm_D19880922 & 42.9950 & -70.6433 & $250 \mathrm{~m}$ & 21.0 & 8.9 & 4.39 & $09 / 22-25 / 1988$ & $423-425$ & 43.83 & $5 Y$ & 4 & 1 \\
\hline A2_40-42cm & AT1-88-A2 & AT1-88-A2_40-42cm_D19880922 & 42.9867 & -70.6467 & $250 \mathrm{~m}$ & 22.3 & 8.9 & 7.13 & $09 / 22-25 / 1988$ & $40-42$ & 46.11 & $10 \mathrm{YR}$ & 4 & 2 \\
\hline A2_ $78-80 \mathrm{~cm}$ & AT1-88-A2 & AT1-88-A2_78-80cm_D19880922 & 42.9867 & -70.6467 & $250 \mathrm{~m}$ & 22.3 & 8.9 & 7.13 & $09 / 22-25 / 1988$ & $78-80$ & 46.62 & $10 \mathrm{YR}$ & 4 & 2 \\
\hline A2_ $141-143 \mathrm{~cm}$ & AT1-88-A2 & AT1-88-A2_141-143cm_D19880922 & 42.9867 & -70.6467 & $250 \mathrm{~m}$ & 22.3 & 8.9 & 7.13 & $09 / 22-25 / 1988$ & $141-143$ & 45.30 & $5 Y$ & 5 & 2 \\
\hline A2_223-225cm & AT1-88-A2 & AT1-88-A2_223-225cm_D19880922 & 42.9867 & -70.6467 & $250 \mathrm{~m}$ & 22.3 & 8.9 & 7.13 & $09 / 22-25 / 1988$ & $223-225$ & 48.17 & N3 & NA & NA \\
\hline A2_273-275cm & AT1-88-A2 & AT1-88-A2_273-275cm_D19880922 & 42.9867 & -70.6467 & $250 \mathrm{~m}$ & 22.3 & 8.9 & 7.13 & $09 / 22-25 / 1988$ & $273-275$ & 44.98 & N3 & NA & NA \\
\hline A2_ $313-315 \mathrm{~cm}$ & AT1-88-A2 & AT1-88-A2_313-315cm_D19880922 & 42.9867 & -70.6467 & $250 \mathrm{~m}$ & 22.3 & 8.9 & 7.13 & $09 / 22-25 / 1988$ & 313-315 & 37.66 & $5 Y$ & 4 & 1 \\
\hline A2_383-385cm & AT1-88-A2 & AT1-88-A2_383-385cm_D19880922 & 42.9867 & -70.6467 & $250 \mathrm{~m}$ & 22.3 & 8.9 & 7.13 & 09/22-25/1988 & 383-385 & 39.27 & $5 Y$ & 4 & 1 \\
\hline A2_439-441cm & AT1-88-A2 & AT1-88-A2_439-441cm_D19880922 & 42.9867 & -70.6467 & $250 \mathrm{~m}$ & 22.3 & 8.9 & 7.13 & 09/22-25/1988 & 439-441 & 44.93 & $5 Y$ & 6 & 1 \\
\hline A2 $519-521 \mathrm{~cm}$ & AT1-88-A2 & AT1-88-A2_519-521cm_D19880922 & 42.9867 & -70.6467 & $250 \mathrm{~m}$ & 22.3 & 8.9 & 7.13 & $09 / 22-25 / 1988$ & $519-521$ & 42.26 & $5 Y$ & 6 & 1 \\
\hline A2_599-601cm & AT1-88-A2 & AT1-88-A2_599-601cm_D19880922 & 42.9867 & -70.6467 & $250 \mathrm{~m}$ & 22.3 & 8.9 & 7.13 & 09/22-25/1988 & 599-601 & 43.58 & $5 Y$ & 4 & 1 \\
\hline A2_669-671cm & AT1-88-A2 & AT1-88-A2_669-671cm_D19880922 & 42.9867 & -70.6467 & $250 \mathrm{~m}$ & 22.3 & 8.9 & 7.13 & $09 / 22-25 / 1988$ & $669-671$ & 41.35 & $5 Y$ & 2 & 1 \\
\hline
\end{tabular}




\section{Vibracores A1 and A2: Sediment Classifications}

\begin{tabular}{|c|c|c|c|c|c|c|c|c|c|}
\hline UNH Sample ID & $\begin{array}{l}\text { CMECS Substrate } \\
\text { Component Group } \\
\text { (Specific) }\end{array}$ & $\begin{array}{l}\text { CMECS Substrate } \\
\text { Component Subgroup } \\
\text { (Specific) }\end{array}$ & $\begin{array}{l}\text { Textural Group from } \\
\% G S M \text { (Gradistat) }\end{array}$ & $\begin{array}{l}\text { Textural Group } \\
\text { from \%SZC } \\
\text { (Gradistat) } \\
\text { ggnores Gravel }\end{array}$ & $\begin{array}{l}\text { Sediment Name from \%GSM } \\
\text { and Mode (Gradistat) }\end{array}$ & $\begin{array}{l}\text { Sediment Name from \%GSM } \\
\text { and Mode (Wentworth Scale) }\end{array}$ & $\begin{array}{l}\text { Sediment } \\
\text { Classification } \\
\text { from Mean Phi } \\
\text { (Gradistat) }\end{array}$ & $\begin{array}{l}\text { Sediment } \\
\text { Classification } \\
\text { from Mean Phi } \\
\text { (Wentworth) }\end{array}$ & Sorting (Gradistat) \\
\hline A1_ $35-37 \mathrm{~cm}$ & Slightly Granuley & $\begin{array}{l}\text { Slightly Granuley Medium } \\
\text { Sand }\end{array}$ & Slightly Gravelly Sand & Sand & $\begin{array}{l}\text { Slightly Very Fine Gravelly } \\
\text { Medium Sand }\end{array}$ & $\begin{array}{l}\text { Slightly Granular Medium } \\
\text { Sand }\end{array}$ & Medium Sand & Medium Sand & $\begin{array}{l}\text { Moderately Well } \\
\text { Sorted }\end{array}$ \\
\hline A1 $100-102 \mathrm{~cm}$ & Slightly Pebbly & $\begin{array}{l}\text { Slightly Pebbly Medium } \\
\text { Sand }\end{array}$ & Slightly Gravelly Sand & Sand & $\begin{array}{l}\text { Slightly Medium Gravelly Medium } \\
\text { Sand }\end{array}$ & Slightly Pebbly Medium Sand & Medium Sand & Medium Sand & $\begin{array}{l}\text { Moderately Well } \\
\text { Sorted }\end{array}$ \\
\hline A1_162-164cm & Slightly Pebbly & $\begin{array}{l}\text { Slightly Pebbly Medium } \\
\text { Sand }\end{array}$ & Slightly Gravelly Sand & Sand & $\begin{array}{l}\text { Slightly Medium Gravelly Medium } \\
\text { Sand }\end{array}$ & Slightly Pebbly Medium Sand & Medium Sand & Medium Sand & $\begin{array}{l}\text { Moderately Well } \\
\text { Sorted }\end{array}$ \\
\hline A1 $247-249 \mathrm{~cm}$ & Granuley & Granuley Coarse Sand & Gravelly Sand & Sand & Very Fine Gravelly Coarse Sand & Granular Coarse Sand & Coarse Sand & Coarse Sand & Poorly Sorted \\
\hline A1 $308-310 \mathrm{~cm}$ & Granuley & Granuley Coarse Sand & Gravelly Sand & Sand & Very Fine Gravelly Coarse Sand & Granular Coarse Sand & Coarse Sand & Coarse Sand & Poorly Sorted \\
\hline A1_365-367cm & Slightly Granuley & Slightly Granuley Fine Sand & Slightly Gravelly Sand & Sand & $\begin{array}{l}\text { Slightly Very Fine Gravelly Fine } \\
\text { Sand }\end{array}$ & Slightly Granular Fine Sand & Medium Sand & Medium Sand & Poorly Sorted \\
\hline A1_423-425cm & Sand & Fine Sand & Sand & Sand & Moderately Well Sorted Fine Sand & Fine Sand & Fine Sand & Fine Sand & $\begin{array}{l}\text { Moderately Well } \\
\text { Sorted }\end{array}$ \\
\hline A2 $-40-42 \mathrm{~cm}$ & Slightly Granuley & $\begin{array}{l}\text { Slightly Granuley Medium } \\
\text { Sand }\end{array}$ & Slightly Gravelly Sand & Sand & $\begin{array}{l}\text { Slightly Very Fine Gravelly } \\
\text { Medium Sand }\end{array}$ & $\begin{array}{l}\text { Slightly Granular Medium } \\
\text { Sand }\end{array}$ & Medium Sand & Medium Sand & $\begin{array}{l}\text { Moderately Well } \\
\text { Sorted }\end{array}$ \\
\hline A2 $78-80 \mathrm{~cm}$ & Slightly Granuley & $\begin{array}{l}\text { Slightly Granuley Medium } \\
\text { Sand }\end{array}$ & Slightly Gravelly Sand & Sand & $\begin{array}{l}\text { Slightly Very Fine Gravelly } \\
\text { Medium Sand }\end{array}$ & $\begin{array}{l}\text { Slightly Granular Medium } \\
\text { Sand }\end{array}$ & Medium Sand & Medium Sand & $\begin{array}{l}\text { Moderately Well } \\
\text { Sorted }\end{array}$ \\
\hline A2_ $141-143 \mathrm{~cm}$ & Slightly Granuley & $\begin{array}{l}\text { Slightly Granuley Medium } \\
\text { Sand }\end{array}$ & Slightly Gravelly Sand & Sand & $\begin{array}{l}\text { Slightly Very Fine Gravelly } \\
\text { Medium Sand }\end{array}$ & $\begin{array}{l}\text { Slightly Granular Medium } \\
\text { Sand }\end{array}$ & Medium Sand & Medium Sand & $\begin{array}{l}\text { Moderately Well } \\
\text { Sorted }\end{array}$ \\
\hline A2 $223-225 \mathrm{~cm}$ & Slightly Granuley & $\begin{array}{l}\text { Slightly Granuley Medium } \\
\text { Sand }\end{array}$ & Slightly Gravelly Sand & Sand & $\begin{array}{l}\text { Slightly Very Fine Gravelly } \\
\text { Medium Sand }\end{array}$ & $\begin{array}{l}\text { Slightly Granular Medium } \\
\text { Sand }\end{array}$ & Medium Sand & Medium Sand & $\begin{array}{l}\text { Moderately Well } \\
\text { Sorted }\end{array}$ \\
\hline A2 $273-275 \mathrm{~cm}$ & Slightly Granuley & $\begin{array}{l}\text { Slightly Granuley Medium } \\
\text { Sand }\end{array}$ & Slightly Gravelly Sand & Sand & $\begin{array}{l}\text { Slightly Very Fine Gravelly } \\
\text { Medium Sand }\end{array}$ & $\begin{array}{l}\text { Slightly Granular Medium } \\
\text { Sand }\end{array}$ & Medium Sand & Medium Sand & $\begin{array}{l}\text { Moderately Well } \\
\text { Sorted }\end{array}$ \\
\hline A2 $313-315 \mathrm{~cm}$ & Slightly Granuley & Slightly Granuley Fine Sand & Slightly Gravelly Sand & Sand & $\begin{array}{l}\text { Slightly Very Fine Gravelly Fine } \\
\text { Sand }\end{array}$ & Slightly Granular Fine Sand & Fine Sand & Fine Sand & Moderately Sorted \\
\hline A2 $383-385 \mathrm{~cm}$ & Slightly Granuley & $\begin{array}{l}\text { Slightly Granuley Very Fine } \\
\text { Sand }\end{array}$ & Slightly Gravelly Sand & Sand & $\begin{array}{l}\text { Slightly Very Fine Gravelly Very } \\
\text { Fine Sand }\end{array}$ & $\begin{array}{l}\text { Slightly Granular Very Fine } \\
\text { Sand }\end{array}$ & Very Fine Sand & Very Fine Sand & $\begin{array}{l}\text { Moderately Well } \\
\text { Sorted }\end{array}$ \\
\hline A2_ $439-441 \mathrm{~cm}$ & Slightly Granuley & $\begin{array}{l}\text { Slightly Granuley Silty Very } \\
\text { Fine Sand }\end{array}$ & $\begin{array}{l}\text { Slightly Gravelly } \\
\text { Muddy Sand }\end{array}$ & Silty Sand & $\begin{array}{l}\text { Slightly Very Fine Gravelly Very } \\
\text { Coarse Silty Very Fine Sand }\end{array}$ & $\begin{array}{l}\text { Slightly Granular Very Coarse } \\
\text { Silty Very Fine Sand }\end{array}$ & Very Fine Sand & Very Fine Sand & $\begin{array}{l}\text { Moderately Well } \\
\text { Sorted }\end{array}$ \\
\hline A2 $519-521 \mathrm{~cm}$ & Muddy Sand & Silty Very Fine Sand & Muddy Sand & Silty Sand & Very Coarse Silty Very Fine Sand & $\begin{array}{l}\text { Very Coarse Silty Very Fine } \\
\text { Sand }\end{array}$ & Very Fine Sand & Very Fine Sand & $\begin{array}{l}\text { Moderately Well } \\
\text { Sorted }\end{array}$ \\
\hline A2 $599-601 \mathrm{~cm}$ & Slightly Granuley & $\begin{array}{l}\text { Slightly Granuley Silty Very } \\
\text { Fine Sand }\end{array}$ & $\begin{array}{l}\text { Slightly Gravelly } \\
\text { Muddy Sand }\end{array}$ & Silty Sand & $\begin{array}{l}\text { Slightly Very Fine Gravelly Very } \\
\text { Coarse Silty Very Fine Sand }\end{array}$ & $\begin{array}{l}\text { Slightly Granular Very Coarse } \\
\text { Silty Very Fine Sand }\end{array}$ & Very Fine Sand & Very Fine Sand & Poorly Sorted \\
\hline A2 $669-671 \mathrm{~cm}$ & Slightly Granuley & $\begin{array}{l}\text { Slightly Granuley Silty Very } \\
\text { Fine Sand }\end{array}$ & $\begin{array}{l}\text { Slightly Gravelly } \\
\text { Muddy Sand }\end{array}$ & Silty Sand & $\begin{array}{l}\text { Slightly Very Fine Gravelly Very } \\
\text { Coarse Silty Very Fine Sand }\end{array}$ & $\begin{array}{l}\text { Slightly Granular Very Coarse } \\
\text { Silty Very Fine Sand }\end{array}$ & Very Fine Sand & Very Fine Sand & Poorly Sorted \\
\hline
\end{tabular}




\section{Vibracores A1 and A2: Grain Size Statistics}

\begin{tabular}{|c|c|c|c|c|c|c|c|c|c|c|c|c|c|c|c|c|c|c|c|c|}
\hline UNH Sample ID & Gravel \% & Pebble \% & Granule \% & Sand $\%$ & Mud $\%$ & Silt \% & Clay \% & Modes & $\begin{array}{c}\text { Mode } 1 \\
\text { (phi) }\end{array}$ & $\begin{array}{c}\text { Mode } 2 \\
\text { (phi) }\end{array}$ & $\begin{array}{c}\text { Mode } 3 \\
\text { (phi) }\end{array}$ & $\begin{array}{r}\mathrm{D}_{10} \\
\text { (phi) }\end{array}$ & $\begin{array}{r}\mathrm{D}_{10} \\
(\mathrm{~mm}) \\
\end{array}$ & $\begin{array}{r}D_{50} \\
\text { (phi) }\end{array}$ & $\begin{array}{c}D_{50} \\
(\mathrm{~mm}) \\
\end{array}$ & $\begin{array}{c}\text { Mean } \\
\text { Size } \\
\text { (phi) } \\
\end{array}$ & $\begin{array}{c}\text { Mean } \\
\text { Size } \\
(\mathrm{mm}) \\
\end{array}$ & $\begin{array}{c}\text { Sorting } \\
\text { (phi) }\end{array}$ & Skewness & Kurtosis \\
\hline A1_ $35-37 \mathrm{~cm}$ & 2.04 & 0.49 & 1.55 & 97.92 & 0.04 & NA & NA & $u$ & 1.25 & NA & NA & 0.18 & 0.88 & 1.04 & 0.49 & 1.04 & 0.49 & 0.62 & -0.07 & 1.11 \\
\hline A1_100-102cm & 2.15 & 1.69 & 0.45 & 97.85 & 0.00 & NA & NA & $u$ & 1.25 & NA & NA & 0.36 & 0.78 & 1.16 & 0.45 & 1.14 & 0.46 & 0.56 & -0.11 & 1.07 \\
\hline A1_162-164cm & 1.82 & 1.31 & 0.52 & 97.78 & 0.40 & NA & NA & $u$ & 1.25 & NA & NA & 0.40 & 0.76 & 1.13 & 0.46 & 1.09 & 0.47 & 0.53 & -0.13 & 1.12 \\
\hline A1 $247-249 \mathrm{~cm}$ & 11.21 & 2.71 & 8.50 & 88.56 & 0.23 & NA & NA & $u$ & 0.75 & NA & NA & -1.14 & 2.20 & 0.65 & 0.64 & 0.56 & 0.68 & 1.08 & -0.21 & 1.24 \\
\hline A1_308-310cm & 8.59 & 0.93 & 7.66 & 90.08 & 1.33 & NA & NA & u & 0.25 & NA & NA & -0.87 & 1.83 & 0.56 & 0.68 & 0.59 & 0.66 & 1.01 & -0.05 & 1.09 \\
\hline A1_365-367cm & 3.27 & 0.50 & 2.77 & 89.94 & 6.79 & NA & NA & B & 2.24 & 0.25 & NA & -0.42 & 1.34 & 1.79 & 0.29 & 1.53 & 0.35 & 1.51 & -0.15 & 1.04 \\
\hline A1_423-425cm & 0.00 & 0.00 & 0.00 & 96.32 & 3.68 & $\mathrm{NA}$ & NA & $u$ & 2.24 & NA & NA & 2.01 & 0.25 & 2.57 & 0.17 & 2.61 & 0.16 & 0.55 & 0.10 & 1.04 \\
\hline A2 $\_40-42 \mathrm{~cm}$ & 1.98 & 0.88 & 1.10 & 97.46 & 0.56 & NA & NA & $u$ & 1.75 & NA & NA & 0.26 & 0.84 & 1.27 & 0.41 & 1.22 & 0.43 & 0.65 & -0.24 & 1.00 \\
\hline A2_78-80 cm & 0.52 & 0.00 & 0.52 & 99.21 & 0.27 & NA & $\mathrm{NA}$ & $u$ & 1.75 & $\mathrm{NA}$ & NA & 0.28 & 0.82 & 1.24 & 0.42 & 1.20 & 0.44 & 0.62 & -0.17 & 0.88 \\
\hline A2_141-143cm & 0.46 & 0.00 & 0.46 & 98.99 & 0.55 & NA & NA & $u$ & 1.75 & NA & NA & 0.50 & 0.71 & 1.37 & 0.39 & 1.03 & 0.49 & 0.60 & -0.20 & 0.95 \\
\hline A2_223-225cm & 0.50 & 0.12 & 0.39 & 98.95 & 0.55 & $\mathrm{NA}$ & $\mathrm{NA}$ & $u$ & 1.75 & NA & NA & 0.21 & 0.87 & 1.21 & 0.43 & 1.17 & 0.44 & 0.69 & -0.08 & 0.88 \\
\hline A2_273-275cm & 0.05 & 0.00 & 0.05 & 99.94 & 0.01 & NA & NA & $u$ & 1.25 & NA & NA & 0.37 & 0.77 & 1.16 & 0.45 & 1.17 & 0.45 & 0.60 & -0.02 & 0.90 \\
\hline A2_313-315cm & 0.33 & 0.00 & 0.33 & 92.93 & 6.74 & 4.61 & 2.13 & $u$ & 2.24 & NA & NA & 1.65 & 0.32 & 2.50 & 0.18 & 2.56 & 0.17 & 0.86 & 0.24 & 1.15 \\
\hline A2_383-385cm & 0.21 & 0.00 & 0.21 & 90.70 & 9.09 & 6.39 & 2.70 & u & 2.24 & NA & NA & 2.53 & 0.17 & 3.14 & 0.11 & 3.12 & 0.12 & 0.67 & 0.17 & 2.02 \\
\hline A2_439-441cm & 0.03 & 0.00 & 0.03 & 89.45 & 10.52 & 8.30 & 2.22 & $u$ & 3.24 & NA & NA & 2.63 & 0.16 & 3.24 & 0.11 & 3.27 & 0.10 & 0.62 & 0.25 & 2.23 \\
\hline A2 $519-521 \mathrm{~cm}$ & 0.00 & 0.00 & 0.00 & 85.46 & 14.54 & 13.16 & 1.38 & $u$ & 3.24 & NA & NA & 2.82 & 0.14 & 3.34 & 0.10 & 3.44 & 0.09 & 0.59 & 0.33 & 1.53 \\
\hline A2_599-601cm & 0.46 & 0.00 & 0.46 & 68.82 & 30.72 & 26.22 & 4.50 & $u$ & 3.24 & NA & NA & 2.36 & 0.20 & 3.49 & 0.09 & 3.67 & 0.08 & 1.34 & 0.36 & 1.86 \\
\hline A2_669-671 cm & 0.23 & 0.00 & 0.23 & 64.45 & 35.32 & 31.88 & 3.44 & $u$ & 3.24 & NA & NA & 2.53 & 0.17 & 3.67 & 0.08 & 3.74 & 0.08 & 1.10 & 0.18 & 1.42 \\
\hline
\end{tabular}




\section{Vibracores A1 and A2: Grain Size Distribution}

\begin{tabular}{|c|c|c|c|c|c|c|c|c|c|c|c|c|c|c|c|c|c|c|c|c|c|c|c|c|}
\hline UNH Sample ID & $\begin{array}{c}\text { Class \% } \\
\text { phi } \\
-3.5 \\
\end{array}$ & $\begin{array}{c}\text { Class \% } \\
\text { phi } \\
-3.0 \\
\end{array}$ & $\begin{array}{c}\text { Class \% } \\
\text { phi } \\
-2.5 \\
\end{array}$ & $\begin{array}{c}\text { Class \% } \\
\text { phi } \\
-2.0 \\
\end{array}$ & $\begin{array}{c}\text { Class \% } \\
\text { phi } \\
-1.5 \\
\end{array}$ & $\begin{array}{c}\text { Class \% } \\
\text { phi } \\
-1.0 \\
\end{array}$ & $\begin{array}{c}\text { Class \% } \\
\text { phi } \\
-0.5 \\
\end{array}$ & $\begin{array}{c}\text { Class \% } \\
\text { phi } \\
0.0 \\
\end{array}$ & $\begin{array}{c}\text { Class \% } \\
\text { phi } \\
0.5 \\
\end{array}$ & $\begin{array}{c}\text { Class \% } \\
\text { phi } \\
1.0 \\
\end{array}$ & $\begin{array}{c}\text { Class \% } \\
\text { phi } \\
1.5 \\
\end{array}$ & $\begin{array}{c}\text { Class \% } \\
\text { phi } \\
2.0 \\
\end{array}$ & $\begin{array}{c}\text { Class \% } \\
\text { phi } \\
2.5 \\
\end{array}$ & $\begin{array}{c}\text { Class \% } \\
\text { phi } \\
\mathbf{3 . 0} \\
\end{array}$ & $\begin{array}{c}\text { Class \% } \\
\text { phi } \\
3.5 \\
\end{array}$ & $\begin{array}{c}\text { Class \% } \\
\text { phi } \\
4.0 \\
\end{array}$ & $\begin{array}{c}\text { Class \% } \\
\text { phi } \\
>4.0 \\
\end{array}$ & $\begin{array}{c}\text { Class \% } \\
\text { phi } \\
5.0 \\
\end{array}$ & $\begin{array}{c}\text { Class \% } \\
\text { phi } \\
6.0 \\
\end{array}$ & $\begin{array}{c}\text { Class \% } \\
\text { phi } \\
7.0 \\
\end{array}$ & $\begin{array}{c}\text { Class \% } \\
\text { phi } \\
8.0 \\
\end{array}$ & $\begin{array}{c}\text { Class \% } \\
\text { phi } \\
9.0 \\
\end{array}$ & $\begin{array}{c}\text { Class \% } \\
\text { phi } \\
10.0 \\
\end{array}$ & 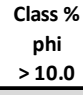 \\
\hline A1_35-37 cm & 0.00 & 0.00 & 0.49 & 0.00 & 0.78 & 0.77 & 1.07 & 2.98 & 10.90 & 30.19 & 32.51 & 16.27 & 2.97 & 0.57 & 0.41 & 0.07 & 0.04 & NA & NA & NA & NA & NA & NA & NA \\
\hline A1_100-102cm & 0.00 & 1.49 & 0.00 & 0.21 & 0.19 & 0.26 & 0.25 & 1.68 & 8.04 & 25.60 & 38.81 & 20.55 & 2.34 & 0.30 & 0.24 & 0.04 & 0.00 & NA & NA & NA & NA & NA & NA & $\mathrm{NA}$ \\
\hline A1 $162-164 \mathrm{~cm}$ & 0.00 & 1.00 & 0.00 & 0.30 & 0.34 & 0.17 & 0.26 & 1.70 & 7.75 & 27.25 & 42.89 & 15.91 & 1.34 & 0.27 & 0.36 & 0.07 & 0.40 & $\mathrm{NA}$ & $\mathrm{NA}$ & $\mathrm{NA}$ & NA & NA & NA & $\mathrm{NA}$ \\
\hline A1_247-249cm & 0.00 & 0.00 & 0.57 & 2.13 & 4.24 & 4.26 & 5.21 & 7.59 & 18.03 & 25.98 & 14.43 & 13.65 & 2.76 & 0.52 & 0.30 & 0.09 & 0.23 & NA & NA & NA & NA & NA & NA & NA \\
\hline A1 $308-310 \mathrm{~cm}$ & 0.00 & 0.00 & 0.00 & 0.93 & 3.08 & 4.58 & 5.54 & 10.27 & 22.91 & 20.61 & 12.73 & 14.90 & 2.13 & 0.46 & 0.35 & 0.16 & 1.33 & NA & NA & NA & NA & NA & NA & NA \\
\hline A1 $365-367 \mathrm{~cm}$ & 0.00 & 0.00 & 0.00 & 0.50 & 1.12 & 1.65 & 5.56 & 8.54 & 8.84 & 6.81 & 6.86 & 17.04 & 19.70 & 9.83 & 5.39 & 1.38 & 6.79 & $\mathrm{NA}$ & NA & NA & NA & NA & NA & $\mathrm{NA}$ \\
\hline A1_423-425cm & 0.00 & 0.00 & 0.00 & 0.00 & 0.00 & 0.00 & 0.02 & 0.02 & 0.11 & 0.19 & 1.00 & 8.27 & 34.04 & 34.56 & 16.45 & 1.66 & 3.68 & NA & NA & NA & NA & NA & $\mathrm{NA}$ & $\mathrm{NA}$ \\
\hline A2 $-40-42 \mathrm{~cm}$ & 0.00 & 0.00 & 0.00 & 0.74 & 0.71 & 0.53 & 1.40 & 2.56 & 7.82 & 19.69 & 30.06 & 31.73 & 3.58 & 0.34 & 0.19 & 0.08 & 0.56 & $\mathrm{NA}$ & NA & NA & NA & NA & NA & $\mathrm{NA}$ \\
\hline A2 $78-80 \mathrm{~cm}$ & 0.00 & 0.00 & 0.00 & 0.00 & 0.19 & 0.33 & 1.04 & 2.92 & 9.69 & 21.64 & 29.06 & 30.65 & 3.54 & 0.38 & 0.22 & 0.07 & 0.27 & NA & NA & NA & NA & NA & NA & $\mathrm{NA}$ \\
\hline A2 $141-143 \mathrm{~cm}$ & 0.00 & 0.00 & 0.00 & 0.00 & 0.25 & 0.21 & 0.53 & 1.54 & 7.14 & 19.43 & 27.63 & 36.65 & 5.07 & 0.44 & 0.48 & 0.08 & 0.55 & NA & NA & NA & $\mathrm{NA}$ & NA & NA & $\mathrm{NA}$ \\
\hline A2 $223-225 \mathrm{~cm}$ & 0.00 & 0.00 & 0.00 & 0.11 & 0.09 & 0.30 & 1.09 & 3.10 & 12.56 & 23.17 & 23.02 & 28.57 & 6.28 & 0.73 & 0.33 & 0.10 & 0.55 & NA & $\mathrm{NA}$ & NA & NA & NA & NA & NA \\
\hline A2 $273-275 \mathrm{~cm}$ & 0.00 & 0.00 & 0.00 & 0.00 & 0.00 & 0.05 & 0.52 & 1.84 & 10.17 & 28.22 & 28.95 & 24.40 & 5.06 & 0.47 & 0.25 & 0.07 & 0.00 & NA & NA & NA & NA & NA & NA & NA \\
\hline A2 $313-315 \mathrm{~cm}$ & 0.00 & 0.00 & 0.00 & 0.00 & 0.00 & 0.33 & 0.05 & 0.06 & 0.17 & 0.73 & 3.14 & 17.89 & 26.72 & 19.57 & 19.87 & 4.73 & NA & 2.83 & 0.93 & 0.64 & 0.21 & 2.13 & 0.00 & 0.00 \\
\hline A2 $383-385 \mathrm{~cm}$ & 0.00 & 0.00 & 0.00 & 0.00 & 0.12 & 0.10 & 0.03 & 0.05 & 0.29 & 0.22 & 0.33 & 0.80 & 4.77 & 29.14 & 46.68 & 8.39 & NA & 3.79 & 1.38 & 0.90 & 0.32 & 0.43 & 0.46 & 1.81 \\
\hline A2_ $439-441 \mathrm{~cm}$ & 0.00 & 0.00 & 0.00 & 0.00 & 0.00 & 0.03 & 0.03 & 0.03 & 0.07 & 0.09 & 0.26 & 0.63 & 3.07 & 19.19 & 52.82 & 13.25 & NA & 5.94 & 1.26 & 0.67 & 0.43 & 0.42 & 0.39 & 1.41 \\
\hline A2 $519-521 \mathrm{~cm}$ & 0.00 & 0.00 & 0.00 & 0.00 & 0.00 & 0.00 & 0.00 & 0.03 & 0.10 & 0.17 & 0.30 & 0.55 & 1.59 & 11.06 & 50.46 & 21.21 & NA & 10.42 & 1.67 & 0.75 & 0.32 & 0.34 & 0.30 & 0.75 \\
\hline A2 $599-601 \mathrm{~cm}$ & 0.00 & 0.00 & 0.00 & 0.00 & 0.20 & 0.26 & 0.13 & 0.11 & 0.15 & 0.30 & 0.53 & 3.65 & 6.19 & 8.53 & 29.43 & 19.82 & NA & 19.23 & 4.31 & 1.74 & 0.93 & 0.50 & 0.62 & 3.37 \\
\hline A2_669-671cm & 0.00 & 0.00 & 0.00 & 0.00 & 0.08 & 0.15 & 0.17 & 0.22 & 0.41 & 0.52 & 0.84 & 1.91 & 4.63 & 9.93 & 22.06 & 23.75 & NA & 28.43 & 1.46 & 1.35 & 0.64 & 0.53 & 0.57 & 2.34 \\
\hline
\end{tabular}


Section 6: Vibracores $A 3$ and $A 4$ 


\section{Vibracores A3 and A4: Identification, Location, and Description}

\begin{tabular}{|c|c|c|c|c|c|c|c|c|c|c|c|c|c|c|}
\hline UNH Sample ID & $\begin{array}{c}\text { Global Core } \\
\text { Link ID }\end{array}$ & BOEM Global Sample ID & $\begin{array}{c}\text { Latitude } \\
\text { NAD83 }\end{array}$ & $\begin{array}{c}\text { Longitude } \\
\text { NAD83 }\end{array}$ & $\begin{array}{c}\text { Position } \\
\text { Uncertainty }\end{array}$ & $\begin{array}{c}\text { Water } \\
\text { Depth }(\mathrm{m})\end{array}$ & $\begin{array}{l}\text { Diameter } \\
\text { (cm) }\end{array}$ & $\begin{array}{l}\text { Core Length } \\
\text { (m) }\end{array}$ & $\begin{array}{l}\text { Vibracore } \\
\text { Collected }\end{array}$ & $\begin{array}{c}\text { Sample } \\
\text { Depth } \\
(\mathrm{cm})\end{array}$ & $\begin{array}{c}\text { Total Wt } \\
(\mathrm{gm})\end{array}$ & $\begin{array}{c}\text { Munsell } \\
\text { Hue }\end{array}$ & $\begin{array}{c}\text { Munsell } \\
\text { Value }\end{array}$ & $\begin{array}{l}\text { Munsell } \\
\text { Chroma }\end{array}$ \\
\hline A3_20-22cm & AT1-88-A3 & AT1-88-A3_20-22cm_D19880922 & 42.9833 & -70.6600 & $250 \mathrm{~m}$ & 25.0 & 8.9 & 5.81 & $09 / 22-25 / 1988$ & $20-22$ & 37.68 & $5 Y$ & 4 & 1 \\
\hline A3_100-102cm & AT1-88-A3 & AT1-88-A3_100-102cm_D19880922 & 42.9833 & -70.6600 & $250 \mathrm{~m}$ & 25.0 & 8.9 & 5.81 & $09 / 22-25 / 1988$ & $100-102$ & 46.71 & $5 Y$ & 6 & 1 \\
\hline A3_145-147cm & AT1-88-A3 & AT1-88-A3_145-147cm_D19880922 & 42.9833 & -70.6600 & $250 \mathrm{~m}$ & 25.0 & 8.9 & 5.81 & $09 / 22-25 / 1988$ & $145-147$ & 40.78 & $5 Y$ & 6 & 1 \\
\hline A3 $265-267 \mathrm{~cm}$ & AT1-88-A3 & AT1-88-A3 $265-267 \mathrm{~cm} \quad$ D19880922 & 42.9833 & -70.6600 & $250 \mathrm{~m}$ & 25.0 & 8.9 & 5.81 & $09 / 22-25 / 1988$ & $265-267$ & 48.84 & $5 Y$ & 6 & 1 \\
\hline A3 $302-304 \mathrm{~cm}$ & AT1-88-A3 & AT1-88-A3_302-304cm_D19880922 & 42.9833 & -70.6600 & $250 \mathrm{~m}$ & 25.0 & 8.9 & 5.81 & 09/22-25/1988 & 302-304 & 66.45 & $5 Y$ & 4 & 1 \\
\hline A3_422-424cm & AT1-88-A3 & AT1-88-A3_422-424cm_D19880922 & 42.9833 & -70.6600 & $250 \mathrm{~m}$ & 25.0 & 8.9 & 5.81 & 09/22-25/1988 & $422-424$ & 30.32 & $5 Y$ & 4 & 1 \\
\hline A3_464-466cm & AT1-88-A3 & AT1-88-A3_464-466cm_D19880922 & 42.9833 & -70.6600 & $250 \mathrm{~m}$ & 25.0 & 8.9 & 5.81 & 09/22-25/1988 & 464-466 & 41.86 & $5 Y$ & 3 & 2 \\
\hline A3_564-566cm & AT1-88-A3 & AT1-88-A3_564-566cm_D19880922 & 42.9833 & -70.6600 & $250 \mathrm{~m}$ & 25.0 & 8.9 & 5.81 & $09 / 22-25 / 1988$ & $564-566$ & 34.66 & $5 Y$ & 3 & 2 \\
\hline A4 $\_8-12 \mathrm{~cm}$ & AT1-88-A4 & AT1-88-A4_8-12cm_D19880922 & 43.0067 & -70.6717 & $250 \mathrm{~m}$ & $20.0^{*}$ & 8.9 & 5.81 & 09/22-25/1988 & $8-12$ & 102.47 & $5 Y$ & 6 & 1 \\
\hline A4_30-32 cm & AT1-88-A4 & AT1-88-A4_30-32cm_D19880922 & 43.0067 & -70.6717 & $250 \mathrm{~m}$ & $20.0^{*}$ & 8.9 & 5.81 & $09 / 22-25 / 1988$ & $30-32$ & 126.72 & $5 Y$ & 4 & 1 \\
\hline A4_90-95cm & AT1-88-A4 & AT1-88-A4_90-95cm_D19880922 & 43.0067 & -70.6717 & $250 \mathrm{~m}$ & $20.0^{*}$ & 8.9 & 5.81 & 09/22-25/1988 & $90-95$ & 341.63 & $5 Y$ & 4 & 1 \\
\hline A4_143-153cm & AT1-88-A4 & AT1-88-A4_143-153cm_D19880922 & 43.0067 & -70.6717 & $250 \mathrm{~m}$ & $20.0^{*}$ & 8.9 & 5.81 & $09 / 22-25 / 1988$ & $143-153$ & 375.22 & $5 Y$ & 4 & 1 \\
\hline A4_213-216cm & AT1-88-A4 & AT1-88-A4_213-216cm_D19880922 & 43.0067 & -70.6717 & $250 \mathrm{~m}$ & $20.0^{*}$ & 8.9 & 5.81 & $09 / 22-25 / 1988$ & $213-216$ & 97.68 & $5 Y$ & 2 & 1 \\
\hline A4_248-253cm & AT1-88-A4 & AT1-88-A4_248-253cm_D19880922 & 43.0067 & -70.6717 & $250 \mathrm{~m}$ & $20.0^{*}$ & 8.9 & 5.81 & $09 / 22-25 / 1988$ & $248-253$ & 101.32 & $5 Y$ & 2 & 1 \\
\hline A4_288-290cm & AT1-88-A4 & AT1-88-A4_288-290cm_D19880922 & 43.0067 & -70.6717 & $250 \mathrm{~m}$ & $20.0^{*}$ & 8.9 & 5.81 & $09 / 22-25 / 1988$ & $288-290$ & 64.66 & $5 Y$ & 4 & 1 \\
\hline A4_326-328cm & AT1-88-A4 & AT1-88-A4_326-328cm_D19880922 & 43.0067 & -70.6717 & $250 \mathrm{~m}$ & $20.0^{*}$ & 8.9 & 5.81 & $09 / 22-25 / 1988$ & $326-328$ & 96.69 & $5 Y$ & 4 & 1 \\
\hline A4_358-360cm & AT1-88-A4 & AT1-88-A4_358-360cm_D19880922 & 43.0067 & -70.6717 & $250 \mathrm{~m}$ & $20.0^{*}$ & 8.9 & 5.81 & $09 / 22-25 / 1988$ & $358-360$ & 83.19 & $5 Y$ & 4 & 1 \\
\hline A4_408-410cm & AT1-88-A4 & AT1-88-A4_408-410cm_D19880922 & 43.0067 & -70.6717 & $250 \mathrm{~m}$ & $20.0^{*}$ & 8.9 & 5.81 & $09 / 22-25 / 1988$ & $408-410$ & 97.19 & $5 Y$ & 4 & 1 \\
\hline A4_444-446cm & AT1-88-A4 & AT1-88-A4_444-446cm_D19880922 & 43.0067 & -70.6717 & $250 \mathrm{~m}$ & $20.0^{*}$ & 8.9 & 5.81 & 09/22-25/1988 & $444-446$ & 47.67 & $5 Y$ & 4 & 1 \\
\hline A4_491-495cm & AT1-88-A4 & AT1-88-A4_491-495cm_D19880922 & 43.0067 & -70.6717 & $250 \mathrm{~m}$ & $20.0^{*}$ & 8.9 & 5.81 & $09 / 22-25 / 1988$ & $491-495$ & 55.22 & $5 Y$ & 4 & 1 \\
\hline A4 $536-539 \mathrm{~cm}$ & AT1-88-A4 & AT1-88-A4_536-539cm_D19880922 & 43.0067 & -70.6717 & $250 \mathrm{~m}$ & $20.0^{*}$ & 8.9 & 5.81 & $09 / 22-25 / 1988$ & $536-539$ & 82.92 & N4 & NA & NA \\
\hline A4_575-577cm & AT1-88-A4 & AT1-88-A4_575-577cm_D19880922 & 43.0067 & -70.6717 & $250 \mathrm{~m}$ & $20.0^{*}$ & 8.9 & 5.81 & $09 / 22-25 / 1988$ & $575-577$ & 107.88 & N2 & NA & NA \\
\hline
\end{tabular}




\section{Vibracores A3 and A4: Sediment Classifications}

\begin{tabular}{|c|c|c|c|c|c|c|c|c|c|}
\hline UNH Sample ID & $\begin{array}{l}\text { CMECS Substrate } \\
\text { Component Group } \\
\text { (Specific) }\end{array}$ & $\begin{array}{l}\text { CMECS Substrate } \\
\text { Component Subgroup } \\
\text { (Specific) }\end{array}$ & $\begin{array}{l}\text { Textural Group from } \\
\% \text { GSM (Gradistat) }\end{array}$ & $\begin{array}{l}\text { Textural Group } \\
\text { from \%SZC } \\
\text { (Gradistat) } \\
\text { Ignores Gravel }\end{array}$ & $\begin{array}{l}\text { Sediment Name from \%GSM } \\
\text { and Mode (Gradistat) }\end{array}$ & $\begin{array}{l}\text { Sediment Name from \%GSM } \\
\text { and Mode (Wentworth Scale) }\end{array}$ & $\begin{array}{l}\text { Sediment } \\
\text { Classification } \\
\text { from Mean Phi } \\
\text { (Gradistat) } \\
\end{array}$ & $\begin{array}{l}\text { Sediment } \\
\text { Classification } \\
\text { from Mean Phi } \\
\text { (Wentworth) }\end{array}$ & Sorting (Gradistat) \\
\hline A3 $20-22 \mathrm{~cm}$ & Sand & Fine Sand & Sand & Sand & Moderately Well Sorted Fine Sand & Fine Sand & Fine Sand & Fine Sand & $\begin{array}{l}\text { Moderately Well } \\
\text { Sorted }\end{array}$ \\
\hline A3 $100-102 \mathrm{~cm}$ & Sand & Fine Sand & Sand & Sand & Moderately Well Sorted Fine Sand & Fine Sand & Fine Sand & Fine Sand & $\begin{array}{l}\text { Moderately Well } \\
\text { Sorted }\end{array}$ \\
\hline A3_145-147cm & Sand & Fine Sand & Sand & Sand & Moderately Well Sorted Fine Sand & Fine Sand & Fine Sand & Fine Sand & $\begin{array}{l}\text { Moderately Well } \\
\text { Sorted }\end{array}$ \\
\hline A3_265-267cm & Sand & Fine Sand & Sand & Sand & Moderately Well Sorted Fine Sand & Fine Sand & Fine Sand & Fine Sand & $\begin{array}{l}\text { Moderately Well } \\
\text { Sorted }\end{array}$ \\
\hline A3 $302-304 \mathrm{~cm}$ & Sand & Fine Sand & Sand & Sand & Moderately Well Sorted Fine Sand & Fine Sand & Fine Sand & Fine Sand & $\begin{array}{l}\text { Moderately Well } \\
\text { Sorted }\end{array}$ \\
\hline A3_422-424cm & Muddy Sand & Silty Very Fine Sand & Muddy Sand & Silty Sand & Very Coarse Silty Very Fine Sand & $\begin{array}{l}\text { Very Coarse Silty Very Fine } \\
\text { Sand }\end{array}$ & Very Fine Sand & Very Fine Sand & $\begin{array}{l}\text { Moderately Well } \\
\text { Sorted }\end{array}$ \\
\hline A3 $464-466 \mathrm{~cm}$ & Slightly Granuley & $\begin{array}{l}\text { Slightly Granuley Silty Very } \\
\text { Fine Sand }\end{array}$ & $\begin{array}{l}\text { Slightly Gravelly } \\
\text { Muddy Sand }\end{array}$ & Silty Sand & $\begin{array}{l}\text { Slightly Very Fine Gravelly Very } \\
\text { Coarse Silty Very Fine Sand }\end{array}$ & $\begin{array}{l}\text { Slightly Granular Very Coarse } \\
\text { Silty Very Fine Sand }\end{array}$ & Very Fine Sand & Very Fine Sand & Poorly Sorted \\
\hline A3_564-566cm & Slightly Granuley & $\begin{array}{l}\text { Slightly Granuley Silty Very } \\
\text { Fine Sand }\end{array}$ & $\begin{array}{l}\text { Slightly Gravelly } \\
\text { Muddy Sand } \\
\end{array}$ & Silty Sand & $\begin{array}{l}\text { Slightly Very Fine Gravelly Very } \\
\text { Coarse Silty Very Fine Sand }\end{array}$ & $\begin{array}{l}\text { Slightly Granular Very Coarse } \\
\text { Silty Very Fine Sand }\end{array}$ & Very Fine Sand & Very Fine Sand & Poorly Sorted \\
\hline A4_8-12cm & Granuley & Granuley Coarse Sand & Gravelly Sand & Sand & Very Fine Gravelly Coarse Sand & Granular Coarse Sand & Coarse Sand & Coarse Sand & Poorly Sorted \\
\hline A4 $30-32 \mathrm{~cm}$ & Granule Mixes & Sandy Granule Gravel & Sandy Gravel & Sand & Sandy Very Fine Gravel & Sandy Granule Gravel & Very Coarse Sand & Very Coarse Sanc & d Poorly Sorted \\
\hline A4_90-95cm & Pebble Mixes & Sandy Pebble Gravel & Sandy Gravel & Sand & Sandy Coarse Gravel & Sandy Pebble Gravel & Fine Gravel & Pebble Gravel & Very Poorly Sorted \\
\hline A4_143-153cm & Granule Mixes & Sandy Granule Gravel & Sandy Gravel & Sand & Sandy Very Fine Gravel & Sandy Granule Gravel & Very Fine Gravel & Granule Gravel & Very Poorly Sorted \\
\hline A4_213-216cm & Slightly Granuley & $\begin{array}{l}\text { Slightly Granuley Medium } \\
\text { Sand }\end{array}$ & Slightly Gravelly Sand & Sand & $\begin{array}{l}\text { Slightly Very Fine Gravelly } \\
\text { Medium Sand }\end{array}$ & $\begin{array}{l}\text { Slightly Granular Medium } \\
\text { Sand }\end{array}$ & Medium Sand & Medium Sand & Poorly Sorted \\
\hline A4_248-253cm & Slightly Granuley & $\begin{array}{l}\text { Slightly Granuley Coarse } \\
\text { Sand }\end{array}$ & Slightly Gravelly Sand & Sand & $\begin{array}{l}\text { Slightly Very Fine Gravelly Coarse } \\
\text { Sand }\end{array}$ & Slightly Granular Coarse Sand & Coarse Sand & Coarse Sand & Poorly Sorted \\
\hline A4_288-290cm & Slightly Granuley & $\begin{array}{l}\text { Slightly Granuley Medium } \\
\text { Sand }\end{array}$ & Slightly Gravelly Sand & Sand & $\begin{array}{l}\text { Slightly Very Fine Gravelly } \\
\text { Medium Sand }\end{array}$ & $\begin{array}{l}\text { Slightly Granular Medium } \\
\text { Sand }\end{array}$ & Medium Sand & Medium Sand & Poorly Sorted \\
\hline A4 $326-328 \mathrm{~cm}$ & Granuley & Granular Medium Sand & Gravelly Sand & Sand & Very Fine Gravelly Medium Sand & Granular Medium Sand & Medium Sand & Medium Sand & Poorly Sorted \\
\hline A4_358-360cm & Slightly Granuley & $\begin{array}{l}\text { Slightly Granuley Medium } \\
\text { Sand }\end{array}$ & Slightly Gravelly Sand & Sand & $\begin{array}{l}\text { Slightly Very Fine Gravelly } \\
\text { Medium Sand }\end{array}$ & $\begin{array}{l}\text { Slightly Granular Medium } \\
\text { Sand }\end{array}$ & Medium Sand & Medium Sand & $\begin{array}{l}\text { Moderately Well } \\
\text { Sorted }\end{array}$ \\
\hline A4 $408-410 \mathrm{~cm}$ & Slightly Granuley & $\begin{array}{l}\text { Slightly Granuley Medium } \\
\text { Sand }\end{array}$ & Slightly Gravelly Sand & Sand & $\begin{array}{l}\text { Slightly Very Fine Gravelly } \\
\text { Medium Sand }\end{array}$ & $\begin{array}{l}\text { Slightly Granular Medium } \\
\text { Sand }\end{array}$ & Medium Sand & Medium Sand & Moderately Sorted \\
\hline A4_444-446cm & Sandy Mud & Very Fine Sandy Silt & Sandy Mud & Sandy Silt & Very Fine Sandy Very Coarse Silt & $\begin{array}{l}\text { Very Fine Sandy Very Coarse } \\
\text { Silt }\end{array}$ & Medium Silt & Fine Silt & Very Poorly Sorted \\
\hline A4_491-495cm & Sandy Mud & Very Fine Sandy Silt & Sandy Mud & Sandy Silt & Very Fine Sandy Very Coarse Silt & $\begin{array}{l}\text { Very Fine Sandy Very Coarse } \\
\text { silt }\end{array}$ & Very Coarse Silt & Coarse Silt & Very Poorly Sorted \\
\hline A4_536-539cm & Slightly Granuley & $\begin{array}{l}\text { Slightly Granuley Medium } \\
\text { Sand }\end{array}$ & Slightly Gravelly Sand & Sand & $\begin{array}{l}\text { Slightly Very Fine Gravelly } \\
\text { Medium Sand }\end{array}$ & $\begin{array}{l}\text { Slightly Granular Medium } \\
\text { Sand }\end{array}$ & Coarse Sand & Coarse Sand & $\begin{array}{l}\text { Moderately Well } \\
\text { Sorted }\end{array}$ \\
\hline A4_575-577cm & Pebble Mixes & Sandy Pebble Gravel & Sandy Gravel & Sand & Sandy Medium Gravel & Sandy Pebble Gravel & Very Coarse Sand & Very Coarse Sa & d Very Poorly Sorted \\
\hline
\end{tabular}




\section{Vibracores A3 and A4: Grain Size Statistics}

\begin{tabular}{|c|c|c|c|c|c|c|c|c|c|c|c|c|c|c|c|c|c|c|c|c|}
\hline UNH Sample ID & Gravel \% & Pebble \% & Granule \% & Sand $\%$ & Mud $\%$ & Silt \% & Clay \% & Modes & $\begin{array}{c}\text { Mode } 1 \\
\text { (phi) }\end{array}$ & $\begin{array}{c}\text { Mode } 2 \\
\text { (phi) }\end{array}$ & $\begin{array}{c}\text { Mode } 3 \\
\text { (phi) }\end{array}$ & $\begin{array}{c}D_{10} \\
\text { (phi) }\end{array}$ & $\begin{array}{c}D_{10} \\
(\mathrm{~mm})\end{array}$ & $\begin{array}{c}D_{50} \\
\text { (phi) }\end{array}$ & $\begin{array}{c}D_{50} \\
(\mathrm{~mm})\end{array}$ & $\begin{array}{c}\text { Mean } \\
\text { Size } \\
(\mathrm{phi})\end{array}$ & $\begin{array}{c}\text { Mean } \\
\text { Size } \\
(\mathrm{mm})\end{array}$ & $\begin{array}{c}\text { Sorting } \\
\text { (phi) }\end{array}$ & Skewness & Kurtosis \\
\hline A3 $20-22 \mathrm{~cm}$ & 0.00 & 0.00 & 0.00 & 97.59 & 2.41 & NA & NA & u & 2.24 & NA & NA & 1.67 & 0.31 & 2.42 & 0.19 & 2.40 & 0.19 & 0.57 & 0.02 & 1.07 \\
\hline A3_100-102cm & 0.00 & 0.00 & 0.00 & 97.66 & 2.34 & NA & NA & $u$ & 2.24 & NA & NA & 1.72 & 0.30 & 2.42 & 0.19 & 2.42 & 0.19 & 0.55 & 0.04 & 1.05 \\
\hline A3_145-147cm & 0.00 & 0.00 & 0.00 & 97.50 & 2.50 & NA & NA & $u$ & 2.24 & NA & NA & 1.76 & 0.29 & 2.45 & 0.18 & 2.45 & 0.18 & 0.55 & 0.07 & 1.08 \\
\hline A3 $265-267 \mathrm{~cm}$ & 0.00 & 0.00 & 0.00 & 98.22 & 1.78 & NA & NA & $u$ & 2.74 & NA & NA & 1.72 & 0.30 & 2.51 & 0.18 & 2.48 & 0.18 & 0.58 & -0.02 & 1.05 \\
\hline A3 $302-304 \mathrm{~cm}$ & 0.00 & 0.00 & 0.00 & 93.53 & 6.47 & 4.22 & 2.25 & $u$ & 2.74 & NA & NA & 2.08 & 0.24 & 2.76 & 0.15 & 2.78 & 0.15 & 0.69 & 0.19 & 1.95 \\
\hline A3_422-424cm & 0.00 & 0.00 & 0.00 & 86.67 & 13.33 & 9.24 & 4.09 & $u$ & 3.24 & NA & NA & 2.51 & 0.18 & 3.23 & 0.11 & 3.26 & 0.10 & 1.04 & 0.32 & 2.23 \\
\hline A3 $\quad 464-466 \mathrm{~cm}$ & 0.11 & 0.00 & 0.11 & 67.95 & 31.94 & 27.07 & 4.87 & $u$ & 3.24 & NA & NA & 2.70 & 0.15 & 3.54 & 0.09 & 3.77 & 0.07 & 1.30 & 0.49 & 1.74 \\
\hline A3_564-566 $5 \mathrm{~cm}$ & 0.06 & 0.00 & 0.06 & 64.90 & 35.04 & 29.83 & 5.21 & $u$ & 3.24 & NA & NA & 2.70 & 0.15 & 3.59 & 0.08 & 3.82 & 0.07 & 1.38 & 0.48 & 1.67 \\
\hline $\mathrm{A} 4 \_8-12 \mathrm{~cm}$ & 22.14 & 5.76 & 16.38 & 74.30 & 3.56 & NA & NA & $u$ & 0.75 & NA & NA & -1.74 & 3.35 & 0.35 & 0.78 & 0.32 & 0.80 & 1.68 & 0.05 & 0.98 \\
\hline A4 $30-32 \mathrm{~cm}$ & 45.10 & 28.30 & 16.80 & 53.81 & 1.09 & NA & NA & B & 0.75 & -2.74 & NA & -3.33 & 10.03 & -0.74 & 1.67 & -0.94 & 1.91 & 1.70 & -0.15 & 0.79 \\
\hline A4_90-95cm & 65.96 & 54.75 & 11.21 & 32.30 & 1.74 & NA & NA & $\mathrm{T}$ & -4.73 & -2.74 & 0.75 & -4.76 & 27.02 & -2.31 & 4.95 & -2.02 & 4.04 & 2.39 & 0.20 & 1.69 \\
\hline A4_143-153cm & 48.78 & 35.05 & 13.73 & 48.09 & 3.13 & NA & NA & B & -0.24 & -3.74 & NA & -4.13 & 17.55 & -0.93 & 1.90 & -1.13 & 2.19 & 2.31 & -0.06 & 0.86 \\
\hline A4_213-216cm & 3.33 & 0.57 & 2.76 & 91.53 & 5.14 & 3.76 & 1.38 & $u$ & 1.25 & NA & NA & -0.23 & 1.18 & 1.20 & 0.44 & 1.21 & 0.43 & 1.27 & 0.11 & 1.47 \\
\hline A4_248-253cm & 4.71 & 1.71 & 3.00 & 91.09 & 4.20 & NA & NA & $u$ & 1.25 & NA & NA & -0.32 & 1.25 & 0.96 & 0.51 & 0.95 & 0.52 & 1.09 & 0.05 & 1.73 \\
\hline A4_288-290cm & 0.40 & 0.00 & 0.40 & 90.72 & 8.88 & 5.60 & 3.28 & $u$ & 1.75 & NA & NA & 0.71 & 0.61 & 1.69 & 0.31 & 1.88 & 0.27 & 1.29 & 0.39 & 2.16 \\
\hline A4 $326-328 \mathrm{~cm}$ & 7.72 & 3.59 & 4.13 & 89.48 & 2.80 & NA & NA & $u$ & 1.75 & NA & NA & -0.57 & 1.48 & 1.17 & 0.44 & 1.03 & 0.49 & 1.13 & -0.25 & 1.46 \\
\hline A4 $358-360 \mathrm{~cm}$ & 1.03 & 0.42 & 0.61 & 95.99 & 2.98 & NA & NA & $u$ & 1.75 & NA & NA & 0.54 & 0.69 & 1.42 & 0.37 & 1.37 & 0.39 & 0.69 & -0.07 & 1.32 \\
\hline A4_408-410cm & 0.08 & 0.00 & 0.08 & 95.59 & 4.33 & NA & NA & $u$ & 1.75 & NA & NA & 0.82 & 0.57 & 1.64 & 0.32 & 1.61 & 0.33 & 0.70 & 0.07 & 1.66 \\
\hline A4_444-4466 cm & 0.00 & 0.00 & 0.00 & 15.96 & 84.04 & 63.12 & 20.92 & B & 4.50 & 1.75 & NA & 3.53 & 0.09 & 5.24 & 0.03 & 6.11 & 0.01 & 2.85 & 0.45 & 1.50 \\
\hline A4_491-495cm & 0.00 & 0.00 & 0.00 & 40.06 & 59.94 & 46.82 & 13.12 & $u$ & 3.73 & NA & NA & 3.14 & 0.11 & 4.34 & 0.05 & 4.84 & 0.03 & 2.25 & 0.55 & 1.93 \\
\hline A4_536-539cm & 1.13 & 0.00 & 1.13 & 97.72 & 1.15 & NA & NA & $u$ & 1.25 & NA & NA & 0.04 & 0.97 & 1.07 & 0.48 & 0.99 & 0.50 & 0.68 & -0.21 & 1.12 \\
\hline A4_575-577cm & 33.65 & 24.52 & 9.13 & 62.48 & 3.87 & NA & NA & B & 0.75 & -3.74 & NA & -3.84 & 14.34 & 0.02 & 0.98 & -0.72 & 1.64 & 2.41 & -0.26 & 1.06 \\
\hline
\end{tabular}


Vibracores A3 and A4: Grain Size Distribution

\begin{tabular}{|c|c|c|c|c|c|c|c|c|c|c|c|c|c|c|c|c|c|c|c|c|c|c|c|c|c|c|}
\hline UNH Sample ID & $\begin{array}{c}\text { Class \% } \\
\mathrm{phi} \\
-4.5 \\
\end{array}$ & $\begin{array}{c}\text { Class \% } \\
\text { phi } \\
-4.0 \\
\end{array}$ & $\begin{array}{c}\text { Class \% } \\
\text { phi } \\
-3.5 \\
\end{array}$ & $\begin{array}{c}\text { Class \% } \\
\text { phi } \\
-3.0 \\
\end{array}$ & $\begin{array}{c}\text { Class \% } \\
\text { phi } \\
-2.5 \\
\end{array}$ & $\begin{array}{c}\text { Class \% } \\
\text { phi } \\
-2.0 \\
\end{array}$ & $\begin{array}{c}\text { Class \% } \\
\text { phi } \\
-1.5 \\
\end{array}$ & $\begin{array}{c}\text { Class \% } \\
\text { phi } \\
-1.0 \\
\end{array}$ & $\begin{array}{c}\text { Class \% } \\
\text { phi } \\
-0.5 \\
\end{array}$ & $\begin{array}{c}\text { Class \% } \\
\text { phi } \\
0.0 \\
\end{array}$ & $\begin{array}{c}\text { Class \% } \\
\text { phi } \\
0.5 \\
\end{array}$ & $\begin{array}{c}\text { Class \% } \\
\text { phi } \\
1.0 \\
\end{array}$ & $\begin{array}{c}\text { Class \% } \\
\text { phi } \\
1.5 \\
\end{array}$ & $\begin{array}{c}\text { Class \% } \\
\text { phi } \\
2.0 \\
\end{array}$ & $\begin{array}{c}\text { Class \% } \\
\text { phi } \\
2.5 \\
\end{array}$ & $\begin{array}{c}\text { Class \% } \\
\text { phi } \\
3.0 \\
\end{array}$ & 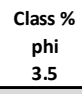 & $\begin{array}{c}\text { Class \% } \\
\text { phi } \\
4.0 \\
\end{array}$ & $\begin{array}{c}\text { Class \% } \\
\mathrm{phi} \\
>4.0 \\
\end{array}$ & $\begin{array}{c}\text { Class \% } \\
\text { phi } \\
5.0 \\
\end{array}$ & $\begin{array}{c}\text { Class \% } \\
\mathrm{phi} \\
6.0 \\
\end{array}$ & $\begin{array}{c}\text { Class \% } \\
\text { phi } \\
7.0 \\
\end{array}$ & $\begin{array}{c}\text { Class \% } \\
\text { phi } \\
8.0 \\
\end{array}$ & $\begin{array}{c}\text { Class \% } \\
\text { phi } \\
9.0 \\
\end{array}$ & $\begin{array}{c}\text { Class \% } \\
\mathrm{phi} \\
10.0 \\
\end{array}$ & $\begin{array}{c}\text { Class } \% \\
\text { phi } \\
>10.0 \\
\end{array}$ \\
\hline A3 $20-22 \mathrm{~cm}$ & 0.00 & 0.00 & 0.00 & 0.00 & 0.00 & 0.00 & 0.00 & 0.00 & 0.00 & 0.11 & 0.30 & 0.77 & 2.95 & 16.87 & 33.14 & 33.42 & 7.72 & 2.29 & 2.41 & $\mathrm{NA}$ & $\mathrm{NA}$ & NA & $\mathrm{NA}$ & NA & $\mathrm{NA}$ & NA \\
\hline A3 $100-102 \mathrm{~cm}$ & 0.00 & 0.00 & 0.00 & 0.00 & 0.00 & 0.00 & 0.00 & 0.00 & 0.00 & 0.00 & 0.06 & 0.13 & 2.01 & 17.65 & 34.07 & 33.96 & 7.61 & 2.17 & 2.34 & NA & NA & NA & NA & $\mathrm{NA}$ & NA & $\mathrm{NA}$ \\
\hline A3 $145-147 \mathrm{~cm}$ & 0.00 & 0.00 & 0.00 & 0.00 & 0.00 & 0.00 & 0.00 & 0.00 & 0.00 & 0.02 & 0.09 & 0.25 & 0.19 & 17.82 & 33.48 & 34.65 & 8.05 & 2.95 & 2.50 & NA & NA & $\mathrm{NA}$ & $\mathrm{NA}$ & NA & $\mathrm{NA}$ & $\mathrm{NA}$ \\
\hline A3 $265-267 \mathrm{~cm}$ & 0.00 & 0.00 & 0.00 & 0.00 & 0.00 & 0.00 & 0.00 & 0.00 & 0.14 & 0.14 & 0.13 & 0.36 & 2.59 & 15.08 & 29.21 & 35.73 & 11.32 & 3.51 & 1.78 & $\mathrm{NA}$ & NA & $\mathrm{NA}$ & NA & $\mathrm{NA}$ & NA & NA \\
\hline A3 $302-304 \mathrm{~cm}$ & 0.00 & 0.00 & 0.00 & 0.00 & 0.00 & 0.00 & 0.00 & 0.00 & 0.03 & 0.05 & 0.06 & 0.19 & 0.99 & 5.80 & 16.81 & 48.36 & 17.16 & 4.08 & NA & 2.39 & 0.78 & 0.62 & 0.43 & 0.31 & 0.43 & 1.51 \\
\hline A3 $422-424 \mathrm{~cm}$ & 0.00 & 0.00 & 0.00 & 0.00 & 0.00 & 0.00 & 0.00 & 0.00 & 0.00 & 0.04 & 0.06 & 0.13 & 0.45 & 1.76 & 5.79 & 26.07 & 32.95 & 19.42 & NA & 5.48 & 1.73 & 1.20 & 0.82 & 0.63 & 0.54 & 2.92 \\
\hline A3_464-466cm & 0.00 & 0.00 & 0.00 & 0.00 & 0.00 & 0.00 & 0.11 & 0.00 & 0.02 & 0.03 & 0.04 & 0.12 & 0.28 & 0.58 & 2.23 & 15.16 & 28.74 & 20.74 & NA & 18.74 & 4.93 & 2.33 & 1.06 & 0.88 & 0.68 & 3.31 \\
\hline A3_564-566cm & 0.00 & 0.00 & 0.00 & 0.00 & 0.00 & 0.00 & 0.00 & 0.06 & 0.00 & 0.01 & 0.06 & 0.10 & 0.19 & 0.54 & 2.16 & 15.99 & 26.77 & 19.07 & NA & 19.88 & 6.16 & 2.50 & 1.30 & 0.89 & 0.87 & 3.45 \\
\hline A4 $8-12 \mathrm{~cm}$ & 0.00 & 0.00 & 0.00 & 0.00 & 1.22 & 4.54 & 8.53 & 7.85 & 9.62 & 10.16 & 11.38 & 12.85 & 9.69 & 8.19 & 5.56 & 2.83 & 2.93 & 1.09 & 3.56 & $\mathrm{NA}$ & $\mathrm{NA}$ & NA & $\mathrm{NA}$ & $\mathrm{NA}$ & NA & $\mathrm{NA}$ \\
\hline A4_30-32 cm & 0.00 & 0.00 & 8.30 & 5.19 & 9.24 & 5.59 & 8.72 & 8.08 & 9.70 & 10.33 & 11.74 & 12.03 & 6.22 & 2.42 & 0.80 & 0.23 & 0.23 & 0.10 & 1.09 & NA & NA & NA & NA & NA & NA & NA \\
\hline A4_90-95cm & 22.21 & 0.00 & 8.09 & 7.98 & 8.93 & 7.54 & 6.93 & 4.28 & 4.07 & 3.57 & 4.52 & 7.72 & 7.05 & 3.28 & 1.06 & 0.51 & 0.32 & 0.20 & 1.74 & NA & NA & NA & NA & NA & NA & NA \\
\hline A4_143-153cm & 5.82 & 5.76 & 6.81 & 5.67 & 5.23 & 5.76 & 6.74 & 7.00 & 8.68 & 8.53 & 8.45 & 7.69 & 4.60 & 4.43 & 3.29 & 1.38 & 0.65 & 0.38 & 3.13 & $\mathrm{NA}$ & NA & $\mathrm{NA}$ & $\mathrm{NA}$ & $\mathrm{NA}$ & NA & NA \\
\hline A4 $213-216 \mathrm{~cm}$ & 0.00 & 0.00 & 0.00 & 0.00 & 0.00 & 0.57 & 1.11 & 1.65 & 3.52 & 6.07 & 10.47 & 18.46 & 20.43 & 16.74 & 8.08 & 3.70 & 2.85 & 1.21 & NA & 1.88 & 1.12 & 0.39 & 0.36 & 0.18 & 0.20 & 1.00 \\
\hline A4_248-253cm & 0.00 & 0.00 & 0.00 & 0.00 & 0.36 & 1.35 & 1.20 & 1.80 & 3.20 & 6.04 & 12.63 & 25.30 & 24.74 & 11.79 & 3.86 & 1.77 & 1.16 & 0.60 & 4.20 & NA & NA & NA & NA & NA & $\mathrm{NA}$ & $\mathrm{NA}$ \\
\hline A4_288-290cm & 0.00 & 0.00 & 0.00 & 0.00 & 0.00 & 0.00 & 0.11 & 0.30 & 0.68 & 1.50 & 3.64 & 8.98 & 22.16 & 32.33 & 10.81 & 3.95 & 4.20 & 2.47 & NA & 2.96 & 1.38 & 0.85 & 0.41 & 0.36 & 0.71 & 2.21 \\
\hline A4_ $326-328 \mathrm{~cm}$ & 0.00 & 0.00 & 3.05 & 0.00 & 0.34 & 0.20 & 1.89 & 2.25 & 2.73 & 5.23 & 9.67 & 16.73 & 23.06 & 23.80 & 5.45 & 1.13 & 1.13 & 0.56 & 2.80 & $\mathrm{NA}$ & $\mathrm{NA}$ & $\mathrm{NA}$ & $\mathrm{NA}$ & $\mathrm{NA}$ & $\mathrm{NA}$ & NA \\
\hline A4_358-360 cm & 0.00 & 0.00 & 0.00 & 0.00 & 0.41 & 0.00 & 0.14 & 0.48 & 0.67 & 1.73 & 5.37 & 14.81 & 31.07 & 32.63 & 7.28 & 1.10 & 0.86 & 0.48 & 2.98 & NA & NA & $\mathrm{NA}$ & NA & $\mathrm{NA}$ & $\mathrm{NA}$ & $\mathrm{NA}$ \\
\hline A4_408-410cm & 0.00 & 0.00 & 0.00 & 0.00 & 0.00 & 0.00 & 0.00 & 0.08 & 0.18 & 0.89 & 2.95 & 9.31 & 24.20 & 42.73 & 12.89 & 1.17 & 0.75 & 0.53 & 4.33 & $\mathrm{NA}$ & $\mathrm{NA}$ & $\mathrm{NA}$ & NA & $\mathrm{NA}$ & NA & NA \\
\hline A4_444-446cm & 0.00 & 0.00 & 0.00 & 0.00 & 0.00 & 0.00 & 0.00 & 0.00 & 0.03 & 0.10 & 0.21 & 0.79 & 1.59 & 2.21 & 0.99 & 0.71 & 2.61 & 6.72 & $\mathrm{NA}$ & 29.60 & 19.58 & 9.27 & 4.66 & 4.30 & 4.35 & 12.26 \\
\hline A4 $491-495 \mathrm{~cm}$ & 0.00 & 0.00 & 0.00 & 0.00 & 0.00 & 0.00 & 0.00 & 0.00 & 0.00 & 0.05 & 0.14 & 0.39 & 0.66 & 1.40 & 1.03 & 2.13 & 14.26 & 19.99 & $\mathrm{NA}$ & 28.94 & 11.36 & 4.37 & 2.15 & 1.53 & 2.13 & 9.46 \\
\hline A4_536-539cm & 0.00 & 0.00 & 0.00 & 0.00 & 0.00 & 0.00 & 0.16 & 0.97 & 2.32 & 5.57 & 11.75 & 24.15 & 34.98 & 16.66 & 1.15 & 0.37 & 0.52 & 0.24 & 1.15 & NA & NA & NA & NA & NA & $\mathrm{NA}$ & NA \\
\hline A4_575-577cm & 0.00 & 6.25 & 12.22 & 1.62 & 2.23 & 2.19 & 4.37 & 4.76 & 6.71 & 9.12 & 11.53 & 13.14 & 11.79 & 6.01 & 1.02 & 0.39 & 1.36 & 1.41 & 3.87 & $\mathrm{NA}$ & $\mathrm{NA}$ & $\mathrm{NA}$ & $\mathrm{NA}$ & $\mathrm{NA}$ & $\mathrm{NA}$ & $\mathrm{NA}$ \\
\hline
\end{tabular}


Section 7: Vibracores A5, A6(1), A6(2) and A6(3) 


\section{Vibracores A5, A6(1), A6(2), and A6(3): Identification, Location, and Description}

\begin{tabular}{|c|c|c|c|c|c|c|c|c|c|c|c|c|c|c|}
\hline UNH Sample ID & $\begin{array}{l}\text { Global Core } \\
\text { Link ID }\end{array}$ & BOEM Global Sample ID & $\begin{array}{c}\text { Latitude } \\
\text { NAD83 }\end{array}$ & $\begin{array}{l}\text { Longitude } \\
\text { NAD83 }\end{array}$ & $\begin{array}{c}\text { Position } \\
\text { Uncertainty }\end{array}$ & $\begin{array}{c}\text { Water } \\
\text { Depth }(\mathrm{m})\end{array}$ & $\begin{array}{l}\text { Diameter } \\
(\mathrm{cm})\end{array}$ & $\begin{array}{l}\text { Core Length } \\
\text { (m) }\end{array}$ & $\begin{array}{l}\text { Vibracore } \\
\text { Collected }\end{array}$ & $\begin{array}{l}\text { Sample } \\
\text { Depth } \\
\text { (cm) }\end{array}$ & $\begin{array}{c}\text { Total Wt } \\
\text { (gm) }\end{array}$ & $\begin{array}{c}\text { Munsell } \\
\text { Hue }\end{array}$ & $\begin{array}{c}\text { Munsell } \\
\text { Value }\end{array}$ & $\begin{array}{l}\text { Munsell } \\
\text { Chroma }\end{array}$ \\
\hline A5_20-22cm & AT1-88-A5 & AT1-88-A5_20-22cm_D19880922 & 43.0033 & -70.6667 & $250 \mathrm{~m}$ & $19.0^{*}$ & 8.9 & 3.36 & $09 / 22-25 / 1988$ & $20-22$ & 71.60 & $10 \mathrm{YR}$ & 4 & 2 \\
\hline A5_80-82 cm & AT1-88-A5 & AT1-88-A5_80-82cm_D19880922 & 43.0033 & -70.6667 & $250 \mathrm{~m}$ & $19.0^{*}$ & 8.9 & 3.36 & $09 / 22-25 / 1988$ & $80-82$ & 66.64 & N4 & NA & NA \\
\hline A5_121-123cm & AT1-88-A5 & AT1-88-A5_121-123cm_D19880922 & 43.0033 & -70.6667 & $250 \mathrm{~m}$ & $19.0^{*}$ & 8.9 & 3.36 & $09 / 22-25 / 1988$ & $121-123$ & 144.93 & N5 & NA & NA \\
\hline A5 $163-167 \mathrm{~cm}$ & AT1-88-A5 & AT1-88-A5_163-167cm_D19880922 & 43.0033 & -70.6667 & $250 \mathrm{~m}$ & $19.0^{*}$ & 8.9 & 3.36 & $09 / 22-25 / 1988$ & $163-167$ & 72.61 & $5 Y$ & 4 & 1 \\
\hline A5 $171-173 \mathrm{~cm}$ & AT1-88-A5 & AT1-88-A5_171-173cm_D19880922 & 43.0033 & -70.6667 & $250 \mathrm{~m}$ & $19.0^{*}$ & 8.9 & 3.36 & 09/22-25/1988 & $171-173$ & 23.83 & $5 Y$ & 4 & 1 \\
\hline A5_205-207cm & AT1-88-A5 & AT1-88-A5_205-207cm_D19880922 & 43.0033 & -70.6667 & $250 \mathrm{~m}$ & $19.0^{*}$ & 8.9 & 3.36 & 09/22-25/1988 & $205-207$ & 18.88 & $5 Y$ & 4 & 1 \\
\hline A5_221-223cm & AT1-88-A5 & AT1-88-A5_221-223cm_D19880922 & 43.0033 & -70.6667 & $250 \mathrm{~m}$ & $19.0^{*}$ & 8.9 & 3.36 & $09 / 22-25 / 1988$ & 221-223 & 14.00 & $5 Y$ & 4 & 1 \\
\hline A5_271-273cm & AT1-88-A5 & AT1-88-A5_271-273cm_D19880922 & 43.0033 & -70.6667 & $250 \mathrm{~m}$ & $19.0^{*}$ & 8.9 & 3.36 & 09/22-25/1988 & $271-273$ & 50.01 & N5 & NA & NA \\
\hline A5_331-333cm & AT1-88-A5 & AT1-88-A5_331-333cm_D19880922 & 43.0033 & -70.6667 & $250 \mathrm{~m}$ & $19.0^{*}$ & 8.9 & 3.36 & 09/22-25/1988 & 331-333 & 49.54 & N5 & NA & NA \\
\hline A6(1) $58-60 \mathrm{~cm}$ & AT1-88-A6 (1) & AT1-88-A6 (1) 58-60cm_D19880922 & 42.9317 & -70.7633 & $250 \mathrm{~m}$ & 22.1 & 8.9 & 2.27 & $09 / 22-25 / 1988$ & $58-60$ & 71.96 & $5 Y$ & 6 & 1 \\
\hline A6(1) $110-112 \mathrm{~cm}$ & AT1-88-A6 (1) & AT1-88-A6 (1)_110-112cm_D19880922 & 42.9317 & -70.7633 & $250 \mathrm{~m}$ & 22.1 & 8.9 & 2.27 & 09/22-25/1988 & $110-112$ & 40.87 & $5 Y$ & 6 & 1 \\
\hline A6(1)-2_148-150cm & AT1-88-A6 (1)-2 & AT1-88-A6 (1)-2_148-150cm_D19880922 & 42.9317 & -70.7633 & $250 \mathrm{~m}$ & 22.1 & 8.9 & 2.27 & 09/22-25/1988 & $148-150$ & 38.86 & $5 Y$ & 6 & 1 \\
\hline A6(1)-2_198-200cm & AT1-88-A6 (1)-2 & AT1-88-A6 (1)-2_198-200cm_D19880922 & 42.9317 & -70.7633 & $250 \mathrm{~m}$ & 22.1 & 8.9 & 2.27 & $09 / 22-25 / 1988$ & $198-200$ & 39.47 & $5 Y$ & 6 & 1 \\
\hline $\mathrm{A} 6(2) \_10-12 \mathrm{~cm}$ & AT1-88-A6 (2) & AT1-88-A6 (2)_10-12cm_D19880922 & 42.9317 & -70.7633 & $250 \mathrm{~m}$ & 22.9 & 8.9 & 1.62 & $09 / 22-25 / 1988$ & $10-12$ & 34.53 & $5 Y$ & 6 & 1 \\
\hline$A 6(2) \_32-34 \mathrm{~cm}$ & AT1-88-A6 (2) & AT1-88-A6 (2)_32-34cm_D19880922 & 42.9317 & -70.7633 & $250 \mathrm{~m}$ & 22.9 & 8.9 & 1.62 & 09/22-25/1988 & 32-34 & 40.74 & $5 Y$ & 4 & 1 \\
\hline$A 6(2) \quad 48-50 \mathrm{~cm}$ & AT1-88-A6 (2) & AT1-88-A6 (2)_48-50cm_D19880922 & 42.9317 & -70.7633 & $250 \mathrm{~m}$ & 22.9 & 8.9 & 1.62 & $09 / 22-25 / 1988$ & $48-50$ & 42.45 & $5 Y$ & 4 & 1 \\
\hline A6(2)_148-150cm & AT1-88-A6 (2) & AT1-88-A6 (2)_148-150cm_D19880922 & 42.9317 & -70.7633 & $250 \mathrm{~m}$ & 22.9 & 8.9 & 1.62 & $09 / 22-25 / 1988$ & $148-150$ & 33.62 & $5 Y$ & 6 & 1 \\
\hline $\mathrm{A} 6(3), 30-32 \mathrm{~cm}$ & AT1-88-A6 (3) & AT1-88-A6 (3)_30-32cm_D19880922 & 42.9317 & -70.7633 & $250 \mathrm{~m}$ & 22.9 & 8.9 & 5.92 & $09 / 22-25 / 1988$ & 30-32 & 74.46 & $10 \mathrm{YR}$ & 6 & 6 \\
\hline A6(3)_123-125cm & AT1-88-A6 (3) & AT1-88-A6 (3)_123-125cm_D19880922 & 42.9317 & -70.7633 & $250 \mathrm{~m}$ & 22.9 & 8.9 & 5.92 & $09 / 22-25 / 1988$ & $123-125$ & 74.24 & $10 \mathrm{YR}$ & 6 & 6 \\
\hline $\mathrm{A} 6(3) \_183-185 \mathrm{~cm}$ & AT1-88-A6 (3) & AT1-88-A6 (3)_183-185cm_D19880922 & 42.9317 & -70.7633 & $250 \mathrm{~m}$ & 22.9 & 8.9 & 5.92 & $09 / 22-25 / 1988$ & $183-185$ & 76.19 & $10 Y R$ & 6 & 6 \\
\hline $\mathrm{A} 6(3) \quad 281-283 \mathrm{~cm}$ & AT1-88-A6 (3) & AT1-88-A6 (3)_281-283cm_D19880922 & 42.9317 & -70.7633 & $250 \mathrm{~m}$ & 22.9 & 8.9 & 5.92 & $09 / 22-25 / 1988$ & 281-283 & 79.79 & $10 Y R$ & 6 & 6 \\
\hline A6(3) $337-339 \mathrm{~cm}$ & AT1-88-A6 (3) & AT1-88-A6 (3) $337-339 \mathrm{~cm}$ DD19880922 & 42.9317 & -70.7633 & $250 \mathrm{~m}$ & 22.9 & 8.9 & 5.92 & $09 / 22-25 / 1988$ & $337-339$ & 116.14 & $5 Y$ & 6 & 1 \\
\hline $\mathrm{A} 6(3) \quad 417-419 \mathrm{~cm}$ & AT1-88-A6 (3) & AT1-88-A6 (3)_417-419cm_D19880922 & 42.9317 & -70.7633 & $250 \mathrm{~m}$ & 22.9 & 8.9 & 5.92 & $09 / 22-25 / 1988$ & $417-419$ & 56.45 & $5 Y$ & 6 & 1 \\
\hline $\mathrm{A} 6(3) \quad 485-487 \mathrm{~cm}$ & AT1-88-A6 (3) & AT1-88-A6 (3) $485-487 \mathrm{~cm}$ DD19880922 & 42.9317 & -70.7633 & $250 \mathrm{~m}$ & 22.9 & 8.9 & 5.92 & 09/22-25/1988 & $485-487$ & 54.80 & $5 Y$ & 6 & 1 \\
\hline$A 6(3) \_560-563 \mathrm{~cm}$ & AT1-88-A6 (3) & AT1-88-A6 (3)_560-563cm_D19880922 & 42.9317 & -70.7633 & $250 \mathrm{~m}$ & 22.9 & 8.9 & 5.92 & $09 / 22-25 / 1988$ & $560-563$ & 62.18 & $5 Y$ & 6 & 1 \\
\hline
\end{tabular}


Vibracores A5, A6(1), A6(2), and A6(3): Sediment Classifications

\begin{tabular}{|c|c|c|c|c|c|c|c|c|c|}
\hline UNH Sample ID & $\begin{array}{l}\text { CMECS Substrate } \\
\text { Component Group } \\
\text { (Specific) }\end{array}$ & $\begin{array}{l}\text { CMECS Substrate } \\
\text { Component Subgroup } \\
\text { (Specific) }\end{array}$ & $\begin{array}{l}\text { Textural Group from } \\
\text { \%GSM (Gradistat) }\end{array}$ & $\begin{array}{l}\text { Textural Group } \\
\text { from \% SzC } \\
\text { (Gradistat) } \\
\text { Ignores Gravel }\end{array}$ & $\begin{array}{l}\text { Sediment Name from \%GSM } \\
\text { and Mode (Gradistat) }\end{array}$ & $\begin{array}{l}\text { Sediment Name from \%GSM } \\
\text { and Mode (Wentworth Scale) }\end{array}$ & $\begin{array}{l}\text { Sediment } \\
\text { Classification } \\
\text { from Mean Phi } \\
\text { (Gradistat) }\end{array}$ & $\begin{array}{l}\text { Sediment } \\
\text { Classification } \\
\text { from Mean Phi } \\
\text { (Wentworth) }\end{array}$ & Sorting (Gradistat) \\
\hline A5_20-22 cm & Pebble Mixes & Sandy Pebble Gravel & Sandy Gravel & Sand & Sandy Medium Gravel & Sandy Pebble Gravel & Very Fine Gravel & Granule Gravel & Very Poorly Sorted \\
\hline A5 $80-82 \mathrm{~cm}$ & Pebble Mixes & Sandy Pebble Gravel & Sandy Gravel & Sand & Sandy Coarse Gravel & Sandy Pebble Gravel & Fine Gravel & Pebble Gravel & Very Poorly Sorted \\
\hline A5_121-123cm & Pebble Mixes & Sandy Pebble Gravel & Sandy Gravel & Sand & Sandy Coarse Gravel & Sandy Pebble Gravel & Fine Gravel & Pebble Gravel & Very Poorly Sorted \\
\hline A5 $163-167 \mathrm{~cm}$ & Pebble Mixes & Sandy Pebble Gravel & Sandy Gravel & Sand & Sandy Coarse Gravel & Sandy Pebble Gravel & Very Coarse Sand & Very Coarse Sand & Very Poorly Sorted \\
\hline A5 $171-173 \mathrm{~cm}$ & Muddy Sand & Silty Very Fine Sand & Muddy Sand & Silty Sand & Very Coarse Silty Very Fine Sand & $\begin{array}{l}\text { Very Coarse Silty Very Fine } \\
\text { Sand }\end{array}$ & Very Fine Sand & Very Fine Sand & Very Poorly Sorted \\
\hline A5_205-207cm & Slightly Pebbly & $\begin{array}{l}\text { Slightly Pebbly Very Fine } \\
\text { Sandy Silt }\end{array}$ & $\begin{array}{l}\text { Slightly Gravelly } \\
\text { Sandy Mud }\end{array}$ & Sandy Silt & $\begin{array}{l}\text { Slightly Fine Gravelly Very Fine } \\
\text { Sandy Very Coarse Silt }\end{array}$ & $\begin{array}{l}\text { Slightly Pebbly Very Fine } \\
\text { Sandy Very Coarse Silt }\end{array}$ & Very Coarse Silt & Very Coarse Silt & Poorly Sorted \\
\hline A5 $221-223 \mathrm{~cm}$ & Sandy Mud & Very Fine Sandy Silt & Sandy Mud & Sandy Silt & Very Fine Sandy Very Coarse Silt & $\begin{array}{l}\text { Very Fine Sandy Very Coarse } \\
\text { Silt }\end{array}$ & Very Coarse Silt & Coarse Silt & Very Poorly Sorted \\
\hline A5 $271-273 \mathrm{~cm}$ & Slightly Granuley & $\begin{array}{l}\text { Slightly Granuley Medium } \\
\text { Sand }\end{array}$ & Slightly Gravelly Sand & Sand & $\begin{array}{l}\text { Slightly Very Fine Gravelly } \\
\text { Medium Sand }\end{array}$ & $\begin{array}{l}\text { Slightly Granular Medium } \\
\text { Sand }\end{array}$ & Medium Sand & Medium Sand & Poorly Sorted \\
\hline A5_331-333cm & Pebbly & Pebbly Medium Sand & Gravelly Sand & Sand & Fine Gravelly Medium Sand & Pebbly Medium Sand & Medium Sand & Medium Sand & Poorly Sorted \\
\hline A6 (1) $58-60 \mathrm{~cm}$ & Pebbly & Pebbly Medium Sand & Gravelly Sand & Sand & Medium Gravelly Medium Sand & Pebbly Medium Sand & Coarse Sand & Coarse Sand & Very Poorly Sorted \\
\hline $\mathrm{A}(1) \_110-112 \mathrm{~cm}$ & Sand & Fine Sand & Sand & Sand & Well Sorted Fine Sand & Fine Sand & Fine Sand & Fine Sand & Well Sorted \\
\hline A6(1)-2_148-150 cm & Sand & Fine Sand & Sand & Sand & Well Sorted Fine Sand & Fine Sand & Fine Sand & Fine Sand & Well Sorted \\
\hline$A 6(1)-2 \_198-200 \mathrm{~cm}$ & Sand & Fine Sand & Sand & Sand & Well Sorted Fine Sand & Fine Sand & Fine Sand & Fine Sand & Well Sorted \\
\hline$A 6(2) \quad 10-12 \mathrm{~cm}$ & Slightly Granuley & Slightly Granuley Fine Sand & Slightly Gravelly S & Sand & $\begin{array}{l}\text { Slightly Very Fine Gravelly Fine } \\
\text { Sand }\end{array}$ & Slightly Granular Fine Sand & Fine Sand & ine Sand & oorly Sorted \\
\hline $\mathrm{A} 6(2)=32-34 \mathrm{~cm}$ & Slightly Granuley & $\begin{array}{l}\text { Slightly Granuley Very Fine } \\
\text { Sand }\end{array}$ & Slightly Gravelly Sand & Sand & $\begin{array}{l}\text { Slightly Very Fine Gravelly Very } \\
\text { Fine Sand }\end{array}$ & $\begin{array}{l}\text { Slightly Granular Very Fine } \\
\text { Sand }\end{array}$ & Fine Sand & Fine Sand & Poorly Sorted \\
\hline $\mathrm{A} 6(2) \_48-50 \mathrm{~cm}$ & Sand & Medium Sand & Sand & Sand & Well Sorted Medium Sand & Medium Sand & Medium Sand & Medium Sand & Well Sorted \\
\hline A6(2)_148-150cm & Sand & Fine Sand & Sand & Sand & Well Sorted Fine Sand & Fine Sand & Fine Sand & Fine Sand & Well Sorted \\
\hline$A 6(3) \quad 30-32 \mathrm{~cm}$ & Sand & Medium Sand & Sand & Sand & Well Sorted Medium Sand & Medium Sand & Medium Sand & Medium Sand & Well Sorted \\
\hline $\mathrm{A} 6(3) \_123-125 \mathrm{~cm}$ & Sand & Medium Sand & Sand & Sand & Well Sorted Medium Sand & Medium Sand & Medium Sand & Medium Sand & Well Sorted \\
\hline A6(3)_183-185cm & Sand & Medium Sand & Sand & Sand & Well Sorted Medium Sand & Medium Sand & Medium Sand & Medium Sand & Well Sorted \\
\hline A6(3) $281-283 \mathrm{~cm}$ & Slightly Granuley & $\begin{array}{l}\text { Slightly Granuley Medium } \\
\text { Sand }\end{array}$ & Slightly Gravelly Sand & Sand & $\begin{array}{l}\text { Slightly Very Fine Gravelly } \\
\text { Medium Sand }\end{array}$ & $\begin{array}{l}\text { Slightly Granular Medium } \\
\text { Sand }\end{array}$ & Medium Sand & Medium Sand & Moderately Sorted \\
\hline $\mathrm{A} 6(3) \quad 337-339 \mathrm{~cm}$ & Slightly Granuley & $\begin{array}{l}\text { Slightly Granuley Medium } \\
\text { Sand }\end{array}$ & Slightly Gravelly Sand & Sand & $\begin{array}{l}\text { Slightly Very Fine Gravelly } \\
\text { Medium Sand }\end{array}$ & $\begin{array}{l}\text { Slightly Granular Medium } \\
\text { Sand }\end{array}$ & Medium Sand & Medium Sand & Moderately Sorted \\
\hline A6(3) $417-419 \mathrm{~cm}$ & Slightly Pebbly & $\begin{array}{l}\text { Slightly Pebbly Very Fine } \\
\text { Sandy Silt }\end{array}$ & $\begin{array}{l}\text { Slightly Gravelly } \\
\text { Sandy Mud }\end{array}$ & Sandy Silt & $\begin{array}{l}\text { Slightly Fine Gravelly Very Fine } \\
\text { Sandy Very Coarse Silt }\end{array}$ & $\begin{array}{l}\text { Slightly Pebbly Very Fine } \\
\text { Sandy Very Coarse Silt }\end{array}$ & Coarse Silt & Medium Silt & Very Poorly Sorted \\
\hline A6(3) $485-487 \mathrm{~cm}$ & Slightly Granuley & $\begin{array}{l}\text { Slightly Granuley Medium } \\
\text { Sandy Silt-Clay }\end{array}$ & $\begin{array}{l}\text { Slightly Gravelly } \\
\text { Sandy Mud }\end{array}$ & Sandy Mud & $\begin{array}{l}\text { Slightly Very Fine Gravelly } \\
\text { Medium Sandy Mud }\end{array}$ & $\begin{array}{l}\text { Slightly Granular Medium } \\
\text { Sandy Mud }\end{array}$ & Fine Silt & Very Fine Silt & Very Poorly Sorted \\
\hline A6(3) $560-563 \mathrm{~cm}$ & Sandy Mud & Very Fine Sandy Silt-Clay & Sandy Mud & Sandy Silt & Very Fine Sandy Very Coarse Silt & $\begin{array}{l}\text { Very Fine Sandy Very Coarse } \\
\text { Silt }\end{array}$ & Medium Silt & Medium Silt & Very Poorly Sorted \\
\hline
\end{tabular}

\begin{tabular}{|lllllll} 
A6(3)_560-563cm Sandy Mud & Very Fine Sandy Silt-Clay & Sandy Mud & Sandy Silt & Very Fine Sandy Very Coarse Silt & Very Fine Sandy Very Coarse & Milt \\
\end{tabular} 


\section{Vibracores A5, A6(1), A6(2), and A6(3): Grain Size Statistics}

\begin{tabular}{|c|c|c|c|c|c|c|c|c|c|c|c|c|c|c|c|c|c|c|c|c|}
\hline UNH Sample ID & Gravel\% & Pebble \% & Granule \% & Sand \% & Mud \% & Silt \% & Clay \% & Modes & $\begin{array}{c}\text { Mode } 1 \\
\text { (phi) }\end{array}$ & $\begin{array}{c}\text { Mode } 2 \\
\text { (phi) }\end{array}$ & $\begin{array}{c}\text { Mode } 3 \\
\text { (phi) }\end{array}$ & $\begin{array}{c}\mathrm{D}_{10} \\
\text { (phi) }\end{array}$ & $\begin{array}{c}\mathrm{D}_{10} \\
(\mathrm{~mm})\end{array}$ & $\begin{array}{r}D_{50} \\
\text { (phi) }\end{array}$ & $\begin{array}{c}D_{50} \\
(\mathrm{~mm}) \\
\end{array}$ & $\begin{array}{c}\text { Mean } \\
\text { Size } \\
\text { (phi) }\end{array}$ & $\begin{array}{c}\text { Mean } \\
\text { Size } \\
(\mathrm{mm}) \\
\end{array}$ & $\begin{array}{c}\text { Sorting } \\
\text { (phi) }\end{array}$ & Skewness & Kurtosis \\
\hline A5_ $80-82 \mathrm{~cm}$ & 66.65 & 54.26 & 12.39 & 30.55 & 2.80 & NA & NA & B & -4.24 & -1.24 & NA & -4.31 & 19.78 & -2.42 & 5.35 & -2.11 & 4.30 & 2.10 & 0.30 & 0.72 \\
\hline A5_121-123cm & 71.31 & 65.52 & 5.79 & 26.42 & 2.27 & NA & NA & $u$ & -4.73 & NA & NA & -4.87 & 29.20 & -4.04 & 16.47 & -2.84 & 7.14 & 2.24 & 0.71 & 0.62 \\
\hline A5_163-167cm & 32.91 & 31.91 & 1.00 & 61.88 & 5.21 & 4.43 & 0.78 & B & -4.24 & 1.75 & NA & -4.25 & 18.99 & 1.19 & 0.44 & -0.23 & 1.17 & 2.86 & -0.49 & 0.64 \\
\hline A5 $171-173 \mathrm{~cm}$ & 0.00 & 0.00 & 0.00 & 61.68 & 38.32 & 31.21 & 7.11 & $u$ & 3.24 & NA & NA & 1.67 & 0.31 & 3.49 & 0.09 & 3.65 & 0.08 & 2.18 & 0.32 & 1.46 \\
\hline A5 $205-207 \mathrm{~cm}$ & 1.03 & 1.03 & 0.00 & 33.93 & 65.04 & 56.91 & 8.13 & $u$ & 4.50 & NA & NA & 2.47 & 0.18 & 4.39 & 0.05 & 4.47 & 0.04 & 1.98 & 0.23 & 2.49 \\
\hline A5 $221-223 \mathrm{~cm}$ & 0.00 & 0.00 & 0.00 & 42.81 & 57.19 & 45.68 & 11.51 & u & 3.73 & NA & NA & 2.17 & 0.22 & 4.32 & 0.05 & 4.60 & 0.04 & 2.43 & 0.32 & 1.80 \\
\hline A5 $271-273 \mathrm{~cm}$ & 1.79 & 0.00 & 1.79 & 93.00 & 5.21 & 4.84 & 0.37 & $u$ & 1.75 & NA & NA & 0.33 & 0.79 & 1.66 & 0.32 & 1.66 & 0.32 & 1.14 & 0.07 & 1.38 \\
\hline A5 $331-333 \mathrm{~cm}$ & 6.01 & 4.20 & 1.81 & 88.67 & 5.32 & 4.48 & 0.84 & B & 1.75 & -2.74 & NA & -0.12 & 1.09 & 1.69 & 0.31 & 1.58 & 0.34 & 1.34 & -0.14 & 1.79 \\
\hline A6(1)_58-60 $\mathrm{cm}$ & 22.42 & 20.15 & 2.26 & 76.82 & 0.76 & NA & NA & B & 1.75 & -3.74 & NA & -3.14 & 8.84 & 1.57 & 0.34 & 0.42 & 0.75 & 2.19 & -0.66 & 2.05 \\
\hline A6(1) $110-112 \mathrm{~cm}$ & 0.00 & 0.00 & 0.00 & 99.41 & 0.59 & NA & NA & $u$ & 2.24 & NA & NA & 1.59 & 0.33 & 2.22 & 0.22 & 2.22 & 0.22 & 0.48 & 0.01 & 0.97 \\
\hline$A 6(1)-2 \quad 148-150 \mathrm{~cm}$ & 0.00 & 0.00 & 0.00 & 99.34 & 0.66 & NA & NA & $u$ & 2.24 & NA & NA & 2.01 & 0.25 & 2.46 & 0.18 & 2.48 & 0.18 & 0.43 & 0.06 & 1.00 \\
\hline$A 6(1)-2 \_198-200 \mathrm{~cm}$ & 0.00 & 0.00 & 0.00 & 99.35 & 0.65 & NA & NA & $u$ & 2.24 & NA & NA & 2.04 & 0.24 & 2.46 & 0.18 & 2.49 & 0.18 & 0.40 & 0.13 & 0.93 \\
\hline AG(2)_10-12cm & 0.86 & 0.00 & 0.86 & 97.19 & 1.95 & NA & NA & $u$ & 2.74 & NA & NA & 0.49 & 0.71 & 2.35 & 0.20 & 2.18 & 0.22 & 1.11 & -0.28 & 1.07 \\
\hline AG(2)_32-34cm & 0.85 & 0.00 & 0.85 & 93.06 & 6.09 & 5.23 & 0.86 & $u$ & 3.24 & NA & NA & 1.10 & 0.47 & 2.79 & 0.14 & 2.67 & 0.16 & 1.14 & -0.20 & 0.96 \\
\hline A6(2)_48-50 $\mathrm{cm}$ & 0.00 & 0.00 & 0.00 & 99.56 & 0.44 & NA & NA & $u$ & 1.75 & NA & NA & 1.52 & 0.35 & 1.88 & 0.27 & 1.94 & 0.26 & 0.42 & 0.22 & 1.09 \\
\hline A6(2)_148-150cm & 0.00 & 0.00 & 0.00 & 99.42 & 0.58 & NA & NA & $u$ & 2.74 & NA & NA & 2.09 & 0.23 & 2.60 & 0.17 & 2.57 & 0.17 & 0.39 & 0.00 & 0.93 \\
\hline$A 6(3)=30-32 \mathrm{~cm}$ & 0.00 & 0.00 & 0.00 & 99.85 & 0.15 & NA & NA & $u$ & 1.75 & NA & NA & 1.11 & 0.46 & 1.68 & 0.31 & 1.64 & 0.32 & 0.40 & -0.07 & 1.10 \\
\hline $\mathrm{A} 6(3) \quad 123-125 \mathrm{~cm}$ & 0.00 & 0.00 & 0.00 & 99.79 & 0.21 & NA & NA & $u$ & 1.75 & NA & NA & 1.20 & 0.43 & 1.77 & 0.29 & 1.79 & 0.29 & 0.45 & 0.08 & 1.30 \\
\hline A6(3)_183-185cm & 0.00 & 0.00 & 0.00 & 99.78 & 0.22 & NA & NA & $u$ & 1.75 & NA & NA & 1.46 & 0.36 & 1.86 & 0.28 & 1.91 & 0.27 & 0.41 & 0.14 & 1.11 \\
\hline A6(3) $281-283 \mathrm{~cm}$ & 0.13 & 0.00 & 0.13 & 99.37 & 0.50 & NA & NA & $u$ & 1.75 & NA & NA & 0.61 & 0.66 & 1.73 & 0.30 & 1.66 & 0.32 & 0.71 & -0.21 & 1.10 \\
\hline A6 (3) $337-339 \mathrm{~cm}$ & 1.01 & 0.07 & 0.94 & 97.94 & 1.05 & NA & NA & $u$ & 1.75 & NA & NA & 0.12 & 0.92 & 1.57 & 0.34 & 1.38 & 0.38 & 0.87 & -0.30 & 1.17 \\
\hline $\mathrm{A} 6(3) \quad 417-419 \mathrm{~cm}$ & 2.59 & 1.82 & 0.78 & 20.89 & 76.52 & 59.80 & 16.72 & $u$ & 4.50 & NA & NA & 3.42 & 0.09 & 4.78 & 0.04 & 5.56 & 0.02 & 2.62 & 0.50 & 1.72 \\
\hline A6(3) $485-487 \mathrm{~cm}$ & 0.09 & 0.00 & 0.09 & 11.18 & 88.73 & 46.63 & 42.10 & $B$ & 6.50 & 1.75 & NA & 3.40 & 0.09 & 7.48 & 0.01 & 7.96 & 0.00 & 3.26 & 0.12 & 1.17 \\
\hline A6(3)_560-563cm & 0.00 & 0.00 & 0.00 & 24.49 & 75.51 & 49.88 & 25.63 & $u$ & 3.73 & NA & NA & 3.51 & 0.09 & 4.90 & 0.03 & 6.23 & 0.01 & 3.06 & 0.63 & 0.97 \\
\hline
\end{tabular}




\section{Vibracores A5, A6(1), A6(2), and A6(3): Grain Size Distribution}

\begin{tabular}{|c|c|c|c|c|c|c|c|c|c|c|c|c|c|c|c|c|c|c|c|c|c|c|c|c|c|c|}
\hline UNH Sample ID & $\begin{array}{c}\text { Class \% } \\
\text { phi } \\
-4.5 \\
\end{array}$ & $\begin{array}{c}\text { Class \% } \\
\text { phi } \\
-4.0 \\
\end{array}$ & $\begin{array}{c}\begin{array}{c}\text { Class \% } \\
\text { phi } \\
-3.5\end{array} \\
\end{array}$ & $\begin{array}{c}\text { Class \% } \\
\text { phi } \\
-3.0 \\
\end{array}$ & $\begin{array}{c}\text { Class \% } \\
\text { phi } \\
-2.5 \\
\end{array}$ & $\begin{array}{c}\text { Class \% } \\
\text { phi } \\
-2.0 \\
\end{array}$ & $\begin{array}{c}\text { Class \% } \\
\text { phi } \\
-1.5 \\
\end{array}$ & $\begin{array}{c}\text { Class \% } \\
\text { phi } \\
-1.0 \\
\end{array}$ & $\begin{array}{c}\text { Class \% } \\
\mathrm{phi} \\
-0.5 \\
\end{array}$ & $\begin{array}{c}\text { Class \% } \\
\text { phi } \\
0.0 \\
\end{array}$ & $\begin{array}{c}\text { Class \% } \\
\text { phi } \\
0.5 \\
\end{array}$ & $\begin{array}{c}\text { Class \% } \\
\text { phi } \\
1.0 \\
\end{array}$ & $\begin{array}{c}\text { Class \% } \\
\text { phi } \\
1.5 \\
\end{array}$ & $\begin{array}{c}\text { Class \% } \\
\text { phi } \\
2.0 \\
\end{array}$ & $\begin{array}{c}\text { Class \% } \\
\text { phi } \\
2.5 \\
\end{array}$ & $\begin{array}{c}\text { Class \% } \\
\text { phi } \\
3.0 \\
\end{array}$ & $\begin{array}{c}\text { Class \% } \\
\mathrm{phi} \\
3.5 \\
\end{array}$ & $\begin{array}{c}\text { Class \% } \\
\text { phi } \\
4.0 \\
\end{array}$ & $\begin{array}{c}\text { Class \% } \\
\mathrm{phi} \\
>4.0 \\
\end{array}$ & $\begin{array}{c}\text { Class \% } \\
\text { phi } \\
5.0 \\
\end{array}$ & $\begin{array}{c}\text { Class \% } \\
\mathrm{phi} \\
6.0 \\
\end{array}$ & $\begin{array}{c}\text { Class \% } \\
\text { phi } \\
7.0 \\
\end{array}$ & $\begin{array}{c}\text { Class \% } \\
\text { phi } \\
8.0 \\
\end{array}$ & $\begin{array}{c}\text { Class \% } \\
\mathrm{phi} \\
9.0 \\
\end{array}$ & $\begin{array}{c}\text { Class \% } \\
\mathrm{phi} \\
10.0 \\
\end{array}$ & $\begin{array}{c}\text { Class } \% \\
\text { phi } \\
>10.0 \\
\end{array}$ \\
\hline $5.20-22 \mathrm{~cm}$ & 0.00 & 19.44 & 16.24 & 4.45 & 4.48 & 3.16 & 5.86 & 5.27 & 6.33 & 4.82 & 4.88 & 6.55 & 8.05 & 4.25 & 1.46 & 0.83 & 0.51 & 0.37 & 3.06 & $\mathrm{NA}$ & $\mathrm{NA}$ & NA & $\mathrm{NA}$ & $\mathrm{NA}$ & NA & NA \\
\hline $5.80-82 \mathrm{~cm}$ & 0.00 & 27.05 & 11.50 & 5.01 & 5.77 & 4.94 & 5.69 & 6.70 & 6.81 & 6.73 & 6.29 & 4.50 & 2.54 & 1.46 & 0.75 & 0.65 & 0.44 & 0.38 & 2.80 & NA & NA & NA & $\mathrm{NA}$ & $\mathrm{NA}$ & NA & NA \\
\hline A5 $121-123 \mathrm{~cm}$ & 45.07 & 5.40 & 5.74 & 4.53 & 2.54 & 2.23 & 2.44 & 3.35 & 4.14 & 4.68 & 5.65 & 6.12 & 3.97 & 1.07 & 0.28 & 0.22 & 0.16 & 0.14 & 2.27 & NA & NA & $\mathrm{NA}$ & NA & $\mathrm{NA}$ & $\mathrm{NA}$ & NA \\
\hline A5 $163-167 \mathrm{~cm}$ & 0.00 & 20.37 & 4.91 & 2.92 & 2.79 & 0.91 & 0.63 & 0.37 & 0.49 & 0.91 & 2.31 & 7.04 & 16.86 & 20.06 & 7.21 & 3.61 & 2.01 & 1.37 & NA & 2.40 & 1.28 & 0.49 & 0.25 & 0.20 & 0.12 & 0.46 \\
\hline A5 $171-173 \mathrm{~cm}$ & 0.00 & 0.00 & 0.00 & 0.00 & 0.00 & 0.00 & 0.00 & 0.00 & 0.11 & 0.05 & 0.13 & 0.67 & 4.78 & 11.93 & 9.13 & 10.64 & 12.28 & 11.95 & NA & 17.86 & 8.52 & 3.53 & 1.30 & 1.22 & 1.03 & 4.87 \\
\hline A5 $205-207 \mathrm{~cm}$ & 0.00 & 0.00 & 0.00 & 0.00 & 0.00 & 1.03 & 0.00 & 0.00 & 0.11 & 0.18 & 0.40 & 0.87 & 1.94 & 3.06 & 2.44 & 2.81 & 6.48 & 15.63 & $\mathrm{NA}$ & 38.74 & 12.84 & 3.71 & 1.62 & 1.24 & 1.32 & 5.56 \\
\hline A5 $221-223 \mathrm{~cm}$ & 0.00 & 0.00 & 0.00 & 0.00 & 0.00 & 0.00 & 0.00 & 0.00 & 0.09 & 0.44 & 0.65 & 1.15 & 2.35 & 3.98 & 3.83 & 5.27 & 8.07 & 16.98 & NA & 22.23 & 15.51 & 5.33 & 2.61 & 1.82 & 2.32 & 7.36 \\
\hline A5_271-273cm & 0.00 & 0.00 & 0.00 & 0.00 & 0.00 & 0.00 & 0.78 & 1.02 & 1.38 & 2.70 & 6.13 & 11.96 & 18.48 & 23.24 & 15.58 & 8.65 & 2.82 & 2.07 & NA & 2.58 & 1.24 & 0.70 & 0.32 & 0.11 & 0.21 & 0.05 \\
\hline A5 $3331-333 \mathrm{~cm}$ & 0.00 & 0.00 & 0.00 & 0.00 & 3.71 & 0.50 & 0.54 & 1.27 & 1.82 & 2.89 & 4.91 & 9.20 & 15.88 & 24.06 & 18.44 & 8.13 & 1.91 & 1.44 & NA & 2.58 & 1.13 & 0.49 & 0.27 & 0.21 & 0.36 & 0.26 \\
\hline A6(1) $588-60 \mathrm{~cm}$ & 0.00 & 0.00 & 9.12 & 1.25 & 6.22 & 3.56 & 1.38 & 0.89 & 0.69 & 0.48 & 0.66 & 3.15 & 17.38 & 34.33 & 10.93 & 6.06 & 2.04 & 1.10 & 0.76 & NA & NA & NA & NA & NA & NA & NA \\
\hline$A 6(1) \_110-112 \mathrm{~cm}$ & 0.00 & 0.00 & 0.00 & 0.00 & 0.00 & 0.00 & 0.00 & 0.00 & 0.02 & 0.03 & 0.15 & 0.68 & 4.10 & 25.48 & 42.68 & 22.98 & 3.00 & 0.28 & 0.59 & $\mathrm{NA}$ & NA & NA & NA & NA & NA & NA \\
\hline$A 6(1)-2 \_148-150 \mathrm{~cm}$ & 0.00 & 0.00 & 0.00 & 0.00 & 0.00 & 0.00 & 0.00 & 0.00 & 0.00 & 0.01 & 0.05 & 0.14 & 0.48 & 8.42 & 42.56 & 40.02 & 7.19 & 0.47 & 0.66 & $\mathrm{NA}$ & NA & NA & NA & $\mathrm{NA}$ & NA & NA \\
\hline A6(1)-2_198-200cm & 0.00 & 0.00 & 0.00 & 0.00 & 0.00 & 0.00 & 0.00 & 0.00 & 0.00 & 0.00 & 0.02 & 0.06 & 0.22 & 5.95 & 45.26 & 40.30 & 6.85 & 0.70 & 0.65 & $\mathrm{NA}$ & $\mathrm{NA}$ & $\mathrm{NA}$ & $\mathrm{NA}$ & $\mathrm{NA}$ & $\mathrm{NA}$ & $\mathrm{NA}$ \\
\hline$A 6(2) 10-12 \mathrm{~cm}$ & 0.00 & 0.00 & 0.00 & 0.00 & 0.00 & 0.00 & 0.18 & 0.67 & 1.90 & 2.93 & 4.34 & 6.02 & 8.73 & 13.07 & 16.31 & 23.96 & 15.66 & 4.27 & 1.95 & NA & $\mathrm{NA}$ & $\mathrm{NA}$ & NA & $\mathrm{NA}$ & NA & $\mathrm{NA}$ \\
\hline$A G(2)=32-34 \mathrm{~cm}$ & 0.00 & 0.00 & 0.00 & 0.00 & 0.00 & 0.00 & 0.46 & 0.39 & 0.72 & 1.77 & 2.18 & 2.98 & 7.09 & 14.45 & 13.04 & 11.61 & 20.08 & 19.13 & $\mathrm{NA}$ & 4.52 & 0.33 & 0.21 & 0.17 & 0.12 & 0.05 & 0.69 \\
\hline $\mathrm{A}(2) \quad 48-50 \mathrm{~cm}$ & 0.00 & 0.00 & 0.00 & 0.00 & 0.00 & 0.00 & 0.00 & 0.00 & 0.00 & 0.01 & 0.06 & 0.29 & 7.40 & 55.27 & 27.27 & 7.82 & 1.21 & 0.24 & 0.44 & $\mathrm{NA}$ & NA & $\mathrm{NA}$ & NA & NA & NA & NA \\
\hline $\mathrm{A} 6(2) \_148-150 \mathrm{~cm}$ & 0.00 & 0.00 & 0.00 & 0.00 & 0.00 & 0.00 & 0.00 & 0.00 & 0.00 & 0.01 & 0.03 & 0.05 & 0.21 & 3.09 & 34.84 & 51.07 & 9.15 & 0.98 & 0.58 & NA & NA & NA & NA & $\mathrm{NA}$ & $\mathrm{NA}$ & $\mathrm{NA}$ \\
\hline$A 6(3)=30-32 \mathrm{~cm}$ & 0.00 & 0.00 & 0.00 & 0.00 & 0.00 & 0.00 & 0.00 & 0.00 & 0.01 & 0.04 & 0.28 & 3.77 & 25.55 & 54.32 & 13.13 & 1.43 & 1.22 & 0.09 & NA & 0.15 & 0.00 & 0.00 & 0.00 & 0.00 & 0.00 & 0.00 \\
\hline$A 6(3) \_123-125 \mathrm{~cm}$ & 0.00 & 0.00 & 0.00 & 0.00 & 0.00 & 0.00 & 0.00 & 0.00 & 0.00 & 0.02 & 0.08 & 2.25 & 18.67 & 53.21 & 19.99 & 3.06 & 2.35 & 0.17 & 0.21 & NA & NA & NA & NA & NA & NA & NA \\
\hline$A 6(3) \_183-185 \mathrm{~cm}$ & 0.00 & 0.00 & 0.00 & 0.00 & 0.00 & 0.00 & 0.00 & 0.00 & 0.01 & 0.01 & 0.04 & 0.83 & 9.87 & 54.52 & 28.32 & 4.06 & 1.99 & 0.14 & NA & 0.22 & 0.00 & 0.00 & 0.00 & 0.00 & 0.00 & 0.00 \\
\hline$A 6(3) 281-283 \mathrm{~cm}$ & 0.00 & 0.00 & 0.00 & 0.00 & 0.00 & 0.00 & 0.00 & 0.13 & 0.69 & 1.83 & 5.32 & 9.17 & 17.04 & 33.61 & 25.76 & 4.33 & 1.52 & 0.08 & 0.50 & $\mathrm{NA}$ & $\mathrm{NA}$ & $\mathrm{NA}$ & $\mathrm{NA}$ & $\mathrm{NA}$ & $\mathrm{NA}$ & $\mathrm{NA}$ \\
\hline $\mathrm{A} 6(3)-337-339 \mathrm{~cm}$ & 0.00 & 0.00 & 0.00 & 0.00 & 0.00 & 0.07 & 0.25 & 0.69 & 2.32 & 4.52 & 8.78 & 11.29 & 16.29 & 36.57 & 12.80 & 3.40 & 1.68 & 0.28 & NA & 0.28 & 0.16 & 0.60 & 0.00 & 0.00 & 0.00 & 0.00 \\
\hline $\mathrm{A} 6(3)-417-419 \mathrm{~cm}$ & 0.00 & 0.00 & 0.00 & 0.00 & 1.57 & 0.25 & 0.61 & 0.17 & 0.04 & 0.07 & 0.10 & 0.18 & 0.38 & 1.22 & 0.77 & 0.79 & 4.36 & 12.98 & NA & 34.16 & 14.91 & 6.65 & 4.08 & 3.23 & 3.24 & 10.25 \\
\hline $\mathrm{A} 6(3) \_485-487 \mathrm{~cm}$ & 0.00 & 0.00 & 0.00 & 0.00 & 0.00 & 0.00 & 0.00 & 0.09 & 0.07 & 0.05 & 0.28 & 0.58 & 1.56 & 2.98 & 1.82 & 1.48 & 1.28 & 1.07 & NA & 3.73 & 11.83 & 15.87 & 15.20 & 10.84 & 7.58 & 23.68 \\
\hline $560-563$ & 0.00 & 0.00 & 0.00 & 0.00 & 0.00 & 0.00 & 0.00 & 0.00 & 0.00 & 0.05 & 0.14 & 0.39 & 0.59 & 0.89 & 0.80 & 1.29 & 4.62 & 15.71 & NA & 28.56 & 11.76 & 5.04 & 4.52 & 4.65 & 4.69 & 16.29 \\
\hline
\end{tabular}


Section 8: Vibracores A7(1), A7(2) and A8 


\section{Vibracores A7(1), A7(2), and A8: Identification, Location, and Description}

\begin{tabular}{|c|c|c|c|c|c|c|c|c|c|c|c|c|c|c|}
\hline UNH Sample ID & $\begin{array}{c}\text { Global Core } \\
\text { Link ID }\end{array}$ & BOEM Global Sample ID & $\begin{array}{c}\text { Latitude } \\
\text { NAD83 }\end{array}$ & $\begin{array}{c}\text { Longitude } \\
\text { NAD83 }\end{array}$ & $\begin{array}{c}\text { Position } \\
\text { Uncertainty }\end{array}$ & $\begin{array}{c}\text { Water } \\
\text { Depth }(\mathrm{m})\end{array}$ & $\begin{array}{l}\text { Diameter } \\
\text { (cm) }\end{array}$ & $\begin{array}{l}\text { Core Length } \\
\text { (m) }\end{array}$ & $\begin{array}{l}\text { Vibracore } \\
\text { Collected }\end{array}$ & $\begin{array}{c}\text { Sample } \\
\text { Depth } \\
(\mathrm{cm})\end{array}$ & $\begin{array}{c}\text { Total Wt } \\
(\mathrm{gm})\end{array}$ & $\begin{array}{c}\text { Munsell } \\
\text { Hue }\end{array}$ & $\begin{array}{c}\text { Munsell } \\
\text { Value }\end{array}$ & $\begin{array}{l}\text { Munsell } \\
\text { Chroma }\end{array}$ \\
\hline$A 7(1) \_10-12 \mathrm{~cm}$ & AT1-88-A7 (1) & AT1-88-A7 (1)_10-12cm_D19880922 & 42.9483 & -70.7533 & $250 \mathrm{~m}$ & 24.4 & 8.9 & 1.32 & $09 / 22-25 / 1988$ & $10-12$ & 43.81 & $5 Y$ & 6 & 1 \\
\hline$A 7(1) \_60-64 \mathrm{~cm}$ & AT1-88-A7 (1) & AT1-88-A7 (1)_60-64cm_D19880922 & 42.9483 & -70.7533 & $250 \mathrm{~m}$ & 24.4 & 8.9 & 1.32 & 09/22-25/1988 & $60-64$ & 106.75 & $10 \mathrm{YR}$ & 4 & 2 \\
\hline A7(1)_120-122cm & AT1-88-A7 (1) & AT1-88-A7 (1)_120-122cm_D19880922 & 42.9483 & -70.7533 & $250 \mathrm{~m}$ & 24.4 & 8.9 & 1.32 & $09 / 22-25 / 1988$ & $120-122$ & 26.85 & $10 \mathrm{YR}$ & 4 & 2 \\
\hline $\mathrm{A} 7(2) 28-30 \mathrm{~cm}$ & AT1-88-A7 (2) & AT1-88-A7 (2) $28-30 \mathrm{~cm}$ D19880922 & 42.9483 & -70.7533 & $250 \mathrm{~m}$ & 25.0 & 8.9 & 2.05 & $09 / 22-25 / 1988$ & $28-30$ & 42.45 & $5 Y$ & 2 & 1 \\
\hline$A 7(2) \_52-56 \mathrm{~cm}$ & AT1-88-A7 (2) & AT1-88-A7 (2)_52-56cm_D19880922 & 42.9483 & -70.7533 & $250 \mathrm{~m}$ & 25.0 & 8.9 & 2.05 & $09 / 22-25 / 1988$ & $52-56$ & 146.67 & $5 Y$ & 2 & 1 \\
\hline $\mathrm{A} 7(2) \_90-94 \mathrm{~cm}$ & AT1-88-A7 (2) & AT1-88-A7 (2)_90-94cm_D19880922 & 42.9483 & -70.7533 & $250 \mathrm{~m}$ & 25.0 & 8.9 & 2.05 & $09 / 22-25 / 1988$ & $90-94$ & 95.26 & $5 Y$ & 6 & 1 \\
\hline A7(2)_134-138cm & AT1-88-A7 (2) & AT1-88-A7 (2)_134-138cm_D19880922 & 42.9483 & -70.7533 & $250 \mathrm{~m}$ & 25.0 & 8.9 & 2.05 & $09 / 22-25 / 1988$ & $134-138$ & 152.52 & $5 Y$ & 4 & 1 \\
\hline A7(2)_160-162cm & AT1-88-A7 (2) & AT1-88-A7 (2)_160-162cm_D19880922 & 42.9483 & -70.7533 & $250 \mathrm{~m}$ & 25.0 & 8.9 & 2.05 & 09/22-25/1988 & $160-162$ & 29.92 & $5 Y$ & 6 & 1 \\
\hline A8_20-22cm & AT1-88-A8 & AT1-88-A8_20-22cm_D19880922 & 42.9417 & -70.7517 & $250 \mathrm{~m}$ & 24.7 & 8.9 & 4.04 & 09/22-25/1988 & $20-22$ & 93.72 & $5 Y$ & 6 & 1 \\
\hline A8 $88-90 \mathrm{~cm}$ & AT1-88-A8 & AT1-88-A8_88-90cm_D19880922 & 42.9417 & -70.7517 & $250 \mathrm{~m}$ & 24.7 & 8.9 & 4.04 & 09/22-25/1988 & $88-90$ & 74.89 & $5 Y$ & 6 & 1 \\
\hline A8 $119-121 \mathrm{~cm}$ & AT1-88-A8 & AT1-88-A8_119-121cm_D19880922 & 42.9417 & -70.7517 & $250 \mathrm{~m}$ & 24.7 & 8.9 & 4.04 & 09/22-25/1988 & $119-121$ & 52.36 & $5 Y$ & 6 & 1 \\
\hline A8_202-204cm & AT1-88-A8 & AT1-88-A8_202-204cm_D19880922 & 42.9417 & -70.7517 & $250 \mathrm{~m}$ & 24.7 & 8.9 & 4.04 & 09/22-25/1988 & 202-204 & 49.23 & $5 Y$ & 6 & 1 \\
\hline A8_282-284cm & AT1-88-A8 & AT1-88-A8_282-284cm_D19880922 & 42.9417 & -70.7517 & $250 \mathrm{~m}$ & 24.7 & 8.9 & 4.04 & 09/22-25/1988 & $282-284$ & 47.01 & $5 Y$ & 6 & 1 \\
\hline A8_384-386cm & AT1-88-A8 & AT1-88-A8_384-386cm_D19880922 & 42.9417 & -70.7517 & $250 \mathrm{~m}$ & 24.7 & 8.9 & 4.04 & $09 / 22-25 / 1988$ & $384-386$ & 46.60 & $5 Y$ & 6 & 1 \\
\hline
\end{tabular}




\section{Vibracores A7(1), A7(2), and A8: Sediment Classifications}

\begin{tabular}{|c|c|c|c|c|c|c|c|c|c|}
\hline UNH Sample ID & $\begin{array}{l}\text { CMECS Substrate } \\
\text { Component Group } \\
\text { (Specific) }\end{array}$ & $\begin{array}{l}\text { CMECS Substrate } \\
\text { Component Subgroup } \\
\text { (Specific) }\end{array}$ & $\begin{array}{l}\text { Textural Group from } \\
\text { \%GSM (Gradistat) }\end{array}$ & $\begin{array}{l}\text { Textural Group } \\
\text { from \% } \mathrm{SZC} \\
\text { (Gradistat) } \\
\text { lgnores Gravel }\end{array}$ & $\begin{array}{l}\text { Sediment Name from \%GSM } \\
\text { and Mode (Gradistat) }\end{array}$ & $\begin{array}{l}\text { Sediment Name from \%GSM } \\
\text { and Mode (Wentworth Scale) }\end{array}$ & $\begin{array}{l}\text { Sediment } \\
\text { Classification } \\
\text { from Mean Phi } \\
\text { (Gradistat) }\end{array}$ & $\begin{array}{l}\text { Sediment } \\
\text { Classification } \\
\text { from Mean Phi } \\
\text { (Wentworth) }\end{array}$ & Sorting (Gradistat) \\
\hline$A 7(1) \_10-12 \mathrm{~cm}$ & Slightly Granuley & $\begin{array}{l}\text { Slightly Granuley Medium } \\
\text { Sand }\end{array}$ & Slightly Gravelly Sand & Sand & $\begin{array}{l}\text { Slightly Very Fine Gravelly } \\
\text { Medium Sand }\end{array}$ & $\begin{array}{l}\text { Slightly Granular Medium } \\
\text { Sand }\end{array}$ & Medium Sand & Medium Sand & Poorly Sorted \\
\hline$A 7(1) 60-64 \mathrm{~cm}$ & Pebble Gravel & Pebble Gravel & Gravel & Silty Sand & Coarse Gravel & Pebble Gravel & Medium Gravel & Pebble Gravel & Very Poorly Sorted \\
\hline$A 7(1) \_120-122 \mathrm{~cm}$ & Pebble Mixes & Silty Sandy Pebble Gravel & Muddy Sandy Gravel & Silty Sand & $\begin{array}{l}\text { Very Coarse Silty Sandy Coarse } \\
\text { Gravel }\end{array}$ & $\begin{array}{l}\text { Very Coarse Silty Sandy } \\
\text { Pebble Gravel }\end{array}$ & Fine Gravel & Pebble Gravel & Very Poorly Sorted \\
\hline A7 $7(2) \quad 28-30 \mathrm{~cm}$ & Slightly Granuley & $\begin{array}{l}\text { Slightly Granuley Coarse } \\
\text { Sand }\end{array}$ & Slightly Gravelly Sand & Sand & $\begin{array}{l}\text { Slightly Very Fine Gravelly Coarse } \\
\text { Sand }\end{array}$ & Slightly Granular Coarse Sand & Coarse Sand & Coarse Sand & Poorly Sorted \\
\hline$A 7(2)=52-56 \mathrm{~cm}$ & Pebble Mixes & Sandy Pebble Gravel & Sandy Gravel & Sand & Sandy Very Coarse Gravel & Sandy Pebble Gravel & Fine Gravel & Pebble Gravel & Very Poorly Sorted \\
\hline A7(2)_90-94cm & Granuley & Granular Coarse Sand & Gravelly Sand & Sand & Very Fine Gravelly Coarse Sand & Granular Coarse Sand & Coarse Sand & Coarse Sand & Poorly Sorted \\
\hline A7(2) $134-138 \mathrm{~cm}$ & Pebble Mixes & Sandy Pebble Gravel & Sandy Gravel & Sand & Sandy Coarse Gravel & Sandy Pebble Gravel & Very Fine Gravel & Granule Gravel & Very Poorly Sorted \\
\hline A7(2)_160-162cm & Pebble Mixes & Silty Sandy Pebble Gravel & Muddy Sandy Gravel & Silty Sand & $\begin{array}{l}\text { Very Coarse Silty Sandy Medium } \\
\text { Gravel }\end{array}$ & $\begin{array}{l}\text { Very Coarse Silty Sandy } \\
\text { Pebble Gravel }\end{array}$ & Coarse Sand & Coarse Sand & Very Poorly Sorted \\
\hline A8 $20-22 \mathrm{~cm}$ & Pebble Mixes & Sandy Pebble Gravel & Sandy Gravel & Sand & Sandy Medium Gravel & Sandy Pebble Gravel & Very Coarse Sand & Very Coarse Sanc & $d$ Very Poorly Sorted \\
\hline A8 $88-90 \mathrm{~cm}$ & Pebble Mixes & Silty Sandy Pebble Gravel & Muddy Sandy Gravel & Silty Sand & $\begin{array}{l}\text { Very Coarse Silty Sandy Coarse } \\
\text { Gravel }\end{array}$ & $\begin{array}{l}\text { Very Coarse Silty Sandy } \\
\text { Pebble Gravel }\end{array}$ & Medium Sand & Medium Sand & $\begin{array}{l}\text { Extremely Poorly } \\
\text { Sorted }\end{array}$ \\
\hline A8_119-121cm & Pebbly & $\begin{array}{l}\text { Pebbly Silty-Clayey Fine } \\
\text { Sand }\end{array}$ & Gravelly Muddy Sand & Silty Sand & $\begin{array}{l}\text { Medium Gravelly Very Coarse } \\
\text { Silty Very Fine Sand }\end{array}$ & $\begin{array}{l}\text { Pebbly Very Coarse Silty Fine } \\
\text { Sand }\end{array}$ & Fine Sand & Fine Sand & $\begin{array}{l}\text { Extremely Poorly } \\
\text { Sorted }\end{array}$ \\
\hline A8_202-204cm & Pebble Mixes & Silty-Clayey Pebble Gravel & Muddy Gravel & Silty Sand & Very Coarse Silty Coarse Gravel & $\begin{array}{l}\text { Very Coarse Silty Pebble } \\
\text { Gravel }\end{array}$ & Medium Sand & Medium Sand & $\begin{array}{l}\text { Extremely Poorly } \\
\text { Sorted }\end{array}$ \\
\hline A8 $282-284 \mathrm{~cm}$ & Pebble Mixes & Silty Sandy Pebble Gravel & Muddy Sandy Gravel & Silty Sand & $\begin{array}{l}\text { Very Coarse Silty Sandy Coarse } \\
\text { Gravel }\end{array}$ & $\begin{array}{l}\text { Very Coarse Silty Sandy } \\
\text { Pebble Gravel }\end{array}$ & Medium Sand & Medium Sand & $\begin{array}{l}\text { Extremely Poorly } \\
\text { Sorted }\end{array}$ \\
\hline A8_384-386cm & Pebbly & Pebbly Silt & Gravelly Mud & Sandy Silt & Coarse Gravelly Very Coarse Silt & Pebbly Very Coarse Silt & Medium Sand & Medium Sand & $\begin{array}{l}\text { Extremely Poorly } \\
\text { Sorted }\end{array}$ \\
\hline
\end{tabular}


Vibracores A7(1), A7(2), and A8: Grain Size Statistics

\begin{tabular}{|c|c|c|c|c|c|c|c|c|c|c|c|c|c|c|c|c|c|c|c|c|}
\hline UNH Sample ID & Gravel \% & Pebble \% & Granule \% & Sand $\%$ & Mud $\%$ & Silt \% & Clay $\%$ & Modes & $\begin{array}{c}\text { Mode } 1 \\
\text { (phi) }\end{array}$ & $\begin{array}{c}\text { Mode } 2 \\
\text { (phi) }\end{array}$ & $\begin{array}{c}\text { Mode } 3 \\
\text { (phi) }\end{array}$ & $\begin{array}{c}D_{10} \\
\text { (phi) }\end{array}$ & $\begin{array}{c}D_{10} \\
(\mathrm{~mm})\end{array}$ & $\begin{array}{c}D_{50} \\
\text { (phi) }\end{array}$ & $\begin{array}{c}D_{50} \\
(\mathrm{~mm})\end{array}$ & $\begin{array}{c}\text { Mean } \\
\text { Size } \\
(\mathrm{phi})\end{array}$ & $\begin{array}{c}\text { Mean } \\
\text { Size } \\
(\mathrm{mm})\end{array}$ & $\begin{array}{c}\text { Sorting } \\
\text { (phi) }\end{array}$ & Skewness & Kurtosis \\
\hline$A 7(1) \_10-12 \mathrm{~cm}$ & 3.37 & 0.18 & 3.19 & 91.74 & 4.89 & 3.75 & 1.14 & $u$ & 1.75 & NA & NA & -0.09 & 1.06 & 1.59 & 0.33 & 1.62 & 0.32 & 1.38 & 0.03 & 1.08 \\
\hline$A 7(1) \_60-64 \mathrm{~cm}$ & 84.80 & 81.02 & 3.78 & 9.98 & 5.22 & 4.75 & 0.47 & $u$ & -4.24 & NA & NA & -4.35 & 20.45 & -3.60 & 12.15 & -3.04 & 8.21 & 2.05 & 0.68 & 2.20 \\
\hline A7(1)_120-122cm & 74.02 & 65.92 & 8.10 & 19.31 & 6.67 & 5.66 & 1.01 & $u$ & -4.24 & NA & NA & -4.39 & 21.01 & -4.02 & 16.25 & -2.34 & 5.07 & 2.81 & 0.90 & 1.10 \\
\hline$A 7(2) \quad 28-30 \mathrm{~cm}$ & 4.19 & 0.00 & 4.19 & 92.70 & 3.11 & NA & NA & $u$ & 1.25 & NA & NA & -0.66 & 1.58 & 0.81 & 0.57 & 0.84 & 0.56 & 1.26 & 0.11 & 1.06 \\
\hline$A 7(2) \_52-56 \mathrm{~cm}$ & 68.36 & 60.70 & 7.66 & 29.52 & 2.12 & NA & NA & $u$ & -5.24 & NA & NA & -5.36 & 40.96 & -3.26 & 9.59 & -2.50 & 5.64 & 2.79 & 0.41 & 0.64 \\
\hline$A 7(2) \_90-94 \mathrm{~cm}$ & 21.16 & 10.22 & 10.94 & 77.84 & 1.00 & NA & NA & $\mathrm{B}$ & 0.75 & -3.24 & NA & -2.04 & 4.10 & 0.32 & 0.80 & 0.17 & 0.89 & 1.61 & -0.19 & 1.10 \\
\hline A7(2)_134-138cm & 69.54 & 58.68 & 10.86 & 28.23 & 2.23 & NA & NA & $\mathrm{T}$ & -4.73 & -3.24 & -2.24 & -4.83 & 28.52 & -2.63 & 6.17 & -1.95 & 3.85 & 2.79 & 0.38 & 0.71 \\
\hline$A 7(2) \_160-162 \mathrm{~cm}$ & 34.60 & 25.16 & 9.43 & 47.40 & 18.00 & 15.24 & 2.76 & $\mathrm{~B}$ & -3.24 & 1.75 & NA & -3.32 & 9.97 & 0.93 & 0.52 & 0.74 & 0.60 & 3.41 & 0.02 & 0.82 \\
\hline A8_20-22cm & 40.78 & 35.54 & 5.24 & 55.50 & 3.72 & NA & NA & $B$ & 0.75 & -3.24 & NA & -4.02 & 16.17 & 0.03 & 0.98 & -0.66 & 1.58 & 2.35 & -0.28 & 0.78 \\
\hline A8 $88-90 \mathrm{~cm}$ & 32.95 & 30.32 & 2.63 & 35.35 & 31.70 & 22.29 & 9.41 & $B$ & -4.24 & 2.74 & NA & -4.31 & 19.79 & 1.99 & 0.25 & 1.38 & 0.39 & 4.85 & -0.03 & 0.68 \\
\hline A8 $119-121 \mathrm{~cm}$ & 17.32 & 11.39 & 5.93 & 47.60 & 35.08 & 23.41 & 11.67 & B & 2.74 & -3.24 & NA & -2.29 & 4.88 & 2.61 & 0.16 & 2.75 & 0.15 & 4.16 & 0.12 & 1.16 \\
\hline A8_202-204cm & 34.22 & 32.05 & 2.17 & 30.30 & 35.48 & 23.37 & 12.11 & $u$ & -4.24 & NA & NA & -4.33 & 20.10 & 2.18 & 0.22 & 1.69 & 0.31 & 5.17 & 0.01 & 0.66 \\
\hline A8_282-284cm & 34.56 & 30.16 & 4.40 & 37.93 & 27.51 & 18.85 & 8.66 & B & -4.24 & 3.24 & NA & -4.19 & 18.19 & 1.44 & 0.37 & 1.08 & 0.47 & 4.64 & 0.05 & 0.75 \\
\hline A8_384-386cm & 27.44 & 24.38 & 3.06 & 32.29 & 40.27 & 28.99 & 11.28 & $\mathrm{~B}$ & -4.24 & 3.24 & NA & -4.24 & 18.86 & 3.03 & 0.12 & 1.98 & 0.25 & 5.06 & -0.13 & 0.83 \\
\hline
\end{tabular}


Vibracores A7(1), A7(2), and A8: Grain Size Distribution

\begin{tabular}{|c|c|c|c|c|c|c|c|c|c|c|c|c|c|c|c|c|c|c|c|c|c|c|c|c|c|c|c|}
\hline UNH Sample ID & $\begin{array}{c}\text { Class \% } \\
\text { phi } \\
-5.0 \\
\end{array}$ & $\begin{array}{c}\text { Class \% } \\
\text { phi } \\
-4.5 \\
\end{array}$ & $\begin{array}{c}\text { Class } \% \\
\text { phi } \\
-4.0 \\
\end{array}$ & $\begin{array}{c}\text { Class \% } \\
\text { phi } \\
-3.5 \\
\end{array}$ & $\begin{array}{c}\text { Class } \% \\
\text { phi } \\
-3.0 \\
\end{array}$ & $\begin{array}{c}\text { Class \% } \\
\text { phi } \\
-2.5 \\
\end{array}$ & $\begin{array}{c}\text { Class \% } \\
\text { phi } \\
-2.0 \\
\end{array}$ & $\begin{array}{c}\text { Class \% } \\
\text { phi } \\
-1.5 \\
\end{array}$ & $\begin{array}{c}\text { Class \% } \\
\text { phi } \\
-1.0 \\
\end{array}$ & $\begin{array}{c}\text { Class \% } \\
\text { phi } \\
-0.5 \\
\end{array}$ & $\begin{array}{c}\text { Class \% } \\
\text { phi } \\
0.0 \\
\end{array}$ & $\begin{array}{c}\text { Class } \% \\
\text { phi } \\
0.5 \\
\end{array}$ & $\begin{array}{c}\text { Class \% } \\
\text { phi } \\
1.0 \\
\end{array}$ & $\begin{array}{c}\text { Class \% } \\
\text { phi } \\
1.5 \\
\end{array}$ & $\begin{array}{c}\text { Class \% } \\
\text { phi } \\
2.0 \\
\end{array}$ & $\begin{array}{c}\text { Class \% } \\
\text { phi } \\
2.5 \\
\end{array}$ & $\begin{array}{c}\text { Class \% } \\
\text { phi } \\
3.0 \\
\end{array}$ & $\begin{array}{c}\text { Class \% } \\
\text { phi } \\
3.5 \\
\end{array}$ & $\begin{array}{c}\text { Class \% } \\
\text { phi } \\
4.0 \\
\end{array}$ & $\begin{array}{c}\text { Class } \% \\
\text { phi } \\
>4.0\end{array}$ & $\begin{array}{c}\text { Class \% } \\
\text { phi } \\
5.0 \\
\end{array}$ & $\begin{array}{c}\text { Class \% } \\
\text { phi } \\
6.0 \\
\end{array}$ & $\begin{array}{c}\text { Class \% } \\
\text { phi } \\
7.0 \\
\end{array}$ & $\begin{array}{c}\text { Class \% } \\
\text { phi } \\
8.0 \\
\end{array}$ & $\begin{array}{c}\text { Class \% } \\
\text { phi } \\
9.0 \\
\end{array}$ & $\begin{array}{c}\text { Class \% } \\
\text { phi } \\
10.0 \\
\end{array}$ & $\begin{array}{c}\text { Class } \% \\
\text { phi } \\
>10.0\end{array}$ \\
\hline A $7(1) \_10-12 \mathrm{~cm}$ & 0.00 & 0.00 & 0.00 & 0.00 & 0.00 & 0.00 & 0.18 & 1.27 & 1.92 & 2.66 & 4.87 & 8.65 & 12.15 & 15.39 & 16.14 & 11.42 & 9.41 & 7.35 & 3.70 & NA & 2.61 & 0.57 & 0.43 & 0.14 & 0.27 & 0.17 & 0.70 \\
\hline$A 7(1) \quad 60-64 \mathrm{~cm}$ & 0.00 & 0.00 & 36.83 & 17.08 & 10.87 & 12.27 & 3.98 & 2.12 & 1.66 & 1.18 & 0.85 & 0.77 & 0.85 & 0.88 & 1.07 & 0.94 & 1.07 & 1.03 & 1.34 & NA & 2.44 & 1.82 & 0.44 & 0.06 & 0.07 & 0.10 & 0.30 \\
\hline$A 7(1) \_120-122 \mathrm{~cm}$ & 0.00 & 0.00 & 52.35 & 0.00 & 7.84 & 1.16 & 4.58 & 5.88 & 2.21 & 2.80 & 2.13 & 1.99 & 1.85 & 1.79 & 2.02 & 1.63 & 1.91 & 1.67 & 1.52 & NA & 2.27 & 1.71 & 1.10 & 0.58 & 0.24 & 0.34 & 0.43 \\
\hline$A 7(2) \_28-30 \mathrm{~cm}$ & 0.00 & 0.00 & 0.00 & 0.00 & 0.00 & 0.00 & 0.00 & 1.05 & 3.14 & 8.81 & 12.11 & 15.30 & 15.32 & 15.19 & 12.00 & 6.35 & 4.04 & 2.30 & 1.28 & 3.11 & NA & $\mathrm{NA}$ & NA & $\mathrm{NA}$ & NA & NA & NA \\
\hline$A 7(2) \_52-56 \mathrm{~cm}$ & 37.85 & 0.00 & 9.66 & 0.00 & 5.39 & 3.76 & 4.04 & 4.22 & 3.44 & 3.68 & 3.53 & 3.92 & 4.09 & 4.51 & 4.25 & 2.46 & 1.54 & 0.98 & 0.56 & 2.12 & NA & NA & NA & NA & NA & NA & NA \\
\hline$A 7(2) \_90-94 \mathrm{~cm}$ & 0.00 & 0.00 & 0.00 & 0.00 & 6.38 & 0.84 & 3.00 & 5.29 & 5.65 & 9.53 & 10.86 & 13.16 & 13.75 & 12.69 & 9.94 & 4.63 & 2.20 & 0.70 & 0.39 & 1.00 & NA & NA & NA & $\mathrm{NA}$ & $\mathrm{NA}$ & NA & NA \\
\hline$A 7(2) \_134-138 \mathrm{~cm}$ & 0.00 & 34.27 & 0.00 & 3.93 & 7.13 & 6.43 & 6.93 & 6.41 & 4.44 & 3.07 & 2.03 & 2.35 & 3.02 & 3.67 & 4.02 & 3.25 & 3.25 & 2.19 & 1.37 & 2.23 & NA & NA & NA & NA & NA & NA & NA \\
\hline$A 7(2) \_160-162 \mathrm{~cm}$ & 0.00 & 0.00 & 0.00 & 6.51 & 10.15 & 2.96 & 5.55 & 3.86 & 5.58 & 3.82 & 3.53 & 4.11 & 4.56 & 5.31 & 6.30 & 5.30 & 5.75 & 4.73 & 4.00 & $\mathrm{NA}$ & 6.45 & 4.28 & 2.87 & 1.64 & 0.92 & 0.75 & 1.09 \\
\hline A8 $20-22 \mathrm{~cm}$ & 0.00 & 0.00 & 10.31 & 2.89 & 13.21 & 6.72 & 2.41 & 3.07 & 2.17 & 3.33 & 5.14 & 11.83 & 16.03 & 8.92 & 3.62 & 1.95 & 2.22 & 1.54 & 0.92 & 3.72 & NA & NA & NA & NA & NA & NA & NA \\
\hline A8_88-90 $\mathrm{cm}$ & 0.00 & 0.00 & 27.27 & 0.00 & 0.00 & 2.02 & 1.03 & 1.09 & 1.54 & 1.76 & 1.88 & 2.48 & 3.15 & 3.60 & 4.22 & 4.02 & 5.17 & 4.52 & 4.54 & NA & 8.15 & 5.92 & 4.95 & 3.27 & 2.31 & 1.82 & 5.27 \\
\hline A8 $119-121 \mathrm{~cm}$ & 0.00 & 0.00 & 0.00 & 0.00 & 6.92 & 2.13 & 2.35 & 2.32 & 3.61 & 2.90 & 3.47 & 4.66 & 5.34 & 5.03 & 5.17 & 4.64 & 5.85 & 5.26 & 5.28 & $\mathrm{NA}$ & 9.17 & 6.01 & 4.77 & 3.47 & 2.56 & 2.16 & 6.95 \\
\hline A8_202-204cm & 0.00 & 0.00 & 31.12 & 0.00 & 0.00 & 0.00 & 0.93 & 0.76 & 1.41 & 1.51 & 1.49 & 2.10 & 2.76 & 3.10 & 3.46 & 3.58 & 4.33 & 4.06 & 3.91 & NA & 7.30 & 6.06 & 5.55 & 4.46 & 3.24 & 2.25 & 6.61 \\
\hline A8 $282-284 \mathrm{~cm}$ & 0.00 & 0.00 & 16.14 & 11.09 & 0.00 & 1.23 & 1.70 & 2.09 & 2.31 & 2.29 & 2.70 & 3.35 & 3.56 & 4.01 & 4.33 & 3.67 & 5.05 & 4.60 & 4.36 & $\mathrm{NA}$ & 7.45 & 5.03 & 3.56 & 2.81 & 2.27 & 1.30 & 5.09 \\
\hline A8_384-386cm & 0.00 & 0.00 & 19.51 & 0.00 & 2.13 & 1.27 & 1.47 & 1.68 & 1.38 & 1.92 & 1.53 & 1.94 & 2.38 & 2.90 & 3.57 & 3.25 & 4.79 & 4.84 & 5.17 & $\mathrm{NA}$ & 9.87 & 8.46 & 6.00 & 4.67 & 2.95 & 2.10 & 6.22 \\
\hline
\end{tabular}




\section{Appendix C: Archived Grain Size Data for Vibracores}

Sediment grain size data from samples from the vibracores taken on the New Hampshire continental shelf in 1984 ("UNH" series) reported in Birch (1986b) and from the vibracores collected in 1988 ("A" series) and reported in Ward (1989) are given below. The "UNH" series includes \% Gravel, \% Sand, and \% Mud for samples with negligible $(<0.9 \%)$ or no gravel content. The " $A$ " series includes mean grain size (phi) and sorting (phi) for the sand fraction only. Details of the anaytical procedures are given in the Methods section of this report.

\begin{tabular}{|lllllllll|}
\hline Core ID & $\begin{array}{l}\text { Sample } \\
\text { Depth }(\mathbf{c m})\end{array}$ & $\begin{array}{l}\text { Gravel } \\
\%\end{array}$ & $\begin{array}{l}\text { Sand } \\
\text { \% }\end{array}$ & $\begin{array}{l}\text { Mud } \\
\%\end{array}$ & $\begin{array}{l}\text { Silt } \\
\%\end{array}$ & $\begin{array}{l}\text { Clay } \\
\%\end{array}$ & $\begin{array}{l}\text { Mean Size } \\
\text { (phi) }\end{array}$ & $\begin{array}{l}\text { Sorting } \\
\text { (phi) }\end{array}$ \\
\hline UNH-4 & 115 & 0.4 & 93.0 & 6.7 & 3.4 & 3.3 & NA & NA \\
UNH-4 & 396 & 0.0 & 59.9 & 40.1 & 31.2 & 8.9 & NA & NA \\
UNH-4 & 619 & 0.9 & 15.6 & 84.5 & 39.8 & 44.7 & NA & NA \\
\hline UNH-6 & 70 & 0.0 & 86.9 & 13.1 & 10.1 & 3.0 & NA & NA \\
UNH-6 & 291 & 0.2 & 7.5 & 92.4 & 41.3 & 51.1 & NA & NA \\
UNH-6 & 474 & 0.0 & 3.6 & 96.5 & 42.7 & 53.8 & NA & NA \\
\hline UNH-6A & 142 & 0.0 & 93.9 & 6.1 & 2.4 & 3.7 & NA & NA \\
UNH-6A & 244 & 0.2 & 92.7 & 7.2 & 3.8 & 3.4 & NA & NA \\
UNH-6A & 550 & 0.0 & 2.2 & 97.9 & 55.1 & 42.8 & NA & NA \\
\hline UNH-9 & 98 & 0.0 & 4.7 & 95.3 & 43.3 & 52.0 & NA & NA \\
UNH-9 & 424 & 0.9 & 1.8 & 98.2 & 41.0 & 57.2 & NA & NA \\
\hline UNH-10 & 30 & 0.4 & 23.6 & 76.1 & 71.1 & 5.0 & NA & NA \\
UNH-10 & 148 & 0.0 & 0.8 & 99.2 & 48.7 & 50.5 & NA & NA \\
UNH-10 & 328 & 0.1 & 0.7 & 99.3 & 38.3 & 61.0 & NA & NA \\
UNH-10 & 449 & 0.3 & 1.2 & 98.4 & 39.4 & 59.0 & NA & NA \\
UNH-10 & 589 & 0.0 & 0.7 & 99.3 & 42.8 & 56.5 & NA & NA \\
\hline UNH-13 & 20 & 0.2 & 90.1 & 9.7 & 4.0 & 5.7 & NA & NA \\
UNH-13 & 250 & 0.0 & 21.7 & 78.2 & 39.9 & 38.3 & NA & NA \\
UNH-13 & 413 & 0.0 & 8.2 & 91.8 & 43.5 & 48.3 & NA & NA \\
\hline UNH-14 & 30 & 0.1 & 92.9 & 7.0 & 3.6 & 3.4 & NA & NA \\
UNH-14 & 155 & 0.0 & 86.7 & 13.4 & 11.1 & 2.3 & NA & NA \\
UNH-14 & 410 & 0.0 & 3.2 & 96.8 & 48.1 & 48.7 & NA & NA \\
UNH-14 & 531 & 0.0 & 1.7 & 98.3 & 45.4 & 52.9 & NA & NA \\
UNH-14 & 733 & 0.0 & 5.7 & 94.2 & 39.3 & 54.9 & NA & NA \\
\hline & & & & & & & & \\
\hline
\end{tabular}




\begin{tabular}{|c|c|c|c|c|c|c|c|c|}
\hline Core ID & $\begin{array}{l}\text { Sample } \\
\text { Depth }(\mathrm{cm})\end{array}$ & $\begin{array}{l}\text { Gravel } \\
\%\end{array}$ & $\begin{array}{l}\text { Sand } \\
\%\end{array}$ & $\begin{array}{l}\text { Mud } \\
\%\end{array}$ & $\begin{array}{l}\text { Silt } \\
\%\end{array}$ & $\begin{array}{l}\text { Clay } \\
\%\end{array}$ & $\begin{array}{l}\text { Mean Size } \\
\text { (phi) }\end{array}$ & $\begin{array}{l}\text { Sorting } \\
\text { (phi) }\end{array}$ \\
\hline A1 & 5 & 3 & 97 & 1 & NA & NA & 1.00 & 0.54 \\
\hline A1 & 70 & $<1$ & 99 & $<1$ & NA & NA & 1.30 & 0.47 \\
\hline A1 & 200 & 1 & 98 & 1 & NA & NA & 1.10 & 0.50 \\
\hline A1 & 310 & 6 & 93 & 1 & NA & NA & 0.90 & 0.77 \\
\hline $\mathrm{A} 1$ & 390 & 0 & 95 & 5 & NA & NA & 2.20 & 0.52 \\
\hline$A 2$ & 5 & 1 & 98 & 1 & $N A$ & NA & 1.40 & 0.48 \\
\hline A2 & 50 & 3 & 96 & 1 & NA & NA & 1.20 & 0.53 \\
\hline$A 2$ & 170 & 1 & 98 & 1 & NA & NA & 1.30 & 0.53 \\
\hline $\mathrm{A} 2$ & 310 & 0 & 92 & 8 & NA & NA & 2.60 & 0.61 \\
\hline$A 2$ & 390 & 0 & 89 & 11 & NA & NA & 3.00 & 0.36 \\
\hline$A 2$ & 500 & 0 & 76 & 24 & NA & NA & 3.20 & 0.34 \\
\hline $\mathrm{A} 2$ & 700 & 3 & 35 & 62 & NA & NA & 3.00 & 0.78 \\
\hline$A 3$ & 5 & 0 & 99 & 1 & NA & NA & 1.70 & 0.72 \\
\hline$A 3$ & 120 & 0 & 98 & 2 & NA & NA & 2.50 & 0.48 \\
\hline A3 & 225 & 0 & 97 & 3 & NA & NA & 2.40 & 0.57 \\
\hline A3 & 370 & 0 & 85 & 15 & NA & NA & 2.70 & 0.58 \\
\hline A3 & 570 & 0 & 51 & 49 & NA & NA & 3.20 & 0.55 \\
\hline A4 & 30 & $28 *$ & 70 & 2 & NA & NA & 0.70 & 0.79 \\
\hline A4 & 220 & 6 & 91 & 3 & $N A$ & NA & 1.20 & 0.97 \\
\hline A4 & 350 & 2 & 96 & 2 & NA & NA & 1.20 & 0.70 \\
\hline A4 & 470 & 0 & 17 & 83 & NA & NA & 3.00 & 0.76 \\
\hline A5 & 50 & $39 *$ & 56 & 5 & NA & NA & 0.60 & 0.90 \\
\hline A5 & 200 & 0 & 33 & 67 & NA & NA & 2.90 & 0.88 \\
\hline A5 & 300 & 2 & 90 & 8 & NA & NA & 1.80 & 1.03 \\
\hline $\mathrm{A} 6(1)$ & 30 & 0 & 97 & 3 & NA & NA & 2.40 & 0.91 \\
\hline$A 6(1)$ & 90 & 0 & $>99$ & $<1$ & NA & NA & 2.20 & 0.41 \\
\hline $\mathrm{A6}(1)$ & 150 & $<1$ & $>99$ & $<1$ & NA & NA & 2.50 & 0.40 \\
\hline$A 6(1)$ & 210 & 0 & $>99$ & $<1$ & $\mathrm{NA}$ & NA & 2.50 & 0.35 \\
\hline$A 6(2)$ & 10 & 3 & 95 & 2 & NA & NA & 2.30 & 0.93 \\
\hline$A 6(2)$ & 30 & 0 & 93 & 7 & NA & NA & 2.60 & 0.89 \\
\hline$A 6(2)$ & 60 & 0 & 99 & 1 & NA & NA & 1.90 & 0.30 \\
\hline$A 6(2)$ & 140 & 0 & 99 & 1 & NA & NA & 2.70 & 0.26 \\
\hline$A 6(3)$ & 30 & 0 & $>99$ & $<1$ & NA & NA & 1.70 & 0.39 \\
\hline$A 6(3)$ & 120 & 0 & $>99$ & $<1$ & NA & NA & 1.80 & 0.46 \\
\hline$A 6(3)$ & 220 & 0 & $>99$ & $<1$ & NA & NA & 2.00 & 0.42 \\
\hline$A 6(3)$ & 350 & $<1$ & $>99$ & $<1$ & NA & NA & 1.70 & 0.57 \\
\hline A6(3) & 470 & 0 & 4 & 96 & NA & NA & NA & NA \\
\hline$A 6(3)$ & 580 & 0 & 2 & 98 & $\mathrm{NA}$ & NA & NA & NA \\
\hline$A 7(1)$ & 10 & 3 & 92 & 5 & NA & NA & 1.70 & 1.10 \\
\hline$A 7(1)$ & 30 & 9 & 83 & 8 & NA & NA & 1.70 & 1.05 \\
\hline$A 7(1)$ & 125 & 12 & 48 & 40 & NA & NA & 1.90 & 1.35 \\
\hline$A 7(2)$ & 30 & 2 & 93 & 5 & NA & NA & 0.90 & 0.98 \\
\hline$A 7(2)$ & 90 & 27 & 71 & 2 & $\mathrm{NA}$ & NA & 0.60 & 0.95 \\
\hline$A 7(2)$ & 195 & 16 & 72 & 12 & $\mathrm{NA}$ & NA & 2.00 & 1.18 \\
\hline A8 & 30 & 16 & 72 & 12 & NA & NA & 1.20 & 1.16 \\
\hline A8 & 60 & 6 & 49 & 45 & NA & NA & 1.90 & 1.34 \\
\hline A8 & 175 & 14 & 45 & 41 & NA & NA & 1.90 & 1.37 \\
\hline A8 & 395 & 8 & 46 & 46 & NA & NA & 1.90 & 1.35 \\
\hline
\end{tabular}

*Textural information is for matrix, excluding large clasts 